\title{
ERKKI SEVÄNEN
}

Järjen harhapolut

Kapitalistinen rationalisaatio ja sen kritiikki Juha Seppälän romaaneissa

Yhtiökumppanit, Paholaisen haarukka ja Mr. Smith 
Järjen harhapolut 



\section{ERKKI SEVÄNEN}

\section{Järjen harhapolut}

Kapitalistinen rationalisaatio ja sen kritiikki Juha Seppälän romaaneissa Yhtiökumppanit, Paholaisen haarukka ja Mr. Smith 
SUOMALAISEN KIRJALLISUUDEN SEURAN TOIMITUKSIA 1468

Teos on Suomalaisen Kirjallisuuden Seuran nimeämien asiantuntijoiden tarkastama.

PEER-REVIEWED

(C) 2021 Erkki Sevänen ja SKS

Erkki Sevänen ® https://orcid.org/oooo-0001-5227-4511

Lisenssi CC BY-NC-ND 4.0 International

Kannen suunnittelu: Timo Numminen

Taitto: Maija Räisänen

EPUB: Tero Salmén

ISBN 978-951-858-281-9 (nid.)

ISBN 978-951-858-389-2 (PDF)

ISBN $978-951-858-388-5$ (EPUB)

ISSN $0355-1768$ (nid.)

ISSN 2670-2401 (verkkojulkaisut)

DOI https://doi.org/10.21435/skst.1468

Teos on lisensoitu Creative Commons CC BY-NC-ND 4.0 International -lisenssillä. Tutustu lisenssiin englanniksi osoitteessa https://creativecommons.org/licenses/by-nc-nd/4.o/ tai suomeksi osoitteessa https://creativecommons.org/licenses/by-nc-nd/4.o/deed.fi.

Teos on avoimesti saatavissa osoitteessa https://doi.org/10.21435/skst.1468 tai lukemalla tämä QR-koodi mobiililaitteella.

Hansaprint Oy, Turenki 2021

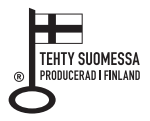




\section{Sisällys}

Esipuhe 7

LUKU I JOHDANTO 10

Tutkimuksen kohde Io

Tehtävänasettelu ja aineistot 15

Aiempi tutkimus 27

Yhteiskunnallinen ja yhteiskuntateoreettinen konteksti 30

Lajikohtaiset kontekstit 36

Kontekstien kaksoistehtävä ja tutkimuksen etenemistapa 47

LUKU II AINEISTO, KÄSITTEET JA TEORIAT 49

Edeltävä tuotanto eli vuodet I986-I999 49

Historiallis-yhteiskunnallinen konteksti 69

Alustava kuvaus tutkimuskohteena olevista romaaneista 8I

Representaatio, arvot, arvottaminen, maailmankatsomus ja ideologia I03

Kapitalismi ja kapitalismikritiikki III

Rationaalisuus, indifferenssi, vieraantuneisuus ja syrjäytyneisyys I22

Rationalisaatiokriittinen romaanityyppi 134

Eksistentialistinen ja eksistentiaalinen ulottuvuus I5I

Intertekstuaaliset ja interdiskursiiviset viittaukset ja metatasot ${ }_{15} 6$

LUKU III YHTIÖKUMPPANIT JA KAPITALISMIN EETOS 159

Henkilöt, tarinalinjat ja narratiivinen rakenne 159

Hillitön pyrkimys rahan ansaitsemiseen kapitalismin eetoksena ${ }_{1} 65$

Kilpailutalouden ankarat lait $\mathrm{I7} 8$

Mielekkyyskriiseihin ajautuminen 187

Tragediaan ja mytologioihin viittaaminen retorisena tehokeinona I99

Yhteenvetoa ja yhtymäkohtia 210

LUKU IV PAHOLAISEN HAARUKKA JA KRIITTISEN KÄRJISTÄMISEN

LOGIIKKA 218

Henkilöt, rakenne ja muoto $2 \mathrm{I} 8$

Markkinakapitalismi välinerationaalisena ja indifferenttinä systeeminä 235

Kaikkialle ulottuva markkinadominanssi 245

Riskiyhteiskunta ja ekologiset näkökohdat 254

Teosten ihmissuhteet, naishahmot ja seksuaalisuuden alueen tavaroituminen 262 
Vieraantuminen, syrjäytyminen ja eksistentiaaliset motiivit 280

Yhteiskunnallisen todellisuuden representoimisen ongelma 293

Kirjallisuuden asema nykykapitalismissa 304

Yhteenvetoa 3 I0

LUKU V MR. SMITH JA KRITIIKIN SUHTEELLISTUMINEN 316

Henkilöt, rakenne ja geneeriset ainekset $3 \mathrm{I} 6$

Kapitalismin dialektiikka 327

Työväenluokkaiset henkilöhahmot 337

Autenttisuuden problematiikka 348

Epäautenttinen elämä ja olemassaolo 365

Autofiktiivinen ja metanarratiivinen ulottuvuus 377

Yhteenvetoa 387

LUKU VI PÄÄTÄNTÄ 392

Kritiikin näkökulma ja arvolähtökohta 392

Yhteenveto tutkimuskohteena olevista teoksista 405

Yksilölliset ja henkilökohtaiset utopiat 4I7

Viitteet 425

English Abstract 446

Lähteet 447

Henkilöhakemisto 475 


\section{Esipuhe}

Tämä kirja perustuu Juha Seppälän tuotantoa kohtaan tuntemaani monivuotiseen mielenkiintoon. Ensimmäiset lukukokemukseni hänen teoksistaan ovat peräisin I990-luvulta, jolloin eräät opiskelijani ryhtyivät laatimaan pro gradu -tutkielmiaan hänen novelleistaan ja romaaneistaan. Opiskelijoitteni tutkielmia edistääkseni päätin tuolloin itsekin tutustua lähemmin Seppälän teoksiin. Huomasin pian ajattelevani, että niiden säästeliään kirkas tyyli, erilaisista ajatustraditioista tietoinen sisältö ja myöhemmin myös niiden taitavasti kehitelty ja rohkean ennakkoluuloton yhteiskunnallinen tematiikka tekevät niistä kiehtovaa luettavaa.

Erillistä tutkimusta Seppälän tuotannosta aloin suunnitella vuoden 2005 tienoilla. Oletin silloin, että tuo tutkimus tulisi tarkastelemaan eksistentiaalisten kysymysten asemaa hänen teoksissaan. Sainkin tämän suuntaista hanketta varten lukuvuodeksi 2007-2008 Suomen Akatemian varttuneen tutkijan apurahan, mutta seuraavina vuosina muut projektini pakottivat minut laittamaan kyseisen hankkeen syrjään kiireellisten töideni listalta. Seuraavan kerran saatoin keskittyä siihen lukuvuodesta 20I6-20I7 lähtien, ensin Suomen Kulttuurirahaston myöntämän apurahan turvin ja sen jälkeen virkatyössäni Itä-Suomen yliopistossa.

Jo ennen lukuvuotta 20I6-20I7 tutkimuskohteessani, Seppälän tuotannossa, tapahtuneet painopisteen muutokset olivat kuitenkin saaneet minut tarkistamaan myös hankkeeni pääkysymystä. Siinä, missä eksistentiaaliset teemat, inhimillisen elämän ja olemassaolon merkitystä 
ja mieltä koskevat pohdiskelut, olivat Seppälän I980- ja I990-luvun teoksissa usein etualalla, 2000-luvun edetessä nuo teemat jäivät yhä enemmän sivuosaan sitä mukaa kuin hänen teoksensa keskittyivät käsittelemään yhteiskunnan markkinallistumiskehitystä. Hänen uuden vuosituhannen ensimmäisellä vuosikymmenellä ja 20ıo-luvun alussa ilmestyneet teoksensa arvioivatkin leimallisesti sitä, mitä yksilöille, yhteisöille ja yhteiskunnalle on tapahtunut tai mitä niille voisi tapahtua, kun kapitalistisen bisnes-logiikan annetaan yhteiskunnassa määrätä "järkevän", rationaalisen toiminnan rajat. Silti näissä kapitalismikriittisissä teoksissakin on mukana eksistentiaalinen ulottuvuus, pyrkimys hahmottaa sitä, millaisia mielekkään elämän ja toiminnan aineksia - tai pikemminkin niitä uhkaavia vakavia riskejä - markkinakapitalistinen yhteiskunta ja maailmanjärjestys ihmisille ja yhteisöille tarjoavat.

Tämä tutkimus kysyy, miten Seppälän vuosina 2000-20I2 ilmestyneet teokset käsittelevät markkinakapitalismin toimintatapojen leviämistä yhteiskuntaan. Tutkimuksen valmistuminen ei olisi ollut mahdollista ilman useiden henkilöiden ja laitosten myötävaikutusta. Merkittävää tutkimukseni etenemisen kannalta on ollut se, että johdin vuosina 20II-20I4 Suomen Akatemian rahoittamaa projektia, joka käsitteli taide-elämän markkinallistumista Suomessa ja muissa länsimaissa. Tutkimukseni on jatkoa sen piirissä alkunsa saaneille töille, erityisesti teoksille Kirjallisuus nykykapitalismissa. Suomalaisen kulttuurin näkökulma (Suomalaisen Kirjallisuuden Seura, 20I8) ja Art and the Challenge of Markets. Volume 2. From Commodification of Art to Artistic Critique of Capitalism (Palgrave Macmillan, 20I8), joista edellisen toimitin Jussi Ojajärven ja Liisa Steinbyn kanssa ja jälkimmäisen Victoria D. Alexanderin, Samuli Häggin ja Simo Häyrysen kanssa. Ne käsittelevät yhtäältä kirjallisuuden ja taiteen alueen markkinallistumista ja toisaalta sitä, millaista kritiikkiä markkinallistuminen on kyseisellä alueella synnyttänyt.

Käsikirjoitusvaiheessa tutkimustani ovat lukeneet ja kommentoineet FT, dosentti Kati Launis ja FT, dosentti Voitto Ruohonen. FL Arto Miettisen kanssa olen voinut vuosien ajan käydä hedelmällisiä keskusteluja Juha Seppälän tuotannosta. Työni edistymisen kannalta näiden kolmen tutkijan apu on ollut korvaamaton. Suomen Akatemia ja Suomen Kulttuurirahasto ovat apurahoillaan turvanneet sen, että olen useina vuosina 
voinut keskittyä projekteihini ja tämän kirjan tekemiseen. Suomalaisen Kirjallisuuden Seuraa kiitän tutkimukseni ottamisesta tiedesarjaansa. Kustannustoimittaja Sara Lavikainen on ammattitaitoisella ja kärsivällisellä otteella vastannut tekstin editoimisesta taittovalmiiksi, mistä kiitän häntä. Jälleen kerran lukuisat keskustelut rakkaan Ullani kanssa ovat terävöittäneet näkemystäni kapitalismikritiikistä taiteessa.

Joensuussa ja Turussa huhtikuussa 202I

Erkki Sevänen 


\section{Luku I Johdanto}

\section{Tutkimuksen kohde}

Käsillä oleva kirjallisuussosiologinen tutkimus kohdistuu Juha Seppälän romaaneihin Yhtiökumppanit (2002), Paholaisen haarukka (2008) ja Mr. Smith (20I2). Yhteistä niille on se, että ne esittävät kriittisen kuvauksen ja arvion nykykapitalismin toimintatavoista ja näiden toimintatapojen vaikutuksista yksilöiden ja yhteisöjen elämään. Ne voidaan siksi sijoittaa kapitalismikriittisen romaanityypin piiriin. Jürgen Habermasin (1987a; г987b) kommunikatiivisen toiminnan teoriaan nojautuen me voimme jakaa yhteiskunnallisen todellisuuden yhtäältä talouden ja politiikan systeemeihin, eli "rahan ja vallan maailmaan", sekä toisaalta ihmisten elämismaailmoihin. Edellä mainituissa romaaneissa käsittelyn kohteena ovat sekä systeemit että elämismaailmat, sekä nykyinen talouselämä että ihmisten yksityisyyden piirit. Ne ovat tässä mielessä laajoja yhteiskunnallisia romaaneja. Ne kuvaavat yhteiskuntaa suhteellisen kattavasti, tavalla, jossa sen monet eri osa-alueet tulevat kuvauksen piiriin.

Varhaistuotannossaan eli I980- ja I990-luvulla ilmestyneissä fiktiivisissä teoksissaan Seppälä käsitteli tavallisesti ihmisten elämismaailmoja. Näin tapahtuu esimerkiksi romaaneissa Hyppynaru (I990a), Sydänmaa (I994a) ja Kuun nousu ja lasku (I999). Ne ovat suppeita yhteiskunnallisia romaaneja siinä mielessä, että niissä yhteiskunnallisesta todellisuudesta kuvauksen kohteeksi on valittu varsin rajallinen osa-alue, ihmisten 
välittömän elämisen ja kokemisen piiri. Talouselämää Seppälä käsitteli ı990-luvulla lähinnä kokoelmaansa Super Market (I99ıа) sisältyvissä muutamissa lyhyissä kertomuksissa, varsinkin "Supermarketissa" (I99Ib), jonka tapa kuvata kulutuskeskeistä nyky-yhteiskuntaa on irvokkaan groteski. Vaikka Seppälän varhaistuotanto keskittyy kuvaamaan lähinnä ihmisten kokemusmaailmaa, nämä teokset eivät pohdi yhteiskunnallisesti vähämerkityksisiä asioita. Niissä käsitellään tai sivutaan myös sellaisia aiheita kuin maaltamuutto, maaseudun ja kaupungin välinen suhde ja lähiöelämän ongelmat. Nämä aiheet on suomalaisessa yhteiskunnassa koettu tärkeiksi viimeistään ı960-luvulta lähtien.

Edellä mainitut Seppälän varhaistuotantoon sisältyvät romaanit eivät ole pelkästään suppeita yhteiskunnallisia romaaneja, vaan ne sisältävät piirteitä muistakin romaanin alalajeista tai lajeja lähellä olevista kirjallisista ilmiöistä. Niinpä esimerkiksi Sydänmaassa ja Kuun nousussa ja laskussa keskeisen sijan saa myös kansallinen ja eksistentiaalinen tematiikka, joka nousee ainakin Sydänmaassa yhteiskunnallisia kysymyksiä tärkeämmäksi sisällön ulottuvuudeksi. Samoin Hyppynarussa yhteiskunnallinen problematiikka jää toissijaiseksi psykologisiin teemoihin nähden. Siksi näitä kolmea romaania ei voida kuvata monipuolisesti pelkän yhteiskunnallisen romaanin käsitteen avulla.

Tämä tutkimus kohdistuu Seppälän laajojen yhteiskunnallisten teosten kauteen. Nuo vuosina 2000-20I2 ilmestyneet teokset käsittelevät yhteiskuntapolitiikassa viime vuosikymmeninä tapahtunutta perustavaa muutosta, sitä, että I980- ja I990-luvulta lähtien niin maailmanjärjestelmä kuin suomalainen yhteiskuntakin on kasvavassa määrin organisoitu yksityiskapitalistisen yritystoiminnan ja markkinoiden pohjalta. Seppälän laajojen yhteiskunnallisten teosten perusteella tämä muutos - jota kutsun yksinkertaisuuden vuoksi kapitalisoitumiskehitykseksi tai markkinallistumiskehitykseksi - ei ole vaikuttanut ainoastaan talouden ja politiikan järjestelmiin, vaan se on muokannut myös kirjallisuuden ja kulttuurin aluetta sekä ihmisten elämismaailmoja ja heidän subjektiuttaan. Tutkimuksen päätehtävänä on analysoida sitä, millaisen kuvan ja arvion Seppälän romaanit tästä kehityksestä antavat.

Vuosina 2000-2012 Seppälä julkaisi romaanit Yhtiökumppanit (2002), Routavuosi (2004e), Ei kenenkä̈̈n maa (2006a), Paholaisen haarukka 
(2008) ja Mr. Smith (20I2). Niistä kolmessa eli Yhtiökumppaneissa, Paholaisen haarukassa ja Mr. Smithissä kapitalismin muodonmuutos ja markkinakapitalismin toimintaperiaatteiden leviäminen yhteiskuntaan ovat pääteemana, jos kohta Mr. Smithissä tämä tematiikka ei hallitse romaania niin selvästi kuin kahdessa ensiksi mainitussa teoksessa. Näitä kolmea teosta voidaan siten pitää nyky-yhteiskunnan romaanimuotoisina representaatioina ja arvioina. Routavuoden näkökulma yhteiskuntaan on rajatumpi. Sen esittämä kritiikki ei kohdistu ensi sijassa kapitalismiin vaan Suomen EU-politiikkaan, joka on romaanin päähenkilön, poliittisen historian opiskelijan Kaarlen mukaan merkinnyt Suomen kansallisen suvereniteetin luovuttamista suuryritysten etuja ajavalle Euroopan unionille. Ei kenenkään maa on vain ohuesti yhteiskunnallinen romaani, jossa yhteiskunnallisten teemojen sijasta korostuu eksistentiaalinen tematiikka.

Näiden romaanien lisäksi Seppälä julkaisi vuosina 2000-20I2 teokset Suuret kertomukset (2000a), Mitä sähkö on? (2004a) ja Takla Makan (20IOa). Suuriin kertomuksiin sisältyvä novelli "Mustalla saarella" (2000b) ja kokoelmaan Mitä sähkö on? sisältyvä "Bisnesenkeli” (2004b) liittyvät suoraan tämän tutkimuksen pääteemaan, yhteiskunnan markkinallistumiseen, ja siksi tarkastelen myös näitä kertomuksia. Lisäksi kiinnitän huomiota jälkimmäisen kokoelman kertomuksiin "Mitä sähkö on?" (2004c) ja "Kimalaisen hunajaa" (2004d), sillä ne ovat tärkeitä Seppälän koko tuotannon ymmärtämisen kannalta.

Vuoden 2012 jälkeen Seppälän tuotanto suuntautui ensi sijassa metakirjallisille urille. Romaanien Matka aurinkoon (20I4) ja Kuoppakaupunki (20I6) pääteema ei nimittäin liity markkinallistumiseen vaan kysymykseen siitä, mitä ja miten kirjailijan tai kertojan tulisi kertoa itsestään ja elämästään. Edellisessä romaanissa tätä kysymystä pohtii eläkkeellä oleva, kuvitteellinen kirjallisuudenprofessori Irma ja jälkimmäisessä psykoottiseen tilaan ajautuva kirjailijahahmo Ilmo Halssi, niin ikään kuvitteellinen henkilö. Seppälän tuotannossa romaani Sankariaika (20I8a) merkitsi kuitenkin paluuta kansallisten ja yhteiskunnallisten kysymysten pariin, sillä se pohtii, miten kansallinen arvo- ja symbolimaailma on Suomessa muotoutunut ja ketkä pyrkivät nykyisin esiintymään tuon perinteen jatkajina. Tämä paluu jäi tosin lyhytaikaiseksi, sillä toistaiseksi 
uusimmassa romaanissaan Syntymättömän testamentti (2020) Seppälä antaa jälleen keskeisen sijan metakirjalliselle tematiikalle, erityisesti kysymykselle, miten kirjallisuus voisi käsitellä toteutuneista asiaintiloista ja tapahtumista poikkeavia mahdollisia ja vaihtoehtoisia tapahtumakulkuja.

Kapitalismikuvaukset ovat I990-luvulta lähtien yleistyneet kirjallisuudessamme. Tätä kehitystä on romaanin osalta tarkastellut Jussi Ojajärvi erityisesti väitöskirjansa Supermarketin valossa (2006) viimeisessä luvussa ja artikkelissaan "Kapitalismista tulee ongelma", joka sisältyy Mika Hallilan, Yrjö Hosiaisluoman, Sanna Karkulehdon, Leena Kirstinän ja Ojajärven itsensä toimittamaan teokseen Suomen nykykirjallisuus 2. Kirjallinen elämä ja yhteiskunta (20I3b). Ojajärven tutkimusten nojalla nykykapitalismi, sen leviämistä I980- ja I990-luvulta lähtien ajanut uusliberalistinen politiikka ja tämän politiikan vaikutukset ihmisten elämään ovat viime vuosikymmeninä olleet suomalaisen kirjallisuuden keskeistä tematiikkaa, jota ovat Seppälän ohella käsitelleet lukuisat, erityisesti romaania tai näytelmää ilmaisumuotonaan käyttävät kirjailijat. ${ }^{1}$ Ojajärvi (20I3b, I5I) rinnastaakin nykytilanteen I900-luvun kahteen ensimmäiseen vuosikymmeneen, jolloin suomalaisissa kirjailijoissa "teollistuminen ja keinottelu herättivät tietoisuuden kapitalismin edellyttämästä luokkajaosta ja rahan vaikutuksista yhteiskuntamoraaliin ja ihmissuhteisiin. Nykykirjallisuudessa tällaiset kysymykset ovat jälleen ajankohtaisia." Luokkaproblematiikan ja markkinallistumis-teemojen käsittelyn ohella nykykirjallisuus pyrkii myös hahmottamaan, millainen on nykykapitalismille ominainen toimintatapa tai -logiikka.

Edellä todetun perusteella voisi päätellä, että yhteiskunnallinen romaani kuuluu suomalaisen nykykirjallisuuden keskeisiin lajeihin. Tätä se käsittääkseni onkin, mutta hieman yllättävältä tuntuu se, että tutkijat näyttävät välttelevän tätä lajikäsitettä. Esimerkiksi Hallilan, Hosiaisluoman, Karkulehdon, Kirstinän ja Ojajärven toimittama Suomen nykykirjallisuus 1. Lajeja, poetiikkaa (20I3a) omistaa kyllä erilliset luvut lyhytproosalle, metafiktiolle, omaelämäkerralle ja autofiktiolle, muttei yhteiskunnalliselle romaanille, joskin kyseisen teoksen toiseen osaan sisältyvä Ojajärven artikkeli keskittyy epäsuorasti, tavallisesti itse käsitettä mainitsematta, yhteiskunnallisiin romaaneihin. Leena Kirstinä ja Risto 
Turunen $(2013,69-72)$ toteavat saman teoksen ensimmäiseen osaan kirjoittamassaan artikkelissa, että sellaisten käsitteiden kuin yhteiskunnallinen romaani ja poliittinen romaani epäsuosiota voi ehkä selittää sillä, että I970-luvun Suomessa ne saivat paljolti vasemmistolaisen leiman. Siksi tutkijat ovat uusliberalistisen politiikan valtakaudella vierastaneet niitä, välttyäkseen leimautumasta niihin liittyneen kirjallisuuskäsityksen myötäilijöiksi. Syyt näiden käsitteiden epäsuosioon olisivat siten olleet enemmänkin poliittisia ja ideologisia kuin tieteellisiä.

Toinen selitys yhteiskunnallisen romaanin käsitteen epäsuosioon liittyy siihen, miten lajit kehittyvät. Alastair Fowler (I997, I70-I89) huomauttaa, että kun lajin piiriin tulee yhä enemmän teoksia, laji muuttuu rajoiltaan ja tunnuspiirteiltään epämääräisemmäksi ja siihen saattaa syntyä uusia alalajeja, jotka alkavat elää kirjallisessa kulttuurissa omaa elämäänsä. Juuri näin on tapahtunut yhteiskunnalliselle romaanille. Se on nykyisin hajautunut useisiin eri alalajeihin, joita ovat esimerkiksi yritysmaailman, työelämän, kaupallistuneiden medioiden, seksibisneksen ja monikulttuurisuuden kuvaukset sekä yhteiskuntaa kokonaisvaltaisesti hahmottavat romaanit. Tätä moninaisuutta kuvattaessa yhteiskunnallisen romaanin käsite on yleisluontoisuutensa vuoksi yksinään riittämätön työväline ja sitä on täydennettävä käsitteistöllä, joka ottaa paremmin huomioon sen alalajien erityispiirteet.

Näistä syistä tämäkään tutkimus ei operoi ensi sijassa yhteiskunnallisen romaanin käsitteellä. Vaikka tutkimuskohteena olevat Seppälän romaanit voidaan sijoittaa sen piiriin, se on käsitteenä varsin laaja-alainen eikä se siksi mahdollista täsmällisen analyysin ja tulkinnan laatimista Seppälän romaaneista. Tämä kävisi ilmi viimeistään siinä vaiheessa, kun tutkimus yrittäisi epätoivoisesti sijoittaa kohdeteokset yhteiskunnallisen romaanin monipolviseen traditioon.

Täsmällisemmän työvälineen Seppälän romaaneja koskevalle tutkimukselle tarjoaa kapitalismikriittisen romaanityypin käsite. Kapitalismikriittinen romaani on yhteiskunnallisen romaanin alalaji, joka jakautuu edelleen suppeampiin alalajeihin. Näistä alalajeista tärkeimmät ovat kapitalistisen luokkajärjestyksen kritiikki ja kapitalistisen rationalisaation kritiikki, lyhyemmin ilmaistuina luokkakritiikki ja rationalisaatiokritiikki. Edellinen kuvaa alempien luokkien alistettua asemaa kapitalistisessa 
yhteiskunnassa tai se esittää kriittisen arvion ylempien luokkien elämäntyylistä ja toimintatavoista. Tällaiset romaanit kyseenalaistavat siten kapitalistisessa tai porvarillisessa yhteiskunnassa vallitsevan luokkajärjestyksen. Jälkimmäinen tyyppi rakentaa kuvaa kapitalistisen talousjärjestyksen toimintalogiikasta ja sen yksilöille ja yhteisöille aiheuttamista vaurioista. Suomalaisessa kirjallisuudessa klassisia kapitalistisen luokkajärjestyksen kritiikkejä ovat Minna Canthin Kovan onnen lapsia (I888) ja Pentti Haanpään Isännät ja isäntien varjot (I935). Canthin näytelmä käsittelee työväenluokan turvatonta asemaa yhteiskunnassa, ja Haanpään romaani osoittaa, millaiseen ahdinkoon I930-luvun alun talouslama ajoi maanviljelijäväestön Suomessa. Rationalisaatiokritiikin klassikkoja suomalaisessa kirjallisuudessa ovat Toivo Pekkasen Tehtaan varjossa (I93I) ja Haanpään Noitaympyrä (kirjoitettu I93I, ilmestyi I955), joissa luodaan erilaisten tarinalinjojen sekä kertojien ja henkilöiden esittämien pohdiskelujen avulla kuvaa siitä, miten teollis-kapitalistinen talousjärjestys ja yhteiskunta toimivat. Tutkimuskohteena olevissa Seppälän teoksissa on piirteitä näistä molemmista tyypeistä, mutta ensi sijassa ne käsittelevät kapitalismin toimintatapaa ja sen aiheuttamaa vieraantuneisuutta. Lisäksi on huomattava, että ne eivät ole pelkkiä talouselämää käsitteleviä romaaneja, vaan ne yhdistelevät tähän romaanityyppiin aineksia muista romaanin lajeista tai lajeja muistuttavista ilmiöistä, erityisesti eksistentiaalisia kysymyksiä käsittelevästä kirjallisuudesta ja metafiktiosta.

\section{Tehtävänasettelu ja aineistot}

Tämän työn pääkohteena ovat Seppälän romaanit Yhtiökumppanit, Paholaisen haarukka ja Mr. Smith, joita täydentävät hänen novellinsa tai kertomuksensa "Mustalla saarella", "Bisnesenkeli", "Mitä sähkö on?” ja "Kimalaisen hunajaa". Kaikki nämä teokset ovat ilmestyneet vuosina 2000-20I2. Kyseinen periodi eroaa Seppälän varhaistuotannosta (vuodet I986-I999) siinä, että hänen aiempia teoksiaan hallitsevat psykologiset, eksistentiaaliset ja kansalliset teemat, kun taas vuosien 2000-20I2 tuotannolle leimallista on ankara yhteiskuntakritiikki. Näissä vuosina 2000-20I2 ilmestyneissä teoksissa muut teemat ovat usein toissijaisia 
yhteiskunnalliseen tematiikkaan nähden tai upotettuina yhteiskunnallisten teemojen yhteyteen, niiden osaksi. Tämä pätee varsinkin Yhtiökumppaneihin ja Paholaisen haarukkaan, jotka pyrkivät välittämään kriittisen arvion markkinallistumiskehityksestä. Samanlainen pyrkimys on tärkeä Mr. Smithissä, joka sisältää lisäksi monipuolisesti kehitellyn eksistentiaalisen tai elämänfilosofisen tason. Lisäksi näihin kaikkiin kolmeen romaaniin on upotettu metakirjallisia teemoja, joiden luonne tosin vaihtelee teoksesta toiseen.

Niin Seppälän varhaistuotantoa kuin hänen myöhempiä teoksiaan käsiteltäessä tarvitaan tietoa eksistentialismista, sillä Albert Camus'n ja Jean-Paul Sartren tapaiset eksistentialistisen kirjallisuuden paradigmaattiset edustajat ovat olleet hänen tuotantonsa kannalta tärkeitä kiinnekohtia. Seppälän teosten esittämät ratkaisut eksistentiaalisiin kysymyksiin eivät silti ole aina klassisen eksistentialismin mukaisia, vaan usein niillä on tietty itsenäisyytensä siihen nähden. Siksi käsitteet eksistentiaalinen ja eksistentiaalifilosofinen sopivat tietyissä, myöhemmin täsmennettävissä suhteissa kuvaamaan paremmin hänen teostensa ominaisluonnetta kuin käsite eksistentialistinen, joka on toki myös relevantti hänen tuotantonsa yhteydessä.

Antamissaan haastatteluissa Seppälä on yleensä itsekin määrittänyt kirjallisen tuotantonsa luonteen tavalla, joka sijoittaa hänet yhtäältä eksistentialismin yhteyteen, mutta toisaalta samalla erottaa hänet tästä intellektuaalisesta suuntauksesta:

Teemat, jotka eivät jätä minua rauhaan, ovat yleensä eksistentiaalisia kysymyksiä, mutta kuitenkin niin, että kieltäydyn olemasta eksistentialisti yhtä painokkaasti kuin joku Camus, koska sekin on jo luokitus. (Seppo Puttosen ja Joni Pyysalon vuonna 2003 Parnassoon tekemä haastattelu Seppälästä; ks. Puttonen \& Pyysalo 2003, 64. $)^{2}$

Tässä Seppälä tekee turhankin jyrkkää eroa itsensä ja eksistentialismin välille, sillä hänen romaaneihinsa sisältyy myös eksistentialistisen ajattelun mukaisia näkemyksiä inhimillisestä olemassaolosta ja kirjallisuudesta. Sitaatti paljastaa silti samalla epäsuorasti myös hänen kirjailijantyönsä toisen keskeisen subjektiivisen lähtökohdan, sen, että kirjailijana hän 
katsoo hahmottavansa maailmaa ensi sijassa yksilöiden kokemuksista käsin. Siksi hän esimerkiksi toteaa vierastavansa nykyisin Väinö Linnaa, jota hän nuoruusvuosinaan, "kaksikymppiseksi asti", piti lempikirjailijanaan: syyt etääntymiseen löytyvät juuri siitä, että "Linna ei paneudu yksilön kokemukseen" (ks. Puttonen \& Pyysalo 2003, 62-63). Yksilökeskeisyyteen liittyen Seppälä suhtautuu oheisessa sitaatissa torjuvasti myös luokitteluihin, mutta todellisuutta koskeva tutkimus ei tietenkään voi luopua kokonaisuuksien hahmottamisesta eikä ilmiöitä yhdistävien piirteiden ja samankaltaisuuksien etsimisestä ja niiden nimeämisestä. Mikäli tutkija olettaisi, että todellisuudessa on olemassa vain ainutkertaisia yksilöitä ja tapahtumia, hän kaventaisi mahdollisuuksiaan laatia maailmasta hallittavissa ja ymmärrettävissä olevia kuvauksia ja teorioita.

Eksistentialismia on pidetty yksilökeskeisenä filosofiana. Sen avulla on vaikea käsitellä ryhmiä, luokkia ja muita kollektiivisia ilmiöitä, sillä se tarkastelee maailmaa yksittäisen ihmisen ja hänen kokemuksensa näkökulmasta (Möbuss 20I5a, I2-I8). Yksilöitä tuotantonsa lähtökohtana Seppälä on painottanut myöhemminkin, esimerkiksi Paholaisen haarukan ilmestymisen yhteydessä. Riitta Kylänpäälle Suomen Kuvalehteen vuonna 2008 antamassaan haastattelussa hän toteaa, että hänen omat teoksensa eivät ole teoreettista pohdintaa. Sen sijasta hänen lähtökohtanaan on yksilön kokemus, kun taas "sosiologi hakee yleistyksiä" (Kylänpää 2008, 58). Jos näin todellakin on, niin on paikallaan kysyä, kuinka laajasti yhteiskuntaa voidaan romaanissa hahmottaa yksilöiden kokemuksista käsin. Voisivatko jotkin tärkeät yhteiskunnallisen todellisuuden puolet jäädä tällöin tavoittamatta?

Tätä kysymystä voidaan lähteä avaamaan tarkastelemalla Terry Eagletonin käsitystä kirjallisuuden kokemuksellisuudesta. Varhaistuotannossaan Eagleton (1976, 72, 77, IOI) ajatteli, että kirjalliset teokset eivät käsittele itse historiaa tai yhteiskuntaa vaan sitä, miten ihmiset kokevat oman aikansa. Siksi, hän jatkoi, kirjallisuutta lukemalla me voimme nähdä, miten ideologia toimii ihmisten mielissä, mutta itse "todellista" historiaa tai yhteiskuntaa me emme opi sen avulla tuntemaan. Tätä päättelyä on pidettävä yksipuolisena. Virheellistä siinä ei ole kirjallisuuden ja kokemuksellisuuden liittäminen kiinteästi toisiinsa, sillä, niin kuin Monika Fludernik (20I0, I8-23) huomauttaa, kertomukset pyrkivät välit- 
tämään lukijoille juuri subjektien kokemuksen elämästä ja maailmasta. Näin kirjallisuuden ja kokemuksellisuuden välillä vallitsee läheinen sidos. Eagletonin päättely on altis kritiikille siitä syystä, että hän erotti jyrkästi toisistaan historiallisen todellisuuden ja ihmisten tavan kokea se. Näin tehdessään hän nojautui positivistissävyiseen erotteluun tosiasioiden ja arvojen välillä, vaikka hän varhaistuotannossaan omaksuikin päävaikutteensa Louis Althusser'n ja Pierre Machereyn strukturalistisesta marxismista. Ero positivismin ja marxismin välillä ei silti ole tässä yhteydessä ylittämätön, sillä positivismia mukaillen strukturalistinen marxismi painotti niin ikään (marxilaisen) tieteen ja ideologian välistä eroa. Hermeneuttisen filosofian näkökulmasta historiaa ja ihmisten kokemusta siitä ei ole kuitenkaan syytä erottaa jyrkästi toisistaan. Historiallinen tai kulttuuris-yhteiskunnallinen todellisuus muodostuu osittain juuri inhimillisistä teoista ja niihin liitetyistä merkityksistä, arvoista ja kokemuksista.

Toisaalta, kuten Habermas (1973, 289; I975, 52-55; 1987b, 223-224) huomauttaa, tässä kohden ei ole myöskään syytä langeta "hermeneuttiseen idealismiin" eli ajatella kulttuuris-yhteiskunnallisen todellisuuden muodostuvan pelkästään merkitysvälitteisestä toiminnasta. Habermasin mukaan tämä kanta sivuuttaa sen, että tuo todellisuus sisältää myös sellaisia puolia, joita ei voida täysin palauttaa merkitysvälitteiseksi toiminnaksi; esimerkiksi kapitalistisessa yhteiskunnassa talouden lainalaisuudet ovat ainakin osittain irtautuneet sosiaalisten toimijoiden kontrollista, minkä vuoksi ne toimivat ja vaikuttavat jossakin määrin toimijoiden "selän takana" ja jopa heitä vastaan. Seppälän yhteiskunnallisia romaaneja tutkittaessa voidaan siksi kysyä, missä määrin ne tavoittavat nämä yhteiskunnan "yliyksilölliset" puolet ja kuinka kattavia tai osuvia ne ovat yhteiskunnan kuvauksina.

Jos Seppälän suhde eksistentialismiin on ollut ambivalentti, niin sama pätee hänen ja uskonnon väliseen suhteeseen. Merja Ylöselle Aamulehteen vuonna 2006 antamassaan haastattelussa hän toteaa kategorisesti, että hän ei pidä itseään uskovaisena ihmisenä. Sen sijasta hän luonnehtii itseään uskonnolliseksi ihmiseksi, joka torjuu ajatuksen persoonallisen Jumalan olemassaolosta ja joka suhtautuu kriittisesti kirkon rooliin yhteiskunnassa. Silti 
minussa on Jumalan mentävä reikä, pieni kuin neulansilmä. Mutta se, mikä kamelille on mahdollista, ei ole Jumalalta onnistunut. Silti etsin ja kaipaan loppuun asti. Se on myös yksi taiteilijantyöni lähtökohta. (Merja Ylösen Aamulehteen vuonna 2006 tekemä haastattelu Seppälästä; ks. Ylönen 2006.)

Siinä, missä kysymykset inhimillisen olemassaolon tarkoituksesta, mielekkään elämän edellytyksistä ja autenttisten kokemusten mahdollisuudesta ovat yhdistäneet Seppälää eksistentialismiin, uskontoa kohti kurkottaessaan hän on ilmeisesti kaivannut sen tarjoamaa henkisyyden ilmapiiriä, eksistentiaalista turvallisuuden tunnetta ja mahdollisuutta armon kokemiseen. Hänen uskonnollisuutensa tai uskonnollismielisyytensä on ollut perustavien elämänkysymysten ja kuoleman mysteerin kanssa painiskelevan ihmisen henkistä etsintää, jossa oma mieli on pidetty avoimena uskonnon suuntaan. ${ }^{3}$

Ylösen Seppälästä tekemän haastattelun sisään on upotettu pienempi haastattelu arkkipiispa Kari Mäkisestä, joka kertoo siinä Seppälän tuotantoa koskevista näkemyksistään. Mäkisen mukaan Seppälä on "tinkimätön kirjailija”, joka asettaa lukijan perustavien kysymysten eteen ja jonka teokset ovat siksi usein ahdistavia:

Mutta kun ahdistusta katsotaan kaihtelematta silmiin, alkaa merkillisellä tavalla raottua valoa. Viimeisimmässä teoksessa sitä kutsutaan armoksi. Eräissä aiemmissa teoksissa tämä puoli erottuu eleettömän kauniissa kuoleman kuvauksissa. (Kari Mäkinen teoksessa Ylönen 2006.)

Armon mainitessaan Mäkinen viittaa Seppälän novellikokoelmaan Mitä sähkö on? (2004a), erityisesti sen niminovelliin "Mitä sähkö on?”. Siinä sähkö toimii vertauskuvana ihmeellisestä, armon kaltaisesta voimasta, jota ihmisen tulisi sisimmässään tuntea voidakseen elää (Seppälä 2004C, I76). Juuri tälle novellikokoelmalle Mäkisen johtama Pyhän Henrikin säätiö antoi vuonna 2005 viidentuhannen euron suuruisen kulttuuripalkinnon. Kokoelman niminovelli määrittää armoa paljolti maallisilla, sähkön ominaisuuksiin liittyvillä sanoilla ja kielikuvilla. 
Samaan kokoelmaan sisältyvässä, paljolti omaelämäkerrallisessa kertomuksessa "Kimalaisen hunajaa" (2004d) armosta ei puhuta niinkään käsitteiden avulla, mutta kertomuksen hartaan ja herkän tunnelman, intiimin sävyn sekä Luukkaan evankeliumiin ja Apostolien tekoihin kohdistuvien viittausten ansiosta armon kokemus näyttäisi läpäisevän tämänkin kertomuksen. Käsittelen näitä kertomuksia lähemmin tutkimukseni viimeisessä luvussa.

Kokoelmassa Mitä sähkö on? esiintyvä armon kokemus tulee lähelle kristillistä teologiaa, jossa "armolla" tarkoitetaan sellaisia asioita kuin Jumalan hyvyys, syntien anteeksisaaminen ja lupaus sielun pelastumisesta kuoleman jälkeen; näistä asioista armon tilassa oleva ihminen pääsee osalliseksi huolimatta puutteistaan ja synneistään, kun hän nöyrtyy vastaanottamaan Jumalan rakkauden ja anteeksiannon.4 Armossa on siten kyse asioista, joita eksistentialismin ateistisen haarauman edustajat, esimerkiksi Beauvoir, Camus ja Sartre, pitävät mahdottomina. Voi tuntua yllättävältä, että Seppälä kirjoitti novellien "Mitä sähkö on?” ja "Kimalaisen hunajaa" kaltaiset kertomukset, koska kritiikissä hänen teostensa maailmoihin oli aiemmin liitetty sellaisia ominaisuuksia kuin "armottomuus", "synkkyys" ja "tylyys". ${ }^{5}$ Myöhemmissä teoksissaan hän ei myöskään ole palannut uskonnollisesti tai kristillisesti sävyttyneeseen armo-motiiviin. Se puuttuu siis hänen myöhemmistä yhteiskunnallisista romaaneistaan, samoin kuin kokoelmaan Takla Makan (20IOa) sisältyvistä kertomuksista "Takla Makan" (2OIOb) ja "Ristin tie" (2OIOC). Näiden novellien päähenkilöt - edellisessä kuolemansairas insinööri ja jälkimmäisessä pääsiäiskulkueeseen osallistuva työtön mies - torjuvat kristillisen uskon ja elämännäkemyksen. Silti Raamattu ja sen sisältämät kertomukset ja vertauskuvat ovat Seppälän teoksia tutkittaessa tärkeitä jo senkin vuoksi, että hänen yhteiskunnalliset romaaninsa hyödyntävät niitä rakentaessaan kriittistä kuvaa nykykapitalismista.

Vaikka olen edellä viitannut Seppälästä tehtyihin haastatteluihin, tutkimukseni asetelma ja tulokset perustuvat tietenkin viime kädessä omiin lukukokemuksiini, havaintoihini ja päätelmiini hänen teoksistaan. Olen lukenut hänen jokaisen painetun teoksensa vähintäänkin kahteen tai kolmeen kertaan ja tutkimuskohteena olevat teokset vielä huomattavasti useammin. Näin tehdessäni olen samalla noudattanut tietoisesti 
klassista hermeneuttisen kehän menetelmää. Tutkimusprosessin aikana olen siis tehnyt jatkuvaa edestakaista liikettä Seppälän tuotantoon perehtymisen ja sen historialliseen, kirjalliseen ja yhteiskunnalliseen kontekstiin tutustumisen välillä ja pyrkinyt kerta kerran jälkeen muodostamaan yhä vivahteikkaamman kuvan siitä ja sen suhteesta muuhun kirjallisuuteen, nyky-yhteiskuntaan ja yhteiskuntateorian traditioihin. Jokaisen lukukerran yhteydessä olen myös tehnyt muistiinpanoja lukemistani teksteistä ja etsinyt niihin sopivaa käsitteistöä.

Ennen viimeisiä lukukertoja, kun olin jo mielestäni päässyt pitkälle tutkimuskohteenani olevien teosten haltuunotossa, otin vielä yhteyttä Porvoon Kirjakeskuksessa sijaitsevaan WSOY:n Kirja-arkistoon, josta sain lainaksi Seppälää koskevan lehtileikekokoelman. Tämä Seppälän kirjailijantyön taustoja valottava aineisto muodostuu hänen teoksiaan koskevista arvosteluista, hänestä tehdyistä haastatteluista ja hänen Aamulehteen kirjoittamistaan kolumneista. Vaikka kyseisessä lehtileikekokoelmassa on selviä aukkokohtia - esimerkiksi sen arvosteluaineisto painottuu I980- ja i990-lukuun -, sen avulla pystyy muodostamaan yleiskuvan siitä, miten Seppälä itse on mieltänyt kirjailijantyönsä ja miten kriitikkokunta on vastaanottanut ja ymmärtänyt hänen teoksensa. Samoin olen hankkinut käyttööni Seppälän Satakunnan Kansan verkkosivuille vuosina 2006-2007 laatiman blogiaineiston. Näissä kirjoituksissa hän esiintyy yhteiskunnan eri ilmiöiden kommentoijana, minkä vuoksi niissä esitettyjä näkemyksiä voi tarpeen tullen verrata hänen teoksissaan ilmeneviin näkemyksiin.

Vuosina 2000-20I2 ilmestyneissä teoksissaan ja kirjoituksissaan Seppälä osallistuu nyky-yhteiskuntaa ja sen luonnetta koskeviin julkisiin keskusteluihin eli nyky-yhteiskunnan määrittämistä koskeviin diskursiivisiin kamppailuihin. Välineinään näissä keskusteluissa hän käyttää kirjallisia teoksia, kolumneja ja blogitekstejä sekä radiokuunnelmia ja radiofeatureja. Tutkimusekonomisista syistä radiokuunnelmat ja radiofeaturet jäävät tässä työssä lähemmän tarkastelun ulkopuolelle. Seppäläähän on toisinaan luonnehdittu julkisuudesta syrjään vetäytyväksi kirjailijaksi, "Porin erakoksi", mutta tällaiset luonnehdinnat ovat ilmeisen harhaanjohtavia. I980-luvulta lähtien hän on esiintynyt jatkuvasti julkisuudessa ja eri medioissa - kuitenkin sillä varauksella, että tällöin hän 
on aina pitänyt tiukan verhon yksityiselämänsä edessä ja suojannut sitä julkisuudelta. I990-luvun alusta lähtien hän on myös toivonut nykykirjallisuudelta suurempaa aktiivisuutta suhteessa yhteiskuntaan. Eräässä I990-luvun alussa antamassaan haastattelussa hän valittelikin sitä, että nykykirjallisuus "ei ilmaise aikaansa", 6 ja vuonna 2003 Parnassossa ${ }^{7}$ julkaistussa haastattelussa hän saattoi jo todeta, että hänen siihenastisesta tuotannostaan Super Market (I991a), Suomen historia (I998) ja Yhtiökumppanit (2002) olivat suoranaisesti "osallistuneet yhteiskunnalliseen keskusteluun". Seuraavina vuosina hän jatkoi "yhteiskunnallisen keskustelun" linjaa aina Mr. Smithiin (20I2) saakka, joka on toistaiseksi hänen viimeisin kapitalismikriittinen romaaninsa.

Tästä näkökulmasta Matka aurinkoon (20I4) ja Kuoppakaupunki (20I6) edustavat Seppälän tuotannossa vetäytymistä pois diskursiivisten kamppailujen näyttämöltä ja keskittymistä kirjoittaja- ja kertojasubjektin itseilmaisua koskeviin ja metakirjallisiin teemoihin. Hän palasi kuitenkin osittain takaisin tuolle näyttämölle Sankariajan (2018a) myötä, sillä sen tematiikka liittyy populistisen nationalismin voimistumiseen nykyyhteiskunnassa.

Seppälän vuosina 2000-20I2 ilmestyneiden teosten yhteiskunnallisena pääkontekstina on maailmanjärjestelmässä ja Suomessa I980- ja I990-luvulla tapahtunut markkinaperustainen käänne yhteiskuntapolitiikassa. Osittain juuri tämän käänteen ja sitä legitimoineen uusliberalistisen diskurssin kanssa hänen tuolloin ilmestyneet yhteiskunnalliset teoksensa "käyvät dialogia". Suomen osalta tuossa käänteessä on kyse siitä, että I990-luvulla Suomessa siirryttiin valtiokeskeisestä ja korporatiivisesta kapitalismista ja laajan hyvinvointivaltion kaudesta tilanteeseen, jossa yksityiskapitalistisen yritystoiminnan ja markkinoiden toimintaedellytyksiä on merkittävästi parannettu. Tämän seurauksena hyvinvointipalveluja ja sosiaaliturvajärjestelmiä on supistettu, työelämään on tuotu lisää joustoja ja lyhytaikaisia työsuhteita ja samalla markkinakapitalismin toimintalogiikkaa on viety perinteisen talouselämän ulkopuolelle, esimerkiksi terveydenhoitoon, joukkoviestintään, yliopistolaitokseen, koulutukseen, kulttuurielämään ja urheiluun. Osana tätä prosessia on ollut Suomen irtautuminen entisistä sidonnaisuuksistaan 
itäiseen naapuriinsa ja maan integroituminen aiempaa kiinteämmin läntiseen maailmaan ja globaaliin kapitalismiin.

Tiivistetysti ja täsmällisesti ilmaisten tämän kirjan tutkimuskysymykset ja tavoitteet voidaan muotoilla seuraavalla tavalla:

(I) Tutkimuksen päätehtävänä on analysoida sitä, millaiseksi Seppälän laajat, vuosina 2000-20I2 ilmestyneet yhteiskunnalliset romaanit esittävät ja arvioivat I980- ja I990-luvulla käynnistyneen murroksen, jonka myötä yhteiskuntaa alettiin organisoida markkinoiden ja yksityiskapitalistisen yritystoiminnan pohjalta.

(2) Koska representaatiot ovat tulkintoja maailmasta, tutkimus tarkastelee samalla sitä, millaisin kirjallisin keinoin Seppälän teokset maailmaa tulkitsevat eli millaisin kirjallisin keinoin ne esittävät ja arvioivat käsittelemäänsä todellisuutta. Kohteina ovat tällöin erityisesti niiden geneeriset ominaispiirteet sekä niiden kompositio, rakenne ja kerrontatapa. Samoin tutkimus tarkastelee sitä, miten Seppälän teokset suhteutuvat kirjallisuuden, kapitalismikritiikin ja yhteiskuntateorian traditioihin esittäessään arvionsa nyky-yhteiskunnasta ja sen tilasta. Tuon näistä traditioista esiin lähinnä sellaisia teoksia, joihin Seppälän teokset viittaavat tai joiden avulla on mahdollista valottaa monipuolisesti hänen teostensa ominaislaatua.

(3) Lopuksi tutkimus kiinnittää huomiota myös siihen, millaista muutosta Seppälän vuosina 2000-20I2 ilmestyneet kapitalismikriittiset teokset merkitsevät hänen tuotannossaan: missä mielessä ne ovat jatkoa hänen aiemmalle tuotannolleen ja missä suhteissa ne puolestaan uudistavat sitä.

Näitä tehtäviä muotoillessani ja tutkimuksen käsitteellisiä viitekehyksiä laatiessani olen tiettyyn rajaan asti noudattanut Hans-Georg Gadamerin teoksessa Wahrheit und Methode. Grundzüge einer philosophischen Hermeneutik (I986, ilmestyi alun perin i960) muotoiltua "kysymyksen 
ja vastauksen dialektiikkaa”. Käsillä oleva tutkimus ei siis ole jo etukäteen, lähtökohtaisesti, sitoutunut tiukasti tiettyihin kysymyksenasetteluihin ja käsitejärjestelmiin, joita se sitten vain soveltaisi sokeasti omaan kohteeseensa; tällöinhän kohteeksi valittujen teosten tehtävänä olisi lähinnä vain kuvittaa ennalta päätettyjä lähtökohtia ja ikään kuin vain todentaa ne kyseenalaistamatta niitä. Uusimaa-lehdessä vuonna 2000 julkaistussa haastattelussa Seppälä on arvostellut kirjallisuudentutkimusta juuri tällaisesta kehäpäättelystä:

[Haastattelija Samu Karvala:] Kun kirjallisuuden tutkijat vuosikymmenten kuluttua analysoivat Seppälän tuotantoa, hän epäilee, että siitä tehdään linjanvetoja, joita hän ei itse allekirjoittaisi.

[Seppälän vastaus:] Tutkija löytää yleensä sen, mitä hän etsii. Ihailemani Paavo Rintalan jokaisesta kirjasta on löydetty Kristus-myytti, tiedostamaton.

(Samu Karvalan Uusimaa-lehteen tekemä haastattelu Seppälästä; ks. Karvala 2000. $)^{8}$

Kehäpäättelyn välttämiseksi tutkijan tulisi Gadamerin mukaan lähestyä kohdettaan suhteellisen avoimin mielin ja olla valmis muuttamaan sitä koskevia ennakkokäsityksiään. Olisi kuunneltava kohteen "omaa ääntä" ja annettava sen itse näyttää, millaiseen teemaan tai kysymykseen se on käsitettävissä vastaukseksi. (Gadamer ı986, 375-384.) Tietyissä rajoissa olen menetellyt juuri näin muotoillessani tämän tutkimuksen päätehtävät. Nuo päätehtävät ovat siis syntyneet osittain sitä kautta, että olen lukenut tutkimuskohteena olevat teokset useaan kertaan ja täsmentänyt yhä uudelleen käsitystäni niistä.

Kokonaisuutena käsillä oleva tutkimus ei kuitenkaan edusta gadamerilaista hermeneutiikkaa, vaan se sijoittuu yhteiskuntateoreettisesti ja sosiologisesti pohjatun tekstintutkimuksen piiriin. Tässä asetelmassa Gadamerin esittämä kysymyksen ja vastauksen dialektiikka on syytä käsittää hedelmälliseksi tutkimukselliseksi apuneuvoksi, joka toimii muistutuksena siitä, että kirjallisten tekstien tulkitsemisen ei tulisi muuttua pelkäksi tutkijan valitsemien teoreettisten lähtökohtien kuvittamiseksi tekstien avulla. Kysymyksen ja vastauksen dialektiikka on hyödyllinen 
apuväline varsinkin tutkimuksenteon alkuvaiheessa, jolloin tutkija on vasta perehtymässä aineistoonsa ja jolloin hän ei ole vielä muodostanut sitä avaavaa käsitekieltä. Silti tässäkään vaiheessa tutkija ei, kaikesta avoimuudestaan huolimatta, pysty tulkitsemaan tekstejä edellytyksettömästi. Niin kuin Gadamer toteaa, tutkijalla on aina oma kielen, kirjallisuuden ja maailman käsittämistapansa, jonka pohjalta hän tekstejä tulkitsee. Siksi tulkinnassa tekstin merkityshorisontti ja tulkitsijan merkityshorisontti "sulautuvat yhteen" - ja vielä tavalla, jossa tekstistä lähtevää ainesta ja tutkijasta lähtevää ainesta ei voida jälkikäteen täysin yksiselitteisesti erottaa toisistaan. (Gadamer I986, 28I-290, 305-3I2.)

Näin raja "tekstiobjektin" ja tekstiä tulkitsevan subjektin välillä murtuu Gadamerilla. Myöhemmin tämän suuntaista käsitystä tulkitsemisesta on kehitelty reseptioestetiikassa, jälkistrukturalismissa, feminismissä, kulttuurintutkimuksessa, kognitiivisessa tutkimuksessa ja Monika Fludernikin (2002) kertomusteoriassa. Niissä kaikissa on ajateltu, että raja kirjallisen tekstin sisäpuolisen ja ulkopuolisen alueen välillä ei ole selkeä eikä yksiselitteinen. Samoin ne ovat korostaneet sitä, että kirjallisuudentutkija on aina riippuvainen oman kulttuurinsa ja yhteiskuntansa maailmankuvasta eikä myöskään pysty täysin välttämään sitä, että tutkijana hän projisoi teksteihin myös henkilökohtaisia ja subjektiivisia merkityksiä.

Habermas on sinänsä jakanut edellä esitetyn käsityksen tekstien tulkitsemisesta, mutta samalla hän on korostanut sitä, että jatkuvaa itsereflektiota harjoittava ja omia lähtökohtiaan eksplikoiva tutkija kykenee tavallista paremmin tulemaan tietoiseksi yhteiskunnallisista ja kulttuurisista sidonnaisuuksistaan ja karsimaan niiden vaikutusta tutkimustyöhönsä. Tekstien tulkitsija ei siten ole täysin peruuttamattomasti kulttuuri- ja yhteiskuntasidonnaisuutensa vanki. Ja edelleen: jos maailmaa koskevat käsitykset kerran ovat aina mukana kirjallisuuden tulkitsemisessa, niin eikö tulkitsemista olisi syytä harjoittaa tietoisesti valittujen ja systemaattisesti kehiteltyjen historia-, kulttuuri- ja yhteiskuntateoreettisten käsitteiden avulla? Gadamer on pääosin torjunut tämän vaihtoehdon, mutta Habermas on vienyt tekstihermeneutiikkaa juuri siihen suuntaan. ${ }^{9}$

Habermas on nykyisen yhteiskuntateoreettisesti pohjatun tekstihermeneutiikan taustahahmo. Hän arvosteli jo I960- ja I970-luvulla humanistista kirjallisuudentutkimusta siitä, että se tarkastelee kirjallisia teks- 
tejä vain suhteessa toisiin kirjallisiin teksteihin ja niiden muodostamiin traditioihin. Tällaisen tarkastelun täydennykseksi hän vaati kirjallisuudentutkimuksen avaamista muun kulttuurin ja yhteiskunnan suuntaan ja sen metodivalikoiman laajentamista kulttuuri- ja yhteiskuntatieteiden menetelmillä ja käsitteillä. Niiden avulla tutkimus voi analysoida sitä, kuinka paikkansa pitävä tekstin ilmaisema yhteiskuntakuva on ja kuinka hyväksyttäviä tekstiin sisältyvät arvot ovat. Habermasilaisessa tekstihermeneutiikassa kirjallisuuden todellisuussuhteen tarkasteleminen on siten olennainen osa tutkimusta, ja valitsemiensa aineistojen avulla tällainen tekstihermeneutiikkaa kykenee itsekin osallistumaan kulttuurisesti ja yhteiskunnallisesti relevantteja kysymyksiä tai teemoja koskevaan julkiseen keskusteluun.

Habermasilaisella yhteiskuntateoreettisesti pohjatulla tekstihermeneutiikalla on läheinen suhde ideologiakritiikkiin. Puhuessaan siitä, että kirjallisuudentutkimuksen pitäisi analysoida teksteihin sisältyviä maailmankuvia ja arvoja, Habermas ajoi takaa sitä, että tutkimuksen tulisi paljastaa tekstien ilmaisemat "ideologiset vääristymät". Ideologian käsitettä hän käytti merkityksessä 'väärä tajunta'. Tässä tutkimuksessa ideologioista puhutaan kuitenkin hieman toisenlaisella tavalla. Vaikka ideologiat edustavat usein rajoittunutta tai virheellistä käsitystä maailmasta, olennaista niissä on myös se, että ne ottavat oman käsityksensä maailmasta itsestäänselvyytenä ja pitävät sitä ainoana oikeana tai parhaimpana näkemyksenä. Näin ne torjuvat omaa maailmankuvaansa koskevan mahdollisen avoimen keskustelun. Tällaista käsitystä ideologioista on viime vuosikymmeninä työstänyt Peter V. Zima (I989).

Habermas ei ole kehittänyt yhteiskuntateoreettisesti pohjattua tekstihermeneutiikkaa yksityiskohtaisesti, vaan hän on lähinnä luonnostellut sen suuntaviivat. Konkreettisemmalla tasolla tällaista yhteiskuntateoreettisesti pohjattua kirjallisuudentutkimusta ovat I970-luvulta lähtien kehittäneet Christa Bürger, Peter Bürger, Jochen Schulte-Sasse ja Peter V. Zima, kaikki Frankfurtin koulun perinteen jatkajia kirjallisuudentutkimuksessa. Hieman toisenlaisista, marxilaisemmista lähtökohdista yhteiskuntateoreettisesti pohjattua tekstihermeneutiikkaa on I970-luvulta lähtien työstänyt Fredric Jameson. Käsillä oleva tutkimus hyödyntääkin Jamesonin näkemystä siitä, miten konteksti voidaan ottaa huomioon 
kirjallisuudentutkimuksessa. Laaja-alaisesti Jamesonin teoriaa ei kuitenkaan tässä tutkimuksessa hyödynnetä, koska tuo teoria operoi monoliittisella kapitalismin käsitteellä. Se ei ota huomioon sitä, että kapitalismilla on useita erilaisia ilmenemismuotoja - esimerkiksi yhdysvaltalainen kapitalismi poikkeaa eräissä suhteissa selvästi pohjoismaisesta ja suomalaisesta kapitalismista. Jameson ei liioin ole tutkimuksissaan antanut keskeistä sijaa rationalisaation käsitteelle, jonka asemasta hän on käyttänyt keskeisenä yhteiskuntateoreettisena käsitteenä termiä reifikaatio tai tavaroituminen. Sitä vastoin tässä tutkimuksessa rationalisaatio on yhteiskuntateoreettisia pääkäsitteitä.

\section{Aiempi tutkimus}

Seppälä on I980-luvun puolivälissä ilmestyneistä ensimmäisistä teoksistaan lähtien ollut kirjallisuuden kentän asiantuntijapiirien arvostama kirjailija, jota suuri yleisö ei ehkä kovin hyvin tunne. Alkutuotannostaan lähtien hän on saanut lukuisia kirjallisuus-, taide- ja kulttuuripalkintoja, ja hänen teoksistaan peräti neljä eli Hyppynaru (I990a), Super Market (I991a), Paholaisen haarukka (2008) ja Mr. Smith (2012) ovat olleet ehdokkaina Finlandia-palkinnon saajiksi. Finlandia-palkintoa hänelle ei tosin ole toistaiseksi myönnetty, mutta silti häntä on usein kutsuttu "kirjailijoiden kirjailijaksi", jonka uran etenemistä muut kirjailijat ovat mielenkiinnolla seuranneet ja jonka teoksista he ovat ottaneet vaikutteita. ${ }^{\text {○ }}$ Putte Wilhelmsson luonnehtii Seppälää myös "kulttikirjailijaksi" - ei ehkä pelkästään hänen nauttimansa laajan arvostuksen vuoksi vaan senkin takia, että tämä Porissa asuva, yksityiselämäänsä tarkasti varjellut ja kirjallisen elämän cocktail-tilaisuuksia johdonmukaisesti karttanut kirjailija on erikoislaatuisuutensa vuoksi kasvanut miltei myyttiseksi hahmoksi suomalaisessa kirjallisessa elämässä (ks. Kylänpää 20I3, 33-34).

Seppälän teoksia on käsitelty jonkin verran tutkimuksessa. Hänen tuotantoaan ovat kapitalismi-teeman näkökulmasta tarkastelleet Jussi Ojajärvi, Tuomas Juntunen ja Erkki Sevänen. Ojajärven väitöskirja Supermarketin valossa. Kapitalismi, subjekti ja minuus Mari Mörön romaanissa Kiltin yön lahjat ja Juha Seppälän novellissa "Supermarket" (2006) käyttää 
Marin Mörön romaanin ohella aineistonaan Seppälän kertomusta "Supermarket" (I99Ib), joka ilmestyi tämän kertomuskokoelmassa Super Market (I99Ia). Ojajärven tutkimuksen pääkysymys koskee sitä, millaista subjektimuotoa kapitalistinen talous ja markkinakoneisto edellyttävät tai suosivat ja miten ne muokkaavat ihmisten subjektiutta. Analyyseissaan ja tulkinnoissaan se keskittyy Mörön romaaniin, kun taas "Supermarketille" se omistaa yhden luvun (s. 39-75). Ojajärven väitöskirja on aikoinaan ollut merkittävä virstanpylväs, sillä se palautti kapitalismi-teeman suomalaiseen kirjallisuudentutkimukseen. Samalla se osoitti, että edellä mainitut Mörön ja Seppälän teokset eivät ole kotimaisessa nykykirjallisuudessa yksittäisiä ilmiötä, vaan kysymys nykykapitalismin luonteesta ja sen vaikutuksista ihmisten elämänkäytäntöihin kuuluu nykykirjallisuutemme pääteemoihin.

Juntusen väitöskirja Virsta väärää, vaaksa vaaraa. Intertekstuaalinen moniäänisyys Juha Seppälän proosassa (20I2) käsittelee Seppälän teoksia intertekstuaalisesta näkökulmasta, jonka Ojajärven tutkimus paljolti sivuuttaa. Seppälän kirjallisten tekstien ominaisluonnetta määrittäessään Juntunen (20I2, II) sanoo, "vain hiukan kärjistäen”, pitävänsä lähtökohtanaan sitä, että nuo tekstit "eivät koostu niinkään luonnollisen kielen sanoista kuin aiempien tekstien palasista”. Seppälä on todellakin erittäin oppinut kirjailija, jonka tekstit vilisevät viittauksia kotimaiseen kirjallisuuteen, länsimaisen kirjallisuuden traditioon, kotimaiseen ja länsimaiseen populaarikulttuuriin, filosofian historiaan ja yhteiskuntatieteisiin. Lisäksi hänen tekstinsä käyttävät hyväksi Raamattua. Juntunen välttää väitöskirjassaan intertekstuaalisuuden tutkimisen tavanomaisen sudenkuopan - sen, että hän rajoittuisi tarkastelemaan pelkästään tekstien välisiä suhteita ja sivuuttaisi tekstien suhteet todellisuuteen. Päinvastoin "kirjallisuuden mimeettisyys ja semioottisuus ovat tulkin[nan] aksioomat, joita ei kyseenalaisteta" kyseisessä väitöskirjassa (Juntunen 2012, I2). Seppälän tuotannosta Juntunen analysoi novelleja "Taivaanranta" (1987b, sisältyy kokoelmaan Taivaanranta, I987a) ja "Pääsiäinen" (I989c, sisältyy kokoelmaan Riikinkukon sulka, I989a) sekä pienoisromaania Hyppynaru (I990a) ja romaania Yhtiökumppanit (2002). Kahta ensimmäistä käsitellessään hän tuo esiin Seppälän läheisen suhteen eksistentialismiin. Siinä, missä Ojajärven ja Juntusen väitöskirjat tarkas- 
televat ensi sijassa Seppälän varhaistuotantoa, Sevänen (20I3c; 20I4b) on kahdessa Seppälää käsittelevässä artikkelissaan keskittynyt tämän kapitalismikriittiseen vaiheeseen. Samalla nuo artikkelit tarkastelevat Seppälän teoksia osana laajempaa kapitalismikriittistä virtausta suomalaisessa nykykirjallisuudessa.

Seppälän tuotantoa koskevassa tutkimuksessa toinen tärkeä tarkastelunäkökulma liittyy kysymykseen kansallisuudesta ja suomalaisuudesta. Tätä kysymystä Seppälä on käsitellyt varsinkin I990-luvun teoksissaan. Hänen kertomuskokoelmaansa Super Market (I99Ia) on pidetty paitsi markkinakäyttäytymisen ja kulutuskeskeisen elämäntavan kritiikkinä myös suomalaisen korkeakirjallisuuden parodiana, jonka groteskeille ja absurdeille kertomuksille kriitikot ovat löytäneet pohjateksteiksi muun muassa Veikko Huovisen, Veijo Meren, Antti Tuurin, Hannu Salaman, Esa Sariolan ja Rosa Liksomin tuotantoa. ${ }^{\text {II }}$ Osittain samansuuntaisella, groteskilla tavalla Seppälä käsitteli suomalaisuutta ja sen ikoneja, erityisesti marsalkka Mannerheimia, kirjassaan Suomen historia (I998), kun taas hänen romaaneissaan Sydänmaa (I994a) ja Kuun nousu ja lasku (I999) suomalaisuutta koskevat kysymykset liittyvät läheisesti eksistentiaalisiin teemoihin ja jäävät osittain niiden varjoon.

Tutkimuksessaan Kansallisia kertomuksia. Suomalaisuus 1990-luvun proosassa (2007) Leena Kirstinä omistaa yhden luvun Sydünmaalle, jota hän luonnehtii eksistentialistiseksi romaaniksi. Arto Miettinen on lisensiaattitutkimuksessaan Kansallisen uudet tulkinnat. Suurten kertomusten problematisoituminen Juha Seppälän tuotannossa (2008) puolestaan tarkastellut suomalaiskansallisen arvo- ja merkitysjärjestelmän kyseenalaistumista Seppälän teoksissa, erityisesti romaaneissa Sydänmaa ja Kuun nousu ja lasku sekä novellikokoelmassa Suuret kertomukset. Kuten Miettinen $(2008$, I0) huomauttaa, kansallinen ulottuvuus on mukana myös Seppälän ensimmäisissä laajoissa yhteiskunnallisissa romaaneissa, sillä Yhtiökumppaneissa "arvioinnin kohteeksi joutuu it-talouden valtaama markkina-Suomi" ja Routavuosi "ottaa puolestaan kriittisen asenteen maamme lähihistoriaan". Nämä romaanit Miettinen jättää kuitenkin paljolti tarkastelunsa ulkopuolelle. Hiljattain ilmestynyt romaani Sankariaika (20I8a), jossa Seppälä palasi takaisin kansallisten kysymysten äärelle, on jäänyt tutkimuksessa toistaiseksi vaille huomiota. ${ }^{\mathrm{I2}}$ 


\section{Yhteiskunnallinen ja yhteiskuntateoreettinen konteksti}

Kirjaimellisesti ottaen konteksti merkitsee suhteuttamista, yhteyteen asettamista. Kontekstuaalisessa lähestymistavassa jotakin todellisuuden tai kirjallisuuden osa-aluetta tarkastellaan suhteessa muihin, siihen vaikuttaviin tai sen kannalta relevantteihin osa-alueisiin. Tässä tutkimuksessa kontekstin kategoria toimii neljällä pääulottuvuudella. Tutkimus analysoi ja tulkitsee Seppälän kapitalismikriittisiä teoksia suhteessa (i) niiden ilmestymisajankohdan historiallis-yhteiskunnalliseen todellisuuteen, (ii) länsimaisen yhteiskuntateorian traditioon, (iii) tiettyjen kirjallisuudenlajien traditioihin ja (iv) Seppälän muuhun tuotantoon.

Seppälän teoksille historiallis-yhteiskunnallista kontekstia muodostaessaan tämä tutkimus käyttää lähteinään suomalaista nyky-yhteiskuntaa, nykykapitalismia ja nykyistä taloudellis-poliittista maailmanjärjestystä koskevaa tutkimuskirjallisuutta, joka on ilmestynyt lähinnä yhteiskuntatieteiden (politiikantutkimus, poliittinen taloustiede, sosiologia) piirissä. ${ }^{13}$ Rekonstruoin tämän tutkimuskirjallisuuden avulla Seppälän romaaneille historiallis-yhteiskunnallisen kontekstin tutkimukseni toisessa pääluvussa. Omassa "marxilaisen hermeneutiikan projektissaan" Fredric Jameson puhuu siitä, että kirjallisten teosten historiallis-yhteiskunnallisessa kontekstissa voidaan erottaa kolme eri tasoa. Kirjallinen teos on mahdollista suhteuttaa (a) sen syntyajankohdan poliittisiin tapahtumiin, (b) tuolloin vallalla olleisiin luokkavoimasuhteisiin ja luokkaideologioihin sekä (c) kyseisen aikakauden ja yhteiskuntamuodon keskeisiin arvopäämääriin ja kehityslinjoihin. (Jameson I986, I7-IO2.) Tämä jaottelu on hyödyllinen Seppälän teoksia tutkittaessa. Tasolla (a) Seppälän vuosina 2000-20I2 ilmestyneet teokset sisältävät viittauksia muun muassa Suomen harjoittamaan EU-politiikkaan sekä Nokia-yhtiön maailmanlaajuisen menestyksen myötä kukoistaneeseen suomalaiseen informaatioteollisuuteen. Samoin niissä käsitellään (b) luokkien asemaa ja sukupuolijärjestystä nykykapitalismissa. Tässä tutkimuksessa Jamesonin mainitsemista suhteuttamiskohteista tärkein on merkityshorisontti (c), sillä ymmärrän Seppälän rationalisaatiokriittiset romaanit suhteellisen kokonaisvaltaisiksi näkemyksiksi ja arvioiksi nykyisestä markkinakapitalistisesta yhteiskunnasta ja sitä hallitsevista arvopäämääristä. 
Seppälän teoksille laaditun historiallis-yhteiskunnallisen kontekstin avulla on mahdollista kiinnittää huomiota siihen, mitä aineksia oman aikansa todellisuudesta nuo teokset sisällyttävät kuvauksiinsa, mitkä puolet ne sivuuttavat ja mitä aikansa todellisuuteen sisältyviä piirteitä ja kehitysnäkymiä ne mahdollisesti kärjistävät ja liioittelevat. Seppälän teosten analysoimisessa tällä lähestymistavalla on silti omat rajansa. Kysymystä siitä, mitä kapitalismi on, nuo teokset nimittäin käsittelevät toistuvasti myös kapitalismia koskevien teorioiden avulla eivätkä pelkästään aikalaistodellisuuteen liittyvin viittauksin. Näiden teosten välittämä kuva nykykapitalismista on siten vahvasti teoreettisesti suodattunut tai "teorioilla kuorrutettu". Siksi Seppälän Suomen Kuvalehdessä esittämä luonnehdinta, jonka mukaan hänen oma tuotantonsa lähtee yksilön kokemuksesta eikä sosiologisista yleistyksistä (ks. Kylänpää 2008, 58), kuvaa epätarkasti hänen kapitalismikriittisiä teoksiaan. Nuo teokset käsittelevät myös kapitalismia erityislaatuisena systeeminä tai talousjärjestyksenä, eivät pelkästään yksilöiden kokemusta kapitalismista. Niistä välittyy käsitys, että yksilöiden kokemusten ohella kapitalismin luonteen ymmärtämiseksi tarvitaan yhteiskuntateoreettisen ajattelun apua.

Seppälän teoksista erityisesti Yhtiökumppanit ja Paholaisen haarukka esittävät nykykapitalismin muodollisesti rationaaliseksi ja tehokkaaksi rahantekokoneeksi, joka sisällöllisellä tasolla kylvää ympärilleen merkityksettömyyttä ja epäautenttisuutta. Peter V. Ziman tutkimukseen Moderne/Postmoderne. Gesellschaft, Philosophie, Literatur (200I) nojautuen voidaan todeta, että myös länsimaiseen yhteiskuntateoriaan sisältyy ajatusperinne, jossa moderni kapitalismi nähdään paljolti juuri tällä tavalla.

Kyseisen ajatusperinteen edustajiksi Zima (200I, 47-48, 6I-62) mainitsee Karl Marxin (I8I8-I883) ja Max Weberin (I864-I920), ja viime vuosikymmenten osalta hän ottaa esille Daniel Bellin (I9I9-20II), Amitai Etzionin (s. 1929) ja Alain Tourainen (s. 1925). Vaikka nämä yhteiskuntateoreetikot ovat edustaneet poliittisesti erilaisia ajatustapoja, he kaikki ovat puhuneet siitä, että lisäarvon ja liikevoiton kasaamisen varaan perustuvalle kapitalismille on sinänsä paljolti yhdentekevää, onko voittoa tuottava asia tosi vai epätosi, ruma vai kaunis, hyvä vai paha: määrällisiin tavoitteisiin pyrkivä kapitalistinen talouselämä pyrkii 
sulkemaan tällaiset kysymykset tarkastelun ulkopuolelle, vaikka sen on periaatteessa toimittava poliittisen järjestelmän ja lainsäädännön asettamissa rajoissa. Muissa suhteissa Bell, Etzioni ja Touraine eroavat sekä toisistaan että Marxista ja Weberistä. Heistä Bell on konservatiivinen, Etzioni kommunitaristinen ja Touraine vasemmistolainen ajattelija. Bellin (I979) mukaan nykykapitalismin perustava ongelma on siinä, että sille ominainen hedonistis-konsumeristinen ja individualistinen arvosuuntaus uhkaa murentaa talouden ja yhteiskunnan toimintakyvyn. Siksi, hän jatkaa, hyvin toimivan nykykapitalismin tulisi pohjautua uskonnollisiin arvoihin. Etzioni (1988; 1996) on antanut vastaavanlaisen aseman moraalille ja yhteisöllisyydelle. Touraine (I992) on puolestaan esittänyt, että länsimaissa yhteisvastuun ja sosiaalisen oikeudenmukaisuuden nimissä toiminut perinteinen työväenliike tarjosi pitkään varteenotettavan vaihtoehdon modernille kapitalismille, mutta sen kuihduttua lähinnä naisliikkeen ja ympäristöliikkeen kaltaiset, laadullisia arvopäämääriä painottavat liikkeet ovat toimineet selvimmin vastavoimina kapitalismille ominaiselle välineelliselle järjelle.

Modernia kapitalistista rationaalisuutta on siis arvosteltu sekä konservatiivien (Bell) että vasemmistolaisten (Marx, Touraine) intellektuellien piirissä. Ehkä jälkimmäinen tapa kritisoida sitä on ollut yhteiskuntateoreetikkojen keskuudessa hallitseva, sillä Marxin ja Tourainen ohella vasemmistolaisen rationaalisuuskritiikin piiriin kuuluvat myös taloushistorioitsija Karl Polanyi sekä Frankfurtin koulun edustajat Theodor W. Adorno, Max Horkheimer, Herbert Marcuse ja Habermas. Tässä ja edellisessä kappaleessa mainituista yhteiskuntateoreetikoista Seppälän teokset sisältävät aineksia erityisesti Weberin ja Habermasin ajattelusta.

Weberin ja Habermasin tutkimuksiin sisältyy Seppälän teosten kannalta tärkeitä erotteluja rationaalisuuden eri muotojen välillä. Teoksessaan Wirtschaft und Gesellschaft (I956, ilmestyi alun perin I92I-I922) Weber kuvaa modernia kapitalismia vastakohtaparien muodollinen rationaalisuus vs. substantiaalinen rationaalisuus ja päämäärärationaalisuus vs. arvorationaalisuus avulla. Habermasin teokseen Theorie des kommunikativen Handelns (1987a ja I987b, molemmat ilmestyivät alun perin I98I) sisältyy samantapainen erottelu menestyksen saavuttamiseen suuntautuneen toiminnan ja yhteisymmärrykseen pyrkivän toiminnan välillä, 
joista edellinen noudattaa kognitivisis-instrumentaalista rationaalisuutta ja jälkimmäinen kommunikatiivista rationaalisuutta. Näihin erotteluihin sisältyy ajatus, että liikevoiton ja lisäarvon tuotannon ja markkinavoimien ehdoilla toimivalle modernille kapitalismille on ominaista taipumus sulkea laadulliset tai substantiaaliset arvot pois talouselämän järjestämisestä ja päästessään valta-asemaan koko yhteiskunnassa se uhkaa tehdä saman muulle yhteiskunnalle. Moderni kapitalismi on tässä mielessä osittain välinpitämätön, indifferentti perustavien arvoerottelujen (moraalinen hyvä vs. moraalinen paha, oikeudenmukaisuus vs. epäoikeudenmukaisuus, tasa-arvo vs. epätasa-arvo) suhteen.

Weberin ja Habermasin tutkimuksilla on tässä työssä erityisasema, jota voidaan osittain valottaa Habermasin (I987a, I58-I9I) ja Anthony Giddensin (I976) kehittämän kaksoishermeneutiikan idean avulla. Sen mukaan kulttuurin ja yhteiskunnan tutkijan tehtävä on tavallaan kahtalainen. Yhtäältä hänen tulee tavoittaa tutkimuskohteena olevien toimijoiden kieli, näiden tapa merkityksellistää maailmaa, mutta samalla hän käyttää teoreettista käsitekieltä tai metakieltä, jolla hän analysoi ja tulkitsee tutkimuskohteidensa puhetta ja näiden esittämiä näkemyksiä todellisuudesta. Vaikka kulttuuria ja yhteiskuntaa koskevassa tutkimuksessa nämä kaksi kieltä, toimijoiden oma kieli ja tutkijan käyttämä käsitekieli, eroavat tavallisesti jonkin verran toisistaan, kaksoishermeneutiikan idean toteuttaminen on helpompaa tilanteessa, jossa niiden välillä on yhteisiä aineksia. Tällöin kohteen käyttämä kieli ja tutkijan käyttämä käsitteistö eivät jää etäälle toisistaan vaan tutkija pystyy vaivattomammin liikkumaan niiden välillä. Tässä tutkimuksessa käytetty yhteiskuntateoreettinen käsitekieli perustuu paljolti Weberin ja Habermasin tuotantoon. Seppälän romaaneissa muun muassa rationaalisuutta ja järjestelmiä koskevat pohdiskelut yhdistävät teoksia weberiläis-habermasilaiseen traditioon.

Toisaalta kaksoishermeneutiikan idea ei tavoita aivan kaikkia käsillä olevan tutkimuksen hermeneuttisia ulottuvuuksia. Tämän tyyppinen yhteiskuntateoreettisesti ja sosiologisesti pohjattu tekstihermeneuttinen tutkimus ei ainoastaan pyri tavoittamaan Seppälän teosten tapaa merkityksellistää maailma (hermeneuttinen ulottuvuus I) ja tulkitsemaan sitä teoreettisen metakielen avulla (hermeneuttinen ulottuvuus 2). Lisäksi 
tutkimus esittää tulkintoja ja arvioita myös nyky-yhteiskunnasta (hermeneuttinen ulottuvuus 3) sekä kirjallisista ja kulttuurisista traditioista (hermeneuttinen ulottuvuus 4). Tutkimuksessani hermeneuttisia tasoja tai ulottuvuuksia on siis mukana ainakin neljä.

Tässä tutkimuksessa sovellettu kontekstin käsite on laaja. Edellä kuvatun yhteiskunnallisen ja yhteiskuntateoreettisen viitekehyksen ohella sen alaan kuuluvat tiettyjen kirjallisuudenlajien traditiot ja Seppälän muu tuotanto. Tällainen laaja kontekstin käsite on välttämätön, sillä ymmärrän kirjallisuuden diskursiiviseksi kentäksi tai muodostumaksi, jossa kirjalliset teokset käsittelevät kulttuurisesti ja yhteiskunnallisesti merkittäviä kysymyksiä. Usein juuri kirjallisuus ottaa ensimmäisenä esimerkiksi ennen tiedettä ja lehdistöä - esiin "julkisuudelta piilossa olleita" ongelmia tai "ilmassa roikkuneita" ajatuksia ja tunteita, tuo ne julkisen huomion kohteiksi ja tekee muun yhteiskunnan niistä selvemmin tietoiseksi. Näin kirjallisuus käy aidosti dialogia muun kulttuurin ja yhteiskunnan kanssa ja se voi toimia niiden itsetiedostuksen forumina. Tätä dialogista ulottuvuutta ovat kirjallisuusteoriassa korostaneet Mihail Bahtin (I992), Hans-Georg Gadamer (I986) ja Hans Robert Jauss (I984) sekä meillä Suomessa Jyrki Nummi (I993), Pertti Karkama (I994), Elina Arminen (2009) ja Liisa Steinby (ent. Saariluoma) (2013). Se, miten laajasti tutkijat ottavat huomioon muun kulttuurin ja yhteiskunnan, ei ole vakio. Väinö Linnan pääteoksia koskevassa monografiassaan Jalon kansan parhaat voimat (I993) Nummi tarkastelee lähinnä Linnan teosten käymää dialogia kansallis-kirjallisen perinteen kanssa, kun taas Karkaman Kirjallisuus ja nykyaika (I994) ymmärtää dialogin erittäin laajasti - se käsittelee nimittäin suomalaista kirjallisuutta suhteessa kulttuurin ja yhteiskunnan modernisaatioon.

Jaan pääosin kyseisten tutkijoiden näkemykset kirjallisuuden dialogisuudesta. Samalla on silti syytä painottaa sitä, että kirjallisuutta ei voida palauttaa pelkäksi ajankohtaisten yhteiskunnallisten ongelmien käsittelyksi. Sillä on myös tietynasteinen itsenäisyytensä muuhun kulttuuriin ja yhteiskuntaan nähden, mikä näkyy siinä, että tietyt, esimerkiksi eksistentiaaliset, teemat toistuvat eri aikakausien ja kulttuurien teksteissä. Samoin kirjallisuus voi reflektoida kirjallisia traditioita ja konventioita sekä omaa rooliaan ja tehtäväänsä kulttuurissa ja yhteiskunnassa. Vaik- 
ka sen tapa käsitellä näitäkin asioita, eksistentiaalisia ja metakirjallisia kysymyksiä, vaihtelee aikakaudesta ja kulttuurista toiseen siirryttäessä, on hyvä pitää mielessä se, että suhteellisen itsenäisyytensä vuoksi se ei kaikilta osiltaan kehity samaa tahtia muun kulttuurin ja yhteiskunnan kanssa.

Kirjallisuuden dialogisuuden aste vaihtelee historiallisesti. Merkittävänä taitekohtana voidaan tässä suhteessa pitää I70o-lukua, sillä silloin länsimainen kirjallisuus irtautui vahvasta sidonnaisuudestaan antiikkiin, kristilliseen mytologiaan ja keskiaikaisiin taruihin ja kääntyi kuvaamaan omaa aikaansa ja yhteisesti jaettua sosiaalista todellisuutta. Tuosta ajankohdasta lähtien edellä kuvattu dialoginen ulottuvuus on ollut keskeinen. Todellisuuden määrittämistä koskeviin yhteiskunnallisiin keskusteluihin tai diskursiivisiin kamppailuihin kirjallisuus on osallistunut aktiivisesti valistuksen kaudella I700-luvulla, realismin ja naturalismin kaudella I830-luvulta I80o-luvun loppuun (Suomessa I880-luvulta I900-luvun alkuvuosikymmeniin), "osallistuvan kirjallisuuden" kaudella ı960- ja I970-luvulla ja uudelleen viime vuosikymmeninä. Äärimuodossaan yhteiskunnallisiin keskusteluihin osallistuva kirjallisuus on muuntunut propagandaksi ja tendenssikirjallisuudeksi, jolloin se on usein tarjonnut lukijoille konkreettisia toimintaohjeita yhteiskunnan muuttamiseksi. Antamissaan haastatteluissa Juha Seppälä on sanoutunut irti tällaisesta kirjallisuudesta, eikä hän siis katso tarjoavansa lukijoille konkreettisia ohjeita siitä, miten yhteiskunta pitäisi järjestää. ${ }^{14}$

Tähän yleisluonnehdintaan on syytä tehdä eräs täsmennys. Niin kuin Saija Isomaa (2009, II4-II9; 20I2a, I4O-I4I; 20I2b, 9-II) huomauttaa, miltei kaikista kirjallisista teoksista on abstrahoitavissa jonkinlainen todellisuutta koskeva väittämä tai kannanotto - "se, mitä teos sanoo elämästä ja maailmasta". Tavallisesti tällainen väittämä on upotettu teoksessa esitettyyn tarinaan ja teoksen kompositioon, jolloin lukija ei huomaa sitä helposti. Sitä vastoin tendenssikirjallisuudessa väittämät ja kannanotot ovat narratiivisesti ohuesti perusteltuja, ja siinä etualalle nousee - tarinankehittelyn ja todellisuuden laaja-alaisen kuvaamisen sijasta - kirjailijan tai teoksen pyrkimys vaikuttaa lukijoihin emotiivisesti ja moraalisesti ja saada heidät omaksumaan teoksessa esitetty kanta todellisuudesta. Seppälän romaanit sisältävät maailmaa koskevia väittä- 
miä ja kannanottoja, mutta ne saavat tavallisesti perustelunsa kyseisissä romaaneissa esitetyistä tarinoista, pohdiskeluista ja representaatioista. Tässä mielessä nuo romaanit eivät ole tendenssikirjallisuutta. Sitä vastoin eräät Seppälän lyhytproosaa sisältävät kertomuskokoelmat voi sijoittaa tendenssikirjallisuuden piiriin. Tämä pätee lähinnä teoksiin Super Market (I991a) ja Suomen historia (I998), joille on - niin kuin niiden tekijäkin on todennut - leimallista kotimaisen kirjallisen tradition, kansallisen symbolimaailman ja eräiden yhteiskunnallisten teemojen tai ilmiöiden tietoisen provokatorinen käsitteleminen. ${ }^{15}$

\section{Lajikohtaiset kontekstit}

Teoreettiset apuvälineet tämän tutkimuksen kohdeteosten ominaisluonteen määrittelyyn löytyvät yhteiskuntateoreettisesti pohjatusta tekstihermeneutiikasta, lajitutkimuksesta, kertomusteoriasta sekä kirjallisuudentutkimusta, sosiologiaa ja filosofiaa yhdistelevistä lähestymistavoista. Yhteiskuntateoreettisesti pohjatun tekstihermeneutiikan ja sosiologian tarjoamaa apua tarkasteltiin jo edellisessä alaluvussa. Yleisessä lajiteoriassa Alastair Fowlerin Kinds of Literature (I997, ilmestyi alun perin I982) on edelleenkin tärkeä lähdeteos, jonka avulla voi ymmärtää lajien muuttumista ja risteytymistä ja uusien lajien syntyä. Kertomusteorian alueella James Phelanin (I996; 2005) "retorisen narratologian" voi luontevasti yhdistää dialogiseen ja diskursiiviseen kirjallisuuskäsitykseen. Phelan käsittää kertomukset inhimillisiksi teoiksi, kirjailijan ja lukijoiden väliseksi viestinnäksi, jossa kirjailija valitsee tietyt kerronnalliset strategiat pyrkiessään välittämään haluamansa merkityssisällöt yleisölle. Gérard Genetten kertomusteoriaa ja lajiteoriaa yhdistelevä ajattelu sisältää puolestaan mielenkiintoisen arkkitekstin käsitteen, jota hyödynnän työssäni.

Genette (1992, ix, 65-69) kutsuu kirjallisuuden lajeja arkkiteksteiksi. Lajit eli arkkitekstit muodostuvat tekstien välisistä suhteellisen pysyvistä muodollisista ja temaattisista suhteista ja samankaltaisuuksista. Tässä mielessä lajit ovat "empiirisiä" muodostelmia, joiden olemassaolo voidaan tunnistaa tutkimalla kirjallisia traditioita. Lajin ja sen yksittäisten 
edustajien välistä suhdetta Genette nimittää arkkitekstuaalisuudeksi. Lajien yksittäiset edustajat eli konkreettiset tekstit muuntelevat aina jossain määrin niitä lajeja, joihin ne pohjautuvat. Lajeista puhuessaan Genette tarkastelee lähinnä kirjallisuuden sisäisiä suhteita viittaamatta laajasti ympäröivään kulttuuriin tai yhteiskuntaan. Hänen tapansa tarkastella lajeja jättää siksi avoimeksi lajien ontologian eli kysymyksen siitä, miten lajit ovat olemassa ja mikä on niiden suhde kirjallisuuden ulkopuoliseen maailmaan. Genetten teoriaa tulkittaessa ja sovellettaessa arkkitekstit on siksi toisinaan ymmärretty abstrakteiksi malleiksi tai abstrahoiduiksi tyypeiksi, jotka eivät ole varsinaisesti olemassa tekstiobjekteina, mutta jotka ohjaavat silti konkreettisten tekstien kirjoittamista ja lukemista (ks. esim. Rossi 2005, II3-II4). Genette (I992, 67-7I) on kuitenkin tarkastellut hypoteettisena mahdollisuutena myös sitä, että lajit voisivat pohjimmiltaan olla historiallisesti ja kulttuurisesti pitkäkestoisia "mentaalisia dispositioita". Niin kutsutut "moodit" tai tyylilajit (eeppinen, lyyrinen, draamallinen, kerronnallinen) ovat hänen mukaansa ilmeisesti olemassa tätäkin vahvemmalla tavalla, sillä niiden voidaan ajatella edustavan ihmismielelle ominaisia "apriorisia" kokemusten ja maailman jäsennystapoja. Jälkimmäistä mahdollisuutta ei voida tässä yhteydessä tarkastella lähemmin, mutta ensiksi mainittu mahdollisuus on tutkimukseni kannalta tärkeä.

Tämä tutkimus edustaa kantaa, jonka mukaan kirjallisuudenlajit ovat samanaikaisesti kognitiivisia ja sosiaalis-kulttuurisia ilmiöitä. "Kognitiivisessa poetiikassaan" Peter Stockwell (2002, 28-34) edustaa samansuuntaista kantaa, sillä hänen mukaansa lajit ovat yhteisöissä esiintyviä tapoja jäsentää ja merkityksellistää maailmaa. Tässä mielessä lajit ovat kieleen rinnastettavissa olevia kommunikatiivisia ja diskursiivisia välineitä (vrt. Steinby 20II, 366, 37I-375). Stockwell jättää kuitenkin auki sen, kuinka laajoja lajeja "kantavat" sosiaaliset yhteisöt ovat ja miten kattavasti kukin laji ilmentää kulttuurissa ja yhteiskunnassa vallalla olevaa maailmankuvaa. Osa lajeistahan on vahvassa mielessä sosiaaliskulttuurisia ilmiöitä, eli ne ilmentävät koko kulttuuriyhteisön tai sen keskeisten osakulttuurien tapaa jäsentää ja merkityksellistää maailmaa. Tällaisia lajeja voitaisiin kutsua kulttuurisiksi arkkiteksteiksi. Kulttuuriset arkkitekstit ovat - samaan tapaan kuin kielen merkitykset ja rakenteet 
- viime kädessä olemassa kulttuuriyhteisön kollektiivisessa tajunnassa; sosiaalis-kulttuurisina pohjateksteinä ne ovat abstrakteja tyyppejä, joita konkreettiset tekstit varioivat.

Suomalaisessa kulttuurissa esimerkiksi raivaajakertomus ja kertomus kovan työn avulla tapahtuvasta eteenpäinmenosta ovat I80o-luvulta lähtien olleet tärkeitä kulttuurisia arkkitekstejä, joita muun muassa J. L. Runebergin runo Saarijärven Paavosta, Aleksis Kiven kertomus Impivaaran korpea raivaavista Jukolan veljeksistä, Hella Wuolijoen luoma Niskavuori-sarja, Väinö Linnan kuvaus itseään kovalla työnteolla ilmaisevasta Koskelan perheestä ja Kalle Päätalon lukuisat romaanit metsätöitä tekevistä ja taloja rakentavista sitkeistä suomalaismiehistä varioivat. Näissä tapauksissa suhde kulttuurin ja kirjallisuuden välillä on selvästi kaksisuuntainen. Kyseiset kirjailijat eivät ole vain ilmentäneet passiivisesti suomalaisessa kulttuurissa vallalla ollutta maailmankuvaa, vaan he ovat samalla olleet aktiivisesti muokkaamassa ja tuottamassa suomalaista kollektiivitajuntaa ja sen tapaa mieltää maailma. (Vrt. Miettinen 2008; Nummi I993.) Huomionarvoista näissä mainittujen kirjailijoiden teoksissa on myös se, että niissä ahkera ja omistautunut työnteko näyttäytyy asiana, jonka kautta henkilöille rakentuu myönteinen minäkuva ja jonka ansiosta he kokevat toimintansa aidosti mielekkääksi.

Näin ymmärrettyä kulttuurisen arkkitekstin käsitettä on mahdollista soveltaa myös kapitalismikriittisten romaanien kirjoon. Honoré de Balzacin ja Charles Dickensin teoksista lähtien länsimaiseen kirjallisuuteen ja kollektiiviseen tajuntaan näyttäisi juurtuneen sävyltään kriittinen kertomus siitä, miten kapitalismin toimintalogiikkaa sokeasti noudattava ihminen menettää vähitellen inhimillisyytensä ja vieraantuu sekä siitä että toisista ihmisistä ja alkaa kohdella heitä pelkkinä omien tavoitteidensa saavuttamisen välineinä - tai muuttuu itse välikappaleeksi muiden toteuttamissa kapitalistisissa toimintaskenaarioissa. Teoreettisen käsitekielen avulla voidaan todeta, että tämän kulttuurisen arkkitekstin piiriin kuuluvat teokset esittävät kapitalismin, lähinnä "vapaan markkinatalouden", välineellistä rationaalisuutta noudattavaksi muodostumaksi, joka on välinpitämätön ihmisten tai alempien luokkien tarpeiden suhteen.

Viime vuosikymmeninä tällainen näkemys kapitalismista on tullut usein esiin paitsi kirjallisuudessa myös elokuvassa ja teatterissa. Eloku- 
van osalta tästä voi esimerkkeinä mainita Oliver Stonen ohjaamat Wall Street (I987) ja Wall Street: the Money Never Sleeps (2011) sekä Martin Scorsesen The Wolf of Wall Street (2013). Nämä kaikki kolme elokuvaa kuvaavat nykyistä finanssikapitalismia ja sen yhtä keskuspaikkaa, New Yorkissa sijaitsevaa Wall Streetiä. Stonen elokuvien keskushahmoa Gordon Gekkoa, jota esittää Michael Douglas, on luonnehdittu nykyiselle finanssikapitalismille ominaisen ahneuden ja häikäilemättömyyden ikoniksi tai ruumiillistumaksi. Teatterin puolelta on syytä nostaa esiin Ryhmäteatterin Päällystakki (2009), Mielipuolen päiväkirja (2015) ja Muodonmuutos (2OI7), joista kaksi ensimmäistä perustuu Nikolai Gogolin novellistiikkaan ja viimeiseksi mainittu Franz Kafkan tuotantoon. Näissä Esa Leskisen ja Sami Keski-Vähälän modernisoimissa teoksissa, groteskeissa satiireissa, nykytalouden hallitsevaksi piirteeksi esitetään se, että sille ominainen ankara kilpailu ja liikevoiton tavoitteleminen ajavat yritysmaailman turvautumaan yhä tehokkaampiin, epäinhimillisempiin ja vieraannuttavampiin toimintatapoihin (Pohjola-Skarp \& Suutela 20I8).

Käytän tästä lajista tai kulttuurisesta arkkitekstistä nimitystä rationalisaatiokritiikki. Sitä edustavat teokset ovat kertomuksia kapitalismin toimintatavoista ja niiden aiheuttamista ongelmista ja vaurioista yksilöille ja yhteisöille. Tutkimuskohteena olevat Seppälän romaanit voi nähdä tämän abstraktin kertomustyypin muunnelmiksi, jos kohta tällainen yleistys ei kata niiden kaikkia geneerisiä ominaispiirteitä. Millainen laji rationalisaatiokriittinen romaani on? Sen luonnetta voidaan selventää käyttämällä hyväksi Anders Petterssonin (2003) tekemää erottelua "kommunikatiivisen" ja "luokittelevan tai teoreettisen" lajiryhmittelyn välille. Kommunikatiivisessa ryhmittelyssä lajina pidetään sitä tapaa, jolla teksti on tarkoitettu luettavaksi. Luokitteleva tai teoreettinen laji on sellainen teosjoukko, jonka edustajia lähinnä vain tutkija tarkastelee yhden ja saman kirjallisen tyypin ilmentyminä. Pääajatuksena tässä Petterssonin tekemässä erottelussa on se, että kirjallisen elämän muut toimijat (kustantajat, kirjailijat, lukijat, kriitikot) ovat sisäistäneet kommunikatiiviset lajiryhmitykset, kun taas luokittelevat tai teoreettiset lajiryhmitykset ovat lähinnä tutkijoiden laatimia kuvauksia tekstejä yhdistävistä piirteistä. (Vrt. Isomaa 2009, I3.) Jälkimmäisissä tapauksissa kirjallisen elämän 
muut toimijat eivät välttämättä ryhmittele tekstejä samalla tavalla kuin tutkijat.

Käsillä oleva tutkimus ymmärtää Seppälän romaanit yhteiskunnallisiksi romaaneiksi. Yhteiskunnallisten romaanien piirissä ne kuuluvat kapitalismikritiikin traditioon, ja tämän alatradition sisällä ne edustavat kriittistä kuvausta ja arviota kapitalistisesta rationalisaatiosta. Näistä lajinimityksistä $\nmid$ hteiskunnallinen romaani edustaa petterssonilaista kommunikatiivista lajiryhmittelyä, sillä sitä on käytetty länsimaisessa kirjallisessa elämässä I8oo-luvulta lähtien. Sama pätee paljolti kapitalismikriittiseen romaaniin. Sitä vastoin rationalisaatiokriittinen romaani ei ole yhtä laajasti käytössä kirjallisessa elämässä, vaan se on enemmänkin tämän tutkimuksen käyttämä käsite, jonka tarkoitus on helpottaa Seppälän romaanien sijoittamista kirjallisuuden traditioiden yhteyteen. Se on tutkimukseni kohdeteosten suhteen relevantti myös siinä mielessä, että nuo romaanit on paljolti tarkoitettu kapitalistisen toimintarationaalisuuden kritiikiksi. Tätä väitettä on mahdollista perustella sekä Seppälän antamien haastattelujen että hänen teostensa ominaispiirteitä koskevien analyysien avulla.

Petterssonin tekemää erottelua voidaan suhteellistaa toteamuksella, että luokittelevat tai teoreettiset lajiryhmittelyt saattavat ajan myötä yleistyä kirjallisessa elämässä. Tällöin myös muut kirjallisen elämän toimijat sisäistävät ne ja alkavat jäsentää tekstien moninaisuutta niiden avulla. Siten he ovat toisin sanoen tulleet tietoisiksi sellaisista tekstien välillä vallitsevista yhdenmukaisuuksista, jotka he olivat aikaisemmin jättäneet vaille huomiota, mutta joiden olemassaolon tutkijoiden tekemät ryhmittelyt ovat paljastaneet heille.

Käsillä olevan tutkimuksen tapa ymmärtää Seppälän romaanit vastaa suurissa linjoissa sitä kuvaa, jonka Seppälä on niistä haastatteluissa antanut. Yhteiskunnallisuus on liittynyt kiinteästi hänen tuotantoonsa I990-luvulta lähtien, jolloin hän kirjoitti institutionalisoitua kansallista arvo- ja symbolimaailmaa purkavat provokatoriset teoksensa Super Market (I991a) ja Suomen historia (I998). Tätä seikkaa, yhteiskunnallisuuden merkitystä tuotantonsa yhtenä lähtökohtana, hän on painottanut Seppo Puttoselle ja Joni Pyysalolle Parnasso-lehden numeroon I/2003 antamassaan haastattelussa (ks. Puttonen \& Pyysalo 2003, 65). Osittain 
muuntuneessa muodossa hän jatkoi yhteiskunnallisuuden linjaa vuosina 2000-20I2, jolloin hän kirjoitti markkinallistumiskehitystä arvostelevat laajat yhteiskunnalliset romaaninsa. Myös tuolloin antamissaan haastatteluissa Seppälä puhui kriittiseen sävyyn siitä, että Suomessa on "viime vuosikymmeninä" eletty "markkinadominanssin" aikaa ja tähän kehityspiirteeseen on liittynyt "vieraantuneisuuden" lisääntymistä yhteiskunnassa (ibid., 65, 7I). Vielä Ville Hännisen (20I4, 24) samaan lehteen vuonna 20I4 tekemässä haastattelussa korostuu se, että "viime vuosina" Seppälän romaanit ovat tavallisesti olleet "kirpeää kapitalismikritiikkiä". Tämä kertoo siitä, että teostensa avulla Seppälä on tietoisesti osallistunut yhteiskunnalliseen dialogiin ja nyky-yhteiskuntaa koskeviin määrittelykamppailuihin. Siksi tutkimukseni keskeinen lähtökohta, Seppälän romaanien ymmärtäminen kriittisiksi kannanotoiksi markkinallistumiskehitystä koskevaan yhteiskunnalliseen keskusteluun, ei ole pääkohdiltaan ristiriidassa sen kanssa, miten Seppälä itse on teoksensa ymmärtänyt.

Tästä yhteensopivuudesta huolimatta käsillä oleva tutkimus ei ole luokiteltavissa "intentionaalisen kritiikin" piiriin. Vaikka tutkimukseni lähtökohtiin kuuluu havainto siitä, että Seppälän romaanit on tarkoitettu kapitalismikritiikiksi ja sellaisina ne myös teksteinä paljolti toimivat, tutkimukseni päätehtävä ei muodostu siitä, että yrittäisin tulkita Seppälän romaaneja niin kuin hän niitä itse tulkitsisi. Kirjailijan aikomuksiin ja tavoitteisiin kiinnittyvän intentionaalisen kritiikin perusongelma on siinä, että kirjalliset teokset voivat sisältää sellaisia merkityspotentiaaleja, joista niiden tekijät eivät ole tietoisia tai jotka voivat poiketa merkittävästi tekijöiden intentioista. Silti kirjailijoista tehdyt haastattelut ovat mielenkiintoista ja hedelmällistä tutkimusmateriaalia, sillä ne tarjoavat tietoa kirjailijoiden itseymmärryksestä. Edellä esitetyistä syistä niistä ei kuitenkaan pidä tehdä tulkintojen oikeellisuuden kriteerejä.

Seppälästä tehtyjä haastatteluja tämä tutkimus käyttää hyväksi myös siksi, että kirjallisuussosiologia on aivan toisella tavalla kiinnostunut reaalisten toimijoiden (kirjailijat, kriitikot, lukijat) tasosta kuin tekstilähtöisempi kirjallisuudentutkimus. Jos diskursiiviset kamppailut liittyvät kiinteästi kirjallisuuteen, kirjallisuussosiologi ei tavallisesti oleta, että tällaisissa kamppailuissa vain tekstit ottavat mittaa toisistaan, että niissä 
vain "tekstit kamppailevat toisiaan vastaan". Kirjallisuussosiologian näkökulmasta tällainen tilanne, "tekstien välinen taistelu", olisi lähellä anomaliaa, sillä tekstit muuttuvat reaalisiksi voimatekijöiksi vain lukukokemusten ja tulkintojen kautta. Siksi kirjallisuussosiologi on kiinnostunut myös siitä, millaisia yhteiskunnallisia voimia - maailmankuvia, ideologioita, luokkia, ryhmiä ja yksilöitä - on tällaisten kamppailujen taustalla ja millaisia pyrkimyksiä niihin osallistuvilla toimijoilla on. Näistä syistä kirjailijaa, esimerkiksi hänen sukupuoltaan, luokka- ja koulutustaustaansa ja maailmankuvaansa koskeva tieto on relevanttia kirjallisuussosiologisessa tutkimuksessa. Yhteiskunnan rakenteet ja lait ja kulttuuriset traditiot eivät välity kirjallisiin teksteihin suoraan ja automaattisesti, vaan niiden ja tekstien välissä on kirjailijasubjekti, jonka kautta kyseiset vaikutteet suodattuvat ja joka muokkaa niitä luovasti työssään. Kirjallisuuden, kulttuurin ja yhteiskunnan välisiä suhteita tulkittaessa ja selitettäessä kirjailijan tai tekijän kategoria on siten periaatteessa tarpeellinen metodinen työväline.

Diskursiiviset kamppailut ovat toimintaa, ja osallistuessaan niihin kirjailija tekee yhteiskunnallisen teon. Tässä suhteessa kirjallisuus on yhteiskunnallisen aktivismin ilmentymä. Toimintaa ja tekoja koskevassa tutkimuksessa otetaan huomioon sekä toimintatilanne että toimijoiden motiivit, uskomukset ja aikomukset, joita koskevan tiedon ajatellaan syventävän toimijoiden käyttäytymistä ja heidän tekojaan koskevaa ymmärrystämme. Samoin kirjailijoiden aikomien merkityspolkujen, heidän teoksiinsa sisältyvien merkityspolkujen ja lukijoiden realisoimien merkityspolkujen vertaileminen toisiinsa voi syventää käsitystämme siitä, miten kirjallinen kulttuuri toimii tai, niin kuin James Phelan ja Peter J. Rabinowitz (20I2b, 29-3I) esittävät, mitä "kirjallisessa viestinnässä" tapahtuu. ${ }^{16}$ Tutkimusekonomisista syistä käsillä oleva tutkimus ei silti etene pitkälle tähän suuntaan vaan on ensi sijassa sellaista tekstintutkimusta, joka käyttää yhtenä aineistonaan Seppälästä tehtyjä haastatteluja ja hänen kolumnejaan ja blogitekstejään.

Miten tutkimuskohteena olevissa Seppälän romaaneissa tulee konkreettisesti esiin se, että ne osallistuvat nyky-yhteiskunnan luonnetta koskeviin diskursiivisiin kamppailuihin? Erityisesti siten, että ne keskittyvät markkinallistumiskehitykseen liittyviin ongelmiin ja epäkohtiin, 
että ne sivuuttavat tuohon kehitykseen liittyvät myönteiset puolet ja että ne toimivat avoimesti vastadiskurssina yhteiskuntapolitiikkaa I980- ja ı990-luvulta lähtien hallinneelle uusliberalismille. Palaan tähän problematiikkaan myöhemmissä pääluvuissa.

Yhteiskunnallisen romaanin ja sen alalajien kehityskulkua on kartoitettu suhteellisen laajasti kirjallisuudentutkimuksessa. Tämän kartoituksen klassikkoja ovat Georg Lukácsin Die Theorie des Romans (I971a, ilmestyi alun perin I9I4-I9I5) ja Lucien Goldmannin Towards a Socio$\log \gamma$ of the Novel (I975, ranskankielinen alkuperäisteos ilmestyi I964), joista edellinen perustuu G. W. F. Hegelin Ästhetik-teoksessa esitettyyn näkemykseen romaanista modernin aikakauden epopeana. I80o-luvulla syntynyttä realistis-naturalistista yhteiskunnallista romaania ja sen asemaa yhteiskunnassa ovat käsitelleet Louis Cazamianin The Social Novel in England 1830-1850. Dickens, Disraeli, Mrs. Gaskell, Kingsley (I973, ranskankielinen alkuperäisteos ilmestyi I903), Amanda Clayboughin The Novel of Purpose. Literature and Social Reform in the Anglo-American World (2007), Jacques Dubois'n Les romanciers du reel. De Balzac à Simenon (2000) ja Wolf Lepeniesin Drei Kulturen. Soziologie zwischen Literatur und Wissenschaft (i988).

Näistä Dubois ja Lepenies puhuvat siitä, että I80o-luvun länsimaisessa kulttuurissa realistis-naturalistista kirjallisuutta pidettiin erityislaatuisena yhteiskuntaa koskevan tiedon muotona, joka kilpaili sosiologian - tuolloin vasta syntyvaiheessaan olevan tieteenalan - kanssa siitä, mikä diskursiivisen toiminnan muoto pystyy antamaan pätevimmän kuvan yhteiskunnasta. Cazamian ja Claybough korostavat puolestaan sitä, että englantilaiseen kirjallisuuteen liittyi tuolloin vahvasti reformistinen ulottuvuus; yhteiskuntaa ja sen epäkohtia käsitellessään Dickensin ja Elizabeth Gaskellin kaltaiset kirjailijat pyrkivät näet vakuuttamaan ylemmät luokat sosiaalisia epäkohtia korjaavien reformien välttämättömyydestä.

Edellisissä kappaleissa mainituissa tutkimuksissa liikutaan ı8oo-luvun ja I9०o-luvun alkupuoliskon kirjallisuudessa. Cazamianin kirja on ilmestynyt alun perin jo vuonna I903, mutta pidän sitä edelleenkin huomionarvoisena tutkimuksena siitä, miten I80o-luvun englantilainen romaani reagoi markkinakapitalismin juurtumiseen tuon ajan yhteiskun- 
taan. Sitä pidempi ajallinen kaari sisältyy Geneviève Sicotten, Martial Poirsonin, Stéphanie Lonclen ja Christian Bietin toimittamaan artikkelikokoelmaan Fiction et économie dans la littérature et les arts du spectacle, XIXe-XXIe siècles (20I3). Tässä Kanadasta, Lavalin yliopistosta käsin julkaistussa artikkelikokoelmassa käsitellään kirjallisuuden suhdetta moderniin talouteen Germaine de Staelistä ja Balzacista aina Michel Houellebecqiin ja nykykulttuuriin saakka.

Suomalaista yhteiskunnallista romaania koskevan tutkimuksen klassikko on Pertti Karkaman Sosiaalinen konfliktiromaani. Rakennetutkimus suomalaisen yhteiskunnallisen realismin pohjalta (I97I). Se analysoi perinteisen suomalaisen realistis-naturalistisen romaanin yhteiskuntakuvaa ja arvomaailmaa ja käyttää niin tehdessään hyväksi välineellisen rationaalisuuden ja arvorationaalisuuden välistä erottelua. Samoin Karkaman Kirjallisuus ja nykyaika (I994) sisältää laajan pohdiskelun välinerationaalisuuden ja arvorationaalisuuden välisestä jännitteestä modernissa kulttuurissa. Uudempaa näkemystä klassisesta suomalaisesta yhteiskunnallisesta kirjallisuudesta edustavat Minna Maijalan Passion vallassa. Hermostunut aika Minna Canthin teoksissa (2008), Riikka Rossin Särkyvä arki. Naturalismin juuret suomalaisessa kirjallisuudessa (2009) ja Saija Isomaan Heräämisten poetiikkaa. Lajeja ja intertekstejä Arvid Järnefeltin romaaneissa Isänmaa, Maaemon lapsia ja Veneh'ojalaiset (2009). Niistä Maijalan tutkimus osoittaa, miten yhteiskunnallisia ongelmia käsitellessään kirjailija, tässä tapauksessa Minna Canth, on sidoksissa omaan aikaansa ja sen ihmiskäsitykseen ja maailmankuvaan. Rossin ja Isomaan tutkimukset edustavat lajiteoreettista tapaa analysoida yhteiskunnallista kirjallisuutta. Ne osoittavat, millaista lajien kirjoa perinteinen realistis-naturalistinen kirjallisuus saattoi yhteiskuntaa kuvatessaan hyödyntää.

Toisen maailmansodan jälkeen ilmestynyttä suomalaista yhteiskunnallista romaania ovat analysoineet Milla Peltonen ja Mikko Carlson. Peltosen tutkimus Jälkirealismin ehdoilla. Hannu Salaman Siinä näkijä missä tekijä ja Finlandia-sarja (2008) käsittelee perinteisen yhteiskunnallisen romaanin problematisoitumista Salaman pääteoksissa. Näissä teoksissa käsitys romaanin mahdollisuuksista kuvata yhteiskuntaa todenmukaisesti suhteellistuu, minkä lisäksi ne tuovat metakirjallisen 
pohdiskelun kiinteästi mukaan yhteiskunnalliseen romaaniin. Carlsonin Paikantuneita haluja. Seksuaalisuus ja tila Christer Kihlmanin tuotannossa (20I4) käsittelee Christer Kihlmanin teoksia sukupuoli-, seksuaalisuusja luokkatematiikan näkökulmasta. Kapitalismiin liittyvän tematiikan ne molemmat sivuuttavat käytännössä.

Viime vuosikymmeninä ilmestyneistä suomalaisista romaaneista ei ole toistaiseksi juurikaan julkaistu sellaisia laajoja tutkimuksia, jotka operoisivat yhteiskunnallisen romaanin ja kapitalismikritiikin käsitteiden avulla. Selvimmin niin tekevät Jussi Ojajärven (2006) väitöskirja Juha Seppälän kertomuksesta "Supermarket” ja Mari Mörön romaanista Kiltin yön lahjat sekä Tuomas Juntusen (20I2) väitöskirja Juha Seppälän varhaistuotannosta ja tämän romaanista Yhtiökumppanit. Laajemmasta näkökulmasta kapitalismin, kulttuurin ja nykykirjallisuuden välisiä suhteita käsittelevät Ojajärven ja Liisa Steinbyn toimittama Minä ja markkinavoimat. Yksilö, kulttuuri ja yhteiskunta uusliberalismin aikakaudella (2008) sekä Ojajärven, Seväsen ja Steinbyn toimittama Kirjallisuus nykpkapitalismissa. Suomalaisen kirjallisuuden ja kulttuurin näkökulma (20I8a). Niistä jälkimmäinen keskittyy suomalaiseen nykykirjallisuuteen ja sen tapaan käsitellä kapitalismia, kun taas edellinen tarkastelee yleisemmin uusliberalismin vaikutusta nykykirjallisuuteen ja nykykulttuuriin.

Edellä esiteltyjen viitekehysten ohella tämä tutkimus tarkastelee Seppälän teoksia suhteessa eksistentiaaliseen tematiikkaan ja metaromaaniin. Eksistentiaalista tematiikkaa käsiteltäessä kiinnitetään myös huomiota Seppälän ja eksistentialismin väliseen suhteeseen. Eksistentialismi on perinteisesti ymmärretty länsimaiseksi filosofis-kirjalliseksi virtaukseksi, jonka juuret ovat I80o-luvun intellektuaalisessa kulttuurissa, erityisesti Fjodor Dostojevskin, Sören Kierkegaardin ja Friedrich Nietzschen tuotannossa ja jota I900-luvulla jatkoivat Nikolai Berdjajev, Edmund Husserl, Martin Heidegger, Karl Jaspers, Paul Tillich ja José Ortega y Gasset sekä Simone de Beauvoir, Albert Camus, Maurice Merleau-Ponty ja Jean-Paul Sartre. Kyse on siis hajanaisesta joukosta filosofeja, teologeja ja kirjailijoita, jotka kaikki käsittelivät yleisellä tasolla inhimillistä olemassaoloa ja ihmisen tapaa olla maailmassa. Näin tehdessään he korostivat ihmisten rakentamien eksistentiaalisten turva- 
kehikoiden haurautta. Tämän yhteisen nimittäjän sisällä heidän välillään oli kuitenkin merkittäviä eroja. Eksistentialismin sisälle mahtuvat yhtäältä Kierkegaardin, Dostojevskin, Berdjajevin (ortodoksinen uskonnonfilosofi), Jaspersin ja Tillichin (protestanttinen teologi) kaltaiset kristilliset ajattelijat sekä toisaalta Nietzschen, Heideggerin, MerleauPontyn, Sartren, Beauvoirin ja Camus'n kaltaiset ateistit tai kristinuskon kriitikot. Poliittis-yhteiskunnallisesti heidän joukossaan on niin "aristokraattisen radikalismin" edustajia (Nietzsche, Gasset) ja fasismin myötäilijöitä (Heidegger) kuin vasemmistolaisia intellektuellejakin (Beauvoir, Merleau-Ponty, Sartre). Lisäksi Beauvoir luetaan feministisen filosofian uranuurtajiin.

Osittain tähän tapaan brittiläinen filosofi David Cooper käsittää eksistentialismin teoksessaan Existentialism. An Introduction (2008, ilmestyi alun perin I990). Viime vuosina julkaistuissa tutkimuksissa on kuitenkin myös alettu korostaa eksistentialismin yhteyksiä varhaisempaan länsimaiseen filosofiseen ajatteluun. ${ }^{\text {I7 }}$ Esimerkiksi Susanne Möbussin kaksiosaisessa teoksessa Existenzphilosophie (2015a ja 2015b) I800- ja I900-luvun eksistentialismi näyttäytyy laajemman länsimaisen ajatusperinteen, "eksistenssifilosofian", osana tai jatkeena. Sen kartoittamisen Möbuss aloittaa kirkkoisä Augustinuksesta ja myöhäisantiikin filosofiasta ja päättää I900-luvun eksistentialisteihin sekä Emmanuel Lévinasiin ja Jacques Derridaan. Vaikka näistä eksistenssifilosofian edustajista Seppälän teokset viittaavat toistuvasti lähinnä vain Camus'hun ja Sartreen, hänkin on painottanut lehtikirjoituksissaan eksistentialismin yhteyksiä varhaiseen länsimaiseen filosofiaan. ${ }^{18}$

Metaromaania koskevan kirjallisuusteorian klassikkoja ovat Linda Hutcheonin (I985; I988) ja Patricia Waughin (1984) tutkimukset, joiden näkemykset metaromaanista ovat vahvasti sidoksissa postmodernistiseen kirjallisuuteen ja konstruktionistiseen tietoteoriaan. Heidän tutkimuksissaan metafiktiiviset ilmaisukeinot näyttäytyvät paljolti mahdollisuutena kyseenalaistaa kirjallinen ja epistemologinen realismi, minkä ohella metafiktiiviset teokset korostavat heidän mukaansa kulttuurin ja yhteiskunnan konstruktiivista, luonnosta ja sen välttämättömyyksistä poikkeavaa luonnetta. Koska Seppälän teoksille on ominaista "realistinen intentio", halu sanoa yhteiskunnallisesta todellisuudesta jotakin pä- 
tevää ja merkityksellistä, niitä eriteltäessä hyödyllisempiä ovat sellaiset tutkimukset, joissa metafiktiivisyyttä ei välttämättä pidetä yhteen sopimattomana kirjallisen realismin ja yhteiskunnallisen romaanin kanssa vaan tärkeänä nykyisen yhteiskunnallisen romaanin ilmaisukeinona. Nykykirjallisuutta koskevassa tutkimuksessa metaromaanin ovat tähän tapaan ymmärtäneet Mark Currie (I995) ja Irmtraud Huber (20I4). Brian Mchale (I987) on puolestaan kehittänyt tämän tutkimuksen kannalta tärkeää metalepsiksen käsitettä, jota tarkastellaan lähemmin myöhemmissä luvuissa.

\section{Kontekstien kaksoistehtävä ja tutkimuksen etenemistapa}

Tämä tutkimus tarkastelee Seppälän vuosina 2000-20I2 ilmestyneitä teoksia suhteessa niiden historiallis-yhteiskunnalliseen kontekstiin, länsimaisen yhteiskuntateorian traditioon, tiettyjen kirjallisuudenlajien traditioon ja Seppälän muuhun tuotantoon. Näillä konteksteilla on tutkimuksessa kaksi tehtävää tai roolia. Yhtäältä tutkimus tulkitsee ja selittää Seppälän teosten ominaispiirteitä niistä käsin. Tällöin se lähtee siitä oletuksesta, että nuo kontekstit vaikuttavat Seppälän teoksiin ja painavat niihin leimansa. Toisaalta Seppälän teokset myös viittaavat noihin konteksteihin ja käsittelevät niitä. Tässä jälkimmäisessä tehtävässä tai roolissa ne saattavat lisätä meidän ymmärrystämme ja tietoamme niistä. Ainakin historiallis-yhteiskunnallisen kontekstin kohdalla me voimme arvioida sitä, kuinka päteviä tai osuvia Seppälän romaanien esittämät näkemykset markkinallistuneesta nyky-yhteiskunnasta ja kapitalismista yleisemmin ovat. Näitä teoksia käsitellessään tämä tutkimus etenee seuraavan logiikan mukaisesti:

Toinen luku alkaa Seppälän aiempaa, vuosina I986-I999 ilmestynyttä tuotantoa koskevalla lyhyellä tarkastelulla. Sen tarkoituksena on luoda pohjaa sen arvioimiselle, missä määrin hänen vuosina 2000-20I2 ilmestyneet teoksensa merkitsevät katkosta hänen tuotannossaan ja missä suhteissa ne ovat jatkoa hänen aiemmalle tuotannolleen. Tämän jälkeen rekonstruoin Seppälän vuosina 2000-20I2 ilmestyneiden teosten yhteiskunnallisen kontekstin ja kuvaan alustavasti eri näkökulmista hänen 
rationalisaatiokriittisiä romaanejaan. Toisen luvun loppupuoli esittelee tutkimuksen yhteiskuntateoreettisen ja lajikohtaisen viitekehyksen.

Kolmas luku on omistettu Yhtiökumppaneiden analysoimiselle, neljäs luku Paholaisen haarukalle ja viides luku Mr. Smithille. Näissä kaikissa luvuissa Seppälän teoksia käsitellään kapitalismikriittisinä romaaneina, joihin on upotettu tai sisäänrakennettu eksistentiaalinen ja metafiktiivinen tematiikka. Lisäksi nämä luvut kiinnittävät huomiota siihen, millaisia muita mahdollisia geneerisiä piirteitä kyseiset romaanit sisältävät.

Luvut III-V käsittelevät sitä, millaisen kuvan ja arvion Seppälän romaanit esittävät nykykapitalismista, miten ne tuovat tähän kuvaamiseen ja arvottamiseen mukaan vieraantuneisuuden problematiikan, merkityskysymykset ja eksistentiaaliset teemat ja miten ne ottavat arvioinnin kohteeksi myös oman luonteensa ja kirjallisuuden asemassa tapahtuneet muutokset. Kuudes luku pohtii sitä, millaisesta arvoperspektiivistä käsin Seppälän teokset kuvaavat ja arvioivat kohdettaan, minkä ohella se tuo kokoavasti esiin tutkimuksen päätulokset. 


\section{Luku II Aineisto, käsitteet ja teoriat}

\section{Edeltävä tuotanto eli vuodet 1986-1999}

Tämän alaluvun tarkoituksena on muodostaa kuva Seppälän varhaistuotannosta, hänen vuosina I986-I999 julkaisemistaan teoksista, jotka toimivat tutkimuksessa yhtenä kontekstina eli tulkintakehyksenä hänen vuosina 2000-20I2 julkaisemilleen teoksille. Alaluku ei kiinnitä yksityiskohtaisesti huomiota hänen kaikkiin teoksiinsa, vaan siinä keskitytään lähinnä hänen romaaneihinsa.

Kirjassaan Suomalaisia nykykirjailijoita (2000) Pekka Tarkka toteaa, että jos Seppälä oli ı980-luvulla ensi sijassa yksilöiden kuvaaja, niin hänen I990-luvun tuotantoaan hallitsevat kansalliset kysymykset eli suomalaiseen kirjallisuuteen, arvomaailmaan ja elämänmuotoon liittyvät teemat. Näiden kahden vaiheen välinen raja ei siis ole jyrkkä, vaan pikemminkin kyse on painotuseroista. Seppälän "yksilökeskeiseen vaiheeseen" kuuluvat hänen novellikokoelmansa Torni (1986), Taivaanranta (I987a) ja Riikinkukon sulka (I989a) sekä hänen ensimmäiset romaaninsa Silta (I988), Hyppynaru (I990a) ja Luru (1992a). "Kansalliseen vaiheeseen" sijoittuvat puolestaan kertomuskokoelmat Super Market (I991a) ja Lähtösavut (I993a), lyhytproosateokset Tunnetko tyypin? Tapauksia, oikkuja, sattumuksia (I995a) ja Suomen historia (I998) sekä romaanit Sydänmaa (I994a) ja Kuun nousu ja lasku (I999). Teosta Jumala oli mies. Romaani rakkaudesta (I996a) on puolestaan pidetty avainromaanina. 
Siinä kirjailijana toimiva yksihuoltajaisä kokee syvän ja tunteenomaisen rakkauden, jota varjostaa se, että rakkauden kohteena oleva nainen sairastuu lopussa kaatumatautiin. Seppälän tuotannossa tämä romaani on sikälikin harvinainen teos, että siinä miehen ja naisen välinen suhde kuvataan miltei varauksitta myönteisessä sävyssä.

Seppälän ensimmäiset romaanit eli Silta, Hyppynaru ja Luru eivät kuulu teemojensa osalta läheisesti yhteiskunnallisen kirjallisuuden piiriin. Silta on murrosikäisen pojan identiteetin muodostumista kuvaava kehitysromaani, ja Hyppynaru ja Luru voidaan sijoittaa psykologisen romaanin ja traumakirjallisuuden piiriin. Koska nämä lajipiirteet voimistuvat Seppälän tuotannossa uudelleen 2oıo-luvulla, palaan näihin kahteen romaaniin tämän tutkimuksen lopussa.

Seppälän ensimmäisten novellikokoelmien henkilöille on ominaista viihtymättömyys yhteiskunnassa. Julkisissa tiloissa ja sosiaalisissa vuorovaikutustilanteissa he eivät tunne olevansa oma itsensä, vaan he välttelevät kommunikaatiota muiden ihmisten kanssa ja kaipaavat omaa rauhallista tilaa, jossa he voisivat olla yksin ajatustensa ja tunteidensa kanssa. Myöhemmissä teoksissa tunne ympäristön vihamielisyydestä ja maailman vieraudesta laajenee usein koskemaan koko inhimillistä elämää ja olemassaoloa, jotka keskushenkilöt kokevat pohjimmiltaan paljolti tarkoituksettomiksi. Näiden teosten elämäntunnelmalle on siksi ominaista resignoitunut sävy, henkilöiden hiljainen mukautuminen tai alistuminen merkitysköyhäksi tai tarkoituksettomaksi kokemaansa elämään. Resignoituneesti elämään asennoituvat erityisesti novellin "Taivaanranta" (I987b) päähenkilöt kuvataiteilija Boman ja biologianopettaja Mutanen, romaanin Sydänmaa keskushenkilö toimittaja Vesa ja romaanin Kuun nousu ja lasku "kaupunkisosiologi". Heitä voi pitää Sartren romaanin Inho (I964, ranskankielinen alkuperäisteos ilmestyi I938) päähenkilön Roquentinin ja Camus'n romaanin Sivullinen (I969, ranskankielinen alkuperäisteos ilmestyi I942) päähenkilön Meursault'n sukulaishahmoina. Näiden tavoin he kokevat sosiaalisen elämän mielivaltaiseksi ja julmaksi peliksi, joka ei tarjoa heille suojaa olemassaolon pohjimmaista tarkoituksettomuutta vastaan.

Seppälän varhaistuotannossa eksistentiaaliset kysymykset tulevat esiin sekä teemojen että elämäntunnelman - tai teoksia hallitsevan ilma- 
piirin - tasolla. Eksistentiaaliset kysymykset koskevat, niin kuin Anthony Giddens (200I, 54-55) toteaa, inhimillistä elämää ja olemassaoloa. Niitä käsiteltäessä pohditaan sellaisia kysymyksiä kuin miten meidän tulisi suhtautua inhimillisen elämän reunaehtoihin: elämän rajallisuuteen, kuoleman tosiasiaan ja siihen, että voidaksemme elää arvokkaalla ja mielekkäällä tavalla meidän tulisi kyetä antamaan elämällemme jokin syvempi merkitys tai tarkoitus. Näitä teemoja voi siis pitää perustavina eksistentiaalisina kysymyksinä. Lisäksi eksistentiaalisiin kysymyksiin kuuluvat Giddensin mukaan subjektin kokemus omasta itsestään (subjektin minä-identiteetti) ja kokemus muista ihmisistä. Samoin Susanne Möbuss (20I5a, I2-I8) sijoittaa "eksistenssiongelmien" yhteyteen subjektin minäkuvan ja todellisuuskäsityksen, sen, miten subjekti mieltää itsensä ja suhteensa maailmaan ja universumiin. Laajemmassa mielessä myös nämä kuuluvat eksistentiaalisten kysymysten joukkoon, vaikka "eksistentiaalisilla teemoilla" tarkoitetaan tässä tutkimuksessa ensi sijassa kappaleen alussa mainittuja kysymyksiä. Tässä rajatussa merkityksessä niissä on kyse siitä, miten me voisimme merkityksellistää inhimillisen elämän ja olemassaolon positiivisella tavalla tai tehdä ainakin omasta elämästämme subjektiivisesti mielekkään.

Eksistentiaalisten teemojen pohtiminen ei vielä sinänsä ole eksistentialismia. Möbuss toteaa, että I80o-luvun lopun ja I90o-luvun eksistentialismi on eksistenssifilosofian erityistapaus. Eksistentialismin suuntaukset korostavat ihmisten luomien merkitysjärjestelmien haurautta. Eksistentialismin ateistisen haarauman edustajat lisäävät tähän sen, ettei ihmisten rakentamien merkitysjärjestysten yläpuolella ole kosmisia tai jumalallisia merkitysjärjestyksiä. Siksi ateistisessa eksistentialismissa ihmisen olemassaoloa luonnehtii perustava tai "traaginen" vierauden kokemus, epäsuhta ihmisen ja maailman välillä. Kokemus syntyy siitä, että ihminen pyrkii luonnostaan tai myötäsyntyisesti löytämään maailmasta merkityksellisyyttä ja näkemään siinä mielekkään merkitysjärjestyksen. Maailma pysyy kuitenkin kuurona ja mykkänä tälle pyrkimykselle: yhteiskunnallinen todellisuus ei nimittäin juurikaan noudata mielekästä merkitysjärjestystä, eikä objektiivisesti katsoen fysikaalisesta luonnosta ja universumista ole löydettävissä minkäänlaista merkitysjärjestystä. Kuten Camus (I97I, 37) kärjistäen kirjoitti, vierauden tai "ab- 
surdiuden tunne syntyy silloin kun ihmisen vetoomus [maailman merkityksellisyydestä] ja maailman järjetön hiljaisuus kohtaavat” toisensa.

Ihmisen ja maailman, keskushenkilöiden ja sosiaalisen todellisuuden välinen jännite on ominainen myös Seppälän varhaisille teoksille. Konkreettisina miljöinä niissä ovat tavallisesti tyhjenevä, elinvoimaansa menettävä maaseutu ja epäviihtyisät kaupunkilähiöt, joihin keskushenkilöt eivät tunne kuuluvansa. Seppälän varhaistuotannon tärkeimpänä yhteiskunnallisena kontekstina voidaankin pitää maaltamuuttoa ja kaupungistumista, suomalaisen yhteiskunnan suurta rakennemuutosta, joka käynnistyi I950- ja I960-luvun vaihteessa ja jatkui intensiivisenä vielä I970-luvulla. Viime vuosikymmeninä tapahtunut väestön keskittyminen kasvukeskuksiin on merkinnyt uutta vaihetta tässä kehityskulussa.

Vuonna I956 syntynyt Seppälä eli osan lapsuuttaan Satakunnan pohjoisosassa sijaitsevassa Karvian pienessä maalaiskunnassa. Kun Karvian kyläkoulu lakkautettiin, hänen opettajina toimineet vanhempansa muuttivat vuonna I970 Poriin, missä Seppälä suoritti koulunkäyntinsä loppuun maan suurimmassa, yli tuhannen oppilaan kokoisessa oppikoulussa. Helsingin Sanomien Kuukausiliitteelle vuonna 200I antamassaan haastattelussa hän totesi, että muutto Poriin oli hänelle, I4-vuotiaalle lukutoukalle, sokki: hän koki tuon keskisuuren suomalaisen teollisuus-

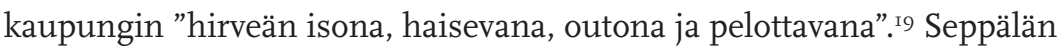
tuotannon ja hänen antamiensa haastattelujen perusteella tuo muutto on, niin kuin elämäkertatutkijat sanoisivat, ollut hänen elämänsä avainkokemuksia, sillä se on muokannut vahvasti hänen mentaliteettiaan ja näkemystään maailmasta. Se selittää osaltaan sitä, että hänen varhaistuotannossaan miljööt ja elämäntunnelma pysyvät koko ajan lähes samanlaisina teoksesta toiseen. ${ }^{20}$

Agraarisista miljöistä ja taustoista huolimatta Seppälän varhaistuotantoa ei ole syytä sijoittaa "maaseutuproosan" piiriin, sen jatkeeksi. ı960-luvun jälkipuolella ja I970-luvulla Suomessa julkaistiin noin sata romaania, jotka tavalla tai toisella käsittelivät maaseudun rakennemuutosta, "suurta muuttoa". Tavallisesti ne kuvasivat ihmisiä, joiden identiteetin perustana oli ollut kyläyhteisö ja joiden elämäntavan ja usein myös elinkeinon kaupungistuminen ja teollistuminen tuhosivat. (Mäkelä I999, 227, 233.) Tämän romaanityypin tunnetuimpia edustajia olivat 
Simo Hämäläinen, Liisa Hännikäinen, Leo Kalervo, Matti Pulkkinen, Kalle Päätalo, Eino Säisä ja Heikki Turunen.

Seppälän varhaistuotanto ottaa etäisyyttä tästä traditiosta. Siinä päähenkilöt ja minäkertojat ovat tavallisesti kaupungissa asuvia keskiluokan tai sivistyneistön edustajia, joiden lapsuudenkoti on sijainnut maaseudulla. Varhaistuotannon teoksissa on myös kuihtuvalle maaseudulle jääneitä henkilöitä, mutta he eivät esiinny kertojina. Heitä koskeva informaatio on miltei aina tarinamaailman ulkopuolisten anonyymien kertojien tai keskiluokkaisten minäkertojien välittämää. Tällainen kerronnallinen strategia toistuu lähes sellaisenaan vielä novellissa "Tikapuut" (2000c), joka sisältyy novellikokoelmaan Suuret kertomukset (2000a). Se kertoo autioituvalla maaseudulla tikapuukauppaa tekevästä mieskaksikosta, Pirhosesta ja Rauniosta, jotka menettävät novellin tapahtumien edetessä kokonaan uskon tekemänsä työn mielekkyyteen ja kunniallisuuteen. Heistä filosofiaa ja sosiologiaa harrastava Pirhonen toimii novellin kertojana, kun taas Rauniota koskeva informaatio tulee esiin Pirhosen kerronnan ja dialogien kautta. Raunioon alentuvasti suhtautuva Pirhonen pitää tätä ongelmatapauksena, joka on lunastanut olemassaolon oikeutuksensa ankaralla työnteolla, mutta joka on novellin nykyisyydessä ajautunut itsetuhon partaalle hiljattain kokemansa avioeron ja työttömyysjakson vuoksi.

Myös romaaneissa Silta (I988), Sydänmaa (I994a) ja Kuun nousu ja lasku (I999) miljöönä toimii paikoitellen maaseutu, mutta niissä maaseudun rakennemuutokseen liittyvät taloudellis-sosiaaliset ongelmat eivät nouse etualalle. Sen sijasta ne keskittyvät käsittelemään identiteetin problematiikkaa, eksistentiaalisia teemoja ja arvokysymyksiä. Sama pätee osittain novelliin "Taivaanranta" (1987b). Näin tehdessään ne eivät kuitenkaan sulje yhteiskunnassa tapahtunutta rakennemuutosta temaattisen käsittelyn ulkopuolelle. Henkilöiden kokemusta maailmasta ja elämästä selitetään niissä jossain määrin yhteiskunnallisilla tekijöillä, viittaamalla siihen, että tuo kokemus liittyy yhteiskunnassa tapahtuneisiin muutoksiin.

Sillassa tällainen yhteiskunnallinen selittäminen on ohutta. Henkilöillä ja paikoilla ei ole erisnimiä tässä I64-sivuisessa pienoisromaanissa, joka rakentuu tarinamaailman ulkopuolisen anonyymin kertojan pu- 
heen varaan. Teoksen päähenkilönä on vanhempiensa kanssa maalta kaupunkiin muuttanut murrosikäinen "poika", jonka identiteetin ja maailmakuvan muotoutumista kertoja kuvaa. Kaupungissa poika kokee olevansa vääränlaisessa ympäristössä, johon hän ei pysty kiintymään. Siksi hänellä on tapana matkustaa viikonloppuisen maalle "papan" ja "mummon" luokse. Ainoastaan näissä maaseudulle sijoittuvissa jaksoissa hän saavuttaa vielä autenttisuuden kokemuksen, kotoisen ja itsestään selvältä tuntuvan yhteyden ympäristöönsä. Papan sairastuttua vakavasti hän menettää kuitenkin tämän kiintopisteen. Sen jälkeen romaanin pohjimmaiseksi tunnelmaksi jää pojan kokemus maailman vieraudesta ja olemassaolon arvoituksellisuudesta. Näin Silta antaa pojan kokemalle vierauden tunteelle yhden selityksen, hänen muuttonsa kaupunkiin, mutta se ei tarkastele tätä ilmiötä, sosiaalista liikkuvuutta, osana yhteiskunnan rakennemuutosta. Romaanina se on lähinnä kehityskertomus, joka kuvaa pojan identiteetin ja maailmankuvan muotoutumista ja hänen seksuaalisuutensa heräämistä tilanteessa, jossa hän on menettänyt entisen turvallisen oloisen elämismaailmansa.

Tarinamaailman ulkopuolisen kertojan varaan rakentuvassa laajassa, hieman yli ıoo-sivuisessa novellissa "Taivaanranta" päähenkilöitä vaivaa selvemmin tunne elämän tarkoituksettomuudesta. Tämäkään tunne ei jää kertomuksessa täysin vaille yhteiskunnallista selitystä. Novellin maaseudulta lähtöisin olevat keskushenkilöt kuvataiteilija Boman ja biologianopettaja Mutanen edustavat resignoituneita mieshahmoja, jotka ovat olleet tavallisia eksistentialistisessa kirjallisuudessa. Sidosta eksistentialismiin korostaa se, että Camus'n esseiden tavoin Boman rinnastaa ihmiselämän Sisyfoksen työhön. ${ }^{2 I}$ "Sisyfos on ihminen yleensä. Jokainen ihminen on Sisyfos", hän huomauttaa Mutaselle (Seppälä I987b, 50). He molemmat kärsivät juurettomuuden ja tarkoituksettomuuden tunteesta, mutta siinä, missä Boman on - usein itsepetoksen avulla - oppinut elämään tämän tunteen kanssa, Mutanen menettää novellin edetessä kokonaan elämänhalunsa ja tekee lopussa itsemurhan. Bomania suojelee itsemurhalta ilmeisesti se, että hän on Mutasta paremmin selvillä siitä, että he kaksi ovat "yhteiskunnan rakennemuutoksen uhreja" ja siten tietyssä määrin syyttömiä tilanteeseensa (Seppälä I987b, I4). Novelli ei kuitenkaan kehitä tämän suuntaista selitystä pidemmälle vaan tuo sen 
esiin lähinnä vain yhtenä näkökulmana päähenkilöidensä tilanteeseen. (Vrt. Juntunen 2012, 24-83.)

Silta ja "Taivaanranta" kuvaavat maaseudulla kasvaneita ja kaupunkiin muuttaneita ihmisiä, jotka kärsivät psyykkisesti ja sosiaalisesti tästä muutoksesta. Ne ovat siten yhteydessä suomalaisen yhteiskunnan suureen rakennemuutokseen, mutta ne sivuuttavat paljolti siihen liittyneet konkreettiset ongelmat ja keskittyvät niiden sijasta tajunnallisiin prosesseihin. Niitä voidaan siksi luonnehtia ohuesti yhteiskunnallisiksi kertomuksiksi. Sama pätee Seppälän ensimmäiseen laajaan ja rakenteellisesti kompleksiseen romaanin Sydünmaa, joka on, niin kuin Margareta Martin (I995) arvostelussaan totesi, vaikeasti omaksuttavissa yhdellä lukukerralla. Näissä suhteissa se muistuttaa läheisesti Seppälän vuosina 2000-20I2 ilmestyneitä romaaneja. Sydänmaa seuraa seitsemän samaan sukuun kuuluvan sukupolven elämää ı8०o-luvun jälkipuolelta I980- ja I990-luvulle saakka. Ensimmäisten sukupolvien elinpiirinä ovat Tampereen pohjoispuolella, Ruoveden tienoolla sijaitsevat suo- ja korpimaisemat, suomalaiset "sydänmaat", kun taas viimeiset sukupolvet elävät Tampereella ja sen läheisyydessä. Seppälän omien sanojen mukaan romaanin pohjana on hänen äidinpuoleisen torpparisukunsa tarina, jota romaani muuntelee ja täydentää etenemislogiikkaansa ja teemankehittelyään palvelevalla kuvitteellisella aineistolla. Kyseisen sukuhaaran monet miehet osallistuivat kansalaissotaan ja Tampereen taisteluihin keväällä ı9ı8 punaisten puolella, kun taas Karviassa asuneet Seppälän isän kaksi setää osallistuivat samoihin taisteluihin valkoisten puolella. "Koskaan en ehtinyt havaita poliittisia jännitteitä sukujen välillä”, Seppälä (I993b) on myöhemmin todennut. ${ }^{22}$

Sydänmaassa on useita eri aikatasoja, ja sen rakenteen kompleksisuutta lisää se, että romaani ei etene kronologisesti tai lineaarisesti vaan liikkuu suhteellisen vapaasti eri aikatasoilla. Tarinamaailman ulkopuolisen, ekstradiegeettisen kertojan ohella Sydänmaassa on kaksi selvästi tunnistettavaa intradiegeettistä, tarinamaailman sisäpuolista kertojaa: kulttuuritoimittaja Vesa ja hänen eläkkeelle siirtynyt äitinsä, jonka nimeä romaani ei mainitse. ${ }^{23}$ Tietynasteista näkökulmien ja kokemistapojen vaihtuvuutta romaaniin tuo se, että ekstradiegeettinen kertoja tarkastelee tarinamaailmaa ja sen tapahtumia eri henkilöiden kannalta. Romaa- 
nin elämäntunnelman ja maailmankuvan tasolla tässä näkökulmien tai fokalisoijien vaihtumisessa ei ole kyse mistään suuresta pluralismista tai, niin kuin Mihail Bahtin (I992) sanoisi, polyfoniasta. Aidosti polyfoninen romaani tuo Bahtinin mukaan esiin erilaisia näkemyksiä romaanissa kuvattuun maailmaan ja kieltäytyy ohjelmoimasta jonkin niistä totuuden mittapuuksi: se on tässä mielessä hierarkioiden ja monologisuuden vastainen tapa käsitellä maailmaa. Sydänmaa on melko etäällä tästä ihanteesta tai romaanityypistä, sillä sen eri kerrontajaksoissa tulee toistuvasti esiin hyvin samanlainen näkemys elämästä ja maailmasta.

Sydänmaan edustaman kompleksisen romaanityypin esikuvana on Seppälällä ilmeisesti alkuaan ollut Paavo Rintalan tuotanto, josta hän teki Turun yliopistossa vuonna I983 kotimaisen kirjallisuuden pro gradu -tutkielmansakin. ${ }^{24}$ Tuomas Juntunen $(2012,7)$ huomauttaa, että Rintala käytti kyseistä, "montaasi-periaatteen" varaan perustuvaa rakennetyyppiä varovaisesti ensimmäisen kerran jo Raamattu-aiheisessa esikoisromaanissaan Kuolleiden evankeliumi (I954) ja I960-luvulla ilmestyneissä sota-aiheisissa romaaneissaan hän kehitteli sitä astetta kompleksisempaan, kollaasimaiseen suuntaan. Toisena mahdollisena rakenteellisena esikuvana voitaneen pitää Hannu Salaman romaania Siinä näkijä missä tekijä (I972), joka perustuu niin ikään erilaisten kertojien ja aikatasojen vuorottelemiseen.

Miesten ja naisten väliset suhteet ovat Sydänmaassa usein ongelmallisia ja niiden osapuolille tuskaisia. Tämä pätee myös Vesaan ja hänen naisystäväänsä Ullaan, joiden seurustelu ei luo heidän välilleen, keskinäisestä vetovoimasta huolimatta, aitoa yhteisyyttä. Seurustelusuhteessaan he molemmat jäävät henkisesti yksin. Suvun aikaisempien polvien kohdalla jännitteet aviopuolisoiden välillä ovat niin ikään olleet tavallisia. Erityisesti näin on laita Vesan äidin vanhempien isovanhempien, Minnan ja Jussin, kohdalla. Minna on pettänyt Jussia, jota hän alkaa sitten inhota ja jonka väkivaltaisuutta hän pelkää. Vapautuakseen elämänsä ankeudesta Minna ilmeisesti tekee itsemurhan; tosin tätä ei sanota suoraan, vaan lukijan annetaan ymmärtää, että yksin järvelle lähtiessään Minna - joka ei sen jälkeen enää esiinny romaanin maailmassa - aikoo päättää elämänsä. Vaikka Sydänmaata verrattiin arvosteluissa usein Väinö Linnan romaanitrilogiaan Täällä Pohjantähden alla,,$^{25}$ merkille 
pantavaa Sydänmaassa on se, että torppareina toimineiden sukupolvien kuvauksissa maanomistusolot ja sosiaaliset epäkohdat eivät nouse siinä etualalle. Näitäkin kuvauksia hallitsevat eksistentialistiset teemat: olemassaolon raskaus, maailman vieraus, aitojen valinnanmahdollisuuksien vähäisyys ja tunne elämän tarkoituksettomuudesta. (Kirstinä 2007, 83.) Tällainen lohduton elämäntunnelma toistuu romaanissa lähes sellaisenaan sukupolvesta toiseen.

Tässä mielessä Sydänmaa purkaa suomalaiseen kulttuuriin perinteisesti sisältynyttä kertomusta korvenraivauksen ja ahkeran työnteon kautta toteutuvasta eteenpäinmenosta. Tuo kertomus on I8oo-luvulta lähtien toiminut suomalaisessa kontekstissa tärkeänä kulttuurisena arkkitekstinä, suomalaisten laajasti jakaman maailmankatsomuksen ainesosana. (Miettinen 2008, 29-36.) Siihen liittyvän kehitysoptimismin on katsottu olevan ominaista myös Linnan romaanitrilogialle, jos kohta tähän on syytä lisätä, että nimenomaan suuri yleisö on lukenut Linnan teosta optimistisena tragediana, pohjimmiltaan myönteisenä kertomuksena siitä, millaisten uhrausten kautta suomalainen yhteiskunta eheytyi ja vaurastui. (Kirstinä 2007, I2.) Linnan romaanin kolmas osa ei silti täysin jaa kehitysoptimismia. Vanhetessaan sekä Akseli Koskela että kansanedustajaksi kohonnut Janne Kivivuori murehtivat sitä, oliko yhteiskunnassa tapahtunut kehitys sittenkään kaikkien siihen uhrattujen työtuntien ja ihmishenkien arvoista. Tähän motiiviin viitatessaan Jyrki Nummi (I993) puhuukin Linnan romaanin kolmannessa osassa esiintyvästä tarkoituksettomuuden kokemuksesta tai "tyhjyyden filosofiasta".

Sukupolvien välisen ketjun edetessä Sydänmaassa tapahtuu aineellista vaurastumista, mutta se ei juurikaan tee ihmisistä aiempaa onnellisempia ja tyytyväisempiä. Tämä tulee esiin erityisesti Vesan äidin kohdalla. Vesan vanhempien välistä suhdetta hiertää se, että Vesan isä on hiljattain ollut uskoton vaimolleen, joka osittain tästä syystä kokee voimakasta turvattomuuden tunnetta:

Omaksi maksettu talo oli palovakuutettu. Irtaimisto oli kotivakuutettu. Ihmiset oli tapaturma-, sairaus-, henki- ja eläkevakuutettu. Koiralla oli omansa. Kun kaiken piti lopulta olla kunnossa ja hyvin, kaikki varmistettu viimeistä ja pienintä piirtoa myöten, kaikki olikin ohi. 
Se tapahtui muutamassa vuodessa, kuin varkain. Oma eläkkeelle jääminen, Vesa Matin avioero, miehen sairaus, jatkuva yksinäisyys, liukuminen mustaan turtumukseen. Ja nyt tämä [aviomiehen uskottomuus], jäinen rengas sydäntä ja rintaa puristamassa, tekemässä melkein hengittämisenkin mahdottomaksi.

Kun kaikki oli varmistettu, putosi kaikelta pohja.

Hän oli kierrellyt huoneissa, joiden katossa paloi kova, räikeä valo. Hän ymmärsi, ettei voisi kävellä koko yötä. (Seppälä I994a, 9I-92.)

Puhujana katkelmassa toimii tarinamaailman ulkopuolinen kertoja, joka toistaa ensin vapaan epäsuoran esityksen keinoin Vesan äidin ajatuksia ja tuntemuksia ja siirtyy sitten selostamaan hänen ulkoista käyttäytymistään. Kyseessä on siis paljolti tekstijakso, jossa tarinamaailman ulkopuolisen kertojan ja Vesan äidin äänet tai diskurssit limittyvät tai sekoittuvat toisiinsa. Keskeistä näissä yhteen limittyvissä kohdissa on se, että aineellisesta vaurastumisesta ja ulkonaisista turvajärjestelyistä huolimatta Vesan äiti ei ole saavuttanut henkistä tai mentaalista turvallisuuden tunnetta ja aviomiehen uskottomuuden jälkeen hän on ajautumaisillaan eksistentiaaliseen kriisiin, tunteeseen siitä, että hänen elämältään on pudonnut pohja pois.

Sama motiivi tulee romaanin lopussa esiin hieman muunnellussa muodossa Vesan tehdessä äitinsä ja tyttärensä Piian kanssa matkan Sydänmaan korpimaisemiin:

Seisoin keskellä Sydänmaan korpea, sinne rakennetun ja hylätyn ihmisasumuksen raunioilla enkä osannut vastata yhteenkään kysymykseen, jotka vyöryivät ylleni ympäröivistä metsistä, häikäisevän siniseltä taivaalta sekä syvältä Koveronjärven uumenista. (Seppälä I994a, 243.)

Resignoituneesti elämäänsä ja työhönsä asennoituva Vesa ei koe olevansa aiempia sukupolvia viisaampi eksistentiaalisten kysymysten äärellä. Myös häntä kalvaa tunne siitä, että aineellisesta vaurastumisesta huolimatta elämässä ei ole tapahtunut henkistä ja eksistentiaalista edistystä. 
Vesa kärsii siten paljolti samoista ongelmista kuin sukunsa edeltävät polvet, erityisesti tarkoituksettomuuden tunteesta. Sydänmaan maailmankuva on siinä mielessä deterministinen, että sen maailmassa edeltävien sukupolvien kohtalo ja valinnat, siinä määrin kuin niihin on ollut mahdollisuutta vaikuttaa, toimivat myöhempien sukupolvien elämän lähtökohtina ja rajoittavat vuorostaan näiden mahdollisuuksia omiin, aitoihin valintoihin. Osittain tästä syystä kärsimys näyttää romaanin maailmassa siirtyvän sukupolvelta toiselle. Nukkuvaa tytärtään katsellessaan Vesa ajatteleekin, että "sillä hetkellä minusta tuntui, että niin kauan kuin eläisin, minut yhdistäisi erottamattomasti Piiaan kärsimys. Myöhemmin tulin tietämään, että olin oikeassa” (ibid., 87). Romaani ei silti kerro niistä Vesan ja Piian myöhemmistä vaiheista, joihin sitaatin mukaan tulee liittymään kärsimystä; niiden kuvitteleminen jää lukijan tehtäväksi. $^{26}$

Myös Kuun nousussa ja laskussa eksistentiaalinen tematiikka nivoutuu yhteen suomalaisen kulttuurin perinteisten osatekijöiden (maaseutumainen elämänmuoto, työn kunnioitus, perhesiteet) käsittelemisen kanssa. Romaani esittää arvion modernista kaupunkimaisesta lähiöelämästä ja elinvoimansa menettäneestä maaseudusta, joiden vastakohtana se sisältää välähdyksenomaisia kuvia maaseudun elämästä sellaisena kuin se parhaimmillaan on ollut. Samalla romaani osoittaa, mitä suomalaisen kulttuurin perinteisille arvokomponenteille on tapahtunut yhteiskunnan rakennemuutosten etenemisen myötä.

Kuun nousu ja lasku sisältää kolme eri tarinalinjaa, jotka leikkaavat paikoitellen toisensa. Päälinjana on kertomus keski-ikäisestä "kaupunkisosiologista", joka on tyytymätön työhönsä nimeltä mainitsemattoman kaupungin virkamiehenä; ilmeisesti hän on työssään tekemisissä kaupunkisuunnittelun kanssa. Tämä kaupunkimiljöössä viihtymättömyyttä poteva virkamies ottaa siksi vuoden virkavapaata työstään. Päätöstään hän perustelee sillä, että hän aikoo sapattivuotensa aikana tehdä "lisurinsa" valmiiksi. Todellisuudessa hänen motiivinsa ovat muualla, ja ne liittyvät paitsi edellä mainittuun viihtymättömyyteen myös hänen haluunsa elää lähellä maaseutua. Sapattivuotensa hän viettääkin paljolti lapsuutensa maalaisympäristössä ja lapsuudenkodissaan, joita hän antaumuksellisesti kunnostaa. 
Kaupunkisosiologi esiintyy romaanissa ainoana tarinamaailman sisäpuolisena minäkertojana. Teoksessa on myös ulkopuolinen kertoja, joka esittää romaanin toisen tarinalinjan, tyhjenevälle maaseudulle jääneen ja epämääräisillä hankkeilla itsensä elättävän Kaukon tarinan. Varhain äitinsä menettänyt ja isänsä kaltoin kohtelemaksi jäänyt Kauko on monessa suhteessa päähenkilön vastakohta, sillä hän ei juurikaan kykene käsitteelliseen ajatteluun. Hänen sosiaalinen elämänsä ja empatiakykynsä ovat hyvin rajoittuneita. Hänellä on avioton lapsi, josta hän ei piittaa lainkaan, mutta jonka elatusmaksut - "vittuvelan", kuten hän sanoo - hänet on määrätty suorittamaan. Yhteistä Kaukolle ja kaupunkisosiologille on se, että molemmille maaseutu, varsinkin metsä ja siellä kulkeminen, merkitsee turvapaikkaa maailman vierautta ja kompleksisuutta vastaan. Mikäli jokin uhkaa tätä turvallisuuden tunnetta, Kauko on herkästi taipuvainen aggressiiviseen käyttäytymiseen.

Romaanin kolmannen tarinalinjan muodostaa fragmentaarinen kertomus kyseisen maalaiskylän kauppatiskillä työskentelevästä lihamestarista, joka toimii samalla paikallisessa harrastajateatterissa ja suhtautuu harrastukseensa intohimoisesti. Hänen sukupuoltaan ei tekstissä määritetä, mutta romaanista kirjoitetuissa arvosteluissa hänet on yleensä mielletty mieheksi. Tämä romaanin päätarinoiden varjoon jäävä tarinalinja tai sivujuonne on lähinnä ulkopuolisen kertojan, mutta osittain myös kaupunkisosiologin esittämä.

Näissä tarinalinjoissa Kuun nousu ja lasku hahmottelee kolme erilaista sosiaalista ja eksistentiaalista elämäntilannetta. Virkavapautensa aikana kaupunkisosiologi näyttäisi olevan sopeutunut yksinoloon ja ajatukseen elämänsä pohjimmaisesta merkityksettömyydestä:

Tunsin epämääräistä haikeutta, en ahdistusta, en mitään kirkasta kipua. Ymmärsin olevani yksin maailmassa, minä en odottanut ketään, kukaan ei odottanut minua, kukaan ei merkinnyt minulle erityisen paljon, minä en kenellekään. Isä oli kuollut, äiti hautaamista vaille. Kaksi naista minulla oli ollut. Kaksi kertaa olin ollut rakastunut. Rakkaus oli kuin savu lokakuisen illan hämärässä, haihtunut taivaalle. Tuntui hyvältä istua vain, tavoittelematta mitään, tietämättä minne mennä ja mitä tehdä, olla vain ja kuunnella vanhan hirsirunkoisen talon hengitystä. (Seppälä I999, 32-33.) 
Näin levollisesti hän kokee yksinolon ja elämänsä pohjimmaisen merkityksettömyyden ainoastaan lapsuutensa maalaisympäristössä. Kun hän tekee erilaisia konkreettisia töitä maaseudulla, hänet valtaa ajoittain huikaiseva tunne elämän täyteydestä. Näin tapahtuu esimerkiksi kesällä hänen niitettyään ensin ojanpenkat ja pestyään sen jälkeen vielä matot: "Elämä olisi saanut päättyä siihen, ajattelin pellon reunaa kävellessäni, nuuhkiessani matoista hehkuvaa aurinkoa ja mäntysuopaa, mutta tiesin samalla, että tuoksu oli petollinen" (Seppälä I999, 206). Itse tilanne on petollinen siksi, että se ei ole pysyvä: kun virkavapaus päättyy, kaupunkisosiologin täytyy taas tottua mitättömänä pitämäänsä paperityöhön ja kaupunkielämän ankeuteen.

Kaupunkisosiologin mielessä maan viljelemiseen ja muokkaamiseen perustuva elämäntapa näyttäytyy yleisemmin kulttuurimuotona, jossa ihmisten oli mahdollista kokea elämäntyytyväisyyttä. Muistellessaan vanhempiaan hän toteaa, että

molemmat vanhempani kuolivat elokuussa, kuussa josta kaikista kuukausista eniten pidin, kypsän viljan ja sadon kuukautena, ja se tuntui minusta hyvältä - ikään kuin heidän koko elämän mittainen kasvu- ja elinympäristönsä olisi määrännyt heidän lähtönsä hetken, ilman värssyjen äiteliä tuonen niittopuheita. (Seppälä I999, 59.)

Olennaista tässä sitaatissa on uskomus, että agraarisessa kulttuurissa ihmisten oli mahdollista hyväksyä osansa maailmassa eikä olemassaoloa mielletty sen suuremmin ongelmaksi. Agraarinen kulttuuri ja sille ominainen luonnonläheinen, syklinen elämänrytmi riitti pääosin elämän merkitysperustaksi ihmisille. Samalla Kuun nousu ja lasku tuo kuitenkin esiin sen, ettei kaikkien tilanne maaseutuyhteiskunnassakaan ollut näin tyydyttävä. Tuo yhteiskunta ei kyennyt tarjoamaan alaluokkaisesta ja rikkinäisestä kotitaustasta lähtöisin olevalle Kaukolle turvallista kasvuympäristöä, jos kohta hänen lapsuutensa ajoittuu siihen vaiheeseen, jolloin perinteinen maaseutuyhteiskunta oli jo alkanut menettää elinvoimaansa. Tässä mielessä kaupunkisosiologi idealisoi jonkin verran perinteistä maaseutuyhteiskuntaa. 
Yhteiskunnan ja kulttuurin modernisaatiokehityksen myötä maaseutuyhteiskuntaan liittyneet myönteiset mahdollisuudet on Kuun nousun ja laskun mukaan menetetty. Työssään kaupunkisosiologi on sikäli ristiriitaisessa tilanteessa, että kaupungin suunnittelemiseen osallistuvana virkamiehenä hän on mukana sellaisten asuinympäristöjen tuottamisessa, joissa asukkaat - mukaan lukien hän itse - kokevat viihtymättömyyttä ja vieraantuneisuutta. Tämän asetelman voi ymmärtää ironisena viittauksena siihen rooliin, joka yhteiskuntatieteilijöillä oli teollistuvan ja kaupungistuvan Suomen rakentamisessa I960- ja I970-luvulla. Modernia suomalaista yhteiskuntaa rakennettaessa he (esimerkiksi Heikki Waris ja Erik Allardt) nimittäin saivat asiantuntijan roolin, jonka puoleen maan korkein johto erinäisissä yhteiskuntasuunnittelun kysymyksissä kääntyi. Siten he olivat osittain vastuussa modernisoituneen Suomen synnystä, niin kuin Kuun nousu ja lasku esittää.

Romaanissa Kaukon toimintaa ohjaa osittain tiedostamaton pelko eksistentiaalisen turvallisuuden tunteen menetyksestä. Lopussa hän kokee monien vastoinkäymisten jälkeen psyykkisen romahduksen, kun hän huomaa, että hänen metsään rakentamansa karhunpyydys ei ole toiminut ja sinne eksynyt karhu on onnistunut murtautumaan siitä ulos:

Hänestä tuntui siltä että häntä oli petetty, alusta lähtien, aina. Äiti oli mennyt sänkyyn makaamaan eikä ollut puhunut mitään, se oli lähtenyt pois eikä ollut vastannut hänen kysymyksiinsä, se oli mennyt jäiseen kuoppaan ja jättänyt hänet yksin. Äijä [isä] oli vetänyt kovavartiset saappaat jalkaansa ja hatun päähänsä ja lähtenyt tietä pitkin mutkan taakse, palattuaan pieksänyt hänet. Hänellä ei ollut kuin itsensä, kukaan ei ollut häntä varten eikä hän voinut luottaa kehenkään, ei opettajaan, ei poliiseihin, ei herroihin eikä narreihin. Kun hän oli lähtenyt itse, ei maailmalla ollut mitään tarjottavaa hänelle. Nyt hänet oli pettänyt metsä, nyt kun se mitä hän oli eniten tavoitellut oli ollut hänen ulottuvillaan: häkki oli tyhjä, kuivunut liha riekaleina maassa ja saalis tiessään. (Seppälä I999, 234.)

Kaukolla on ollut rikkonainen lapsuus, minkä jälkeen hän on elättänyt itsensä epämääräisillä, puoliksi laittomilla töillä. Siksi metsä, suomalai- 
sen kirjallisuuden perinteinen topos, on jäänyt hänen eksistentiaalisen turvallisuuden tunteensa viimeiseksi kiinnekohdaksi. Sen romahdettua hänen altaan hän aikoo ensin ampua itsensä, mutta luopuu sitten aikeestaan ja lähtee "kävelemään kovaa vauhtia, vihan sumentamin silmin ja määrätietoisin askelin” (Seppälä I999, 235). Romaani ei kerro, mihin hän menee ja mihin hän vihansa kohdistaa.

Edellä on käytetty ilmaisua eksistentiaalinen turvallisuuden tunne. Se on muunnos Anthony Giddensin (2000, 92-III) käsitteestä ontologinen turvallisuus. Giddensiä mukaillen tässä tutkimuksessa "eksistentiaalisella turvallisuuden tunteella" tarkoitetaan perustavaa luottamusta toisiin ihmisiin sekä sosiaalisen elämän ja ympäröivän maailman järkevyyteen ja mielekkyyteen. Mentaalinen perusta tälle luottamukselle luodaan varhaislapsuudessa, lapsen ja hänen vanhempiensa välisessä empaattisessa ja emotionaalisessa vuorovaikutuksessa, mutta traditionaalisessa yhteiskunnassa sen ylläpitämisestä huolehtivat myös tiiviit sukulaissuhteet, paikallisyhteisöt, uskonnolliset kosmologiat ja perityt traditiot. Giddens jatkaa, että tarkkaan ottaen tällaisen turvallisuuden tunteen vastakohtana ei ole pelkkä turvattomuuden tunne vaan ahdistus, pelonsekainen tunne olemassaolon mielekkyyden menettämisestä. Kuvaan tässä tutkimuksessa sitä silti usein myös käsitteellä eksistentiaalinen turvattomuuden tunne.

Siinä missä kaupunkisosiologi kokee autenttisuuden hetkiä arkisia askareita tehdessään ja luonnossa liikkuessaan ja Kauko metsässä samoillessaan, osuuskaupassa työskentelevä lihamestari tuntee elävänsä mielekkäästi vain toimiessaan näyttelijänä: "Hänestä tuntui, että hän aina vasta silloin alkoi muuttua ihmiseksi, itsekseen. Aina muulloin hän oli joku toinen, jossakin tympeässä roolissa, joka ei ollut häntä varten” (Seppälä I999, 72). Lihamestarin ongelmana on se, että hän tekee vieraantunutta, ulkoapäin määräytynyttä työtä, jonka jättämää henkistä tyhjiötä hän pyrkii paikkaamaan teatteriharrastuksensa avulla. Romaani vihjaa kuitenkin ironisesti siihen, että näin tehdessään tämä Teatterikorkeakoulun pääsykokeissa kahdeksan kertaa reputtanut henkilö nojautuu subjektiiviseen illuusioon, sillä teatterikriitikot ja muut ihmiset eivät näe hänen harrastustaan oikeaksi tai suureksi taiteeksi. Hänen autenttiseksi kokemansa harrastustoiminta jää siten vaille laajempaa sosiaalista arvostusta. 
Millainen maailmankatsomus Seppälän romaaneista välittyi ennen kuin hän siirtyi teoksissaan käsittelemään yhteiskunnan markkinallistumista? Tähän kysymykseen vastattaessa voidaan Ilkka Niiniluodon (I994, 40-66, 280-30I) tavoin erottaa toisistaan maailmankuva, maailmankatsomus ja elämänkatsomus. Maailmankuva on kognitiivinen ilmiö, ja se sisältää enemmän tai vähemmän perusteltuja käsityksiä historiasta, yhteiskunnasta ja luonnosta. Lisäksi siihen voi sisältyä käsityksiä ihmisen olemuksesta ja hänen suhteestaan luontoon ja mahdolliseen yliluonnolliseen todellisuuteen tai kosmiseen järjestykseen. Maailmankatsomus on maailmankuvaa laajempi ilmiö, sillä se ei muodostu pelkästään kognitiivisista osista vaan myös arvoista ja toimintaohjeista. Se ei siis puhu ainoastaan siitä, millainen maailma on, vaan myös siitä, millainen maailman tulisi olla ja mitä meidän tulisi tehdä maailmassa. Lisäksi Niiniluoto sijoittaa maailmankatsomukseen tietokäsityksen tai tieto-opin, joka vastaa kysymykseen siitä, miten maailmaa koskeva tieto hankitaan ja perustellaan. Elämänkatsomuksella Niiniluoto tarkoittaa ihmisen henkilökohtaista käsitystä elämän(sä) tarkoituksesta sekä omasta paikastaan ja tehtävästään maailmassa.

Kirjallisuudentutkimuksen kannalta maailmankuva ja maailmankatsomus ovat näistä käsitteistä käyttökelpoisimmat. Tämän tutkimuksen pohjana olevan dialogisen käsityksen mukaan moderni kirjallisuus käy keskustelua kulttuurissa esiintyvien tai siinä vallalla olevien maailmankuvien ja maailmankatsomusten pätevyydestä. Tavallisesti maailmankuvat ja maailmankatsomukset ovat luonteeltaan kollektiivisia. Tosin tämä ei ole aivan välttämätöntä, sillä ihmisen maailmankuva tai maailmankatsomus sisältää usein myös henkilökohtaisia ja yksilöllisiä aineksia, jotka erottavat sen jossakin määrin ryhmien, luokkien, kansakuntien ja kokonaisten kulttuuripiirien tai sivilisaatioiden maailmankuvista ja maailmankatsomuksista. Olennaista maailmankuvissa ja maailmankatsomuksissa on se, että ne puhuvat maailmasta yleisellä tasolla, eivät vain tämän tai tuon ihmisen elämästä ja elinpiiristä.

Elämänkatsomuksen käsitteen käyttöarvo on kirjallisuutta tutkittaessa rajallinen. Se viittaa ihmisen henkilökohtaiseen käsitykseen elämän(sä) tarkoituksesta ja omasta asemastaan maailmassa. Me voimme siis yhdellä tasolla puhua kaunokirjallisten henkilöiden, esimerkiksi kaupunki- 
sosiologin elämänkatsomuksesta Kuun nousussa ja laskussa. Tällöin on kuitenkin pidettävä mielessä se, että kaunokirjalliset henkilöt edustavat harvoin vain itseään; tavallisesti he ovat osa sitä kokonaisuutta, jonka avulla kirjallinen teos sanoo jotakin elämästä ja maailmasta yleisellä tasolla. Siksi varsinkin laajoja kaunokirjallisia kokonaisuuksia analysoitaessa maailmankuvan ja maailmankatsomuksen käsitteet ovat tarpeellisia.

Seppälän varhaistuotannon välittämä kuva maailmasta on selkeä. Samoin siitä voidaan rekonstruoida tietynlainen arvonäkökulma, mutta siitä on vaikea löytää toimintaohjeita tai tieto-opillisia kantoja. Siksi rajoitunkin seuraavassa vain kahteen ensiksi mainittuun maailmankatsomuksen osatekijään: maailmankuvaan ja arvoihin. ${ }^{27}$ Seppälän varhaisissa romaaneissa maailma on sikäli yksitasoinen tila, että siitä puuttuu kosminen ylätaso, joka antaisi tehtävän ja merkityksen inhimilliselle olemassaololle. Tässä mielessä ihmiset ovat maailmassa yksin, vailla kosmisen järjestyksen antamia tukipisteitä. Siksi heidän on omin voimin ja omien keinojensa avulla yritettävä tehdä elämästään merkityksellinen ja mielekäs. Tätä vapautta käytettäessä perustava valinta liittyy itse elämään. Ulla esittää Vesalle Sydänmaassa kysymyksen "Kun puhuit eksistentialismista; mitä ihminen loppujen lopuksi voi valita?", johon Vesa vastaa "Koko elämänsä" (Seppälä I994a, II9-I2I). Tämä kohta viittaa epäsuorasti muun muassa Camus'n (I97I) esseisiin, joiden mukaan perustava filosofinen kysymys liittyy siihen, valitseeko ihminen itsemurhan vai elämän. Valitessaan elämän ihmisen tulisi pyrkiä autenttiseen itsetoteutukseen. Yhteiskunnassa tämä on kuitenkin vaikeaa, sillä yhteiskunta estää usein tuon pyrkimyksen toteuttamisen ja saa ihmiset mukautumaan ulkoapäin asetettuihin pakkoihin. Mikäli ihminen luopuu kyseisestä pyrkimyksestä, hänen osakseen jää elämän pohjimmaiseen merkityksettömyyteen alistunut ja tyytynyt resignoitunut asenne. Tällainen asenne on hallitsevana Seppälän vuosina I986-I999 ilmestyneissä novelleissa ja romaaneissa.

Kuun nousu ja lasku täsmentää edellä muotoiltua maailmankuvaa viittauksella siihen, että suomalaisen kulttuurin perinteiset arvokomponentit (elinvoimainen maaseutumainen elämäntapa ja sen työkulttuuri, perhesiteet) ovat aikoinaan lisänneet ihmisten mahdollisuuksia kokea elämänsä ja toimintansa aidosti merkitykselliseksi, mutta kulttuurissa ja 
yhteiskunnassa tapahtuneiden muutosten myötä he ovat etääntyneet näistä tukipisteistä ja paljolti menettäneet ne. Siksi he kärsivät kyseisen romaanin keskushenkilöiden tavoin vakavasta merkityskadosta. Kuun nousu ja laskun maailmankuva eroaa siten Sydänmaan maailmankuvasta. Edellisen romaanin mukaan juuri yhteiskunnallinen modernisaatiokehitys on osittain synnyttänyt nykyistä sukupolvea vaivaavat eksistentiaaliset ongelmat, kun taas Sydänmaa painottaa pikemminkin sitä, että toteutuneesta yhteiskuntakehityksestä huolimatta, siitä riippumatta, ihmiset kärsivät kaikkina aikoina perustavasta eksistentiaalisesta merkityskadosta.

Vaikka Seppälän varhaistuotannon maailmankatsomuksessa on selviä yhtymäkohtia eksistentialismiin, sen maailmankatsomus poikkeaa jossakin määrin esimerkiksi klassisesta sartrelaisesta eksistentialismista, jota edustavat Sartren romaani Inho (I964) sekä hänen tutkimuksensa L'être et le néant (I973) ja L'existentialisme est un humanisme (I945, teoksessa Sartre 2007). Tässä vaiheessa, I930- ja I940-luvulla, Sartre katsoi, että vapaus on ihmistä määrittävä olemuksellinen seikka. Ei siis ole olemassa kosmista tai jumalallista maailmanjärjestystä, joka antaisi etukäteen, apriorisesti, inhimilliselle olemassaololle ja elämälle määrätyn merkityksen. Päinvastoin ihmisten on itse yritettävä luoda elämästään merkityksellinen; näin ajateltaessa ihmiset ovat Sartren tunnetun sanonnan mukaan "tuomitut vapauteen", mikä herättää heissä "metafyysistä ahdistusta". Tällainen ahdistus ei ole Sartresta kielteinen asia, vaan hän pitää sitä osoituksena siitä, että yksilö on oivaltanut eksistentiaalisen vapautensa. Tuon vapauden toteuttamisen suurimpana esteenä Sartre pitää ihmisille ominaista taipumusta mukautua sosiaalisiin rooleihinsa ja yhdenmukaisuuden paineeseen. Varhaistuotannossaan hän kiisti kuitenkin kaikenlaisen determinismin, ajatuksen, että ihmisen henkinen konstituutio määräytyisi yhteiskunnallisista ja biologisista tekijöistä. Tämän sijasta hän korosti sattuman ja mielivaltaisuuden merkitystä inhimilliselle olemassaololle. (Ks. Sartre I973, 516, 563-565, 639; 2007, I7-72.)

Seppälän ja Sartren teoksia yhdistää ajatus, että pyrkiessään tekemään elämästään merkityksellisen ihminen ei voi tukeutua kosmiseen järjestykseen ja siksi hänen vapautensa herättää hänessä ahdistusta. Seppälän teosten käsitys ihmisen eksistentiaalisesta tilanteesta on silti huomatta- 
vasti yhteiskunnallisempi kuin Sartren varhaistuotannossa esitetty abstraktin filosofinen käsitys. Seppälän teokset puhuvat siitä, että kulttuuriset ja yhteiskunnalliset tekijät (Silta, Kuun nousu ja lasku) ja edeltävien sukupolvien tekemät valinnat (Sydänmaa) rajaavat ihmisten mahdollisuuksia itsetoteutukseen, mutta toisaalta nuo tekijät voivat myös tarjota heille aineksia siihen (Kuun nousu ja lasku). Sartren varhaistuotannon näkökulmasta tällainen käsittelytapa on liian deterministinen. Yhteiskunnalliset tekijät Sartre otti laajemmin huomioon vasta siinä vaiheessa, kun hän pyrki yhdistelemään eksistentialismia ja marxismia toisiinsa. Tämän vaiheen tunnetuin filosofinen tutkimus on Critique de la raison dialectique (I960). Siinä Sartre kirjoittaa, että yhteiskunnassa vallitsee "niukkuus" niistä välineistä, joilla ihmiset toteuttavat eksistentiaalisia "projektejaan" ja tämä puolestaan aiheuttaa ristiriitoja yksilöiden, ryhmien ja luokkien välille. (Ks. Sartre I960, 200-224, 26I-278, 30I-377. Ks. myös Möbuss 20I5b, 230-262.) Tässä vaiheessa Sartre siis kurkotti luokkien ja luokkataistelun suuntaan, ulottuvuuteen, jota Seppälän varhaistuotanto ei ota laajasti temaattisen pohdiskelun kohteeksi.

Silti Seppälän varhaisissa teoksissa esiintyvien henkilöiden luokkakuva on varsin yhdenmukainen. Henkilöhahmot edustavat entistä maalaisköyhälistöä (Vesan esivanhemmat Sydänmaassa), nykyistä maasedulla elävää työväenluokkaa (Kauko ja lihamestari Kuun nousussa ja laskussa) tai sosiaalisen nousun kokenutta, maaseudulta kaupunkiin siirtynyttä väestöä, jonka isovanhempien ja ehkä myös vanhempien luokka-asema on ollut alhainen (Boman ja Mutanen "Taivaanranta" -novellissa, Vesa ja hänen lähisukulaisensa Sydänmaassa, kaupunkisosiologi Kuun nousussa ja laskussa). Tähän viimeksi mainittuun ryhmään kuuluvien henkilöiden tajunta ja kokemusmaailma ovat hallitsevia Seppälän varhaisissa teoksissa, jotka kuvaavat ensi sijassa ensimmäisen tai toisen polven sivistyneistön kokemusta maailmasta, sen tapaa jäsentää ja arvioida maailmaa. Näiltä henkilöiltä puuttuu kehittynyt luokkatietoisuus. Heitä ei juurikaan kiinnosta se, mitä laajempaa yhteiskuntaluokkaa he edustavat, millainen on tuon luokan asema ja tehtävä yhteiskunnassa ja mikä on sen suhde muihin luokkiin. Sen sijasta heitä vaivaavat enemmänkin heidän omaan elämismaailmaansa liittyvät kysymykset. 
Vaikka Seppälän keskushenkilöt ovat henkisesti sidoksissa maaseutuun, teokset eivät aina esitä maaseutua myönteisessä valossa. Varsinkin SYdänmaassa maaseutumainen elämänmuotokaan ei kykene lievittämään henkilöiden kokemaa ahdistusta. Silti Seppälän teoksiin sisältyvät myönteiset kohtaukset liittyvät usein juuri luontoon ja maaseutuun. Agraarisen elämänmuodon ja sen perinnön vaikutus tulee selvimmin näkyviin työnteon kuvauksissa. Seppälän teoksissa työ on myönteinen ja henkilöiden identiteettiä rakentava asia lähinnä silloin, kun siihen liittyy konkreettista käsillä tekemistä ja kun sitä ei tehdä pelkän rahan ansaitsemisen takia. Niinpä Sillan päähenkilö, murrosikäinen poika, kokee suurta iloa raivatessaan pappansa kanssa metsää ja kootessaan isänsä kanssa vanhoista hirsistä aittaa. Samoin Sydänmaassa Vesa omistautuu siivoamiseen, marjojen mehustamiseen, tyttärensä syntymäpäivien järjestämiseen ja ylipäänsäkin tyttärensä hoitoon ja kasvatukseen. Sitä vastoin työtään sanomalehden kulttuuritoimittajana hän ei pidä "oikeana työnä".

Seppälän varhaistuotanto on leimallisesti miesten kokemusmaailman kuvausta. Sen miespuoliset päähenkilöt ovat paljolti hyväksyneet nykyaikaisen työnjaon sukupuolten välillä, sillä he kokevat omikseen myös monet naisten elämänpiiriin perinteisesti kuuluneet työt. Tässä suhteessa heitä voi pitää "nykyaikaisina". Sitä vastoin "perinteisiä suomalaisia miehiä" he ovat siinä suhteessa, että he ovat vähäpuheisia, sulkeutuneita ja sosiaalisesti kömpelöitä. Heidän on myös vaikea tulla toimeen nykyaikaisten naisten kanssa, jotka - toisin kuin edeltävien sukupolvien naiset - eivät enää välttämättä uhraudu lastensa ja perheidensä puolesta ja jotka rakentavat omaa elämäänsä koulutuksen ja ansiotyön kautta. Nämä naiset ovat myös sopeutuneet miehiä paremmin moderniin kaupunkielämään. Näistä syistä Seppälän teosten miespuoliset päähenkilöt eivät osaa luoda heihin vuorovaikutteista suhdetta. Sen sijasta heidän suhtautumistapansa naisiin jää helposti ulkopuoliseksi, esineellistäväksi ja seksualisoivaksi, mikä tuotiin toistuvasti esiin myös näitä teoksia koskevissa sanomalehtikritiikeissä. ${ }^{28}$

Ehkä Seppälän vahva side agraariseen Suomeen selittää osaltaan sitä, että kapitalismi ei juurikaan tule esiin hänen varhaistuotannossaan. Siihen kuuluvista teoksista ainoastaan Super Market (I990a) käsittelee 
nykykapitalismia ja sekin vain lyhyesti, vaikka kolumneissaan Seppälä kommentoi tuolloin tiiviisti oman aikansa yhteiskuntaa. ${ }^{29}$ Kapitalismin ja talouden sivuuttamista voi pitää yllättävänä, sillä haastatteluissa Seppälä on luonnehtinut itseään "yleisvasemmistolaiseksi" henkilöksi, joka suhtautuu samalla kriittisesti vasemmiston, lähinnä sosialidemokraattien, rooliin vuosituhannen vaihteen politiikassa..$^{\circ}$ Muutoin hänen teostensa välittämä kuva sosiaalisesta elämästä on usein niin synkkä, että joku voisi kysyä, miten yhteiskunnan markkinallistuminen voisi enää huonontaa tuota kuvaa. ${ }^{\text {I }}$ Yhden mahdollisen vastauksen tähän kysymykseen tarjoaa Seppälästä vuonna 2004 tehty haastattelu. Siinä hän totesi, että markkinallistumiskehityksen edetessä vaaraksi muodostuu se, että ihmisen ainoaksi arvoksi saattaa jäädä hänen "välineellinen arvonsa". ${ }^{2}$ Seuraavissa pääluvuissa on tarkoitus selvittää, kuvaavatko hänen teoksensa nykykapitalismin todellakin niin totaaliseksi koneistoksi, että sen välineellinen toimintalogiikka on vallannut koko yhteiskunnan.

\section{Historiallis-yhteiskunnallinen konteksti}

Kirjassaan Ästhetische Erfahrung und literarische Hermeneutik (I984, ilmestyi alun perin I982) Hans Robert Jauss esittää, että kirjallista tekstiä tulkitessaan tutkijan pitäisi rekonstruoida se kulttuurin ja yhteiskunnan kehitykseen liittyvä tilanne tai kysymys, joka on tekstin kannalta relevantti ja johon teksti on käsitettävissä vastaukseksi. Seppälän vuosina 200020I2 ilmestyneiden teosten kohdalla tällaisena tilanteena toimii yhteiskuntapolitiikassa I980- ja I990-luvulla tapahtunut markkinaperustainen käänne, jota tuntematta hänen teoksiaan on vaikea ymmärtää. Tuota käännettä ei silti tule nähdä näiden teosten deterministiseksi syyksi (vrt. Karkama I998b, 79-82). Temaattisella tasolla Seppälä olisi periaatteessa voinut sivuuttaa kapitalismin ja keskittyä noina vuosina toisenlaisten teosten, esimerkiksi viihdyttävien lukuromaanien kirjoittamiseen, niin kuin monet kirjailijat Suomessa tekivät. Tuolloin edellä mainittu uusi yhteiskunnallinen tilanne olisi ilmennyt tai kuvastunut hänen teoksissaan muulla tavoin, lähinnä tahattomasti. Tai voidaan myös sanoa, että tuolloin juuri viihteellisten ainesten selkeä ilmaantuminen hänen teok- 
siinsa olisi ollut oire tai merkki yhteiskunnassa ja kirjallisuuden tuotantojärjestelmässä tapahtuneesta merkittävästä muutoksesta.

Seppälän teosten historiallis-yhteiskunnallista kontekstia rekonstruoitaessa ei ole järkevää rajoittua siihen, mitä Suomessa on tapahtunut ı980- ja ı990-luvulta lähtien. Pystyäkseen kuvaamaan ja selittämään tätä kotimaista kehitystä tutkimuksen on suhteutettava se Suomen kansainvälisessä asemassa ja maailmanjärjestelmässä tapahtuneisiin muutoksiin. I980-luvulla alkoi muotoutua uusi taloudellis-poliittinen maailmanjärjestys tai uusi kapitalistinen maailmanjärjestelmä, jonka piiriin valtaosa maailman maista jo I990-luvulla kuului. Täydessä mitassa myös Suomesta tuli osa sitä ı9९०-luvulla.

Keskeisiä aineksia tuossa maailmanjärjestelmässä ovat olleet kaupankäynnin ja rahamarkkinoiden vapaus, ankara markkinakilpailu ja finanssikapitalismin nousu maailmantalouden hallitsevaksi sektoriksi. Aiempi kapitalistinen maailmanjärjestelmä, niin kutsuttu Bretton Woods -järjestelmä, toimi vain rajoitetusti näiden ainesten pohjalta. Järjestelmän nimitys viittaa siihen, että toisen maailmansodan lopussa, vuonna 1944, Yhdysvallat kutsui 44 liittolaisvaltiotaan konferenssiin Bretton Woodsiin, joka sijaitsee Carrollin kaupungissa New Hampshiren osavaltiossa. Siellä valtioiden oli tarkoitus sopia uuden ja avoimen maailmantalouden periaatteista, jotka korvaisivat maailmansotien välillä ja toisen maailmansodan aikana harjoitetun protektionismin. Yhdysvallat halusi siis jo tuolloin lisätä maailmantaloudessa kilpailua ja vapautta, mutta pyrkimystä rajoitti I940-luvun lopulla alkanut kylmä sota. Siksi Yhdysvallat ryhtyi yhteistyöhön liittolaistensa kanssa ja muodosti niiden kanssa taloudellisen, poliittisen ja sotilaallisen liittouman Neuvostoliittoa ja sosialistista maailmanjärjestelmää vastaan. Talouspolitiikkansa välineiksi liittouma perusti Maailmanpankin (I944), Kansainvälisen valuuttarahaston (I945) ja GATT-sopimuksen (I948), jotka ovat samalla olleet Yhdistyneiden kansakuntien (I945) jäsenorganisaatioita. GATTsopimuksen oli tarkoitus edistää vapaata kauppaa kapitalististen maiden välillä, mutta sopimus koski vain teollisuustuotteita, kun taas maataloustuotteet, palvelut ja tekijäoikeudet jäivät sen ulkopuolelle. GATT-sopimusten seuraajaksi perustettu Maailman kauppajärjestö (I995) on ollut huomattavasti tehokkaampi purkamaan maailmankaupan esteitä. 
(Gilpin 200I, 43, 86, 2I7-2I8, 234-260; Patomäki \& Teivainen 2003, 29, 58, 75, II6-II7.)

Toisen maailmansodan jälkeen luotu kapitalistinen maailmanjärjestelmä perustui talouden laajaan ohjailuun. Rahoitusmarkkinat ja pankit alistettiin tiukkaan kansalliseen sääntelyyn, ja samoin kapitalistisen maailmanjärjestelmän piirin kuuluneet valtiot ja niiden keskinäiset yhteistyöjärjestöt rajoittivat kansainvälisten pääomaliikkeiden ja rahamarkkinoiden toimintaa. Kansallisella tasolla tätä järjestelmää täydensi keynesiläinen politiikka, joka painotti vakaata taloudellista kasvua ja hyvinvointia. Sen mukaan tätä kautta läntiset maat kykenisivät turvaamaan työllisyyden ja integroimaan alemmat luokat demokraattisesti hallittuihin kapitalistisiin yhteiskuntiin. I950-luvulta aina I970-luvulle asti läntisille maille olikin ominaista hyvinvointivaltion ja sen palvelujen laajentamiseen liittynyt julkisten menojen kasvu. Tuloverotus oli tuolloin voimakkaan progressiivista, mikä kavensi tuloeroja eri väestöryhmien välillä. (Gilpin 200I, 98, IOI, 2I7-2I8; Kiander 20I3, 23.)

Espanjalainen sosiologi Manuel Castells (2000, 80-98, I37-I44) toteaa, että amerikkalainen ja brittiläinen taloudellis-poliittinen eliitti oli jo I970-luvulla tyytymätön edellä kuvattuun järjestelmään, joka sen mielestä rasitti Yhdysvaltain ja Ison-Britannian valtiontaloutta eikä enää tuonut näihin maihin riittävästi talouskasvua. Kasvuvertailuissa Yhdysvallat ja Iso-Britannia näyttivätkin jäävän Japanin ja Länsi-Saksan kaltaisten dynaamisten maiden varjoon. Presidentti Ronald Reaganin (I98I-I989) ja pääministeri Margaret Thatcherin (I979-I990) kaudella kyseinen järjestelmä korvattiin nykyisellä, uusliberalistisella järjestelmällä, jonka pohjana on usko siihen, että erilaiset hyödykkeet ja palvelut voidaan tuottaa tehokkaimmin ja laadukkaimmin yksityisten yritysten välisen vapaan kilpailun kautta. Uusliberalistisessa yhteiskuntamallissa valtio ei siksi juurikaan harjoita yritystoimintaa eikä se puutu laajasti talouselämän toimintatapoihin. David Harveyn $(2008,7)$ sekä Vivien Ann Schmidtin ja Mark Thatcherin (20I3b, 4-8) mukaan tässä mallissa valtion tehtävänä on lähinnä raivata esteitä markkinoiden tieltä ja turvata lainsäädäntönsä avulla rationaalinen markkinajärjestys.

Uusliberalistisessa mallissa maailmanjärjestelmän ja kansallisten yhteiskuntien tulisi toimia markkinaperustaisesti eli ne pitäisi organi- 
soida markkinoiden ja yksityiskapitalistisen yritystoiminnan pohjalta. Käytännössä tuon mallin toteuttaminen on merkinnyt kansallisten yhteiskuntien markkinallistumista. Tässä prosessissa kapitalistisen yrityssektorin ja markkinoiden toimintatapa on kasvavassa määrin ulotettu yhteiskunnan eri osa-alueille, perinteisen talouselämän ulkopuolelle. Samalla valtioiden omistamia yrityksiä ja laitoksia on yksityistetty ja julkisia palveluja on supistettu. Jäljelle jääneeseen julkiseen sektoriin on sitten sovellettu uuden julkisjohtamisen periaatteita (New Public Management). Tämä doktriini kehitettiin Yhdysvalloissa ja Isossa-Britanniassa I970- ja I980-luvulla, ja OECD:n ja Euroopan unionin kautta se on sittemmin levinnyt koko Eurooppaan ja läntiseen maailmaan (Alasuutari \& Lampinen 2006, 56-58; McGuigan 2009, I42; Sulkunen 2006, I7). Se on muodostanut opillisen pohjan nykyisille hallinnollisille käytännöille, joissa julkisia laitoksia johdetaan ja arvioidaan paljolti samalla tavalla kuin yksityisiä liikeyrityksiä.

Näiden muutosten ohella keskeistä uusliberalistisessa järjestelmässä on ollut rahamarkkinoiden irrottaminen tai "vapauttaminen" valtioiden harjoittamasta kansallisesta sääntelystä sekä kansainvälisen kaupan ja investointien vapauttaminen (Castells 2000, 137). Siksi maailmantaloutta ovat viime vuosikymmeninä ensi sijassa liikutelleet jättimäiset pankki- ja rahoitusyhtiöt, joiden toimintaan valtioilla ei ole juurikaan ollut halua puuttua. Kehittyneen digitaalisen teknologian avulla ne ovat nopeasti, muutamilla napinpainalluksilla pystyneet käsittelemään suunnattoman suuria rahavirtoja ja siirtämään niitä eri puolille maapalloa.

Jim McGuigan (2009, IO2-IO3) toteaa, että kokonaisuudessaan nykykapitalismi on merkinnyt siirtymistä "postfordistiseen" pääoman kasaamiseen muotoon. Kun edeltävä eli "fordistinen" vaihe rakentui liukuhihnatuotannon ja mekaanisen teollisuustyön varaan, nykyinen tuotannon ja markkinoinnin organisaatiomuoto on joustavampi ja verkostomaisempi. Samalla painopiste tavaroiden arvonmuodostuksessa on muuttunut. Puhtaasti fyysinen tai manuaalinen työ on menettänyt siinä suhteellista osuuttaan, kun taas tutkimus- ja kehitystyön, tuotesuunnittelun ja muotoilun osuus on kasvanut. Nykykapitalismille on siksi ominaista huomion kiinnittäminen (luonnon)tieteisiin ja teknologiaan, joita se kohtelee paljolti kaupallisesti ja yhteiskunnallisesti hyödynnettävissä olevien 
keksintöjen eli innovaatioiden ja talouskasvun lähteenä. Samalla yliopistolaitos, korkeampi koulutus ja tieteellinen tutkimus on kasvavassa määrin mukautettu palvelemaan talouselämän ja yritysten kansainvälisen kilpailukyvyn tehostamisen tarvetta. Tutkimuskirjallisuudessa tätä ilmiötä on kutsuttu akateemiseksi kapitalismiksi (ks. Cartwell \& Kauppinen 20I4). Nimityksen on tarkoitus tuoda esiin tieteen ja korkeamman koulutuksen läheinen sidos nykytalouden kasvutarpeisiin.

Akateeminen kapitalismi on osittain päällekkäinen kognitiivisen kapitalismin kanssa, joka on sitä laajempi ilmiö. Kognitiivisen kapitalismin käsite viittaa siihen, että nykytalous ei hyödynnä vain tietoa, koulutusta ja teknologiaa. Se valjastaa käyttöönsä myös ihmisten kognitiiviset ja sosiaaliset taidot (affektiiviset kyvyt, vuorovaikutustaidot, viestinnälliset taidot), ja siinä arvonmuodostus tapahtuu kollektiivisen innovoimisen ja verkostoitumisen kautta, digitaalisen teknologian avulla. Sen tyypillisiä aloja ovat korkeateknologian tuotanto, finanssisektori, palvelusektori, mediat ja kulttuuriteollisuus. (Ks. Moulier-Boutang 2007.)

Nykykapitalismista puhuttaessa viitataan myös immateriaalitalouteen ja luovaan talouteen. Niiden sekä akateemisen ja kognitiivisen kapitalismin välillä vallitsee läheinen suhde. Väljässä mielessä immateriaalitalouden käsite painottaa sitä, että nykykapitalismissa immateriaalisten tekijöiden (tutkimustyö, teknologinen kehitystyö, tuotesuunnittelu, muotoilu) osuus tavaroiden arvonmuodostuksessa on usein suurempi kuin ruumiillisen työn ja materiaalisten tekijöiden osuus. Ahtaassa mielessä immateriaalitaloudella tarkoitetaan aineettomien tavaroiden, esimerkiksi patenttien, tekijänoikeuksien, tavaramerkkien, ohjelmistolisenssien, viihteen ja elämysten tuotantoa ja niitä koskevaa kaupankäyntiä. Paljolti samalla tavalla luova talous tarjoaa kuluttajille elämyksiä, merkityksiä, tyylejä ja identiteetin rakennusaineita, jotka välitetään heille jonkin materiaalisen substraatin (painotuotteet, videot, CD, DVD) avulla. (Bruun, Eskelinen, Kauppinen \& Kuusela 2009; McGuigan 2009, I49-165.)

Kapitalismin edelliseen vaiheeseen verrattuna nykyinen vaihe on osoittautunut dynaamiseksi ja muuntautumiskykyiseksi muodostumaksi, jonka tulevaa kehitystä on vaikea ennustaa luotettavasti. Samalla tämä muodostuma on epävakaa, altis äkillisille ja jyrkille muutoksille. Robert 
Gilpinin (200I, 7-9, 26I-277) mukaan sen epävakauden ilmeisin syy on kansainvälisessä finanssisektorissa, joka on nykyisin maailmantalouden haavoittuvin osa ja jossa otetaan suuria riskejä. Tämä tuli erityisen selvästi ilmi Yhdysvalloissa vuonna 2007 puhjenneessa kriisissä, jonka jälkiseurauksista maailma kärsi useiden vuosien ajan. Tavallisten ihmisten elämässä nykyvaiheen tuomat muutokset ilmenevät ennen kaikkea siten, että työstä on tullut rasittavampaa ja työsuhteista epävarmempia. Se puolestaan vaikeuttaa pitkäjänteisten tulevaisuudensuunnitelmien laatimista. (Sennett 2002, 22, I3I; 2007, 39.) Toisaalta tavalliset ihmiset ovat talouteen yhteydessä myös kuluttajina. McGuigan (2009, IO3-IO4, II4) kirjoittaa, että - samoin kuin edeltävässä vaiheessa - nykyisinkin massatuotanto edellyttää massakulutusta ja siksi nykytalous näkee suurta vaivaa iskostaakseen ihmisiin konsumeristisen asenteen, "vietelläkseen" heidät kuluttajiksi. Se ei ole ollut vaikeaa, sillä usein ihmiset kokevat juuri kuluttamisen alueena, jossa he voivat vapaasti toteuttaa itseään. Naiivi tai sokea kuluttaminen on kuitenkin yhteiskunnallisesti ja ekologisesti riskialtis ilmiö, sillä se ylläpitää luonnonvaroihin kohdistuvaa rasitusta ja lisää näin ekologisten riskien todennäköisyyttä.

Oliko Suomi vuosina I944-I990 lainkaan osa kapitalistista maailmanjärjestelmää? Tuolloin Suomi oli omintakeista politiikkaa harjoittava läntinen maa, jolla oli poikkeuksellinen suhde Neuvostoliittoon. (Kuisma 20I3, I96-I97.) Kun muissa länsimaissa hyvinvointivaltiota alettiin rakentaa laajemmin I950-luvulla, Suomi siirtyi samaan vaiheeseen I96o-luvulla. Pohjoismaisen tason suomalainen hyvinvointivaltio saavutti i980-luvulla, jolloin monissa muissa maissa jo ryhdyttiin supistamaan julkisia palveluja. Suomessa ja muissa Pohjoismaissa samaan tilanteeseen tultiin I990-luvun alussa. Kuvatessaan suomalaisen hyvinvointivaltion jatkokehitystä vuoden 2010 horisontista Risto Heiskala ja Anu Kantola (20I0, I29) toteavat, että julkisiin palveluihin I990-luvun alkupuolella tehtyjen leikkausten jälkeen noita järjestelmiä ei enää laajennettu eikä niiden korvaustasoja korostettu. Siksi esimerkiksi terveydenhoitopalvelut ja mielenterveyspalvelut alkoivat tuolloin rapautua.

Talousjärjestelmänsä osalta Suomi oli i99o-luvun alkuun asti "valtiokapitalistinen" maa (Haapala 20IO, 3I) tai "valtiokapitalismin ja hallinnoidun kapitalismin yhdistelmä" (Heiskala 2006, 24). Omistamiensa 
lukuisten yritysten ja teollisuuslaitosten kautta valtio oli Suomessa merkittävä taloudellinen toimija, ja yhdessä suurimpien puolueiden ja etujärjestöjen kanssa se säänteli laajasti yhteiskuntaa. (Kuisma 20I3, I98-202.) Siten hallitsemistapa oli Suomessa korporatiivinen, eturyhmien välistä yhteistyötä painottava. Se oli myös presidenttivaltainen, sillä tasavallan presidentillä oli Suomessa laajat valtaoikeudet. Suomen ja Neuvostoliiton välinen YYA-sopimus ja idänkauppa, joka muodosti jopa $15-20 \%$ Suomen viennistä, korosti niin ikään presidentin erityisasemaa. (Alasuutari 2006, 47-48; Tiihonen 2006, 82-88.) Toisaalta markkinoiden rooli oli Suomessa rajattu ja tarkkaan säännelty. Suomi oli siten talousjärjestelmänsä osalta kaukana angloamerikkalaisista markkinaperustaisista maista, joiden sijasta se muistutti enemmänkin Ranskan, Italian, Japanin ja muiden Pohjoismaiden kaltaisia valtiokeskeisiä kapitalistisia yhteiskuntia.

Siirtyminen kohti markkinakapitalismia aloitettiin Suomessa tilanteessa, jossa hyvinvointivaltion ylläpitäminen hallitsi yhteiskuntapolitiikkaa. Ensimmäisiä merkkejä muutoksesta oli vuosina I984-I987 toteutettu rahoitusmarkkinoiden vapauttaminen valtion ja Suomen Pankin tiukasta ohjailusta, ja hieman myöhemmin Harri Holkerin johtama porvarillinen hallitus (I987-I99I) aloitti valtion omistamien yritysten yksityistämisen ja valtion laitosten muuttamisen liikelaitoksiksi. Dramaattisempi näistä toimenpiteistä oli rahoitusmarkkinoiden vapauttaminen, sillä se johti luottojen määrän räjähdysmaiseen kasvuun ja holtittomaan lainanottoon, minkä seurauksena Suomi ajautui vuosina I990-I99I pankkikriisiin. Vastaavanlainen kriisi koettiin tuolloin myös Norjassa ja Ruotsissa, mutta Suomessa kriisi oli syvempi, sillä se sattui samaan aikaan Neuvostoliiton hajoamisen ja idänkaupan romahtamisen kanssa. Ennätysvuonna I994 Suomessa oli lähes puoli miljoonaa työtöntä. Kansainvälisen valuuttarahaston (IMF) puoleen kääntynyt Esko Ahon porvarillinen hallitus (I99I-I995) pyrki ratkaisemaan kriisin synnyttämät ongelmat noudattamalla Valuuttarahaston suosittelemaa markkinahenkistä politiikkaa. Heikki Patomäen mukaan

täysin vastoin maalaisjärkeä tai tutkimustietoa lamasta syytettiin sitä, että markkinat eivät olleet tarpeeksi vapaita Suomessa. - - 
Tämä epäuskottava tulkinta meni läpi jopa monien ay-johtajien keskuudessa. Niinpä Esko Ahon johtama uusi porvarihallitus vastasi talouskriisiin tiukalla IMF-tyylisellä vyönkiristyskuurilla ja kiihdyttämällä uusliberaaleja uudistuksia Suomessa. (Patomäki 2007, 68.)

Valuuttarahaston suositusten mukaisesti Ahon hallitus leikkasi julkisia menoja, muun muassa sosiaaliturvaa ja työttömyysturvaa, ja jatkoi valtion omistamien yritysten yksityistämistä ja valtion laitosten muuttamista liikelaitoksiksi. Lisäksi valtionhallinnossa otettiin I990-luvun alkupuolella laajasti käyttöön uuden julkisjohtamisen tai "tulosjohtamisen" periaatteet (Patomäki 2007, 74-76). Valuuttarahasto ei Suomen kohdalla toiminut poikkeuksellisesti, sillä I980-luvulta lähtien se oli säännöllisesti asettanut järjestämiensä lainojen ehdoksi sen, että lainanottajavaltio sitoutuu toteuttamaan markkinaperustaista politiikkaa ja supistamaan julkisia menoja (Gilpin 200I, 26I-267; Patomäki \& Teivainen 2003, 25, 29; Stiglitz 2004). Pyrkiessään integroimaan maamme uuteen kapitalistiseen maailmanjärjestykseen suomalainen poliittis-taloudellinen eliitti seurasi kuuliaisesti tätä politiikkaa. Integroimista syvensivät YYA-sopimuksen lakkauttaminen (I992) ja Suomen liittyminen Euroopan unioniin (I995), Maailman kauppajärjestöön (I995) ja Euroopan unionin alaiseen Euroopan talous- ja rahaliittoon (I999). Samaan aikaan ja vielä myöhemminkin tasavallan presidentin valtaoikeuksia kavennettiin Suomessa asteittain, minkä jälkeen Suomi on muistuttanut myös poliittisen järjestelmänsä osalta entistä enemmän läntisiä parlamentaarisia demokratioita.

Tämä kehityskulku ei synnyttänyt Suomessa laajaa vastarintaa. Pertti Alasuutarin $(2006,43-44,59)$ mukaan sitä selittää paljolti se, että reaalisosialismin kriisiytyminen i980-luvulla Puolassa, Neuvostoliitossa ja sen jälkeen koko itäisessä Euroopassa murensi täkäläisen vasemmiston piirissä uskoa siihen, että valtiojohtoinen sosialismi olisi kapitalismia parempi vaihtoehto. Siksi uusliberalismi nousi jo I980-luvulla suomalaisessa poliittisessa mielipiteenmuodostuksessa hallitsevaan asemaan. Tätä laajaa konsensusta ilmentää se, että Holkerin hallituksen (I987-I99I) ajoista lähtien hallitukset ovat Suomessa noudattaneet kes- 
kenään miltei samanlaista politiikkaa, joka on parantanut liike-elämän ja markkinoiden toimintaedellytyksiä ja muuttanut julkista sektoria yritysmaailman kaltaiseksi yhteiskunnallisen toiminnan alueeksi (Heiskala 2006, 34).33 Tällaisen politiikan seuraukset ovat olleet ristiriitaiset.

Asioita hieman yksinkertaistaen voi sanoa, että I990-luvun puolivälistä vuoteen 20ıo saakka Suomi koki nopean ja voimakkaan taloudellisen kasvun kauden, jonka aikana se otti bruttokansantuotteella mitattuna paikkansa maailman rikkaimpien maiden joukossa. Niin ikään Suomi oli I990-luvun lopussa ja 2000-luvun alussa Yhdysvaltain ja Singaporen kanssa "maailman kilpailukykyisin maa" (Castells 2004, 3I4-3I5). Nousun pääveturina oli Nokia-yhtiö ja sen kehitys maailman johtavaksi matkapuhelinten valmistajaksi. Nokian ilmiömäisen menestyksen seurauksena ICT-alasta (informaatio- ja viestintäteknologiasta / tieto- ja informaatioteollisuudesta) tuli Suomessa muutaman vuoden ajaksi kansantaloudellisesti merkittävin talouden sektori, joka ohitti painoarvoltaan perinteisen metsäteollisuuden (puu- ja paperiteollisuuden) ja metalliteollisuuden. "Kansantaloudesta" puhuminen on tosin tässä kohden harhaanjohtavaa. Jo 2000-luvun alussa yli puolet suomalaisten suuryritysten osakkeista oli ulkomaalaisten omistajien, yleensä suursijoittajien ja eläkerahastojen hallussa, ja samalla ulkomaisten yritysten toiminta oli levittäytynyt Suomeen tavalla, jota olisi i980-luvulla ollut vaikea kuvitella (Heiskala \& Kantola 20I0, I30; Wilenius 2006, 233-235).

Saavutettu vauraus ei ole jakautunut tasaisesti, sillä uusliberalistinen politiikka on syventänyt eroja niin luokkien kuin alueidenkin välillä. David Harvey (2008, 24, I47) onkin määrittänyt uusliberalismin suoranaiseksi "luokkavallan palauttamisen projektiksi", josta ovat hyötyneet lähinnä suuryrittäjät ja suuromistajat. Samoin ranskalainen taloustieteilijä Thomas Piketty (2016) on laajoihin tilastollisiin aineistoihin vedoten esittänyt, että uusliberalismi on merkinnyt paluuta I80o- ja I9०o-luvun vaihteen tilanteeseen, jossa vallitsi jyrkkä vastakohta pienen ja rikkaan yläluokan ja muun väestön välillä. Nämä yleistykset pätevät Yhdysvaltoihin ja useisiin OECD-maihin (Patomäki 2007, I77). Suomikin kuuluu vauraisiin OECD-maihin, mutta I990-luvulla ja 2000-luvun alussa toteutuneesta tuloerojen kasvusta huolimatta Suomi on edelleen maailman tasa-arvoisimpia maita. Uusliberalistisen politiikan myötä Suomeen 
on kyllä muodostunut vauras ja suhteettomastikin rikastunut yläluokka (5-Io \% väestöstä), mutta toisaalta keskiluokka ja työväenluokka ovat tulojensa, koulutuksensa ja elämäntapansa osalta lähentyneet toisiaan. Lisäksi Suomessa on nykyisin laaja köyhien, pitkäaikaistyöttömien ja syrjäytyneiden ihmisten kerrostuma, joka on muodostanut I2-I5 \% väestöstä. ${ }^{34}$

Edellä nykykapitalismista on puhuttu monoliittisesti, yhtenä järjestelmänä. Nykyisessä kapitalismiteoriassa ei aina rajoituta tällaiseen puhetapaan, vaan siinä erotetaan toisistaan erilaisia nykykapitalismin tyyppejä. Tämän viime vuosikymmeninä syntyneen tutkimusperinteen klassikkoja ovat Peter A. Hallin ja David Soskicen toimittama Varieties of Capitalism. The Institutional Foundations of Comparative Advantage (200I) ja Vivien Ann Schmidtin The Future of European Capitalism (2002). Lisäksi Vivien Ann Schmidtin ja Mark Thatcherin toimittama Resilient Liberalism in Europe's Political Economy (2013a) on sikäli hyödyllinen teos, että se tarkastelee Euroopan maiden ja niiden talouksien kehitystä I980-luvulta 20ıo-luvulle saakka. Suomessa tätä tutkimusperinnettä on edustanut Risto Heiskala (2006).

Hallin ja Soskicen toimittama teos puhuu ensinnäkin liberaalista markkinataloudesta tai liberaalista markkinakapitalismista, joka on ollut vallalla angloamerikkalaisissa maissa - Australiassa, Irlannissa, IsossaBritanniassa, Kanadassa, Uudessa Seelannissa, Yhdysvalloissa - sekä Hong Kongissa ja eräissä "postsosialistisissa" maissa, esimerkiksi Virossa, Latviassa, Liettuassa ja I990-luvun Venäjällä. Tässä tyypissä markkinoilla on ratkaiseva rooli talouselämän koordinoimisessa, kun taas talouselämään kohdistuva ulkoinen sääntely on haluttu siinä minimoida. Tyyppi perustuu uskomukseen, että vallitsevien oikeusnormien puitteissa markkinat kykenevät paljolti muodostamaan itseään sääntelevän järjestelmän, joka ei normaalioloissa tarvitse valtion väliintuloa.

Koordinoitu markkinatalous tai koordinoitu markkinakapitalismi on puolestaan ollut vallalla useissa läntisen ja keskisen Euroopan maissa, esimerkiksi Belgiassa, Hollannissa, Itävallassa, Saksassa, Sloveniassa, Sveitsissä ja Tšekin tasavallassa. Samoin Pohjoismaat eli Islanti, Norja, Ruotsi, Suomi ja Tanska edustavat sitä. Euroopan ulkopuolella sen piiriin kuuluvat muun muassa Etelä-Korea, Japani ja Taiwan. Näissä 
maissa ei täysin luoteta markkinoiden kykyyn säännellä itseään ja muuta talouselämää, vaan niissä sosiaaliset toimijat harjoittavat talouselämään kohdistuvaa sääntelyä. Pohjoismaissa valtio, poliittiset puolueet ja erilaiset eturyhmät ovat tässä suhteessa tärkeitä toimijoita, kun taas Etelä-Koreassa ja Japanissa vastaavassa asemassa ovat valtio sekä pankkien ja teollisuuden yhteenliittymät. ${ }^{35}$

Hallin ja Soskicen kirja mainitsee Ranskan esimerkkinä kolmannesta tyypistä, valtiojohtoisesta kapitalismista ryhtymättä lähemmin tarkastelemaan sitä. Vivien Ann Schmidt (2002) käsittelee valtiojohtoista kapitalismia omana tyyppinään. Hän erottelee kolme erilaista eurooppalaisen nykykapitalismin tyyppiä: "markkinakapitalismi" (joka vastaa "liberaalia markkinakapitalismia" Hallin ja Soskicen teoksessa), "hallinnoitu kapitalismi" (joka vastaa "koordinoitua markkinakapitalismia" Hallin ja Soskicen teoksessa) sekä "valtiokapitalismi". Viimeksi mainitussa tyypissä valtio on keskeinen yritystoiminnan harjoittaja tai se ohjailee laajasti talouselämää. Länsi-Euroopassa Ranska on selvin valtiojohtoisen kapitalismin edustaja, ja monet muutkin Välimeren maat (Espanja, Italia, Kreikka, Portugali) ovat lähellä sitä. Euroopan ulkopuolella tyypin piiriin ovat 2000-luvun alusta viime vuosiin asti kuuluneet Argentiina, Brasilia, Uruguay ja Venezuela, jotka ovat vaihtelevalla menestyksellä pyrkineet yhdistämään toisiinsa poliittisen demokratian ja valtion vahvan roolin talouselämässä. Toisaalta Vladimir Putinin johtama Venäjä, samoin kuin Turkki ja Unkari ovat sekoitus puoliautoritaarista poliittista järjestelmää ja valtiojohtoista kapitalismia. Kiina on puolestaan selvin esimerkki autoritaarisen poliittisen järjestelmän ja valtiokapitalismin yhdistelmästä. ${ }^{36}$

Edellä kuvatusta moninaisuudesta huolimatta Yhdysvallat on hallinnut nykyistä globaalia talousjärjestystä. Se on esimerkiksi dominoinut Kansainvälistä valuuttarahastoa ja Maailmanpankkia, joissa päätökset on tehty "dollari per ääni" -periaatteella ja joissa Yhdysvallat on halutessaan voinut estää minkä tahansa epämieluisana pitämänsä hankkeen etenemisen. Maailman kauppajärjestö on toiminut hieman demokraattisemmin, mutta senkin jäseniksi tultuaan Intia (I995) ja Kiina (200I) ovat joutuneet tinkimään protektionismistaan ja avaamaan talouttaan ulkomaiselle pääomalle. Nykyisessä maailmanjärjestyksessä perinteiset valtiokeskeiset maat ovat siten joutuneet muuntumaan kohti anglo- 
amerikkalaista yhteiskuntamallia. Euroopassa tämän mallin keskeinen ylläpitäjä on ollut Euroopan unioni alaorganisaatioineen. Se on pyrkinyt luomaan Euroopasta yhtenäisen markkina-alueen, jonka sisällä pätee tavaroiden, palvelujen, työvoiman ja pääoman vapaan liikkumisen periaate. ${ }^{37}$

David Harvey (2008, 26, I47), Heikki Patomäki (2007, 267) ja Thomas Piketty (20I6) ovat esittäneet, että uusliberalismia ei tule pitää ratkaisuyrityksenä nykymaailmaa vaivaaviin ongelmiin vaan enemmänkin pyrkimyksenä kääntää historian pyörä taaksepäin klassisen markkinakapitalismin kauteen. Tämä väite pitää ainakin sikäli paikkansa, että uusliberalismi on pyrkinyt lakkauttamaan sen, mitä työväenliike ja vasemmisto I900-luvulla saavuttivat: vahvan ammattiyhdistysliikkeen, laajan hyvinvointivaltion ja vasemmiston keskeisen roolin valtioiden harjoittamassa politiikassa. Klassisesta markkinakapitalismista poiketen nykykapitalismi ei silti tule toimeen ilman aktiivista valtiota. Laajan hyvinvointivaltion kauteen verrattuna valtion rooli on tosin muuttunut, sillä valtio ei enää toimi ensi sijassa demokratian, hyvinvoinnin ja yhteiskunnan kiinteyden turvaajana. Sen päätehtävä liittyy nykyisin kansallisen kilpailukyvyn ylläpitämiseen. Tätä tehtävää toteuttaessaan valtio on Philip G. Cernyn (I990; 2010), Tore Fougnerin (2006) ja Bob Jessopin (2002; 20I6) mukaan muuttunut kilpailukykyvaltioksi, kun taas Risto Heiskala ja Anu Kantola (20I0) puhuvat tässä yhteydessä valmentajavaltiosta.

Vaikka uusliberalistisen ideologian alkuperäiset kehittäjät halusivat minimoida valtion roolin talouselämässä, ı980- ja I990-luvulla vallalle tullut uusliberalistinen maailmanjärjestys on ollut riippuvainen vahvasta ja aktiivisesta valtiosta, erityisesti siitä syystä, että miltei kaikkialla juuri valtio on osoittautunut talouselämää hyödyttävän kansallisen innovaatioja tiedepolitikan keskeiseksi koordinoijaksi ja rahoittajaksi. Osittain juuri siksi 2000-luvulla yleistyneet puheet uudesta valtiokeskeisyyden (neo-statism) aikakaudesta ovat perusteltuja (vrt. Schmidt, Vivien Ann $2016,5)$.

Kansallisen kilpailukyvyn politiikan konkreettiset ilmenemismuodot ovat jossain määrin vaihdelleet eri maissa. Bernd Belina (20II, 90) ja Manuel Castells $(2000,142)$ toteavat, että Yhdysvallat on ajanut kan- 
sallista etuaan nimenomaan pyrkimällä saattamaan "vapaan markkinatalouden" toimintaperiaatteet vallitseviksi kaikkialla maailmassa. Amerikkalaiset suuryritykset ja poliittiset johtajat ovat nimittäin ajatelleet, että hyödyn tästä tulevat lopulta korjaamaan amerikkalaiset yritykset, jotka ovat - näin amerikkalainen eliitti on olettanut - ylivertaisia ulkomaisiin yrityksiin nähden ja jotka voivat nojautua tehokkaaseen amerikkalaiseen tutkimus- ja kehitystyöhön. Näin tehdessään Yhdysvallat on samalla määrittänyt reunaehdot sille, miten taloudellista kilpailua maailmanjärjestelmässä käydään.

\section{Alustava kuvaus tutkimuskohteena olevista romaaneista}

Seppälän vuosina 2000-20I2 ilmestyneistä teoksista intensiivisimmin edellä kuvattua kehitystä arvioivat Yhtiökumppanit (2002), Routavuosi (2004e) ja Paholaisen haarukka (2008). Romaaneissa Ei kenenkään maa (2006a) ja Mr. Smith (20I2) tämä ulottuvuus ei ole mukana yhtä ilmeisellä tavalla, mutta jälkimmäisessä teoksessakin kertojat ja keskushenkilöt esittävät toteavan puhetyylinsä avulla havaintoja ja väittämiä kapitalismista ja sen luonteesta.

Routavuosi ja Ei kenenkään maa eivät ole tämän tutkimuksen varsinaisina tutkimuskohteina. Routavuosi edustaa poliittista romaania, yhteiskunnallisen romaanin yhtä alalajia. Sen sukulaisteoksena, ehkä myös intertekstinä voi pitää Fjodor Dostojevskin kertomusta Kirjoituksia kellarista (venäjänkielinen alkuperäisteos ilmestyi I864). Molemmissa päähenkilönä on sosiaalisesti erakoitunut, hermoherkkä mies, joka esittää toisinaan teräviä havaintoja todellisuudesta, mutta tuottaa niiden vastapainoksi myös maailmaa koskevia epätavallisia ja houreenomaisia kuvitelmia. Niinpä Routavuodessa läheiset (päähenkilön isä ja naisystävä) epäilevät päähenkilön, poliittisen historian opiskelijan Kaarlen mielenterveyttä, kun taas Kaarle itse leikittelee ajatuksella, että hullussa maailmassa vain hulluiksi leimatut ihmiset kykenevät näkemään maailman oikean luonteen: "Minulla oli kiusausta uskoa teoriaan, jonka mukaan hullut eivät ole hulluja, vaan hullun maailman rinnalla vain näyttävät siltä, koska maailmalla tarkoitetaan enemmistöä” (Seppälä 2004e, 97). 
Kaarlen mielessä maailman sisäinen järkevyys on murskautunut markkinavoimien jalkoihin. Hän syyttää näiden voimien irtipääsystä Euroopan unionia ja vetää samalla yhtäläisyysmerkit autonomian kaudella toteutetun Suomen venäläistämispolitiikan ja Suomen Euroopan unioniin liittymisen välille. Molemmat merkitsevät hänelle Suomen itsenäisyyden alasajoa. Siksi Kaarle samaistuu Igoo-luvun alun aktivisteihin, erityisesti Lennart Hohenthaliin eli Erik Alfvéniin, joka kantaa romaanissa nimeä Eric ja jonka vanhat muistiinpanot ja kirjoitukset Kaarle hankkii käyttöönsä. Samoin kenraalikuvernööri Nikolai Bobrikovin ampunut Eugen Schauman esiintyy romaanin henkilövalikoimassa. Kaarlen inho Suomen EU-politiikkaa ja sen toteuttajia, "demareita", kohtaan kasvaa romaanissa niin suureksi, että yhä sekavammaksi käyvässä mielessään hän suunnittelee vastustavansa sitä terroritekojen avulla. ”Demareista" puhuessaan hän ei viittaa pelkästään sosialidemokraatteihin vaan kaikkiin niihin ryhmittymiin, jotka ovat antautuneet globaalien markkinavoimien edessä:

Oli vain yhtä suurta demaripuoluetta yhdistävä myöntyvyys pääomien vapaalle liikkuvuudelle, kansalaisten oikeuksista luopumiselle keinottelijoiden ja ylikansallisten yhtiöiden hyväksi, palkkojen, sosiaaliturvan tason ja ympäristösäännösten kutistamiselle kansainvälisen kaupan vuoksi ja yhdenmukaiselle kulutuskulttuurille. (Seppälä 2004e, I52.)

Kaarle hahmottaa siis vihollisekseen poliittisen enemmistön. I980ja I990-luvun vaihteesta Routavuoden ilmestymisajankohtaan (2004) saakka kaikki kolme vanhaa pääpuoluetta eli keskusta, kokoomus ja sosialidemokraatit olivat hallitusvastuussa ollessaan ajaneet markkinahenkistä politiikkaa, jonka toteuttajiin kuuluivat myös Paavo Lipposen (SDP) johtamat hallitukset (I995-2003). ${ }^{38}$ Syyttä ei Kaarle toteakaan, että "kun aamulla heräsin, ajattelin ensimmäiseksi kuinka väärässä maailma oli” (Seppälä 2004e, 95). Vaikka Kaarle ei toteuta terroristisia aikeitaan maailmaa kohtaan, romaani päättyy seesteiseen kuvaan Eugen Schaumanista ja tämän tekemän poliittisen murhan merkityksestä Suomen tulevaisuudelle. ${ }^{39}$ 
Routavuoden kerronta perustuu tarinamaailman ulkopuolisen kertojan ja tarinamaailman sisäpuolisten minäkertojien vaihteluun. Kaarle on sen keskeisin minäkertoja. Häntä voi pitää kertojana epäluotettavana, sillä hänen tapansa kohdella läheisiään, esimerkiksi naisystäväänsä, osoittautuu romaanissa moraalisesti kyseenalaiseksi ja romaanin edetessä hän näyttää myös menettävän todellisuudentajunsa. Takertuessaan epätoivoisesti kansalliseen historiaan ja sen merkkihenkilöihin EU:ta ja globalisaatiota vastustava Kaarle tulee lähelle populistista nationalismia. Äärioikeistolaisuutta ja muukalaisvihamielisyyttä hänen ajatteluunsa ei silti sisälly: hänen vihansa kohdistuu EU:n byrokraattiseen koneistoon ja kotimaiseen taloudellis-poliittiseen eliittiin, ei Suomeen saapuneisiin maahanmuuttajiin.

Tällaista Kaarlelle ominaista EU-kritiikkiä ja nationalismia on esiintynyt myös poliittisen vasemmiston piirissä, ja muista nykykirjailijoista esimerkiksi Sirkku Peltola ja Hannu Salama ovat olleet sitä lähellä. Esimerkiksi näytelmässään Suomen hevonen (2006) Peltola kritisoi EU:n maatalouspolitiikkaa, ja Salaman romaaneissa Elämän opetuslapsia I-IV (1997-2006) ja Sydän paikallaan (2010) jatkuvan piikittelyn kohteena on paitsi EU myös siihen sitoutunut suomalainen taloudellis-poliittinen eliitti. Eurooppalaisen vasemmistoälymystön piirissä suhtautuminen EU:hun ei kuitenkaan ole ollut ehdottoman torjuvaa. Esimerkiksi Habermasin (2OI2, ix, IO2-IO3, IIO, I25) mukaan EU:n toimintaan liittyviä ongelmia ei voida ratkaista yrittämällä palata takaisin itseään suojeleviin kansallisiin yksiköihin vaan kehittämällä Euroopan mitassa kansalaisyhteiskuntaa ja lisäämällä kansalaisten vaikutusmahdollisuuksia EU:n sisällä. Habermasin reseptinä on näin ollut vaatimus, että EU:n tulee jalkautua poliittisen eliitin ja suuryritysten ajamasta hankkeesta ensi sijassa tavallisten kansalaisten hankkeeksi.

Routavuoden pääteemana ei ole markkinakapitalismin leviäminen yhteiskuntaan. Sen sijasta se käsittelee EU:n ja kansallisvaltioiden välistä suhdetta sekä terrorismille myönteisen mielenlaadun syntymistä EU:hun ja globaaliin kapitalismiin tyytymättömissä ihmisissä. Ei kenenkään maa on Routavuotta ohuemmin yhteiskunnallinen romaani. Sen yhtenä teemana on konflikti aiemman sosiaalisen järjestyksen ja markkinakäyttäytymisen leviämisen välillä, minkä lisäksi siinä tärkeäksi nou- 
see eksistentiaalinen ulottuvuus. Keskushenkilönä romaanissa on pian eläkkeelle siirtyvä seurakuntayhtymän puistopäällikkö Matti Hirvonen, joka vastaa seurakuntansa hautausmaiden kunnosta ja ulkoasusta. Hänelle hautausmaat edustavat "pyhyyden järjestelmää" ja "Jumalan puistoa" (Seppälä 2006a, 52, 72). Hautausmaat ovat, näin hän ajattelee, paikka perustavanlaatuisille pohdiskeluille, sillä niiden "kauneuden keskellä ihmiset muistavat poisnukkuneita omaisiaan, pohtivat olemassaolon syvimpiä kysymyksiä ja tekevät tiliä itsensä ja Jumalan kanssa” (ibid., 75). Näin ylläpidetyn pyhyyden sosiaalisen järjestyksen uhkana toimii romaanissa sekalainen yrittäjä Kosti Grundsten, joka Hirvosen tyrmistykseksi aikoo tehdä voimaperäisesti bisnestä hautakivien kunnostamisella. Kun tällainen toiminta ei osoittaudu tuottoisaksi, Grundsten ryhtyy perustamaan internettiin virtuaalista hautausmaata.

Näiden henkilöiden välistä ristiriitaa kehitellessään sisäistekijä ja tarinamaailman ulkopuolinen anonyymi kertoja eivät asetu kummankaan puolelle. Kertojan puheessa tulee painotetusti esiin vanitas-motiivi, ajatus kaiken inhimillisen toiminnan perimmäisestä turhuudesta ja katoavaisuudesta. Tämän motiivin perusta ei ole romaanissa uskonnollinen vaan lähinnä geofyysinen, sillä kerrontajaksoissaan samainen kertoja pohdiskelee tähtien ja planeettojen syntyä ja tuhoutumista sekä sitä, millaisia tuhoisia seurauksia mahdollisella komeetan tai asteroidin maahansyöksyllä olisi maapallolle ja ihmiselämälle. Tästä näkökulmasta Hirvosen ja Grundstenin toimet näyttävät huvittavan vähämerkityksisiltä. Näiltä osin Ei kenenkään maa tulee lähelle inhimillisiä heikkouksia ja inhimillisten tekojen pinnallisuutta käsitteleviä satiireja, jos kohta sen perussävy ei olekaan purevan ivallinen vaan pikemminkin humoristinen ja ironisen myötäelävä (vrt. Kivistö 2007b, 9-10, I3-I4, I7-23).

Yhtiökumppanit, Paholaisen haarukka ja Mr. Smith eroavat Routavuodesta ja Ei kenenkään maasta siinä, että ne keskittyvät käsittelemään kapitalismin uusia, I980- ja I990-luvulla yleistyneitä toimintamuotoja. Yhtiökumppaneissa tapahtumien keskuspaikkana on verkkomainontaa tuottava yritys, joka laajentaa toimintansa peliteollisuuden pariin. Kyseessä on siis "informationaalisen kapitalismin" tai "luovan talouden" alueella toimiva yritys. Tosin romaani itse ei käytä näitä käsitteitä, jotka olivat tuolloin vasta tulossa yleiseen kielenkäyttöön. Niiden sijasta se pu- 
huu "sisällöntuotannosta" hyödyntäen näin käsitettä, jota on niin ikään käytetty usein puhuttaessa nykytalouden mukanaan tuomista uusista toimintamuodoista. Yhtiökumppanit ei käsittele laajasti markkinakapitalismin leviämistä yhteiskunnan eri osa-alueille, mutta se kiinnittää huomiota niihin vaikutuksiin, joita talouden uusilla toimintamuodoilla on niin yksilöihin kuin heidän keskinäisiin suhteisiinsakin.

Paholaisen haarukka on sikäli Yhtiökumppaneita laajempi yhteiskunnallinen romaani, että se käsittelee myös yhteiskunnan eri osa-alueiden markkinallistumista ja niiden muuntumista talouselämän erityislaatuisiksi haaraumiksi tai siihen läheisesti kytköksissä oleviksi sosiaalisen toiminnan alueiksi. Romaanin päähenkilö, sijoitusneuvoja ja varallisuudenhoitaja Lari Laine, tarkastelee maailmaa pankki- ja finanssipääoman näkökulmasta, nykykapitalismin keskuksesta käsin. Hän elää ja toimii maailmassa, jossa myös "julkishallinto piti saada muistuttamaan kilpailullisia markkinoita" (Seppälä 2008, 69) ja jossa terveydenhoito ja korkeampi koulutus on sidottu kiinteästi taloudelliseen arvonmuodostukseen. Näin Paholaisen haarukka esittää nyky-yhteiskunnan pitkälle markkinallistuneeksi muodostumaksi, jossa markkinoiden ulkopuolinen alue on kutistunut lähes olemattomaksi.

Taloussosiologi Patrik Aspers (20II, 58-59) huomauttaa, että markkinallistumiseen liittyy sosiaalisten suhteiden muodollistumista. Tämä selittyy sillä, että markkinallistuminen depersonalisoi ihmissuhteita, muuttaa niitä asiakassuhteiksi. Näin tapahtuu myös Paholaisen haarukassa, jonka yhtenä teemana on ihmisten välinen kohtaamattomuus, ihmisten kyvyttömyys eläytyä toistensa maailmoihin ja näkökantoihin. Kriittinen ajattelu ei ole silti sen maailmassa kokonaan kuollut. Sitä edustaa lähinnä elokuvaohjaaja Laura Laine, Lari Laineen sisar, joka tekee elokuvaa vieraantumisesta ja syrjäytymisestä. Hänet kuvataan poikkeukselliseksi taiteilijaksi, sillä romaanin maailmassa markkinallistuminen on edennyt myös kulttuurituotannon alueelle ja muuntanut sen kasvavassa määrin viihdeteollisuuden haaraumaksi.

Paholaisen haarukka on myös Yhtiökumppaneita historiallisempi romaani, sillä se sisältää viittauksia kapitalismin edeltävään vaiheeseen, perinteisen teollisuuskapitalismin aikakauteen. Romaanissa esiintyvä "Jumalan Kyyneleksi" kutsuttu henkilö, työväenluokan alimpaan kastiin 
tai kerrostumaan kuulunut mies, oli teollisuuskapitalismin aikaan töissä erään konepajan levyhallissa. Tuossa vaiheessa yhteiskunnalliset valta- ja alistussuhteet olivat vielä paljolti arkiajattelun tavoitettavissa. Samoin työväestö kykeni perinteisen teollisuuskapitalismin oloissa ylläpitämään yhteisöllisyyden tunteita ja muotoja. Seuraavassa sitaatissa äänessä on tarinamaailman ulkopuolinen kertoja, mutta kerronta fokalisoi levyhallin työyhteisöä paljolti Jumalan Kyyneleen näkökulmasta:

Konepaja oli ollut yhteisö.

Erityisesti konepajan levyhalli oli ollut yhteisö. Siinä oli kovapalkkaisia urakkamiehiä, lähinnä levyseppiä ja joitakin kokeneempia polttoleikkaajia ja hitsaajia, mutta siinä yhteisössä kukin tunsi saavansa ansionsa mukaan. Elleivät aina oikealla, kaikki hallissa olivat kuitenkin samalla puolella. Tummansinisissä haalareissaan ja harmaissa kypärissään he näyttivät sotilailta, amerikkalaisilta kersanteilta, merijalkaväen miehiltä.

Kaikki tiesivät, kenellä oli valta ja ketä piti vihata.

He tiesivät, kuka heidän vihollisensa oli, ja se tiesi, keitä he olivat. Miaxan, Ludiomil, Xanor.

Kaikkien vihan kohde oli sama, siitä huolimatta, että se maksoi heidän palkkansa. Kun he kello kuusitoista seisoivat pitkässä kellokorttijonossa, kun enää muutamat valtavan hallin sinisistä hitsiliekeistä suhisivat ja kun Jumala lopulta salli myös lestadiolaisen levysepän tehtaan pillin huutaessa oikaista selkänsä, he kaikki olivat samalla puolella.

Kun kahdeksan tunnin tilapäinen kuolema oli tilapäisesti ohi.

Nyt kukaan ei tiennyt.

Kaikki oli sotkettu, sekoitettu kuin maiseman värit sateen raiskaamassa ikkunaruudussa. (Seppälä 2008, IO-II.)

Sitaatin kuvaamassa tilanteessa vallitsee vastakohta yhteisöllisen ja arkiajattelulle avautuneen teollisuuskapitalismin sekä nykyisen globaalin markkinakapitalismin välillä. Tämän siirtymän myötä perinteiset teollisuustyöpaikat ovat kadonneet "Kiinaan, Viroon tai Romaniaan" (Seppälä 2008 , I2). Samalla työelämästä ja yhteiskunnasta on rapautunut yhtei- 
söllisyys ja maailma on muuttunut arkiajattelulle käsittämättömäksi. Siirtymä on tehnyt Jumalan Kyyneleestä syrjäytyneen miehen, joka elää turruttamalla mielensä päihteillä sekä Miaxanin, Ludiomilin ja Xanorin kaltaisilla masennuslääkkeillä. Oheisen sitaatin perusteella Seppälän kapitalismikriittiset romaanit on siten ensi tuntumalta syytä nähdä nimenomaan nykyisen markkinakapitalismin kritiikiksi. Kysymystä siitä, missä määrin ne voidaan ymmärtää kaikenlaisen kapitalismin kritiikiksi, tarkastellaan lähemmin myöhemmissä luvuissa.

Edeltäjiensä tavoin Mr. Smith käsittelee nykytaloudelle ominaisia toimintamuotoja. Romaanin keskushenkilö Mr. Smith on konsultti ja riskienhallinnan ammattilainen, jonka omistama yritys on menestynyt hankkeissaan taloudellisesti hyvin. Itseymmärryksessään hän katsoo päässeensä finanssikapitalismin eli "rahoitusmarkkinoiden helmoihin" (Seppälä 20I2, IO6) ja olevansa siksi turvassa tulevien talouskriisien puhjetessa - itsemääritys, jota romaanin kokonaisuus ei liiemmälti aseta kyseenalaiseksi. Mr. Smithissä historiallinen näkökulma kapitalismiin avautuu paljolti "herra Schmidtin" mukaan nimettyjen kerrontajaksojen kautta. Niissä Smith konstruoi isoisälleen herra Schmidtille elämäkerran, jossa hän kuvaa sitä, millaista tämän elämä ja liiketoimet todennäköisesti olivat ı900-luvun alkuvuosikymmenten Venäjällä ja Suomessa. Vaikka nuo jaksot on kerrottu minämuodossa - mikä antaa vaikutelman siitä, että niissä kuuluisi Smithin isoisän oma ääni -, romaanin alussa niiden kirjoittajaksi osoitetaan Smith. Nämä herra Schmidtin mukaan nimetyt jaksot ovat kiinnostavia siksi, että niistä välittyy tietty kuva kapitalismista sellaisena kuin se oli Venäjällä ja Suomessa klassisen markkinaliberalismin kauden loppuvaiheessa I900-luvun alkuvuosikymmeninä.

Kapitalismin historiallisia muodonmuutoksia Mr. Smith valottaa myös Erno Mannisen ja hänen isänsä Orvo Mannisen kautta. Orvo Manninen, eläkkeelle siirtynyt maakuntalehden päätoimittaja, ihmettelee toistuvasti media-alalla tapahtuneita muutoksia ja kokee alalla yleistyneen kaupallisuuden ja "sosiaalipornon" tympeäksi (Seppälä 20I2, 83). Toisaalta hänen poikansa Erno, "teatteritieteen maisteri", on mukautunut tähän muutokseen, sillä tämä vaihtoi aikoinaan journalismin opintonsa teatteritieteen opintoihin ja siirtyi sitten myöhemmin luovan 
talouden ydinalueelle, ICT-alalle, kehittämään älypuhelimia ja niiden sovelluksia. Nykyiselle "luovalle taloudelle" ominaisia toimintamuotoja edustaa romaanissa myös Erkka Torro, joka on luonut kaupallisesti menestyksellisen uran suuren yleisön rakastamana viihdekirjailijana.

Kaikkien edellä mainittujen romaanien eli Yhtiökumppaneiden, Paholaisen haarukan ja Mr. Smithin keskushenkilöt edustavat lähinnä ylempiä luokkia. Nämä romaanit eivät siten ole ensi sijassa kuvauksia siitä, millaisen riiston ja hyväksikäytön kohteeksi alemmat luokat joutuvat nykyisin tai millaista taloudellis-sosiaalista eriarvoisuutta nykykapitalismi synnyttää. Pikemminkin ne käsittelevät nykykapitalismia yleisemmällä tasolla ja nostavat esiin ongelmia, joista myös ylempien luokkien edustajat saattavat kärsiä nyky-yhteiskunnassa.

Edellä mainittujen romaanien henkilövalikoimaa voi verrata yhteiskuntatieteiden tarjoamaan kuvaan suomalaisen yhteiskunnan luokkarakenteesta. Jani Erolan toimittamassa tutkimuksessa Luokaton Suomi? Yhteiskuntaluokat 2000-luvun Suomessa (2010) luokkajaon kriteereinä käytetään sitä, millaisessa ammatissa henkilö toimii, kuinka itsenäistä hänen työntekonsa on, missä määrin hänen työntekoaan valvotaan ja millaista erityisosaamista se vaatii. Tällä perusteella kyseinen tutkimus erottaa toisistaan ylemmät professioammatit ("yläluokka", esimerkiksi yritysten omistajat ja toimitusjohtajat, kansanedustajat, tuomarit ja lääkärit), alemmat professioammatit ("ylempi keskiluokka", esimerkiksi opettajat, tutkijat, asiantuntijat ja osa kirjailijoista ja taiteilijoista), toimistotyöntekijät ("keskiluokka", esimerkiksi alemmat pankkitoimihenkilöt ja sihteerit), yksityisyrittäjät (pienyrittäjät, käsityöläiset), maanviljelijät ja työväestön, joista työväestö jakautuu ammattitaitoiseen työväestöön (kirvesmiehet, muurarit, työnjohto), asiakaspalvelun työntekijöihin (sairaanhoitaja, tarjoilija, kaupankassa, kampaaja) ja muuhun työväestöön (koneenhoitaja, varastotyöntekijä). Tällainen jaottelu perustuu ulkoisiin, havaittavissa oleviin tunnusmerkkeihin. Se sivuuttaa henkilöiden subjektiivisen luokkasamaistumisen, siis sen, mihin luokkaan he itse katsovat kuuluvansa. Tämä puoli, samoin kuin ihmisten tapa kokea yhteiskunnallinen todellisuus, jää kyseisessä jaottelussa tarkastelun ulkopuolelle. Koska kirjallisuus välittää informaatiota juuri ihmisten kokemusmaailmoista ja subjektiivisesta ulottuvuudesta, oheinen jaottelu 
antaa varsin karkean apuvälineen luokkaproblematiikan tarkastelemiselle Seppälän teoksissa ja nykykirjallisuudessa. Suurista väestöryhmistä puhuttaessa tällaiset jaottelut ovat silti välttämätön vaihe, jotta tutkimus aiheesta voi edetä.

Taulukko I. Suomalaisten 25-83-vuotiaiden luokka-asema vuosina I970 ja 2000

\begin{tabular}{|c|c|c|c|c|c|c|}
\hline Luokka & $\begin{array}{l}\text { Esimerkki- } \\
\text { ammatteja }\end{array}$ & $\begin{array}{l}\text { Arkikielinen } \\
\text { nimitys }\end{array}$ & $\begin{array}{l}\text { Naiset } \\
\text { I970 }\end{array}$ & $\begin{array}{l}\text { Naiset } \\
2000\end{array}$ & $\begin{array}{c}\text { Miehet } \\
\text { I970 }\end{array}$ & $\begin{array}{c}\text { Miehet } \\
2000\end{array}$ \\
\hline $\begin{array}{l}\text { I } \\
\text { Ylemmät } \\
\text { professio- } \\
\text { ammatit }\end{array}$ & $\begin{array}{l}\text { Tuomari, lääkäri, } \\
\text { ylempi johtaja, } \\
\text { kansanedustaja }\end{array}$ & $\begin{array}{l}\text { Eliitti, } \\
\text { yläluokka }\end{array}$ & 2 & 5 & 7 & I2 \\
\hline $\begin{array}{l}\text { II } \\
\text { Alemmat } \\
\text { professio- } \\
\text { ammatit }\end{array}$ & $\begin{array}{l}\text { Opettaja, tutkija, } \\
\text { kirjailija ja asian- } \\
\text { tuntija }\end{array}$ & $\begin{array}{l}\text { Ylempi } \\
\text { keskiluokka }\end{array}$ & IO & 22 & I5 & 23 \\
\hline $\begin{array}{l}\text { IIIa } \\
\text { Toimisto- } \\
\text { työntekijät }\end{array}$ & $\begin{array}{l}\text { Alempi pankki- } \\
\text { toimihenkilö, } \\
\text { sihteeri }\end{array}$ & $\begin{array}{l}\text { (Alempi) } \\
\text { keskiluokka }\end{array}$ & 8 & I4 & o & I \\
\hline $\begin{array}{l}\text { IIIb } \\
\text { Asiakas- } \\
\text { palvelun } \\
\text { työntekijät }\end{array}$ & $\begin{array}{l}\text { Sairaanhoitaja, } \\
\text { tarjoilija, kaupan- } \\
\text { kassa, kampaaja }\end{array}$ & $\begin{array}{l}\text { Työtätekevät, } \\
\text { köyhät, } \\
\text { alaluokka }\end{array}$ & 28 & 27 & 4 & 4 \\
\hline $\begin{array}{l}\mathrm{IVa+b} \\
\text { Yksityis- } \\
\text { yrittäjät } \\
\end{array}$ & $\begin{array}{l}\text { Pienyrittäjät, } \\
\text { käsityöläiset }\end{array}$ & Pienporvaristo & 4 & 6 & 7 & IO \\
\hline $\begin{array}{l}\text { IVc } \\
\text { Maan- } \\
\text { viljelijät }\end{array}$ & & & I7 & 5 & I6 & 6 \\
\hline $\begin{array}{l}\text { V-VI } \\
\text { Ammatti- } \\
\text { taitoinen } \\
\text { työväestö }\end{array}$ & $\begin{array}{l}\text { Hitsari, } \\
\text { kirvesmies, } \\
\text { muurari, } \\
\text { työnjohto } \\
\end{array}$ & & 7 & 5 & 25 & 23 \\
\hline $\begin{array}{l}\text { VIIa } \\
\text { Muu } \\
\text { työväestö }\end{array}$ & $\begin{array}{l}\text { Koneenhoitaja, } \\
\text { varastotyöntekijä }\end{array}$ & $\begin{array}{l}\text { Työtätekevät, } \\
\text { köyhät, } \\
\text { alaluokka }\end{array}$ & 24 & I5 & 22 & 20 \\
\hline \multirow[t]{2}{*}{$\begin{array}{l}\text { VIIb } \\
\text { Muu } \\
\text { työväestö } \\
\text { maatalou- } \\
\text { dessa } \\
\end{array}$} & $\begin{array}{l}\text { Metsuri, } \\
\text { kalastaja, } \\
\text { eläintenhoitaja }\end{array}$ & $\begin{array}{l}\text { Työtätekevät, } \\
\text { köyhät, } \\
\text { alaluokka }\end{array}$ & o & I & 4 & I \\
\hline & & & $100 \%$ & $100 \%$ & $100 \%$ & $100 \%$ \\
\hline
\end{tabular}

Lähde: Erola 20ıоb ja 20Iоc; Sevänen 20ıза. 
Taulukkoa I tulkittaessa merkittävä seikka liittyy maanviljelijöiden ja työväestön vähenemiseen ja professioammattien (luokat I ja II) osuuden kasvuun. Kun vielä kauan toisen maailmansodan jälkeen Suomi oli leimallisesti maanviljelijöiden ja työväestön, ruumiillista työtä tekevien ihmisten maa, vuoteen I970 mennessä maanviljelijöiden osuus oli pudonnut I6 prosenttiin ja vuoteen 2000 mennessä noin viiteen prosenttiin. Työväenluokan suhteellisen osuuden vähenemisestä huolimatta suomalaiselle yhteiskunnalle oli vielä vuonna 2000 ominaista verraten laaja työväenluokka. Mikäli työväenluokkaan sijoitetaan luokkien V-VIIa\&b ohella asiakaspalvelun työntekijät eli luokka IIIb, vuonna 2000 työväenluokan osuus oli sekä naisista (48\%) että miehistä (48\%) hieman alle puolet; vuonna I970 naisten osuus oli puolestaan 59 prosenttia ja miesten osuus 55 prosenttia. Samaan aikaan professioammattien (luokat I ja II) edustajien suhteellinen osuus on kasvanut niin naisten kuin miestenkin puolella: naisten puolella I2 prosentista 27 prosenttiin ja miesten puolella 22 prosentista 35 prosenttiin. Tässä mielessä kaksi ylintä luokkaa ovat vallanneet lisää alaa suomalaisessa yhteiskunnassa kapitalismin muodonmuutoksen myötä.

Samaan aikaan luokkien väliset suhteet ovat jäsentyneet toisessakin mielessä uudella tavalla. Nyky-yhteiskunnassa eri ammatit ovat lähentyneet toisiaan, sillä niistä monissa tarvitaan muodollista koulutusta, kielitaitoa, tietotekniikan hallitsemista ja sosiaalisia taitoja. Näin eri ammatit edellyttävät osittain samanlaisia taitoja, eikä ammattiryhmien tai luokkien väliltä välttämättä myöskään löydy elämäntavan suhteen suuria eroja. (Ks. Melin 2oıo.) Kaksi luokkaa poikkeaa silti tästä kuvasta. Uusliberalistisen politiikan seurauksena ylin luokka (luokka I, ylemmät professioammatit) on kasvattanut merkittävästi tulojaan, minkä vuoksi se muodostaa Suomessa nykyisin etuoikeutetun luokan. Toisaalta suomalaiseen yhteiskuntaan on muodostunut suhteellisesta köyhyydestä kärsivien ihmisten kerrostuma, johon kuuluvat ihmiset edustavat lähinnä työväestöä, mutta osa heistä on pienyrittäjiä tai jopa ylimpien ammattiryhmien edustajia (Erola 20IOb; 20IOc). Suhteellisesti köyhinä pidetään ihmisiä, joiden tulot ovat alle $60 \%$ ihmisten keskimääräisestä tulotasosta. Vuonna 2007 tällaisia ihmisiä oli Suomessa I4 \% väestöstä, ja yksinhuoltajaperheiden lapsista peräti kolmannes (32\%) eli tuolloin 
suhteellisen köyhyysrajan alapuolella (Julkunen 20ı0). Koska pääosa yksinhuoltajista on naisia, yksinhuoltajuuteen liittyvä köyhyys on vahvasti sukupuolittunut ilmiö.

Sivuuttaessaan ihmisten omat luokkaidentifikaatiot ja heidän tapansa kokea asemansa yhteiskunnassa taulukko I vaikenee niistä asioista, joista kirjallisuus on perinteisesti tarjonnut tietoa. Tätä puolta, ihmisten identifikaatioita ja kokemistapoja on käsitelty jonkin verran uudemmassa luokkatutkimuksessa. Tärkeitä tutkimuksia tässä suhteessa ovat AnuHanna Anttilan, Ralf Kaurasen, Kati Launiksen ja Jussi Ojajärven Luokan ääni ja hiljaisuus. Yhteiskunnallinen luokkajärjestys 2000-luvun alun Suomessa (20I6) sekä Anu Kantolan ja Hanna Kuuselan Huipputuloiset. Suomen rikkain promille (20I9, ilmestyi alun perin 20I8). Niistä edellinen käsittelee köyhien ja syrjäytyneiden ihmisten kokemusta omasta elämäntilanteestaan ja jälkimmäinen tarkastelee Suomen rikkaimman väestökerrostuman vaurauden perustaa ja sen yhteiskuntakuvaa ja arvomaailmaa. Yhdessä Erolan toimittaman tutkimuksen kanssa ne muodostavat mielekkään vertailukohdan Seppälän romaaneille, sillä Seppälän teoksetkin käsittelevät yhtäältä ylempien luokkien ja syrjäytymisvaarassa olevien ihmisten tilannetta ja toisaalta näihin sosiaalisiin kerrostumiin kuuluvien ihmisten tapaa kokea elämänsä markkinalogiikan hallitsemassa nyky-yhteiskunnassa.

Tällaisessa vertailussa on toki omat ongelmansa. Niistä keskeisin liittyy siihen, että Seppälän romaanien tapa kuvata henkilöitään on modernille kirjallisuudelle tyypillinen eli paljolti skemaattinen, luonnosmainen. Niissä jätetään siis mainitsematta tai kertomatta monia sellaisia seikkoja, joiden avulla tutkija voisi määrittää henkilöiden luokka-aseman täsmällisesti. Näillä varauksin sijoitan heidät seuraavaksi suomalaisen yhteiskunnan luokkarakenteeseen. Laatimani kuvaus on vain suuntaa antava tai likimääräinen, sillä edellä mainituista syistä Seppälän romaanihenkilöiden luokka-asemaa ei voida määrittää yksiselitteisesti.

Lähinnä Seppälän romaanien keskushenkilöt edustavat ylempiä ja alempia professioammatteja, siis luokkia I ja II. Tämä pätee Yhtiökumppaneiden Olliin, joka on romaanissa kuvatun yhtiön pääomistaja ja toimitusjohtaja (luokka I). Hänen ystävänsä tai kaverinsa Pete, romaanin keskeisin henkilö, on yhtiön tulospalkattu luottomies, joka on 
lisäksi harjoittanut vuosikausia tuottoisaa sijoitustoimintaa. (Ks. Seppälä 2002, 40-4I, 227.) Koulutuksensa, asemansa ja ammattinsa ("art director", mainosgraafikko) perusteella Pete kuuluu lähinnä luokkaan II, mutta toisaalta sijoitustoiminnassa hankitun varallisuuden ansiosta hän edustaa enemmänkin luokkaa I, "omistavaa luokkaa". Mr. Smithin nimihenkilön luokka-asema on hieman epäselvä. Romaani kertoo hänen johtavan omaa, konsultoimiseen ja riskienhallintaan erikoistunutta "kommandiittiyhtiötään" eli henkilöyhtiötään, jonka kuluista ja veloista hän on siis vastuussa koko omaisuudellaan. "Äänettömänä yhtiömiehenä" tässä kommandiittiyhtiössä toimii "Lötjönen"-niminen mies, joka ei osallistu yhtiön johtamiseen. Hän saa osansa yhtiön tuotosta, mutta toisaalta hän on yhtiön menoista taloudellisesti vastuussa vain yhtiöön sijoittamansa pääoman verran. (Ks. Seppälä 20I2, 20-23, I06.) Romaani jättää auki sen, kuinka iso tämä yritys on ja onko sillä Smithin ja Lötjösen lisäksi muuta palkattua työvoimaa. Muutoin romaani alleviivaa sitä, että Smith on vauras ja menestynyt yrittäjä, joka harjoittaa yhtiönsä kautta myös sijoitustoimintaa ja jonka vauraus perustuu siksi ensi sijassa hänen saamiinsa huomattaviin osinkotuloihin. Näillä varauksin hänet voi sijoittaa luokkaan I.

Yhtiökumppaneiden ja Mr. Smithin keskushenkilöt eivät siten edusta suuryritysten omistajia ja niiden johtoporrasta, mutta toisaalta he eivät myöskään kuulu perinteiseen pienyrittäjäkuntaan (taksiautoilijat, kampaamoalan yrittäjät, parturit, käsityöläiset). Tämän sijasta he edustavat lähinnä suppealla henkilökunnalla toimivia, nykykapitalismissa yleistyneitä yritystoiminnan muotoja (ICT-talous, sijoitustoiminta, konsultointi, riskienhallinta). Paholaisen haarukan Lari Lainetta voidaan puolestaan luonnehtia ekonomistiksi, finanssikapitalismin piirissä toimivaksi ja sen etuihin sitoutuneeksi rahoitusalan ammattilaiseksi, joka toimii työssään varsin itsenäisesti. Romaani antaa niukasti tietoa hänen asemastaan pankkimaailmassa. Mikäli ajatellaan, ettei hän toimi ylemmissä johtotehtävissä (luokka I), hänet voidaan sijoittaa luokkaan II (ylempi keskiluokka).

Ylempien luokkien piiriin kuuluu myös Mr. Smithissä sivuhenkilönä esiintyvä Orvo Manninen (entinen maakuntalehden päätoimittaja); historiallisten anakronismien välttämiseksi hänen luokka-asemaansa mää- 
ritettäessä on Erolan toimittaman kirjan sijasta tukeuduttava suomalaisen yhteiskunnan aiempia kehitysvaiheita käsitteleviin tutkimuksiin. $4^{\circ}$ Tällaisten tutkimusten perusteella makuntalehtien päätoimittajat edustivat omana aikanaan yläluokkaa. Mr. Smithissä nimihenkilön isoisä herra Schmidt, jonka romaani sanoo eläneen vuosina I893-I939, on kauppakoulun käynyt vakuutusasiamies ja liikemies, millä perusteella hänet voidaan sijoittaa keskiluokkaan tai keskiluokan ja yläluokan välimaastoon..$^{4} \mathrm{Mr}$. Smithin henkilöistä Erno Manninen sijoittuu lähinnä luokkaan II, sillä tämä teatteritieteen maisteri toimii suhteellisen itsenäisissä ja vastuullisissa tehtävissä ICT-talouden piirissä, mutta hän ei kuulu kapitalisteihin, omistavaan kerrostumaan. Alempien professioammattien (luokka II, ylempi keskiluokka) tai keskiluokan (luokka III) piiriin kuuluvat Yhtiökumppaneissa Peten ja Ollin yhtiön muut työntekijät, Paholaisen haarukassa ohjaaja Laura Laine, verkkotuottaja Kari Lehtonen ja sosiaalipsykologi Saija Lehtonen ja Mr. Smithissä kirjailija Erkka Torro. Tämän tarkemmin heitä on vaikea luokitella, sillä nämä romaanit antavat niukasti tietoa heidän taloudellis-sosiaalisesta asemastaan ja koulutustasostaan tai heidän työtehtäviensä luonteesta. ${ }^{42}$

Kyseisten romaanien henkilövalikoima on painottunut kahteen tai kolmeen ylimpään luokkaan. Työväenluokkaa ei esiinny Yhtiökumppaneissa käytännössä ollenkaan. Paholaisen haarukassa sitä edustavat Jumalan Kyynel ja taksikuski Klaus. Heistä kumpikaan ei kuulu niin sanottuun ammattitaitoiseen tai asemastaan ylpeään työväestöön. Jumalan Kyynel on irtautunut tuotantoelämästä ja päätynyt syrjäytyneen ja päihderiippuvaisen työläisen asemaan. Klaus puolestaan ajaa "renkinä" taksia muutaman kerran viikossa ja opiskelee muun ajan "maisematutkimusta ja kulttuurituotantoa", minkä ohella hänet on hyväksytty opiskelemaan "Creative Business Management -maisteriohjelmaan" (Seppälä 2008, 20-2I). Mr. Smithissä työväenluokkaa, sen alempaa kerrostumaa, edustavat satunnaisilla työsuhteilla itsensä elättävät, syrjäytymisvaarassa olevat Briscilla ja Rane. Lisäksi romaanissa esiintyy amerikkalaista mustaa työväenluokkaa edustava Donald Southbrook. Hänet kuvataan arvokkuutensa säilyttäneeksi työläiseksi, vaikka hän on menettänyt ensin asuntonsa ja sen jälkeen myös perheensä vuonna 2007 alkaneen pankki- ja finanssikriisin seurauksena; tarinamaailman nykyisyydessä hän 
toimii Erno Manniselle vuokratun työsuhdeasunnon puutarhan ja uimaaltaan hoitajana Yhdysvalloissa. Erno Manninen käyttää Donaldista mielessään nimitystä "Equity”. Seppälän romaaneissa Equity, jonka nimi merkitsee suomeksi sellaisia asioita kuin 'oikeus' ja 'kohtuus', on lähimpänä perinteisen luokkatietoisen työläisen hahmoa.

Ylempiin luokkiin painottuminen tulee esiin myös Seppälän romaanien narratiivisessa rakenteessa. Näissä romaaneissa on useita erilaisia kertojia, mutta heidän joukossaan ei ole alaluokkaisia henkilöitä. Yhtiökumppaneiden kerronta rakentuu kolmen tarinamaailman sisäpuolisen minäkertojan varaan, kun taas Paholaisen haarukassa ja Mr. Smithissä kerrontaa vievät eteenpäin tarinamaailman ulkopuolinen anonyymi kertoja ja joukko tarinamaailman sisäpuolisia, lähinnä ylempiä luokkia ja keskiluokkaa edustavia minäkertojia. Alaluokkaisten kertojien puuttuminen tästä valikoimasta viittaa yleisemmällä tasolla siihen, että kontrollin problematiikka liittyy myös Seppälän teosten kaltaisiin kompleksisiin ja kokeellisia aineksia sisältäviin romaaneihin. Yhteiskunnallisesti suuntautuneessa kertomusteoriassa, esimerkiksi Andrew Gibsonin (I996) ja Mark Selzerin (I984) tutkimuksissa, on esitetty, että nimenomaan perinteinen realistinen, kaikkitietävän kertojan varaan rakentuva romaani edustaa ideologista valvontaa ja kontrollia, sillä siinä kertoja voi vapaan epäsuoran esityksen keinoin puuttua mielin määrin henkilöidensä ajatuksiin ja puheisiin (ks. myös Hägg 20II). Tämän näkemyksen kannattajat ovat usein pitäneet erilaisia kerronnallisia ratkaisuja käyttäviä modernistisia ja postmodernistisia romaaneja tiukasta ideologisesta kontrollista vapautuneina ilmaisumuotoina.

Epäilemättä kaikkitietävä kertoja on Gibsonin ja Selzerin tarkoittamassa mielessä vallankäyttäjä. Paholaisen haarukassa ja Mr. Smithissä tämä vallankäytön ulottuvuus ilmenee varsinkin niissä jaksoissa, joissa tarinamaailman ulkopuoliset anonyymit kertojat kuvaavat alaluokkaisia henkilöitä. He eivät näytä luottavan siihen, että nuo henkilöt (Jumalan Kyynel Paholaisen haarukassa; Briscilla, Rane ja Donald Southbrook Mr. Smithissä) kykenisivät itse reflektoimaan tilannettaan. Sen sijasta he selittävät lukijalle, mitkä tekijät ovat aiheuttaneet henkilöiden tilanteen. Toisaalta alaluokkaisten henkilöiden kuvaamista ei ole monopolisoitu anonyymeille kertojille, vaan heitä tarkastellaan myös muista narratiivi- 
sista positioista käsin. Niinpä Jumalan Kyynel on anonyymin kertojan ja kahden minäkertojan (ekonomisti Lari Laine ja ohjaaja Laura Laine) kuvauksen kohteena, ja he esittävät hänestä näkemyksiä, jotka eivät kaikilta osin sovi yhteen toistensa kanssa. Kaikkitietävän kertojan ja vapaan epäsuoran esityksen osuuden väheneminen ei siten tee kerronnasta välttämättä asenteetonta. Pikemminkin Seppälän romaanien kaltaisissa kompleksisissa teoksissa kysymys kerronnan välittämistä asenteista on muuttunut aiempaa monitulkintaisemmaksi.

Seppälän romaanien välittämistä asenteista ja ideologioista voidaan yleisellä tasolla todeta, että nuo romaanit kuuluvat kapitalismikritiikin piiriin, mutta ne eivät harjoita tuota kritiikkiä ensi sijassa työväenliikkeen ja työväenluokan piirissä esiintyneiden perinteisten ja nykyisten ideologioiden näkökulmasta. Sen sijasta ne edustavat enemmänkin modernille länsimaiselle älymystölle luonteenomaista kapitalismikritiikin muotoa. Ymmärtääksemme paremmin tällaisen kritiikin luonnetta meidän on siksi syytä pohtia, mitä älymystö on.

Älymystön asema yhteiskunnassa vaihtelee jonkin verran maasta toiseen siirryttäessä, mutta miltei kaikkialla älymystön perustehtävä on ollut samanlainen: maailmankuvien ja maailmankatsomusten systematisoiminen, niiden tulkitseminen, kritisoiminen ja kehittäminen. Esimerkiksi ranskalaisessa yhteiskunnassa älymystö on perinteisesti hoitanut tätä tehtäväänsä melko itsenäisesti. Tämä tulee näkyviin muun muassa Pierre Bourdieun luokkateoriassa, joka kiinnittyy vahvasti ranskalaiseen yhteiskuntaan, mutta jonka Bourdieu on taipuvainen esittämään yleisemmin pätevänä teoriana modernin yhteiskunnan luokkarakenteesta.

Älymystö on usein sijoitettu keskikerrostumiin, yläluokan ja työväenluokan väliin jäävien sosiaalisten kerrostumien joukkoon, mutta Bourdieun luokkateoriassa älymystö kuuluu yläluokkaan. Älymystö muodostuu johtavista kirjailijoista, taiteilijoista, filosofeista, tutkijoista, journalisteista, kulttuurikeskustelijoista ja yhteiskunnallisista ajattelijoista. Se on Bourdieun mukaan osa yläluokkaa, jonka sisällä se on kuitenkin alisteisessa asemassa suhteessa taloudelliseen ja poliittiseen eliittiin, yläluokan hallitseviin fraktioihin. Sillä on runsaasti tiedollista ja kulttuurista pääomaa, mutta vähemmän taloudellista pääomaa ja poliit- 
tista valtaa kuin hallitsevilla fraktioilla. Siksi se on Bourdieun mukaan ollut kriittinen yläluokan hallitsevia fraktioita kohtaan ja vastustanut taloudellisten ja poliittisten arviointiperusteiden tuomista taiteen ja kulttuurin kentälle. Niiden sijasta se on painottanut taiteen riippumattomuutta talouden ja politiikan kentistä, mikä on käytännössä merkinnyt vaatimusta siitä, että juuri älymystön edustajien pitää toimia asiantuntijoina ja määrittelyvallan käyttäjinä taiteen ja kulttuurin kysymyksissä. Suhteessaan alempiin luokkiin älymystö on puolestaan omaksunut holhoavan ja opettavaisen asenteen. Se on siis tuntenut yhtäältä sympatiaa alempia luokkia kohtaan, mutta toisaalta se on katsonut, että kansa ei tiedä omaa parastaan ja siksi sitä pitää valistaa.43

Suomalaisen yhteiskunnan luokkarakenteen kuvauksista puuttuu usein älymystön kategoria, niin kuin on asianlaita edellä käsitellyssä Jani Erolan toimittamassa kirjassakin. Suomalaista älymystöä on siksi käsitelty lähinnä erillistutkimuksissa. Niissä on tuotu esiin se, että Suomessa ei ole juurikaan ollut Bourdieun kuvaamaa itsenäistä älymystöä. Pikemminkin älymystö toimi Suomessa pitkään läheisessä suhteessa valtioon sekä kansallisiin ja yhteiskunnallisiin liikkeisiin. Suomesta ovat siten paljolti puuttuneet Émile Zolan ja vanhenevan Jean-Paul Sartren kaltaiset, itsenäisyyttään varjelleet "julkiset intellektuellit", jotka intellektuaalisen kentän perusarvoihin (totuus, oikeudenmukaisuus) vedoten tekivät kriittisiä interventioita politiikan kentälle ja arvostelivat julkisuudessa sen "vääristymiä". (Vrt. Bürger, Peter 2007.) Suomalaisen älymystön paradigmaattisina edustajina voi pitää J. W. Snellmania ja Raoul Palmgrenia. Edellinen on keskeinen hahmo suomalaisuusideologian ja valtiofennomanian kehittäjänä ja jälkimmäinen vasemmistolaisen kulttuuripolitiikan ideoijana. Molemmissa tapauksissa intellektuelli toimi tietyn kollektiivin - valtion tai yhteiskunnallisen liikkeen - palveluksessa, sen maailmankatsomuksen kehittäjänä, jos kohta Palmgrenin suhde vasemmistopuolueisiin oli löyhä eikä hän suostunut alistumaan niiden määräysvaltaan. ${ }^{44}$

Edellä mainittu tiivis sidonnaisuus valtioon sekä kansallisiin ja yhteiskunnallisiin liikkeisiin pätee ı8०o-lukuun ja pääosin ı900-lukuun. Sitä vastoin I900-luvun viimeisistä vuosikymmenistä lähtien suomalainen älymystö näyttää etääntyneen, mutta ei kuitenkaan irronneen tuosta 
sidonnaisuudesta. Tämä tulee ilmi kyselyssä, jonka sosiologit Keijo Rahkonen ja J. P. Roos toteuttivat I980- ja I990-luvun vaihteessa yhdessä Helsingin Sanomien kanssa. Siinä he esittivät valitulle joukolle kirjailijoita, taiteilijoita, tutkijoita, journalisteja, poliitikkoja ja kulttuurialan virkamiehiä kysymyksen, kuka näiden mielestä oli Suomen johtava intellektuelli. Ylivoimaiseksi ykköseksi kyselyssä tuli filosofi G. H. von Wright, jonka jälkeen seuraavaksi eniten ääniä saivat Paavo Haavikko ja Johannes Salminen. Yhteenvetona kyselystä Rahkonen ja Roos (I992, II5) totesivat, että Suomessa tyypillinen intellektuellin statuksen saanut henkilö oli tuolloin miespuolinen humanistisen alan tutkija, filosofi tai kirjailija. Tavallisesti hän oli sidoksissa valtioon - joko siten, että hän työskenteli jossakin yliopistossa, tai siten, että hän nautti valtion myöntämää apurahaa. Kun Helsingin Sanomat uusi kyselyn vuosituhannen vaihteessa, ykköseksi tuli jälleen G. H. von Wright, jonka jälkeen seuraavilla sijoilla olivat Max Jakobson ja Juha Siltala (ks. myös Nygård 2020, 43-46).

Filosofiset pääteoksensa von Wright julkaisi toisen maailmansodan jälkeisinä vuosikymmeninä analyyttisen filosofian piirissä, mutta uransa loppuvaiheessa, lähinnä I980- ja I990-luvulla hän tuli Suomessa ja muissa Pohjoismaissa tunnetuksi ennen kaikkea modernin teknologiauskon ja välineellisen järjen kriitikkona. Hänen tämän vaiheen tunnetuin teoksensa on Myten om framsteget (I993), jonka mukaan nykyyhteiskunnalle ominainen talouskasvun ideologia, teknologiausko ja kulutuskeskeinen elämäntapa muodostavat vakavan uhkatekijän paitsi ympäristölle myös itse yhteiskunnalle. Rationalisaatiokriitikkona von Wright sai vaikutteita Marxilta, Weberiltä ja Habermasilta, mutta olisi liioiteltua sijoittaa hänet tällä perusteella Frankfurtin koulun edustaman kriittisen teorian piiriin. Hänen tuolloin saavuttamansa kiistaton asema maamme johtavana intellektuellina näyttää silti viittaavan siihen, että rationalisaatiokritiikillä oli vuosituhannen vaihteen molemmin puolin Suomessa legitiimi asema älymystön ja humanistis-yhteiskuntatieteellisen sivistyneistön piirissä. ${ }^{45}$

Seppälän teoksissa ilmenevä rationalisaatiokritiikki eroaa von Wrightin edustamasta kritiikistä siinä, että se painottuu talouteen eikä se siten anna teknologialle niin keskeistä asemaa kuin von Wright antoi. Se on 
myös tiukemmin sidoksissa Weberin ja Habermasin näkemyksiin kapitalismista. Siten Seppälän romaanit vievät rationalisaatiokritiikkiä von Wrightin ajattelua radikaalimpaan tai ainakin vasemmistolaisempaan suuntaan. Näistä romaaneissa tässä suhteessa tärkein on Paholaisen haarukka (2008), jolla on yhtymäkohtia varsinkin Habermasin ajatteluun..$^{6}$ Sen saama myönteinen vastaanotto kertoo siitä, että Suomessa kirjallisuusinstituution eliittiryhmät ja lukeva yleisö eivät suinkaan torju rationalisaatiokritiikkiä.47 Päinvastoin ne pitävät sitä kiintoisana puheenvuorona nykyisestä yhteiskunnasta. Seppälän tapauksessa tätä hyväksyntää on edesauttanut se, että uransa alusta lähtien häntä on pidetty taidokkaana kirjailijana, joka on uudistanut kirjallista perinnettä. Niinpä hän on I980- ja I990-luvun vaihteesta lähtien nauttinut lähes keskeytyksettä valtion taiteilija-apurahaa. Antamissaan haastatteluissa hän on silti intellektuelleille luonteenomaisella tavalla korostanut henkistä riippumattomuuttaan, sitä, että voidakseen toimia kriittisenä keskustelijana kirjailijan tulee säilyttää itsenäisyytensä eikä hän saa ryhtyä yhteistyöhön vallanpitäjien kanssa. ${ }^{4}$ Tämä viittaa siihen, että Seppälä on paljolti sisäistänyt perinteisen länsimaisen käsityksen intellektuellista lahjomattomana "totuudenpuhujana".

Seppälän kapitalismikriittisissä teoksissa ilmenevän yhteiskuntakäsityksen perusteella voisi lisätä, että Seppälä on kirjailija-intellektuellina ollut itsenäinen myös suhteessa työväenliikkeen ja vasemmiston organisaatioihin. Näiden organisaatioiden harjoittamasta yhteiskuntakritiikistä hänen teoksensa eroavat siinä, että taloudellis-sosiaalisten kysymysten ja "tulonjakokamppailun" sijasta keskeisen aseman niissä saavat rationalisaatio-teema ja merkityskysymykset. Silti romaanit osoittavat myötätuntoa työväenluokan alemmalle, syrjäytymisvaarassa elävälle kerrostumalle, vaikka tuon kerrostuman tapa mieltää yhteiskunta ei juurikaan tule niissä esille. Ehkä tätä työväenluokan oman äänen puuttumista voidaan osittain myös selittää työväenluokan poliittisessa käyttäytymisessä tapahtuneilla muutoksilla.

Kirjassaan Capital et idéologie (20I9) Thomas Piketty puhuu siitä, että nykyisessä maailmanjärjestyksessä vasemmisto ja työväenluokka ovat kasvavassa määrin eriytymässä toisistaan. Poliittinen vasemmisto nojaa länsimaissa yhä enemmän älymystön ja keskiluokan tukeen, kun taas 
työväenluokka on, esimerkiksi Ranskassa, paljolti siirtynyt populistisen ja kansallismielisen äärioikeiston kannattajaksi. Tällä tavalla poliittisen vasemmiston ja työväenluokan maailmankatsomukset ovat osittain ajautuneet ristiriitaan keskenään. Nämä Pikettyn esittämät havainnot pätevät myös Suomeen, mutta Seppälän tuotannossa ristiriita tulee esiin vasta Sankariajassa (20ı8a) ja siinäkin melko epäsuorasti. Hänen aiemmissa romaaneissaan käyttämänsä kerrontatekniset ratkaisut ovat estäneet tehokkaasti populistista kansallismielistä ideologiaa kannattavan työväestön ja sen oman puheen pääsyn romaanien maailmoihin. Noissa romaaneissa tarinamaailman ulkopuoliset anonyymit kertojat sekä keski- ja yläluokkaiset henkilökertojat selittävät nimittäin lukijalle toistuvasti sen, millaisista tekijöistä teosten työväenluokkaisten henkilöiden elämäntilanne johtuu.

Vaikka Seppälän romaanit antavat niukasti tilaa alempien luokkien "omalle puheelle", ne kiinnittävät huomiota näiden luokkien asemaan ja tietyssä määrin ne voidaan käsittää niiden näkökulmasta harjoitetuksi kapitalismikritiikiksi. Ylimpänä näkökulmana niissä on silti älymystön keskuudessa vaalittu käsitys kapitalismista. Sellaisina niitä, varsinkin Yhtiökumppaneita ja Paholaisen haarukkaa, leimaa armoton nykykapitalismin tuomitseminen. Nykykapitalismin keskeisiä ylläpitäjiä, ylimpiä luokkia, kuvatessaan ne pyrkivät osoittamaan, millaiseen merkityskatoon yläluokan hallitsema talouselämä yhteiskunnan johtaa. Tätä kritiikkiä ne eivät esitä karikatyyrien avulla, tekemällä yläluokkien edustajista vastenmielisiä hahmoja, mutta heitä ei myöskään ole varustettu vivahteikkaalla sisäisellä elämällä. He edustavat sikäli köyhtynyttä subjektiutta, että heidän ajatustapansa on kapitalistisen hyötylogiikan läpitunkema.

Kaiken kaikkiaan Seppälän teosten välittämä kuva yläluokista on kuitenkin maltillinen. Näissä romaaneissa esiintyvistä yläluokkaisista henkilöhahmoista puuttuu lähes kokonaan sellainen "empatiakuilu", joka on Anu Kantolan ja Hanna Kuuselan tutkimuksen Huipputuloiset (2019) mukaan ominainen Suomen rikkaimmalle väestönosalle. Kyseinen tutkimus osoittaa, että tuon väestönosan arvomaailma on äärimmäisen meritokratistinen - eli huipputuloiset ajattelevat, että yhteiskunnassa vaurauden pitää tiukasti jakautua tekojen ja saavutusten perusteella. Tässä 
valossa syrjäytyneet ja syrjäytymisvaarassa olevat ihmiset näyttäytyvät "luusereina", jotka käyttävät oikeudettomasti hyväksi hyvinvointivaltion palveluja ja jotka eivät ota itse vastuuta elämästään. Samoin kyseinen väestönosa arvostelee hyvinvointivaltiota siitä, että verovarojen avulla se "paapoo" syrjäytyneitä ja syrjäytymisvaarassa olevia ihmisiä. Pohjoismaisen hyvinvointivaltion sijasta rikkain kerrostuma arvostaa enemmän amerikkalaista kapitalismia, jossa köyhien tukeminen perustuu tarveharkintaan ja hyväntekeväisyyteen. (Kantola \& Kuusela 2019, I20-I27, I7I-I88, 237-24I, 247-248, 254-257, 294, 300-30I.) Vaikka Seppälän teosten yläluokkaiset päähenkilöt ovat monin paikoin kyynisiä luomuksia, suhteessaan alaluokkiin he eivät ilmennä näin jyrkkää arvomaailmaa.

Seppälän kapitalismikriittiset teokset eivät rajoitu yksilöiden arkisen elämänpiirin kuvaamiseen, vaan ne kiinnittävät huomiota myös taloudessa, työelämässä, politiikassa ja julkisella sektorilla tapahtuneisiin muutoksiin. Lisäksi ne kysyvät, mitä itse kirjallisuudelle on tapahtunut yhteiskunnan markkinallistumisprosessissa. Tavoittavatko ne siten yhteiskunnan "totaliteettina" Seppälän aiempia teoksia paremmin?

Totaliteetin ihanne on keskeinen Georg Lukácsin (I97Ib) realisminteoriassa, joka asetti esikuvan asemaan Balzacin, Leo Tolstoin ja Thomas Mannin tavan kuvata yhteiskuntaa laajasti ja historiallisesti muuttuvana muodostumana. Käsitys yhteiskunnasta on Lukácsin päivistä kuitenkin siinä mielessä muuttunut, että nykyisiä yhteiskuntia ei voida ajatella toistensa suhteen suljetuiksi, "laatikkomaisiksi" kansallisiksi muodostumiksi. Kansalliset yhteiskunnat olisi pikemminkin miellettävä avoimiksi järjestelmiksi, jotka ovat sidoksissa erilaisiin kansainvälisiin ja globaaleihin järjestelmiin ja sulautuneet monin paikoin yhteen niiden kanssa. Siksi yhteiskunnan kokonaisvaltaisen kuvaamisen ihanne asettaa nykykirjallisuuden aiempaa huomattavasti vaativamman tehtävän eteen; tällaisessa kuvauksessa pitäisi nimittäin ottaa huomioon myös kohteena olevan kansallisen yhteiskunnan asema kansainvälisissä järjestelmissä ja maailmanjärjestyksessä. Ilmeisesti totaliteetin ihanne ei silti ole täysin toteuttamiskelvoton, sillä Fredric Jameson (20I8) on katsonut Hannu Raittilan romaanin Pamisoksen purkaus (2005) välittävän lukijoille välähdyksenomaisia näkymiä globaalin nykykapitalismin toimintatavoista. Jussi Ojajärvi (20I6, I03-IO5) on nostanut samassa 
mielessä esille Miika Nousiaisen "kvartaalitalousromaanin" Metsäjätti (20II), joka kuvaa perinteisen suomalaisen metsäteollisuuden alasajoa sen fuusioituessa osaksi globaalien kilpailijoidensa toimintaa.

Totalisointipyrkimys on siinä mielessä ominaista myös Seppälän romaaneille, että niissä kuvauksen kohteeksi on yritystoiminnan, työelämän ja subjektien elämismaailmojen lisäksi otettu yhteiskunnan muitakin osa-alueita. Samalla niihin sisältyy viittauksia kansainvälisiin ja globaaleihin taloudellisiin ja poliittisiin järjestelmiin. Nuo romaanit suuntautuvat siten kohti nykyistä yhteiskunnallista todellisuutta, jonka ominaisluonnetta ne pyrkivät määrittämään ja arvioimaan. Ne voitaisiin siksi sijoittaa modernin tai avantgardistisen realismin piiriin. 49 Nämä kaksi käsitettä viittaavat tässä yhteydessä siihen, että nuo romaanit pyrkivät sanomaan jotakin tärkeää ja olennaista nykyisestä yhteiskunnallisesta todellisuudesta, mutta ne eivät tee sitä pelkästään perinteiselle realismille ominaisella tavalla, vaan ne hyödyntävät myös modernismin ja postmodernismin kehittämiä ilmaisukeinoja sekä erilaisia kokeellisia kerronnallisia ja rakenteellisia ratkaisuja.

Lukácsin edustamista realismin ja totaliteetin ihanteista Seppälän romaanit poikkeavat muissakin suhteissa. Lukács (I97Ib, 500-550) odotti "suuren realismin" kuvaavan kriittisesti yhteiskunnassa vallitsevia luokkavastakohtia ja tuovan samalla esiin yhteiskuntakehityksen pääsuunnan. Tämä on hänen mukaansa mahdollista erityisesti sitä kautta, että realismissa henkilöt toimivat tyyppeinä: he ovat samanaikaisesti konkreettisia, eläviä yksilöitä ja yhteiskunnallisesti edustavia hahmoja. Näin he kykenevät ilmentämään luokkien ja yhteiskunnallisten voimien mentaliteetteja ja maailmankatsomuksia. Seppälän romaanit eivät painotu luokkavastakohtien käsittelemiseen eikä niihin sisälly visiota siitä, millainen yhteiskuntajärjestys tulee aikoinaan mahdollisesti korvaamaan nykykapitalismin. Mitä hänen henkilöhahmoihinsa tulee, niin he eivät ole niinkään monipuolisesti kuvattuja konkreettisia ihmisiä vaan pikemminkin kirjallisia luomuksia, joiden tehtävänä on ilmentää rationalisoitumiskehityksen aiheuttamia psyykkisiä ja sosiaalisia vaurioita.

Seppälän romaanit eivät myöskään ole totalisoivia romaaneja siinä mielessä, että ne kuvaisivat "yhteistä kansallista kokemusta" nykykapitalismista - siihen tapaan kuin Väinö Linnan pääteosten on tulkittu 
käsittelevän suomalaisten jakamaa traumaattista muistoa ja tietoa lähihistoriastaan. Seppälä on I990-luvulta lähtien painottanut sitä, että myöhäismoderniin kulttuuriin liittyvä ihmisten kokemismaailmojen fragmentoituminen ja niiden eriytyminen toisistaan on tehnyt tällaiset linnalaiset, kokoavat "suuret kertomukset" mahdottomiksi. Yhden ja kaikkia ihmisiä yhdistävän kokemistavan sijasta nykykulttuuria leimaa hänen mukaansa kokemusmaailmojen moninaisuus. Sydänmaa (1994a) ja Kuun nousu ja lasku (1999) ovat Seppälän tuotannossa ensimmäiset teokset, jotka ilmaisevat romaanimuodon keinoin tämän suuntaista näkemystä nykykulttuurista. Niissä molemmissa on monia eri kertojia ja fokalisoijia, ja niille ovat ominaisia nopeat siirtymät kerrontajaksoista, aikatasoista ja tarinalinjoista toiseen..$^{\circ}$

Seppälän vuosina 2000-20I2 ilmestyneet romaanit jatkavat eteenpäin siitä, mihin Sydänmaa ja Kuun nousu ja lasku jäivät. Myös vuosina 2000-20I2 ilmestyneet romaanit ovat kompositionsa sekä aika- ja kerrontarakenteensa osalta kompleksisia teoksia. Kielen tasolla niitä, varsinkin Paholaisen haarukkaa, luonnehtii lyhytsanainen, toteava esitystapa ja tyyli, joka eri juurikaan selittele henkilöiden toimintaa eikä pohjusta sitä laajasti. Paikoitellen vuosina 2000-20I2 ilmestyneet teokset muodostuvat nopeasti vaihtuvista, miltei välähdyksenomaisista näkymistä romaaneissa kuvattuun maailmaan ja henkilöiden tapaan kokea se. Tällaiset ratkaisut palvelevat sen esittämistä, että nykykulttuurissa on monia eri kokemuksia maailmasta - riippuen esimerkiksi kokijan sukupuolesta ja hänen asemastaan yhteiskunnassa. Tutkimuskohteena olevissa Seppälän romaaneissa kaikkien henkilöiden kokemusmaailmaan vaikuttaa kuitenkin yleensä voimakkaasti se, että he elävät ja toimivat markkinoiden pohjalta organisoidussa yhteiskunnassa. Tämä tuottaa heissä erilaisia vieraantuneisuuden muotoja ja patologioita. Seppälän teoksista puuttuvat siten elämäänsä tyytyväiset ja henkisesti hyvinvoivat ihmiset. Tässä mielessä - keskittyessään markkinallistumiskehityksen aiheuttamaan pahaan oloon - ne ottavat itse asiassa vain rajallisesti huomioon nykykulttuuriin liittyvän ihmisten kokemusmaailmojen erilaisuuden ja moninaisuuden.

Seppälän vuosina 2000-20I2 ilmestyneet teokset antavat vaikutelman tietoisesta artistisuudesta ja kokeellisuudesta. Tätä teostensa omi- 
naispiirrettä Seppälä ei ole pyrkinyt peittelemään. Päinvastoin vuonna 20 I4 hän kuvasi Parnassossa kehitystään kirjailijana näin:

Aluksi olin uskollisempi todellisuudelle. Kirjani ovat kehittyneet artefaktimaisempaan suuntaan. Ne ovat kirjoitettuja pikemminkin kuin kerrottuja. En pyri jäljittelemään maailmaa vaan luomaan kokonaisvaltaisia vaikutelmia lähes kubistiseen malliin piittaamatta juonellisuuteen tai uskottavuuteen liittyvistä kysymyksistä. (Seppälän Ville Hänniselle Parnassoon vuonna 20I4 antama haastattelu; ks. Hänninen 20I4, 26.)

Tähän voi lisätä sen, että - toisin kuin oheinen sitaatti ehkä antaa ymmärtää - tutkimuskohteena olevat romaanit sisältävät myös mimeettisiä ja uskottavia yksityiskohtia eli viittauksia yhteisesti jaettuun havaintotodellisuuteen. Suomalainen lukija pystyy siksi tunnistamaan niissä esimerkiksi suomalaisesta nykytodellisuudesta otettuja aineksia. Kohdeteoksissa on kuitenkin samalla myös aineksia, jotka palvelevat enemmänkin tarinankehittelyn ja romaanin etenemisen omaa, sisäistä logiikkaa tai jotka ilmentävät ja havainnollistavat tiettyä näkemystä ja arviota nyky-yhteiskunnasta. Maailman jäljittelemisen ohella kyseiset romaanit harjoittavat "filosofista" pohdiskelua siitä, mitä kapitalismi on, millainen läpikotaisin kapitalisoitunut yhteiskunta on tai olisi ja miten kirjallisuuden pitäisi siihen asennoitua. Ne tinkivät mimeettisen, maailmaa havaintotasolla jäljittelevän kuvauksen vaatimuksesta ja antavat tilaa kapitalismia ja kirjallisuutta koskeville abstrakteille pohdiskeluille ja arvioinneille.

\section{Representaatio, arvot, arvottaminen, maailmankatsomus ja ideologia}

Edellisissä alaluvuissa on käsitelty Seppälän varhaistuotantoa ja hänen vuosina 2000-20I2 ilmestyneiden teostensa yhteiskunnallista taustaa sekä esitetty alustavia luonnehdintoja Yhtiökumppaneista, Paholaisen haarukasta ja Mr. Smithistä. Tässä ja seuraavissa alaluvuissa esitellään 
ja avataan niitä käsitteitä, joita näiden romaanien analyysiluvuissa käytetään.

Retorisessa kertomusteoriassaan James Phelan (I996; 2005) erottaa kertomuksen henkilöissä kolme ulottuvuutta: (a) mimeettisen (henkilö todellista ihmistä muistuttavana olentona), (b) temaattisen (henkilö kertomuksen sisällön tai teeman ilmentäjänä, ideana) ja (c) synteettisen (henkilö kirjallisena konstruktiona, henkilön funktio kertomuksen etenemisen kannalta) ulottuvuuden. Alun perin Phelan sovelsi kolmijakoa mimeettinen-temaattinen-synteettinen vain henkilöiden analysoimiseen, mutta myöhemmin hän on hyödyntänyt sitä laajemmin kertomusten käsittelemisessä (ks. Phelan \& Rabinowitz 20ı2a, 8). Kun kolmijako laajennetaan kertomusten analysointiin, mimeettisen ulottuvuuden sijasta olisi kuitenkin parempi puhua representativisesta ulottuvuudesta ja lisätä, että kertomukset voivat esittää todellisuutta mimeettisellä tai ei-mimeettisellä tavalla.

Phelanin mallista puuttuu (d) metakirjallinen ulottuvuus, jota voi pitää retorisen analyysin neljäntenä tasona. Brian Richardson (20I2, I32) mainitsee omana tasonaan myös (e) intertekstuaalisen ulottuvuuden, joka menee osittain päällekkäin metakirjallisen ulottuvuuden kanssa. Metakirjalliset teokset kommentoivat (dI) omaa itseään, (d2) muita kirjallisia teoksia ja/tai (d 3 ) kirjallisessa kulttuurissa vallalla olevia konventioita ja kirjallisuuskäsityksiä; tapauksissa $\left(\mathrm{d}_{2}\right)$ ja $\left(\mathrm{d}_{3}\right)$ metakirjalliset teokset ovat siten välttämättä samalla intertekstuaalisia. Metakirjallinen ja intertekstuaalinen ulottuvuus voivat myös esiintyä toisistaan erillään. Tähän ryhmään kuuluvat ne tapaukset, joissa viittaukset muihin teoksiin eivät sisällä näiden teosten kommentoimista. Samalla tavalla viittausten ja metatason kommenttien välillä häilyvät (f) interdiskursiiviset ainekset, joissa kirjallinen teos viittaa muihin taidelajeihin ja (tieteellisiin, filosofisiin, ideologisiin, uskonnollisiin) diskursseihin ja ehkä myös kommentoi niitä.

Tässä tutkimuksessa ulottuvuuksien (a) ja (b) analysoimisessa keskeisiä ovat representaation käsite lähikäsitteineen, arvon käsite, kapitalismin käsite sekä vieraantumisen käsite ja sen sukulaiskäsitteet. Ulottuvuuden (c) käsittelyssä tutkimus nojautuu lähinnä Phelanin ja Richard Walshin (2007) näkemyksiin. Ulottuvuuksien (d) ja (e) tarkastelussa 
tutkimus tukeutuu yhtäältä metafiktiivisyyttä koskeviin teorioihin, ja toisaalta se tarkastelee kohteena olevia Seppälän teoksia suhteessa kapitalismikriittisen romaanin ja eksistentiaalisia teemoja käsittelevän kirjallisuuden traditioihin. Ulottuvuutta (f) käsitellessään tutkimus kiinnittää ennen kaikkea huomiota siihen, miten Seppälän teokset hyödyntävät Raamattua, eksistentialistista filosofiaa sekä kapitalismiteorian ja yhteiskuntateorian traditioita.

Kirjassaan Portti ja polku. Tutkimus kirjallisuuden semiotiikasta (20II, 42) Harri Veivo erottaa Charles Sanders Peircen merkkiteorian pohjalta toisistaan merkin välittömän ja dynaamisen objektin. Jokaisella merkillä on välitön objekti, mutta ei välttämättä dynaamista objektia. Esimerkiksi "Jumalan Kyynel" viittaa fiktiiviseen henkilöhahmoon Juha Seppälän romaanissa Paholaisen haarukka. Hän on tämän nimen välitön objekti, mutta häntä ei ole olemassa dynaamisena objektina, todellisena yksilönä. Siksi ei ole järkevää kysyä, kuvaako tuo romaani Jumalan Kyyneleen oikein tai totuudenmukaisesti. Tilanne muuttuu kuitenkin, mikäli me pidämme Jumalan Kyyneltä suomalaisen keski-ikäisen syrjäytyneen ja alkoholisoituneen työläismiehen edustajana, joka joutui asiaa syvemmin tajuamatta uusliberalistisen yhteiskuntapolitiikan ja globalisaation uhriksi. Tässä tulkinnassa on mielekästä arvioida hänen hahmoaan uskottavan ja epäuskottavan mittapuiden avulla. (Vrt. myös Veivo 20ıо.)

Välittömän ja dynaamisen objektin käsitteitä voi soveltaa myös kokonaisiin romaaneihin. Yhtiökumppaneiden välittömänä objektina on siinä kuvattu fiktiivinen ICT-alan yritys. Niin kutsuttu fiktionaalisten maailmojen teoria, jota on kehitellyt muun muassa Thomas G. Pavel (I986), on usein rajoittunut tarkastelemaan kirjallisuuden tätä puolta. Se on pitänyt mimesiksen tai representaation käsitettä tutkimuksessa lähes tarpeettomana, sillä sen mukaan fiktiiviset maailmat ovat reaalimaailmasta etääntyneitä tekstuaalisia konstruktioita. Tällaisen näkemyksen kritiikkinä on syytä Wolfgang Iserin (I993) tavoin esittää, että kaunokirjalliset teokset, "fiktiot", eivät muodostu pelkästään fiktiivisistä aineksista, vaan ne sisältävät myös tunnistettavissa olevia aineksia reaalimaailmasta: ne sisältävät siten sekä kuvitteellisia että todellisuudesta lainattuja aineksia. Richard Walsh $(2007,45)$ on lisäksi huomauttanut, että Pavelin käsitys ei kykene selittämään kirjallisuuden roolia kulttuurissa eikä se ota huo- 
mioon lukijoiden tapaa suhteuttaa lukemansa todellisuuteen. Käsillä oleva tutkimus jakaa tämän kritiikin. Dialogisen ja diskursiivisen kirjallisuuskäsityksen näkökulmasta todellisuussuhde on konstitutiivinen ulottuvuus modernissa kirjallisuudessa. Siksi Seppälän romaaneista voi sanoa, että niiden dynaamisena objektina on uusliberalistisen murroksen tai käänteen jälkeinen suomalainen yhteiskunta - ja yleisemmin nykyinen markkinakapitalistinen yhteiskunta. Ne representoivat ja arvioivat tätä kapitalististen markkinoiden pohjalta organisoitua yhteiskuntaa.

Representaatio koskee objektien välistä suhdetta. Tavallisesti representaatiolla tarkoitetaan jonkin esittämistä jonkinlaiseksi. Niinpä Yhtiökumppaneissa kuvattu fiktiivinen ICT-alan yritys toimii todellisen ICTtalouden ja yleisemmin nykykapitalismin, tämän romaanin dynaamisen objektin, representaationa. Tässäkin tapauksessa on mielekästä kysyä, millaisen kuvan tai käsityksen kyseinen romaani välittää kohteestaan, vaikkei tällainen kysymyksenasettelu tietenkään tavoita kohteensa kaikkia puolia.

Kirjalliset representaatiot sisältävät mimeettisiä ja ei-mimeettisiä aineksia. Omassa kertomusteoriassaan Paul Ricoeur (1984, 52-87) esittää, että kertomukset ottavat aineksensa yhteisestä kulttuurisesta ja sosiaalisesta todellisuudesta, mutta kaikki nuo ainekset eivät siirry kertomuksiin sellaisenaan, vaan kertomukset muuntelevat niitä ja järjestelevät niitä uudelleen. Ricoeur luonnehtiikin kertomuksia konfiguraatioiksi eikä pelkiksi todellisuuden figuratiivisiksi esityksiksi. Hänen mukaansa keskeinen väline tässä luovassa prosessissa on juonellistaminen, asioiden esittäminen toisiinsa liittyvien tapahtumien tai tilanteiden sarjana. Juoni ei kuitenkaan ole Seppälän yhteiskunnallisissa romaaneissa keskeisin konfiguratiivinen elementti, vaikka niihin sisältyy juonellisia tarinalinjoja, esimerkiksi Jumalan Kyyneleen tarina Paholaisen haarukassa sekä Briscillan ja Ranen tarinat Mr. Smithissä. Näihin romaaneihin liittyvä luova tai konfiguratiivinen panos tulee enemmänkin ilmi niiden tavassa käyttää rinnakkaiskerronnan tekniikkaa ja vapaata siirtymistä eri tarinalinjojen ja aikatasojen välillä.

Kyseiset romaanit eivät ainoastaan kuvaa nykyistä yhteiskuntaa, vaan ne myös arvioivat sitä. Menemättä lähemmin arvon käsitteeseen liittyviin määrittelyvaikeuksiin tässä yhteydessä voidaan todeta, että arvot 
ovat haluamisemme ja pyrkimisemme kohteita (Airaksinen I987, I30). Nykyisissä arvon käsitettä koskevissa filosofisissa tarkasteluissa on tapana ajatella, että arvot eivät ole asioiden fysikaalisia ominaisuuksia, vaan ne ilmentävät subjektin tapaa suhtautua asioihin. Tällaista kantaa on tapana kutsua relationaaliseksi, sillä se määrittää arvot objektin ja subjektin väliseksi suhteeksi. Arvofilosofisena kantana relationaalinen käsitys on oikean suuntainen, mutta se ei riitä kuvaamaan arvojen asemaa kulttuurissa ja yhteiskunnassa. Arvot nimittäin kuuluvat kulttuurin ja yhteiskunnan keskeisiin rakennusaineisiin, ja ne realisoituivat sosiaalisten instituutioiden toimintatavoissa ja sosiaalisissa käytännöissä. Tällaiset arvot ovat olemassa samalla tavalla kuin sosiaaliset normit ja kulttuurissa käytetyt diskurssit tai maailman jäsennystavat; toisin sanoen ne eivät ole luonnonolioiden kaltaisia fyysisiä objekteja vaan sosiaalis-kulttuurisia tai sosiaalis-henkisiä muodostumia.

Yhteiskunnallisten murrosten yhteydessä arvojen asema ja keskinäinen järjestys voi muuttua. Siirtyminen laajan hyvinvointivaltion kaudesta nykyiseen kilpailuyhteiskuntaan on merkinnyt tällaista muutosta. Sen myötä liiketaloudellisten arvojen sekä taloudellisen individualismin ja egoismin asema yhteiskunnassa on vahvistunut (Niiniluoto I994, I87I88, I92). Tämän prosessin kääntöpuolena on ollut se, että samaan aikaan laajan hyvinvointivaltion kaudelle ominaiset taloudelliset (tuloerojen kaventaminen, hyvinvoinnin jakaminen), poliittiset (demokratian lisääminen) ja sosiaaliset (tasa-arvon ja integraation edistäminen) arvot ovat menettäneet asemiaan. Virallisessa politiikassa niitä tärkeämmäksi arvoksi on noussut taloudellisen kasvun ja yritysten kansainvälisen kilpailukyvyn edistäminen, jota on usein toteutettu laajan hyvinvointivaltion kaudelle ominaisten arvojen kustannuksella.

Arvon käsitettä lähellä on arvottamisen käsite. Arvottaessaan jotakin ilmiötä subjekti pyrkii määrittämään sen, miten hyvin kyseinen ilmiö toteuttaa hänen omia, tärkeinä pitämiään arvoja. Esimerkiksi jos ihmiset pitävät yhteiskunnallista oikeudenmukaisuutta ja luonnon monimuotoisuutta tärkeinä arvoina, he voivat pohtia sitä, missä määrin nykyinen talousjärjestys toteuttaa näitä arvoja, ja arvottaa näin nykyistä talousjärjestystä oikeudenmukaisuuden toteutumisen ja luonnon monimuotoisuuden kunnioittamisen näkökulmasta. Arvottaessaan erilaisia ilmiöitä 
ihmiset saattavat myös erehtyä. Puutteellisten tietojensa vuoksi he eivät välttämättä pysty arvioimaan kunnolla tai oikein sitä, missä määrin jokin asiantila, ilmiö tai tapahtuma toteuttaa heidän tärkeinä pitämiään arvoja.

On useita erilaisia tapoja, joilla kirjalliset teokset ilmaisevat arvoja ja joilla ne arvottavat maailmaa. Kertojien ja henkilöiden esittämien suorien arvokannanottojen lisäksi niihin kuuluvat kirjailijan valitsemat lajit (tragedia, komedia, tragikomedia, farssi) ja tyylilajit (traaginen, koominen, tragikoominen, farssimainen). Lisäksi arvot ja arvottaminen ilmenevät kirjallisuudessa usein epäsuorasti, eräänlaisen seurausetiikan muodossa, niin kuin Marko Nystrand (20I2) toteaa. Tällöin kirjallinen teos näyttää, millaisia seurauksia joillakin arvoilla ja niitä toteuttavalla toiminnalla on. Juuri tällä tavalla, seurausetiikan tai näyttämisen avulla, kirjallisuus usein myös harjoittaa kulttuurin ja yhteiskunnan tilan kriittistä arvioimista.

Ehkä tällainen rakenteellinen tapa ilmaista arvoja on kirjallisuudessa keskeisin. Phelan ja Rabinowitz (20I2a, 6; 20I2b, 29-3I; 20I2c, 58) kirjoittavat, että juuri kertomuksen etenemissuunta aina loppuratkaisuihin saakka tuo kertomukseen tietynlaisen, hallitsevan äänen ja ilmapiirin ja samalla se paljastaa parhaiten sisäistekijän, kertomuksen ylimmän auktoriteetin, tavoitteet ja arvomaailman. Phelan ja Rabinowitz korostavat sitä, että sisäistekijän intentioita ja arvomaailmaa ei useinkaan voida samaistaa kirjailijan intentioihin ja arvomaailmaan, vaikka jälkimmäisiä koskeva tieto onkin hyödyllistä ja relevanttia kirjallisten teosten analysoimisessa ja tulkitsemisessa. Retorisessa analyysissa ja tulkinnassa keskeistä on heidän mukaansa joka tapauksessa sisäistekijään liittyvän "intentionaalisuuden järjestelmän” tunnistaminen.

Tämän pääluvun alussa esiteltiin maailmankatsomuksen käsite ja todettiin, että maailmankatsomus sisältää kognitiivisen osan (maailmankuva eli käsitykset ihmisestä, historiasta, yhteiskunnasta, luonnosta ja mahdollisesta yliluonnollisesta todellisuudesta), arvo-osan (käsitys siitä, millainen maailman tulisi olla) ja toiminnallisen osan (käsitys siitä, miten meidän tulisi toimia maailmassa). Käytän maailmankatsomuksen käsitettä hyväksi myös myöhemmissä luvuissa. Lisäksi käytän samaisissa luvuissa ideologian käsitettä, jolla tässä yhteydessä viitataan luokkien, 
ryhmien ja kollektiivien maailmankatsomuksiin. Tätä käsitettä voidaan soveltaa kuvattaessa Seppälän romaanien henkilöitä. Samoin käsillä oleva tutkimus pyrkii yleisemmällä tasolla osoittamaan, että nuo romaanit ilmaisevat länsimaiselle älymystölle perinteisesti ominaista näkemystä kapitalismista, sen piirissä vaalittua maailmankatsomusta ja ideologiaa.

Tutkimus ei siten tarkoita ideologialla ensi sijassa "hallitsevaa luokkaa palvelevaa väärää tajuntaa" (Adorno, Marcuse, Habermasin varhaistuotanto), "systemaattisesti vääristynyttä kommunikaatiota" (Habermasin myöhäistuotanto) eikä "vallan käyttöön asettunutta merkitysten tuotantoa" (kulttuurintutkimus). Kirjassaan Ideologie und Theorie. Eine Diskurskritik (I989, 56, 235) Peter V. Zima huomauttaa, että markkinayhteiskunnassa vaihtoarvojen tai kaupallisten arvojen hallitsevuus synnyttää erilaisia protestiliikkeitä ja vaihtoehtoista ajattelua, joka saatetaan esittää ideologisen diskurssin muodossa. Ideologisen diskurssin avulla tällaiset liikkeet ja ryhmät ilmaisevat intressejään ja näkökantaansa yhteiskuntaan. Tyypillistä ideologialle on Ziman mukaan se, että "ideologinen subjekti" ei reflektoi kunnolla maailmankatsomustaan eikä hän halua käydä sitä koskevaa avointa dialogia. Sen sijasta hän on taipuvainen esittämään sen ainoana oikeana tai itsestään selvänä tapana jäsentää maailma. Tieteelliset teoriatkin sisältävät usein ideologiselle diskurssille ominaisia, hatarasti perusteltuja aineksia. Samoin ne saattavat ilmentää luokkien ja ryhmien intressejä ja niiden näkökantaa maailmaan, mutta tiedeinstituutiossa tutkijat joutuvat periaatteessa perustelemaan näkemyksiään ja tarjoamaan ne julkisen kollegiaalisen arvion kohteeksi.

Zima jatkaa, että eivät ainoastaan hallitsevat ryhmät ja intellektuellit tuota ideologiaa vaan toimintamahdollisuuksiaan lisätäkseen myös hallitut ja alistetut ryhmät tekevät samoin. Tämä huomautus sopii kuvaamaan uusliberalistisen ideologian ja "vapaan markkinatalouden" ehdoilla toteutunutta globalisaatiota, joka on eri puolilla maailmaa synnyttänyt yhtäältä globaalia demokratiaa vaativia liikkeitä sekä toisaalta fundamentalistisiin ja äärinationalistisiin arvoihin nojaavia liikkeitä. Nämä liikkeet ovat kehittäneet uusliberalismista poikkeavia, vaihtoehtoisia näkemyksiä siitä, miten yhteiskunta tulisi järjestää..$^{\text {I }}$

Seppälän romaanien tarjoama kuva nyky-yhteiskunnasta on synkkä. Tuota kuvaa ei välitetä lukijalle ilman perusteita, sillä se esitetään yhteis- 
kuntaa koskevien havaintojen sekä erilaisten tarinalinjojen, vertauskuvien, intertekstuaalisten viittausten ja käsitteellisten pohdiskelujen kautta. Tässä mielessä romaanit ottavat etäisyyttä ideologiseen diskurssiin, mutta ne eivät siltikään ole bahtinilaisessa mielessä polyfonisia teoksia. Bahtinin (I992) mukaan aidosti polyfoniset romaanit sisältävät monia erilaisia ääniä ja näkökantoja, joita ne eivät aseta hierarkkiseen järjestykseen, esimerkiksi tiedolliseen tai moraaliseen paremmuusjärjestykseen. Näin avoin relativismi on vierasta tutkimuskohteena oleville romaaneille.

Arvosteluissa Seppälän vuosina 2000-20I2 ilmestyneet teokset miellettiin toisinaan saarnoiksi tai moraliteeteiksi tai korostettiin muulla tavoin niiden ja uskonnollisten - siis hengellis-ideologisten - tekstien välisiä yhtymäkohtia. ${ }^{22}$ Samoihin aikoihin antamissaan haastatteluissa Seppälä esitti itsekin, että kirjailijana hänessä on "jotakin sellaista eettistä rigoristia, joka oli ominaista vanhemmalle suomalaiselle lyriikalle".53 Ilmeisesti hän viittasi tällä maailmansotien välillä vaikuttaneisiin suomalaisiin runoilijoihin, lähinnä Uuno Kailaaseen, Yrjö Jylhään ja Juhani Siljoon, joiden tuotannon ominaisluonnetta Kai Laitisen Suomen kirjallisuuden historia (I98I) kuvaa eettisen rigorismin käsitteen avulla. Laitisen (I98I, 398-403) mukaan näiden runoilijoiden tuotanto on jatkuvaa henkistä ponnistelua pois ahdistavan synnintunnon kahleista. Synnintunnon yhtenä perustana oli jännite kristillisen arvomaailman ja modernin kulttuurin välillä. Kansallisella, kristillis-siveellisellä arvomaailmalla oli edellen vahva vaikutus kyseisiin runoilijoihin, jotka olivat samalla jo astuneet modernin kaupunkikulttuurin ja modernien aistinautintojen maailmaan. Tästä ristiriidasta vapautuakseen he kävivät runoissaan eettistä ja sielullista kilvoittelua kohti henkistyneempää elämänkäsitystä, mikä toi tietynlaisen kireyden, pingottuneisuuden ja pessimismin sävyn heidän runoihinsa.

Myös Seppälän teoksissa tulee toisinaan esiin jännite "hengen todellisuuden" ja seksuaalisuuden välillä. Tällaisten tekstikatkelmien mukaan seksuaalisuuttaan toteuttaessaan ihminen toteuttaa samalla "itsessään eläintä”, mikä puolestaan johtaa usein kärsimykseen (miesten ja naisten väliset suhteet) tai itseinhoon (itsetyydytys). (Ks. Seppälä I988, 43; 2008, 238.) Seksuaalisuuteen ei siis liity mitään "korkeampia" merkityksiä, vaan se on pikemminkin voima, joka yhdistää ihmiset eläinkuntaan ja 
saa heidät käyttäytymään kärsimystä ja häpeää tuottavalla tavalla. En silti pitäisi tätä jännitettä ja sen työstämistä Seppälän tuotannon, varsinkaan hänen kapitalismikriittisten teostensa, keskeisenä motiivina. Näiden romaanien eräs keskeinen motiivi on ristiriita hengen tai merkityksen todellisuuden ja markkinakapitalismin välillä. Tätä ristiriitaa käsitellessään Seppälä on pitänyt yhtenä esikuvanaan Michel Houellebecqia, joka on hänen laillaan kuvannut romaaneissaan yhteiskunnan markkinallistumista. Esseessään "Houellebecq karkaa" (2oIod) Seppälä toteaa, että tässä ranskalaisen nykykirjallisuuden edustajassa on "klassista totuudenpuhujaa, jollaisesta ei koskaan pidetä. Hän on poliittisesti epäkorrekti, rujo ja raadollinen.” (Ibid., 63.) Seppälä ja Houellebecq ovat molemmat ottaneet etäisyyttä postmodernismiin usein liitetystä epistemologisesta relativismista, jonka vastapainoksi he kuvaavat nykykapitalismia melko ehdottomin äänenpainoin ja vakaasta arvoperspektiivistä käsin. Houllebecqissa Seppälää (ibid., 63-65) on miellyttänyt myös tämän teosten "latinalainen kovuus" ja "epäsentimentaalisuus", ominaisuudet, jotka voisi paljolti liittää myös Seppälän omiin teoksiin.

\section{Kapitalismi ja kapitalismikritiikki}

Yhtiökumppanit, Paholaisen haarukka ja Mr. Smith käsittelevät ensi sijassa nykytaloudessa voimistuneita toimintamuotoja, joita ovat lähinnä ICT-ala, immateriaalitalous, luova talous ja finanssikapitalismi. Ne olivat osittain olemassa jo nykytilannetta edeltävissä vaiheissa, mutta tuolloin niillä ei ollut yhtä keskeistä asemaa kuin nykyisin eikä niistä aina käytetty niiden nykyisiä nimityksiä. Raymond Williamsilta (I988, I39-I45) periytyvää sanontaa käyttääkseni edeltävissä vaiheissa immateriaalitalous ja luova talous olivat "orastavia", siis muotoutumassa ja laajenemassa olevia toimintamuotoja, jotka ovat vasta nykykapitalismissa ja sitä koskevassa tutkimuksessa saavuttaneet näkyvän aseman.

Missä määrin klassiset, lähinnä Marxin ja Weberin kehittämät teoriat kapitalismista sopivat kuvaamaan nykykapitalismia ja missä määrin niillä on käyttöarvoa Seppälän romaaneja tutkittaessa? Nuo teoriathan on laadittu toisenlaisessa historiallisessa tilanteessa. Teoriaansa kehittäes- 
sään Marx piti lähtökohtanaan englantilaista laissez-faire-kapitalismia eli I8oo-luvun englantilaista markkinakapitalismia, jonka hallitsevana alana oli teollisuustuotanto. Weber liikkui tutkimuksissaan laajalla historiallisella ja maantieteellisellä säteellä, ja hän tarkasteli uskonnon ja taloudellisen toiminnan välistä suhdetta eri kulttuuripiireissä, lähinnä Euroopassa, Pohjois-Amerikassa ja Aasiassa. Hänen tunnetuin teoksensa Protestanttinen etiikka ja kapitalismin henki (I980, saksankielinen alkuperäisteos ilmestyi I904-I906) käsittelee I500-luvulla syntynyttä protestanttista yrityskulttuuria ja siinä vallinnutta läheistä suhdetta kapitalistisen yritteliäisyyden, moraalin ja uskonnon välillä. Ajallisesti se käsittelee I500-I700-lukuja, jolloin aristokraattisen sääty-yhteiskunnan sisällä kehittyneet kapitalistisen yritystoiminnan muodot keskittyivät maataloustuotteiden tuotantoon ja kaupankäyntiin. Myöhemmin kapitalismista tuli hallitseva taloudellisen toiminnan muoto ja samalla se etääntyi uskonnollis-moraalisista juuristaan. Se toimi I700- ja I800luvun vaihteesta lähtien ensi sijassa omia lakejaan noudattavana "mekaanisena" järjestelmänä, joka oli pitkälle itsenäistynyt uskonnollismoraalisesta sääntelystä (Weber I980, 52, I34-I35).

Vastauksena edellisessä kappaleessa asetettuun kysymykseen voi todeta, että Marxin ja Weberin kehittämät teoriat kapitalismista eivät ole riittäviä välineitä nykykapitalismia kuvattaessa. Marx ja Weber eivät tietenkään osanneet ennustaa tarkasti, millaisia muotoja kapitalismilla on tulevaisuudessa, eivätkä he myöskään pystyneet näkemään, miten tärkeä rooli valtiolla tulisi ı930-luvulta lähtien olemaan kansallisissa talouksissa ja maailmantaloudessa. Siksi heidän teorioissaan I80o-luvun kapitalismi ja valtio näyttäytyvät paljolti toistensa suhteen erillisinä järjestelminä, jotka eivät juurikaan ohjaile toisiansa. Lisäksi Marxin arvoteoriaa, hänen kapitalismikäsityksensä perustaa, pidetään nykyisin ongelmallisena.

Pääoman ensimmäisessä, vuonna I867 ilmestyneessä osassa Marx (I979, 45-88, 455-505) määrittää tavaran (vaihto)arvon työajan avulla. Hänen mukaansa tavaran (vaihto)arvon määrää sen tuottamiseen käytetty yhteiskunnallisesti välttämätön työaika eli se aika, joka tavaran valmistamiseen normaalioloissa kuluu. Tässä arvossa Marx erotti työntekijälle päätyvän osan (työpalkan) ja lisäarvon, joka kuuluu kapitalistille sillä 
perusteella, että hän on työläisen käyttämien tuotantovälineiden (tehtaat, koneet) omistaja. Jo I8oo-luvulla monet teoreetikot katsoivat, ettei Marxin teoria pysty selittämään esimerkiksi ylellisyystuotteiden arvoa, joka ei ole välttämättä missään suorassa suhteessa niiden valmistamiseen käytettyyn työaikaan. Scott Lash (20I0, 98-IO०) huomauttaa, että nykyisin tavaratuotanto on mutkikas prosessi, johon liittyy paljon tutkimus-, kehitys-, suunnittelu- ja muotoilutyötä. Tässä prosessissa ruumiillisen työn osuus - josta Marx omassa teoriassaan lähinnä puhuu - on menettänyt painoarvoaan. Vielä etäämpänä perinteisestä työstä ollaan "spekulatiivisen talouden" eli sijoitustoiminnan alueella. Sijoittaja voi tietenkin esimerkiksi tuotantoon sijoittamiensa varojen avulla osallistua uusien arvojen luomiseen, mutta hänen toimillaan ei aina ole selvää yhteyttä uuden vaurauden luomiseen. Aina sijoittaja ei niinkään tuota uutta arvoa, vaan hän pikemminkin pyrkii riskejä ottamalla saamaan markkinoilta haltuunsa siellä jo olevaa varallisuutta (Gilpin 200I, 26I-277; Krugman 2012, 96-106).

Myös edellä esitetyllä Marx-kritiikillä on omat heikot kohtansa. Mikäli ajatellaan, että sijoittajan hallussa oleva kasautunut arvo tai varallisuus perustuu alun perin lukuisten ihmisten tekemään työhön ja heidän tuottamaansa arvoon, Marxin teoria ei ole neuvoton spekulatiivisen talouden analysoijana ja selittäjänä. Marxilaisten tutkijoiden toistaman käsityksen mukaan kaikki todellinen arvo perustuu viime kädessä työhön ja sen aikaansaamaan vaurauteen. Tähän problematiikkaan ei valitettavasti ole mahdollisuutta paneutua tässä tutkimuksessa lähemmin.

Kestävää Marxin teoriassa on ajatus, että kapitalistinen talous perustuu lisäarvon tuotantoon. Marxin jälkeen tämän ajatuksen ovat jakaneet monet muut yhteiskuntateoreetikot, muiden muassa Weber, Karl Polanyi (2009), Georg Lukács (1977), Jürgen Habermas (1987a; I987b) sekä Luc Boltanski ja Ėve Chiapello (I999). Kapitalistisen talouden luonteenomainen piirre on se, että kapitalistinen yrittäjä ei tuota hyödykkeitä omaan henkilökohtaiseen käyttöönsä. Sen sijasta hän suuntaa yrityksensä tuotannon alusta lähtien markkinoille, joilla hyödykkeitä käsitellään tavaroina eli myytävissä ja ostettavissa olevina tuotteina. Siten kapitalismi eroaa aiemmista taloudellisen toiminnan muodoista, joissa hyödykkeitä valmistettiin pääosin tuottajien ja heidän mahdollisten isäntiensä 
omaan käyttöön. Kapitalismi ei ensi sijassa kiinnity käyttöarvoihin, vaan se on tavaratuotantoa eli myyntiä ja kaupankäyntiä varten valmistettujen hyödykkeiden tuotantoa. Sellaisena sitä vie eteenpäin liikevoitto-motiivi ja pyrkimys kasata lisäarvoa. Yritystoimintaa harjoittaessaan kapitalistinen yrittäjä olettaa, että markkinoilla hän saa tuottamistaan hyödykkeistä huomattavasti enemmän vaihtoarvoa tai rahallista arvoa kuin niiden valmistamiseen on hänen yritykseltään kulunut. Ilman tällaista oletusta modernin kapitalistisen talousjärjestelmän sisäinen rationaalisuus olisi kyseenalaista. Tosin Weber (I956) ja Polanyi (I957) katsoivat, että myös varhaisissa sivilisaatioissa ja antiikissa esiintyi jonkin verran voitontavoitteluun tähtäävää tuotantoa, mutta heidän mukaansa vasta modernissa länsimaisessa sivilisaatiossa siitä tuli hallitseva taloudellinen toimintatapa, joka on ohjannut laajasti koko yhteiskunnan kehitystä.

Kapitalismin muista ominaispiirteistä edellä mainitut tutkijat eivät ole olleet aivan samaa mieltä. Marxin teoriassa lisäarvon tuotanto edellyttää "vapaan", tuotantovälineiden omistuksesta irrotetun työväenluokan olemassaoloa. Lisäarvon tuotanto on Marxin mukaan mahdollista vain siinä tapauksessa, että kapitalistinen yrittäjä löytää markkinoilta tavaran, joka kykenee tuottamaan enemmän arvoa kuin sen ylläpitäminen ja uusintaminen vaatii erilaisten kustannusten muodossa. Tällainen tavara on työntekijän hallussa oleva työvoima, jonka kapitalisti ostaa tai vuokraa käyttöönsä. Marxin teoriassa kapitalismi ei siten voi toteutua ilman työväenluokkaa ja siihen kohdistuvaa hyväksikäyttöä tai riistoa. Weber ei antanut työväenluokalle näin keskeistä asemaa modernin tai, niin kuin hän sanoi, "rationaalisen" kapitalismin tunnusmerkkien joukossa. Pikemminkin hän korosti sitä, että moderni kapitalismi perustuu myös lainsäädännön pohjalta muotoutuneeseen markkinajärjestykseen, oikeudellisesti sitoviin sopimuksiin taloudellisten toimijoiden välillä, kotitalouden ja yritystoiminnan erottamiseen toisistaan, yritysten harjoittamaan kirjanpitoon sekä tieteen ja teknologian tulosten laajamittaiseen hyödyntämiseen taloudessa (Weber I980, I2-46).

Klassisen markkinakapitalismin tai laissez-faire-kapitalismin kaudella (I800-I930) kapitalismi ei painanut leimaansa koko yhteiskuntaan samalla tavalla välittömästi kuin nykyisin. Scott Lash ja John Urry (I987, I3-I6) toteavat, että tuossa vaiheessa länsimaiset yhteiskunnat raken- 
tuivat funktionaalisen eriytymisen varaan. ${ }^{54} \mathrm{Ne}$ olivat siis jakautuneet sisäisesti erilaisiin osajärjestelmiin (talous, politiikka, oikeus, tiede, koulutus, taide, uskonto), joista kullakin oli omat tehtävänsä ja toimintatapansa. Tällaiset osajärjestelmät olivat myös suhteellisen itsenäisiä toisiinsa nähden. Kapitalistisen talouden toimintaperiaatteet eivät siten olleet levinneet tuolloin laajasti muualle yhteiskuntaan. Kirjassaan Suuri murros. Aikakautemme poliittiset ja taloudelliset juuret (2009, 245-247; englanninkielinen alkuperäisteos ilmestyi I944) Polanyi kuvaa sitä, miten klassisen markkinakapitalismin kaudella englantilaiset talousliberalismin kannattajat pyrkivät pitämään talouselämän ja valtion erillään toisistaan. Tosin ı80o-luvun jälkipuolelta lähtien Englannissa, samoin kuin Ranskassa ja Saksassa, säädettiin jyrkän talousliberalismin opeista poikenneita lakeja, jotka koskivat terveydenhuoltoa, tehdasolojen järjestämistä, sosiaaliturvaa sekä naisten ja lasten käyttämistä teollisuuden työvoimana. Talousliberalistit pyrkivät luomaan itseään sääntelevät kapitalistiset markkinat, joiden he uskoivat takaavan rauhanomaisen kehityksen niin kansallisissa yhteiskunnissa kuin maailmantaloudessakin, mutta Polanyin mukaan tällainen politiikka johtikin raivokkaaseen kilpailuun valtioiden välillä ja lopulta myös ensimmäiseen maailmansotaan (I9I4-I9I9), Wall Streetin pörssiromahdukseen (I929) ja yleismaailmalliseen lamakauteen (I929-I933).

Näistä ongelmista selvitäkseen läntiset valtiot asettivat talouden, erityisesti pankit ja finanssisektorin, tiukan sääntelyn alaisuuteen. Lisäksi jo I930-luvulla ne alkoivat kehittää sosiaalipalvelujen järjestelmiä, joiden tarkoituksena oli turvata rauhanomainen yhteiskuntakehitys ja integroida alemmat luokat yhteiskuntaan. Tältä pohjalta luotiin toisen maailmansodan jälkeen uusi kapitalistinen maailmanjärjestys (Bretton Woods -järjestelmä) ja perinteinen länsimainen hyvinvointivaltio. Tuo järjestys painotti valtion keskeistä roolia yhteiskunnassa ja sen velvollisuutta säännellä yhteiskunnan eri osajärjestelmiä ja turvata niiden toimintakyky. Samoin järjestys rajoitti taloudellista kilpailua, markkinavoimien vaikutusalaa yhteiskunnassa sekä valuuttavirtojen ja pääomien liikkeitä. Yhteiskunta- ja arvofilosofisesta näkökulmasta voidaan todeta, että kyseinen, I970- ja I980-luvun vaihteeseen asti (Suomessa I990luvun alkuun asti) voimassa ollut järjestelmä pyrki perustamaan yhteis- 
kunnan aiempaa selkeämmin substantiaalisten arvoperiaatteiden varaan. Se ei enää uskonut siihen, että markkinamekanismit ja niiden edustama "näkymätön käsi" olisivat paras ja kaikkien kannalta mielekkäin tapa järjestää yhteiskunta. Sen sijasta se pyrki valtion toimenpiteiden sekä talouteen ja muuhun yhteiskuntaan kohdistuneen sääntelyn avulla lisäämään substantiaalisten arvoperiaatteiden painoarvoa ja vaikutusalaa yhteiskunnassa. Se pyrki siis kaventamaan tuloeroja, lisäämään kansalaisten taloudellis-sosiaalista turvallisuutta ja hyvinvointia sekä edistämään tasa-arvoa ja oikeudenmukaisuutta. Bretton Woods -järjestelmään liittyneen hyvinvointivaltioajattelun mukaan markkinamekanismit eivät vapaasti toimiessaan pysty takaamaan näiden arvojen toteutumista

Yhteiskuntakehityksen nykyisessä vaiheessa valtion ja talouden välinen suhde on muuttunut. Vuosina I945-I980 yhteiskuntapolitiikka perustui länsimaissa vahvan ja muuta yhteiskuntaa laajasti sääntelevän ja ylläpitävän valtion ideaan, kun taas nykyisessä vaiheessa valtion tehtäväkenttä on supistunut ja valtio on osittain luopunut roolistaan yhteiskunnan eri osa-alueiden rahoittajana. Tämän myötä useat kansalliset yhteiskunnat ja maailmanjärjestelmä on organisoitu uudelleen markkinakapitalistiselta pohjalta. Näin monet sellaiset yhteiskunnan osa-alueet (terveydenhoito, joukkoviestintä, urheilu, koulutus, kulttuuri), joiden ylläpitämisessä valtiolla ja erilaisilla aatteellisilla järjestöillä oli ennen keskeinen asema, on paljolti muutettu yksityiskapitalistisen liiketoiminnan ja voitontavoittelun alueiksi. Siten myös nykykapitalismi perustuu liikevoiton tavoittelemisen ja lisäarvon tuotannon varaan. Aiemmista kapitalismin vaiheista se eroaa ennen kaikkea siinä, että kapitalistinen talous ei enää ole mikään erillinen saareke yhteiskunnassa. Kun yhteiskuntaelämä on I980-luvulta lähtien organisoitu kasvavassa määrin markkinakapitalistiselta pohjalta, koko yhteiskunta on yhä enemmän alkanut muistuttaa markkinoita. Sen seurauksena kapitalistisen talouden ulkopuolinen alue on kutistunut yhteiskunnassa merkittävästi. Toinen tärkeä erityispiirre nykytaloudessa liittyy siihen tapaan, jolla nykykapitalismi pyrkii liikevoittoon ja lisäarvon tuotantoon. Kuten aiemmin todettiin, immateriaaliset tekijät ovat saaneet nykytaloudessa keskeisen aseman.

Millaisia substantiaalisia arvoperiaatteita nykykapitalismin perusteluiksi on esitetty? Friedrich von Hayek (I899-I992), uusliberalistisen ta- 
lous- ja yhteiskuntateorian perustajahahmo, puolusti vapaata markkinataloutta taloudellisten ja arvofilosofisten perusteiden avulla. Yhtäältä von Hayek esitti, että erilaiset hyödykkeet ja palvelut voidaan yhteiskunnassa tuottaa tehokkaimmin ja laadukkaimmin yksityisten yritysten välisen kilpailun kautta. Osittain tämän vuoksi valtion ei tule itse harjoittaa yritystoimintaa eikä sen pitäisi sekaantua laajasti talouselämän toimintaan. Samoin von Hayek katsoi, että keskusjohtoinen suunnitelmatalous johtaa väistämättä voimavarojen tuhlaukseen, sillä se ei pysty mitenkään ottamaan huomioon kaikkea sitä informaatiota, jota rationaalisesti toimivassa talouselämässä tarvitaan; tähän pystyy hänen mukaansa vain moniin eri yrityksiin hajautunut talouselämä. Arvofilosofinen perustelu von Hayekin ajatteluun tuli selvimmin sitä kautta, että hän piti liberaalia markkinakapitalismia yksilöllisen vapauden ehtona. Tehokkaasti toimivan talouden ja yksilönvapauden turvaksi tarvitaan hänen mukaansa vain minimaalista valtiota, joka takaa lakiensa avulla rationaalisen markkinajärjestyksen sekä yksilöiden perusoikeudet ja toimintavapauden. (Ks. von Hayek 2005; Lagerspetz 2013.)

Samanlainen kytkentä vapaan markkinatalouden, yksilönvapauksien ja minimaalisen valtion väliltä löytyy filosofi Robert Nozickilta (I9382002), joka edustaa libertarismia, ääri-individualistista perinnettä. Tunnetussa teoksessaan Anarchy, State, and Utopia (1974) hän määrittää perustaviksi arvoiksi yksilön oikeuden elämään, vapauteen ja henkilökohtaiseen omaisuuteen. Tältä pohjalta hän piti hyvinvointivaltiota ja verotuksen kautta suoritettuja varallisuuden- ja tulojensiirtoja moraalisesti tuomittavina ja yksilöiden perustavia vapauksia rajoittavina järjestelyinä. Ideaalisessa tilanteessa valtion tehtävien tulisi Nozickin mukaan rajoittua siihen, että se ylläpitää yhteiskunnassa lainkuuliaisuutta ja sopimuksiin perustuvaa järjestystä. Muut tehtävät, esimerkiksi köyhistä huolehtiminen, tulee tällöin jättää vapaan kansalaistoiminnan ja hyväntekeväisyyden varaan. (Ks. myös Wolff I99I.)

Von Hayekin ja Nozickin tapa puolustaa taloudellista individualismia ja miltei rajoittamatonta markkinayhteiskuntaa on altis kritiikille. Markkinakapitalistinen järjestelmä romahti ıو००-luvun alkuvuosikymmeninä länsimaissa kohtalokkain seurauksin, ja samoin ı980-luvun jälkeen eri puolilla maailmaa esiintyneet talouskriisit osoittavat sen, että demo- 
kraattisesta poliittisesta ohjauksesta etääntynyt kapitalismi on vahingollinen järjestely niin talouden kuin koko yhteiskunnankin kannalta. I980-luvun jälkeen vakavia talouskriisejä on ollut muun muassa Suomessa, Norjassa ja Ruotsissa I990-luvun alkupuolella, Meksikossa vuosina I994-I995, Itä- ja Kaakkois-Aasiassa vuosina I997-2000 ja Yhdysvalloissa vuodesta 2007 eteenpäin. Ne ovat johtaneet syviin talouselämän häiriötiloihin ja yhteiskunnalliseen epävakauteen, mistä ovat eniten kärsineet köyhät ihmiset. Samoin nykyinen massatuotantoon ja massakulutukseen perustuva talousjärjestys on kestämätön luonnolle ja ympäristölle, minkä ohella uusliberalistinen maailmanjärjestys on ongelmallinen myös yksilöiden sosiaalisten ja poliittisten oikeuksien kannalta. Se on nimittäin luonut tilanteen, jossa valtiot eivät ole niinkään kiinnostuneita demokratian ja hyvinvoinnin turvaamisesta kansalaisilleen vaan enemmänkin "kotimaisten" yritysten kansainvälisen kilpailukyvyn edistämisestä ja kansallisten instituutioidensa muokkaamisesta houkuttelevaksi toimintaympäristöksi yrityksille ja sijoittajille. Nykyinen, ankaraan kilpailuun perustuva maailmanjärjestelmä houkuttelee siksi valtioita "kansallisen edun" nimissä turvautumaan epädemokraattiseen tai autoritaariseen hallitsemistapaan, niin kuin on tapahtunut Venäjällä, Unkarissa ja Turkissa. ${ }^{55}$

Seppälän teoksissa esitetty kapitalismikritiikki nojaa edellä mainittuihin näkökohtiin, mutta se ei palaudu niihin. Sen luonteen ymmärtämiseksi on tarpeen ottaa esiin Luc Boltanskin ja Ève Chiapellon näkemys kapitalismikritiikistä. Yhteisessä kirjassaan Le nouvel esprit du capitalisme (I999) he esittävät, että I80o-luvun alkupuolelta lähtien yhteiskunnassa vaikuttanut kapitalismikritiikki voidaan jakaa kahteen päähaaraumaan: sosiaaliseen ja taiteelliseen kritiikkiin. Sosiaalista kritiikkiä ovat ensi sijassa harjoittaneet reformistiset ja antikapitalistiset liikkeet, ja siinä pääteemoja ovat olleet riiston, alistamisen ja epätasa-arvon kysymykset. Esimerkiksi työväenliike nousi eri puolilla Eurooppaa aikoinaan kapitalismia vastaan tällaisten näkökantojen pohjalta. Nuo samat teemat ovat olleet jossain määrin esillä myös taiteessa, mutta taiteellinen kapitalismikritiikki on, ainakin Ranskassa, painottunut autenttisuuden, itsensä toteuttamisen ja merkityksen teemoihin. (Boltanski \& Chiapello I999, 33-90, 24I-285, 423-576, 579-629. Ks. myös Ratiu 20I8; Sevänen 
20I4a.) Nämä molemmat teemakokonaisuudet ovat sisältyneet myös viime vuosikymmeninä harjoitettuun kritiikkiin. Siinä uutta on kuitenkin se, että ekologisista näkökohdista on tullut keskeisiä nykykapitalismin toimintatapojen kriittisessä arvioimisessa. Siten ekologinen kritiikki jonka Boltanski ja Chiapello kyllä mainitsevat, mutta jättävät lähemmin käsittelemättä - voidaan nähdä nykyisen kapitalismikritiikin kolmanneksi päähaaraumaksi. ${ }^{56}$

Boltanski ja Chiapello katsovat siis, että ranskalaisessa kulttuurissa harjoitettu taiteellinen kapitalismikritiikki on ensi sijassa ollut kapitalistisen toimintarationaalisuuden ja sen kielteisten seurausten (epäautenttisuus, vieraantuneisuus, merkityskato) arvostelemista. Suomalaisessa kirjallisuudessa harjoitettu kapitalismikritiikki tai yhteiskuntakritiikki näyttäisi poikkeavan tästä siten, ettei se ole yhtä selvästi painottunut rationalisaatio-teemaan. Toistaiseksi laajin tutkimus suomalaisesta kirjallisuudesta näiltä osin on Pertti Karkaman Sosiaalinen konfliktiromaani. Rakennetutkimus suomalaisen yhteiskunnallisen realismin pohjalta (I97I), joka tarkastelee suomenkielisen yhteiskunnallisen romaanin kehitystä I880-luvulta I96o-luvun alkuun saakka. Sen perusteella klassinen suomenkielinen yhteiskunnallinen romaani otti ensi sijassa kohteekseen suomalaisessa yhteiskunnassa vallinneen taloudellis-sosiaalisen eriarvoisuuden, varsinkin maalaisköyhälistön turvattoman aseman, mutta samalla se oli kriittinen sen suhteen, että "määrälliset" tai "välineelliset arvot" olivat saaneet alaa niin yläluokan kuin alaluokankin keskuudessa. Näin perinteinen suomalainen yhteiskunnallinen romaani yhdisteli toisiinsa "sosiaalista" ja "taiteellista" kritiikkiä, jos asetelmaa kuvataan Boltanskin ja Chiapellon käsitteiden avulla.

Seppälän teoksiin sisältyvä kapitalismikritiikki antaa keskeisen sijan merkityksen ja autenttisuuden teemoille. Hänen romaaninsa käsittelevät myös yhteiskuntaluokkia ja epätasa-arvoa, mutta nämä kysymykset ovat niissä toissijaisia merkityksen ja autenttisuuden teemoihin nähden. Näiltä osin ne jatkavat Boltanskin ja Chiapellon hahmottelemaa taiteellisen kapitalismikritiikin perinnettä. Ekologiset näkökohdat ovat niistä esillä Paholaisen haarukassa, jonka eräissä jaksoissa sijoitusneuvoja Lari Laine, elokuvaohjaaja Laura Laine ja verkkotuottaja Kari Lehtonen, kaikki intradiegeettisiä kertojia, pohdiskelevat ilmastonmuutoksen ja 
kasvihuoneilmiön vaikutuksia yhteiskuntaan ja ihmisten elämään (ks. Seppälä 2008, I22-I27, 2II-2I6, 259-260). Ekologiset kysymykset jäävät näin kyseisessä romaanissa sivuteemaksi, mutta romaanin kokonaisuudessa ne eivät ole irrallisia. Ne liittyvät sen pääteeman kehittelemiseen, näkemykseen, että nykykapitalismi on välinpitämätön, indifferentti perustavien - moraalisten, ekologisten, yhteisöllisten - arvojen suhteen.

Edellä on puhuttu kapitalismikritiikistä avaamatta lähemmin itse kritiikin käsitettä. Usein kritiikillä tarkoitetaan vain kielteisyyttä, arvosteltavan kohteen ei-hyväksyttävien ja huonojen puolien esiintuomista. Näin kritiikki ja kriittisyys ymmärretään usein arkielämässä. Laajemmassa mielessä kritiikissä on kuitenkin kyse kohteen arvioimisesta jostakin tietystä arvonäkökulmasta tai mittapuusta käsin. Esimerkiksi jos pidämme tasa-arvoa tärkeänä arvona, voimme arvioida sitä, missä suhteissa jokin yhteiskunnallinen järjestely toteuttaa tätä arvoa ja missä suhteissa järjestely on ristiriidassa sen kanssa. Laajemmassa mielessä kritiikki voi siis tuoda kohteestaan esiin sekä myönteisiä että kielteisiä puolia eikä se välttämättä päädy kohteen kieltämiseen. (Vrt. Boltanski 20II.) Kritiikkiä tarkasteltaessa tärkeää on myös se, millaisten argumenttien avulla se esittää kohteestaan arvion. Mikäli se ei tuo kunnolla esiin omia perusteitaan, se lähenee, niin kuin Zima (I989) toteaa, ideologista diskurssia.

Kritiikki on ollut yleisesti hyväksytty instituutio moderneissa yhteiskunnissa niiden perustamisesta eli I700-luvulta lähtien. Boltanski ja Chiapello eivät tarkastele lähemmin kritiikin syntyvaihetta, mutta klassinen esitys tästä puolesta on Habermasin Julkisuuden rakennemuutos. Tutkimus yhdestä kansalaisyhteiskunnan kategoriasta (2004), jonka saksankielinen alkuperäisversio ilmestyi vuonna I962. Teos kuvaa sitä, miten ensin Englannissa ja myöhemmin myös muissa Euroopan maissa muotoutui suhteellisen vapaa julkisen mielipiteenmuodostuksen alue, jonka forumeina olivat sanomalehdet, kirjallisuuslehdet ja kahvilat. Valistuneet kansalaiset alkoivat käydä kriittistä keskustelua yhteiskunnan ja kulttuurielämän ilmiöistä ja vallanpitäjien toimenpiteistä. Tällaista kriittisen julkisuuden ja keskustelun mahdollisuutta on pidetty liberaalisdemokraattisissa maissa niin tärkeänä, että sen asema on tavallisesti pyritty turvaamaan perustuslakien sananvapauspykälissä. Tämä ei ole Habermasin mukaan kuitenkaan pystynyt estämään sitä, että I९०o- 
luvulta lähtien klassinen julkisuuden idea on kasvavassa määrin rappeutunut tiedostusvälineiden kaupallistumisen ja viihteellistymisen seurauksena.

Liberaalis-demokraattisissa maissa kritiikki on siis nähty myönteiseksi, yhteiskunnan kehitystä eteenpäin vieväksi voimaksi. Boltanski ja Chiapello (I999, 69-90) toteavat, että kapitalismikaan ei lähtökohtaisesti torju itseensä kohdistuvaa kritiikkiä. Itse asiassa se tarvitsee kritiikkiä, sillä kritiikki paljastaa sille vallitsevan talousjärjestyksen ongelmakohdat ja sitä uhkaavat riskit ja vaarat. Sen ansiosta vallitsevan talousjärjestyksen ylläpitäjät voivat muuttaa toimintatapojaan ja tapaansa legitimoida kapitalismi, ja toisinaan he myös toteuttavat kritiikin vaatimia uudistuksia. Boltanskin ja Chiapellon tutkimuksessa toistuukin ajatus, että kritiikki on pikemminkin ollut kapitalismia uudistava ja vahvistava voima kuin sen horjuttaja.

Habermasin sekä Boltanskin ja Chiapellon esittämät käsitykset julkisuudesta ja kritiikistä viittaavat siihen, että modernin julkisuuden alueella kirjallinen teos voi toimia yhteiskuntakritiikin roolissa silloinkin, kun sen tekijä ei ole sitä sellaiseksi tarkoittanut. Tällainen on mahdollista, koska modernissa yhteiskunnassa kriittisen keskustelun mahdollistava julkisuus on toiminut institutionalisoituna rakenteena, joka ei tottele yksittäisen ihmisen tahtoa ja toiveita. ${ }^{57}$ Siten julkisuuden alueelle saapuvat esitykset ja puheenvuorot ymmärretään vähintäänkin potentiaalisesti näkemyksiksi tai kannanotoiksi yleisemmin merkittävistä kysymyksistä. Ensi sijassa tämä koskee lehdistöä ja poliittista julkisuutta, mutta osittain samalla tavalla kaunokirjallisuuttakaan ei ole modernissa kulttuurissa pidetty pelkkänä kirjailijoiden itseilmaisuna vaan myös kulttuurisesti ja yhteiskunnallisesti merkittävänä diskurssina. Koska se on I700-luvulta lähtien ymmärretty fiktiiviseksi, mielikuvituksen varaan perustuvaksi esitykseksi, sillä on ollut lehdistöä ja tiedettä suurempi vapaus erilaisten maailmankuvien ja yhteiskuntakäsitysten kriittisessä testaamisessa (Schmidt, Siegfried I989, I5-27, 409-438). Siksi kirjallinen teos voi olla osa diskursiivisia kamppailuja silloinkin, kun kirjailija ei ole sitä sellaiseksi tarkoittanut. 


\section{Rationaalisuus, indifferenssi, vieraantuneisuus ja syrjäytyneisyys}

Rationaalisuuden käsite ei ole vain osa käsillä olevaa tutkimusta varten laadittua teoriakieltä, vaan myös Seppälän romaanit hyödyntävät sitä. "Rationaalisuudella" tarkoitetaan tavallisesti sellaisia asioita kuin ajattelun johdonmukaisuus ja ristiriidattomuus, uskomusten ja näkemysten huolellinen perusteleminen sekä toiminnan pohjaaminen harkinnan ja vaihtoehtojen punnitsemisen varaan. Tällainen käsitys muodostaa pohjan myös rationaalisuutta koskeville filosofisille teorioille. Niissä rationaalisuuden päämuotoina on pidetty uskomusrationaalisuutta ja toiminnallista rationaalisuutta, joista jälkimmäinen on vielä jaettu välinerationaalisuuteen ja arvorationaalisuuteen. (Niiniluoto I994, 44-66.) Näiden erottelujen alkuperä palautuu Aristoteleeseen ja Immanuel Kantiin, joista edellinen teki eron maailmaa reflektoivan järjen (logos) ja toimintaan ankkuroituneen järjen (fronesis) välille ja jälkimmäinen erotti puhtaan tai teoreettisen järjen käytännöllisestä järjestä. Maailmaa reflektoiva tai teoreettinen järki liittyy uskomusrationaalisuuteen ja käytännöllinen järki toiminnalliseen rationaalisuuteen. Uskomusrationaalisuudesta ovat olleet kiinnostuneita lähinnä loogikot ja tietoteoreetikot, kun taas yhteiskuntafilosofit ovat työstäneet teoriaa toiminnallisesta rationaalisuudesta. Tämän tutkimuksen kannalta näistä tärkeämpi on toiminnallinen rationaalisuus..$^{8}$

Uskomusrationaalisuutta koskevassa tutkimuksessa keskeinen ongelma liittyy siihen, millä ehdoin tieteissä esitetyt väittämät ja teoriat edustavat hyväksyttävissä olevaa tietoa (Niiniluoto I994, 47). Taustaajatuksena tässä on se, että uskomukset ovat rationaalisia ja ne täyttävät hyväksyttävissä olevan tiedon tunnuspiirteet, mikäli ne on perusteltu asiallisesti. Tieteissä esitettyjen uskomusten ja näkemysten perusteluina voivat olla esimerkiksi metodisesti kontrolloidut havainnot, systemaattinen empiirinen tutkimustyö, aiemmin kerätty tieto sekä havainnoista ja teorioista johdetut päätelmät. Tällaista tarkastelutapaa, jossa arvioidaan uskomusten, näkemysten ja representaatioiden sekä niiden tueksi esitettyjen perusteiden pätevyyttä, voidaan hyödyntää myös kirjallisuuden tutkimisessa, vaikka kirjallisuudentutkijat ovat usein keskittyneet tar- 
kastelemaan sitä, millaisin kirjallisin, kielellisin ja narratiivisin keinoin tekstit välittävät näkemyksiä ja representaatioita maailmasta.

Seppälän romaaneista suorimmin uskomusrationaalisuuteen liittyviä kysymyksiä käsittelee Paholaisen haarukka. Se arvioi eräissä yhteyksissä sitä, missä määrin nykyinen kapitalismi nojaa rationaaliseen, perusteltavissa olevaan tietoon. Silti Seppälän muitakin romaaneja voidaan tarkastella uskomusrationaalisesta näkökulmasta. Tällöin pohditaan sitä, millaisen kuvan nyky-yhteiskunnasta ne välittävät ja millaisten nykyyhteiskuntaa koskevien havaintojen, pohdiskelujen ja teorioiden avulla tuo kuva on luotu tai "perusteltu".

Toiminnalliseen rationaalisuuteen liittyvät teemat ovat selvimmin esillä Paholaisen haarukassa ja Mr. Smithissä. Ne puhuvat noista teemoista tavalla, joka tuo mieleen Weberin ja Habermasin näkemykset välinerationaalisuuden ja arvorationaalisuuden välisestä suhteesta kapitalismissa. Nykytaloutta kuvatessaan Paholaisen haarukka lainaakin habermasilaista käsitteistöä. Habermasin yhteiskuntateoria pohjautuu puolestaan osittain Weberin teoksiin, joissa esitettyä teoriaa modernista yhteiskunnasta hän on kehittänyt kriittisesti eteenpäin.

Teoksessaan Wirtschaft and Gesellschaft (1956, ilmestyi alun perin I92I-I922) Weber erottaa toisistaan neljä eri toiminnan tyyppiä, jotka ovat (I) päämäärärationaalinen toiminta (Zweckrationalität), (2) arvorationaalinen toiminta (Wertrationalität), (3) traditionaalinen toiminta (traditionales Handeln) ja (4) tunteenomainen toiminta (affektuelles Handeln). Tyyppi (I) edustaa nimestään huolimatta välinerationaalisuutta, sillä siinä ei pohdita itse päämäärien tai tavoitteiden järkevyyttä tai mielekkyyttä vaan sitä, millaisten keinojen avulla päämäärät tai tavoitteet - liikevoitto, yrityksen markkinaosuuden kasvu - voidaan saavuttaa taloudellisesti, tehokkaasti ja tarkoituksenmukaisesti. Siinä tavoitteet ja päämäärät otetaan annettuina, kyseenalaistamatta niitä, ja toiminta pyrkii saavuttamaan ne mahdollisimman "rationaalisesti". Rationaalisuuden tätä muotoa on myös kutsuttu instrumentaaliseksi tai proseduraaliseksi rationaalisuudeksi. Tyypissä (2) toiminta saa mielensä tai järkevyytensä siitä, että siinä yritetään toteuttaa jotakin perustavana pidettyä uskonnollista, moraalista, esteettistä tai yhteisöllistä arvoa. Kun ihmiset haluavat muuttaa maailman Jumalan tahdon mukaiseksi tai lisätä siihen kauneutta, 
oikeudenmukaisuutta ja suvaitsevaisuutta, heidän lähtökohtansa on arvorationaalinen. Tyypissä (3) toimitaan syvään juurtuneiden tapojen ja tottumusten pohjalta ja tyypissä (4) tunteiden ja tunnetilojen ohjaamina. (Weber I956, 6I, I29. Ks. myös Aspers 20II, 56-57.)

Kyseinen typologia on analyyttinen tai ideaalityyppinen. Tyypit (I) (4) eivät esiinny todellisuudessa sellaisinaan, vaan tavallisesti toiminta sisältää aineksia niistä kaikista. Modernissa markkinakapitalismissa tyypistä (I) tulee silti Weberin mukaan hallitseva taloudellisen toiminnan ulottuvuus. Modernissa taloudessa esiintyy myös sellaista yritystoimintaa, jossa painotetaan arvorationaalisuutta. Esimerkkinä tästä voidaan mainita Välimeren maissa toimivat perinteiset perheyritykset (hotellit, ravintolat, erikoisliikkeet), jotka eivät pyri niinkään toimintansa jatkuvaan laajentamiseen ja taloudellisten voittojensa kasvattamiseen vaan enemmänkin tietyn kulttuurin tai elämäntavan ylläpitämiseen ja siihen tarvittavan taloudellisen pohjan luomiseen. Silti kapitalismissa tällaisen toimintatavan on vaikea tai mahdotonta kohota hallitsevaksi toimintamuodoksi. Syiksi tähän Weber esitti sen, että pyrkimys tehokkuuteen karsii markkinakilpailusta muita arvolähtökohtia. (Ks. Gronow 20I3, 42-43.) Tässä mielessä arvorationaalisuutta tavoitteleva yritystoiminta, "eettinen kapitalismi", voi vapaassa markkinataloudessa toteutua vain rajoitetussa mittakaavassa.

Siinä määrin kuin tyyppi (I) muuntaa maailman mitattavissa ja laskettavissa oleviksi suureiksi, se edustaa Weberillä muodollista rationaalisuutta. Tyyppi (2) edustaa puolestaan materiaalista tai substantiaalista rationaalisuutta. Vastaavanlainen erottelu sisältyy Habermasin (1987a; I987b) teoriaan, joka tekee eron strategisen ja kommunikatiivisen toiminnan välille. Strateginen, menestyksen ja hyödyn tavoittelemiseen suuntautuva toiminta noudattaa kognitiivis-instrumentaalista rationaalisuutta, ja siinä menestystä ja hyötyjä pyritään saavuttamaan suunnitelmallisen, tehokkaan ja kognitiivisesti tai tiedollisesti pohjatun toiminnan avulla. Kommunikatiivisessa rationaalisuudessa toiminnan ensisijaisena tavoitteena on ymmärtää toista osapuolta sekä muodostaa yhteinen arvo- ja merkitysmaailma toimijoiden välille. Habermasin teoriassa kognitiivis-instrumentaalinen rationaalisuus on ollut vallalla moderneissa talouden ja politiikan järjestelmissä tai "systeemeissä". Sitä vastoin arki- 
sissa elämismaailmoissa modernit subjektit ovat toimineet ensi sijassa kommunikatiivisen rationaalisuuden pohjalta.

Habermasia on arvostelu siitä, että alun perin hän kiinnitti suoraviivaisesti kognitiivis-instrumentaalisen rationaalisuuden talouden ja politiikan järjestelmiin sekä kommunikatiivisen rationaalisuuden subjektien elämismaailmoihin. Axel Honneth (I988, 328-332), Frankfurtin koulun nykyinen keskushahmo, on huomauttanut, että yhteiskunnan kaikilla osa-alueilla esiintyy strategista ja kommunikatiivista toimintaa. Siten myös talouden ja politiikan järjestelmissä on kommunikatiiviseen rationaalisuuteen perustuvia osakulttuureja eikä subjektien toiminta elämismaailmoissa ole täysin riippumatonta strategisista tavoitteista, hyödyn ja menestyksen tavoittelemisesta. Elämismaailmoissa toimiessaan subjektien tulisi kuitenkin ottaa laajasti huomioon kanssasubjektien toiveet ja tavoitteet, sillä muutoin he eivät pysty luomaan ympärilleen hyvin toimivaa elämismaailmaa.

Samoin on syytä välttää ajatusta, että kognitiivis-instrumentaalinen rationaalisuus tai välinerationaalisuus olisi sinänsä moraalisesti kyseenalainen ilmiö ja arvorationaalisuus tai kommunikatiivinen rationaalisuus puolestaan "luonnostaan" myönteinen asia. Ensiksi mainittu rationaalisuuden muoto ei ole sinänsä ongelmallinen, sillä sitä esiintyy kaikkialla yhteiskunnan ja yksilöiden suunnitelmallisessa toiminnassa. Ongelmaksi se muodostuu lähinnä silloin, kun sitä harjoitetaan kyseenalaisten tavoitteiden pohjalta tai kun sen toteuttaminen aiheuttaa vahinkoa. Tällainen kielteinen mahdollisuus liittyy moderniin kapitalismiin, jossa tavoitellaan tehostetun välinerationaalisesti toimimalla liikevoittoa - asiaa, jonka järkevyys tai mielekkyys on Weberin mukaan itsessään ongelmallista. Toisaalta myös arvorationaalinen toiminta saattaa olla perustavalla tavalla ongelmallista. Ajatellaan vaikkapa tilannetta, jossa ihminen lähtee elämässään uskonnollisista tai ekologisista arvoista ja pyrkii sitten toimimaan johdonmukaisesti niiden hyväksi. Mikäli hän on lisäksi arvofundamentalisti, hän on valmis välineellistämään lähes kaiken muun palvelemaan arvojaan. Siten hän saattaa jopa hyväksyä terrorin ja väkivallan arvojaan edistäviksi välineiksi. Tässä tapauksessa välinerationaalisuus on alistettu palvelemaan sokeasti arvorationaalisuutta. 
Weberin ja Habermasin teoriat modernisaatiosta ja rationaalisuudesta herättivät I980- ja I990-luvulla akateemisessa maailmassa vilkasta keskustelua. Saksalainen filosofi Wolfgang Welsch käy tuota kriittistä keskustelua osaltaan läpi tutkimuksessaan Vernunft. Die zeitgenössische Vernunftkritik und das Konzept der transversalen Vernunft (I995). Siinä hän toteaa, että Habermasin järjen tai rationaalisuuden käsitteen ansiona voi pitää sitä, että se estää ajautumasta totalisoivaan käsitykseen rationaalisuudesta. Tämä ansio perustuu siihen, että Habermasin käsite erottaa toisistaan useita eri rationaalisuuden lajeja ja alalajeja. Hänen teoriansa käyttökelpoisuutta vähentää kuitenkin se, että pääteoksissaan Habermas irtautuu usein subjektien ja sosiaalisten toimijoiden maailmoista ja siirtyy tarkastelemaan "järjen eri momenttien" keskinäisiä suhteita ja näiden momenttien kiinnittymistä yhteiskunnan instituutioihin ja järjestelmiin. Jotta kyseinen teoria olisi kuvausvoimainen, tutkijan tulee osata soveltaa sitä myös subjektien ja toimijoiden tasoa koskeviin tarkasteluihin. (Welsch I995, I25-I26.) Pyrin tutkimuksessani noudattamaan tätä metodologista periaatetta, jonka mukaan rationaalisuuden eri muodot liittyvät siis sekä yhteiskunnan järjestelmien toimintatapoihin että subjektien ja heitä esittävien kaunokirjallisten henkilöiden mentaliteetteihin ja tekoihin.

Weberin ja Habermasin teorioita koskevassa keskustelussa on pohdittu myös sitä, ovatko ne kulttuurisesti riittävän erottelukykyisiä vai onko ne laadittu länsimaisen sivilisaation pohjalta. Epäilijöiden mukaan ne eivät ehkä ota huomioon sitä, että muissa kulttuuripiireissä on saatettu kehittää länsimaisesta rationaalisuuskäsityksestä poikkeavia rationaalisuuden muotoja. Weberin kohdalla tällainen kritiikki ei ole kovin osuvaa, sillä hän kehitti omaa käsitystään vertailevien uskontososiologisten tutkimustensa avulla; niissä hän vertasi toisiinsa modernia länsimaista ja aasialaista kulttuuria. Koska Habermasin teoria perustuu osittain Weberin tutkimuksiin, siinäkin on epäsuorasti mukana vertaileva ulottuvuus. Habermas onkin esittänyt, että hänen teoriansa rationaalisuuden eri lajeista ja alalajeista on sovellettavissa länsimaisen kulttuuripiirin ulkopuolisiin kulttuuripiireihin. Koska käsillä olevassa tutkimuksessa keskitytään Suomeen ja länsimaihin, tähän problematiikkaan ei ole tarpeen mennä syvemmälle. Tässä tutkimuksessa käytetty rationaalisuuskäsitys 
on joka tapauksessa ollut suhteellisen yleisesti käytössä (länsimaisessa) tieteessä, sillä Weberin ja Habermasin ohella vastaavanlaista rationaalisuuskäsitystä ovat kehitelleet Martha C. Nussbaum (I990; 20I2), Nicholas Rescher (1988), G. H. von Wright (I985; I987; I993) ja Ilkka Niiniluoto (I994). Vaikka tuo käsitys ei ole ongelmaton, sitä ei ole syytä hylätä. Teorioiden käyttökelpoisuuden yhtenä arviointikriteerinä voidaan pitää sitä, kuinka laajasti niiden avulla voidaan kuvata, tulkita ja selittää maailmaa ja sen ilmiöitä. Uskon tämän tutkimuksen osoittavan, että kyseinen rationaalisuuskäsitys tarjoaa monipuolisen välineistön Seppälän teosten tarkastelemiselle. 59

Weberin teorian mukaan modernissa yhteiskunnassa vallitsee siinä mielessä jännite rationaalisuuden eri muotojen välillä, että tehokkuuteen pyrkivät instituutiot ja organisaatiot joutuvat usein karsimaan toiminnastaan arvorationaalisia näkökohtia. Habermas (I987b, I7I-293, 489-547) on niin ikään puhunut rationaalisuuden eri muotojen välisestä jännitteestä "myöhäismodernissa yhteiskunnassa". Hänen mukaansa modernisaatiokehityksen etenemisen myötä kapitalistisen talouden ja poliittis-hallinnollisen järjestelmän lait ja toimintatavat, "rahan ja vallan mediat", ovat yhä syvemmin tunkeutuneet elämismaailmoihin ja "kolonialisoineet" ne. Tämä prosessi on murtanut elämismaailmojen omaehtoista kehitystä ja köyhdyttänyt niihin varastoitunutta erityislaatuista sosiaalista ja kulttuurista pääomaa, minkä seurauksena "sosiaaliset patologiat" ja "mielekkyyskriisit" ovat yleistyneet myöhäismodernissa yhteiskunnassa. Habermasilla elämismaailmojen köyhtyminen, niiden omaehtoisen kehityksen murtuminen ei siis johdu pelkästään kapitalistisen talouden ja markkinoiden toimintatapojen leviämisestä niihin, vaan sitä aiheuttaa myös "sosiaalivaltion" eli hyvinvointivaltion harjoittama, muuhun yhteiskuntaan kohdistuva byrokraattinen sääntely. Ne molemmat tuovat elämismaailmoihin aineksia, jotka eivät niihin alkuaan kuulu.

Weberin ja Habermasin teorioihin sisältyy näkemys, että kapitalistisella taloudella on taipumus toimia indifferentisti. Muodollisessa mielessä tehokas kapitalistinen yritys tai kapitalistinen talousjärjestelmä saattaa sulkea tarkastelun ulkopuolelle tai marginalisoida kysymykset hyvästä ja pahasta, oikeasta ja väärästä, massatuotannon ja massakulutuksen yhteiskunnallisesta mielekkyydestä tai luonnonvarojen kiihtyvän hyväksi- 
käytön järkevyydestä. Näissä suhteissa kapitalismi on luonteeltaan amoraalinen eli se pyrkii, Friedrich Nietzschen tunnettua sanontaa lainataksemme, asettumaan "hyvän ja pahan tuolle puolen". ${ }^{60}$ Siksi se on usein aiheuttanut yhteiskunnassa suurta tuhoa, mutta toisaalta valtio on kerta kerran jälkeen paikkaillut sen yksilöille ja yhteiskunnalle aiheuttamia vahinkoja. Kirjassaan The Crisis of the European Union (2012, IO2-IO3, IIO; saksankielinen alkuperäisteos ilmestyi 20II) Habermas ottaa kriittisen kannan tällaisten toimien viimeaikaisiin ilmenemismuotoihin. Hänen mukaansa on "skandaalimaista", että vuonna 2007 Yhdysvalloissa alkaneen ja eri puolille maailmaa levinneen talouskriisin kulut on monissa maissa maksatettu paljolti valtion eli veronmaksajien rahoilla, vaikka sen maksajana tulisi olla holtittomaan riskinottoon langennut finanssisektori.

Seppälän romaaneista indifferenssin teemaa käsittelee selvimmin Paholaisen haarukka. Sen maailmassa muodollisesti rationaalinen, mutta substantiaalisesti indifferentti kapitalismi tuottaa yhteiskuntaan ja yksilöiden elämismaailmoihin vieraantuneisuutta, mielekkyyskriisejä ja sosiaalisia patologioita. Vieraantumisteorian klassikkona voi edelleen pitää Marxin Taloudellis-filosofisia käsikirjoituksia 1844, jos kohta siihen sisältyviä ajatuksia on täydennettävä myöhemmällä tutkimuksella (vrt. Jameson 20II, 2). Kapitalismissa vieraantumista aiheuttaa Marxin (I978, 2I7-232) mukaan ennen kaikkea se, että kapitalisti ei ole kiinnostunut työläisen kokonaispersoonallisuudesta, vaan kapitalisti käsittelee työläistä esineenä, työvoima-tavarana, jonka hän on palkannut korvausta vastaan käyttöönsä ja josta hän voi halutessaan sanoutua irti. Se aiheuttaa työläisessä vieraantumista neljällä eri ulottuvuudella.

Kapitalismissa työläinen vieraantuu Marxin mukaan ensinnäkin työnsä tuloksesta, jota hän ei saa omaan käyttöönsä, sillä se kuuluu tuotantovälineiden omistajalle, kapitalistiselle yrittäjälle. Toiseksi työläisessä tapahtuu itsevieraantumista, sillä hän ei voi työssään kehittää kaikkia potentiaalisia kykyjään ja taitojaan vaan lähinnä vain niitä valmiuksia, jotka hyödyttävät kapitalistista yrittäjää. Kolmanneksi työntekijä vieraantuu ihmisen "lajiolemuksesta" - siitä, että vierasmääritteisessä kapitalistisessa työssä hänellä ei ole mahdollisuuksia vapaaseen itsetoteutukseen vaan hän joutuu toteuttamaan ulkopäin määrättyjä tehtäviä tai pakkoja. ${ }^{61}$ 
Neljänneksi kapitalismi aiheuttaa myös sosiaalista vieraantuneisuutta. Tämä ulottuvuus jää kuitenkin Taloudellis-filosofisissa käsikirjoituksissa vain muutaman hajanaisen huomion varaan. Laajemmin Marx ja hänen työtoverinsa Friedrich Engels puhuvat siitä Kommunistisen puolueen manifestissa (I848). Siinä he esittävät, että kapitalismille ominainen jatkuva uusiutumisen ja laajentamisen tarve saa sen kerta kerran jälkeen murtamaan kaikki totunnaiset sosiaaliset ja yhteisölliset siteet ihmisten väliltä (Marx \& Engels I978, 337-348). Tässä mielessä se heikentää ihmisten kiinnittymistä yhteisöihin.

Marx-tutkimuksessa on aikoinaan käyty vilkasta keskustelua siitä, millainen suhde vallitsee Taloudellis-filosofisissa käsikirjoituksissa ja Pääomassa (jälkimmäisen ensimmäinen osa ilmestyi vuonna I867) esiintyvien vieraantumisen käsitteiden välillä. Tuossa keskustelussa asetettiin toisinaan vastakkain "nuori, humanistinen Marx" ja "Pääoman Marx tai kypsä Marx". Ajatuksena oli tällöin se, että ihmisen lajiolemuksesta puhuessaan nuori Marx kritisoi kapitalismia tietystä arvoperspektiivistä ja filosofis-antropologisesta ihmiskäsityksestä käsin, kun taas Pääoman Marx luopui näistä lähtökohdista ja samaisti vieraantuneisuuden tavarafetisismiin ja lisäarvon tuotannossa tapahtuvaan työläisten riistämiseen. Tämän tulkinnan mukaan Marx siis luopui Pääomassa nuoruudentuotantoonsa sisältyvästä arvoperspektiivistä. Kyseistä vastakkainasettelua on kuitenkin pidettävä virheellisenä. Joachim Israel (I974, I5) toteaa, että Marxin molemmissa kehitysvaiheissa sellaiset arvofilosofiset lähtökohdat kuin ihmisen vapautus ja ihmisen itsetoteutus ovat keskeisiä. (Ks. myös Hänninen 20II, 24I-242; Zima I989, I85.) Ilman arvolähtökohtia on itse asiassa mahdotonta harjoittaa yhteiskuntakritiikkiä, sillä siinä olemassa olevaa yhteiskuntaa verrataan, vähintäänkin epäsuorasti, siihen, millainen yhteiskunta voisi olla tai millainen sen tulisi olla.

Marxilla vieraantumisesta kärsii lähinnä työväenluokka, sillä hän hahmottaa vieraantumisen sen näkökulmasta. Weberillä muodollisrationaalisen toiminnan yleistymisen aiheuttamat ongelmat koskettavat periaatteessa koko modernia yhteiskuntaa, myös ylempiä luokkia, sillä hänen mukaansa tuon toimintatyypin yleistyminen ja kulttuurin syvenevä maallistuminen tuottavat yhdessä mielekkyyskriisejä (Sinnverluste) tai eksistentiaalisia kriisejä. Niissä on kyse siitä, että muodollisesti rationali- 
soituneessa, mutta substantiaalisesti köyhässä maailmassa yksilöiden on usein vaikea löytää elämälleen tarkoitusta ja syvempää mieltä. Moderni läntinen sivilisaatio uhkaa siten etäännyttää ihmiset mielekkääksi ja autenttiseksi koetusta elämästä, eikä se välttämättä pysty tyydyttämään heidän eksistentiaalisia tarpeitaan. Weber oli taipuvainen ajattelemaan, että vain uskonto voi aidosti toimia syvästi tarkoitukselliseksi ja mielekkääksi koetun elämän pohjana. Modernissa sivilisaatiossa ongelmana on kuitenkin se, että ihmisten on vaikea sitoutua uskontoon. Koska uskonto ei sovi yhteen rationaalisen maailmankuvan kanssa, sen sisäistäminen edellyttäisi ihmisiltä "intellektuaalista uhrausta", johon nämä eivät yleensä ole valmiita (Weber 2009, 6I-66).

Tätä asetelmaa kuvatessaan Weber ei puhunut "vieraantumisesta" vaan lähinnä "mielekkyyskriisistä" tai "merkityskadosta". Siksi häntä ei voida pitää varsinaisena vieraantumisteoreetikkona. Toisaalta, niin kuin edellä kävi ilmi, häntä ei myöskään ole lupa sivuuttaa moderniin kulttuuriin liittyvästä vieraantumisesta puhuttaessa. (Langman 20I2, 54, 56.) Weberiläinen näkemys moderniin kulttuuriin liittyvistä ongelmista muodostaa hedelmällisen lähtökohdan Seppälän romaanien analysoimiselle. Niiden ylimpiin luokkiin kuuluvat keskushenkilöt, varsinkin Yhtiökumppaneiden Pete ja Olli sekä osittain myös Paholaisen haarukan Lari Laine ja Mr. Smithin nimihenkilö, kärsivät merkityskadosta tai he ovat kyynisesti mukautuneet elämään ja toimimaan yhteiskunnassa, joka ei tarjoa heille syvempiä merkityskokemuksia, vaikka se palkitsee heidät runsain mitoin rahallisesti.

Kommunikatiivisen toiminnan teoriassaan Habermas pitää Weberin näkemystä mielekkyyskriiseistä liioiteltuna. Hänen mukaansa siinä jää ymmärtämättä se, että rationalisoitumisesta ja maallistumisesta huolimatta elämismaailmat ovat edelleen tarjonneet subjekteille aineksia, joiden ansiosta he voivat kokea elämänsä merkitykselliseksi. Elämismaailmojen aineksia ovat muun muassa rakastettu tai puoliso, perhe, suku, ystävät, työ ja harrastukset; ne ovat osaltaan ehkäisseet mielekkyyskriisien yleistymistä modernissa sivilisaatiossa. Silti Habermaskin (I987a, 205-366; I987b, 449-488) oli i980-luvun alussa ilmestyneessä teoriassaan huolissaan siitä, että kapitalistisen talouden laajenemistarpeiden ja poliittis-hallinnollisen ohjausjärjestelmän vaatimusten tun- 
keutuminen elämismaailmoihin köyhdyttää näihin maailmoihin sisältyviä kulttuurisia varantoja. Tässä suhteessa tuo prosessi on luonut pohjaa mielekkyyskriisien yleistymiselle. Habermas ei kuitenkaan tarkastellut teoriassaan uusliberalistista vaihetta, joten tässä suhteessa sitä on syytä täydentää - niin kuin käsillä oleva tutkimus tekee - nykykapitalismia koskevilla tutkimuksilla.

Markkinallistumiskehitys on tehnyt ajankohtaisiksi Marxin teorian vieraantumisesta sekä Weberin ja Habermasin näkemykset mielekkyyskriiseistä (ks. Braun \& Langman 20I2). Samalla nykytutkimus on täydentänyt niitä syrjäytymisen ja syrjäytyneisyyden käsitteillä. Siinä, missä Marxin vieraantumisteoria puhui kapitalistisessa työssä ja tavaratuotannossa tapahtuvista prosesseista, syrjäytymisen ja syrjäytyneisyyden käsitteillä viitataan tilanteeseen, jossa yksilö jää pysyvämmin koulutusmahdollisuuksien ja työelämän ulkopuolelle eikä siksi pysty kunnolla kiinnittymään yhteiskuntaan ja toteuttamaan itseään. Kroonisesta joukkotyöttömyydestä kärsivässä nyky-yhteiskunnassa syrjäytyminen, vieraantuneisuuden erityismuoto, on vakava ongelma. Paholaisen haarukassa esiintyvä Jumalan Kyynel, pitkäaikaistyöttömyydestä kärsivä päihteiden monikäyttäjä, kuvataan nimenomaan "syrjäytyneeksi" mieheksi (Seppälä 2008, 73, I26). Samanlainen luonnehdinta sopii osittain Mr. Smithissä esiintyviin Briscillaan ja Raneen, vaikka kyseinen romaani ei sitä avoimesti käytäkään. Tämä työväenluokan alinta kerrostumaa edustava pariskunta elättää itsensä lyhytaikaisilla työsuhteilla, eivätkä he pysty ottamaan elämäänsä kunnolla hallintaansa vaan ovat pikemminkin pysyvästi syrjäytymisvaarassa. Yhteiskunnalliselta asemaltaan Briscilla ja Rane ovat Kuun nousussa ja laskussa esiintyvän Kaukon, syrjäytymisvaarassa olevan maalaisköyhälistön edustajan, sukulaishahmoja, mutta heitä kuvataan ja arvioidaan empaattisemmin kuin epätoivoisesti käyttäytyvää Kaukoa.

Vieraantumisen ja syrjäytymisen teemojen näkökulmasta mielenkiintoisina voi myös pitää sosiaalipsykologian piirissä tehtyjä tutkimuksia masennuksesta. Jukka Tontti ja Anders Petersen, molemmat sosiaalipsykologeja, huomauttavat, että viime vuosikymmeninä masennuksesta on tullut läntisissä maissa yleinen ilmiö, josta kärsivät erityisesti kaupungeissa asuvat keski-ikäiset naiset, vähemmässä määrin myös miehet. 
Tontin (2005, 389-390) mukaan masennuksen taustalla ovat "ilmeisesti” julkisten instituutioiden ja sosiaaliturvajärjestelyjen rapautuminen ja kollektiivisen solidaarisuuden tunteiden mureneminen yhteiskunnassa, joka vaatii yksilöiltä yhä enemmän "itseohjautuvuutta”. Jos yksilö kokee tämän vaatimuksen liian kuormittavaksi ja mahdottomaksi, hän on vaarassa sairastua masennukseen ja tällöin hän eristäytyy helposti normaalista sosiaalisesta elämästä.

Petersen (20II, 6, 9-I2, I4-I5, 2I) puhuu vastaavasti nyky-yhteiskuntaan liittyvästä "itsensä toteuttamisen" ihanteesta ja normista. Hän toteaa, että nykykapitalismi lupaa yksilöille autenttista itsetoteutusta, ylellisiä kulutusmahdollisuuksia ja vapautta muodostaa itse oma elämäntyylinsä. Monilla yksilöillä ei ole riittävästi resursseja toteuttaa näitä ihanteita. Tietoisuus ihanteiden ja heidän omien resurssiensa välisestä ristiriidasta saattaa aiheuttaa heissä "kroonisen stressireaktion", joka uuvuttaa heidät ja saa heidät lopulta sairastumaan masennukseen. Tällöin nämä yksilöt passivoituvat ja heidän on vaikea nähdä yhteiskunnassa ja omassa elämässään mielekästä tulevaisuusperspektiiviä. Richard Sennettin (2002, II, I9, 23, I04, I3I, I59; 2007, IO-I3, 39-40, 65-69, I60-I62, I80) mukaan tällaista neuvottomuutta ja tulevaisuusperspektiivin katoamista voi yksilöissä aiheuttaa sekin, että joustavuutta vaativa sekä äärimmäisen epävakaaksi osoittautunut nykyinen työelämä kylvää ihmisten keskuuteen "ontologista turvattomuutta" ja estää heitä kehittämästä pitkäkestoisia suunnitelmia ja projekteja elämänsä varalle (ks. myös Braun 20I2, 40, 43).

Edellä esitellyissä teorioissa vieraantumista, syrjäytymistä ja masennusta selitetään yhteiskunnallisilla tekijöillä. Ne ovat sinänsä tarpeellisia Seppälän teosten analysoimisessa, mutta niitä on täydennettävä eksistentialistisella käsityksellä vieraantumisesta. Seppälän teoksissa nimittäin tulee paikoitellen esiin sen suuntainen näkemys vieraantumisen syistä.

Eksistentialismin pääedustajat katsoivat, että yhteiskunnan rakenteet, normit ja olosuhteet voivat helpottaa tai pahentaa ihmisen kokemaa vierauden tunnetta, mutta viime kädessä tuota tunnetta ei voida kokonaan poistaa. Tämä johtuu heidän mukaansa inhimillisen tajunnan luonteesta sekä ihmisen ja maailman välisestä perustavasta epäsuhdasta. 
Heidegger, Beauvoir, Camus ja Sartre esittivät, että ihmiselle on luontaisesti ominaista pyrkiä näkemään maailma merkityksellisenä ja löytää siitä mielekäs merkitysjärjestys, mutta tämä pyrkimys on tietyiltä osin tuomittu epäonnistumaan. Universumissa ei nimittäin itsessään ole mitään kosmista järjestystä, joka antaisi merkityksen yksittäisille asioille ja tapahtumille ja inhimilliselle olemassaololle. Merkityksettömyys on siten universumin konstitutiivinen ominaisuus. Siksi ihmisten on tyydyttävä elämään itse luomiensa merkitysjärjestysten varassa, siinä määrin kuin he siihen pystyvät. Yksittäisen subjektin ja hänen kehityksensä näkökulmasta ongelmallista kulttuurisissa ja sosiaalisissa merkitysjärjestyksissä on kuitenkin se, että niihin sitoutuessaan subjekti alkaa helposti käyttäytyä konformistisesti, jolloin järjestykset rajoittavat hänen eksistentiaalista vapauttaan, hänen mahdollisuuksiaan muodostaa itselleen sellainen elämä, jonka hän ehkä voisi kokea subjektiivisesti merkityksellisemmäksi. ${ }^{62}$ Ajoittain Beauvoir ja Sartre näkivät sosiaalisuuden vieläkin kielteisemmin, sillä he ajattelivat, että myös ihmissuhteet ja niihin liittyvä seksuaalisuus rajoittavat aina väistämättä ihmisten vapautta.

Tietynasteinen vierauden tai kodittomuuden tunne on siis eksistentialistien mukaan ominaista ihmisen tavalle olla maailmassa. Tällainen motiivi tulee esiin myös Seppälän teoksissa, erityisesti laajassa novellissa "Taivaanranta" (I987b) sekä romaaneissa Silta (I988) ja Sydänmaa (I994a). Seppälän kapitalismikriittisissä romaaneissa se tulee paikoitellen esiin Paholaisen haarukassa (2008) ja Mr. Smithissä (20I2). Samoin sen suuntainen motiivi tai ajatusjuonne sisältyy Routavuoteen (2004a) ja novellikokoelmaan Takla Makan (2010), jotka jäävät kuitenkin tässä tutkimuksessa lähemmän tarkastelun ulkopuolelle.

Eksistentialistisesta vieraantumisteoriasta on käyty filosofiassa ja ihmistieteissä runsaasti keskustelua. Yhteiskuntatieteiden piirissä sen on usein katsottu johtavan konservatiiviseen asenteeseen, sillä sen mukaan vieraantuneisuutta ei voida kokonaan poistaa yhteiskuntaa muuttamalla vaan tietyssä määrin se kuuluu ihmisen tapaan olla maailmassa. Esimerkiksi Herbert Marcuse (I980a) arvosteli I940-luvun lopussa eksistentialismia juuri siitä, että se "ontologisoi" ahdistuksen ja vierauden kokemuksen eli katsoo sen kuuluvan inhimillisen olemassaolon perusrakenteeseen, ja samanlaisin argumentein myös Lucien Goldmann 
(I975; เ976) arvosteli aikoinaan ranskalaista eksistentialismia. Näitä lähellä oleva arvio sisältyy Pertti Karkaman teokseen Kulttuuri ja demokratia. Kirjoituksia kulttuurin nykytilasta (I998a). Teoksessaan Karkama kirjoittaa, että nykyinen uusliberalistinen kapitalismi on rapauttanut yhteiskunnasta monia sosiaalisia turvaverkkoja ja kollektiivisen solidaarisuuden muotoja, minkä takia epävarmuus, turvattomuus ja ahdistus ovat lisääntyneet yhteiskunnassa. Samalla eksistentialismi ja sen sukuiset ajatustavat ovat jälleen kerran nousseet keskeiseen asemaan niin ihmisten arkitajunnassa kuin kulttuurielämässä ja populaarissa nykyfilosofiassakin. ${ }^{63}$

Karkaman (I998a, 32-33, 49) pääajatuksena on se, että eksistentialismin nykyinen suosio, samoin kuin eksistentiaalisten ongelmien yleistyminen nykykulttuurissa, on seurausta "pidäkkeettömän liberalistisen kapitalismin" voittokulusta. Mielestäni ajatus pitää osittain paikkansa, mutta en jaa kantaa, että eksistentialistinen näkemys ihmisen asemasta maailmassa on täysin virheellinen. Eksistentiaalista ahdistusta ja vierauden kokemusta voidaan tuskin selittää tyhjentävästi pelkästään yhteiskunnallisilla tekijöillä, ja siksi on järkevää kuunnella, mitä sanottavaa eksistentialisteiksi kutsutuilla filosofeilla ja kirjailijoilla on niistä. Näin myös monet nykysosiologit, muun muassa Ulrich Beck (I99I; I995) ja Anthony Giddens (2000; 200I), ovat ajatelleet. Varhaisemmassa artikkelissaan "Modernismin haasteet" (I990) Karkamakin on lähellä tällaista näkemystä. Siinä hän toteaa, että eksistentiaalisen ahdistuksen ja vierauden kokemuksen kaltainen mentaalinen tila on esiintynyt useissa historian ja kirjallisuushistorian vaiheissa. Tällä perusteella hän olettaa, että se on ollut yleinen, joskaan ei välttämättä "ehdoton" tai universaali ilmiö historiassa (Karkama I990, 22-23).

\section{Rationalisaatiokriittinen romaanityyppi}

Kun puhutaan rationalisaatiosta kirjallisuuden ja taiteen yhteydessä, on syytä erottaa toisistaan kaksi asiaa. Rationalisaatio voi yhtäältä olla kirjallisen teoksen teemana, jolloin teos keskittyy käsittelemään rationalisoitumista ja sen vaikutuksia. Toisaalta modernissa, I700-luvulla synty- 
neessä sivilisaatiossa kirjallisuus edustaa kulttuurisena ilmaisumuotona jo itsessään erityislaatuista rationaalisuuden tyyppiä, joka eroaa modernia sivilisaatiota hallitsevasta rationaalisuuden tyypistä.

Habermas (1983, 26-27) luonnehtii modernille länsimaiselle kirjallisuudelle ja taiteelle ominaista rationaalisuuden tyyppiä esteettis-ekspressiiviseksi rationaalisuudeksi. Hänen teoriassaan se on kommunikatiivisen rationaalisuuden alalaji - samaan tapaan kuin moraalis-praktinen rationaalisuus, joka jää tässä tutkimuksessa tarkastelun ulkopuolelle. Esteettis-ekspressiivisessä rationaalisuudessa on kyse siitä, että kirjallisen teoksen tai taideteoksen herättämä kokemus laajentaa ja syventää subjektien kokemusmaailmaa ja auttaa heitä reflektoimaan omaa elämäntilannettaan ja suhdettaan maailmaan. Tämä kokemus kuuluu rationaalisuuden piiriin siksi, että se lisää subjektien itseilmaisu- ja reflektiokykyä. ${ }^{64}$

Habermasin näkemyksiin sisältyy epäsuorasti ajatus, että kirjallisuus ja taide auttavat harrastajiaan ymmärtämään paremmin sitä, mikä vallitsevassa yhteiskuntajärjestyksessä on historiallisesti ja kulttuurisesti ehdollista. Habermasia selvemmin tätä ajatusta on kuitenkin kehittänyt Niklas Luhmann. Vaikka Luhmann ei teksteissään puhu kirjallisuudelle ja taiteelle ominaisesta rationaalisuudesta, hänen esittämänsä ajatukset ovat tässä yhteydessä relevantteja. Luhmannin mukaan länsimaisen kirjallisuuden ja taiteen pääfunktio on I700-luvulta lähtien liittynyt kontingenssi-tietoisuuteen. Koska mielikuvitus ja fiktiivisyys ovat olleet modernin kirjallisuuden ja taiteen perusominaisuuksia, moderni kirjallisuus ja taide ovat opettaneet ihmiset kuvittelemaan, miltä toisenlainen maailma näyttäisi. Näin ne ovat ylläpitäneet ihmisissä tietoisuutta siitä, että olemassa olevat yhteiskunnalliset arvot, säännöt ja muodostumat voidaan periaatteessa korvata toisenlaisilla arvoilla, säännöillä ja muodostumilla. Modernin kirjallisuuden ja taiteen luomien maailmojen näkökulmasta vallalla oleva kulttuuris-yhteiskunnallinen todellisuus näyttäytyy siten osittain kontingenttina, satunnaisena - eikä välttämättömänä - muodostumana. Näin ne ovat lisänneet harrastajissaan vaihtoehtojen tajua ja kykyä kriittiseen ajatteluun. (Luhmann I997b, 2I5-300; 2008, I89-245.) 65

Suomessa samanhenkistä näkemystä on kehitellyt Hanna Meretoja, joka on tutkimuksissaan puhunut siitä, että kirjallisuus ylläpitää kult- 
tuurissa mahdollisuuksien tajua, tietoisuutta siitä, että kulttuurinen ja sosiaalinen järjestys voidaan periaatteessa rakentaa useilla eri tavoilla (ks. esim. Meretoja 20I5; 20I8). Tällaista näkemystä kehitellessään hän ei tosin ole nojautunut Luhmanniin vaan lähinnä hermeneuttisen filosofian traditioon ja Martha C. Nussbaumin tuotantoon. Käsillä olevan tutkimuksen kannalta huomionarvoista on myös se, että artikkelissa "Why We Read: The Plural Values of Literature" Meretoja ja artikkelin toinen kirjoittaja Pirjo Lyytikäinen näkevät kirjallisuudelle ominaisen arvopotentiaalin poikkeavan "puhtaasti välineellisestä rationaalisuudesta" (ks. Meretoja \& Lyytikäinen 20I5, I, 3-4).

Habermasin tavoin Nussbaum ja amerikkalainen germanisti Mark William Roche ovat puhuneet kirjallisuudelle ominaisesta rationaalisuudesta. Tutkimuksessaan Love's Knowledge (I990) Nussbaum kehittelee Aristoteleen käytännöllisen viisauden käsitteen pohjalta ajatusta siitä, että kirjallisuus poikkeaa länsimaissa vallalla olevasta teknisestä tai luonnontieteellisestä rationaalisuudesta. Hänen mukaansa kirjallisuuden erityislaatu liittyy arvoihin ja tunteisiin ja siksi kirjallisuustieteen tulisi nojautua moraalifilosofian ja etiikan teorioihin. Samalla Nussbaum on torjunut monille rationaalisuusteorioille ominaisen tavan erottaa tunteet ja järki selvästi toisistaan. Sen vastapainoksi hän on kehitellyt kantaa, jonka mukaan tunteilla on oma elämän ja maailman ymmärtämistä lisäävä tiedollinen aspektinsa. ${ }^{66}$ Tuoreemmassa kirjassaan Not for Profit. Why Democracy Needs the Humanities (2012) hän puhuu myös siitä, että nykyinen talouden ylivalta yhteiskunnassa ei ole uhka vain kirjallisuudelle ja humanistiselle kulttuurille. Se uhkaa myös demokratian perustaa, sillä, Nussbaum jatkaa, juuri kirjallisuus opettaa lukijoille sellaisia arvoja - empatiakykyä, kykyä ymmärtää toisen ihmisen sisäistä maailmaa ja hänen erityisyyttään, kykyä ymmärtää ja arvostaa vieraita kulttuurimuotoja -, jotka ovat tarpeen demokraattisen ja moniarvoisen yhteiskunnan toimivuuden kannalta.

Edellä mainittuihin uhkatekijöihin myös Roche kiinnittää huomiota tutkimuksessaan Why Literature Matters in the 21st Century (2004). Siinä hän toteaa, että arvorationaalisuuden muotona kirjallisuuden tärkeimpiä tehtäviä tällä vuosisadalla tulisi olla teknologian, tieteen ja kapitalismin välisen liiton ja ylipäänsäkin yhteiskuntaa hallitsevan teknisen tai väli- 
neellisen järjen kriittinen analysoiminen. Tätä tehtävää vaikeuttaa hänen mukaansa kuitenkin se, että nykykulttuurin keskeinen kehityspiirre kirjallisuuden, taiteen ja tieteen avaaminen laajemmin markkinavoimille ja välinerationaaliselle toiminnalle - tyhjentää kirjallisuutta kasvavassa määrin "moraalisesta sisällöstä" ja muuttaa sitä viihteen osa-alueeksi (Roche 2004, I-2, 7). Roche ei silti päädy kirjassaan pessimistisiin tulevaisuudennäkymiin, vaan hän osoittaa luottavansa edelleen "suuren kirjallisuuden" kykyyn tuottaa kriittisiä arvioita kulttuurin ja yhteiskunnan keskeisistä arvopäämääristä.

Länsimaisessa kulttuurissa I700-luku on ollut tärkeä vuosisata yhteiskunnallisesti suuntautuneen kirjallisuuden syntymisen kannalta. Tuon vuosisadan kuluessa eurooppalainen kirjallisuus etääntyi klassisoivasta paradigmasta ja mytologisesta aihepiiristä ja kääntyi ympäröivän sosiaalisen todellisuuden, erityisesti porvarillisen elämänpiirin kuvaamiseen. Porvaristo nousi tuolloin muutoinkin keskeiseen asemaan kirjallisessa kulttuurissa, sillä kapitalististen toimintatapojen yleistymisen ja porvarisluokan voimistumisen myötä kirjailijat ja lukeva yleisö olivat I700-luvulla kasvavassa määrin lähtöisin tästä luokasta. Porvarillista elämänpiiriä käsitellessään kirjailijat kuvasivat oman aikansa tapakulttuuria, muun muassa rakkaussuhteiden muodostumista, avioliittojen solmimista, perheiden perustamista ja säätyrajoitusten vaikutusta näihin tapahtumiin. Tuossa vaiheessa kirjallisuus ei ollut niinkään kriittinen porvaristoa kohtaan, vaan se pikemminkin antoi ilmaisun nousevan porvariston ideologialle ja maailmankatsomukselle, niin kuin Ian Watt esittää teoksessaan The Rise of the Novel. Studies in Defoe, Richardson and Fielding (I987, ilmestyi alun perin 1957).

Wattille nousevan porvariston ideologian kannalta keskeisin romaani I700-luvun englantilaisessa kirjallisuudessa on Daniel Defoen Robinson Crusoe (I7I9), joka esittää päähenkilönsä herooisena kapitalistisena yrittäjänä. Watt (1987, 60-92) toteaa, että sellaisena Robinson tarkastelee maailmaa ensi sijassa hyötynäkökulmasta ja arvioi asioita niiden mahdollisen kaupallisen tai taloudellisen arvon kannalta. Tällaisesta ihmistyypistä alettiin I80o-luvulla käyttää nimitystä homo oeconomicus. Weberin ja Habermasin käsitteillä ilmaistuna kyse on siitä, että Robinson toimii ensi sijassa kapitalistisen välinerationaalisuuden pohjalta. 
Sen vaikutusta häneen lieventää tosin hänen uskonnollisuutensa, johon turvautumalla hän voi ilman tunnontuskia toimia myös orjakauppiaana ja kolonialistisena valloittajana. Wattin (ibid., 64, 80) mukaan voimakkainta hänen toimissaan on silti taloudellinen motiivi, jota hänen uskonnollisuutensa vain vaivoin hillitsee. Defoe oli muussakin tuotannossaan kiinnostunut kapitalistisen rationaalisuuden ilmenemismuodoista, joita hän kuvasi ilman suurempaa moralisointia. Esimerkiksi romaanin Moll Flanders (I722) päähenkilö on prostituoitu ja seikkailija, jolle koko maailma näyttäytyy suunnattomina markkinoina; niillä ihmiset, mukaan lukien Moll Flanders, käyvät kauppaa kaikella sillä, mikä on heidän hallussaan ja omistuksessaan. Nämä Defoen kaksi romaania ovat siis kertomuksia kapitalistisen väline- ja markkinarationaalisuuden pohjalta toimivista ihmisistä, mutta - toisin kuin I8oo-luvun realismi - ne eivät aseta tuota toimintatapaa syvemmin kyseenalaiseksi, vaan pikemminkin ne esittävät sen suhteellisen järkevänä ja käytännöllisenä käyttäytymismuotona.

Modernin kapitalismikriittisen romaanin historia aloitetaan tavallisesti ı830-luvulta, jolloin klassinen teollisuuskapitalismi tai sääntelemätön markkinatalous, laissez-faire-kapitalismi, oli Englannissa ja Ranskassa kohonnut hallitsevaksi taloudelliseksi toimintatavaksi. Kirjallisuus reagoi melko nopeasti tähän muutokseen. Yhtäältä kirjallisuus muodosti kokonaiskuvaa tuosta murroksesta ja sen myötä syntyneestä uudesta yhteiskunnasta. Tämän linjan tunnetuimpia edustajia ovat Stendhal, Honoré de Balzac, Gustave Flaubert, Émile Zola, Ivan Turgenev, Leo Tolstoi, Theodor Fontane, Heinrich Mann ja Thomas Mann, joita on pidetty länsimaisen hteiskuntaromaanin edustajina. Toisaalta monet kirjailijat kiinnittivät huomiota myös laissez-faire-kapitalismin ja teollistumisen synnyttämiin epäkohtiin ja ongelmiin, esimerkiksi taloudelliseen egoismiin, luokkaristiriitoihin, työväestön taloudellis-sosiaaliseen kurjuuteen, naisten ja lasten käyttämiseen teollisuuden työvoimana, prostituution ja alkoholismin yleistymiseen sekä moraalisten ja yhteisöllisten siteiden rapautumiseen. Tällaisia aiheita kriittisesti käsitteleviä romaaneja alettiin I80o-luvulla kutsua sosiaalisiksi romaaneiksi, ongelmaromaaneiksi tai sosiaalisiksi tendenssiromaaneiksi, ja vastaavanlaisia lajinimityksiä käytettiin näytelmistä. Tätä yhteiskunnallisen kirjallisuuden linjaa 
edustivat muun muassa George Sand (Aurore Dupin), Eugéne Sue sekä Edmond ja Jules de Goncourt Ranskassa ja Charlotte Brontë, William Makepeace Thackeray, Charles Dickens, George Eliot (Mary Anne Evans), Elizabeth Gaskell ja George Bernard Shaw Englannissa. Samoin työväenliike alkoi Englannissa, Ranskassa ja Saksassa jo ı830- ja I840-luvulla tuottaa omaa, taisteluhenkistä kirjallista kulttuuriaan, joka oli propagandistisuutensa vuoksi lähellä tendenssikirjallisuutta. ${ }^{67}$

Realistis-naturalistisen kirjallisuuden valtakaudella yhteiskuntaromaanit erosivat sosiaalisista romaaneista ennen kaikkea laajuutensa vuoksi. Ne kuvasivat yhteiskuntaa ja sen eri puolia monipuolisesti, jos kohta kuvaaminen tapahtui aina jostakin tietystä näkökulmasta. Esimerkiksi Stendhalin romaaneissa yhteiskunta näyttäytyy ensi sijassa poliittisena muodostumana, valtasuhteina, kun taas Balzacille se oli markkinaperustaisen käyttäytymisen sekä asemia, varallisuutta ja statuksia koskevan sosiaalisen kilpailun aluetta (Dubois 2000, I70-206; 2007, 23-39, 238-246). Tolstoi puolestaan kuvasi venäläistä yhteiskuntaa ja sen eri säätyjen ja luokkien elämää näkökulmasta, joka oli osittain yhtenevä yläluokan elämänpiirin kanssa, mutta joka otti samalla kriittistä etäisyyttä yläluokan etuoikeutettuun asemaan. Näiden kolmen kirjailijan romaanit olivat laaja-alaisia myös siinä mielessä, että ne kuvasivat pitkiä historiallisia kehityskaaria ja sijoittivat henkilönsä tiettyyn paikkaan ja asemaan näissä kehityskaarissa.

Sosiaaliset romaanit ja näytelmät käsittelivät yhteiskuntaa suppeammin, jonkin rajatun aiheen näkökulmasta. Ne eivät aina tyytyneet vain epäkohtien kuvaamiseen, vaan usein ne pyrkivät myös herättämään lukijoissa moraalisen suuttumuksen tunteita sen vuoksi, että valtaa pitävät eivät toimineet tehokkaasti epäkohtien poistamiseksi. Siten sosiaaliset romaanit ja näytelmät olivat usein samalla tendenssikirjallisuutta. Sellaisena ne sisälsivät yhteiskuntaa koskevan väittämän tai teesin ja usein myös suoremman tai epäsuoremman toimintaohjeen, joka tähtäsi kuvattujen epäkohtien poistamiseen. Tutkimuksessaan The Novel of Purpose. Literature and Social Reform in the Anglo-American World (2007) Amanda Claybough esittää, että ı80o-luvulla englantilaista ja amerikkalaista kirjallisuutta sävytti laajalti tällainen reformistinen eetos. Sen pohjana oli uskomus, että kuvaamalla epäkohtia ja ongelmia "sellaisina kuin ne 
todella ovat" kirjallisuus pystyy vakuuttamaan yläluokan sosiaalisten reformien tarpeellisuudesta. Eräissä tapauksissa ı80o-luvun englantilaiset ja amerikkalaiset kirjailijat saivatkin aikaan välittömiä tuloksia. Selkeimpänä esimerkkinä tästä Claybough $(2007,24,32)$ mainitsee Harriet Beecher-Stowen romaanin Oncle Tom's Cabin (I85I-I852), joka vaikutti Yhdysvalloissa orjuuden vastaisen kansalaismielipiteen yleistymiseen ja sitä kautta myös orjuuden muodolliseen lakkauttamiseen seuraavalla vuosikymmenellä.

Yhteiskuntaromaani ja sosiaalinen romaani ovat tämän tutkimuksen kannalta sinänsä relevantteja käsitteitä, mutta samalla ne ovat liian laaja-alaisia. Siksi tutkimus työskentelee suppeammalla kapitalismikriittisen romaanin käsitteellä. Sen päämuotoja ovat kapitalistisen luokkajärjestyksen kritiikki ja kapitalistisen rationalisaation kritiikki. Osa niiden piiriin kuuluvista teoksista jatkaa lähinnä yhteiskuntaromaanin traditiota, osa puolestaan sosiaalisen romaanin traditiota. Länsimaisessa kirjallisuudessa kapitalistisen tai porvarillisen luokkajärjestyksen klassisia kriittisiä kuvauksia ovat Georg Sandin La ville noire (I860), Émile Zolan L'Assommoir (1877) ja Germinal (1885), Thomas Mannin Buddenbrooks (I90I), Upton Sinclairin The Jungle (I906), Sinclair Lewisin Babbitt (I922), Ivar Lo-Johanssonin Godnatt, jord (I933), Horace McCoyn They Shoot Horses, Don't They? (1935), John Steinbeckin The Grapes of Wrath (1939) ja Miguel Ángel Asturiasin Banaani-trilogia (I950-1960).

Näistä useimmissa käsitellään myötätuntoisesti työväenluokan turvatonta asemaa ja kärsimyksiä, mutta kuvaus voi myös kohdistua ylempiin luokkiin, niin kuin Mannin ja Lewisin romaaneissa tapahtuu.* Työväes-

* Sandin La ville noire on utopistisia aineksia sisältävä romaani, jossa työväestön taloudellis-sosiaalinen asema ja yhteiskuntarauha turvataan luokkien (tehtaanomistajan ja työläisten) välisen yhteistyön ja sen mahdollistamien sosiaalisten uudistusten kautta. Zolan L'Assommoir kuvaa Pariisin työläiskaupunginosia vaivaavaa kurjuutta ja alkoholismia ja Germinal ranskalaisten hiilikaivostyöläisten elämää. Mannin Buddenbrooks on ironis-kriittinen kuvaus saksalaisen kauppiaissuvun - ja yleisemmin perinteisen perhekapitalismin - rappeutumisesta. Sinclairin The Jungle tarkastelee kriittisesti amerikkalaista elintarviketeollisuutta (teurastamoja) siirtolaistyöläisten näkökulmasta, kun taas Lewisin Babbitt analysoi amerikkalaista liikemiesluokkaa ja sen konformistista käyttäytymiskoodia. Lo-Johanssonin romaanissa kuvauksen kohteena on ruotsalainen maatyöväestö, "muonamiesluokka". McCoyn ja Steinbeckin romaanit valottavat köyhien ja alaluokkaisten ihmisten vaikeaa tilannetta suuren talouslaman aikana Yhdysvalloissa. Guatemalalaisen Asturiasin Banaani-trilogia sisältää romaanit Viento fuerte (1950, Voimakas tuuli), El Papa Verde (1954, Vihreä paavi) ja Los ojos de los enterrados (1960, Haudattujen silmät). Se käsittelee köyhien guatemalalaisten banaanintuottajien ja yhdysvaltalaisen suurkapitalismin välisiä ristiriitoja. 
töä ja alempia luokkia kuvatessaan yllä mainitut romaanit osoittavat enemmän tai vähemmän selvästi, että näiden luokkien kärsimys on seurausta porvarillis-kapitalistisen yhteiskunnan valtarakenteista ja luokkavoimasuhteista. Silloin kun tällaiset romaanit kritisoivat kapitalistisessa yhteiskunnassa vallitsevaa luokkajärjestystä sosialistisesta perspektiivistä käsin, ne voidaan samalla sijoittaa sosialistisen kirjallisuuden ja usein myös työläiskirjallisuuden piiriin, jos kohta työläiskirjallisuus ei aina jaa sosialistista ideologiaa. Sosialistinen perspektiivi sisältyy muun muassa Maksim Gorkin romaaniin Äiti (venäjänkielinen alkuperäisteos ilmestyi I907), joka institutionalisoitiin Neuvostoliitossa I930-luvulla sosialistisen realismin perusteokseksi. Venäjällä ı ९०o-luvun alussa vallinneen luokkajärjestyksen kritisoiminen on tosin siinä vain yksi kuvauksen ulottuvuuksista, jonka ohella se käsittelee vallankumouksellisen liikkeen toimintaa ja naispuolisen päähenkilönsä poliittisen tietoisuuden kehitystä. Edellisessä kappaleessa mainituista romaaneista useimmat kuvaavat ja arvioivat työväenluokan tilannetta lähinnä valistuneen porvarillisen älymystön näkökulmasta. Työläiskirjallisuuden piiriin niistä on selvimmin luettu Lo-Johanssonin Godnatt, jord. Tämä ruotsalaista maalaisköyhälistöä kuvaava "kollektiiviromaani” ei sisällä voimakkaita sosialistisen ideologian aineksia, sillä se on samalla Lo-Johanssonin kirjailijaksi tulemisen esivaiheita valottava omaeläkerrallinen kehitysromaani (Nilsson 2006, 63-70, I4I-I42, I54-I69). Voimakkaampi kytkös sosialistiseen ideologiaan on Sinclairilla. Hän solmi läheiset suhteet amerikkalaisen vasemmiston järjestöihin ja lehtiin, ja hän analysoi monissa teoksissaan - muun muassa romaanissa The Jungle - sosialistisen ja vasemmistolaisen liikkeen piirissä esiintyneitä ideologisia suuntauksia (Wienen 20I2, 64-99).

Kapitalistista toimintarationaalisuutta ja sen aiheuttamia kielteisiä seurauksia ovat länsimaisessa kirjallisuudessa käsitelleet erityisesti Balzacin Eugénie Grandet (I833), Le Père Goriot (I835) ja Illusions perdues (I837-I843), Maupassantin Bel-Ami (1885), Zolan L'Argent (I89I), Hermann Brochin Die Schlachwandler-trilogian (I93I-I932) kolmas osa Huguenau, oder, Die Sachlichkeit - 1918 (I932), Bertolt Brechtin Drei Groschen Roman (I934), Bret Easton Ellisin American Psycho (I99I), Don DeLillon Cosmopolis (2003) sekä Michel Houellebecqin Les particules 
élémentaires (1998), Plateforme (200I), La Possibilité d'une Île (2005) ja La carte et le territoire (20IO). . Viime vuosikymmeninä tämä romaanityyppi näyttää olleen luokkajärjestyksen kritiikkiä suositumpi romaanityyppi.

Fowlerin lajiteoriassa kullakin lajilla on oma geneerinen repertoaarinsa, joka muodostuu lajia edustavia teoksia yhdistävistä sisällöllisistä ja muodollisista piirteistä ja jonka perusteella laji ja sen edustajat voidaan tunnistaa. Tavallisesti mikään jonkin yksittäisen lajin edustajista ei jaa kaikkia asianomaiseen lajirepertoaariin kuuluvia piirteitä, ja toisaalta samaa lajia edustavilla teoksilla voi olla myös sellaisia ominaisuuksia, jotka yhdistävät niitä muihin lajeihin. Wittgensteinin myöhäisfilosofiaa hyödyntäen Fowler toteaakin, että lajia pitää koossa sen edustajien välinen löysä perheyhtäläisyyksien verkosto. Lajin edustajat muistuttavat toisiaan ja ovat monin eri tavoin suhteissa toisiinsa, mutta mikään yksittäinen piirre ei välttämättä esiinny kaikissa lajin edustajissa. Me voimme sijoittaa jonkin teoksen jonkin tietyn lajin piiriin, mikäli se jakaa riittävän määrän kyseisen lajin repertoaariin sisältyviä piirteitä tai mikäli tähän repertoaariin kuuluvat piirteet painavat siihen hallitsevalla tavalla leimansa. Lajien rajojen ja tunnusmerkkien häilyvyyden vuoksi lajeja ei voida määrittää yksityiskohtaisesti. Määritysten on oltava abstrakteja ja yleisluontoisia. (Fowler I997, I8, 4I, 55.) Tämä mielessä on syytä vielä pohtia, millaisia aineksia rationalisaatiokriittiset romaanit sisältävät.

Paradigmaattiset rationalisaatiokriittiset teokset esittävät näkemyksensä kapitalismista päähenkilöitä koskevien juonellisten tarinalinjojen ja elämäkerrallisen muodon avulla, kuvaamalla päähenkilöiden elämässä vaihetta, jolloin he ajautuivat konfliktiin ympäristönsä kanssa. Balzacin Ukko Goriot'ssa (1985, ranskankielinen alkuperäisteos ilmestyi ı835) ja Kadonneissa Illuusioissa (I983b, ranskankielinen alkuperäisteos ilmestyi I837-I843) päähenkilö, molemmissa tapauksissa provinssista Pariisiin saapuva nuori kunnianhimoinen mies, haluaa valtaa, asemia ja menestystä. Hän joutuu kuitenkin huomaamaan, että niitä ei ole mahdollista

* Zolan L'Argent kuvaa ranskalaisen finanssipääoman maailmaa ja sen toimintatapoja. Romaanin keskushenkilö, keinottelijaksi ryhtyvä ja kyltymättömän ahneeksi kuvattu pankinjohtaja Saccard hävittää tapahtumien edetessä pankkinsa monien osakkeenomistajien rahat ja säästöt. Muita leipätekstissä mainittuja romaaneja tai ainakin niiden kirjoittajia tarkastellaan tässä tutkimuksessa vielä myöhemmin, joten kyseisiä romaaneja ei ole nyt tarpeen ottaa lähemmin esille. 
saavuttaa kunniallisella tavalla. Suurporvariston ja markkinavoimien hallitsemassa yhteiskunnassa menestystä voi saavuttaa vain siten, että ihminen arvioi maailmaa ja muita ihmisiä siltä kannalta, miten hän voisi hyötyä niistä. Balzacin teoksissa vallitsee siten jyrkkä vastakohta Pariisin ja provinssien välillä: edellinen määrittyy kapitalisoituneeksi sosiaaliseksi tilaksi jälkimmäisen edustaessa arkaaista elämänmuotoa, jossa elämää jäsentävät perityt tavat ja uskomukset.

Toisaalta mikäli henkilö on Balzacin teoksissa jo saavuttanut asemaa yläluokassa, nuo teokset osoittavat, millaisia aineellisia ja henkisiä vaurioita hänen (liike)toimensa saavat aikaan. Näin tapahtuu Eugénie Grandet’ssa (I983a, ranskankielinen alkuperäisteos ilmestyi I833), jonka keskushenkilönä on ahne ja rikas viinitilallinen herra Grandet. Hänen habitukseensa on personifioitunut "ainoa nykyajan jumala johon uskotaan, Raha kaikessa mahtavuudessaan" (Balzac ı983a, 43). Niinpä hän keskittyy kylmäkiskoisesti liiketoimiinsa ja omaisuutensa kasvattamiseen ja luo samalla lähipiiriinsä rakkaudettoman ilmapiirin, josta hänen vaimonsa, tyttärensä ja sukulaisensa joutuvat kärsimään. Hänen vastakohtanaan toimii hänen tyttärensä Eugénie, joka kaikesta huolimatta kykenee epäitsekkääseen ja pyyteettömään rakkauteen, "ihmisluonnon jaloimpiin tunteisiin" (Balzac I983a, 43). Samoin hänen vaimonsa ja palvelijattarensa edustavat arvorationaalista käyttäytymistä, jolle on ominaista arkinen ja epäitsekäs huolehtiminen toisista ihmisistä. (Boucher 20I3; Dubois 2000, I70-189.)

ı80o-luvun romaaneissa naisten elämismaailma toimii usein vastavoimana miesten edustamalle välineelliselle toiminnalle, mutta tämä yleistys ei pidä aina Balzacin kohdallakaan paikkaansa. Esimerkiksi Ukko Goriot'ssa asetelma on päinvastainen, sillä siinä nimihenkilö toimii sokean ja ehdottoman isänrakkauden ohjaamana ja hänen molemmat tyttärensä ovat sisäistäneet Pariisin seurapiireille ominaisen egoistisen toimintatavan. Charles Dickens puolestaan kytkee yhteen arvorationaalisuuden ja köyhyyden. Hänen teoksissaan köyhät ovat säilyneet moraalisesti turmeltumattomina tai viattomina juuri siksi, että he ovat köyhiä; he saattavat siten menettää tämän ominaisuutensa, mikäli he sattuvat rikastumaan. (Cazamian I973, I49-I54; Suomela 2007, I37-I4I.) Köyhyyden ylevöittämistä ei silti voida pitää rationalisaatiokriittisten romaanien 
perusominaisuutena, sillä Dickens omaksui sen kristillisestä kertomusperinteestä. Sitä vastoin hänen sydämettömät liikemieshahmonsa ovat klassisia esimerkkejä siitä, miten ı80o-luvun romaani kritisoi laissezfaire-kapitalismia. Sydämetön ja häikäilemätön henkilöhahmo on myös Maupassantin romaanin Bel-Ami (I987, ranskankielinen alkuperäisteos ilmestyi I885) nimihenkilö, joka nousee naisiin tekemänsä eroottisen vaikutuksen, komean ulkomuotonsa ja moraalista piittaamattoman egoistisen käyttäytymisensä avulla omistavaan luokkaan ja yhteiskunnan johtaviin piireihin. Samoin kuin Ukko Goriot'ssa, tässäkin romaanissa yläluokkaisen seurapiirin jäsenet käyvät kauppaa paitsi aineellisella omaisuudellaan myös statuksillaan, tuttavuussuhteillaan ja rakkaussuhteillaan.

Jo I900-luvun alkupuolella elämäkerrallisen muodon ja narratiivisen aineksen osuus väheni rationalisaatiokriittisissä romaaneissa, ja niihin alkoi sisältyä esseemäisiä jaksoja. Selkeä esimerkki tästä kehityksestä on Hermann Brochin modernistisen Unissakävijät-trilogian viimeinen osa Liikemies Huguenau eli asiallisuus 1918 (I994, saksankielinen alkuperäisteos ilmestyi I932), joka sisältää laajoja pohdiskelevia jaksoja "arvojen rappiosta" ja "arvojärjestelmistä". Siinä arvojen rappiota edustaa ennen kaikkea liikemies Huguenau, joka liiketoimintojaan edistääkseen turvautuu tarpeen tullen tappamiseen, pettämiseen ja huijaamiseen. Vielä selvemmin kapitalismin, moraalittomuuden ja rikollisuuden kytkee yhteen Bertolt Brechtin Kerjäläisromaani (I97I, saksankielinen alkuperäisteos ilmestyi I934), jossa menestyvän kapitalistin ja ovelan rikollisen hahmot sulautuvat yhteen. Tässä vaiheessa rationalisaatiokuvaukset alkoivat myös risteytyä dystopioiden kanssa. Näin tapahtuu jo H. G. Wellsin romaanissa Kun nukkuja herää (200I, englanninkielinen alkuperäisteos ilmestyi I899) ja dystopia-romaanin toisessa klassikossa, Aldous Huxleyn teoksessa Uusi uljas maailma (I984, englanninkielinen alkuperäisteos ilmestyi I932). Nämä kaukaiseen tulevaisuuteen sijoittuvat romaanit pyrkivät osoittamaan, miten vaarallinen yhdistelmä syntyy kapitalistisen toimintarationaalisuuden, luonnontieteiden ja teknologisen edistysuskon välisestä liitosta.

Tässä yhteydessä ei ole syytä käsitellä uudempaa rationalisaatiokritiikkiä, sillä sitä tarkastellaan myöhemmissä luvuissa. Sen piiriin kuuluvat 
romaanit, esimerkiksi Don DeLillon, Bret Easton Ellisin ja Michel Houellebecqin teokset kuvaavat usein nyky-yhteiskunnan muodostumaksi, jota välineellinen järki ja markkinavoimat hallitsevat yhä totaalisemmin ja jossa arvorationaalisuuden alue on kutistunut lähes olemattomaksi. Tällaisissa romaaneissa kriittinen kärki tulee tavallisesti esiin siinä, että niissä esiintyy vieraantuneisuudesta kärsiviä henkilöitä ja patologista käyttäytymistä (häikäilemätön egoismi, rikollisuus, murhat). Näiden ilmiöiden syyksi esitetään kapitalistisen talouden toimintatavat. Samantyyppisiin seurauksiin voidaan vielä lisätä eksistentaalisten mielekkyyskriisien kuvaukset, jotka ovat yleistyneet nykyisessä rationalisaatiokritiikissä.

Kuvatessaan teollistumisen ja sääntelemättömän markkinakapitalismin aiheuttamia epäkohtia perinteinen länsimainen realistis-naturalistinen kirjallisuus pyrki usein tilanteeseen, jossa julkinen valta ja ylemmät luokat puuttuisivat talouselämän toimintatapoihin tai huolehtisivat markkinavoimien armoille jääneistä ihmisistä. Paljolti samanlainen eetos liittyi suomalaiseen realistis-naturalistiseen kirjallisuuteen. Historiallisen kehityksen eriaikaisuudesta johtuen teollistumisen ja kapitalismin läpimurto tapahtui Suomessa hieman myöhemmin kuin Euroopan keskusmaissa. Tavallisesti se ajoitetaan tutkimuksessa I840-I860-luvuille, jolloin Suomessa toteutettiin monia merkittäviä markkinoiden ja teollisuuden toimintaedellytyksiä edistäneitä uudistuksia. (Kuisma 2013, III-I87.) Niiden myötä rahatalous levisi maaseudulle, ja Euroopan keskusmaiden tavoin suomalainen yhteiskunta joutui jatkossa kärsimään uuteen talousjärjestelmään liittyvistä suhdannevaihteluista ja lamakausista.

ı880-luvulla läpimurtonsa tehneessä suomalaisessa realistis-naturalistisessa kirjallisuudessa näkyvän sijan saivat sosiaaliset romaanit ja tendenssikirjallisuus. Tämä luonnehdinta pätee varsinkin Minna Canthin romaaniin Köyhää kansaa (I886) ja hänen näytelmiinsä Työmiehen vaimo (I885) ja Kovan onnen lapsia (I888), Teuvo Pakkalan työläismiljööseen sijoittuviin romaaneihin Elsa (I89I) ja Vaaralla (I894) ja K. A. Tavaststjernan romaaniin Hårda tider (I89I). Ne ottivat kuvauksen kohteeksi sellaisia epäkohtia kuin tavallisen kansan turvaton ja kurjuuden leimaama taloudellis-sosiaalinen asema, naisten epätasa-arvoinen 
asema avioliitossa ja yhteiskunnassa sekä alaluokkaisten naisten ajautuminen prostituutioon. Ajankohdan suomalaisessa kirjallisuudessa laaja-alaista yhteiskuntaromaania lähelle tulee vain Arvid Järnefeltin Maaemon lapsia (I905), joka käsittelee I900-luvun alun suomalaisen yhteiskunnan perusongelmaa, maanomistussuhteita, ja erittelee samalla eri luokkien (yläluokka, sivistyneistö, talolliset, torpparit, tsaarinvallan virkamiehet) välisiä ristiriitoja tässä asiassa. Järnefeltin romaanin kuvaama ongelma kärjistyi Suomessa kapitalismin kehityksen alkuvaiheessa, I80o-luvun jälkipuolella ja I9०o-luvun alussa, sillä metsäteollisuuteen ja rahatalouteen sidoksissa olleet maanomistajat saattoivat käyttää torppareitaan, vuokraviljelijöitään, lähes pidäkkeettömästi hyväksi halpana työvoimana. Silti torpparilaitosta ei voida pitää tyypillisenä moderniin kapitalismiin kuuluvana ilmiönä muuten kuin ehkä siinä abstraktissa mielessä, että se ilmentää räikeässä muodossa moderneihin taloudellisiin valtasuhteisiin liittyvää riiston ja hyväksikäytön mahdollisuutta. Siksi se on usein nähty kapitalismin varhaisvaiheeseen periytyneenä feodaalisena tai esimodernina jäänteenä, jonka sijasta kapitalismi suosii rationaalisempia ja poliittisesti tarkoituksenmukaisempia arvontuotannon menetelmiä. (Karisto-Takala-Haapola I997, I9-29.) Osittain näistä syistä Järnefeltin Maaemon lapsia, jossa torpparilaitos on muutenkin vain yksi kuvauksen kohteista, kuuluu lähinnä epäsuorassa mielessä kapitalismikritiikin piiriin (vrt. Isomaa 2009).

Selvempi yhteys modernin kapitalismin kritisoimiseen on Maiju Lassilan romaanilla Kuolleista herännyt (I9I6) ja Maria Jotunin näytelmällä Kultainen vasikka (I9ı8). Edellisessä, kansankomediaa muistuttavassa teoksessa eletään läpikotaisin tavaroituneessa maailmassa, jossa ihmiset käyvät kauppaa sillä, mitä heillä sattuu olemaan, ja jossa he pyrkivät alituisesti hyötymään toisistaan taloudellisesti. Jotunin näytelmä kuvaa naisten taloudellisesti epäitsenäistä asemaa ja sota-aikana yleistyneen taloudellisen keinottelun ja välineellisen hyötyajattelun vaikutusta ihmissuhteisiin. Astetta moniulotteisemman kuvan kapitalismista tarjoavat Pentti Haanpään romaanit Noitaympyrä (I93I) ja Isännät ja isäntien varjot (I935), jotka on nähty suomalaisessa kirjallisuudessa ensimmäisinä laaja-alaisina kuvauksina kapitalismista. Haanpään romaanien sukulaisteoksena voi pitää Toivo Pekkasen romaania Tehtaan varjossa (I93I), 
jossa on samalla vahvoja kehitysromaanin piirteitä. (Ks. myös Isomaa 2009, 20I2a, 20I2b, 20I3; Rossi 2005, 2009; Sevänen 20I4b.)

Suomalainen kirjallisuus on siis jo I88o-luvulta lähtien tematisoinut kuvauksen kohteeksi kapitalismin, siihen liittyvän luokkajärjestyksen ja sen toimintatavat. Edellä mainituista teoksista kapitalistisen luokkajärjestyksen kritiikkiä edustavat selvimmin Canthin romaani Köyhää kansaa ja hänen näytelmänsä Kovan onnen lapsia, Pakkalan Vaaralla ja Elsa, Tavaststjernan Hårda tider ja Haanpään Isännät ja isäntien varjot. Tosin viimeiseksi mainittu ei kuvaa vain sitä, miten teollisuuskapitalismille ominainen hallitseva luokka - tehtailijat, pankkiirit, vuorineuvokset - syrjäytti maailmansotien välillä talonpoikaistoa yhteiskunnan huipulta, vaan se kiinnittää huomiota myös siihen, miten kapitalismin toimintatavalle ominaiset suhdannevaihtelut heittelevät yksilöitä ja luokkia erilaisiin asemiin yhteiskunnassa. Sitä yksiselitteisemmin teollis-kapitalistisen yhteiskunnan toimintalogiikkaa, "ratsionalisointia" (ks. Pekkanen I967, I20) käsittelevät Pekkasen Tehtaan varjossa ja Haanpään Noitaympyrä. Jotunin Kultainen vasikka on puolestaan sikäli erityislaatuinen teos, että se yhdistelee toisiinsa kapitalistisen talousjärjestyksen ja patriarkaalisen sukupuolijärjestyksen kritiikkiä. Lassilan Kuolleista herännyt käsittelee huumorin keinoin kapitalistisen rationalisaation yhtä ulottuvuutta, sosiaalisten suhteiden muuttumista hyöty- ja kauppasuhteiksi.

Kapitalismiin tai porvarilliseen yhteiskuntaan liittyvän luokkajärjestyksen kritiikki ulottuu suomalaisessa kirjallisuudessa nykypäiviin asti. Sitä jatkoivat myöhemmin muun muassa Väinö Linnan Täällä Pohjantähden alla (I959-I962), Marianne Alopaeuksen Mörkrets kärna (I965), Lassi Sinkkosen Solveigin laulu (I970), Pirkko Saision Elämänmeno (1975) ja Sisarukset (1976), Christer Kihlmanin Kallis prinssi (1976, ruotsinkielinen alkuperäisteos ilmestyi I974) ja Gerdt Bladhs undergång (I987) ja Arto Salmisen Varasto (I998). Myös Hannu Salaman romaanit sisältävät porvarillisen yhteiskunnan luokkajärjestyksen kritiikkiä, mutta ne eivät yhtä selvästi kuulu tähän yhteyteen. Niissä keskeisen sijan saa työväenliikkeen ja vasemmistoälymystön sisäisten ristiriitojen käsitteleminen. Tämä piirre tulee vahvasti esiin sekä hänen pääteoksissaan Siinä näkijä missä tekijä (I972) ja Finlandia-sarja (I976-I983) että hänen myö- 
häisissä teoksissaan Elämän opetuslapsia I-IV (I998-2005) ja Sydän paikallaan (2010). ${ }^{68}$

Toisen maailmansodan jälkeisinä vuosikymmeninä suomalainen yhteiskunnallinen romaani keskittyi luokkakulttuurien kuvaamiseen. Rationalisaatio-teema jäi siinä sivuosaan, vaikkakaan tällainen näkökulma ei hävinnyt kuvauksesta. Teemaa edusti muun muassa työläiskirjallisuuden piiriin kuuluvan Samuli Parosen (I9I7-I974) tuotanto, joka sisältää pohdiskeluja teknologian merkityksen kasvusta taloudessa ja yhteiskunnassa ja joka toimii siten teknologis-taloudellisen rationalisaation kritiikkinä. (Hosiaisluoma I990, II-I2, I85.) Hieman toisella tavalla kyseinen teema tulee esille Sinkkosen Sumuruiskussa (I968) ja Kihlmanin Kallis prinssi -romaanissa.

Sumuruiskun aihe on erikoinen, sillä romaani kuvaa Suomessa toimivaa neuvostoliittolaista autoalan yritystä ja sen maalaamoa. Romaanin etenemissuunta ja sen tapahtumat osoittavat, että tuon yrityksen toimintatavat eivät juurikaan poikkea kapitalististen yritysten toimintatavoista. Samoin romaanin keskushenkilö, maalarista työnjohtajaksi kohoava Heinonen oppii oman kokemuksensa myötä, että sen organisaatiossa eteenpäin pääsee lähinnä kyynisen laskelmoinnin, eikä niinkään aatteellisen idealismin, kautta. Kihlmanin Kallis prinssi valottaa kriittisesti eri puolilta suomenruotsalaista yläluokkaa, sen taloudellisesti menestynyttä ja vaurasta fraktiota. Sen keskushenkilö, vaatimattomista oloista rikkauksiin kohonnut häikäilemätön liikemies Donald Blaadh yrittää kirjoittaa romaanissa muistelmiaan. Ne eivät etene toivotulla tavalla, sillä vanhetessaan hän on tajunnut, että hänen arvomaailmansa on ollut kyseenalainen ja paikoin vääristynyt: "Huomasin että olin aikaisemmin tarkastellut koko elämää jotenkin työn näkökulmasta. Se, mikä oli hyväksi liikkeelle, oli ylipäätäänkin hyvää ja sen parempaa mitä suuremman voiton se tuotti. Ylipäätään. Yksinkertainen ja vaivaton elämänfilosofia." (Kihlman ı976, I7.) Tässä mielessä Kallis prinssi yhdistelee kapitalistisen luokkajärjestyksen kuvaamiseen rationalisaatiokritiikkiä (vrt. Ruohonen I995).

Markkinallistumiskehityksen myötä kapitalismin toimintatapojen käsitteleminen on yleistynyt suomalaisissa romaaneissa ja näytelmissä I990-luvulta lähtien. Niistä tämä tutkimus ottaa esille lähinnä sellaisia 
teoksia, joilla on selviä yhtymäkohtia Seppälän romaanien kanssa tai joiden avulla voidaan valottaa hänen romaaniensa ominaislaatua. Tällaisiin teoksiin kuuluvat erityisesti Hannu Raittilan romaanit Ei minulta mitään puutu (1998) ja Pamisoksen purkaus (2005), Arto Salmisen Kalavale. Kansalliseepos (2005), Tommi Melenderin Kunnian mies (2007) ja Ranskalainen ystävä (2009) sekä Miika Nousiaisen Metsäjätti (2OII). Samoin Kari Hotakaisen romaanit Ihmisen osa (2009), Jumalan sana (20II) ja Luonnon laki (2013) kuvaavat nykytalouden ja markkinahenkisen yhteiskuntapolitiikan vaikutuksia ihmisten elämään, minkä ohella Luonnon laki pohtii samalla hyvinvointivaltion säilymisen edellytyksiä. Leena Krohnin Unelmakuolema (2004) ja Maarit Verrosen Karsintavaihe (2008) rakentavat puolestaan tulevaisuuteen sijoittuvan dystopian keinoin kuvan siitä, millaiseen maailmaan markkinallistumiskehityksen eteneminen saattaa pahimmillaan johtaa. Tässä yhteydessä relevantteja ovat myös Karo Hämäläisen "finanssitrillerit" Erottaja (20II) ja Kolmikulma (2OI2), jotka yhdistelevät finanssimaailman toimintatapojen kuvaukseen jännitys- ja rikoskirjallisuuden piirteitä. Niissä finanssisektorille ominainen ankara taloudellinen kilpailu ajaa keskushenkilöt rikoksiin ja moraalisesti kyseenalaisiin tekoihin. ${ }^{69}$

Tämä tutkimus näkee suomalaisen yhteiskunnallisen tai kapitalismikriittisen romaanin kehityksen eri tavalla kuin Pertti Karkaman Sosiaalinen konfliktiromaani (I97I). Se käsittelee kahdeksaatoista suomalaista romaania Juhani Ahon Papin tyttärestä (1885) ja Minna Canthin Hannasta (I886) aina Väinö Linnan trilogiaan Täällä Pohjantähden alla (I959-I962) asti. Sen mukaan klassinen suomalainen yhteiskunnallinen romaani varioi samaa rakennekuviota; "rakenteella" se tarkoittaa romaanissa esiintyvien henkilöiden välisiä suhteita. Karkaman tutkimissa romaaneissa yhteiskunta jakautuu yhtäältä rikkaisiin ja köyhiin, yläluokkaan ja alaluokkaan. Kirjailijoiden tai kertojien sympatiat ovat köyhien ja alaluokan puolella, mutta he vierastavat niille ominaista kollektivismia, luokkavihaa ja materialismia. Yhteistä yläluokalle ja alaluokalle on se, että niissä molemmissa aineellisiin, määrällisiin tai välineellisiin arvoihin pyrkiminen on muuttunut hallitsevaksi piirteeksi teosten henkilöiden elämässä. Toisaalta laadullisia tai substantiaalisia arvoja edustavat romaaneissa "problemaattiset yksilöt", jotka eivät täysin samaistu 
kumpaankaan perusluokkaan. Tällaisia yksilöitä ovat esimerkiksi Aapeli Muttinen Joel Lehtosen Putkinotkossa (1920), Samuel Oino Pekkasen Tehtaan varjossa (I93I), Pate Teikka ja maisteri Raunio Haanpään Noitaympyrässä (I93I) ja räätäli Halme Linnan trilogiassa. Usein juuri teosten problemaattiset yksilöt ilmaisevat Karkaman mukaan kirjailijoiden omaa arvomaailmaa.

Karkaman tutkimus ei tee selvää eroa kirjailijan, sisäistekijän, kertojan ja henkilöiden välille. Näitä erotteluja tarvitaan varsinkin puhuttaessa nykykirjallisuudesta, jolle on ominaista osittainen luopuminen kaikkitietävästä kertojasta ja sen korvaaminen monilla eri kertojilla ja kerronnallisilla näkökulmilla. Nykytutkimuksen horisontista voidaan sanoa, että Karkaman teos kuvaa lähinnä romaanien ylimpien auktoriteettien eli sisäistekijöiden ja kaikkitietävien kertojien arvomaailmaa ja yhteiskuntakäsitystä, joka ovat hänen tutkimissaan romaaneissa ilmeisesti paljolti yhtenevät problemaattisten yksilöiden maailmankuvan kanssa.

Karkaman teos kuljettaa mukanaan rationalisaatio-teemaa, "välineellisten arvojen problematiikkaa", mutta se käyttää tätä käsitettä väljästi, sitomatta sitä tiukasti kapitalismi-teemaan. Ilmeisesti näin tapahtuu siitä syystä, että Karkaman tarkastelemista romaaneista teollis-kapitalistisen talousjärjestelmän toimintatapaa käsittelevät laajemmin vain Tehtaan varjossa ja Noitaympyrä. Muut hänen analysoimansa romaanit tarkastelevat suomalaista maalaisköyhälistöä yhteiskunnan luokkajärjestyksen osana tai ne kuvaavat sitä ilmiönä, jonka asemaa ja tilannetta ne eivät laajasti selitä kapitalistisen tai porvarillisen yhteiskunnan valtarakenteista käsin. Edellistä maalaisköyhälistön käsittelytapaa edustavat Karkaman aineistossa Haanpään Isännät ja isäntien varjot ja Linnan Täällä Pohjantähden alla, kun taas Ilmari Kiannon Punaisen viivan (I909) voi mainita esimerkkinä romaanista, jossa maalaisköyhälistön kuvaamiseen ei liity kapitalismikriittistä ulottuvuutta. Sen sijasta Kiannon romaani keskittyy kuvaamaan, miten korpiseuduilla elänyt ja "vuosituhantisen herravihan" sisäistänyt suomalainen maalaisköyhälistö joutui ensimmäisten eduskuntavaalien aattona sosialistien harjoittaman - romaanin mukaan yhteiskunnallista todellisuutta vääristävän - demagogisen propagandan, "uskonvilleyden" valtaan (ks. Kianto I9०9, I04, II9). Sen kritiikki kohdistuu siten sosialistiseen liikkeeseen eikä porvarilliseen yhteiskuntaan. 
Maalaisköyhälistöä se pitää lähinnä annettuna, inhimilliseen elämänjärjestykseen kuuluvana ilmiönä.

\section{Eksistentialistinen ja eksistentiaalinen ulottuvuus}

Seppälän romaaneissa nykytalouden toimintakäytännöt aiheuttavat henkilöissä sosiaalista vieraantumista, eksistentiaalisia mielekkyyskriisejä ja patologista käyttäytymistä. Näiltä osin eksistentiaaliset motiivit ja teemat ovat niissä alisteisia nykykapitalismin toimintakäytäntöjen kuvauksiin nähden eli ne on upotettu kyseisten kuvausten osatekijöiksi. Tämä luonnehdinta ei kuitenkaan kuvaa tyhjentävästi Seppälän romaanien merkityssisältöä. Niissä nimittäin tulee toisinaan myös esiin ateistiselle eksistentialismille ominainen käsitys siitä, että eksistentiaalista ahdistusta ja vieraantumista ei ole mahdollista poistaa kokonaan - näin siitä syystä, että ateistisen eksistentialismin mukaan nuo kokemukset yksinkertaisesti kuuluvat inhimillisen olemassaolon luonteeseen sekä ihmisen ja maailman väliseen perustavaan epäsuhtaan.

Tässä tutkimuksessa ei ole järkevää yrittää rekonstruoida sitä, miten länsimainen tai suomalainen kirjallisuus on käsitellyt eksistentiaalisia teemoja. Se olisi tehtävänä liian laaja, eikä siitä ole toistaiseksi tehty perustutkimusta. Kattavaa kartoittamista hankaloittaisi myös Paul Ricoeurin (I984) esittämä havainto, jonka mukaan eksistentiaalinen ulottuvuus liittyy kaikkeen kertomusmuotoon. Ricoeurin mukaan inhimillisen olemassaolon ajallinen luonne, sen ajallinen rajallisuus, voidaan parhaiten tavoittaa ajassa etenevien kertomusten kautta. Samalla fiktiiviset kertomukset tarjoavat lukijoille historiantutkimusta syvemmän näkymän inhimillisen olemassaolon historiallisesti ja kulttuurisesti ehdolliseen luonteeseen. Ne näyttävät, että menneisyydessä eläneillä ihmisillä on ollut omat elämänprojektinsa ja edellytyksensä, joiden pohjalta he ovat merkityksellistäneet elämäänsä sekä maailmaa ja kokemustaan siitä.

Ricoeur näkee eksistentiaalisen ulottuvuuden kirjallisen kulttuurin syvärakenteeksi, joka liittyy sellaisiinkin teoksiin, jotka eivät eksplisiittisesti käsittele eksistentiaalisia teemoja. Tällaisetkin teokset lisäävät lukijoiden ymmärrystä inhimillisestä olemassaolosta. Rajatummassa merki- 
tyksessä eksistentiaaliset teemat tulivat länsimaisessa kulttuurissa tärkeiksi kulttuurin modernisoitumisen myötä, siirryttäessä keskiajasta uuteen aikaan. Tämä selittyy Anthony Giddensin (2000, 79-I50; 200I, 35-69) mukaan siitä, että modernisaatiolle ominainen maallistuminen, rationalisoituminen ja kapitalismin yleistyminen ovat murentaneet eksistentiaalisen turvallisuuden tunteen perinteisten kiinnekohteiden asemaa länsimaisessa sivilisaatiossa. Uskonnollisten kosmologioiden, perittyjen traditioiden, paikallisyhteisöjen ja sukulaisuussiteiden menetettyä entisen ominaispainonsa länsimaisessa sivilisaatiossa tämä sivilisaatio ei ole kyennyt kehittämään riittävästi sellaisia välineitä, joiden avulla ihmiset voisivat käsitellä eksistentiaalisia ongelmiaan ja tuottaa niihin positiivisia ratkaisuja.

Filosofisesti ja yhteiskuntateoreettisesti suuntautuneessa kirjallisuuden tutkimuksessa eksistentiaalisen ulottuvuuden ja moderniteetin välinen suhde on usein nähty samalla tavalla kuin Giddens sen näki. Tutkimuksessaan Die Theorie des Romans (I971a, ilmestyi alun perin I9I4-I9I5) Georg Lukács puhuu siitä, että romaanista tuli kirjallisuuden valtalaji siinä historian kehitysvaiheessa, jolloin traditionaaliset kosmologiat ja uskonnollis-metafyysiset maailmankuvat menettivät otteensa ihmisiin ja jolloin elämän merkityksestä muodostui heille ongelma (Lukács I971a, 47, 50-51). Siksi romaaniin liittyy Cervantesin Don Quijotesta (1605-16I5) lähtien eksistentiaalisen etsinnän motiivi, eli romaani on pyrkinyt löytämään olemassaolosta ja todellisuudesta jonkin mielen tai tarkoituksen. Lukács (I97ıa, 77) päätyy tutkimuksessaan yleistykseen, jonka mukaan modernia romaania luonnehtii "miehekkään kypsä näkemys": todellisuus ei voi olla koskaan täysin mielekäs, vaikka se ilman syvempää mieltä uhkaakin näyttäytyä subjektille mitättömänä ja banaalina. Siten tietynasteinen resignaatio, alistuminen tai mukautuminen eksistentiaaliseen merkitys- tai mielekkyyskatoon, on kiinteä osa modernin romaanin maailmankuvaa.

Eksistentiaalinen tematiikka on siis liittynyt uuden ajan alusta lähtien länsimaiseen kirjallisuuteen. Varsinaista eksistentialismia, sen ateistista haaraumaa, luonnehtii ajatus siitä, että inhimillisellä olemassaololla ei ole kestävää merkitysperustaa ja että ihminen elää tässä mielessä tyhjässä universumissa, josta puuttuvat pohjimmaiset merkitykset. Tällaista 
tyhjyyden kokemusta eivät ihmisten luomat sosiaaliset ja kulttuuriset merkitysjärjestelmät pysty eksistentialistien mukaan kokonaan poistamaan. Tämän suuntainen ajatusjuonne tuli esiin jo I80o-luvun jälkipuoliskon filosofis-kirjallisessa kulttuurissa, erityisesti Friedrich Nietzschen ja Arthur Schopenhauerin teoksissa. I900-luvun vaihteessa sitä jatkoi elämänfilosofiaksi kutsuttu mannermaisen filosofian virtaus, jonka nimekkäitä edustajia olivat Henri Bergson, Wilhelm Dilthey, Ludwig Klages ja Oswald Spengler. Jo ennen toista maailmansotaa kyseinen virtaus alkoi sulautua yhteen Heideggerin, Beauvoirin, Camus'n ja Sartren nimiin liitetyn eksistentialismin kanssa, minkä jälkeen elämänfilosofian käsite katosi vähitellen julkisesta kulttuurikeskustelusta. (Ikonen

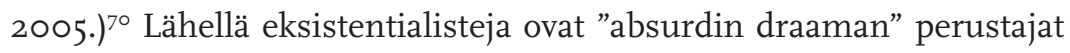
Samuel Beckett, Eugene Ionesco ja Harold Pinter, jotka luopuivat näytelmissään perinteisen draaman teleologisesti etenevästä rakenteesta ja toiminnallisuudesta ja ilmaisivat episodimaisen rakenteen avulla kokemusta ihmiselämän pohjimmaisesta merkityksettömyydestä. Heihin verrattuna esimerkiksi Camus on kirjailijana lähinnä perinteisen tai klassisen muodon taitaja, joka vältteli teoksissaan radikaaleja muotokokeiluja.

Toisen maailmansodan jälkeen eksistentialismista tuli Ranskassa kulttuurielämää hallinnut muoti-ilmiö, jonka ajatukset levisivät eri puolille läntistä maailmaa, myös Suomeen. Camus'n, Sartren ja eksistentialistien suosiman Franz Kafkan teoksia julkaistiin toisen maailmansodan jälkeisinä vuosikymmeninä ahkerasti suomeksi, ja samoihin aikoihin absurdia teatteria, erityisesti Beckettin näytelmiä, esitettiin täkäläisillä näyttämöillä. Eksistentialismille oli Suomessa tuolloin ilmeinen sosiaalinen tilaus, sillä sodan jälkeen niin yhteiskunnallinen kuin maailmanpoliittinenkin tilanne oli suomalaisesta näkökulmasta muuttunut perustavasti. Tuula Hökkä (I999, 72) toteaa, että vierauden ja outouden tunteet ja kokemus suljetussa tilassa olemisesta olivat tavanomaisia tuon ajankohdan suomalaisessa proosassa, erityisesti Juha Mannerkorvella, Pentti Holapalla, Jorma Korpelalla, Eeva-Liisa Mannerilla ja Marko Tapiolla. Samoin tutkijat ovat nähneet tuon ajankohdan suomalaisessa kirjallisuudessa yhtymäkohtia dostojevskilaiseen psykologiseen (Jorma Korpela, Paavo Rintala) ja kristilliseen (Helvi Hämäläinen, Paavo Rintala, 
Mika Waltari) eksistentialismiin (ks. esim. Hökkä I999; Komu I995). Eksistentialismi vaikutti myös I960-I980-lukujen suomalaiseen yhteiskunnalliseen romaaniin, sillä viittauksia siihen löytyy muun muassa Marianne Alopaeuksen, Samuli Parosen ja Hannu Salaman teoksista. (Ks. Hosiaisluoma I990, I69-I73; Peltonen 2008, 73. . $^{\text {7 }}$

Miten eksistentialistinen ja eksistentiaalinen romaani voitaisiin määritelmällisesti erottaa toisistaan? Eksistentialistisen romaanin maailmankuvaa on mahdollista kuvata tämän romaanityypin paradigmaattisten edustajien, Sartren Inhon ja Camus'n Sivullisen, avulla. Yhteistä niille on (i) näkemys siitä, että inhimillisellä olemassaololla ei ole kosmista, etukäteen annettua merkitysperustaa, (ii) minkä vuoksi ihmisen pitäisi itse tehdä elämästään merkityksellinen. (iii) Tämä on kuitenkin käytännössä erittäin vaikeaa, sillä yksilöiden on järjestettävä elämänsä niin, että se sopii yhteen kulttuuristen ja sosiaalisten merkitysjärjestysten asettamien ehtojen kanssa. Nämä järjestykset ovat paljolti mielivaltaisia, vailla syvempää perustaa, ja ne estävät usein yksilöitä toteuttamasta eksistentiaalista vapauttaan. (iv) Siksi maailman vieraus, ihmisen ja universumin välinen epäsuhta luonnehtii ihmisen tapaa olla maailmassa. (v) Tähän liittyen eksistentialismille on ominaista kokemus olemassaolon absurdiudesta ja traagisuudesta. (vi) Silti eksistentialistisen romaanin henkilöt saattavat yrittää toteuttaa aktiivisesti eksistentiaalista vapauttaan tai, mikä tavallisempaa, he luopuvat tästä vapaudestaan ja alistuvat tai mukautuvat resignoituneesti merkitysköyhään elämäänsä, niin kuin Sarten ja Camus'n romaanien päähenkilöt tekevät.

Ranskalaisessa kirjallisuudessa eksistentialismin kultakautta seurasi I960-luvulta lähtien uusromaanin aika. Myös monet sen edustajista olivat sisäistäneet ajatuksen, että ihminen elää pohjimmiltaan merkityksistä tyhjässä universumissa, mikä ei kuitenkaan johtanut heillä absurdiuden tai traagisuuden kokemukseen. Pikemminkin he ottivat sen tyynesti ajattelunsa ja teostensa yhdeksi lähtökohdaksi, minkä vuoksi heitä ei yleensä luokitella eksistentialisteiksi. (Ks. lähemmin Meretoja 2004; 2007; 2008a; 2010.) Samasta syystä Milan Kunderaakaan ei pidetä eksistentialistina, vaikka hänen teoksensa keskittyvät eksistentiaalisiin teemoihin. Hänen romaaninsa Olemisen sietämätön keveys (I985, tšekinkielinen alkuperäisteos ilmestyi I984), Kuolemattomuus (I992, 
tšekinkielinen alkuperäisteos ilmestyi I990) ja MerkityksettömyYden juhla (20I5, ranskankielinen alkuperäisteos La fête de insignificance ilmestyi 20I3) ovat henkevästi laadittuja tutkielmia siitä, miten nykyihminen voisi merkityksellistää elämänsä positiivisesti tai miten meidän tulisi suhtautua siihen, että inhimilliseltä merkityksenannolta puuttuu objektiivinen tai kosminen perusta. Liisa Saariluoma (I998; I95, I97; 2005, I52-I53, 2I4-2I6) toteaa, että romaaneissaan Kundera on tutkinut kolmea erityistä tapaa, joilla moderni subjekti voisi merkityksellistää elämäänsä ja olemassaoloaan positiivisesti. Nuo tavat ovat hedonismi, estetismi ja rakkaus, mutta ne kaikki osoittautuvat Kunderan teoksissa hauraiksi, ja siten modernin subjektin on tyydyttävä eksistentiaalisen tilanteensa ongelmallisuuteen nykymaailmassa. Näissä teoksissa on ehkä pessimistinen pohjavire, mutta niitä ei hallitse kokemus olemassaolon absurdiudesta ja traagisuudesta. Pikemminkin ne käsittelevät sitä, miten modernin ihmisen tulisi elää edellä hahmotellun eksistentiaalisen tilanteensa kanssa.

Vielä etäämmällä eksistentialismista ovat sellaiset romaanit, jotka selittävät merkityksettömyyden kokemusta yhteiskunnasta käsin. Michel Houellebecq kuuluu tällaisiin kirjailijoihin. Sylvain David (2013, I47) toteaa, että Houellebecqin romaanit osoittavat, millaisia riskejä kapitalismin leviäminen sosiaalisen elämän eri osa-alueille tuottaa. Niistä tärkeimpiä on julkisuuden, ihmissuhteiden ja sosiaalisen elämän tavaroituminen, banalisoituminen ja pinnallistuminen ja tätä kautta myös merkityksettömyyden tunteen leviäminen kulttuuriin. Nykykapitalismia kuvatessaan Houellebecq päätyykin visioihin, jotka julistavat loppua kulutus- ja nautintokapitalismin ja seksiteollisuuden "turmelemalle" ihmislajille. Hänen esikoisromaaninsa Halujen taistelukenttä (2009, ranskankielinen alkuperäisteos ilmestyi I994) päähenkilölle on ominaista melankolinen alistuminen nyky-yhteiskunnan tuottamaan merkityskatoon, mutta jo Houellebecqin toisessa romaanissa Alkeishiukkaset (2002, ranskankielinen alkuperäisteos ilmestyi I998) eräs keskushenkilöistä, biologi Michel Djerzinski, kehittää solujen kloonaamisen mahdollistavan menetelmän. Tulevaisuuteen sijoittuvassa utopiassa tai dystopiassa Mahdollinen saari (2006, ranskankielinen alkuperäisteos ilmestyi 2005) ihmislajin on paljolti korvannut kloonauksen avulla lisääntyvä uusi 
ihmislaji. Tuon uuden ihmislajin edustajat eivät tunne seksuaalista halua tai elämisen intohimoa eivätkä juuri suruakaan oman kuolemansa lähestyessä. He uskovat silti aitoon ja pyyteettömään rakkauteen ja sen kykyyn lisätä elämän merkityksellisyyttä. Tämä Houellebecqin romaaneissa ilmenevä kehityslinja näyttäisi kertovan siitä, että kyseisten romaanien kirjoittaja on menettänyt uskonsa nyky-yhteiskunnan kykyyn tuottaa mielekkäitä elämänmuotoja. Mielekäs elämänmuoto on niiden mukaan mahdollinen vain toisenlaisten yhteiskunnallisten edellytysten ja toisenlaisen ihmiskuvan vallitessa. (Vrt. Meretoja 2008b; 2008c.)

Houllebecqin romaaneissa eksistentiaalinen tematiikka tai merkityksen prolematiikka on upotettu rationalisaatiokriitikin osatekijäksi. Samanlainen upottaminen on paljolti ominaista Yhtiökumppaneille, Paholaisen haarukalle ja Mr. Smithille, joissa esiintyy kuitenkin sivujuonteina eksistentialismia lähellä olevia aineksia. Silti nämä romaanit eroavat tässä suhteessa selvästi Seppälän varhaistuotantoon kuuluvista "Taivaanranta"-novellista ja Sydünmaa-romaanista, joita hallitsee eksistentialistinen maailmankuva ja elämäntunnelma.

\section{Intertekstuaaliset ja interdiskursiiviset viittaukset ja metatasot}

Seppälän romaaneille on ominaista intertekstuaalisten ja interdiskursiivisten viittausten ja kommenttien runsaus. Tällaiset viittaukset ja kommentit muodostavat määrällisesti niin laajan kokonaisuuden, että niiden selvittämiseen vaadittaisiin oma tutkimuksensa. Siksi tässä tutkimuksessa on mahdollista ottaa niistä esille lähinnä vain sellaiset tapaukset, jotka liittyvät käsillä olevan tutkimuksen pääteemaan eli kysymykseen siitä, miten Seppälän romaanit kuvaavat ja arvioivat yhteiskunnassa tapahtunutta markkinallistumiskehitystä.

Intertekstuaalisuus ja metafiktiivisyys ovat aina liittyneet kirjallisuuteen, mutta niiden rooli on korostunut modernismista ja postmodernismista lähtien. Modernismi ja postmodernismi voidaan paljolti ymmärtää perinteisen realismin kritiikiksi. Niissä osaksi romaania tulivat metakirjalliset tasot ja esseemäiset pohdiskelut, joiden pyrkimyksenä ei 
kuitenkaan yleensä ollut kuvata ulkoista todellisuutta entistä monipuolisemmin. Pikemminkin ne kyseenalaistivat käsityksen, että ihminen voisi saavuttaa totuudenmukaista, objektiivisesti pätevää tietoa maailmasta tai että maailma voitaisiin esittää totuudenmukaisesti kielen ja kerronnan keinoin. Postmodernistisessa kirjallisuudessa on ollut tavallista korostaa tiedon ja sosiaalisen todellisuuden (identiteetti, sukupuoli) konstruktiivista luonnetta, sitä, että ne ovat historiallisesti ja kulttuurisesti muuttuvia sosiaalisia ilmiöitä. ${ }^{2}$

Nykykirjallisuus on etääntynyt tällaisista epistemologisista ja ontologisista teemoista, samoin postmodernismille ominaisesta tavasta korostaa kulttuurin ja yhteiskunnan konstruktiivista luonnetta. Tämä käy ilmi muun muassa Irmtraud Huberin englanninkielistä nykykirjallisuutta käsittelevästä tutkimuksesta Literature after Postmodernism. Reconstructive Fantasies (20I4). Sen mukaan englanninkielinen nykykirjallisuus - esimerkiksi Margaret Atwood ja Jonathan Franzen - käyttää usein hyväksi modernismin ja postmodernismin suosimia kerrontatapoja, joita nykykirjallisuus on hionut eteenpäin. Sitä kiinnostavat silti enemmän käytännölliset kysymykset, lähinnä arvoihin, kommunikaatioon ja subjektien itsetoteutukseen liittyvät teemat. Lisäksi nykykirjallisuudelle on siinä mielessä ominaista realistinen eetos, että se näyttää luottavan kirjallisuuden kykyyn sanoa jotakin tärkeää kulttuurin ja yhteiskunnan ominaisluonteesta. Tämä ei tarkoita sitä, että nykykirjallisuus olisi tyylillisessä ja romaaniteknisessä mielessä palannut perinteiseen realistiseen kerronta- ja kuvaustapaan, vaan, niin kuin edellä todettiin, pikemminkin se suosii uusia muotokokeiluja. (Huber 20I4, I-2, 5-7, I5, I7, 24-42, 5I,

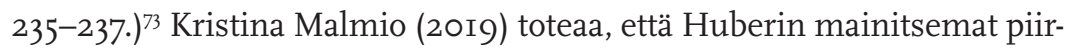
teet ovat voimistuneet myös suomenruotsalaisessa nykykirjallisuudessa, esimerkiksi Monika Fagerholmin, Malin Kivelän, Hannele Mikaela Taivassalon, Johanna Holmströmin, Lars Sundin ja Kjell Westön teoksissa. Tämä viittaa hänen mukaansa siihen, että suomenruotsalainen nykykirjallisuuskin on siirtymässä postmodernismin jälkeiseen aikaan.

Vaikka tutkimuksessa ei vallitse yksimielisyyttä siitä, missä määrin postmodernismi on liittynyt suomenkieliseen kirjallisuuteen, Huberin esittämät havainnot näyttävät monilta osin pätevän myös suomenkieliseen nykyromaaniin. Leimallista sille on ollut yhtäältä yhteiskunnallis- 
ten teemojen paluu romaanin keskiöön ja toisaalta metatasojen ja abstraktien pohdiskelujen tuominen osaksi romaanin rakentumistapaa. (Vrt. Hallila 20I3.) Metakirjalliset pohdiskelut eivät ole yllättäviä, sillä markkinallistumiskehitys on muuttanut merkittävästi kirjailijantyön luonnetta ja kirjallisuusinstituution toimintatapoja. Kirjallisessa elämässä on siten viime vuosikymmeninä ollut meneillään muutosprosessi, jota kirjallisuus on aktiivisesti reflektoinut. Tutkimuskohteena olevat Seppälän romaanit ovat osa tätä reflektoimistyötä.

Konkreettisemmalla tasolla Seppälän romaanien metatasot käsittelevät monenlaisia kysymyksiä. Ne pohtivat erityisesti sitä, (i) mikä on niiden oma suhde kirjallisuuden lajeihin, (ii) millainen suhde vallitsee todellisuuden ja sitä esittävän representaation välillä, (iii) millainen kirjallisuuden tehtävän yhteiskunnassa tulisi olla ja (iv) miten nykyinen kirjallisuusinstituutio toimii. Kysymys (i) on keskeinen Yhtiökumppaneissa ja Mr. Smithissä ja kysymykset (ii) - (iv) Paholaisen haarukassa, minkä ohella Seppälä reflektoi Mr. Smithissä omaa kirjailijuuttaan. Koska nämä metatason teemat ovat näin heterogeenisiä, niihin liittyviä teoreettisia kysymyksiä käsitellään erikseen kyseisten romaanien tarkastelemisen yhteydessä. 


\section{Luku III Yhtiökumppanit ja kapitalismin eetos}

\section{Henkilöt, tarinalinjat ja narratiivinen rakenne}

Ilmestyessään Yhtiökumppanit (2002) oli harvinainen tapaus suomalaisessa kirjallisuudessa. I990-luvun puolivälistä alkaneen taloudellisen nousukauden seurauksena Suomesta oli 2000-luvun alkuun mennessä tullut kapitalismin mallimaa, jonka kehitystä politiikan ja talouselämän asiantuntijat eri puolilla maailmaa kiinnostuneina seurasivat. Kehityksen moottorina toimi Nokia-yhtiö, joka oli vuonna I999 noussut maailman suurimmaksi telekommunikaatioyhtiöksi. Esimerkiksi sosiologi Manuel Castellsin ja filosofi Pekka Himasen yhteinen kirja The Information Society and the Welfare State. The Finnish Model (2002) selittää innostuneesti Suomen menestystä sillä, että täällä markkinoiden ja yritysten toimintamahdollisuuksien lisäämiseen on onnistuttu yhdistämään suhteellisen toimiva hyvinvointivaltio ja vahva kansallinen identiteetti. Ilmeisenä puutteena Castells ja Himanen (2002, I54) pitivät kylläkin sitä, että "sisällöntuotanto" - kokemusten, merkitysten ja identiteettien tuottaminen - ei ollut Suomessa vielä vahvaa: Suomessa ei siis ollut ymmärretty riittävän selvästi sitä, että ostaessaan Nokian kännykän kuluttaja ei osta pelkkää laitetta vaan myös tietyn elämäntavan, merkitysmaailman ja identiteetin osatekijän. Samassa hengessä opetusministeriö julkaisi 2000-luvun ensimmäisellä vuosikymmenellä useita erillisiä raportteja, jotka kaavailivat Suomen siirtyvän lähitulevaisuudessa "mate- 
riaali-intensiivisestä elinkeinorakenteesta" kohti "merkitys-intensiivistä elinkeinorakennetta".74

Jälkikäteen arvioiden tällaiset ennustukset olivat tietenkin liioitellun optimistisia, mutta 2000-luvun alun ilmapiirissä vain harva rohkeni kyseenalaistaa ne julkisesti. Yhtiökumppanit kuuluu näihin kyseenalaistajiin. Se keskittyy kuvamaan kuvitteellista ICT-alan yritystä ja siinä työskenteleviä henkilöitä. Näissä suhteissa sille rinnakkaisena teoksena voi pitää Juha Jokelan näytelmää Mobile Horror (2003), joka käsittelee niin ikään kriittisesti ICT-taloutta. Kapitalismi-sana ei esiinny vielä tässä Seppälän romaanissa eksplisiittisesti, sillä "kapitalismista" hän alkoi puhua vasta Routavuodesta (2004e, I6, 30, 96) lähtien. Kun Yhtiökumppanit suhteutetaan historiallis-yhteiskunnalliseen kontekstiinsa, se näyttäytyy tulkintana ja arviona kapitalistisen talouden uusista toimintatavoista. Näihin uusiin toimintatapoihin on tutkimuskirjallisuudessa viitattu sellaisilla käsitteillä kuin immateriaalinen talous, luova talous tai informationaalinen kapitalismi. Ne kaikki sisältävät ajatuksen, että informaation tai tiedon tuottamisesta, soveltamisesta ja kauppaamisesta on nykykapitalismissa tullut merkittävä talouden haarauma ja arvonmuodostuksen osatekijä.

Yhtiökumppaneiden nimi on monimerkityksinen. Se viittaa yhtäältä keskushenkilön Peten (Pertin) ja hänen vaimonsa Terhin väljähtyneeseen avioliittoon, jota pitävät enää koossa yhteiset pienet lapset ja rutiinit sekä yhteiset muistot heidän välillään aiemmin kukoistaneesta intohimosta ja rakkaudesta. Toisaalta romaanin nimi viittaa myös Peteen ja hänen ystäväänsä Olliin, jotka ovat pyörittäneet yhdessä ICT-alan yritystä: Olli sen pääomistajana ja toimitusjohtajana, Pete tulospalkattuna graafisena suunnittelijana eli "art directorina". Romaanin alussa tai sen nyt-hetkessä yrityksellä menee jo huonosti. Takaumajaksoissa käy ilmi, että alkuvaiheessaan yhtiö oli keskittynyt valmistamaan internet-sivuja ja grafiikkaa pienyhtiöille, jolloin se toimi lähinnä mainostoimistona. Tämän tulonlähteen kutistuttua yhtiö siirtyi myös peliteollisuuden alueelle. Sen jälkeen yhtiöllä meni muutaman vuoden ajan taloudellisesti erinomaisesti, minkä ansiosta näinä huippuvuosina heidät listattiin "paikkakunnan Nokia-miljonäärien joukkoon" (YK, 98).* Siinä vaiheessa

* Käytän luvuissa III-VI Yhtiökumppaneista lyhennettä YK silloin, kun siteeraan sitä tai viittaan siihen muuten sivunumeroiden tarkkuudella. 
Pete ja Olli kävivät myös Kaliforniassa tutustumassa amerikkalaiseen ICT-alaan ja sen toimintatapoihin:

Kun palasimme, olimme kelvollisia kiertelemään luennoimassa alan näkymistä ympäri Suomea ja nostamaan luennoista palkkioita, joita emme enää edes hävenneet. Ei ollut meidän vikamme, että olimme osuneet kultasuoneen, ja vaikka emme olleet ainoita, ei meitä toistaiseksi ollut liikaa. Meillä oli missio: olimme tulleet maailmaan murskataksemme toimialan toisensa jälkeen. Uusi raivasi tieltään vanhaa, ja me kuvittelimme olevamme kehityksen kärjessä. Vastaväitteet kuittasimme toistelemalla Ollin mottoa: epäselvästi ajateltu, jos ollenkaan. (YK, 51.)

Tässä Peten kerrontajaksossa tulee esiin uusliberalistiselle diskurssille ominainen ajatus "luovasta tuhosta" - siis siitä, että mennäkseen eteenpäin kapitalistisen talouselämän on aina silloin tällöin uusiuduttava ja tuhottava entisiä vaurauden lähteitä, esimerkiksi yrityksiä ja työpaikkoja. Pete ja Olli ovat romaanissa sisäistäneet tämän ajatuksen. Sen alkuperäisenä muotoilijana pidetään itävaltalais-amerikkalaista taloustieteilijää Joseph Schumpeteriä (I883-I950), joka kehitti sen Marxin tutkimusten pohjalta. Marxiin tukeutuen Schumpeter (20IO) esitti, että kapitalismissa uusien tuotantomuotojen ja uuden vaurauden luominen on mahdollista vain sitä kautta, että tämä dynaaminen taloudellinen toimintatapa rapauttaa jo luotua vaurautta ja tuhoaa aiemmin käytettyjä tuotantovälineitä. Siten jopa sodat ja talouskriisitkin ovat Schumpeterin mukaan olleet tarpeellisia kapitalismissa, sillä ne ovat vauhdittaneet sen kehitystä ja avanneet sille tien uuden vaurauden luomiseen. Uusliberalistisesta ajattelusta poiketen Schumpeter ei kuitenkaan uskonut kapitalismin tulevaisuuteen, vaan hän ennusti sen korvautuvan aikanaan sosialistisella talousjärjestyksellä. Yhtiökumppaneissa Peten ja Ollin pyörittämä yritys päihittää tai "tuhoaa" huippuvuosinaan kilpailijansa, mutta tämä menestys tapahtuu suurten henkilökohtaisten uhrausten tai tuhojen kustannuksella. Sen myötä Pete vieraantuu vähitellen vaimostaan ja lapsistaan ja ajautuu lopulta eksistentiaaliseen kriisiin tai mielekkyyskriisiin. Samanlaiseen tilaan päätyvä Olli tekee romaanin lopussa itsemurhan. 
Yhtiökumppaneissa Peten ja Ollin yrityksen toiminnan laajentaminen peliteollisuuden piiriin on sinänsä taloudellisesti oikeansuuntainen ratkaisu, mutta ennen pitkää se ajaa yrityksen ankaraan kilpailuun alan muiden yritysten kanssa. Tästä haasteesta selvitäkseen ja välttääkseen edessä uhkaavan konkurssin yritys pyrkii kehittämään markkinat ällikällä lyövän tietokoneroolipelin, jonka suunnittelua romaanin kerrontajaksot eri puolilta valottavat. Näissä jaksoissa romaani esittää samalla kriittisen arvionsa "sisällöntuotannosta".

Peten, Terhin ja Ollin lisäksi romaanin henkilövalikoima koostuu Peten ja Ollin yrityksen muista työntekijöistä. Heistä tärkeimmäksi osoittautuu Kirsi, jonka Pete ja Olli palkkaavat yhtiönsä toimistosihteeriksi alkuvuosien jälkeen; tapahtumien edetessä Kirsi ja Pete alkavat seurustella keskenään ja suunnitella yhteistä elämää. Kertojina romaanissa toimivat pääasiassa Pete, Kirsi ja Peten isä, joka liikkuu omissa kerrontajaksoissaan jatkosodan tapahtumissa. Romaanin nykyisyydessä Peten isä ei ole enää keskeinen henkilö vaan etäinen taustahahmo, joka on vielä elossa Peten aloittaessa työuraansa, mutta jonka kuolemasta Petelle välitetään tieto romaanin viidennessä osassa, vaajat kymmenen vuotta Peten uran alkamisen jälkeen (YK, 34-36, I86). Pete keskittyy omissa kerrontajaksoissaan lähinnä työuransa ja yhtiönsä kehityshistorian kuvaamiseen ja yhä sotkuisemmaksi muuttuvan tunne-elämänsä ilmaisemiseen. Kirsin kerrontajaksot antavat tietoa hänen lapsuudestaan ja nuoruudestaan. Kirsin jaksoissa keskeistä on se, että hänen isänsä varhainen kuolema on järkyttänyt hänen eksistentiaalista turvallisuuden tunnettaan ja tehnyt hänet mentaalisesti hauraaksi ja turvallisuutta kaipaavaksi ihmiseksi. Näiden kolmen minäkertojan ohella romaanissa on pitkä, dialogien varaan rakentuva draamallisen kerronnan jakso (ibid., I67-I77), jossa Pete, Kirsi, Olli ja yhtiön muut työntekijät pohtivat yhdessä yhtiön tilaa ja omaa elämäntilannettaan.

Niin kuin aiemmin (ks. sivut 88-93) todettiin, romaanin henkilöistä Pete ja Olli kuuluvat ylimpiin luokkiin: kapitalististen yrittäjien, tulospalkattujen avainhenkilöiden ja menestyvien sijoittajien kerrostumaan. Muista työntekijöistä romaani antaa informaatiota Susannasta (myyntisihteeri) ja Kirsistä (toimistosihteeri). He edustavat lähinnä alempaa keskiluokkaa (luokka III), jos kohta Susanna tulee koulutuksensa 
(ekonomi) osalta lähelle ylempää keskiluokkaa (luokka II). Myös Peten isä (myyntimies) sijoittuu lähinnä keskiluokkaan. Romaanissa ei käytännössä juurikaan esiinny työväenluokkaisia henkilöitä, ellei sellaiseksi sitten lasketa romaanin neljännessä osassa lyhyen aikaa esiintyvää Lassea, virkistyskeskuksen hoitajaa tai talonmiestä.

Pituudeltaan 237-sivuinen Yhtiökumppanit muodostuu kuudesta osasta ja 9г:stä luvusta tai kerrontajaksosta. Sen luvut ovat tavallisesti lyhyitä, vajaan kolmen sivun pituisia, joskin neljäs osa (YK, IOI-I78), jossa henkilöt kokoontuvat suunnittelemaan tietokonepeliä erääseen rentoutumiskeskukseen, sisältää muutaman kymmensivuisen jakson. Romaanissa on kolme keskeistä tarinalinjaa, joissa Pete (46 kerrontajaksoa), Kirsi (23 kerrontajaksoa) ja Peten isä (I6 kerrontajaksoa) vievät minämuodossa romaania eteenpäin. He ovat samalla romaanin keskeiset fokalisoijat. Näytelmämuotoon kirjoitettu jakso (ibid., I66-I77) on anonyymin, tarinamaailman ulkopuolisen kertojan esittämä, sillä hän on kirjoittanut ylös henkilöiden repliikit ja hän antaa henkilöiden replikoidessa tietoa heidän teoistaan, ilmeistään ja eleistään. Ulkopuolisen kertojan osuus rajoittuu tähän jaksoon eikä hän siis esiinny muualla romaanissa. Näiden ohella yhtiön muulla henkilökunnalla (Olli ja Susanna) ja rentoutumiskeskuksen talonmiehellä (Lasse) on romaanissa kullakin yksi minämuotoinen kerrontajakso. ${ }^{75}$ Peten vaimolla ja lapsilla ei ole omia kerrontavuoroja, vaan lukija saa heistä tietoa vain Peten kerrontajaksojen kautta. Hallitsevana romaanissa on Peten ääni ja hänen tapansa kokea työnsä ja elämänsä informationaalisen nykytalouden asettamissa puitteissa.

Edellä on esitelty Yhtiökumppaneiden henkilöt ja keskeiset tarinalinjat. Tekstin pintatasolla nuo tarinalinjat eivät ole helposti tunnistettavissa. Ensimmäisellä lukukerralla tämä fragmentaarista ja epäjatkuvaa kerrontatapaa hyödyntävä romaani voi vaikuttaa kaoottiselta. Lukija joutuu näkemään runsaasti vaivaa päätellessään, kuka romaanissa toimii kulloinkin kertojana ja millä aikatasolla kukin kerrontajakso liikkuu, ja muodostaessaan sitten näiden erillisten jaksojen perusteella kuvan kustakin henkilöstä ja henkilöiden keskinäisistä suhteista. Keskeisenä motiivina romaanissa toimii Peten ja hänen sukunsa miespuolisten jäsenten kiihkeä pyrkimys ansaita rahaa ja heidän uskonsa rahan ihmeitä 
tekevään voimaan. Tämä usko kärsii romaanissa haaksirikon. Siksi Yhtiökumppaneita voidaan lukea modernina yhteiskunnallisena moraliteettina eli kertomuksena siitä, mitä yksilöille ja yhteisöille tapahtuu, kun yhteiskunnassa aletaan seurata "vääriä arvoja". ${ }^{6}$

Tärkeänä symbolina romaanissa esiintyy sfinksin hahmo. Romaanin alussa Pete kehittelee yhtiölleen logon, tyylitellyn sfinksin pään. Egyptiläisessä mytologiassa sfinksillä oli leijonan ruumis ja ihmisen pää ja kasvoiksi sille oli yleensä annettu faaraon tai jonkun arvohenkilön kasvot. Antiikin kreikkalaiset kehittelivät sfinksin hahmoa edelleen. Heidän mytologiassaan sfinksin ylävartalolla oli usein naisenhahmo ja alavartalolla leijonanhahmo, minkä lisäksi he antoivat sfinksille kotkansiivet ja käärmeenhännän. Sfinksi esitti ohikulkeville arvoituksen ja nielaisi jokaisen, joka ei osannut vastata siihen oikein. Tässä mielessä sfinksi edusti kreikkalaisille onnettomuuksia, tuhoa ja kuolemaa.

Seppälän romaanissa Peten ja Ollin yritys, markkinat ja Kirsi rinnastetaan sfinksin asettamaan haasteeseen. Heidän yrityksensä on tällainen haaste siinä mielessä, että mikäli Pete ja Olli eivät löydä ratkaisua sen toiminnan kehittämiseen, on sen edessä tuhon tie. Sama pätee markkinoihin; mikäli yritys ei pärjää markkinoilla, sen edessä on jälleen tuhon tie. Kirsiä Pete ei alussa koe riskiksi, vaan hän uskoo, että Kirsin kautta hänelle aukeaa uudelleen mahdollisuus kokea intohimoa, rakkautta ja merkitystä - asioita, jotka hän on itse tuhonnut keskittymällä työhönsä ja yhtiönsä kehittämiseen ja laiminlyömällä siten vaimoaan ja lapsiaan. Vielä vähän ennen romaanin loppuratkaisuakin Pete on tämän illuusion vallassa:

Juuri tällä hetkellä en vielä tiennyt että kreikkalaiset tekivät siivin varustettuja naissfinksejä. Ne kuvasivat naispuolisia kuoleman demoneja jotka vaanivat ohikulkijoita, esittivät heille arvoituksen ja nielaisivat jokaisen, joka ei kyennyt vastaamaan niiden kysymyksiin. En nähnyt siipiä, en tiennyt että Kirsi oli tuo kysymys. (YK, 230-23I. $)^{77}$

Katkelma edustaa niin sanottua kaksoistietoisuutta tai kahden eri diskurssin limittymistä toisiinsa kerronnassa. Katkelma tuo yhtäältä esiin 
sen, millainen käsitys Kirsistä Petellä oli ennen romaanin loppuratkaisua, ja toisaalta hänen tietoisuutensa siitä, että hänen tuolloinen käsityksensä Kirsistä oli väärä. Hän ei siis vielä ennen romaanin loppuratkaisua tiennyt sitä, että Kirsi edusti riskiä; tämä paljastuu hänelle vasta romaanin lopussa. Kyseisen, loppuratkaisua edeltävän kohdan Pete kertoo siten ajallisesti myöhemmästä perspektiivistä käsin, jolloin hän jo kykenee arvioimaan kriittisesti aiempia ajatuksiaan ja tekojaan.

Romaanin yllättävässä loppuratkaisussa Petelle ja lukijalle - mutta ei Kirsille - paljastuu, että Pete ja Kirsi ovat sukulaisia. Jatkosodan aikana Peten isällä oli nimittäin ollut Viipurissa lyhytaikainen suhde erääseen naiseen, joka oli suhteen seurauksena synnyttänyt myöhemmin pojan, Kirsin tulevan isän. Kymmenisen vuotta sodan päättymisen jälkeen Peten isä oli sitten mennyt naimisiin toisen naisen kanssa ja saanut myös tämän kanssa pojan, Peten. Näin Kirsin isä ja Pete ovat velipuolia, saman miehen lapsia. Kun tämä totuus valkenee Petelle hänen ja Kirsin välisissä yöllisissä keskusteluissa, Pete jättää Kirsin, joka jää yöhön yksin ihmettelemään Peten käyttäytymistä ja omaa tilannettaan. Palaan tähän ratkaisuun tämän luvun lopussa.

\section{Hillitön pyrkimys rahan ansaitsemiseen kapitalismin eetoksena}

Yhtiökumppaneiden teleologinen etenemistapa, siinä ilmenevä "intentionaalisuuden järjestelmä" (ks. Phelan \& Rabinowitz 20I2b, 29-3I), pyrkii osoittamaan, millainen tuhoa ympärilleen kylvävä järjestelmä informationaalinen nykytalous on ja millaisia seurauksia yksilöille ja heidän lähiyhteisöilleen aiheutuu, kun he tavoittelevat taloudellista menestystä kaikin voimin. Romaanin henkilöille ja heidän läheisilleen tällainen toiminta aiheuttaa suuria henkisiä vaurioita. Juuri tässä mielessä romaaniin on sisäänrakennettu modernin moraliteetin koodi, kertomus siitä, millaisia kielteisiä seurauksia yksilöille ja yhteisöille "väärien arvojen" seuraamisesta aiheutuu.

Moraliteettien tai moraliteettinäytelmien historiallinen alkuperä on keskiaikaisissa allegorisissa näytelmissä. Niiden tarkoitusperä oli didak- 
tinen, ja ne käsittelivät hyvän ja pahan voimien välistä kamppailua ihmisen sielussa. Kenties tunnetuin keskiaikaisista moraliteettinäytelmistä on I400-luvun lopussa kirjoitettu Everyman. Allegorialle tyypilliseen tapaan sen narratiiviset toimijat eivät ole konkreettisia yksilöitä vaan abstrakteja ominaisuuksia ja niiden edustajia (Jumala, Sanansaattaja, Kuolema, Jokamies, Toveruus, Hyvät Teot, Omaisuus, Tieto, Kauneus, Voima). Hyvä ja paha ymmärrettiin kristillisissä moraliteeteissa Raamatun pohjalta eli hyvää oli se, mikä sai ihmisen toimimaan Jumalan tahdon ja kristillisen elämänkäsityksen mukaisesti, ja pahaa se, mikä houkutteli hänet kiusauksiin ja syntiin ja sai hänet poikkeamaan uskonnollisen kilvoittelun tieltä. ${ }^{7}$ Näin moraliteetti edellytti vakaata ja ehdotonta arvojärjestelmää, jonka pohjalta hyvä ja paha olivat selvästi erotettavissa toisistaan.

Juuri moraliteettiin liittyvä ehdottomuuden vaatimus, samoin kuin kulttuurin ja yhteiskunnan modernisoitumiseen liittyvä maallistuminen, selittää sitä, että moraliteetti menetti suosiotaan moderniin maailmaan siirryttäessä. Silti myös modernit yhteiskunnalliset romaanit saattavat sisältää moraliteetin piirteitä. Esimerkiksi Dickensin romaaneissa ja kertomuksissa jakolinja hyvän ja pahan välillä on selkeä, ja ne osoittavat, millaisia tuhoisia seurauksia esimerkiksi taloudellisella egoismilla, väärillä arvoilla, on muulle yhteiskunnalle, erityisesti köyhille (Cazamian I973, II7-I74; Claybough 2008, 52-84). Tosin lajiteoreettisesta näkökulmasta Dickensin teosten hallitsevana piirteenä on pidetty melodramaattisuutta. Niiden tapa kuvata sosiaalista maailmaa perustuu mustavalkoisiin asetelmiin (hyvä/paha, viaton/turmeltunut, köyhä/rikas), minkä ohella ne pyrkivät vaikuttamaan lukijoihin voimakkaasti emotionaalisesti ja herättämään heissä moraalisen hyväksynnän tai vastenmielisyyden tunteita kuvattuja tapahtumia kohtaan. Lajeina moraliteetti ja melodraama ovat siinä mielessä sukulaisilmiöitä, että niissä molemmissa maailmaa käsitellään ensi sijassa moraalisten kategorioiden ja arvoerottelujen avulla.

Yhtiökumppaneissa Pete ei alussa ymmärrä, millainen yhteiskunnallinen järjestelmä nykytalous on. Hän kiinnittyy ja sitoutuu siihen uransa alussa ja liittää taloudelliseen menestykseen miltei samanlaisia pyhyyden ja merkityksellisyyden tuntemuksia kuin kristillisen maailmankuvan 
sisäistäneet ihmiset ovat perinteisesti liittäneet kristillisiin kertomuksiin, rituaaleihin ja symboleihin. Peten kokemus taloudellisesta menestyksestä on tässä rajatussa mielessä uskonnollissävyinen tai pseudouskonnollinen.

Tällainen tulkinta - jossa Yhtiökumppaneiden katsotaan arvostelevan nykyistä yhteiskuntaa siitä, että se on nostanut bisneksenteon miltei uskonnon asemaan - saa tukea Seppälän lehtikirjoituksista, erityisesti hänen Suomen Kuvalehdessä vuonna 200I julkaisemastaan tekstistä "In It We Trust". Siinä hän ei tosin puhu niinkään informationaalisesta taloudesta vaan enemmänkin informaatioteknologiasta ja sen kaupallisista sovelluksista. Kyseisen kirjoituksen mukaan "informaatioteknologia kaupallisine sovelluksineen on melko kollektiivisesti korvannut uskonnon tai vähintään toimii vastauksena uskonnolliseen kaipuuseen" (Seppälä 200Ib, 6o). Tässä mielessä informaatioteknologiasta ja sen kaupallisista sovelluksista on tullut nykyajan uskonto, jossa "analyytikot" toimivat "papin" roolissa (ibid.). Sitä, että uskonto ja informaatioteknologia ovat nyky-yhteiskunnassa sekoittuneet toisiinsa, korostaa myös Seppälän kirjoituksen otsikko. Se on muunnos tunnetusta amerikkalaisesta iskulauseesta "In God We Trust", joka on painettu myös dollariseteleihin. Kirjoituksen otsikossakin informaatioteknologia ("It") on ottanut uskonnon ("God") paikan. Yhtiökumppanit eroaa tästä artikkelista lähinnä siinä, että Yhtiökumppaneiden mukaan nykykulttuurissa uskonnon korvaajaksi ei ole niinkään asettunut informaatioteknologia vaan informationaalinen talous ja sen myötä yhteiskuntaan levinnyt liiketaloudellisten arvojen ylikorostus.

Yhtiökumppanit alkaa kohtauksella, jossa Pete käy mittauttamassa hallussaan olevan, vuonna I799 painetun kuparilantin arvon. Tämän perintökolikon rahalliseksi arvoksi tai vaihtoarvoksi määrittyy 2,5 markkaa, mutta Petelle sillä on huomattavasti suurempi "muistoarvo" (YK, 7). Kolikko on kulkenut Peten suvussa sukupolvelta toiselle. Hänen suvussaan varsinkin miehet ovat olleet kiinnostuneita rahasta, sen ansaitsemisesta ja omaisuutensa kartuttamisesta, mutta samalla tämä rahaan kohdistuva kiintymys ja kiinnostus on usein aiheuttanut heidän keskuudessaan ja lähipiirissään onnettomuuksia. Esimerkiksi Peten isän isoisällä, ammatiltaan sepällä, oli tapana pitää työstään maksuksi saamiaan kolikkoja 
suussaan, minkä vuoksi hänelle kehittyi suuhun syöpäkasvain. Samoin Peten isällä, joka sodassa ollessaan kantoi edellä mainittua perintökolikkoa mukanaan "onnenlanttina", oli myöhemmin tapana laittaa rahaa suuhunsa. Sama toistuu Peten kohdalla: hän oli esimerkiksi kahden ja puolen vuoden ikäisenä puolittain vahingossa nielaissut sukunsa perintökolikon, joka oli hänen vanhempiensa helpotukseksi kuitenkin tullut ulosteiden mukana pois. (Ibid., 8-9, 22, 29.)

Suvun miesten kiinnittymisestä rahaan ja sen ansaitsemiseen on konkreettisesti seurannut se, että he eivät oikein osaa kommunikoida ihmisten kanssa - vaikka rahaa he osaavatkin tehdä. Tämä toistuu Peten kohdalla, joka omistautuu täysin työlleen eikä siksi juurikaan elä samassa puhe- ja merkitysmaailmassa vaimonsa Terhin ja kahden pienen poikansa kanssa. Suvun aiemmista miehistä Pete poikkeaa siinä, että hän antautuu rahan ansaitsemiseen ja omaisuutensa kartuttamiseen heitä huomattavasti holtittomammin ja ryhtyy jo opiskeluaikanaan harjoittamaan sijoitustoimintaa. (YK, 36.) Hänen edeltäjänsä suvussa olivat sen sijaan tehneet ahkerasti työtä ja eläneet säästäväisesti ja saaneet tällä tavalla kokoon varallisuutta. Peten isä oli vielä kiinni tässä perinteessä. Romaanissa Pete luonnehtiikin häntä muodollista koulutusta vailla olleeksi hiljaiseksi mieheksi, joka "myi mitä tahansa, mutta sen pääartikkelit olivat vakuutukset ja kirjasarjat". Tätä kautta isä pystyi jättämään Petelle perinnöksi omaisuutta "parin miljoonan [markan] arvosta". (Ibid., 2I-22, 98.)

Rahan luonnetta koskevissa teoreettisissa pohdiskeluissa raha on toisinaan ymmärretty pelkäksi taloudellisen vaihdon välineeksi. Tällaisessa käsityksessä korostetaan usein myös sitä, että raha voi saada erilaisia konkreettisia ilmenemismuotoja ja periaatteessa mitä erilaisimmat asiat voisivat seteleiden ja kolikoiden sijasta toimia taloudellisen vaihdon välineinä - edellyttäen, että yhteiskunnassa vain päästäisiin tästä sopimukseen. Näin ajateltaessa raha ymmärretään puhtaasti funktionaalisesti. Taloussosiologi Frederick F. Wherry (2OI2, 8I-IO2) huomauttaa kuitenkin, että taloudellisen funktion ohella rahalla on ollut muitakin funktioita. Esimerkiksi kansalliset valuutat ovat olleet osa sitä symbolija merkkimaailmaa, jolla kansakunnat ovat erottautuneet toisistaan ja määrittäneet omaa identiteettiään. 
Yhtiökumppaneissa Pete ja hänen sukunsa menevät rahan merkityksellistämisessä vieläkin pidemmälle. Suvun miesten välillä jatkuvuuden ja keskinäisen yhteyden tunne liittyy paljolti juuri rahaan ja heidän siihen projisoimiinsa merkityksiin. Isänsä kuoltua Pete sai haltuunsa pahvilaatikon, joka sisälsi muun muassa sukukirjan ja peltisen kolikkorasian. Sukukirjaan oli kirjattu suvun jäsenten nimet. Lisäksi pahvilaatikossa oli resuinen Uusi testamentti, jonka takakanteen oli violetilla värillä kirjoitettu "Olkaa turvallisin mielin sillä minä olen voittanut maailman". Kyseinen lause on lainaus Johanneksen evankeliumin kohdasta, jossa Jeesus -hieman ennen kuin hänet vangitaan ja myöhemmin ristiinnaulitaan - kertoo opetuslapsilleen tulevista vainon ja hajanaisuuden vuosista ja rauhoittelee samalla heitä:

Tämän minä olen teille puhunut, että teillä olisi minussa rauha. Maailmassa teillä on ahdistus; mutta olkaa turvallisin mielin: minä olen voittanut maailman. (Evankeliumi Johanneksen mukaan I6:33. Vuonna I933 käyttöön otettu suomennos.)*

Oheinen kohta kehottaa luottamaan Jeesukseen ja kristilliseen uskoon, mutta Raamattu ja sen opetukset eivät ole ohjaamassa Peteä, niin kuin ne eivät myöskään juurikaan ohjanneet hänen isänsä toimintaa. Niiden sijasta Peteä, hänen isäänsä ja osittain myös suvun edeltävien polvien miehiä on ohjannut raha ja pyrkimys oman, henkilökohtaisen omaisuuden kartuttamiseen. Juuri tässä mielessä suvun miehet, erityisesti suvun nuoremmat miessukupolvet ovat romaanin mukaan seuranneet intohimoisesti vääriä jumalia ja vääriä arvoja. Tämä rahaan liitetty uskonnollissävyinen, mutta pohjimmiltaan kuitenkin maallistunut merkitysvivahde tulee erityisen selvästi näkyviin kohdassa, jossa Pete kertoo, että heidän perheessään edellä mainittu perintönä kulkenut pahvilaatikko, varsinkin siihen sisältyvä kuparikolikko

* Käytän tässä tutkimuksessa tavallisesti lähteenäni vuonna 1992 ilmestynyttä Raamatun suomennosta. Silloin, kun siteeraan varhaisempia Raamatun suomennoksia tai kun viittaan muuten niihin, mainitsen siitä aina erikseen. 
otettiin esiin vain juhlapyhinä, yhteisöllisen tasapainon järkkyessä tai hetkinä, joihin sisältyi muuten poikkeuksellista latausta. Muistan ainakin isän 50-vuotispäivän, illan jolloin äiti joutui sairaalaan, ja oman rippijuhlapäiväni. (YK, 44.)

Kuparikolikko otettiin esiin silloin, kun Pete ja hänen sukunsa halusivat juhlistaa jotakin ja korostaa jonkin tapahtuman erityistä merkitystä. Näin suvun keskuudessa kuparikolikolla miellettiin olevan miltei pyhittävää voimaa. Toisaalta suku tukeutui kuparikolikkoon myös silloin, kun se haki opastusta tulevaisuuden varalle. Peltisessä rasiassa säilytetyt rahat olivat ikään kuin perheraamatun asemassa ja edustamassa sitä "viisautta", johon kiinnittyen suvun miehet olivat toimineet. Pete toteaakin, että hänen suvussaan ja perheessään "älykkyys ja kolikkolipas liitettiin yhteen" (YK, 30).

Suhteessaan rahaan Pete ja hänen sukulaismiehensä ovat lähellä sitä suhtautumistapaa, jota Weber ja Marx ovat käsitelleet tutkimuksissaan. Protestanttisessa etiikassa ja kapitalismin hengessä Weber käyttää avainkäsitteenään kapitalismin henkeä tai kapitalismin eetosta. Sillä hän viittaa siihen mielenlaatuun tai mentaliteettiin, jota moderni kapitalismi edellyttää. Kapitalististen toimintatapojen yleistyminen oli Weberin mukaan mahdollista vain sillä ehdolla, että ihmiset luopuivat laajemmin traditionaalisista toimintatavoista, joissa he työskentelivät vain omaa, välitöntä tarpeentyydytystään varten. Kapitalististen toimintatapojen yleistyminen edellytti sitä, että ihmiset käsittivät työnteon kutsumukseksi ja täyttivät sillä maallisen elämänsä. Weberin mukaan juuri protestanttinen uskonpuhdistus loi uuden ajan alussa tällaisen modernin ammattietiikan, sillä se piti työtä suoranaisesti Jumalan ihmiselle määräämänä kutsumuksena tai tehtävänä maailmassa. Siksi protestanttisten lahkojen piiriin kuuluneet ihmiset olivat aktiivisia liiketoiminnan harjoittajia ja toimeliaita yritysten perustajia. Modernin kapitalismin hengen Weber määritteli toimintatavaksi, jossa pyritään ammattimaisen systemaattisesti ja rationaalisesti liikevoiton saavuttamiseen ja varallisuuden kartuttamiseen muodollisesti laillisin keinoin. Tämän eetoksen tyypillisiä ilmenemismuotoja olivat esimerkiksi Benjamin Franklinin (I706-I790) tekstit, 
joiden kirjoittaja uskonnolliselta pohjalta ymmärsi rahan ansaitsemisen elämäntehtäväkseen. (Weber I980, 36-56.)

Tietyssä suhteessa Pete ja hänen sukunsa miehet toimivat weberiläisittäin ymmärretyn kapitalismin hengen mukaisesti. Franklinin tavoin hekin ovat intohimoisesti kiinnittyneet rahan ansaitsemiseen ja omaisuutensa kasvattamiseen, mikä muodostaa heidän elämänsä pääsisällön. Heidän suhtautumistapansa rahaan sisältää silti myös piirteitä, joita Marx kuvasi Pääoman ensimmäisessä osassa, sen tavara- ja rahamuotojen analyyseissä, tavarafetisismin käsitteen avulla. Ilmiönä tavarafetisismi syntyy Marxin mukaan rahan ja tavaroiden vaihdossa ja kiertokulussa, ei niinkään itse tuotantoprosessissa. Rahan ja tavaroiden kiertokulussa, esimerkiksi tavaroita ostaessaan ja myydessään tai rahaa sijoittaessaan sosiaaliset toimijat unohtavat helposti rahan ja tavaroiden yhteiskunnallisen luonteen, sen, että niihin on tiivistynyt tai esineellistynyt yhteiskunnallista työtä ja työn hyväksikäyttöä. Ääritapauksessa he saattavat kuvitella, että he ovat tekemisissä vain fyysisten esineiden kanssa ja että rahalla itsessään on mystinen kyky kasvaa korkoa ja tuottaa lisää rahaa. Tällöin

ihmisten keskinen tietty yhteiskunnallinen suhde saa heidän silmissään olioiden keskisen suhteen mielikuvituksellisen muodon. Löytääksemme jotakin tätä vastaavaa meidän täytyy paeta uskonnollisen maailman usvakerroksiin. Siellä ihmisaivojen tuotteet näyttävät eläviltä, keskenään ja ihmisten kanssa suhteissa olevilta itsenäisiltä olennoilta. Samoin on ihmiskäden tuotteiden laita tavaramaailmassa. Tätä minä sanon fetisismiksi, joka takertuu työn tuotteisiin, mikäli niitä tavaroina tuotetaan, ja joka siis on erottamattomasti tavaratuotantoon kuuluva. (Marx I979, 79.)

Marxille tavarafetisismi edusti mystifioivaa näkemystä rahasta ja tavaratuotannosta, sillä hänen mukaansa siinä katoaa näkyvistä kapitalistiseen tavaratuotantoon liittyvä taloudellisen riiston ja hyväksikäytön ulottuvuus. Yhtiökumppaneissa Pete ja hänen sukunsa miespuoliset edustajat ovat tällaisen rahaa koskevan väärän tietoisuuden vallassa. Romaanin 
edetessä Pete joutuu kuitenkin huomaamaan, ettei hänen suvultaan saamansa henkinen tai kulttuurinen perintö, intohimoinen pyrkimys rahan ansaitsemiseen ja henkilökohtaisen omaisuuden kartuttamiseen, kanna häntä elämässä tarpeeksi pitkälle, vaan se päinvastoin tyhjentää hänet henkisesti.

On tarpeen vielä täsmentää sitä, millainen kuva Yhtiökumppaneissa välittyy nykykapitalismin ja uskonnon välisestä suhteesta. Kuten aiemmin todettiin, tuo kuva on tietyiltä osin weberiläinen, sillä Weberin käsittelemien protestanttisten yrittäjien tavoin Pete, ja hänen laillaan yhtiön pääomistaja Olli, on intohimoisesti suuntautunut rahan ansaitsemiseen, varallisuutensa kartuttamiseen ja yritystoiminnan harjoittamiseen. Mutta toisaalta kapitalismin ja uskonnon välinen suhde on Yhtiökumppaneissa myös perustavasti erilainen kuin Weberin tutkimuksessa, joka siis tarkastelee kapitalistisen yritystoiminnan ja protestanttisten lahkojen omaksumien moraalikäsitysten välistä vuorovaikutusta I500-I700-luvuilla. Kyseiset lahkot toimivat lähinnä Englannissa, Skotlannissa, Hollannissa, Saksassa, Sveitsissä, Ranskassa ja Yhdysvalloissa. Tuolloin kapitalistista yritystoimintaa harjoittivat erityisesti protestanttisesta uskonpuhdistuksesta innoituksensa saaneet henkilöt, jotka pitivät maallista työtä Jumalan heille määräämänä tai osoittamana kutsumuksena. Talouden alueella he toimivat sisäistämänsä uskonnollisen vakaumuksen pohjalta. Yritystoimintaansa harjoittaessaan he eivät siksi viime kädessä tavoitelleet maallista rikkautta vaan oman sielunsa autuutta ja Jumalan kunnian lisäämistä maailmassa. Erityisen selvästi talouden alistaminen korkeammille, uskonnollis-moraalisille arvopäämäärille tuli esiin protestantismin äärimuodoissa, joissa

maailma palvelee Jumalan kunniaa ja vain sitä. Valittu kristitty on olemassa siksi, ja vain siksi, että hän lisäisi Jumalan kunniaa maailmassa ja panisi hänen käskynsä omalta osaltaan täytäntöön. Mutta Jumala haluaa kristityn sosiaalista menestystä, sillä hän haluaa, että elämä muotoutuu sosiaalisesti hänen käskyjensä mukaan ja suuntautuu tuota tarkoitusta vastaavasti. Kalvinistinen sosiaalinen työ maailmassa on yksinomaan työtä "in majorem gloriam dei". Siksi tämä luonne on myös ammattityöllä. Se on tämänpuoleisen 
elämän kokonaisuuden palveluksessa. (Weber I980, 78. Kursivoinnit alkuperäisen tekstin.)

Protestanteille, erityisesti kalvinisteille, sosiaalinen elämä ja yritystoiminta olivat eräänlaista kristillistä lähetystyötä, jossa he katsoivat muokkaavansa maailmaa enemmän Jumalan tahdon mukaiseksi ja poistavansa siitä keskiajalla luotuja vääristyneitä sosiaalisen ja hengellisen elämän muotoja. Monille protestanteille oma menestyminen sosiaalisessa ja taloudellisessa elämässä oli samalla merkki siitä, että he olivat myös hengellisestä näkökulmasta oikealla tiellä, että Jumala oli suopea heidän toimilleen ja siunasi ne menestyksellä.

Protestanttisessa ajatustavassa omaisuuden karttumista ja rikastumista ei siis pidetty sinänsä synteinä. Pikemminkin protestantit katsoivat, että omaisuutta ja vaurautta voidaan käyttää tavalla, joka palvelee Jumalan kunniaa ja tekee maailmasta enemmän hänen tahtonsa mukaisen. Tällainen näkemys sulki kuitenkin pois nautinnonhaluisen elämäntavan, jonka eräänä ilmentymänä protestantit pitivät maallista kirjallisuutta ja taiteita. Kunnollisen, vaurastuneen protestantin tuli elää askeettisesti ja pitää huoli "hänelle uskotuista leivisköistä":

Ihmisellä on velvoitus hänelle uskottua omaisuutta kohtaan, hänet on alistettu sen palvelevaksi isännöitsijäksi tai suorastaan "hankintakoneeksi”. Tämä ajatus painoi raskaana puritaanin elämää. Mitä suuremmaksi omistus kasvaa, sitä raskaammaksi kasvaa vastuu siitä, jos askeettinen elämänvire kestää kokeen. Omaisuus on säilytettävä vähentymättömänä Jumalan kunniaksi ja sitä on lisättävä väsymättömällä työllä. (Weber ı980, I26. Kursivoinnit alkuperäisen tekstin.)

Ilmeinen seuraus kulutuksen hillitsemisestä oli pääomanmuodostus, mikä mahdollisti varojen sijoittamisen yritystoiminnan laajentamiseen. I500-I700-luvuilla protestanttisista lahkoista lähtöisin olevilla henkilöillä olikin Weberin tutkimien maiden talouselämässä merkittävä rooli. Kapitalismin historiassa kyseiset vuosisadat merkitsivät Weberille ihanteellista vaihetta, jolloin uskonnollis-moraaliset ja yhteisölliset siteet 
- yleisemmin: arvorationaaliset periaatteet - kykenivät vielä sääntelemään laajasti kapitalistisen talouden kehitystä ja pehmentämään sen vaikutusta muuhun yhteiskuntaan. I70o-luvun lopussa kapitalismin kehityksessä tultiin kuitenkin murrosvaiheeseen, minkä jälkeen uudistunut, "voittoisa" kapitalismi alkoi toimia puhtaammin liiketaloudelliselta ja välinerationaaliselta pohjalta, paljolti vapaana uskonnollis-moraalisesta ja yhteisöllisestä sääntelystä (Weber I980, 62, I35). Tähän on tosin lisättävä, että Weberin näkemys pätee lähinnä Eurooppaan. Sitä vastoin Yhdysvalloissa yritystoiminta, uskonnollinen ja poliittinen elämä sekä joukkoviestintä ovat nykypäiviin asti kietoutuneet toisiinsa, eikä sikäläinen kapitalismi ole suhteessa erilaisiin uskontokuntiin ollut niin itsenäinen kuin englantilainen, ranskalainen ja saksalainen kapitalismi.79

Vaikka Yhtiökumppanit viljelee uskontoon liittyviä rinnastuksia, siinä eletään weberiläisittäin ajatellen "voittoisan kapitalismin" vaiheessa, jolloin uskonto ei enää laajalti sääntele taloudellista toimintaa. Yhtiökumppaneissa kapitalismia ylläpitävät liiketaloudelliset arvot ovat korvanneet uskonnon ja ottaneet sen paikan inhimillistä toimintaa ohjaavana "perimmäisenä arvo-orientaationa". Romaani antaa eri tavoin ymmärtää sen, että se kuvaa kapitalismin maallistunutta, välinerationaalisuuden hallitsemaa vaihetta. Selkein viittaus tähän sisältyy kuvauksiin pahvilaatikosta, joka on Peten perheessä kulkenut perintönä sukupolvelta toiselle ja joka sisältää sukukirjan, kolikkorasian ja resuisen Uuden testamentin. Peten mukaan suvun miespolvien seuratessa toisiaan kyseinen perintö muuttui vähitellen "vaatimattomaksi vanhojen rahojen kokoelmaksi" (YK, 32, 44). Kuvaus viittaa siihen, että Peten esivanhemmilla ahkera työnteko, säästäväisyys ja uskonnollinen motivaatio olivat alun perin liittyneet kaikki toisiinsa. Myöhemmin yhteys alkoi purkautua, ja Peten isän kohdalla siitä oli enää jäljellä kurinalainen tai "protestanttinen" elämänasenne, jota luonnehtivat ahkera työnteko, säästäväisyys ja pidättyväinen asenne kuluttamiseen - kaikki tämä ilman vahvaa uskonnollista motivaatiopohjaa. Peten kohdalla purkautuminen kiihtyy entisestään, sillä hän suhtautuu työntekoon ja rahan ansaitsemiseen holtittomammin kuin aiemmat sukulaisensa.

Tätä eri sukupolvissa tapahtunutta muutosta voidaan kuvata protestanttisen työeetoksen tai työmoraalin käsitteen avulla. Sen näkökulmasta 
Peten esivanhemmat toimivat paljolti sisäistetyn protestanttisen työmoraalin pohjalta eli he mielsivät oman työntekonsa pitkälle uskonnollisessa valossa. Peten isän kohdalla sidonnaisuus ahkeran ja yritteliään työnteon ja uskonnon välillä on katkennut, minkä vuoksi hänen voidaan sanoa edustavan maallistunutta protestanttista työeetosta. Anu Kantolan ja Hanna Kuuselan (20I9, I45-I47, I64) tutkimuksen mukaan juuri tällainen työeetos on tavallinen suomalaisen yhteiskunnan vauraimmassa kerrostumassa. Siinä pitkäjänteinen työnteolle omistautuminen, sitkeähenkinen yritteliäisyys ja jatkuva pyrkimys oman, henkilökohtaisen omaisuuden kartuttamiseen on muodostunut ihmisen elämän keskeiseksi sisällöksi, jota hän ei perustele uskonnollissävyisesti. Pete on osittain irtautunut tästä protestanttisen työeetoksen maallistuneestakin muodosta, sillä hän ei enää toimi samalla tavalla kurinalaisesti ja itseään kontrolloiden kuin hänen sukunsa edellinen polvi.

Edellä esitetyn, Peten suvun historiaa koskevan kertomuksen avulla Yhtiökumppanit painottaa siis sitä, että esivanhempiensa tilanteeseen verrattuna Pete toimii maallistuneessa yritysmaailmassa. Tätä samaa näkökohtaa korostaa tekstikatkelma, joka kertoo Ollin ja Peten pyörittämän yhtiön alkuperästä. Katkelman mukaan yhtiön on alun perin omistanut ja sitä on alkuaan rahoittanut lähinnä "vatsaansa sijoittanut Jumalan mies". Tämä lihava ja uskonnollista vakaumustaan sanomalehdissä julistanut mies myi sittemmin vaikeuksiin ajautuneen yrityksensä Ollille, jonka johdolla se nousi taas uudelleen jaloilleen. (YK, 4O, 55.) Myös tämän katkelman voi tulkita puhuvan siitä, että uskonnolliselta pohjalta toimineen kapitalismin rapautuessa se korvautui tiukemmin liiketaloudelliselta pohjalta toimivalla kapitalismilla.

Omassa tutkimuksessaan Tuomas Juntunen (2012, I83) katsoo, että Yhtiökumppaneiden henkilöhahmot, lähinnä Pete ja Olli, ovat "parodiaa Weberin kuvaamasta protestanttisesta yrittäjästä". Niin kuin edellä kävi ilmi, näin ei minusta ole asianlaita. Yhtiökumppanit ei kuvaa ollenkaan protestanttista yrittäjää, vaan sen kuvauskohteena on yrittäjä, jonka elämää ja toimintaa uskonto ei enää juurikaan sääntele. Jos tätä romaania ajatellaan parodiaksi, niin siinä parodisen alentamisen kohteena on "sisällöntuotanto"-diskurssi. 
Sisällöntuotanto-diskurssi liittyy kapitalismin luonteen muuttumiseen, siihen, että I980- ja I990-luvulta lähtien kapitalistisen talouden toimintatavat ovat levinneet kulttuurin alueelle. Jim McGuigan (2009, I49-I65) toteaa, että yhtenä merkkipaaluna tässä leviämisessä oli Tony Blairin pääministerikausi (I997-2007) Isossa-Britanniassa. Kautensa alussa Blairin hallitus julkaisi "luovaa taloutta" tai "luovaa teollisuutta" koskevan ohjelmansa, jossa se ajoi laajamittaista kulttuurielämän ja talouden integroimista toisiinsa, niiden yhdistämistä luovaksi taloudeksi. Luovan talouden osa-alueiksi se näki muun muassa radio- ja televisiotoiminnan, digitaalisen median, mainonnan, muotoilun, muodin, esittävät taiteet, peliteollisuuden, urheilun, turismin sekä elokuva-, kirja- ja ääniteteollisuuden. Blairin hanke oli menestys, sillä EU-alueen sisällä aikoinaan tehdyissä vertailuissa Isolla-Britannialla oli taloudellisesti painoarvoltaan suurin luovan talouden sektori. (McGuigan 2009, I59. Ks. myös Alexander 20I8, 74-77.) Muut maat seurasivat nopeasti sen esimerkkiä, ja nekin alkoivat tuottaa omia luovan talouden visioitaan. Suomessa "sisällöntuotantoon" tai "luovaan talouteen" liitettyä innostusta piti yllä varsinkin se, että Nokia Oy oli vuosituhannen vaihteeseen mennessä kasvanut maailman johtavaksi matkapuhelinten valmistajaksi. Näiden tekijöiden vaikutuksesta Suomessakin ilmestyi vuosituhannen vaihteessa kymmeniä selvityksiä "sisällöntuotannosta", tavallisesti valtionhallinnon tai elinkeinoelämän teettäminä. Ala koettiin tuolloin todelliseksi nykytalouden dynaamiseksi kärkialaksi. Niinpä 2000-luvun ensimmäisen vuosikymmenen aikana opetusministeriö julkaisi Suomessa useita raportteja, joissa se kaavaili suomalaisen talouselämän laajamittaista yhdentymistä media- ja kulttuurisektorin kanssa. ${ }^{80}$

Yhtiökumppaneissa sana "sisältö" tai "sisällöntuotanto" esiintyy monissa yhteyksissä, tavallisesti neljännessä osassa, jossa yhtiön henkilökunta suunnittelee uutta videopeliä. Tuossa videopelissä esiintyy Ilpo-niminen mieshahmo; hän "työskentelee uusmediayrityksessä, joka tuottaa sisältöjä tajuntateollisuussektorille" (YK, I46; kertojana Pete). Monilta osin kyseinen videopeli on kertomus sisällöntuottajista, jotka ovat väsymässä epämielekkääksi kokemaansa työhön. Samalla tavalla Peten ja Ollin yhtiön henkilökunta kokee sisällöntuotannon banaaliksi asiaksi, jonka mielekkyyttä se epäilee voimakkaasti. Niinpä ilmaisu "sisältä tyhjä" tois- 
tuu usein tilanteessa, jossa henkilökunta kuvailee luomiensa pelihahmojen mielenmaisemaa (ibid., I3I). Voimallisimin tätä epäilyä ilmentää Pete: "Me tuotetaan sisältöö. Se tarkottaa sitä että sitä ei ole, että sitä täytyy tehdä, että ihmiset on tyhjiä, että elämässä ei oo sitä. Me täytetään niiden pää paskalla." (Ibid., I33.) Hetkeä myöhemmin hän rinnastaa vielä uudelleen sisällöntuotannon paskaan: "Paskaa se on. Mutta eihän sen tekeminen tässä ajassa mitenkään kunniatonta oo, kaikki sitä tekee." (Ibid., I34.) Näin sanoessaan Pete on samalla tietoinen siitä, että yhtiöllä ei juurikaan ole muuta vaihtoehtoa kuin yrittää menestyä sisällöntuottajana, viihdeteollisuuden toimijana; muutoin sitä uhkaa toiminnan kutistuminen ja alasajo. Tämän kehityskulun hintana on se, että Pete ja Olli tyhjenevät henkisesti ja he saavat lopulta "vahingon sielulleen", niin kuin Matteuksen evankeliumia (I6:26) vapaasti siteeraava Pete toteaa (YK, I54). ${ }^{8 \mathrm{I}}$

Suomalaisessa nykykirjallisuudessa ehkä vain Hannu Raittilan Ei minulta mitään puutu (I998) kuvaa uskonnon ja talouden välistä suhdetta tavalla, joka tuo läheisesti mieleen Weberin tutkimuksen protestanttisen lahkojen ja kapitalistisen talouden välisestä suhteesta. ${ }^{82}$ Raittilan romaani on siten mahdollista ymmärtää "protestanttiseen yrittäjään" kohdistuvaksi kritiikiksi. Sen kollektiivisena keskushenkilönä on suviseurojaan järjestävä ja niille kokoontuva lestadiolaisyhteisö, joka on elämäntapansa osalta lähellä askeettista tai kalvinistista protestantismia. Romaanin Raamattuun (Psalmit 23:I-6) viittaava nimi on ironinen, sillä Psalmeissa lausuma "Ei minulta mitään puutu" liittyy tekstiyhteyteen, joka tuo esiin uskon kaikkivoipaisuuden, sen, että uskonsa varassa elävä ihminen voi luottaa siihen, että hän saa Jumalalta kaiken tarvitsemansa. Sitä vastoin lestadiolaisyhteisölle pelkkä usko ei riitä, vaan yhteisö suuntautuu intohimoisesti myös maalliseen toimintaan, mitä se tosin perustelee uskonnon avulla. Melko suoraviivaisesti sen jäsenet ajattelevat, että heidän maallisessa toiminnassa saavuttamansa menestys on osoitus siitä, että he kuuluvat Jumalan valittuihin, "pelastettuihin".

Tämä uskomus legitimoi Raittilan kuvaamassa lestadiolaisyhteisössä suuruudenhullut sosiaaliset, taloudelliset ja teknologiset kuvitelmat. Yhteisö rakentaa massiivisen, kahdeksallekymmenelletuhannelle ihmiselle tarkoitetun joukkotapahtuman, jolla on oma voimalansa, radioasemansa 
ja satelliittiyhteytensä Amerikkaan ja jossa lestadiolaiset yrittäjät harjoittavat liiketoimiaan. Romaanin kunnianhimoinen toiminta rinnastuu Baabelin tornin rakentamiseen Raamatussa. Rangaistuksena siitä, että Baabelin tornia rakentaneet ihmiset pyrkivät tulemaan Jumalan kaltaisiksi, Jumala hajottaa Raamatussa ihmiskunnan eri kieliä puhuviin ja eri seudulla asuviin ryhmiin, "niin etteivät he ymmärrä toistensa puhetta" (Ensimmäinen Mooseksen kirja Iı:I-9). Raittilan romaani käyttää hyväksi tätä kertomusta, samoin kuin Ensimmäiseen Mooseksen kirjaan (luvut 6-8) sisältyvää kertomusta vedenpaisumuksesta. Lopussa rankkasade yllättää suviseurojaan pitävän lestadiolaisyhteisön ja pehmentää peltoalueen maaperän suviseurojen alla, minkä vuoksi seurat keskeytetään ja pelloilla olevat autot poistuvat kuljettajineen ja seurueineen eri suuntiin.

Raittilan romaani pyrkii osoittamaan, miten vaarallinen yhdistelmä syntyy toimintansa oikeellisuuteen järkähtämättömästi uskovan uskonnollisen yhteisön, nykyisen teknologian ja markkinakapitalismin välisestä liitosta. Samalla se kiinnittää huomiota siihen, että lestadiolainen herätysliike levittää yhteiskuntaan markkinahenkistä asennetta. On kuitenkin syytä kysyä, kuinka edustava kuvaus tämä on nykykapitalismista. Lestadiolainen herätysliike edustaa lähinnä askeettista kapitalismia, joka on jäänteenomainen ilmiö nykykapitalismissa. Askeettisuuden sijasta nykykapitalismi painottaa pikemminkin hedonismia, laajaa kulutusta suosivaa eetosta. Tämä puoli nykykapitalismista jää Raittilan romaanissa paljolti piiloon. Tosin sitä voidaan myös lukea astetta korkeammalla abstraktiotasolla, jolloin se toimii kapitalistiselle talousjärjestelmälle ominaisen jatkuvan kasvu- ja laajentumishalun, "kasvu-hybriksen" kritiikkinä. Tällaisessa luennassa jää sivuseikaksi se, että Raittilan romaanissa tuon kasvu-hybriksen yhtenä moottorina on lestadiolainen herätysliike.

\section{Kilpailutalouden ankarat lait}

Yhtiökumppaneissa Petellä on omat motiivinsa sille, että hän on lähtenyt mukaan Ollin johtamaan ICT-alan yritykseen. Nämä motiivit liittyvät 
rahan ansaitsemiseen, henkilökohtaiseen omaisuuden kartuttamiseen ja taloudellisen menestyksen saavuttamiseen. Romaanissa informationaalinen talous ei silti kaikilta osin osoittaudu sellaiseksi kuin Pete alun perin ajatteli sen olevan. Kapitalistisella talouselämällä on oma logiikkansa. Sen palvelukseen astuessaan yksittäinen toimija ei useinkaan voi tehdä juuri muuta kuin noudattaa tuota logiikkaa, vaikka hänen subjektiiviset motiivinsa olisivat alkuaan poikenneet siitä. Tässä suhteessa Yhtiökumppanit on kertomus siitä, miten nykytalouden käytäntöihin yhä syvemmin uppoutuva Pete joutuu sovittamaan elämänsä ja toimintansa kapitalismin lakeihin ja miten hän muuttuu tässä prosessissa yhä enemmän ulkoapäin määräytyneeksi ihmiseksi. Sellaisena hänet kuvataan vieraantuvaksi subjektiksi, joka menettää kykynsä vapaaseen itsetoteutukseen.

Markkinakapitalismissa talouselämän perustavat lait toteutuvat kilpailun välityksellä, mikä näkyy siinä, että menestyvän yrityksen täytyy toteuttaa kolme ehtoa. Ensinnäkin sen tuotteille pitää olla riittävästi kysyntää, sillä vain siten se voi saada tuotannostaan markkinoilla enemmän rahallista arvoa kuin tuotteiden valmistaminen siltä vaatii erinäisten kustannusten muodossa. Toiseksi sen tuotteiden kysynnän tulee olla pitkäaikaista - eikä kertaluontoista -, sillä muussa tapauksessa sillä ei ole edellytyksiä pysyväisluonteisen liiketoiminnan harjoittamiseen. Markkinakapitalismissa nämä kaksi ehtoa joudutaan tavallisesti toteuttamaan "avoimessa tilassa", eli menestyäkseen yrityksen pitää kolmanneksi pystyä harjoittamaan voitollista liiketoimintaa tilanteessa, jossa se kilpailee muiden saman alan yritysten kanssa. Muiden yritysten kanssa käytävä kilpailu markkinaosuuksista ja asiakkaiden ja kuluttajien ostopäätöksistä pakottaa siksi yrityksen tehostamaan ja uudistamaan jatkuvasti toimintaansa siten, että sen tuotteet löytävät paremmin ostopäätöksiä tekevät asiakkaat ja kuluttajat. Mitä ankarampi kilpailutilanne on, sitä vähemmän yrityksellä on varaa levätä laakereillaan: paikallaan pysymisen sijasta sen on jatkuvasti mietittävä toimintansa tehostamista ja uudistamista. (Vrt. Boltanski \& Chiapello I999, 37-4I; Weber I980, I2-I3.)

Vaatimus kansallisten yhteiskuntien ja maailmantalouden avaamisesta kilpailulle ja markkinavoimille on ollut I970- ja I980-luvun 
vaihteesta lähtien keskeinen elementti uusliberalistisessa politiikassa ja toimintastrategiassa. Uusliberalismi on perustellut avaamista sillä, että taloudellisten toimijoiden välinen markkinakilpailu johtaa koko yhteiskunnan kannalta parhaimpaan mahdolliseen tulokseen, siihen, että voittajiksi selviytyvät lopulta parhaimpia tuotteita ja palveluja tarjoavat yritykset. Samoin kilpailua on perusteltu sillä, että sen ansiosta tuotteiden hinnat pysyvät alhaisella tasolla - toisin kuin sellaisessa tilanteessa, jossa monopoliasemassa olevat yritykset ja kartellit pystyvät asettamaan hinnat haluamalleen tasolle. (Ks. Castells 2000, 96-98, I37; Schmidt, Vivien Ann \& Thatcher 20I3a, 4-5.) Uusliberalistisen oppirakennelman luojiin kuulunut Friedrich von Hayek (2005) piti vapaata markkinakilpailua niin tärkeänä "terveen talouselämän" rakenneperiaatteena, että hänen mukaansa valtion tulee lainsäädäntönsä avulla kriminalisoida monopolien ja kartellien muodostaminen. Muilta osin valtiolla tulee hänen mukaansa olla minimaalinen rooli talouselämässä.

Yhtiökumppaneissa Peten minämuotoinen kerronta ja tietokonepelin suunnittelemisen yhteydessä olevat kerrontajaksot tuovat esiin sen, miten Peten ja Ollin yritys on pyrkinyt selviytymään edellä mainituista ehdoista ja haasteista. Näissä jaksoissa käy ilmi, että yritys oli aloittanut toimintansa verkkomainonnan ja grafiikan luomisella. Pelkästään tätä tietä kulkemalla sen ei kuitenkaan ollut mahdollista toimia pitkään menestyksekkäästi. "Kun oivalsimme (liian myöhään) että kuivuisimme pois ellemme keksisi jotakin uutta, levitimme palettimme tietokonepeleihin", Pete toteaa yhtiön kehityskaarta kuvatessaan (YK, 46. Kursivointi alkuperäisen tekstin). Toiminnan laajentaminen tietokonepeleihin oli välttämätöntä, koska houkuttelevalta näyttävälle verkkomainonta-alalle tuli koko ajan lisää uusia yrittäjiä, mikä pakotti Peten ja Ollin uudistamaan yhtiönsä toimialaa.

Alussa uusi strategia vaikuttikin onnistuneelta, sillä muutaman vuoden ajan yhtiöllä meni taloudellisesti hyvin ja samalla uudistus teki Petestä ja Ollista rikkaita. "Yllättävän nopeasti niiden [tietokonepelien] liikevaihto nousi tasoihin mainontamme kanssa; näimme mihin suuntaan maailma oli kulkemassa. Ja niin näki moni muukin”. (YK, 46.) Sitaatin viimeinen virke viittaa siihen, että muutaman vuoden kuluttua kilpailutilanne muuttui myös peliteollisuudessa yrityksen kannalta han- 
kalaksi. Selviytyäkseen vaikeuksistaan yritys päätti siksi kehittää "markkinat ällikällä lyövän" tietokonepelin, jota sen työntekijät kokoontuvat romaanin neljännessä osassa (s. IOI-I78) suunnittelemaan. Romaani päättyy tilanteeseen, jossa yrityksen toiminnan jatkuminen on epävarmaa ja jossa Olli on hirttänyt itsensä skannerinjohtoon. Siihen mennessä yritys on ehtinyt toimia kahdeksan vuoden ajan.

Vaikka Yhtiökumppaneiden kertojat eivät käytä eksplisiittisesti rationaalisuuden käsitettä, romaani sisältää useita sellaisia jaksoja, jotka käsittelevät epäsuorasti, rationaalisuuden käsitettä mainitsematta, Peten ja Ollin ajautumista yhä syvemmälle välinerationaaliseen ajatteluun ja toimintaan. Esimerkiksi kuvatessaan yhtiönsä sisällä alkuvuosina vallinnutta työnjakoa ja kiristyvän markkinakilpailun vaikutusta yhtiön omaksumiin toimintatapoihin Pete toteaa:

Pikku hiljaa myynti hidastui, mutta asiakasfirmojen koko kasvoi. Huomasimme, että emme olleet ainoa sivuja tarjoava yritys. Tehtäväni yhteyshenkilön roolissa oli vakuuttaa asiakas kyvystämme parhaaseen verkkomainontaan. Minun oli osattava myydä illuusio, johon saaliin tuli hirttäytyä. Olli teki myyntiä enemmän kuin minä, mutta silti se ajan mittaan kävi rasittavimmaksi osaksi työtäni. Tuli vaihe, jolloin kypsyin siihen lopullisesti, mutta se tapahtui vasta pari vuotta myöhemmin. Silloinkaan en päässyt täysin eroon myymisestä: syöttiin tarttunut asiakas otti minuun yhteyttä ja alkoi kysellä, miksi firmamme ja miksi juuri minä olisin paras henkilö maailmassa suunnittelemaan heidän verkkosivunsa. Ellen aikaisemmin tietänyt, mitä tarkoitetaan kyynisyydellä, opin tuntemaan käsitteen. Opin sen itseltäni. (YK, 46.)

Merkille pantavaa sitaatissa on se, että Pete rinnastaa asiakkaiden hankkimisen ja myyntityön metsästykseen tai saalistamiseen. Mahdolliset asiakkaat olivat hänelle "saaliita" tai peräti hyväuskoisia hölmöläisiä, jotka hänen piti saada "hirttäytymään" heille esitettyyn "illuusioon" tai "syöttiin". Tällöin Pete ei ensi sijassa pyrkinyt ymmärtämään asiakasfirmojensa todellisia tarpeita, vaan hän näki asiakkaansa välineiksi, joita palvelemalla ja hyväksi käyttämällä hän saattoi kasvattaa yhtiönsä myynti- 
tulosta. Sitaatin viimeiseen virkkeeseen sisältyvä huomautus siitä, että tätä kautta Pete oppi tuntemaan "kyynisyyden", voidaan ymmärtää tällaisen toimintatavan varovaiseksi problematisoimiseksi. Sisimmässään Peten oli, ainakin jälkikäteen, vaikea täysin hyväksyä tai sulattaa tuota toimintatapaa, joka sisälsi moraalisesti arveluttavia piirteitä, mutta joka ilmeisesti hyväksytään modernissa talouselämässä usein paljolti itsestäänselvyytenä. Samalla romaani tuo kuitenkin esiin sen, että juuri talouselämän lait - menestymisen pakko, kireä kilpailutilanne, jatkuva uusiutumisen tarve - ajoivat Peten ja yhtiön omaksumaan nuo toimintatavat. Näin Yhtiökumppaneiden kriittinen kärki kohdistuu enemmänkin nykyisen talousjärjestyksen lakeihin kuin niiden puristuksissa tempoileviin yksilöihin.

Edellä siteerattu Yhtiökumppaneiden kohta liittyy myös indifferenssin teemaan. Sitaatissa Pete kertoo siitä, että pyrkiessään edistämään yrityksensä liiketaloudellista menestystä hän joutui usein laittamaan moraalis-sosiaaliset näkökohdat sivuun. Painotetusti indifferenssin teema tulee kuitenkin Yhtiökumppaneissa esiin jaksoissa, joissa Peten ja Ollin yrityksen henkilökunta lähtee virkistyskeskukseen suunnittelemaan yhtiölle uutta tietokonepeliä. Nämä jaksot alkavat suurin piirtein romaanin puolivälissä, sivulta II7, ja ne päättyvät sivulle I77. Määrällisesti sivut II7-I77 kattavat lähes neljäsosan (6I sivua) koko romaanin laajuudesta (237 sivua), mutta käytännössä aivan kaikkea tätä tilaa ei ole annettu tietokonepelin suunnittelemiselle. Muutamassa kohdassa suunnittelutyön etenemisen katkaisevat Peten isästä ja Kirsin lapsuudesta informaatiota antavat lyhyet kerrontajaksot. Lisäksi sivuilla I67-I77 on draamallisen kerronnan jakso, jossa yhtiön henkilökunnan jäsenet käyvät kiivasta dialogia keskenään. Romaanin etenemislogiikan kannalta dialogisen jakson tehtävänä on tuoda esiin henkilökunnan kokemaa eksistentiaalista turvattomuutta ja henkistä tyhjyyttä sekä pohjustaa sitä, että romaanin lopussa Ollin päätyy itsemurhaan.

Tietokonepelissä on tarkoitus seurata yhtiön henkilökunnan kehittämien, keksittyjen henkilöhahmojen elämää ja heidän toimiaan työelämässä ja yritysmaailmassa. Tähän peliin henkilökunnan jäsenet projisoivat väistämättä myös omia pettymyksiään ja huoliaan sekä omia kokemuksiaan työelämästä ja yritysmaailmasta. Projisoimista tai avautu- 
mista helpottaa se, että suunnittelutyön yhteydessä he käyttävät runsaasti alkoholia. Yleisemmällä tasolla tietokonepeli ja sen suunnitteleminen toimivat romaanissa mise en abyme -rakenteena tai upotuksena, joka ilmaisee tiivistetysti Yhtiökumppaneiden temaattisen sisällön, sen näkemyksen nykyisestä informationaalisesta taloudesta. Suunnittelutyön yhteydessä paljastuu koko "sisällöntuotannon" tai "elämysteollisuuden" onttous. Pete, Olli ja yhtiön muut työntekijät ovat tietoisia tästä, ja välillä he tuntevat syyllisyyttä siitä, mitä he ovat tekemässä. Nousuhumalassa oleva Pete luonnehtii työtään suoranaisesti "paskan tekemiseksi":

Paskaa se on. Mutta eihän sen tekeminen tässä ajassa mitenkään kunniatonta oo, kaikki sitä tekee. Jos et tee, et tee mitään. Välillä se vaan pysäyttää tuijottamaan vastapäisen talon seinään, se on likasenharmaa, eloton, tyhjä. Meidän on valittava valehtelemisen ja syrjäytymisen välillä. (YK, I34-I35.

Tässäkin sitaatissa tulee esiin ajatus siitä, että vallitseva talousjärjestys ja siihen liittyvä kilpailu asiakkaista ei jätä yhtiölle muita vaihtoehtoja. Sen on joko seurattava taloudellisia suhdanteita tai kuihduttava vähitellen pois markkinoilta. Syrjäytymisen vaihtoehdoksi jää siksi jatkaa liiketoimintaa, jota yhtiön henkilökunta ei koe sisällöllisesti arvokkaaksi. Menestyksellistä liiketoimintaa harjoittaakseen yhtiön on näin laitettava arvorationaaliset näkökohdat sivuun ja keskityttävä tehokkaasti niihin keinoihin, joilla se voi parantaa tulostaan. Yleisemmällä tasolla yhtiön toiminnassa konkretisoituu modernin markkinakapitalismin perusdilemma - se, että markkinatalouteen on vaikea yhdistää pysyvästi arvorationaalisia toimintaperiaatteita.

Yhtiökumppanit esittää peliteollisuuden substantiaalisesti arvottomaksi toiminnaksi. Tämän näkemyksen romaani sisällyttää myös yhtiön suunnittelemaan tietokonepeliin, jossa se käsittelee samalla nykyistä työelämää. Kyseisessä pelissä esiintyy Nisse-niminen kuvitteellinen hahmo, atk-insinööri, jonka kokemus työelämästä on musertavan synkkä:

Aina on helvetillinen kiire. Elämä on liian hidas, se pitää ohittaa. Ole nopea ja nokkela. Nisse on oppinut, että jokainen on saatanan 
yksin ja että kilpailussa on vain kilpailijoita. Vastaa vain niihin soittopyyntöihin ja meileihin joista voi hyötyä. Puhu pahaa takana. Naura edessä. Nosta pehmeästi, paina kovaa. (YK, I37.)

Kertojana Nisseä kuvaavassa katkelmassa on Pete, joka suunnittelee sitä, miten Nisse kokee nykyisen työelämän. Nissen kokemukset ja näkemykset työelämästä ovat pitkälti samanlaisia kuin Petenkin. Tekstikatkelmassa Nissen ja Peten äänet sekoittuvat toisiinsa. Jyrkemmän tulkinnan mukaan äänessä on pelkästään Pete, joka on siirtänyt omat pettymyksensä ja negatiiviset tunteensa kuvitteellisen olennon, Nissen, tajunnansisällöiksi.

Yhtiökumppanit ilmestyi kaksi vuotta aikaisemmin kuin Juha Siltalan tutkimus Työelämän huonontumisen lyhyt historia. Muutokset hyvinvointivaltion ajasta globaaliin hyperkilpailuun (2004), joka kuvaa siirtymistä laajan hyvinvointivaltion kaudesta uusliberalistiseen kapitalismiin. Siltalan tutkimus on vaikuttanut paljon suomalaisten käsityksiin siitä, mitä työelämässä on tapahtunut viime vuosikymmeninä, ja samoin se on muokannut suomalaisessa nykykirjallisuudessa esiintyviä työelämän kuvauksia. Siinä tulee esiin useita teemoja, jotka esiintyvät myös Seppälän romaanissa. Näitä ovat esimerkiksi työrytmin, kilpailun ja tulosvaatimusten kiristyminen työpaikoilla ja työntekijöiden välisen solidaarisuuden rapautuminen. Nämä ilmiöt vähentävät työn mielekkyyttä ja lisäävät työperäistä uupumusta ja masennusta. Niin Seppälän romaanin kuin Siltalan teoksenkin mukaan markkinallistumiskehityksen myötä muodonmuutoksen kokenut työelämä on I990-luvulta lähtien ollut tekijöilleen usein pelkkää kärsimystä ja vain harvoin se on voinut toimia heille positiivisen minäkuvan rakennusaineena.

Seppälän aiemmassa tuotannossa työelämä koetaan pitkälti yhtä negatiivisesti. Hänen I990-luvulla ilmestyneet teoksensa kuvaavat usein elämäntilannetta, jossa päähenkilöt - erityisesti toimittaja Vesa Sydänmaassa (1994a) ja kaupunkisosiologi Kuun nousussa ja laskussa (I999) - eivät koe tekemäänsä työtä riittävän arvokkaaksi ja mielekkääksi. Näiden romaanien ja Yhtiökumppaneiden välillä ei ole jyrkkää eroa. Pikemminkin Yhtiökumppanit jatkaa ja radikalisoi kuvauslinjaa, jonka juuret löytyvät jo Seppälän aiemmista teoksista. 
Pitääkö Yhtiökumppaneiden ja Siltalan tutkimuksen antama kuva työelämästä paikkansa? Tähän voi vastata toteamalla, että ne kiinnittävät huomiota vain kielteisiin puoliin. (Vrt. Julkunen 2005, 85.) Työelämän muutosten alullepanijoita ja puolustajia ovat olleet elinkeinoelämän ja julkisen sektorin johtoportaat, joiden ohella näistä muutoksista ovat taloudellisesti eniten hyötyneet ylimmät yhteiskuntaluokat. Tästä kokonaisuudesta Yhtiökumppanit ottaa tarkastelun kohteeksi vain yhden puolen, ylimpien luokkien - eli Peten ja Ollin - taloudellisen vaurastumisen, mutta samalla se pyrkii osoittamaan, että talouden ja työelämän uudistumisen seurauksena sekä ylimmät luokat että keskiluokka ovat uudenlaisessa tilanteessa. "Uudessa taloudessa" ne joutuvat nimittäin kärsimään sellaisista ongelmista - epävarmuudesta, työn kuormittavuuden lisääntymisestä, työn mielekkyyden katoamisesta -, joista perinteisesti kärsivät lähinnä alemmat luokat. Niinpä Yhtiökumppaneissa kaikkien luokkien edustajat kuvataan uuden talouselämän kaltoin kohtelemiksi henkilöiksi, mutta eniten sen aiheuttamista vaurioista kärsivät Pete ja Olli. Tämän suuntainen kuva ei ole harvinainen 2000-luvun alun suomalaisessa kirjallisuudessa, sillä se tulee esiin myös Juha Jokelan näytelmässä Mobile Horror (2003) ja Pasi Lampelan näytelmässä Westend (2005). Niissä informationaalista taloutta pyörittävien ihmisten, erityisesti yrittäjien ja toimitusjohtajien, esitetään joutuneen tilanteeseen, jossa heillä on vain vähän todellisia vaihtoehtoja. Ankarassa markkinakilpailussa menestyminen vaatii heiltä ja heidän lähipiiriltään kohtuuttomia ponnistuksia, minkä vuoksi he - toimitusjohtaja Terhi Mobile Horrorissa ja yritysjohtaja Olli Westendissä - kärsivät työuupumuksesta, masennuksesta ja mielekkyyskriiseistä.

Kun nämä kolme teosta asetetaan historiallis-yhteiskunnalliseen kontekstiinsa, niiden voidaan ajatella näyttävän lukijoille ja katsojille, millaisen hinnan yritykset ja suomalainen talouselämä ovat joutuneet maksamaan siitä, että niistä on tullut kilpailukykyisiä tai että niiden kautta Suomesta oli tullut "maailman kilpailukykyisin maa". Tässä mielessä ne toimivat vastadiskurssina Suomessa harjoitetulle viralliselle yhteiskuntapolitiikalle ja talouspuheelle.

Tietokonepeliä ja sen suunnittelemista kuvaavissa jaksoissa toistuu eri yhteyksissä näkemys, jonka mukaan informationaalinen talous hä- 
vittää yhteiskunnasta laadulliset erot. Tarkastellessaan ja arvioidessaan maailmaa siltä kannalta, missä määrin erilaiset asiat ja ilmiöt ovat muutettavissa tavaroiksi, myytävissä ja ostettavissa oleviksi elämysteollisuuden tuotteiksi, se latistaa erot syvällisen ja pinnallisen, pyhän ja banaalin, eksistentiaalisesti merkityksellisen ja eksistentiaalisesti merkityksettömän väliltä ja johtaa näin elämän sisällölliseen tai henkiseen köyhtymiseen. Seuraavassa sitaatissa Lasse, virkistyskeskuksen huoltotai talonmies, osallistuu tietokonepelin suunnitteluun. Sitaatin alussa olevat, lainausmerkeillä varustetut lauseet ovat hänen reagointiaan aiempaan keskusteluun, jossa Pete on alkanut puhua Jumalasta ja Susanna, yhtiön markkinointisihteeri, on kertonut, että hänen mielessään Jumala on "karhee mies jolla on syvä basso, jostain Matti Salmisen ja John Waynen väliltä" (YK, I53-I57). Lasse suhtautuu ironisesti sekä näihin puheenvuoroihin että itse elämysteollisuuden ideaan:

Lasse: "Annetaan Nisselle Jumala". "Karhee mies, jostain Matti Salmisen ja John Waynen väliltä." Voi jumalauta. Jos minä loin ihmisen omaksi kuvakseni, niin en minä ihan Matti Salmista tarkottanut. Itseäni minä. Mutta Jumalallakin on oikeus epäonnistua.

Minä olin pässi. Minä annoin niille ainokaisen poikani. Nyt Jumalan poikaa kuljetetaan kadulla pääsiäisenä. Se, että valvotaan yö ja leikitään ristin tietä, on elämys, elämysteollisuutta. Se on saatanan rehellistä, matkan varrelle pystytetään kohta makkarakojut ja olutteltat ja seurataan Jeesuksen menoa niinkun formulakisaa, Jeesus kaartaa Snelkulle ja eikun hanaa ja sitten tiukka jarrutus Suomen Pankin kohdalla, se on sopiva paikka lätkästä pojalle kakku. En voi syyttää poikaa siitä että se vihaa isäänsä. (YK, I62.)

Vapaasti tulkiten Lassen puheenvuorossa on kyse siitä, että Uudessa testamentissa Jumala lähetti Jeesuksen maailmaan pelastamaan ihmiset, mutta nykykulttuuri on valmis tekemään Jeesuksesta ja hänen kärsimyksestään viihteellisen spektaakkelin, jonka yhteydessä se tarjoaa yleisölle erilaisia kaupallisia palveluita. Nykykulttuuri on valmis tavaroittamaan tai tuotteistamaan sen, mitä on aiemmin totuttu pitämään pyhänä ja mikä on toiminut perustana ihmisten merkityksellisuuden 
kokemuksille. Siksi nykykulttuuri murentaa tuota perustaa ja tuottaa yhteiskuntaan henkisiin kriiseihin ajautuneita ihmisiä. Yhtiökumppaneissa tällaisesta kriisistä kärsivät selvimmin Pete, Olli ja Kirsi. Tosin Kirsi on näistä kolmesta sikäli moniulotteisin henkilö, että hänen kokemaansa ahdistusta ja turvattomuutta romaani selittää ensi sijassa hänen lapsuudenkokemustensa avulla eikä pelkästään taloudessa ja työelämässä tapahtuneilla muutoksilla. Lasse ja Susanna poikkeavat näistä kolmesta siinä suhteessa, että he eivät kärsi niinkään akuutista kriisistä, vaan pikemminkin he ovat mukautuneet sisällyksettömään, substantiaalisesti köyhään elämäänsä.

\section{Mielekkyyskriiseihin ajautuminen}

Yhtiökumppaneissa kuvatun yrityksen henkilökunta kärsii eri tavoin vieraantuneisuudesta. He ovat vieraantuneet työnsä tuotteista, omasta itsestään, toisistaan ja vapaasta itsetoteutuksesta. Paljolti juuri tämän tyyppisiä vieraantuneisuuden muotoja Marx (I978, 2I7-232) käsitteli nuoruudentuotannossaan. Toisin kuin nuori Marx, Yhtiökumppanit ei kuitenkaan kuvaa näitä muotoja kapitalistien työntekijöihin kohdistaman riiston seurauksiksi. Sen mukaan niiden syynä on markkinakilpailun ja välinerationaalisen toiminnan valta-asema kapitalismissa.

Lisäksi Yhtiökumppanit kuljettaa mukanaan kertomusta siitä, miten Pete, Olli ja yhtiön muut työntekijät ajautuvat merkitysköyhään elämään ja eksistentiaalisiin kriiseihin. Peten kohdalla ajautumisen perussyy löytyy siitä, että hän oli isänsä tavoin jo nuorena sisäistänyt kapitalistisen eetoksen. Sen mukaisesti hän on nähnyt elämäntehtäväkseen rahan ansaitsemisen, omaisuutensa kartuttamisen ja taloudellisen menestyksen saavuttamisen. Siitä, millaisen työn avulla hän tuota eetosta toteutti, hän ei ollut uransa alussa eikä myöhemminkään kovin tarkka. Hänelle riitti pitkään se, että hänen tekemänsä työ oli rahallisesti tuottoisaa. Niinpä hän ryhtyi heti opintojensa jälkeen harjoittamaan ICT-alan töitä ja sijoitustoimintaa, ja suuremmassa mittakaavassa hän palasi sijoitustoimintaan yhtiöstään saamiensa miljoonatulojen jälkeen. Siinä vaiheessa, kun yhtiön toiminta oli ajautunut vaikeuksiin, hän oli sijoitustensa ansiosta 
jo niin varakas, että halutessaan hän olisi voinut elää loppuelämänsä taloudellisesti turvatussa asemassa pelkillä korkotuloillaan. (YK, 36, 54-55, 74, 98, 20I.)

Vähitellen Pete alkaa huomata, että keskittyessään intohimoisesti abstraktiin toimintaan, rahan ansaitsemiseen ja rikastumiseen, hän on tyhjenemässä henkisesti. Hänen tekemällään abstraktilla työllä ei ole ollut hänelle riittävää substantiaalista arvoa:

Rahan omistaminen tuntui sinänsä yhdentekevältä. Sen tekeminen oli ollut hauskaa ja stimuloinut elämääni, mutta tietyllä tavalla se oli osoittautunut pettymykseksi, substanssiltaan tyhäksi. Kun heräsin aamulla, minusta ei tuntunut siltä että minulla oli paljon rahaa. En tuntenut mitään. Raha oli pelkkä sopimus, järjestely tai määrittely omistussuhteiden perustaksi. Se ei ollut mitään todellista. Se ei ollut samaa kuin toiminta. Se ei viime kädessä ratkaissut mitään. Se leijui avaruudessa kuin pallo jolla seisomme. Jos ihmisellä on pelkästään rahaa, hänellä ei ole paljon. Jos elää rahan varassa, ei elä minkään varassa. Se ei motivoi pitkälle. Se on eri asia kuin jos rahaa karttuu kaiken sen kautta, missä elämän voima, virtu, ilmenee (jos ihmisellä on onnea rahassa ja rakkaudessa, niin kuin olin jostain kuullut).

Raha ei saanut minua unohtaman kuolevaisuuttani, päinvastoin se oli muistutus, osoitus siitä. Jokin siinä kuitenkin veti puoleensa. (YK, 55-56. Kursivointi alkuperäisen tekstin.)

Vaurastuminen ja rikastuminen eivät olisi ongelmia, mikäli ne olisivat seurausta siitä, että ihminen on tehnyt intohimoisesti arvokkaaksi ja mielekkääksi kokemaansa työtä ja vaurastunut sen sivutuotteena. Pete ei kuitenkaan ole harjoittanut liiketoimiaan tältä pohjalta, vaan niitä on ohjannut lähinnä ahneus. Sitaatissa hän on tullut tilanteeseen, jossa hän alkaa epäillä, että hän ei ehkä enää pysty jatkamaan tällä tavalla, että pelkkä abstrakti voitonhimo ei enää motivoi riittävästi hänen toimiaan. Sitaatin loppukappale viittaa siihen, että tällainen voitonhimo ei lakkauta eksistentiaalisia ongelmia eikä se auta ihmistä käsittelemään niitä. 
Kyseinen sitaatti sisältyy jaksoon (s. 54-56), jossa Pete kertoo rikastumisestaan ja elämänsä henkisestä köyhtymisestä. Tuomas Juntunen (20I2, I67-I7I) on huomauttanut, että Yhtiökumppanit korostaa sitaatissa esiintyvää ajatusketjua viittauksilla, jotka koskevat ruotsalaisen kirjailijan Axel Munthen (1857-1949) omaelämäkerrallista teosta The Story of San Michele (I929, ilmestynyt suomeksi nimellä Huvila meren rannalla). Munthe oli koulutukseltaan lääkäri ja psykiatri, joka työskenteli muun muassa Pariisissa ja Italiassa ja jonka potilaisiin kuului kuninkaallisia ja aristokraatteja eri puolilta Eurooppaa. Vaikka tämä teki hänestä rikkaan ja kuuluisan miehen, hän ei ollut tyytyväinen luksuselämäänsä. Päästäkseen sopuun itsensä kanssa hän muutti Caprin saarelle Italiaan ja hankki sieltä itselleen kauniin talon, "huvilan meren rannalta". Italianvuosinaankin hän otti edelleen vastaan rikkaita potilaita, mutta hoiti toisaalta köyhiä potilaitaan ilmaiseksi ja harjoitti samalla myös luonnonsuojelutoimintaa.

Yhtiökumppaneissa ilmaisu "huvila meren rannalla" esiintyy kolme kertaa. Ensimmäisen kerran se mainitaan jaksossa, jossa Pete kertoo säästäväisen isänsä sentään hankkineen perheelleen huvilan meren rannalta, ja toisen ja kolmannen kerran jaksoissa, jossa Pete mainitsee perineensä ja omistavansa huvilan meren rannalta (YK, 2I, 63, 74; Juntunen 20I2, I68). Pelkkä rahan ansaitseminen ei siis loppujen lopuksi määrännyt Peten isän kaikkea toimintaa, vaan hänellä oli myös perheeseensä liittyviä substantiaalisia arvopäämääriä. Pete sen sijaan näkee perimässään talossa meren rannalla lähinnä vain haltuunsa päätyneen omaisuuskertymän.

Silti aiemmin siteeraamani kohta osoittaa sen, että Pete on alkanut jo suhteellisen varhain ajatella, että ehkä hänen valitsemansa, rahan ansaitsemiseen keskittyvä elämäntapa ei sittenkään ole ollut mielekäs. Hän ei kuitenkaan pysty luopumaan siitä. Epäilyjä ja lieviä itsesyytöksiä hänen mielessään aiheuttaa myös sen tajuaminen, että keskityttyään vuosien ajan pakonomaisesti töihinsä ja liiketoimiinsa hän on vieraantunut perheestään:

Emme olleet puhuneet aikoihin kunnolla, vuosiin. Vähät puheemme koskivat miltei poikkeuksetta poikia ja niiden asioita, koulua, 
vaatteita ja harrastuksia. Minä en ollut isä, joka kuljetti lapsia muskarissa tai seisoi myöhemmin jalkapallokentän tai kaukalon reunalla. Terhi oli sellainen äiti. Jossakin hämärässä mielessäni tiesin eläväni väärin, mutta ympäristössä jossa kaikki elivät väärin se ei rassannut minua kohtuuttomasti. (YK, 75.)

Lainauksessa Pete kuvaa suhdettaan vaimoonsa Terhiin ja poikiinsa Veksiin ja Ekkuun. Sitaatti osoittaa, että hektisten työvuosien jälkeen hän ei enää elä samassa elämismaailmassa perheensä kanssa. Hän ei ole enää osa muiden perheenjäsenten muodostamaa arvo-, merkitys- ja tunneyhteisöä tai habermasilaista kommunikatiivista yhteisöä. Sen sijasta hän on yhä useammin täyttänyt vapaa-aikansa erilaisilla työhönsä liittyvillä seminaarimatkoilla tai hän on viettänyt viikonloppunsa istumalla kotona työpapereidensa ja tietokoneensa äärellä ilman syvempää yhteyttä perheeseensä. Peten vieraantumista tästä kommunikatiivisesta yhteisöstä ja sille ominaisesta kulttuurista korostaa hänen taipumuksensa uskottomuuteen. Liike- ja seminaarimatkoillaan hän on nimittäin toisinaan pettänyt vaimoaan seksuaalisesti (YK, IO-I3). Yhtiökumppaneiden neljännen osan alku sisältää myös lyhyen kuvauksen siitä, miten Pete ja Terhi yrittivät Ollin hankkimia pornokasetteja katselemalla ja sitä seuranneella kiihkeällä rakastelemisellaan löytää vielä toisensa ja välillään aiemmin vallinneen yhteyden. Jonkin ajan kuluttua he joutuivat kuitenkin pettyneinä toteamaan, että pornosta ei ollut heidän suhteensa korjaajaksi:

Kun kasetit oli moneen kertaan kelattu, pakottauduin elämäni ensimmäisen kerran käymään pornoliikkeessä ja vuokrasin lisää vastaavia. Vähitellen touhusta alkoi mennä maku, ja muutaman viikon kuluttua Terhi sanoi että hän ei enää halua katsoa niitä. Kasetit olivat vedenjakaja, josta lähtien suhteemme taittui etäisemmäksi, herättämästään kiihkosta huolimatta ne eivät saattaneet meitä lähemmäs toisiamme. (YK, IO4.)

Pornon katsomista koskevaa jaksoa (s. I03-IO5) on mahdollista tulkita mimeettisesti tai referentiaalisesti, jolloin sen funktio on lähinnä kriitti- 
nen: se näyttäisi viittaavan siihen, että pornoteollisuuden tuotteet eivät pysty paikkaamaan ihmisten välistä vieraantuneisuutta, todellisten ihmissuhteiden puutetta. Koska Yhtiökumppanit ei kuitenkaan kehittele tätä kriittistä motiivia pidemmälle, kyseisen jakson tehtävän voi mieltää enemmänkin kirjalliseksi tai, Phelanin (I996, 2I-22) käsitteistöä käyttäen, synteettiseksi. Pornokasettien katsomista koskevan jakson, samoin kuin muiden edellä siteerattujen jaksojen, päätehtävänä on pohjustaa romaanin myöhempiä tapahtumia, erityisesti Peten ajautumista mielekkyyskriisiin ja suhteeseen Kirsin kanssa.

Tämän mielekkyyskriisin kuvaamiseen keskittyy romaani neljäs osa (s. IOI-I78), joka kattaa kolmasosan romaanin pituudesta. Neljännessä osassa käy ilmi, että yhtiön muut työntekijät, varsinkin Olli, ovat paljolti samanlaisessa henkisessä tilanteessa kuin Pete. Weberin (2009, 34, 38 42, 52-53, 59, 62-66) modernisaatioteorian näkökulmasta tilanne ei ole yllättävä, sillä Weberin mukaan modernin länsimaisen sivilisaation yhtenä perustavana ongelmana on se, että maallistuneessa yhteiskunnassa pelkkä välinerationaalinen toiminta ei välttämättä pysty muodostamaan riittävää motivaatiopohjaa inhimilliselle elämälle ja toiminnalle. Tämä puolestaan lisää mielekkyyskriisejä yhteiskunnassa. Peten työssään ja liiketoimissaan saavuttama taloudellinen menestys ja hänen työhönsä liittyvä mahdollisuus itsetoteutukseen ovat alkuvuosina innostaneet häntä jatkamaan toimiaan, mutta kilpailun kiristyessä ICT-alalla hänen yhtiönsä toiminta on yhä enemmän pelkkää reagointia ulkoisiin haasteisiin ja kapeneviin markkinanäkymiin. Näiden taloudellisten pakkojen seurauksena yhtiö päätyy valmistamaan tuotteita, tietokonepelejä, joiden valmistamista sen henkilökunta ei koe arvokkaaksi ja joihin uhrattu aika ja työmäärä ylittävät heidän psyykkisen sietokykynsä. Tässä mielessä he ovat vieraantuneet myös työnsä tuloksista. Romaani pohjustaa ja selittää siis monin eri tavoin neljännessä osassa kuvattua kriisitilannetta.

Kerronnan etenemisen ja jännitteiden tiivistymisen kannalta neljäs osa muodostaa Yhtiökumppaneiden intensiivisimmän osan. Siinä pääkertojina toimivat Pete, Kirsi ja Peten isä. Pete käsittelee omissa kerrontajaksoissaan lähinnä yhtiönsä tilaa ja omaa elämäntilannettaan, Kirsi muistelee isänsä sairastumista syöpään ja tämän viimeisiä elinviikkoja ja Peten isä kertoo osallistumisestaan jatkosodan ratkaisutaisteluihin 
kesällä I944 Äyräpäässä. Nämä kerrontajaksot ovat lyhyitä, tavallisesti vain muutaman sivun pituisia, ja niiden nopean vaihtumisen myötä se näkökulma, josta käsin romaanin maailmaa kulloinkin tarkastellaan, vaihtuu ripeästi. Kolmen pääkertojan esittämien tarinalinjojen ohella neljänteen osaan sisältyy tietokonepelin suunnittelemista käsitteleviä jaksoja, joissa kertojina toimivat Peten ja Kirsin ohella Olli, Susanna ja Lasse ja jotka antavat lisäinformaatiota yhtiön tilasta ja sen työntekijöiden tavasta kokea työnsä ja elämäntilanteensa. Tietokonepeli toimii romaanissa fiktiona fiktion sisällä. Sen sisältö ei siis ole romaanin maailmassa todellisuutta, vaikka yhtiön henkilökunta projisoi siihen omia kokemuksiaan työelämästä ja ympäröivästä yhteiskunnasta. Näin se toimii romaanissa myös mise en abyme -rakenteena, joka tuo esiin romaanin perusnäkemyksen nykyisestä työelämästä ja informationaalisesta taloudesta. Sivuille I66-I77 sijoitettu draamallisen kerronnan jakso tai näytelmämuotoon kirjoitettu jakso sijaitsee romaanin maailmassa todellisen ja fiktiivisen välimaastossa. Se liittyy monin tavoin romaanin aiempiin tapahtumiin ja teemoihin, mutta samalla se sisältää leikinomaisia osuuksia, joissa henkilöt eivät puhu ja käyttäydy "aivan tosissaan". Näytelmämuotoon kirjoitetussa jaksossa henkilöiden esittämien puheenvuorojen lomaan on siroteltu anonyymin kertojan kommentteja, joissa tämä selostaa, mitä henkilöt tekevät puhuessaan tai miten he reagoivat toisiinsa toiminnan tasolla. Anonyymi kertoja esiintyy romaanissa vain tässä jaksossa.

Yhteistä neljännessä osassa esiintyville henkilöille on kriisikokemus tai toiminta uhkaavan romahduksen estämiseksi. Olli ja Pete kärsivät syvästä työuupumuksesta ja tarkoituksettomuuden tunteesta, ja Kirsiä puolestaan vaivaa pitkään kestänyt masennus ja eksistentiaalinen turvattomuuden tunne. Toisella aikatasolla Peten isä käy jatkosodan ratkaisutaisteluissa kamppailua elämästään. Nämä jaksot hän kertoo toteavan asialliseen sävyyn, kauhistelematta tai korostamatta näkemäänsä tuhoa ja hävitystä. Tyylillisesti ne muistuttavat sodan kokeneiden miesten kertomia kansanomaisia sotajuttuja, mutta niiden kirjallisena esikuvana lienee ollut Paavo Rintalan romaani Sotilaiden äänet. Kannaksen läpimurtotaisteluista 1944 (I966), jonka Rintala koosti ja järjesti Yleisradion äänitearkistoon tallennetuista sotakertomuksista. Toisaalta Yhtiökump- 
paneissa Peten isän kertomukset ovat osittain myös lainaa Seppälän aiemmasta tuotannosta, niin kuin Juntunen (2012, I45) on huomauttanut. Romaanin kolmannessa osassa, sivuilla 86-87, sijaitseva Peten isän kerrontajakso toistaa nimittäin hieman muunneltuna Super Marketiin (I99Ia) sisältyvän lyhyen sota-aiheisen kertomuksen "Katujyrässä Viipurissa" (I990d), ja viidennessä osassa, sivuilla I92-I93, sijaitseva jakso kertoo muunnellussa muodossa samaan kokoelmaan sisältyvän kertomuksen "Äyräpää I" (I990c). Näiden kriisien ja taistelujen ohella yhtiön johtajat ja työntekijät käyvät romaanin neljännessä osassa kamppailua yhtiön toiminnan jatkamiseksi.

Edellä mainitut kriisit, kamppailut ja taistelut limittyvät ja rinnastuvat neljännessä osassa toisiinsa monin eri tavoin. Ehkä mielenkiintoisin rinnastus kulkee kapitalistisen markkinakilpailun ja sodankäynnin välillä. Neljäs osa ja romaanin loppu näyttävät, millaista henkistä ja fyysistäkin tuhoa kapitalistinen markkinakilpailu aiheuttaa yksilöiden ja yhteisöjen elämässä. Tämä tuho rinnastuu romaanissa siihen tuhoon ja hävitykseen, jonka Peten isä näki omakohtaisesti jatkosodan ratkaisutaisteluissa. Romaani vihjaa siihen, että ilmeisesti nämä molemmat tuhot olisivat olleet toisenlaisessa historiallisessa ja yhteiskunnallisessa tilanteessa vältettävissä. Neljäs osa päättyy nimittäin lyhyeen jaksoon (s. I78), jossa Peten isä kertoo sodassa näkemistään "turhista kuolemista".

Neljännessä osassa, jossa Pete ja Olli ovat ajautuneet syvään työuupumukseen ja mielekkyyskriisiin, on useita viittauksia Raamattuun, Jumalaan ja eksistentiaalisiin teemoihin. Esimerkiksi kuvatessaan muille omaa henkistä tilannettaan vahvassa nousuhumalassa oleva Pete toteaa: "Mä pelkään vitun paljon enemmän sitä että saan vahingon sielulleni, että en ole enää ihminen. Mä olen saanu jo. Kaikki mun ratkaisut on tapahtunu jotenki mun ulkopuolella, ne on kusipääratkaisuja. Se on samaa kuin synti." (YK, I54.) Sitaatin alku sisältää viittauksen Matteuksen evankeliumiin (I6:26), jossa Jeesus huomauttaa opetuslapsilleen rikastumiseen ja maailmallisuuteen sisältyvistä vaaroista: "Mitä hyödyttää ihmistä, jos hän voittaa omakseen koko maailman mutta menettää sielunsa? Millä ihminen voi ostaa sielunsa takaisin?” Merkille pantavaa tässä sitaatissa on se, että se liittää sielun menettämisen tai sielullisen vahingon juuri kaupankäyntiin tai liialliseen taloudellisten arvojen ko- 
rostamiseen. Matteuksen evankeliumin nojalla voi siksi päätellä, että tällaiseen korostamiseen ihmiset saattoivat syyllistyä myös kapitalismia edeltävissä talousjärjestyksissä.

Edellä oleva lainaus Peten puheesta on myös käsitettävissä klassisen ateistisen eksistentialismin suhteellistamiseksi. Klassisessa ateistisessa eksistentialismissa, esimerkiksi Heideggerilla ja Sartrella, ihmistä luonnehtii eksistentiaalinen vapaus. Kosmisista merkitysjärjestyksistä vapaassa universumissa ihminen on siis periaatteessa vapaa antamaan elämälleen ja olemassaololleen sellaisen merkityksen kuin hän itse haluaa, mutta käytännössä hänen vapauttaan rajoittavat aina sosiaaliset merkitysjärjestykset. Tämän ohella inhimillisen olemassaolon "tragiikka" selittyy klassisen eksistentialismin mukaan ihmismielen ja maailman välisestä epäsuhdasta, siitä, että ihminen pyrkii näkemään maailman merkityksellisenä ja projisoimaan siihen mielekkään merkitysjärjestyksen, jollaista universumissa ei kuitenkaan ole ja jollaisen ihminen voi löytää yhteiskunnastakin vain rajoitetusti. (Cooper 2008, 34-36, I09I25.) Tämä on klassisen ateistisen eksistentialismin ydinsisältö, johon Heidegger ja Sartre tekivät uransa jälkipuolella lisäyksiä, esimerkiksi kiinnittämällä huomiota siihen, miten teknologia ja välineellinen toiminta (Heidegger) tai luokkaerot (Sartre) rajoittavat ihmisen eksistentiaalisen vapauden toteuttamista. Näin tehdessään Heidegger läheni Adornolle ja Horkheimerille ominaista välineellisen järjen kritiikkiä ja Sartre puolestaan marxismia.

Peten repliikki "kaikki mun ratkaisut on tapahtunu jotenki mun ulkopuolella, ne on kusipääratkaisuja. Se on samaa kuin synti" tematisoi arvioinnin kohteeksi klassisen eksistentiaalisen vapauden idean. Repliikissä Pete toteaa, että hänen ratkaisunsa ovat olleet voimakkaasti ulkoisesti determinoituja, talouden lainalaisuuksien määräämiä, ja tämä toteamus pätee myös Ollin toimintaan. Tässä mielessä Yhtiökumppanit ei sinänsä torju eksistentiaalisen vapauden ideaa, mutta se näyttää sanovan, että talouden lakien hallitsemassa yhteiskunnassa tästä vapaudesta ja ihmisen mahdollisuudesta itsetoteutukseen ei ole paljoakaan jäljellä. Nyky-yhteiskunnassa ihmistä ei niinkään määritä hänen eksistentiaalinen vapautensa vaan juuri se, että hänen elämänsä ja toimintansa ovat voimakkaasti riippuvaisia talouden laeista ja toimintatavoista. Nämä lait 
ja toimintatavat ovat jopa muodostuneet yhteiskunnassa "perimmäisten totuuksien" määrittäjiksi:

Missä sanotaan ettei rahan tekeminen voisi olla elämän ainut tarkoitus? Vuosituhansia, miljoonia on kokeiltu ja etsitty parempaa. Onko sitä löytynyt? Jos ei kukaan saatana tiedä mikä on elämän tarkoitus niin miksei se silloin voi olla vaikka rahan tekeminen. Ainakin se on paljon hauskempaa kuin moni muu asia. (YK, I58.)

Tässä puhujana on Olli, joka on pitänyt rahan ansaitsemista ja voittojen kasaamista elämänsä perimmäisenä tarkoituksena tai päämääränä. Tällainen näkemys elämän tarkoituksesta ei kuitenkaan kanna yksilöä pitkälle, mistä osoituksena on Ollin päätyminen itsemurhaan romaanin viidennessä osassa (s. 22I-223).

Yhtiökumppanit ottaa muillakin tavoin etäisyyttä eksistentiaalisen vapauden ideasta. Irvokkaimmalta vastakohta tämän idean ja yhteiskunnallisen todellisuuden välillä vaikuttaa ehkä tilanteessa, jossa yhtiön väki suunnittelee yhdessä tietokonepeliä. Pohtiessaan sitä, millaisia hahmoja he siihen kehittävät, Olli ehdottaa: "Me voidaan simuloida elämää, päättää kohtaloista. Elämä nousee ja laskee. Kaikesta seuraa aina jotain. Nää on roolihahmoja, niiden elämä koostuu valinnoista, ja pelaaja saa pelatessaan tehdä ne valinnat. Koko vitun kaupungin valinnat. Eiks oo nerokasta?” (YK, I29). Tunteen tai illuusion valinnanvapaudesta yksilö voi siis vielä saavuttaa kuluttamalla viihdeteollisuuden tuotteita, antautumalla peliteollisuuden asiakkaaksi. Eksistentialistisen ajattelun näkökulmasta tällaista asetelmaa voi kuitenkin pitää vapauden idean rappeutumisena ja osoituksena ihmisen miltei täydellisestä vieraantuneisuuden tilasta nyky-yhteiskunnassa.

Edellä sanotun nojalla voi todeta, että yhteiskunnallisena romaanina Yhtiökumppanit sisältää pikemminkin eksistentiaalisia kuin eksistentialistisia aineksia. Se kuvaa nykytalouden markkinalogiikan hallitsemaksi indifferentiksi järjestelmäksi, joka ei tunnista laadullisia eroja erilaisten asioiden välillä, esimerkiksi eroa pinnan ja syvyyden, pyhän ja profaanin tai eksistentiaalisesti merkityksellisen ja merkityksettömän välillä. Jakso, 
jossa Pete puhuu raamatullisessa sävyssä sielunsa saamasta vahingosta, jatkuu myöhemmin näin:

Ei Jumalaa ole. Markkinat pani sen viralta. Siitä saa huonon tuoton. Mä avasin yks ilta telkkarin. Siellä talk show -juontajan vieraana oli toisen talk show -vieraan juontaja. Toinen haastatteli toista suorassa lähetyksessä, yhtä hyvin ne olisivat voineet runkata toisiaan. Mä on varma että niitä vituttaa kun ne ei voi pyytää Jumalaa suoraan lähetykseen. Jos Jumala suostuis tulemaan, se tietäis että sen pitäis etukäteen opetella joitain nokkeluuksia. Jos se ei olisi hauska, sitä ei toista kertaa pyydettäisi. Koska se ei tule, sitä ei ole. (YK, I54.)

Sitaatin alussa esiintyvää ajatusta siitä, että Jumalaa ei ole, on mahdollista tulkita Nietzschen filosofian avaamassa viitekehyksessä, niin kuin Tuomas Juntunen (20I2, I74-I76) tekee. On kuitenkin syytä huomata se, että Yhtiökumppaneissa ajatus "Jumalan kuolemasta tai katoamisesta" esiintyy hieman erilaisessa yhteydessä kuin se esiintyi ı80o-luvun kirjallis-filosofisessa kulttuurissa. Nietzschellä kyseinen ajatus liittyy lähinnä länsimaisen kulttuurin maallistumiseen eikä kapitalistisen talouden ylivaltaan yhteiskunnassa (Zima 200I, 42-43, I30). Vaikka nämä kaksi prosessia - kulttuurin maallistuminen ja kapitalististen toimintatapojen yleistyminen - ovat reaalisessa historiallis-yhteiskunnallisessa todellisuudessa kytkeytyneet toisiinsa, Nietzsche asetti niistä tarkastelunsa kohteeksi lähinnä maallistumisen. Yhtiökumppaneissa puhe Jumalan katoamisesta on kiertoilmaisu sille, että nykyinen talousjärjestelmä toimii indifferentillä tavalla riistäen siten ihmisiltä mahdollisuuden kokea pyhyyden ja merkityksellisyyden tunteen. Mitä erilaisimpien asioiden muuttaminen tavaroiksi, myytävissä ja ostettavissa oleviksi tuotteiksi, tuottaa yhteiskuntaan ihmisiä alentavaa pinnallisuutta ja banaaliutta. ${ }^{83}$

Vaikka Yhtiökumppanit ottaa etäisyyttä eksistentialismin klassikoihin, se sisältää suoria ja epäsuoria viittauksia eksistentialistissävyiseen traditioon. Viittausten tehtävänä on tuoda painotetummin esille romaanin eksistentiaalinen tematiikka. Näin tapahtuu muun muassa näytelmämuotoon kirjoitetussa jaksossa. Sen alussa humalainen Olli keskeyttää tietokonepelin suunnittelun ja ottaa esille ladatun revolverin, jolla hän 
osoittelee muita ja ampuu sitten pullon rikki. Näin tehdessään hän haluaa herättää muissa todellisia tunteita - autenttista pelkoa ja kauhua vastakohtana sille, että työntekijät ovat siihen asti tuottaneet vain simuloitua tietokonepelien todellisuutta. Tässä mielessä näytelmäjakso tuo etualalle nykykulttuurin ja autenttisuuden ihanteen välisen ristiriidan. Ollin leikittelevän uhitteleva käyttäytyminen uhkaa kuitenkin karata hallinnasta, ja samalla se nostaa näkyviin henkilöiden välisiä jännitteitä ja kielteisiä tunteita. Romaanissa henkilöt eivät nimittäin muodosta mitään keskinäisten lojaalisuussiteiden koossa pitämää yhteisöä. Tämä tulee lukijalle selväksi viimeistään silloin, kun Pete suunnittelee Ollin itsemurhan jälkeen ottavansa konkurssikypsän yhtiön haltuunsa:

Olin osallistunut yhtiön toimintaan henkisin panoksin, tästä lähtien tekisin sen myös aineellisin, ottaisin firman omakseni ja toiminimen haltuuni. Tiesin mitä tekisin. (Maksaisin velkoja pois. Tarjoaisin pojalle töitä kilometritehtaalta, Susannalle kertoisin mitä tarkoitetaan toiminnan rationalisoinnilla, jonkin aikaa firma olisi yhtä kuin minä ja Kirsi.) (YK, 227. Kursivointi ja sulkumerkit alkuperäisen tekstin.)

Pete on ollut yhtiössä korkeaa tulospalkkausta nauttiva "kakkosmies", mutta tulevaisuudessa hän aikoo ostaa yhtiön omiin nimiinsä. Hänen itsevarmuuttaan lisää se, että hänen mielestään yhtiön toiminnan kriisiytyminen ei ole ollut seurausta pelkästään kiristyneestä markkinakilpailusta ICT-alalla, vaan osittain siihen on ollut syypäänä myös Ollin taitamaton tapa johtaa yhtiötä. (YK, 200.) Näytelmämuotoon kirjoitetussa jaksossa, joka siis edeltää ajallisesti sitaatissa esitettyä tilannetta, humalainen Pete on silti mennyt puolittain mukaan Ollin aloittamaan leikilliseen käyttäytymismuotoon ja peräänkuuluttanut hänen laillaan autenttisia tunteita: "Tää on leikin loppu, peli on pelattu. Se ei tule huomenna, se tulee nyt. Jonkin asian pitää jumalauta olla totta ja oikeeta. Oikee sisältö, saatana, ei tyhjä kuva väsyneestä miehestä joka roikkuu silmät ummessa ja on saatanan väsynyt kaikkeen! Ei peliä perkele!” (Ibid., I73.)

Peten repliikki viittaa Samuel Beckettin näytelmiin Leikin loppu (alkuperäisteos ilmestyi I957) ja Huomenna hän tulee (alkuperäisteos ilmestyi 
I953). Silti Yhtiökumppaneiden näkemys "merkityksettömyydestä" ei vastaa Beckettille ja absurdille draamalle ominaista maailmankuvaa. Vaikka henkilöiden väliset sosiaaliset suhteet ovat Beckettin näytelmissä usein raadollisia, hänen näytelmänsä eivät juurikaan selitä merkityksettömyyden kokemusta niistä käsin eivätkä ne aseta sitä mihinkään konkreettiseen historiallis-yhteiskunnalliseen selitysyhteyteen; pikemminkin ne ottavat sen annettuna, inhimillistä olemassaoloa sinänsä määrittävänä peruskokemuksena. Sitä vastoin Yhtiökumppanit selittää henkilöidensä ajautumista eksistentiaaliseen kriisiin paljolti "sosiologisesti", sijoittamalla heidät tiettyyn konkreettiseen yhteiskunnalliseen tilanteeseen, josta heidän kriisinsä aiheutuu.

Siksi Yhtiökumppanit on ensi sijassa yhteiskunnallinen eikä eksistentiaalinen romaani. Eksistentiaalinen ulottuvuus ei ole siinä yhteiskunnallisesta tematiikasta erkaantunut tai itsenäistynyt ulottuvuus, vaan se on upotettu yhteiskunnallisten teemojen sisälle. Siten romaani poikkeaa Seppälän varhaistuotantoon sisältyvästä Sydänmaasta (I994a), jossa pääpaino on eksistentiaalisessa, ei yhteiskunnallisessa, ulottuvuudessa. Siinä henkilöiden kokemaa ahdistusta, vieraantuneisuutta ja tarkoituksettomuuden tunnetta ei selitetä ensi sijassa yhteiskunnasta käsin, vaan niiden esitetään paljolti kuuluvan "ihmiseen osaan maailmassa".

Edellä siteerattu Peten tulevaisuudensuunnitelmia käsittelevä tekstikatkelma on ainoa sellainen kohta, jossa Yhtiökumppanit käyttää eksplisiittisesti sanaa "rationalisointi". Tästä huolimatta rationaalisuus on romaanin pääteemoja, sillä se näyttää, millaisiin tehokkuutta ja tuloksellisuutta kasvattaviin keinoihin Ollin ja Peten yritys turvautuu, kun se yrittää menestyä ICT-alan markkinakilpailussa. Oheisessa sitaatissa Pete on vakuuttunut siitä, että Ollin tehtyä itsemurhan yrityksen toiminnan "järkiperäistäminen" edellyttää myös sitä, että yhtiön uutena johtajana hän irtisanoo Susannan ja "pojan" eli kohtelee näitä pelkkinä tarpeettomiksi osoittautuneina tuloksenteon välikappaleina. Tällainen näkökohta, jossa kapitalismin esitetään kohtelevan työntekijöitään pelkkinä esineinä tai tavaroina, on ollut tavallinen luokkaproblematiikkaan keskittyvissä kapitalismikriittisissä romaaneissa, mutta Yhtiökumppaneissa se jää sivuosaan. 


\section{Tragediaan ja mytologioihin viittaaminen retorisena tehokeinona}

Yhtiökumppanit alkaa kohtauksella, jossa Pete käy mittauttamassa hallussaan olevan, vuonna I799 painetun kuparikolikon nimellisen arvon. Istuessaan sen jälkeen asemaravintolassa odottamassa junavuoroaan hän pohtii omaa tilannettaan: "Mieleni oli sekaisin krapulasta ja viime kuukausien tapahtumista, elämästä. Miten kauan voisin jatkaa näin? Kuinka kauan menisin vielä kotiin, koska puhuisin Terhille, jos puhuisin, mitä sanoisin?” (YK, I8.) Romaanin alussa Pete on siis tilanteessa, jossa hänen ja Kirsin välille on muodostunut rakkaussuhde ja hän pohtii vaimonsa ja perheensä jättämistä. Sen jälkeen kerronta siirtyy ajassa taaksepäin, ja uudelleen se palaa alussa esiteltyyn Peten elämäntilanteeseen viidennen osan lopussa (s. 228 ja 230-23I), vähän ennen romaanin päättymistä. Romaanin alku ja loppu sijoittuvat siten ajallisesti suurin piirtein samaan ajankohtaan. Niiden väliin jäävissä jaksoissa Pete puhuu suvustaan, perheestään ja yhtiön toiminnan kehityksestä, Kirsi kertoo lapsuudestaan ja nuoruudestaan ja Peten isä osallistumisestaan jatkosotaan ja sen ratkaiseviin taisteluihin. Romaanin kolmannessa osassa (s. 59-Ioo) Peten ja Kirsin tarinalinjat leikkaavat jo toisiaan, sillä siinä Kirsi on tullut yhtiöön toimistosihteeriksi. Heidän ensitapaamisensa kuvataan kuitenkin vasta viidennessä osassa, jossa kerrotaan, miten he olivat tutustuneet toisiinsa Ruotsin-laivalla ja miten tuon matkan päätteeksi Pete oli pyytänyt Kirsiä tulemaan yhtiöön työharjoittelijaksi (s. I99-209, 2II-2I2, 2I5-2I7). Heidän suhteensa kehitystä ei siis valoteta romaanissa kronologisesti, vaan siinäkin on siirtymiä aikatasosta toiseen.

Yhteiskunnallisena moraliteettina Yhtiökumppanit osoittaa, millaisia seurauksia "väärien arvojen" vallalle pääsystä on yksilöille ja yhteisöille. Yhteiskunnallisella tasolla vääristyneitä arvoja edustaa romaanissa informationaalinen nykytalous, joka aiheuttaa romaanin mukaan epäautenttisuutta ja vieraantuneisuutta yhteisöjen ja yksilöiden elämässä. Vääristyneisiin arvoihin kiinnittymisestä seuraa romaanin maailmassa rangaistus. Peten kohdalla rangaistuksena voi pitää sitä, että työhönsä ja sijoitustoimintaansa keskittyessään hän vieraantuu vaimostaan ja lap- 
sistaan, kokee vähitellen toimintansa yhä epätyydyttävämmäksi ja solmii sitten rakkaussuhteen Kirsiin, jonka hän tunnistaa lopussa sukulaisekseen. Tunnistamisen perusteena on Kirsin esittämä lyhyt kertomus siitä, miten hänen isoäitinsä ja isoisänsä olivat kohdanneet toisensa Viipurissa jatkosodan loppuvaiheessa:

Mummi oli kahdeksantoista kun faija syntyi. Se ei ollut suostunut kertomaan muuta kuin sen, että kaikki tapahtui Viipurissa sodan aikana ja nopeasti niinku siihen aikaan usein. Isä oli pantu siellä alulle ja se oli olemassa parikuisena ituna kun mummi lähti viimesen kerran kotikaupungistaan. Ja sen että faijan isä oli sotilas joka oli näyttänyt mummille onnenlanttia jonka voimalla se aikoi selviytyä sodasta hengissä. Se oli puolen sillingin kuparikolikko vuodelta I799. (YK, 236.)

Sotilas, Kirsin isänisä, oli kantanut mukanaan Peten suvussa perintönä eteenpäin siirtynyttä onnenlanttia, joka oli myös Peten isällä mukana jatkosodassa. Tajuttuaan Kirsin isoisän ja oman isänsä olevan näin yksi ja sama henkilö Pete poistuu Kirsin asunnosta ja tarjoaa alhaalla taksikuskille maksuksi kyseistä kuparikolikkoa: "Vietkö tällä yli?” (YK, 235.) Sana "yli" on tässä yhteydessä kaksimerkityksinen. Se ei niinkään viittaa perillemenoon vaan pikemminkin mytologisen kuoleman virran ylittämiseen. Antiikin Kreikan mytologiassa kuolemanlautturi Kharon vei kuolleiden sielut kuolemanvirran yli manalaan, mikäli nämä tarjosivat hänelle siitä maksuksi kolikon; siksi kreikkalaisilla oli tapana laittaa kuolleiden kielen alle kolikko ennen kuin vainajat haudattiin (Commelin I953, I28). Yhtiökumppaneiden loppu nojautuu tähän mytologiseen kertomusperinteeseen. Taksikuskin kieltäydyttyä ottamasta kolikkoa maksuksi Pete istuu takapenkillä ja laittaa kolikon kielensä päälle: "Katsoin miestä silmiin. Kun vedin kolikon kieleni mukana suuhuni, kuljettaja alkoi selvästi pelätä” (YK, 235). Kohtaus viittaa siihen mahdollisuuteen, että Pete voisi tehdä itsemurhan, mutta romaani ei avoimesti vie tapahtumia tähän pisteeseen. Kohtauksen jälkeen romaanissa on enää vain Kirsin esittämä lyhyt loppujakso, jossa hän jää henkisesti murtuneena ihmettelemään Peten lähtöä. Romaanin loppu on siten avoin, 
mutta kuitenkin riittävän selvä osoittamaan, millaista tuhoa bisneksentekoon keskittyvä elämäntapa saa aikaan Petessä ja hänen lähipiirissään.

Seppälän romaani kehittelee edellä mainittua rikkomusten ja rangaistusten ketjua lukuisten intertekstuaalisten ja interdiskursiivisten viittausten ja metatasoisten kommenttien avulla. Niiden asema romaanin kokonaisuudessa vaihtelee. Osa niistä on keskeisiä teoksen etenemisen ja sen pääteemojen kehittelemisen ja ilmaisemisen kannalta, kun taas osalla on enemmänkin pääteemoja täydentävä tai lukijan mielenkiintoa ylläpitävä tehtävä. Pääteemojen kehittelemisen ja ilmaisemisen kannalta keskeinen etenemisvaihe romaanissa on neljäs osa (s. IOI-I78), joka sisältää sekä tietokonepelin suunnittelemista kuvaavan jakson (s. I25-I62) että näytelmämuotoon kirjoitetun jakson (s. I67-I77). Näiden kahden mise en abyme -rakenteen tai upotuksen välinen raja on liukuva, sillä tietokonepelin suunnittelemista tapahtuu jonkin verran vielä näytelmämuotoon kirjoitetussa jaksossakin. Tällaiset upotukset tekevät Yhtiökumppaneista itsereflektiivisen tai itseään tiedostavan metafiktiivisen romaanin. Ne tuovat korostuneella tavalla esiin romaanin välittämän näkemyksen ICT-taloudesta ja sen aiheuttamista vahingoista yksilöille ja yhteisöille.

Kyseisten upotusten sisällä on eräitä lyhyempiä viittauksia ja kommentteja, joiden suhde romaanin pääteemoihin ei ole aivan yhtä kiinteä kuin näillä kahdella upotuksella. Tällaisia viittauksia on esimerkiksi kohdassa, jossa Olli tai Pete - kerronnasta ei käy varmuudella ilmi se, kumpi heistä esittää tämän vuodatuksen - selostaa Kirsille, millaisia pelejä kuluttajat hakevat pelimarkkinoilta:

Jotain sairasta sen pitää olla, ei ne muuten jaksa, ne ei kestä arkee, jotain helvetin anomalioita ja patologioita. Maasika ei kestä arkea. Nyt kaavitaan jo kaukalon pohjaa, kaikki on kammattu läpi, naiset nuolee naisia ja miehet miehiä, kaikki haluaa olla homoja ja lesboja, narkkareita, kuteita myydään kuolemaantuomituilla ja aidsiin kuolevilla ja keskitysleirivangeilla. - - Mä haluan jotain suurta. Jotain todella isoo, lopullista. Mä haluan että helikopterit tulee taivaalta niinkun heinäsirkkaparvi ja Wagner soi. Maasika ei kestä arkea ja silloin tarvitaan meitä. (YK, I4O-I4I.) 
Katkelma sisältää viittauksen Paavo Rintalan romaaniin Sissiluutnantti (I963) ja Francis Ford Coppolan Vietnam-aiheiseen elokuvaan Apocalypse Now (I979), jossa Richard Wagnerin ooppera Valkyyrioiden ratsastus (I870) soi taustalla amerikkalaissotilaiden hyökätessä helikoptereidensa avulla vietnamilaiseen kylään. Katkelma muuntelee Rintalan romaanista lainaamaansa ainesta, sillä Rintalalla "maasika" viittaa jalkaväkimiehiin, kun taas Yhtiökumppaneissa se on keskivertokansalaisen tai keskivertokuluttajan nimitys. (Juntunen 20I2, I72-I74.) Peliteollisuutta tarkastellaan katkelmassa hieman toisesta näkökulmasta kuin romaanin muissa kohdissa, joissa se näyttäytyy epäautenttisena ja banaalina tuotantoalana. Tässä katkelmassa pelialaa lähestytään kuluttajien, pelaajien, näkökulmasta ja siinä korostetaan, miten alan on kehiteltävä yhä houkuttelevampia ja hätkähdyttävämpiä tuotteita tavoittaakseen kuluttajat. Näin katkelma täydentää romaanin välittämää perusnäkemystä ICT-taloudesta.

Perustavimmat intertekstit Yhtiökumppaneissa ovat Raamattu, Aristoteleen Runousoppi, kreikkalainen mytologia ja Weberin tutkimus protestanttisen moraaliajattelun ja kapitalismin kehityksen välisestä suhteesta. Raamatun ja Weberin tutkimuksen merkitystä Yhtiökumppaneille on käsitelty jo aiemmin tässä pääluvussa. Siksi seuraavaksi siirrytään tarkastelemaan sitä, miten tämä romaani hyödyntää Runousoppia ja kreikkalaista mytologiaa.

Yhtiökumppaneihin sisältyvien temaattisten jännitteiden kehittelemisen kannalta romaanin neljäs osa (s. IOI-I78) toimii kliimaksina, joka valmistelee myöhemmissä osissa esitettyjä ratkaisuja. Tällaisina ratkaisuina voi pitää Ollin päätymistä itsemurhaan ja Peten päätöstä ottaa yhtiö haltuunsa (viides osa, s. I79-23I). Samoin niihin kuuluu Peten ja Kirsin välisen rakkaussuhteen päättyminen tai raukeaminen (kuudes osa, s. 233-237). Neljäs osa, jossa yhtiön vahvasti humalainen henkilökunta käyttäytyy ekspressiivisesti ja viljelee jatkuvasti alatyylisiä ilmaisuja, sisältää farssimaisia piirteitä, mutta sitä seuraavissa osissa tapahtumat etenevät traagiseen suuntaan. Saatuaan tiedon siitä, että Olli on hirttänyt itsensä skannerinjohtoon, Pete tiivistää yhteenvedonomaisesti: 
Siinä oli kaikki suuren tragedian ja suuren farssin ainekset. Siihen sisältyi ihailtavaa tyylitajua ja insinöörin ivatuinta fakki-idiotismia. Vuosiin en ollut ehtinyt käydä teatterissa, jonkun hassun elokuvan katsoin joskus telkkarista vuokravideoiden lisäksi, ja nyt elämä pelasi teatteria silmieni edessä. (YK, 22I.)

Välittömässä mielessä Peten kommentit koskevat Ollin itsemurhaa, mutta oheista katkelmaa voi myös pitää luonnehdintana siitä, millaisia geneerisiä aineksia Yhtiökumppanit sisältää neljännestä osasta eteenpäin. Näissä osissa romaani ei kuvaa ainoastaan henkilökohtaisiin katastrofeihin tai "tragedioihin" päättyvää, paikoitellen farssimaisia piirteitä sisältävää tapahtumaketjua, vaan se pohtii myös sitä, voidaanko Yhtiökumppaneita itseään pitää tragediana.

Runousopissaan Aristoteles käsittelee sitä, millainen on tragedian, varsinkin hyvin toimivan tragedian rakenne ja sommittelu ja millaisista aineksista tällainen tragedia muodostuu. Hän lähtee siitä, että tragedia on arvokkaan ja loppuun asti suoritetun, pituudeltaan rajoitetun toiminnan jäljittelemistä. Tragedia on siten toiminnan ja elämän eikä niinkään ihmisten jäljittelemistä, mutta voidakseen jäljitellä toimintaa ja elämää tragedian on käytettävä toimivia henkilöitä, joilla on omat motiivinsa ja pyrkimyksensä. Keskeistä toiminnan jäljittelemisessä on juoni, joka koostuu alusta, keskikohdasta ja lopusta ja jossa todennäköisyyden ja välttämättömyyden lakien pitäisi sitoa tapahtumat toisiinsa. (Aristoteles I967, 2I-30.)

Vaikka Aristoteles piti tragediaa ensi sijassa toiminnan jäljittelemisenä, hän kiinnitti myös huomiota tragedian keskushenkilöiden ominaispiirteisiin. Hänen mukaansa tragediassa tapahtumat liikkeelle panevana voimana on hamartia eli traaginen tai kohtalokas rikkomus, johon henkilö ei sorru ilkeyttään tai pahuuttaan vaan tietämättömyyttään. Näin tapahtuu esimerkiksi Sofokleen Kuningas Oidipuksessa. (Aristoteles I967, 32, 35, 70.) Sen pohjana on kertomus siitä, kuinka Theban kuninkaalle Laiokselle ja hänen puolisolleen Iokasteelle syntyi poika, jonka Delfoin oraakkeli ennusti aikuisena surmaavan isänsä ja naivan äitinsä. Tästä pelästyneenä hänen vanhempansa määräsivät palvelijan viemään hänet metsään ja surmaamaan hänet siellä. Palvelija ei kuitenkaan henno- 
nut surmata poikaa vaan antoi hänet metsässä tapaamalleen Korintin kuninkaan palvelijalle, joka puolestaan vei hänet kuninkaalleen; tämä otti sitten pojan omaksi lapsekseen ja antoi hänelle nimeksi "Oidipus". Nuorukaiseksi vartuttuaan Oidipus sai vihiä edellä mainitusta oraakkelin ennustuksesta, josta pelästyneenä hän päätti lähteä pois Korintista vanhempinaan pitämänsä hallitsijaparin luota. Jo matkalla Thebaan hän surmasi oikean isänsä Laioksen ja tämän sotilaan, joiden kanssa hän oli joutunut sanaharkkaan, ja Thebassa hän nai myöhemmin Iokasteen, jota hän ei tunnistanut oikeaksi äidikseen. (Lindskog I968, 8I-85.) Sofokleen näytelmän pohjatekstinä on tämä mytologinen kertomus, jonka kreikkalainen yleisö hyvin tunsi ja johon se kyseisen näytelmän suhteutti.

Sofokleen Kuningas Oidipus alkaa tilanteesta, jossa Oidipus on Iokasteen kanssa hallinnut vuosikausia Thebaa. Kaupunki on nyt joutunut ruttovitsauksen ravistelemaksi. Oidipus tiedustelee papeiltaan neuvoa siihen, miten Theba voisi vapautua vitsauksesta. Papit vastaavat hänelle, että jumalat lopettavat vitsauksen vasta sitten kun Laioksen surmaaja on saanut rangaistuksensa. Tässä mielessä Kuningas Oidipuksessa on kyse rikkomuksesta ja rangaistuksesta. Surmaamalla isänsä ja naimalla äitinsä Oidipus on rikkonut sekä kosmista järjestystä vastaan (isänmurha) että yhteisöllisiä sääntöjä vastaan (oman äidin naiminen), eikä hänen syyllisyyttään poista näytelmässä se, että hän on tehnyt nämä rikkomukset tietämättään. Kosmisen ja yhteisöllisen järjestyksen säilyttämisen vuoksi hänen on saatava rangaistuksensa. Sofokleen näytelmä kuvaa sitä, miten totuus vähitellen, pala palalta paljastuu Oidipukselle ja miten hän lopullisen varmistuksen saatuaan puhkaisee silmänsä ja lähtee maanpakoon. Iokaste on puolestaan hetkeä aikaisemmin hirttänyt itsensä. Aristoteleen (I967, 29-30) teoriassa peripetia, "käännekohta", merkitsee toiminnan kääntymistä vastakkaiseen suuntaan, ja anagnoorisis, "tunnistaminen", viittaa kohtaan, jossa totuus paljastuu päähenkilölle. Aristoteles piti Kuningas Oidipuksen peripetiana loppupuolella olevaa kohtaa, jossa sanansaattajan tuoma viesti paljastaa epäilysten jo vaivaamalle Oidipukselle sen, että hän ei olekaan Korintin hallitsijaparin lapsi; tällöin hän myös viimein tunnistaa täysin itsensä ja tilanteensa kauheuden. 
Yhtiökumppanit poikkeaa Aristoteleen tragediakäsityksestä siinä, että se ei "jäljittele" vain yhtä toimintalinjaa, vaan siinä on useita eri toimintalinjoja, jotka romaanin neljännestä osasta lähtien limittyvät toisiinsa. Entä mikä täsmällisesti ottaen on Peten rikkomus? Mistä hän oikeastaan saa rangaistuksen? Hänen ilmeisin rikkomuksensa on insestinen suhde Kirsiin, rikkomus, jonka hän tekee - niin kuin hamartian käsite edellyttää - tietämättään. Romaani pohjustaa eri tavoin tätä tekoa. Alusta lähtien Kirsin minämuotoisista kerrontajaksoista käy ilmi, että Kirsi on ollut erityisen kiintynyt isäänsä, jonka varhainen kuolema jätti häneen sisimpäänsä syvän tyhiön. Romaani sisältää viittauksia siihen, että hän on tuntenut tiedostamatonta eroottista kiinnostusta isäänsä kohtaan ja vastaavasti hän on vältellyt ikäistensä nuorukaisten lähestymisyrityksiä. (YK, I4, I9, 42, 52-53, 70-7I, 8I, 9I.) Näistä syistä Kirsi tuntee aikuisena vetoa itseään hieman vanhempiin miehiin. "Papereista olin nähnyt, että se oli minua yksitoista vuotta nuorempi, ja kuitenkin minusta tuntui, että olisin käynyt sen isäksi”, kuvailee Pete (35 vuotta) ensivaikutelmiaan Kirsistä (24 vuotta) (ibid., 88-89). Katkelma viittaa heidän ikäeroonsa, mutta romaanin loppuratkaisun näkökulmasta sitä voi myös lukea vihjeenä insestisen suhteen mahdollisuudesta heidän välillään. Kun Petelle sitten lopussa paljastuu, että Kirsi on hänen veljensä tytär, hän toteaa kauhistuneena "Olisin antanut puhkoa silmäni" (ibid., 235). Oidipuksen tarinan tunteva lukija osaa viimeistään tällä perusteella yhdistää sen antiikin mytologiaan ja Sofokleen näytelmään. (Vrt. Juntunen 20I2, I46-I52.)

Insestinen suhde Peten ja Kirsin välillä ei silti ole Seppälän romaanissa keskeisin rikkomus, vaan se ainoastaan alleviivaa romaanin päärikkomusta. Tuo päärikkomus on se, että antautuessaan intohimoisesti rahan ansaitsemiseen ja omaisuutensa kartuttamiseen Pete vieraantuu vaimostaan ja lapsistaan ja päätyy lopulta paniikkitunnelmissa tekemään työtä, jonka hän kokee substantiaalisesti epämielekkääksi. Näin hän on ajautunut merkitysköyhään tilanteeseen, jossa Kirsin ilmaantuminen hänen elämäänsä on näyttäytynyt hänelle mahdollisuutena päästä uudelleen osalliseksi intohimon, rakkauden ja merkityksellisyyden kokemuksista. Näin ajateltaessa insestinen suhde Kirsiin on vain seurausta siitä, että Peten toimintatapa on ollut vääristynyt. 
Täyttäessään elämänsä bisneksenteolla Pete sortui myös hybrikseen: väärään itsekorostukseen tai liioiteltuun käsitykseen rikastumisen merkityksestä elämässä. Tässäkin suhteessa hän rinnastuu antiikin tragedioiden sankareihin; näiden, esimerkiksi Oidipuksen, rikkomuksena on se, että he ylittivät sen rajan, jonka jumalat olivat ihmisille asettaneet. ${ }^{84}$ Samanlaiseen rajanylitykseen viittaa romaanissa katkelma, jossa Pete kertoo seppänä toimineesta isoisänsä isästä:

Se teki metallista mitä tahtoi. Se oli takonut työkaluja, avaimia ja lukkoja. Ehkä se olisi voinut tehdä rahaakin jos se olisi halunnut, tai aseita. Joskus minusta tuntui, että vanhan sepän mahti oli siirtynyt minulle, joka muokkasin materiaaleja, luontoa. (Tällöin vielä uskoin, että minulla oli voima alistaa raha ja halutessani tehdä sitä lisää. Uskoin, että se kaikki oli minun käsissäni.-- ) (YK, ı०9. Kursivointi alkuperäisen tekstin.)

Uransa alkuvuosina Pete koki olevansa kaikkivoipa. Tällaisen mielentilan vallassa hän ei ottanut vastaan ympäristöstä tulleita varoitussignaaleja. Kyseinen katkelma sisältyy lukuun, jonka alussa Pete puhuu siitä, että hänen isoisänsä isä sairastui lopulta kielisyöpään pidettyään sepäntöistään maksuksi saamiaan kolikoita suussaan. Tämän Pete toki mainitsee, mutta hän sivuuttaa sen vähämerkityksisenä, sillä hän on lumoutunut isoisänsä isän osoittamasta taidosta ja vallasta. Videopelin suunnittelemista kuvaavassa osassa hän on jo vastaanottavaisempi vaaroista kieliville signaaleille, mutta samalla hän katsoo, että hänen on pakko toimia niin kuin hän toimii: "Jossain vaiheessa koneen ois luullu huutavan: FATAL ERROR, FATAL ERROR. Mutta nää koneet ei huuda eikä kaadu, ne lykkää sisältöö niinkun paskaa, helvetin huono vertaus, koska se on niin saatanan tosi" (YK, I53). Rajanylityksestä, "kohtalokkaasta erheestä", Peteä rangaistaan sillä, että hän ajautuu eksistentiaaliseen kriisiin. Samoin hänen kuvittelemansa uuden elämän mahdollisuus osoittautuu häpeälliseksi insestiseksi suhteeksi.

Tässä pääluvussa käsiteltiin aiemmin sitä, että Peten suhtautumista rahaan ja sen ansaitsemiseen on mahdollista kuvata Marxin tavarafetisismin käsitteen avulla. Tuo mahdollisuus perustuu siihen, että tavara- 
fetisismin vallassa olevan ihmisen tavoin Pete on taipuvainen ajattelemaan, että rahalla itsellään on mystinen kyky lisääntyä ja tuottaa lisäarvoa. Edellä lainattu sitaatti osoittaa, että Peten käsitys tuotannollisesta toiminnasta ja taloudellisten arvojen alkuperästä ei ole ainoastaan fetisistinen vaan myös mytologisoitu. Monien kansojen mytologioissa juuri sepän hahmosta tuli rautakaudella myyttinen sankari, sillä teknisten taitojensa ansiosta hän oli avainasemassa yhteisön tuotannollisessa toiminnassa. Niinpä tällaisissa mytologioissa hänet kuvattiin usein lähes puolijumalalliseksi olennoksi, jolla oli hallussaan yliluonnollisia taitoja. Kalevalaisessa mytologiassakin "seppo Ilmarista" luonnehditaan mieheksi, "jok on taivoa [taivasta] takonut, ilman kantta kalkutellut" (Kalevala I947, 85. Ks. myös Hakamies 20I2). Uransa alkuvaiheessa Pete näkee isoisänsä isän ja bisneksenteon paljolti tällaisessa myyttisessä valossa, mutta myöhemmin hänen näkemyksensä niistä muuttuu realistisemmaksi. Oheisen sitaatin jälkipuoli, kursivoitu osa, viittaa tähän hänessä tapahtuneeseen muutokseen.

Vaikka Yhtiökumppanit hyödyntää Aristoteleen ja Sofokleen teoksia, sitä ei voi pitää tragediana siinä mielessä kuin Aristoteles tragedian ymmärsi. Aristoteleen (I967, 2I, 3I-32) mukaan tragedian tulee olla arvokkaan toiminnan jäljittelemistä eikä sen sankari saa olla moraalisesti kelvoton tai epätavallisen hyveellinen. Nämä molemmat ominaisuudet vievät nimittäin pohjaa siltä, että yleisö voisi samaistua sankariin voimakkaasti, tuntea pelkoa hänen puolestaan ja sääliä häntä. Peten toimintaa on vaikea pitää arvokkaana, sillä häntä ajaa eteenpäin ahneus ja intohimoinen pyrkimys rahan ansaitsemiseen, ja tästä syystä hän laiminlyö jatkuvasti perhettään. Liioin ei hänen ajautumistaan eksistentiaaliseen kriisiin kuvata romaanissa myötätuntoisesti, vaan hänet näytetään lukijalle humalaisena ja ekspressiivisesti käyttäytyvänä ahdistuneena sisällöntuottajana. Ehkä tärkeintä on kuitenkin se, että antiikin tragediat perustuvat mytologiseen maailmankuvaan, jossa jumalat pitivät viime kädessä huolta moraalisen maailmanjärjestyksen säilymisestä ja jossa ihminen ei voinut välttyä jumalten hänelle määräämältä kohtalolta. Siksi antiikin tragedioissa yksilön, esimerkiksi Oidipuksen, tuhoutuminen on samalla osoitus moraalisen maailmanjärjestyksen ja yhteisöllisten arvojen voitosta, siitä, että näitä arvoja vastaan toimimisesta seurasi rangais- 
tus. Pete toimii aivan toisenlaisessa maailmassa. Hänen mahdollinen tuhoutumisensa, esimerkiksi itsemurhansa, ei palauttaisi moraalista maailmanjärjestystä vaan antaisi vain uusille peteille tai uusille sisällöntuottajille tilaisuuden tulla mukaan ICT-alalla vallitsevaan markkinakilpailuun. Tässä mielessä kulttuurin maallistuminen ja kapitalismin lakien ylivalta yhteiskunnassa ovat murentaneet maaperän klassisen tragedian elinvoimaisuuden alta. ${ }^{85}$

Arvosteluissa Yhtiökumppaneita ei aikoinaan pidetty aivan niin loisteliaana romaanina kuin Routavuotta ja Paholaisen haarukkaa, jotka saivat monilta kriitikoilta kiittävät, paikoin jopa ylistävät arviot. Esimerkiksi Helsingin Sanomissa Antti Majander (2002) luonnehti Yhtiökumppaneiden loppuratkaisua "nokkelaksi taikatempuksi", joka luiskahtaa "antikliimaksin" puolelle. Totta onkin, ettei romaanin juonenkehittely kaikilta osiltaan noudata todennäköisyyden ja välttämättömyyden lakeja, joita Aristoteles piti tärkeinä hyvin toimivalle tragedialle. Epätodennäköiseltä romaanissa vaikuttaa erityisesti se, että Pete sattuu rakastumaan juuri siihen naiseen, jonka isän hänen isänsä laittoi sota-aikana Viipurissa alulle. Samoin epätodennäköiseltä vaikuttaa se, että Kirsin sukuhaara on asettunut juuri sille samalle paikkakunnalle, jossa Petekin asuu.

Ilmeisesti Seppälä on turvautunut tällaiseen juonenkehittelyyn siitä syystä, että hän on halunnut osoittaa, miltä nykytalous näyttää silloin kun sitä tarkastellaan "korkeammasta arvonäkökulmasta" käsin. Yhtiökumppanit ei arvostele nykytaloutta siitä, että se tuottaa luokkapohjaista ja alueellista eriarvoisuutta ja lisää syrjäytyneiden määrää yhteiskunnassa. Kyseinen romaani ei liioin puhu alistamisesta, riistosta tai sorrosta. Niiden sijasta sen näkökulma kapitalismiin on ennen kaikkea arvokriittinen - se arvostelee nykytaloutta siitä, että se vie yhteiskunnan epäautenttiseen tilaan. Lisätäkseen tällaisen kritiikin vaikuttavuutta Yhtiökumppanit on ottanut käyttöönsä paitsi Weberin kapitalismiteorian myös Raamatun, Aristoteleen tragediakäsityksen, Sofokleen näytelmän ja antiikin mytologian.

Jos bisneksenteon sokaiseman Peten toimintaa tarkastellaan antiikin mytologioiden ja kristinuskon edustamien absoluuttisten arvojärjestelmien näkökulmasta, se on ehdottomasti moraalisesti väärin. Siten romaani ikään kuin kutsuu länsimaisen kulttuurin mytologiset taivaan ja 
kohtalon voimat arvioimaan ja tuomitsemaan Peteä. Yhtiökumppanit ei kuitenkaan vie loppuun asti tätä absoluuttisiin arvoihin vetoamista, vaan korostamalla Peten ja yhtiön tilanteen farssimaisia piirteitä teos tuo esiin myös sen, ettei maallistunut nykykulttuuri voi enää ratkaista arvokysymyksiä oletettuihin kosmisiin auktoriteetteihin vetoamalla; näin se itse vetää absoluuttisiin arvoihin vetoamiselta "maton jalkojen alta". Samanlainen tehtävä on romaanin juonensommittelun epäuskottavilla ja epätodennäköisillä yksityiskohdilla. Näin Yhtiökumppanit sisältää ristiriitaisia aineksia: yhtäältä se viittaa absoluuttisten arvojen ja voimien suuntaan, mutta toisaalta siinä eletään maallistuneessa nykykulttuurissa, joka kiistää tällaisten arvojen olemassaolon. Siksi romaaniin sisältyvät mytologiset ainekset toimivat lopulta lähinnä retorisina tehokeinoina, joiden avulla teos alleviivaa käsittelemänsä tematiikan tärkeyttä. Näin ajateltaessa sitä voi pitää yhteiskunnallisena moraliteettina, joka sanottavaansa painottaakseen lainaa piirteitä klassisesta tragediasta ja länsimaisen kulttuurin perustavista mytologioista.

Yhtiökumppanit eroaa siten konservatiivisesta markkinakapitalismin kritiikistä, jota ovat edustaneet muun muassa sosiologi Daniel Bell ja amerikkalaiset fundamentalistiliikkeet. Nämä ovat arvostelleet kapitalismia siitä, että se on korvannut absoluuttiset - kristilliset tai kristilliskansalliset - arvot kapitalistisella tuloksenteolla ja yksilökeskeisellä hedonistisella kulutuskulttuurilla. Siksi se ei niiden mukaan pysty tarjoamaan kestävää perustaa terveelle kansalliselle ja yhteisölliselle elämälle. Terve yhteiskuntaelämä on, ne jatkavat, mahdollinen vain kristillisten tai kristillis-kansallisten arvojen pohjalta, sillä tällaiset arvot pystyvät rajoittamaan markkinakapitalismille ominaista hillittömyyttä, sen taipumusta kasvaa jatkuvasti rajojensa yli ja ulottaa toimintatapansa mitä erilaisimmille elämänalueille. (Ks. Bell I979; Castells 2004, 87-Io०.) Siten on ymmärrettävää, että Yhtiökumppanit ei vie absoluuttisiin arvoihin viittaamista loppuun asti, vaan se kyseenalaistaa lopulta itsekin tällaisen viittaamisen. Koska absoluuttisiin arvoihin perustuva yhteiskunta johtaa helposti autoritariseen hallitsemistapaan, se ei välttämättä ole toivottava ratkaisu nykykapitalismin mukanaan tuomiin ongelmiin. 


\section{Yhteenvetoa ja yhtymäkohtia}

Yhtiökumppanit keskittyy kuvaamaan informationaalista taloutta ja siinä tehtävää työtä sekä näiden vaikutusta henkilöiden elämismaailmoihin (avioliittoon, perhe-elämään ja ihmissuhteisiin). Se ei tarjoa kokonaiskuvaa yhteiskunnasta, jonka monet osa-alueet, esimerkiksi valtio ja muu julkinen sektori, jäävät siinä kuvauksen ulkopuolelle. Se, että talous ei Yhtiökumppaneissa määrää totaalisesti kaikkien henkilöiden elämismaailmaa, tulee esiin niissä kohdissa, joissa Pete puhuu perheestään: vaimostaan Terhistä, joka toimii erikoishammashoitajana, sekä kouluiän kynnyksellä olevista pojistaan Veksistä ja Ekusta.

Yhdelläkään hänen perheenjäsenistään ei ole omia kerrontavuoroja, eikä romaanin tapahtumia juurikaan kerrota heidän näkökulmistaan. Romaanin useissa jaksoissa kuvataan Peten ja hänen perheensä välistä vastakohtaa. Pete toimii kapitalistisen hyötyajattelun maailmassa, kun taas Terhi elää Veksin ja Ekun kanssa yhteisessä arvo-, merkitys- ja tunneyhteisössä, habermasilaisesti ymmärretyssä arvorationaalisuuden tai kommunikatiivisen rationaalisuuden maailmassa. Petestä tuntuu, että hänen ainoa luontainen kommunikointivälineensä on raha, jolla ei kuitenkaan ole käyttöä Terhin, Veksin ja Ekun muodostamassa yhteisössä: "Jos olisin mennyt sanomaan niille: minulla on paljon rahaa, ne olisivat katsoneet minua mitään ymmärtämättä, niin luulen, tai ei, vaan minusta välittämättä. Mitä sitten? Minä en pystynyt sanomaan pojilleni mitään.” (YK, 76.) Tämän vastakohdan myötä tunneside ja vetovoima Peten ja Terhin välillä on hiipumassa: "Me olimme kuin yhtiökumppanit. Joskus yllätin itseni ajattelemasta perhettämme toiminnallisena yksikkönä, joka muistutti mitä tahansa taloudellista yhteenliittymää. Se tuntui kipeältä ja hävettävältä, tiesin että me olimme rakastaneet toisiamme." (Ibid., 77.) Peten habitus on bisnesajattelun läpitunkemaa. Siksi hän on menettänyt kykynsä kommunikoida mielekkäällä tavalla tunteita ja keskinäistä huolenpitoa painottavassa perheyhteisössä.

Yhtiökumppaneiden kuvaamassa maailmassa välinerationaalisuudesta ja kapitalistisesta markkinakäyttäytymisestä on tullut taloudessa ja työelämässä hallitseva toimintatapa, mutta sen ohella tuossa maailmassa esiintyy kutistunut arvorationaalisuuden tai substantiaalisen rationaali- 
suuden alue - se osa yhteiskuntaa, jossa Habermasin mukaan toimijoiden ensisijaisena tavoitteena on keskinäinen ymmärrys sekä yhteisen arvo- ja merkitysmaailman luominen ja ylläpitäminen. Peten perheen ohella tähän arvorationaaliseen maailmaan kuuluvat Peten ja Ollin välinen ystävyyssuhde, joka tosin viilenee romaanin edetessä, sekä Peten ja Kirsin välille syntyvä rakkaussuhde. Siksi en voi varauksitta jakaa Tuomas Juntusen tapaa tulkita Yhtiökumppaneita: "Kyse ei ole enää realistisesta todellisuuden kuvaamisesta vaan pikemminkin teoreettisesta kokeesta, mahdollisesta maailmasta, jossa kaikki toimii puhtaasti uusliberalistisen talouden logiikan mukaisesti” (Juntunen 2012, I60).

Tässä yhteydessä on syytä erottaa toisistaan (i) Yhtiökumppaneissa kuvattu talouden ja työelämän alue, (ii) siinä kuvattu laajempi sosiaalinen todellisuus ja (iii) sen kontekstina toimiva todellinen yhteiskunta. Juntusen esittämä tulkinta pätee lähinnä tapaukseen (i) eli Yhtiökumppanit todellakin esittää informationaalisen talouden olevan "uusliberalistisen logiikan" läpitunkema ja hallitsema elämänalue. Sen ohella Yhtiökumppaneiden kuvaamassa laajemmassa sosiaalisessa todellisuudessa on kuitenkin myös kutistunut arvorationaalisuuden tai kommunikatiivisen rationaalisuuden alue, jota edustavat Peten vaimo ja heidän lapsensa sekä Peten ja Ollin välinen ystävyyssuhde ja Peten ja Kirsin välinen rakkaus. Mitä romaanin ilmestymisajankohdan suomalaiseen yhteiskuntaan eli tapaukseen (iii) tulee, niin Yhtiökumppanit ei kuvaa sitä laajasti vaan ainoastaan rajatuilta osin. Se ei siten ainakaan eksplisiittisesti esitä, että todellinen suomalainen yhteiskunta olisi - informationaalisen talouden tavoin - muuttunut välinerationaalisuuden ja kapitalistisen markkinakäyttäytymisen läpitunkemaksi muodostumaksi.

Yhtiökumppanit ei kaikilta osin noudata mimeettis-realistista tapaa kuvata todellisuutta, vaan se poikkeaa siitä tietyissä suhteissa. Nuo poikkeamat ovat paljolti seurausta siitä, että Yhtiökumppanit pyrkii toimimaan nykyaikaisena moraliteettina ja varoitustarinana. Paljolti juuri tämä seikka, moraliteetin ja varoitustarinan etenemisen logiikka, tuo siihen liioittelevia, kärjistäviä ja paikoin epäuskottaviakin aineksia. Näissä aineksissa on kyse siitä, mitä Richard Walsh (2007) ja Paul Ricoeur (I984) kutsuvat kertomusten konfiguratiiviseksi puoleksi. Niklas Luhmann (I997b) puolestaan puhuu samassa mielessä kirjallisuuden ja 
taiteen autopoieettisuudesta. Sillä hän tarkoittaa, että kirjalliset teokset ottavat kyllä aineksia todellisuudesta, mutta ne sovittavat ne omaan logiikkaansa, esimerkiksi valittujen genre-konventioiden ja tyyliperiaatteiden asettamiin ehtoihin, ja täydentävät niitä tarpeen tullen fiktiivisillä aineksilla. (Ks. myös Sevänen 200I.) Kirjallinen teos ottaa siis aineksia tai figuureja todellisuudesta, mutta se muuntelee niitä omien tarkoitusperiensä mukaisesti ja asettaa ne uusiin merkitysyhteyksiin, osaksi teoksen kompositiota ja etenemistapaa. Tuloksena tällaisesta uudelleenjärjestelemisestä on enemmän tai vähemmän konfiguratiivinen ja autopoieettinen, enemmän tai vähemmän omaa logiikkaansa noudattava kokonaisuus, joka esittää kompleksisella tavalla todellisuutta.

Yhtiökumppaneissa on runsaasti aineksia, jotka ovat peräisin sen ilmestymisajankohdan suomalaisesta todellisuudesta. Niihin kuuluvat erityisesti uusliberalismin nousu hegemoniseksi taloudellispoliittiseksi ideologiaksi ja toimintastrategiaksi, markkinavoimien eteneminen yhteiskunnassa, informationaalisen sektorin, ICT-alan ja "sisällöntuotannon" painoarvon kasvu taloudessa, kilpailun kiristyminen taloudessa ja yhteiskunnan eri osa-alueilla sekä työelämässä tapahtuneet muutokset ja työn kuormittavuuden lisääntyminen. Nämä kaikki ainekset esiintyvät Yhtiökumppaneissa, joka on mukauttanut ne kompositioonsa ja etenemistapaansa, muunnellut niitä ja lisännyt niiden yhteyteen uutta ainesta. Tuota uutta ainesta, joka on luonteeltaan enemmän tai vähemmän kirjallista, ovat romaanin lukuisat viittaukset Raamattuun ja antiikin mytologiaan sekä Peten isän elämää koskevan tarinalinjan ja Kirsin lapsuutta ja nuoruutta käsittelevän tarinalinjan kuljettaminen rinnan Petestä ja hänen yhtiöstään kertovan tarinalinjan kanssa. Tuloksena tästä on kokonaisuus, joka esittää erilaisilla tavoilla todellisuutta ja on samalla nykykirjallisuudelle luonteenomainen kannanotto siitä, millaisia riskejä uusliberalistinen politiikka ja informationaalinen talous aiheuttavat yhteiskunnassa. Nämä riskit liittyvät ennen kaikkea siihen, että ne lisäävät yhtäältä välineellisen ajattelun ja toiminnan osuutta yhteiskuntaelämässä ja toisaalta köyhdyttävät arvorationaalisuuden aluetta.

Rationalisaatiokriittisissä romaaneissa kapitalistinen voitontavoittelu esitetään tavallisesti toiminnaksi, jonka harjoittaja ajautuu ristiriitaan yhteisöllisen ja yksilöllisen hyvän kanssa. Kyseistä romaanityyppiä edus- 
tava teos voi välittää tällaisen näkemyksen sekä kokonaisrakenteensa että yksityiskohtiensa avulla. Yhtiökumppanit käyttää hyväksi näitä molempia keinoja. Niin kuin tässä pääluvussa on käynyt ilmi, sen etenemistapa ja loppuratkaisut näyttävät, millaisia psyykkisiä, fyysisiä ja sosiaalisia vaurioita informationaalisessa taloudessa harjoitettu voitontavoittelu ja kilpailu aiheuttavat yksilöille ja heidän lähipiirilleen. Lopuksi on vielä syytä kiinnittää huomiota romaanin erääseen yksityiskohtaan, joka toteuttaa teoksessa paljolti samanlaista tehtävää.

Tämän pääluvun viidennessä alaluvussa todettiin, että Yhtiökumppaneissa Pete sortuu aivan tietynlaiseen rajanylitykseen, suurenneltuun käsitykseen rahan ansaitsemisen ja taloudellisen menestyksen merkityksestä elämässään. Jakso, jossa Pete puhuu ihannoivaan sävyyn isoisänsä isän sepäntaidoista, tuo tämän eetoksen konkreettisesti esiin (ks. YK, Io9). Taloudellisen menestyksen saavuttamiseen liittyvä rajanylitysmotiivi yhdistää Yhtiökumppaneita konkreettisesti rationalisaatiokriittisen romaanin traditioon. Balzacin Ukko Goriot'sta (1985, ranskankielinen alkuperäisteos ilmestyi I835) lähtien rationalisaatiokriittisiin romaaneihin on sisältynyt kuvauksia tilanteista, joissa henkilöt ovat taloudellisen menestyksen vuoksi valmiita riskeeraamaan oman ja lähiyhteisönsä hyvinvoinnin. Näin tehdessään he eivät piittaa yhteiskunnassa vallalla olevista kirjoitetuista ja kirjoittamattomista säännöistä tai "rajoista”. Thomas Piketty on tässä mielessä kiinnittänyt huomiota talouden ja rikollisuuden väliseen läheiseen suhteeseen Ukko Goriot'ssa. Siinä kyyninen ja puolittain rikollisten maailmassa elävä Vautrin yrittää houkutella romaanin päähenkilöä Èugene de Rastignacia tekemään murhan, jotta Rastignac pääsisi käsiksi suureen perintöön. Vautrinin näkemykseen mukaan rikastuminen ei ole mahdollista opintojen ja oman työn kautta vaan ainoastaan siten, että ihmisellä on omistuksessaan suuret korkotulot mahdollistavaa perintövarallisuutta. Tämä näkemys kuvaa Pikettyn mukaan suhteellisen pätevästi I8oo-luvun ranskalaista yhteiskuntaa, jossa perintövarallisuus todellakin oli opintoja ja työtä huomattavasti tärkeämpi vaurauden lähde. (Piketty 20I6, 342-343. Ks. myös Ruohonen 20I8, I56-I57.) Rajanylitys-motiivin kannalta tärkeämpää on ehkä kuitenkin se, että Balzacilla on tapana demonisoida kapitalistit. Vautrinin tavoin he ovat hänen teoksissaan usein poikkeuksellisia, ylimitoitetun 
tai hillittömän kunnianhimon ja ahneuden riivaamia ihmisiä, jotka ovat oman etunsa vuoksi valmiita uhraamaan avioliittonsa ja perhe-elämänsä ja uhmaamaan ihmisten välistä kanssakäymistä koskevia sosiaalisia ja juridisia sääntöjä.

Hermann Brochin Liikemies Huguenau eli asiallisuus 1918 (I994) ja Bertolt Brechtin Kerjäläisromaani (I97I) sisältävät niin ikään edellä kuvatun kaltaisen rajanylityksen. Brechtin satiirisessa romaanissa se on tosin paljolti teeman asemassa, sillä Kerjäläisromaanin maailmassa kapitalistinen liiketoiminta ja rikollisuus ovat kietoutuneet erottamattomasti toisiinsa. Tuossa maailmassa ankara markkinakilpailu ja taloudellisen voiton tavoitteleminen saavat yhdessä aikaan tilanteen, jossa rikollisiin menetelmiin turvautuminen näyttäytyy paljolti normaalin liiketoiminnan luontevana ja johdonmukaisena jatkeena. Näin ajattelevat myös romaanin keskushenkilöt: kukoistavaa liiketoimintaa pyörittävä ja siinä kerjäläisiä hyväksi käyttävä J. J. Peachum ja suurliikemieheksi kohoava Macheath, alamaailman kasvatti. Brochin romaanin kuvaamassa maailmassa rikollisuus ei ole aivan näin keskeisessä asemassa. Siinä nimihenkilö Huguenau turvautuu taloudellista menestystä saavuttaakseen tarpeen tullen huijaamiseen ja petkuttamiseen. Räikeimmillään hänen amoraalisuutensa on tilanteessa, jossa hän käyttää ensin seksuaalisesti hyväksi sokissa olevaa naista ja tappaa hieman myöhemmin ilman mitään tunnontuskia tämän aviomiehen, hankalana pitämänsä liikekumppanin. (Ks. Broch I994, 76-8I, I23-I26, 259-265, 289-29I, 294.) Myöhemmin hän kohoaa vähitellen yhteisössään arvostetuksi ja kunniallisena pidetyksi kansalaiseksi. Tätä ilmiökokonaisuutta romaanin kertoja luonnehtii "arvojen rappioksi". Sillä hän viittaa siihen paradoksaaliseen tilanteeseen, että kapitalistinen liiketoiminta kuuluu modernissa yhteiskunnassa hyväksyttyihin ja arvostettuihin toimintamuotoihin, mutta samaan aikaan sen harjoittajat saattavat taloudellisen menestyksen ja voitontavoittelun nimissä sortua moraalisesti ja juridisesti tuomittaviin tekoihin.

Bret Easton Ellisin American Psycho (I99I) on ääriesimerkki siitä, miten rationalisaatiokriittiset romaanit kuvaavat kapitalismille ominaista laajentumishalua, rajojen rikkomista ja indifferenssiä. Sen päähenkilö, nuori miljonääri Patrick Bateman on menestyvä pörssimeklari, joka viet- 
tää tavallisesti vapaa-aikaansa kollegoidensa kanssa, mutta joka ajautuu vähitellen pakkomielteidensä riivaamaksi sarjamurhaajaksi. Hän tappaa muun muassa "homon ja sen koiran", eläintarhassa näkemänsä 5-vuotiaan lapsen ja osan rakastajattaristaan. Romaani kuvaa hänen tekemiään raakoja murhia varsin yksityiskohtaisella tavalla, mutta samalla se jättää avoimeksi sen, tekeekö hän ne kaikki oikeasti vai onko osa niistä hänen mielikuvituksensa tuotetta. Kuitenkin riippumatta siitä, ovatko nuo murhat romaanin maailmassa todellisia vai päähenkilön kuvitelmia, ne on mahdollista nähdä myös vertauskuvallisesti. Niiden avulla Ellisin romaani pyrkii yhtäältä tavoittamaan I980-luvun finanssikapitalismille - "juppikapitalismille" - ominaisen hillittömyyden ja pidäkkeettömyyden, rajojen puuttumisen, ja tuomaan toisaalta esiin sen, että äärimuodossaan kapitalistinen välinerationaalisuus tuhoaa harjoittajassaan empatiakyvyn ja kyvyn reflektoida omaa toimintaa moraalisesti.

Rajanylitys-motiivi sisältyy usein myös nykytaloutta kriittisesti kuvaaviin suomalaisiin romaaneihin. Niistä voidaan esimerkkeinä mainita Tommi Melenderin Kunnian mies (2007), Karo Hämäläisen Kolmikulma (2OII) ja Erottaja (20I2) sekä Hannu Raittilan Ei minulta mitään puutu (I998), jota käsiteltiin jo edellä (ks. tämän pääluvun toista alalukua). Kunnian miehen nimi on ironinen, sillä romaani kuvaa kuvitteellista varainhoitoyhtiötä ja yleisemmin nykyistä finanssikapitalismia, jossa menestyminen edellyttää usein luopumista kunniallisesta käytöksestä. Yhtiön johtaja ja keskeinen omistaja Markus Aurelius ihailee suomalaissyntyistä, mutta Yhdysvalloissa asuvaa bisnesgurua Frans Fanonia, joka on rakentanut talousoppinsa - ainakin monien lukijoiden silmissä - kunniattoman käyttäytymisen varaan. Fanon pitää suomalaiselle yritysmaailmalle luennon, jonka viesti on yksinkertaisesti tämä:

Erottuakseen muista ja nujertaakseen kilpailijansa yrityksen on turvauduttava kaikkiin käytettävissä oleviin keinoihin. - - Jokainen menestyvä yritys elää jatkuvassa muutoksen tilassa ja on valmis koettelemaan julkisen vallan ja yleisten moraalikäsitysten asettamia pidikkeitä ja rajoituksia. (Melender 2007, I88-I89.) 
Kapitalismin amoraalisuutta Fanon puolustelee sillä, että kapitalismin "uutta luovaa ydintä", sen jatkuvaa hakeutumista uusille alueille ei pidä tukahduttaa, sillä se kadottaisi talouselämän dynaamisuuden. Fanon on itsekin vaarassa joutua tällaisen pidäkkeettömän käyttäytymisen uhriksi, sillä Markus Aurelius järjestää kodissaan hänen kunniakseen juhlat, joissa tämä kuusikymppinen bisnesguru vetäytyy erään naisen kanssa makuuhuoneeseen ja videoi siellä humalapäissään heidän rakastelunsa. Video päätyy myöhemmin Markus Aureliuksen haltuun, joka voi tarvittaessa käyttää sitä Fanonia vastaan. Romaanissa nykykapitalismi murentaa siten yhteiskunnan perustana olevia moraalis-sosiaalisia arvoja.

Samoin Hämäläisen talouselämää käsittelevissä romaaneissa, finanssitrillereissä, esiintyy keskeisissä tehtävissä henkilöitä, joilla sopivien toimintatapojen valitseminen on paljolti tarkoituksenmukaisuuskysymys ja jotka eivät juurikaan vaivaa itseään moraalisilla tai lainopillisilla pohdiskeluilla. Kolmikulmassa tällaisia henkilöitä ovat salkunhoitaja Ilari Rautavaara, romaanin päähenkilö, ja hämäräperäistä liiketoimintaa, esimerkiksi ihmisten kaappaamista, harjoittava Irene Adler, jonka vakioasiakkaita ovat saksankielisellä alueella toimivat suurpankit ja vakuutusyhtiöt. Erottajassa eletään puolestaan vuotta 2008, jolloin maailmalle on paljastunut, että amerikkalainen investointipankki Lehman Brothers on kaatumassa riskisijoituksiinsa. Romaanin päähenkilöihin kuuluva sijoitusneuvoja Rainer Olavi Oraspää eli "Rotta Oraspää" on sijoittanut asiakkaidensa varoja kyseiseen yritykseen, mitä hän nyt yrittää paljastumiseensa asti peittää epätoivoisesti niin laillisin kuin laittominkin keinoin. Myös tässä romaanissa finanssimaailma toimii paljolti vailla moraalista kompassia. Kertoessaan erään romaanin sivuhenkilön, Marko Auvisen, etenemisestä urallaan tarinamaailman ulkopuolinen kertoja toteaa: "Aika on nopeasti karistanut Auvisesta epäilyt ja juurruttanut filosofian, joka poistaa moraaliset esteet: jos me emme myy, tulee vielä joku härskimpi ja käärii asiakkaan rahat" (Hämäläinen 20II, 90). Liiketaloudellista menestystä tavoitellessaan monet romaanin henkilöistä sortuvatkin juridisesti ja/tai moraalisesti tuomittaviin tekoihin, joita tarinamaailman ulkopuolinen kertoja kriittisesti reflektoi. Tällainen henkilö on erityisesti sijoitusneuvoja Krista Saukkonen, romaanin pääkonna, joka vastustajiaan kukistaessaan toimii yhteistyössä alamaailman kanssa. 
Yhtiökumppaneissa taloudellisen menestyksen saavuttamiseen liittyvä toiminta ei ole näin dramaattista. Pete ja Olli eivät sorru rikoksiin, mutta he ylittävät muutoin sen rajan, jonka toisella puolella heidän toimensa alkavat vaurioittaa sekä heitä itseään että heidän lähipiiriään. Peten kohdalla perussyynä tähän on jo nuorena sisäistetty modernin kapitalismin eetos, jonka mukaisesti hän on nähnyt elämäntehtäväkseen rahan ansaitsemisen ja taloudellisen menestyksen. Tällä pyrkimyksellä on hänelle alkuaan ollut sekä taloudellista että eksistentiaalista merkitystä, mutta antautuessaan yhä syvemmin sen toteuttamiseen hän joutuu huomaamaan, ettei se riitäkään hänelle elämän merkitysperustaksi. Samoin hän joutuu tunnustamaan, että tuota pyrkimystä toteuttaessaan hän on vähitellen tuhonnut avioliittonsa ja menettänyt yhteyden lapsiinsa. Silti hän ei pysty luopumaan valitsemastaan ja paikoitellen vääränä pitämästään elämäntavasta, vaan romaanin osittain avoimesti päättyvissä loppujaksoissa hän päinvastoin elättelee - turhaksi osoittautuvia - toiveita siitä, että hän voisi vielä jatkaa elämäntyyliään uuden naisystävänsä Kirsin avulla. Näin hän on peruuttamattomasti takertunut nykykapitalismin verkkoihin.

Nykytaloutta määrittäessään Yhtiökumppanit nojautuu weberiläiseen käsitykseen siitä, että ammattimainen pyrkimys rahan ansaitsemiseen muodollisesti laillisin keinoin luonnehtii I500-luvulta lähtien yleistynyttä kapitalistista toimintatapaa ja sen eetosta. Nykykapitalismia ja sen eetosta ei yhteiskuntateoriassa määritetä ihan tällä tavalla, vaan sitä käsitellessään tutkijat ovat tuoneet esiin eräitä lisämääreitä. Niitä tarkastellaan lähemmin viidennessä luvussa, Mr. Smithin käsittelemisen yhteydessä. 


\section{Luku IV Paholaisen haarukka ja kriittisen kärjistämisen logiikka}

\section{Henkilöt, rakenne ja muoto}

Yhtiökumppaneiden tavoin Paholaisen haarukkaa voidaan lukea modernina yhteiskunnallisena moraliteettina. Sekin kuvaa, millaista tuhoa ja vahinkoa yksilöille ja yhteisöille aiheutuu, kun yhteiskunnassa aletaan palvoa "vääriä jumalia" eli kapitalistisia markkinoita, kilpailua ja tuloshakuisuutta. Edeltäjäänsä selvemmin se korostaa kyseisen arvomuutoksen radikaalisuutta. Tällainen korostus sisältyy jo romaanin alkujaksoihin, jotka antavat samalla lukijalle viitteitä siitä, miten hänen pitäisi tulkita romaanin myöhemmät pohdiskelut ja tapahtumat. Teoksen alkupuolella pankkimaailmassa toimiva sijoitusneuvoja ja varallisuudenhoitaja Lari Laine kuvaa uskonto- ja magia-aiheisilla vertauskuvilla pankki- ja sijoitustoiminnan nousua talouden keskeiseksi osa-alueeksi:

Me [sijoitusneuvojat, varallisuudenhoitajat] olimme yhteisön pappeja, shamaaneja, jotka saimme ihmisten puolesta yhteyden tuonpuoleiseen.

Me astuimme kuvaan tilanteessa, jossa ihmiset eivät enää tienneet.

Me myimme sitä varallisuudenhoitona. 
Me olimme shamaaneja, johdimme uusia rituaaleja, uhrasimme jumalille vuohen, purimme pässin kieltä ja kiipesimme lopulta paalun nokkaan silmät sidottuina ja eläimen sydäntä suussamme kantaen.

Meidän toimintamme oli yhtä rationaalista kuin Jeesuksen lihan syöminen ja veren juominen kirkossa. Me olimme uusi Jumala, jonka ne saattoivat tunnistaa ja hyväksyä sen jälkeen kun vanha oli tapettu. Pappi Eelin pojat kävivät varastamassa uhrilihaa alttarilta, ottivat pappien osuudesta ja kiristivät uhraajia. He käyttivät haarukantapaista otinta ja leimautuivat Jumalan silmissä kelvottomiksi. (PH, 28-29.)*

Pankki- ja finanssipääoman nousun myötä uudet arvot ja uusi maailmankuva, eräänlainen uudenlainen uskonto sille ominaisine shamaaneineen ja pappeineen, ovat korvanneet entiset arvot ja maailmaa koskevat uskomukset. Nämä uudet arvot ja uskomukset osoittautuvat romaanin edetessä tuhoisiksi, sillä ne rampauttavat henkisesti tai fyysisesti monet romaanin henkilöistä.

Oheinen sitaatti rinnastaa sijoitusneuvojat ja varallisuudenhoitajat shamaaneihin ja pappeihin. Yleisemmällä tasolla tuo metaforinen rinnastus antaa ymmärtää, ettei kapitalismi voi perustua pelkästään tietoon ja rationaalisiin päätöksiin. Weberillä ja Habermasilla länsimaisen sivilisaation modernisoitumiskehitys on kulttuurin ja yhteiskunnan lisääntyvää maallistumista, intellektualisoitumista ja rationalisoitumista - lyhyesti sanoen prosessi, jossa mystisen ja maagisen maailmankuvan ainekset menettävät vähitellen merkitystään kulttuurin ja yhteiskunnan rakennusaineina. Tosin Weber katsoi, että rationalisoitumisen etenemisestä huolimatta moderni kapitalismi sisältää väistämättä myös irrationaalisia aineksia muun muassa siitä syystä, että kapitalismille ominainen "voitonhimo" ja hillitön pyrkimys lisäarvon saavuttamiseen ovat itsessään vailla rationaalista pohjaa (Weber I980, 43-99. Ks. myös

* Käytän luvuissa IV-VI Paholaisen haarukasta lyhennettä PH silloin, kun siteeraan sitä tai viittaan siihen muuten sivunumeroiden tarkkuudella. 
Gronow 20I3, 42-43). Paholaisen haarukan mukaan nykykapitalismi sisältää irrationaalisia tai ei-rationaalisia aineksia lähinnä siksi, että sijoitustoiminnassa ei voi nojautua pelkästään koeteltuun tietoon. Kellään ei voi olla hallussaan kattavaa ja varmaa tietoa markkinamekanismien toiminnasta ja niiden tulevasta kehityksestä, ja siksi sijoituspäätöksiä joudutaan tekemään osittain uskon ja toiveiden varassa. Tämän Lari Laine tuo sitaatissa esiin magiasta ja uskonnosta ottamiensa rinnastusten avulla.

Siten Paholaisen haarukka arvioi nykykapitalismia myös uskomusrationaalisuuden näkökulmasta. Edellä käsitellyt kohdat painottavat sitä, että nykyisessä finanssikapitalismissa taloudellisten päätösten uskomusrationaalisuuden aste ei ole aina korkea. Tämä puute liittyy siihen, että pankki- ja sijoitustoiminnassa päätösten perusteina on aina tiedon ohella myös toiveita ja tunteita. Samoin nykyisessä käyttäytymistieteellisessä talousteoriassa katsotaan, että sijoitusmarkkinoilla toimivien sijoittajien päätöksiä ohjaavat tiedon ja harkinnan ohella heidän sijoitusobjekteihin projisoimansa fantasiat, toiveet ja tunteet. Tämä ei tee onnistuneita sijoituspäätöksiä mahdottomiksi, mutta se osoittaa, että sijoitustoiminta on tässäkin mielessä osittain riskialtis "hyppy epävarmuuteen ja tuntemattomaan".

Käyttäytymistieteellisessä talousteoriassa näitä näkökohtia on painottanut erityisesti Richard H. Thaler, taloustieteen Nobel-palkinnon vuonna 2017 saanut yhdysvaltalainen tutkija. Tuotannossaan hän ei ole puhunut ainoastaan sijoitustoimintaan liittyvistä ei-rationaalisista tai, niin kuin hän itse sanoo, "kvasirationaalisista" aineksista vaan myös siitä, että omaa (koti)talouttaan hoitavat ihmiset eivät liioin aina toimi liiketaloudellisessa mielessä kovin rationaalisesti tai tuloshakuisesti. Liikevoittojen tavoittelemisen sijasta heidän toimintaansa ohjaa enemmänkin pyrkimys vakauteen ja turvallisuuteen, minkä vuoksi he saattavat vältellä pientenkin ja todennäköisesti tuottoisien taloudellisten riskien ottamista. Tosin kotitaloudet eroavat suuryrityksistä siinä, että ne eivät pysty palkitsemaan itseään riskinotosta siten kuin suuryritykset, jotka ovat viime vuosikymmeninä kannustaneet johtajiaan riskinottoon ja myös palkinneet heitä siitä avokätisesti. (Thaler I994; 20I5. Vrt. Kotkavirta $2013,75-77,8 \mathrm{I}-84$.) 
Weberiläisen toimintateorian näkökulmasta Thalerin esittämät ajatukset eivät ole yllättäviä. Weberin mukaan inhimilliseen toimintaan liittyy välinerationaalisen laskelmoinnin ohella aina arvorationaalisia ja tunteenomaisia ulottuvuuksia, joiden ohella sitä ohjaavat perityt tavat. Tätä pätee myös moderniin kapitalismiin, vaikka Weber katsoikin, että se pystyy karsimaan itsestään suhteellisen tehokkaasti pois ei-rationaalisia aineksia. Muun muassa näistä syistä weberiläinen toimintateoria on relevantti myös nykytutkimuksen ja nykyisen talousteorian kannalta (Aspers 20II, 40-80; Wherry 2012, IO-I3).

Kapitalismia kritisoidessaan Paholaisen haarukka käyttää Yhtiökumppaneiden tavoin hyväksi Raamattua ja sen vuosituhansia vanhan uskonnollisen mytologian arvovaltaa. Edellä olevan sitaatin viimeiseen kappaleeseen sisältyvä huomautus pappi Eelin pojista - jotka "kävivät varastamassa uhrilihaa alttarilta, ottivat pappien osuudesta ja kiristivät uhraajia. He käyttivät haarukantapaista otinta ja leimautuivat Jumalan silmissä kelvottomiksi” - on peräisin Vanhaan testamenttiin sisältyvästä Ensimmäisestä Samuelin kirjasta (2:I2-I8). Siinä pappi Eelin poikien virheeksi tai synniksi osoittautuu se, että he toimivat vastoin niitä varsin yksityiskohtaisia määräyksiä, jotka Jumala oli asettanut uskonnollisten kulttimenojen suorittamiselle. Samuelin kirjat, joita on kaikkiaan kaksi, ja yleisemminkin Vanha testamentti kuvaavat muutoinkin laajasti sitä, mihin epäjumalien palvominen ja rituaalien omaksuminen muista, "pakanallisista" uskonnoista saattoivat israelilaiset johtaa. Käsittääkseni edellä olevan sitaatin kohta "me olimme shamaaneja, johdimme uusia rituaaleja, uhrasimme jumalille vuohen, purimme pässin kieltä ja kiipesimme lopulta paalun nokkaan silmät sidottuina ja eläimen sydäntä suussamme kantaen" on Seppälän laatima vapaa mukaelma tällaisista kuvauksista. Tästä näkökulmasta pankki- ja finanssipääoman hallitsema nykytalous merkitsee Paholaisen haarukan mukaan perustavaa arvovääristymää, jonka romaani rinnastaa metaforisesti epäjumalien palvomiseen. ${ }^{86}$

Sivuilla 218-2I9 siteerattu Paholaisen haarukan kohta sisältää myös maininnan siitä, että uhrilihaa varastaneet pappi Eelin pojat "käyttivät haarukantapaista otinta ja leimautuivat Jumalan silmissä kelvottomiksi". Tuota mainintaa on mahdollista pitää selityksenä sille, miksi Seppälän 
romaanin nimenä on juuri "Paholaisen haarukka". Siteeratussa kohdassa maininta viittaa jumalattomien tekojen tekemiseen ja pyhinä pidettyihin sääntöihin kohdistuneisiin rikkomuksiin. Näin ilmaisu "Paholaisen haarukka" alleviivaa sitä, että markkinakapitalismin etenemisen ja voimistumisen myötä syntynyt uudenlainen yhteiskunta on kestämätön, että se edustaa rikkomusta perustavia tai substantiaalisia arvoja vastaan. Mitä nuo perustavat arvot ovat, sitä Paholaisen haarukka ei määritä kovin eksplisiittisesti, vaan pikemminkin lukijan on pääteltävä ne romaanissa esitettyjen tapahtumien ja pohdiskelujen avulla. Tähän kysymykseen palataan vielä tämän pääluvun lopussa ja kuudennessa luvussa.

Toisen kerran viittaus Paholaisen haarukkaan esiintyy luvussa, jossa elokuvaohjaaja Laura Laine keskustelee sosiaalipsykologi Saija Lehtosen kanssa ja kysyy häneltä:

- Tiedätkö sinä mikä on Paholaisen haarukka?

- En.

- Sosiologina voisit tietää.

- En tiedä. (PH, I89.)

Laura Laine luonnehtii Paholaisen haarukkaa "optiseksi illuusioksi", joka "perustuu meidän tapaamme käyttää suoria kulmia kolmiulotteisuuden vihjeinä” (PH, I89). Huomautus sisältää vihjeen siitä, että romaanissa Paholaisen haarukka on kyse myös illuusioiden käsittelemisestä, niiden kuvaamisesta ja paljastamisesta, minkä jälkeen markkinakapitalistinen yhteiskunta osoittautuu joksikin muuksi kuin miksi se itsensä esittää. Näin ajateltaessa tämä romaani esittää olevansa ideologiakritiikkiä siinä mielessä kuin Theodor W. Adorno ja muut Frankfurtin koulun perustajahahmot sanaa "ideologia" käyttivät. Heidän teoksissaan ideologia on 'väärää tajuntaa' ja ideologiakritiikin tehtävänä on puolestaan paljastaa yhteiskunnassa esiintyvät ja hallitsevan ryhmittymän etuja suojaavat virheelliset maailmankuvat ja vääristyneet arvot. (Ks. esim. Horkheimer \& Adorno 2008, 162-221.) Laura Laineen esittämä huomautus "sosiologina voisit tietää" on ymmärrettävissä tätä taustaa vasten. Se viittaa siihen, että sosiologit tuntevat väärän tajunnan tai illusorisen tajunnan käsitteen ja sitä koskevan keskustelutradition. 
Paholaisen haarukka nimeää Yhtiökumppaneita selvemmin uusliberalismin syypääksi siihen, mitä yhteiskunnassa on tapahtunut viime vuosikymmeninä. Liberalistisen ja uusliberalistisen talous- ja yhteiskuntateorian edustajista romaanissa ovat esillä muun muassa Milton Friedman (I9I2-2006) sekä Adam Smith (I723-I790) ja jälkimmäisen esittämä oletus markkinoita ohjaavasta "näkymättömästä kädestä" (PH, II6-II7, 2I3-2I4). Romaani kuvaa ja arvioi markkinakapitalismia ja sen toimintatapoja useista eri näkökulmista. Teoksen yhdeksi hallitsevaksi teemaksi nousee myös vieraantuneisuus eri muodoissaan.

Seppälän romaaneista Paholaisen haarukka on kaikkein artistisin ja kokeellisin. Henkilöhahmot ovat siinä vain ohuesti mimeettisiä, todellisten ihmisten kaltaisia. "Oikeiden", kokonaisvaltaisesti kuvattujen ihmisten sijasta he ovat enemmänkin yhteiskunnan nykytilan ja sen kehitysnäkymien ilmentymiä tai tiivistymiä, abstrakteja olentoja. Monet heistä kuvataan eri tavalla syrjäytyneiksi tai vieraantuneiksi hahmoiksi, joilta puuttuu vivahteikas henkinen elämä. Tässä suhteessa Paholaisen haarukka muistuttaa Don DeLillon romaania Cosmopolis (2003), jonka päähenkilö, suurkapitalisti Eric Packer on vain muutaman ominaispiirteen - lähes täydellisen vieraantuneisuuden ja ohentuneen tai yksiulotteisen subjektiuden - ilmentymä (ks. Steinby \& Tirronen 20I8). Samalla tavalla abstrakteja ovat Paholaisen haarukan henkilöt. Phelanin (I996, 2I-22) kolmijakoa mimeettinen-temaattinen-synteettinen sovellettaessa voi sanoa, että sinänsä syrjäytyneisyys ja vieraantuneisuus ovat nykyyhteiskuntaan liittyviä todellisia asiaintiloja, mutta tehdessään niistä henkilöidensä ainoita tai hallitsevia ominaispiirteitä kyseinen romaani poikkeaa mimeettisen representaation ja todennäköisyyden periaatteista ja muuntaa luonteenpiirteet enemmänkin teemankehittelynsä materiaaliksi.

Osittain juuri siksi, että Paholaisen haarukka on artistinen, abstrakti ja kokeellisia aineksia sisältävä romaani, tässä yhteydessä on syytä kysyä, millainen romaani se oikeastaan on geneerisessä mielessä. Olen aiemmin luonnehtinut sitä rationalisaatiokriittiseksi romaaniksi, jossa on modernin moraliteetin piirteitä. Tämä luonnehdinta ei kata sen kaikkia lajityypillisiä piirteitä, mistä ehkä kertoo omalla tavallaan se, että Parnassoon kirjoittamassaan arvostelussa Lauri Sihvonen $(2008,75)$ kuvasi sitä 
"virkeäksi satiiriksi", joka on tosin sellaisena "tylyä luettavaa". Satiirin tavoin Paholaisen haarukalle on todellakin ominaista kriittisyys, kärjistäminen ja liioitteleminen, mutta siitä puuttuu eräs satiireja yhdistävä tärkeä piirre: kohteen kritisoiminen tekemällä se naurettavaksi ja naurunalaiseksi. Tyypillisiin satiireihin verrattuna tämän romaanin sävy on vakava, ja luultavasti vain harva lukija löytää siitä minkäänlaista huumoria tai komiikkaa. Satiirin tunnusmerkit eivät siis täyty sen kohdalla.

Palataan Paholaisen haarukalle luonteenomaiseen kärjistävään tapaan käsitellä todellisuutta. Paljolti juuri sen vuoksi tätä romaania on vaikea lukea loppuun asti mimeettisesti, realistis-naturalistisena kuvauksena markkinallistuneesta nyky-yhteiskunnasta. Perinteisiä realistis-naturalistisia yhteiskuntaromaaneja se muistuttaa toki yhtäältä siinä, että niiden tavoin se pyrkii esittämään suhteellisen laajan kuvan yhteiskunnasta, ja toisaalta siinä, että sekin keskittyy epäkohtiin ja ongelmiin, joita se kuvaa paikoin inhorealistisella tavalla, lukijoita shokeeraten. Naturalismiin sitä yhdistää myös determinismi, periaate, jonka mukaisesti sen kuvaamassa fiktiivisessä yhteiskunnassa kapitalismin ja markkinoiden lait sääntelevät raudanlujin ottein henkilöiden elämää ja tekoja. (Vrt. Rossi 2009, 25-29, 34, 225-252.)

Realistisuuden ja mimeettisyyden vaikutelmaa lisäävät Paholaisen haarukassa edelleen sellaiset tekstijaksot, jotka viittaavat reaalisen yhteiskuntakehityksen aiheuttamiin laajoihin rakenteellisiin muutoksiin. Näissä tekstijaksoissa käsitellään perinteisen teollisuuskapitalismin hiipumista, finanssisektorin keskeistä asemaa nykytaloudessa, talouselämän digitalisoitumista, uusliberalismin nousua yhteiskunnan hallitsevaksi ideologiaksi, tuloerojen kasvua ja markkinallistumisprosessin etenemistä yhteiskunnan eri osa-alueille - Paholaisen haarukan maailmassa terveydenhoitoon, yliopistoihin, korkeampaan koulutukseen, joukkoviestintään, kulttuurituotantoon, kirjallisuuteen sekä ihmisten mieliin ja subjektiuteen. Mutta tällä tavalla, markkinallistumiskehitystä edustavien ainesten kasaamisen ja kärjistämisen kautta, Paholaisen haarukassa muodostuu lopulta fiktiivinen yhteiskunta, joka toimii lähes yksinomaan markkinakapitalismille ominaisen välineellisen järjen mukaisesti. Se on läpikapitalisoitunut fiktiivinen yhteiskunta, josta arvorationaalisuus on katoamassa ja jossa ihmisten elämismaailmatkin ovat 
lähes tyhjentyneet kommunikatiivisesta rationaalisuudesta. Romaani sivuuttaa siten sen, että reaalisessa yhteiskunnassa on vielä arvorationaalisia aineksia, esimerkiksi ympäristöliike ja naisliike sekä kutistunut hyvinvointivaltio ja sen puolesta toimivat voimat. Siksi tätä romaania ei voi kokonaisuudessaan lukea realistis-mimeettisenä oman aikansa yhteiskunnan kuvauksena, vaikka se sisältää runsaasti sen mukaisia aineksia.

Paholaisen haarukkaa ei myöskään ole syytä lukea kuvitelmana siitä, millaiseen maailmaan markkinakapitalismin eteneminen saattaa tulevaisuudessa johtaa. Tällaista tulkintamahdollisuutta vastaan puhuu se, että romaani esittää kuvaavansa omaa aikaansa. Sen nyt-hetki on vuoden 2008 kesäkuukausissa, mikä tulee ilmi romaanissa esiintyvän verkkotuottaja Kari Lehtosen tavassa päivätä blogikirjoitustensa kirjoittamisajakohdat. Näitä yhden tai kahden sivun pituisia blogitekstejä on romaanissa viisi, ja niistä ensimmäinen on päivätty "I3.6.2008" ja viimeinen "I8.8.2008". (PH, I7-I8, 259-260). Kyseisten blogikirjoitusten avulla Paholaisen haarukka korostaa realistista intentiotaan, sitä, että se kiinnittyy vankasti oman aikansa yhteiskuntaan ja pyrkii käsittelemään sitä ja siihen liittyviä ilmiöitä.

Käsillä oleva tutkimus ei siis kiistä tätä realistis-mimeettistä ulottuvuutta Paholaisen haarukassa. Samalla tutkimus haluaa kuitenkin tuoda esiin sen, että suhtautuessaan reaalitodellisuuteen ja sen ilmiöihin varsin valikoivalla ja kärjistävällä tavalla Paholaisen haarukka laajenee myös hahmotelmaksi siitä, millainen lähes läpikotaisin markkinallistunut yhteiskunta on tai olisi nykytietämyksen ja nykykokemuksen valossa. Siksi sen geneeristä ominaisluonnetta kuvattaessa hedelmällisen lisänäkökohdan tarjoaa spekulatiivisen fiktion käsite. Paholaisen haarukka yhdistää realistis-naturalistisen yhteiskuntaromaanin piirteisiin spekulatiivisen fiktion piirteitä.

Saija Isomaa ja Toni Lahtinen (20I7, 7-8) kirjoittavat, että spekulatiiviset fiktiot ovat ajatuskokeita, jotka kuvaavat sitä, millaista olisi elämä maailmassa tiettyjen, spekulatiivisten fiktioiden asettamien ehtojen vallitessa. Koska spekulatiivinen fiktio käsittelee usein kielteisiä ja ei-toivottuja vaihtoehtoja, se toimii usein samalla dystopiana tai ainakin se sisältää tavallisesti dystooppisia sävyjä. Spekulatiiviset fiktiot kuvaavat 
usein tulevaisuuden maailmoja niin kuin tieteisromaaneissa on tapana tehdä, mutta ne voivat myös toimia nykytodellisuutta tai menneisyyttä käsittelevinä romaaneina. Niiden pohjana on, Isomaa ja Lahtinen jatkavat, "entäpä jos" -rakenne. Tällöin nykyisyyttä käsittelevä spekulatiivinen fiktio on muotoa "entäpä jos me elämmekin maailmassa, jossa..." tai muotoa "entäpä jos onkin olemassa sellaisia maailmoja, joissa...". Vastaavasti tulevaisuutta käsittelevä fiktio on muotoa "entäpä jos maailma muuttuukin tulevaisuudessa paikaksi, jossa...”. Lisäksi spekulatiivinen fiktio voi käsitellä vaihtoehtoisia, todellisesta kehityksestä poikkeavia historian kehityskulkuja.

Paholaisen haarukka on mahdollista ajatella rationalisaatiokriittiseksi romaaniksi, joka sisältää aikalaistodellisuuteen viittaaville spekulatiivisille fiktioille ominaisia piirteitä. Noita piirteitä voi lukea samalla tavalla kuin spekulatiivisia fiktioita yleensä luetaan eli tässä tapauksessa ajatuskokeena siitä, millainen läpikotaisin markkinallistunut yhteiskunta olisi. Koska Paholaisen haarukan kuvaama fiktiivinen yhteiskunta rakentuu myös reaalisesta yhteiskunnasta otetuista aineksista, sisältää tämä romaani samalla realistisille romaaneille ominaisen mimeettisen, reaalitodellisuutta muistuttavan ulottuvuuden. Toisaalta se kärjistää kuitenkin aikalaistodellisuudesta ottamiaan aineksia ja sivuuttaa siinä sellaiset piirteet, jotka eivät edusta markkinallistumiskehitystä. Niinpä sen fiktiivisessä maailmassa hyvinvointivaltio on lähes kadonnut ja pulaan joutuneet yksilöt on jätetty tuuliajolle, markkinavoimien varaan. Sijoittaessani toisessa pääluvussa suomalaisen nyky-yhteiskunnan hallinnoidun kapitalismin tai koordinoidun markkinakapitalismin piiriin katsoin, ettei näin pitkälle markkinallistunut yhteiskunta ole Suomessa ainakaan vielä todellisuutta. Hyvinvointivaltion palveluja ei ole Suomessa niinkään lakkautettu, vaan pikemminkin julkisella sektorilla on ollut vaikeuksia rahoittaa niitä, minkä vuoksi ne ovat osittain rapautuneet.

Paholaisen haarukkaa ei siis ole syytä pitää pelkkänä realistis-mimeettisenä yhteiskuntaromaanina. Mimeettisten tasojen ohella siinä on mukana spekulatiivisille fiktioille ominainen "entäpä jos" -ulottuvuus. Tuon ulottuvuuden myötä se laajenee hahmotelmaksi tilanteesta, jossa markkinakapitalismi ja sille ominainen välineellinen järki ovat kaapanneet haltuunsa yhteiskunnan eri osa-alueet ja jossa ne ovat tunkeutuneet 
pitkälle myös ihmisten elämismaailmoihin ja subjektiuteen. Paholaisen haarukan tekstuaalisella pintatasolla nämä reaaliseen yhteiskuntaan viittaavat mimeettiset ainekset ja reaalisen yhteiskunnan pohjalta kehitellyt hahmotelmat sulautuvat tavallisesti yhteen, mutta ne voidaan erottaa toisistaan yhteiskuntateoreettisesti pohjatun tekstianalyysin keinoin.

Tälle romaanille ominainen, enemmän tai vähemmän kärjistävä tapa ottaa haltuun markkinallistumiskehitys ei ole epätavallinen nykykirjallisuudessa. Vastaavanlainen kuva hyvinvointivaltion kurjistumisesta tulee esiin esimerkiksi Arto Salmisen romaaneissa. Salmisen Kalavale. Kansalliseepos (2005) kuvaa yhteiskuntaa, jossa käydään ankaraa kilpailua ja jossa hyvinvointivaltion turvaverkot eivät ole vastaanottamassa kilpailussa hävinneitä; sen sijaan he putoavat tyhjän päälle eli oman onnensa tai sukulaisavun varaan (ks. Ojajärvi 20I6). Ilmapiiriltään astetta synkempi on Maarit Verrosen epämääräiseen tulevaisuuteen sijoittuva dystopiaromaani Karsintavaihe (2008), jossa yhteiskuntarauhaa ei saavuteta jaetun hyvinvoinnin ja luokkien keskinäisen solidaarisuuden kautta vaan psyykenlääkkeiden ja väkivaltakoneistojen alempiin luokkiin kohdistamien pakkokeinojen avulla. Verrosen romaani toimii siten kokonaisvaltaisemmin spekulatiivisen fiktion tavoin. Siihen verrattuna Seppälän ja Salmisen romaanit ovat lähinnä teoksia, joihin sisältyy spekulatiivinen ulottuvuus. Sellaisina ne kiinnittyvät selvemmin nyky-yhteiskuntaan, johon liittyviä ei-toivottuja ja pelkoa herättäviä kehitysnäkymiä ne paisuttelevat. Sitä vastoin Verrosen romaanin kuvaamassa autoritaarisessa tulevaisuuden yhteiskunnassa ovat toteutuneet täydessä mitassa ne kauhuskenaariot, riskit ja negatiiviset kehitysmahdollisuudet, jotka sisältyvät heikommassa muodossa markkinallistumiskehityksen nykyiseen vaiheeseenkin.

Kärjistävästä kuvaustavasta huolimatta, tai ehkä pikemminkin juuri sen ansiosta, Paholaisen haarukkaa on pidetty tärkeänä yhteiskunnallisena puheenvuorona ja taidokkaana romaaniteknisenä kokonaisuutena. Näistä samoista seikoista nimittäin monet kriitikot kiittelivät sitä. ${ }^{87} \mathrm{Yh}$ teiskunnallisten ongelmien esittäminen kärjistetyllä tavalla on I800luvulta lähtien ollut yhteiskunnallisissa romaaneissa ja näytelmissä yleisesti käytetty strategia. Osallistuessaan yhteiskunnallisen todellisuuden määrittämistä koskeviin diskursiivisiin kamppailuihin tällaiset romaanit 
ja näytelmät ovat usein juuri voimakkaiden kärjistysten ansiosta saaneet huomion kiinnittymään niiden kuvaamiin sosiaalisiin epäkohtiin ja ongelmiin.

Pituudeltaan 267-sivuinen Paholaisen haarukka muodostuu 77 luvusta, jotka on ryhmitelty lyhyeen prologiin ja kuuteen pääosaan. Luvut ovat jälleen lyhyitä, keskimäärin 3-4 sivun pituisia. Niiden alusta puuttuu usein maininta siitä, kuka niissä toimii kulloinkin kertojana. Siksi Paholaisen haarukan narratiivinen rakenne ei välttämättä aukea lukijalle yhdellä lukukerralla, vaan hän joutuu sen hahmottamiseksi lukemaan romaanin useaan kertaan ja käyttämään aktiivisesti hyväksi lähiluvun ja päättelytaidon menetelmiä. Romaanin kerrontarakenteessa hallitsevassa asemassa ovat tarinamaailman ulkopuolinen anonyymi kertoja ja finanssimies Lari Laine, joista edellinen toimii ainoana kertojana 23 luvussa ja jälkimmäinen 27 luvussa. Paikoitellen lukijan on vaikea erottaa näitä kahta kertojaa toisistaan, sillä eräissä luvuissa Lari Laine tarkastelee romaanin maailmaa samalta ontologiselta ja epistemologiselta tasolta kuin anonyymi kertoja. Esimerkiksi sivuilla $6_{I}-\sigma_{3}$ näyttäisi olevan tarinamaailman ulkopuolisen anonyymin kertojan äänellä kuvattu jakso, jossa Saija Lehtonen masturboi yksin kotonaan ja samalla hänen lemmikkinsä, häkissä oleva rotta, tarkkailee häntä katseellaan. Seuraavassa jaksossa (s. 64-65) kuitenkin Lari Laine kommentoi tuota jaksoa:

Saija Lehtonen ei olisi nähnyt itseään näin. Edes elokuvaa käsikirjoittava ja ohjaava sisareni ei olisi nähnyt häntä näin. Tuo on kertojan tekstiä, joku voisi sanoa että miehen katse, mutta kertoja voi vetäytyä sukupuolettomuutensa taakse. Kertoja voi olla kuka tahansa, leikata keskelle mitä tahansa ja sanoa aivan mitä hyvänsä. Kertoja ilmentää yhtä tapaa kuvata tekeillä olevan elokuvan mahdollista käsikirjoitusmateriaalia. (PH, 64.)

Sitaatissa mainitaan Laura Laineen elokuva siksi, että tuo elokuva kuvaa myös Kari ja Saija Lehtosen välistä suhdetta ja heidän kasvavaa vieraantumistaan toisistaan. Sitaatissa esiintyvä ilmaisu "miehinen katse" sisältää toiveen siitä, että lukija ei tulkitsisi Saija Lehtosta käsittelevää jaksoa pelkäksi miehisen katseen tai diskurssin ilmentymäksi tai pel- 
käksi naisen seksuaalisuuden esineellistämiseksi. Edellä mainitut kerrontajaksot eivät anna suoraan vihjettä siitä, miten lukijan sitten pitäisi ymmärtää tuo kohtaus. Romaanin kompositio ja kokonaisrakenne viittaavat kuitenkin siihen, että nyky-yhteiskunnassa laajalle levinnyt naisten esineellistäminen on yhteydessä paitsi arkielämän sukupuolittuneisiin valtasuhteisiin myös talouselämän ja markkinoiden rakenteisiin ja toimintatapoihin.

Oheinen sitaatti edustaa metalepsis-strategiaa, kertomuksille ominaisten ontologisten ja kerronnallisten rajojen ylittämistä, josta muu muassa Brian McHale (I987, II9-I20, I30, I64-I65, 226-227, 23I-232) tutkimuksissaan puhuu. Tällainen ylittäminen on McHalen mukaan ollut tavallista postmodernistisissa fiktioissa, jotka ovat kyseistä strategiaa käyttäessään halunneet osoittaa "todellisuuden konstruktiivisen luonteen", sen, että "todellisuus on diskursiivisesti tuotettua". Oheisessa sitaatissa, jossa Lari Laine siirtyy romaanikonventioiden vastaisesti hetkeksi tarinamaailman ulkopuolisen kertojan rooliin, Paholaisen haarukka ei niinkään harjoita ontologista eikä epistemologista pohdiskelua, vaan pikemminkin se antaa lukijalle tulkintavihjeitä ja leikittelee samalla kerronnan sovinnaisten käytänteiden rikkomisella.

Gérard Genetten (ı980) luomaa käsitteistöä käytettäessä voidaan sanoa, että Lari Laine toimii Paholaisen haarukassa ensi sijassa tarinamaailman sisäisenä, intradiegeettisenä kertojana, mutta eräissä luvuissa hän esiintyy myös sellaisena ylemmän eli ekstradiegeettisen tason kertojana, joka osallistuu romaanin maailman tapahtumiin. Tätä jälkimmäistä kertojatyyppiä Genette kutsuu ekstradiegeettiseksi homodiegeettiseksi kertojaksi - erotuksena ekstradiegeettisestä heterodiegeettisestä kertojasta, joka ei osallistu kertomansa tarinan tapahtumiin. Toisaalta Paholaisen haarukassa näiden kahden ekstradiegeettisen kertojan erottamista toisistaan helpottaa se, että eräissä luvuissa ekstradiegeettinen heterodiegeettinen kertoja tarkastelee Lari Lainetta ulkoapäin (ks. PH, 7I, I72, 193-196, 205-207).

Lari Laineella on Paholaisen haarukassa toisessakin mielessä kaksoistehtävä. Yhtäältä hän antaa lukijalle informaatiota finanssimaailman toimintatavoista eli tässä suhteessa hän edustaa "kapitalismin itseymmärrystä". Nykyisen talousjärjestyksen asiamiehenä ja puolustajana hän 
kykeneekin esittämään huomattavasti terävämpiä analyyseja ja talousteoreettisia pohdiskeluja kuin Yhtiökumppaneiden Pete, jonka ajatusmaailma liikkuu pääosin oman yrityksen menestyksen turvaamisessa ja siinä, mikä koskettaa välittömästi häntä. Toisaalta Lari Laine on Paholaisen haarukassa myös kritiikin kohde. Kritiikkiä häntä ja nykykapitalismia kohtaan esittävät lähinnä hänen sisarensa elokuvaohjaaja Laura Laine ja teoksen sisäistekijä. Romaanin etenemistapa osoittaa, että kapitalistisen toimintarationaalisuuden sisäistänyt Lari Laine on itsekin aktiivisesti ylläpitämässä sitä maailmaa, joka luo syrjäytyneitä ja väkivaltaisiä yksilöitä, mutta tästä Lari Laine ja hänen luokkansa eivät ota moraalista ja yhteiskunnallista vastuuta. "Olet vastuussa itsestäsi, et muista ihmisistä. Etiikka on sitä, että juuri sinä toteutat itseäsi", toteaa hän eräässä yhteydessä (PH, III). Siten Lari Laineen esittämät tulkinnat maailmasta ovat rajoittuneita ja yksipuolisia - mutta eivät kokonaan epätosia, sillä muussa tapauksessa hänen henkilöhahmonsa avulla ei olisi mahdollista laatia uskottavaa kuvaa nykykapitalismista.

Anonyymin kertojan ja Lari Laineen kertomien lukujen ohella I3 lukua romaanista on omistettu Laura Laineen elokuvakäsikirjoitukselle; nämä luvut ovat otoksia tai kohtauksia hänen vieraantumista ja syrjäytymistä kuvaavasta elokuvakäsikirjoituksestaan. Romaanissa ne erottuvat muusta tekstistä siten, että niiden alkuun on aina laitettu merkintä "EXT" tai "INT". ${ }^{88}$ Kolme lukua muodostuu puolestaan verkkotuottaja Kari Lehtosen blogiteksteistä, ja yhdeksässä luvussa on useita eri kertojia. Noissa yhdeksässä luvussa äänessä ovat erilaisin yhdistelmin ja muunnoksin anonyymi kertoja, Lari Laine ja Laura Laine, minkä lisäksi niissä on mukana Kari Lehtosen blogitekstejä ja otteita Laura Laineen käsikirjoituksesta. ${ }^{89}$

Paholaisen haarukassa on siis kolme henkilökertojaa ja tarinamaailman ulkopuolinen, ekstradiegeettinen kertoja. Nuo henkilökertojat ovat varallisuudenhoitaja-sijoitusneuvoja Lari Laine, elokuvaohjaaja Laura Laine ja verkkotuottaja Kari Lehtonen. Muut henkilöt - Lari ja Laura Laineen isä kelloseppä Lauri Laine, Lari Laineen vaimo kirjastonhoitaja Johanna, Kari Lehtosen vaimo sosiaalipsykologi Saija Lehtonen, taksinkuljettaja Klaus ja hänen naisystävänsä Henna, Jumalan Kyynel ja hänen 
"isovanhempansa" Eero ja Rauha Raivio* - eivät juurikaan tule esiin omalla äänellään, vaan heitä koskeva informaatio on tavallisesti edellä mainittujen kertojien välittämää.

Samoin kuin Yhtiökumppaneissa, myös Paholaisen haarukassa henkilökertojat edustavat ylempiä yhteiskuntaluokkia. Alemmilla luokilla ei ole käytännössä tässäkään romaanissa omaa ääntä, vaikka kertojat tarkastelevat välillä romaanin maailmaa niiden kokemusmaailman näkökulmasta. Tästä huolimatta Paholaisen haarukka voidaan ymmärtää kritiikiksi ylempiä luokkia ja niiden ylläpitämää yhteiskuntajärjestystä kohtaan.

Laura Laine tekee Paholaisen haarukan maailmassa elokuvaa syrjäytymisestä ja vieraantumisesta. Lari Laine toimii ilmeisesti myös tämän elokuvan tuottajana, mikä selittää sen, että hän tuntee suurta mielenkiintoa sen tekemistä kohtaan ja esittää näkemyksiään elokuvan ja kulttuurin asemasta nykykapitalismissa. ${ }^{\circ}$ Romaani sisältää useita katkelmia Laura Laineen elokuvan käsikirjoituksesta, joka toimii romaanissa sisäkkäiskertomuksena ja romaanin todellisuutta kommentoivana mise en abyme -rakenteena. Elokuvassaan Laura Laine käsittelee erityisesti Jumalan Kyyneleeksi kutsumaansa nelikymppistä pitkäaikaistyötöntä miestä, joka ei ole perinteisen teollisuuskapitalismin hiipumisen jälkeen löytänyt itselleen mielekästä paikkaa yhteiskunnassa ja jonka oikeaa nimeä romaani ei mainitse. Nimen Jumalan Kyynel Laura Laine on antanut hänelle siksi, että miehen oikean korvan taakse on tatuoitu sinipunainen pisara. Elokuvassa häntä esittää palkattu näyttelijä. Romaanin todellisuudessa oikea Jumalan Kyynel on päihteiden monikäyttäjä, joka kuljeskelee kaupungilla uhkaavana ja herkästi väkivaltaan turvautuvana. Useissa eri yhteyksissä romaani rinnastaa hänet amerikkalaisen tv-yhtiön HBO:n tuottaman fiktiivisen Kylmä rinki -sarjan keskushenkilöön James Robsoniin, sadistiin, joka kärsii vankilatuomiota kadulla satunnaisesti tapaamansa mustan miehen murhasta (PH, 33, I99). Paholaisen haarukassa Jumalan

* Eero ja Rauha Raivio eivät Paholaisen haarukassa ole Jumalan Kyyneleen biologisia isovanhempia. He olivat häneen yhteydessä jo siinä vaiheessa, kun hän varttui sijaisperheissä, lastenkodissa ja nuorisokodissa. Hänen tultuaan täysi-ikäiseksi Eero Raiviosta tuli hänen "valvojansa" parin vuoden ajaksi, ja samalla "Eero-vaari" järjesti hänelle asunnon ja työpaikan ja auttoi muutoinkin häntä. Raiviot toimivat siis hänelle osittain isovanhempina ja sellaisina he loivat häneen kiintymyssuhteen. Ks. PH, 67, 144-147. 
Kyyneleen uhriksi valikoituu, ensi silmäyksellä sattumalta, Lari ja Laura Laineen isä kelloseppä Lauri Laine, jonka Jumalan Kyynel ruhjoo aivokuolleeksi iskemällä tarkkuuskellon hänen takaraivoonsa.

Paholaisen haarukassa metalepsis-strategiaa lähellä on myös se, että teoksen maailmassa todellisuutta ja siitä tehtyä esitystä (Laura Laineen ohjaama elokuva, Kari Lehtosen kirjoittamat blogitekstit) on toisinaan hankala erottaa toisistaan. Tässäkään ilmiössä ei silti ole ensi sijassa kyse konstruktionistisen ontologian ja epistemologian puolustamisesta. Pikemminkin Paholaisen haarukka pyrkii niiden avulla osoittamaan, että immateriaalisessa nykytaloudessa todellisuus ja todellisuutta koskevat esitykset tai representaatiot ovat monin paikoin kietoutuneet toisiinsa. Kansainvälisten situationistien johtohahmo Guy Debord (I93I-I994) ja hänen jälkeensä sosiologi-yhteiskuntafilosofi Jean Baudrillard (I929-2007) kuvasivat tätä ilmiötä käsitteiden spektaakkeli ja spektaakkeliyhteiskunta avulla. Paholaisen haarukka ei mainitse suoraan nimeltä näitä kahta teoreetikkoa, mutta sen eräissä kerrontajaksoissa Lari Laine pohdiskelee elokuvan ja "spektaakkelin" luonteen muuttumista nyky-yhteiskunnassa (PH, 43-46). Mr. Smith sisältää puolestaan avoimen viittauksen Baudrillardiin (Seppälä 20I2, 38-4I), mikä kertoo siitä, että Seppälä on tuntenut mielenkiintoa hänen ajatteluaan kohtaan.

Laura Laineen elokuvaan, Lari Laineen pohdiskeluihin ja Kari Lehtosen blogiteksteihin liittyy lisäksi siinä mielessä metakirjallinen funktio, että niissä pohditaan kirjallisuuden, elokuvan ja taiteen asemaa yhteiskunnassa. Tällainen metakirjallinen ulottuvuus läpäisee paljolti Paholaisen haarukan. Samoin romaani kuvaa yhtäältä Jumalan Kyyneleen syrjäytymistä ja Kari ja Saija Lehtosen avioeroon päättyvää suhdetta sekä toisaalta näitä kahta tapahtumaa käsittelevän elokuvan tekemistä. Näin nämä metanarratiiviset jaksot tematisoivat pohdiskelun kohteeksi sen, miten kirjallisuus ja taide representoivat todellisuutta.

Yhtiökumppaneiden tavoin Paholaisen haarukka hyödyntää rinnakkaiskerronnan tekniikkaa eli sen nopeaan tahtiin vaihtuvissa kerrontajaksoissa seurataan vuoron perään eri tarinalinjojen ja henkilöiden elämäntilanteen etenemistä. Koska henkilöt eivät juurikaan muutu kerronnan edetessä ja koska kerronnasta puuttuvat lähes kokonaan ajalliset kiinnekohdat eli maininnat tapahtumien ajankohdista, romaani synnyttää 
vaikutelman tapahtumien osittaisesta samanaikaisuudesta. Tätä vaikutelmaa vahvistavat Lari Laineen pohdiskelut nykyiselle "verkostoyhteiskunnalle" ominaisesta aikakäsityksestä:

Verkostoyhteiskunta tappoi, tuhosi lineaarisen ajan. Se ei tunnustanut aikavyöhykkeitä.

Ihmiset eläisivät miten sattui, eri tahdissa, ajasta ja paikasta piittaamatta. Ei teollisen ajan aikatauluja, pakkoja, standardeja, viikko ei alkaisi mistään eikä päättyisi mihinkään.

Aika oli satunnainen ja ajaton, sitä ei ollut.

Verkoston rakenteessa kello ei käynyt eikä pysähtynyt, se menetti merkityksensä.

Sitä ei tarvittu, koska reaaliaika oli aina ja kaikkialla. (PH, 228.)

Sitaatissa esitetty käsitys verkostoyhteiskunnasta ja sille ominaisesta "ajattomasta ajasta" on peräisin lähinnä Manuel Castellsilta, joka kuvaa sen avulla nykyistä, "informationaalista" kapitalismia. Castellsin mukaan keskeistä nykykapitalismissa on digitaalinen teknologia ja informaationsiirto, joiden avulla talous, erityisesti finanssisektori ja pääomamarkkinat ovat muuttuneet kansalliset rajat ylittäväksi, globaaliksi verkostoksi. Tämä maailmanlaajuinen verkosto on toiminnassa jatkuvasti, viikonpäivistä ja vuorokaudenajoista riippumatta. Siksi teolliselle yhteiskunnalle ominainen aikakäsitys, ajan osittaminen mekaanisesti tarkkoihin jaksoihin, menettää nyky-yhteiskunnassa merkitystään. Silti, Castells (2000, 465-466; 2004, I82-I83) jatkaa, aika on erityisen kallista uudelle talousjärjestelmälle, sillä siirtojen eli transaktioiden nopeus on siinä ratkaisevaa: tässä järjestelmässä tietokoneet analysoivat itse niihin tullutta informaatiota ja ne on ohjelmoitu tekemään päätöksiä ja suosituksia.

Samaan seikkaan, ajan kalleuteen, Kari Lehtonen viittaa eräässä blogitekstissään. Siinä hän puhuu siitä, että robottiensa avulla

maailman johtava taloustiedon välittäjä Thomson Financial pystyy julkistamaan ensimmäiset tulosuutisensa o,3 sekuntia sen jälkeen kun yhtiöt ovat julkaisseet osavuosikatsauksensa. Tietokannat ovat 
valmiina, robotti suhteuttaa uudet tiedot tietokantoihinsa ja tulostaa kokonaisin lausein uutiset siitä, täyttikö yhtiö odotukset vai ei. (PH, I7.)

Lari Laine ja Kari Lehtonen ovat molemmat tämän uuden talousjärjestelmän puolella, sen asiamiehiä. Vanhaa maailmaa, perinteistä teollista yhteiskuntaa romaanissa edustavat Jumalan Kyynel ja kelloseppä Lauri Laine, joille ajan mekaaninen osittaminen eripituisiin jaksoihin on vielä tärkeää; romaanin maailmassa he molemmat tuhoutuvat. Kriittistä näkökulmaa nykyiseen kapitalismiin edustavat romaanissa ennen kaikkea Laura Laine ja romaanin sisäistekijä.

Lari Laineen ja Kari Lehtosen esittämissä pohdiskeluissa nykyinen maailmanjärjestys käsitetään globaaliksi muodostumaksi, jossa talouselämän pyörät ovat käynnissä taukoamatta. Esittääkö Paholaisen haarukka myös tarinamaailmansa kautta nyky-yhteiskunnan tällaiseksi globaaliksi sosiaaliseksi tilaksi, ja jos se sen tekee, niin tuleeko se näin lähelle spatiaalisen eli tilallisen muodon käsitettä? Näihin kysymyksiin voi vastata toteamalla, että tarinamaailman tasolla kyseinen romaani näyttäisi kiinnittyvän suomalaiseen todellisuuteen, sillä esimerkiksi henkilöiden nimet ovat siinä järjestään suomalaisia. Sitä on kuitenkin vaikea lukea pelkkänä representaationa suomalaisesta yhteiskunnasta, sillä se ei korosta, että sen henkilöt elävät ja toimivat Suomessa; itse asiassa se ei missään vaiheessa kerro edes sitä, mihin kaupunkiin sen tapahtumat sijoittuvat.9 Tämä ja romaanissa esiintyvät pohdiskelut verkostoyhteiskunnan ja markkinakapitalismin luonteesta viittaavat siihen, että Paholaisen haarukka sisältää myös yleisemmän tason näkemyksen siitä, miten kapitalististen markkinoiden valtaan joutunut yhteiskunta toimisi ja millaisia seurauksia sen toiminatavoista on ihmisille.

Tavallisesti romaaneihin sisältyy sekä temporaalinen että spatiaalinen ulottuvuus. Edellinen oli romaaneissa pitkään, I900-luvun alkuun saakka hallitseva, mutta modernismista lähtien se on joutunut antamaan tilaa spatiaaliselle ulottuvuudelle. Tämän kehityskulun ääripisteeksi voi ajatella romaanityyppiä, joka luopuu täysin kronologisuudesta ja lineaarisuudesta. Tällainen tyyppi on tosin puhtaasti hypoteettinen rajaarvo, sillä käytännössä romaanin on vaikea luopua kokonaan ajallisen 
etenemisen vaikutelmasta ja romaanin lukeminenkin tapahtuu ajassa etenevänä prosessina. (Ks. Smitten \& Daghistany I98I.) Niinpä myös Paholaisen haarukkaan sisältyy selviä temporaalisia aineksia, vaikka se on Seppälän romaaneista lähimpänä spatiaalisen muodon käsitettä. Hänen romaaneissaan spatiaalinen ulottuvuus alkoi korostua Sydänmaasta (I994a) ja Kuun noususta ja laskusta (I999) lähtien. Sitä vastoin Sillassa (I988) aika on romaanin kokonaismerkityksen kannalta tärkeässä osassa, sillä Silta kuvaa tiettyä henkistä tai psyykkistä kehitysprosessia. Toisaalta Sydänmaassa, "historiallisessa romaanissa", ajassa etenevät prosessit eivät ole samalla tavalla merkityksellisiä. Sydänmaan pääteemana on ajatus olemassaolon raskaudesta, vieraudesta ja pohjimmaisesta tarkoituksettomuudesta, ja tällainen elämäntunnelma toistuu siinä yhä uudelleen ja uudelleen eri sukupolvien kuvauksissa.

Seuraavissa alaluvuissa tarkastellaan sitä, millaisen kuvan Paholaisen haarukka antaa markkinakapitalismista järjestelmänä tai "systeeminä", jonka toimintalogiikka on vallannut koko yhteiskunnan (toinen ja kolmas alaluku). Sen jälkeen käsitellään tähän romaaniin sisältyviä pohdiskeluita "riskiyhteiskunnasta" (neljäs alaluku) ja romaanissa kuvattuja naishahmoja (viides alaluku), joiden vapautumispyrkimysten se esittää osittain jääneen nykykapitalismin jalkoihin. Kuudes alaluku on omistettu solidaarisuuden ja yhteisöllisyyden rapautumisen teemalle ja vieraantumisen problematiikalle, ja seitsemännessä ja kahdeksannessa alaluvussa tarkastelun kohteena ovat Paholaisen haarukan metakirjalliset tasot. Yhdeksäs alaluku toimii yhteenvetona tässä pääluvussa käsitellyistä asioista.

\section{Markkinakapitalismi välinerationaalisena ja indifferenttinä systeeminä}

Millainen muodostuma markkinakapitalismi on järjestelmänä tai systeeminä, joka noudattaa omaa, erityistä rationaalisuusperiaatettaan? Paholaisen haarukka vastaa tähän kysymykseen erilaisten tarinalinjojen sekä keskushenkilöiden ja anonyymin kertojan esittämien pohdiskelujen avulla. Heti romaanin alussa tarinamaailman ulkopuolinen, anonyymi 
kertoja selvittää, millaisessa yhteiskunnassa masennuslääkkeitä käyttävä Jumalan Kyynel elää:

Hän eli systeemissä, jossa tehtiin strategisia päätöksiä instrumentaalisen järjen ohjaamana, systeemissä jota integroi raha ja hallinnollinen valta ja jossa voittajiksi selviytyneistäkin tiristettiin elämänvoima pikkuhiljaa, tasaisesti puristamalla, kuin oikeaoppisesti aseen liipasinta vetämällä, laukausten ja valehtelemisen hetkellä silmää räpäyttämättä. Silmiä räpäyttämättä systeemi toisti sanomaa, että talous toimii luonnonlakien alaisena vastaavalla tavalla kuin toimivat fysiikan lait.

Väkivalta oli ainut yhdistävä linkki hänen ja ympäröivän maailman välillä, kieli jota kumpikin käytti ja viime kädessä myös ymmärsi. (PH, ıо.)

Sitaatissa esiintyvä näkemys siitä, että kapitalismi toimii "instrumentaalisen järjen" ohjaamana, on alkuaan peräisin Weberiltä, mutta "myöhäismodernia" yhteiskuntaa kuvatessaan myös Habermas on käyttänyt samaa ilmaisua. Sitaatissa esiintyvät ilmaisut "systeemi", "strategiset päätökset", "systeemi jota integroi raha ja hallinnollinen valta" ovat lainauksia Habermasin pääteoksesta Theorie des kommunikativen Handelns (เ987a; เ987b). Siinä hän kuvaa myöhäismodernia taloutta ja politiikkaa järjestelmäksi, jota ohjaavat rahan ja hallinnollisen vallan mediat ja joka on yhä voimakkaammin tunkeutunut ihmisten elämismaailmoihin. $9^{2}$

Habermasin teoriaa systeemistä, jota ohjaa välineellinen tai instrumentaalinen järki, Paholaisen haarukka hyödyntää kuitenkin hieman toisin kuin miten Habermas itse puhui systeemistä ja sen suhteesta muuhun yhteiskuntaan. Habermasilla "systeemi", jolla hän siis tarkoitti kapitalistisen talouden ja kehittyneen sosiaalivaltion välistä liittoumaa, on kyllä kasvavassa määrin ulottanut lonkeronsa muualle yhteiskuntaan, myös ihmisten elämismaailmoihin, joissa oli aiemmin selvemmin vallalla kommunikatiivinen rationaalisuus. Mutta silti Habermas katsoi, että tämä prosessi, jossa systeemi "kolonialisoi" elämismaailmoja, ei ole kokonaan poistanut kommunikatiivista rationaalisuutta subjektien elämismaailmoista vaan lähinnä lisännyt niissä mielekkyyskriisien ja 
"patologisen" käyttäytymisen määrää. Sen sijaan Paholaisen haarukan kuvaamassa maailmassa kommunikatiivisen rationaalisuuden alue on kutistunut mitättömäksi saarekkeeksi yhteiskunnassa. Romaanin nykyisyydessä sitä edustaa lähinnä Laura Laine ja hänen syrjäytymistä ja vieraantuneisuutta käsittelevä elokuvansa.

Paholaisen haarukka (2008) ilmestyi 27 vuotta myöhemmin kuin Habermasin teorian ensimmäinen versio (I98I). Tämä ajallinen etäisyys ja sen kuluessa tapahtunut markkinallistumiskehitys selittävät osaltaan sitä, että subjektien elämismaailmat ovat Paholaisen haarukassa miltei tyhjentyneet kommunikatiivisesta rationaalisuudesta ja köyhtyneet samalla kulttuurisesti tai substantiaalisesti. Jumalan Kyyneleen ja Saija Lehtosen onnettomat elämäntilanteet ovat romaanissa selvimpiä esimerkkejä siitä, millaisia ongelmia ja vaurioita markkinalogiikan tunkeutuminen elämismaailmoihin aiheuttaa niissä eläville subjekteille. Silti tämä ei ole koko totuus kyseisen romaanin suhteesta reaaliseen yhteiskuntakehitykseen. Paholaisen haarukka ei pelkästään representoi todellisessa yhteiskunnassa tapahtunutta markkinallistumiskehitystä, vaan se kehittää sen pohjalta myös hahmotelman miltei läpikotaisin markkinallistuneesta yhteiskunnasta. Sen kuvaamasta fiktiivisestä yhteiskunnasta on paljolti karsittu pois sellaiset piirteet, jotka pehmentäisivät tuota kuvaa ja muistuttaisivat, että reaalisessa yhteiskunnassa on edelleen merkittäviä arvorationaalisen toiminnan muotoja. Habermas (20I2) on pitänyt demokratian syventämiseen tähtäävää kansalaisaktivismia tällaisen toiminnan yhtenä ilmentymänä, kun taas Alain Touraine (I992) mainitsee ympäristöliikkeen ja naisliikkeen esimerkkeinä toimintamuodoista, jotka edustavat kapitalistisesta voitontavoittelusta poikkeavaa tapaa järjestää yhteiskunta.

Nykykapitalismin Paholaisen haarukka esittää siis järjestelmäksi, jossa tavoitellaan välinerationaalisesti toimimalla mahdollisimman suurta liikevoittoa; järjestelmäksi, joka yhteiskunnan eri osa-alueille laajetessaan levittää välinpitämätöntä asennoitumista laadullisiin ja substantiaalisiin arvoerotteluihin. Paholaisen haarukan eräät jaksot täydentävät tätä Weberin ja Habermasin teorioihin pohjautuvaa näkemystä verkostoYhteiskunnan idealla, jonka pääkehittäjänä pidetään Manuel Castellsia. (Ks. PH, I7-I8, 227-228.) Tuo idea korostaa sitä, että uusliberalistisessa 
maailmanjärjestyksessä talouselämä on organisoitunut globaalien rahavirtojen ympärille: pääoman, hallinnan ja informaation maailmanlaajuisten verkostojen varaan. Perinteisiin, suhteellisen suljettuihin kansallisiin talousjärjestelmiin tai "kansantalouksiin" verrattuna näitä verkostoja voidaan luonnehtia avoimiksi ja dynaamisiksi järjestelmiksi, joissa tapahtuu jatkuvasti muutoksia ja joiden tulevaa kehitystä on hankala ohjata ja ennustaa (Castells 200o, 465-466, 476, 500-502). Paholaisen haarukan mukaan tällainen maailmanjärjestys ei marginalisoi ainoastaan Jumalan Kyyneleen kaltaisia alaluokkaisia ja heikosti koulutettuja ihmisiä vaan se tekee myös Saija Lehtosen tapaisesta korkeasti koulutetusta naisesta prekariaatin.

Oman viittauskohteensa Paholaisen haarukassa muodostaa uusliberalistinen diskurssi. Siinä keskeistä on ollut vaatimus, että valtion tulisi mahdollisimman pitkälle vetäytyä taloudellisen toiminnan harjoittamisesta ja sääntelemisestä ja muun yhteiskunnan ylläpitämisestä; sen sijasta yhteiskunnan tulisi toimia markkinaperustaisesti tai itseohjautuvasti. Uusliberalistinen itseohjautuvuuden idea tai ajatus itseään sääntelevistä markkinoista voidaan palauttaa Adam Smithin tunnettuun näkemykseen siitä, että suotuisissa olosuhteissa markkinamekanismi on ikään kuin "näkymätön käsi". Sen ohjaavan vaikutuksen alaisuudessa omia etujaan ajavien yksilöiden pyrkimyksistä muodostuu hyvin toimiva ja kaikkia palveleva yhteiskuntakokonaisuus. (Schmidt, Vivien Ann \& Thatcher 20I3b, 4-8.) Paholaisen haarukka viittaa eri yhteyksissä tähän itseohjautuvuuden ideaan, tavallisesti ironisessa ja parodisessa sävyssä (ks. PH, 57, 67). Laajimmin ajatus on esillä jaksossa, jossa sijoitusneuvoja Lari Laine pohdiskelee nykytalouden digitalisoitumista:

Ongelma on siinä, että edes te, jotka finanssoidussa todellisuudessa kuvittelette hallitsevanne elämäänne, ette tiedä mikä näkymätön käsi nyt on: itsekseen osakekauppaa käyvä ja sitä algoritmeillä ohjaava tietokoneorganismi, joka etsii jatkuvasti teknisen analyysin keinoin erilaisia trendejä, ja kun sellainen löytyy, alkaa vahvistaa sitä.

Vitsi on siinä, että kysymyksessä on Milton Friedmanin toteen käynyt vitsi. Friedman laski usein leikkiä: jos hän saisi päättää, kes- 
kuspankit perustuisivat niin puhtaasti taloustieteeseen, että niitä johtaisivat suurtietokoneet ihmisten koskematta. (PH, II7.)

Katkelma mainitsee nimeltä Milton Friedmanin (I9I2-2006), joka kuuluu uusliberalistisen talous- ja yhteiskuntateorian pääkehittäjiin. Sivuutan tässä kysymyksen siitä, missä yhteydessä Friedman on katkelmassa mainitun vitsin esittänyt. Tärkeämpää on pitää mielessä, että uusliberalistinen kapitalismi on kiinnittänyt erityishuomiota digitaalisen teknologian kehittämiseen. Tuon teknologian ansiosta se on pystynyt luomaan nykyisen kaltaisen globaalin talousjärjestyksen, jossa eri puolilla maailmaa sijaitsevat toiminta-alueet ovat jatkuvasti ja reaaliajassa yhteydessä toisiinsa ja jossa pääomaa ja valuuttaa voidaan tietokoneiden avulla siirtää nopeasti paikasta toiseen. Näin uusliberalismia on siivittänyt eteenpäin visio pitkälle digitalisoidusta taloudesta. (Castells 2000, 18, 28-76, 92, 465, 502.) Paholaisen haarukassa kyseinen katkelma ilmentää sitä, että käytännössä tuo visio on johtanut tilanteeseen, jossa talouspolitiikka erotetaan yhä selvemmin arvoista ja merkityskysymyksistä.

Ajatus siitä, että kapitalistinen talous noudattaa samanlaisia lakeja kuin luonto tai että sen perustana olevat lait ovat rinnastettavissa luonnonlakeihin, on ollut tavallinen kapitalismin puolustukseksi tarkoitetuissa ideologioissa. Tällaista vallitsevien taloudellisten toimintatapojen luonnollistamista on esiintynyt myös klassisessa ja uusklassisessa taloustieteessä sekä uusliberalistisessa ajattelussa. Niissä on oletettu, että kaikissa ihmisten ylläpitämissä yhteiskunnissa ja kaikkina aikakausina taloudellinen toiminta on perustunut välineelliseen rationaalisuuteen, maailman arvioimiseen etujen ja hyötyjen näkökulmasta. (Gilpin 200I, 46-76.) Sivulla 236 olevassa sitaatissakin anonyymi kertoja puhuu siitä, että "silmiä räpäyttämättä systeemi toisti sanomaa, että talous toimii luonnonlakien alaisena vastaavalla tavalla kuin toimivat fysiikan lait", ja samassa yhteydessä hän luonnehtii tällaista käsitystä "valehtelemiseksi". Tuon siteeratun kohdan viimeisessä kappaleessa kertoja esittää yleisemmällä tasolla kielteisen arvionsa nykyisestä talouden ja politiikan järjestelmästä. Siinä hän katsoo nykyisen talouden ja politiikan järjestelmän harjoittavan rakenteellista väkivaltaa Jumalan Kyyneleen kaltaisia, työelämästä syrjäytettyjä yksilöitä kohtaan, jotka vastaavat tähän väkivaltaan 
periaatteessa samalla tavalla, aggressiivisella ja väkivaltaisella käyttäytymisellä.

Sivulla 236 siteerattu kohta pitää myös ankaraa taloudellista kilpailua, "jossa voittajiksi selviytyneistäkin tiristettiin elämänvoima pikkuhiljaa, tasaisesti puristamalla", nykykapitalismin keskeisenä tunnuspiirteenä. Kansallisten yhteiskuntien ja maailmantalouden avaaminen markkinavoimille ja yritysten väliselle kilpailulle on I970- ja I980-luvun vaihteesta lähtien ollut keskeinen elementti uusliberalistisessa käytännön politiikassa. Tätä avaamista uusliberalismi on perustellut oletuksella, jonka mukaan taloudellisten toimijoiden välinen markkinakilpailu johtaa koko yhteiskunnan kannalta parhaimpaan mahdolliseen tulokseen, siihen, että kilpailussa voittajiksi selviytyvät lopulta parhaimpia tuotteita ja palveluja tarjoavat yritykset. (Castells 2000, 96-98, I37; Schmidt, Vivien Ann \& Thatcher 20I3a, 4-5.) Paholaisen haarukassa taloudellinen kilpailu ja kansallisten talouksien avautuminen globaaleille markkinavoimille nähdään toisessa valossa. Sivulla 236 olevan sitaatin jälkeen anonyymi kertoja puhuu siitä, että Jumalan Kyynel oli menettänyt työpaikkansa konepajalla juuri siitä syystä, että konepajan omistanut teollisuusyritys oli siirtänyt toimintansa ulkomaille. Uusliberalismin pohjalta organisoidussa maailmanjärjestelmässä tällaiset siirtymiset ovat olleet tavallisia ilmiöitä. "Avoimessa" tai "vapaassa" maailmantaloudessa yritykset voivat periaatteessa aina siirtää toimintansa sellaisiin maihin, jotka tarjoavat niille aiempaa edullisemmat toimintaedellytykset ja laajemmat mahdollisuudet arvonlisäykseen.

Paholaisen haarukassa uusliberalismin kritiikkiä edustaa niin ikään se, että romaani käsittelee nykytaloudelle ominaista kilpailua niiden ihmisten kannalta, jotka tällainen kilpailu syrjäyttää työelämästä (Jumalan Kyynel) tai sysää pätkätöihin (taksikuski Klaus, sosiaalipsykologi Saija Lehtonen). Toisaalta romaani osoittaa, että ankaralla kilpailulla on vakavia seurauksia myös ylemmille luokille. Pankkimies Lari Laine luonnehtiikin nykykapitalismia rahantekokoneeksi, jota hän on sitoutunut pitämään käynnissä:

Olin kytkenyt elämäni ja kohtaloni rahaan, eikä minulla ollut oikeutta valittaa. En pitänyt itseäni kansalaisena, olin rahan puolella. 
Koska suuryrityksillä ei ollut perimmäisiä oikeuksia ja velvollisuuksia samalla tavalla kuin ihmisillä oli - ne olivat pelkkiä rahan tekemistä varten rakennettuja koneita - ei minullakaan niitä ollut. Nuo koneet olivat määritelmällisesti itsekkäitä. Olin asettunut vetämään niiden vankkureita. Ylämäessä saatoin silti joskus puuskuttaa ja suupieliini saattoi ilmestyä vaahtoa. Mikä oli elämän tarkoitus? Saada ihmiset luovuttamaan rahansa pankille tietyllä korolla ja lainata ne niille takaisin suuremmalla korolla.

Mutta minä elin tulevaisuutta, kapitalistista aikaa, protestanttista siirrettyjen nautintojen aikaa. Minulla ei ollut mahdollisuutta elää täyttä elämää juuri nyt, tässä hetkessä. (PH, 79.)

Tässä kapitalismin ydinsisällöksi määrittyy voittojen kasaaminen, pyrkimys "saada ihmiset luovuttamaan rahansa pankille tietyllä korolla ja lainata ne takaisin suuremmalla korolla”. Sitaatissa Lari Laine esittää myös kysymyksen elämän tarkoituksesta. Sen voi ymmärtää koskevan kysymystä siitä, riittääkö voittojen kasaaminen ihmiselämän tarkoitukseksi, tai kysymystä siitä, missä määrin kapitalismin toimintatapa ottaa huomioon ihmisten eksistentiaaliset tarpeet. Sitaatin loppu viittaa siihen, että finanssipääoman toimintakäytäntöjä pyörittäessään Lari Laineen on pakko sivuuttaa eksistentiaaliset tarpeensa. "Täyttä elämää" tai aidosti merkityksellistä elämää hän uskoo voivansa elää vasta myöhemmin, työuransa jälkeen.

Kyseiseen sitaattiin on upotettu aineksia Weberin teoksesta Protestanttinen etiikka ja kapitalismin henki (I980, saksankielinen alkuperäisteos ilmestyi I904-I906). Siinä Weber kuvaa, miten uudella ajalla muotoutunut protestanttinen yrityskulttuuri suhtautui torjuvasti nautintoihin, kulutukseen ja suureelliseen elämäntapaan, joita protestanttiset yrittäjät pitivät poikkeamina Jumalan säätämästä elämänjärjestyksestä. Omaa elämäntapaansa, sitä, että hän "eli tulevaisuutta, kapitalistista aikaa, protestanttista siirrettyjen nautintojen aikaa", Lari Laine ei perustele tällä tavalla, uskonnollis-moraalisesti. Hänen kohdallaan pidättyväisyyttä ja tiukkaa itsekontrollia painottavalla elämäntavalla on puhtaasti maallinen perusta, sillä hänen työnsä pankki- ja finanssimaailmassa vaatii melko kokonaisvaltaista omistautumista ja sitoutumista. Tällaisen protestantti- 
sen työeetoksen maallistuneen muodon on tutkimuksessa todettu olevan tavallinen suomalaisen yläluokan vauraimmassa kerrostumassa, jonka edustajat siirtyvät usein joutilaaseen elämänvaiheeseen vasta yritystoiminnasta tai talouselämän johtotehtävistä luovuttuaan (Kantola \& Kuusela 2019, I45-I47).

Edellä olevassa sitaatissa Lari Laine luonnehtii suuryrityksiä "rahan tekemistä varten rakennetuiksi koneiksi". Kapitalismin rinnastaminen ei-inhimillisiin, mekaanisiin koneistoihin on ollut tavallista rationalisaatiokriittisessä perinteessä. Jo Weber (I980, I26) puhui siitä, että I500-I700-luvuilla eläneet askeettiset protestanttiset yrittäjät saattoivat muuttua pelkiksi omaisuuden "hankintakoneiksi", jotka pidättäytyivät nauttimasta työnsä tuloksista. Samoin taloushistoriallisissa tutkimuksissa on esitetty, että ı80o-luvulla vallinneen yksityisyrittäjyyden kauden jälkeen kapitalistista talouselämää alkoivat hallita osakeyhtiöt ja erilaiset liittoutumat. Tämän myötä perheyritysten rooli talouselämässä kutistui ja keskeiseen asemaan nousivat suuryritykset ja niiden palkatut toimitusjohtajat, "sieluttomat teknokraatit". Sivuilla 240-24I oleva sitaatti on mahdollista ymmärtää tätä taustaa vasten, mutta sen voi suhteuttaa myös Paholaisen haarukan ilmestymisajankohtaan.

Suomessa vuonna 2006 uusitun osakeyhtiölain viidennessä pykälässä todetaan, että osakeyhtiön "toiminnan tarkoituksena on tuottaa voittoa osakkeenomistajille, jollei yhtiöjärjestyksessä määrätä toisin".93 Tämä laki koskee sinänsä sekä liiketoimintaan keskittyviä osakeyhtiöitä että asunto-osakeyhtiöiden kaltaisia yhtiöitä, joista jälkimmäiset eivät tavallisesti toimi liiketaloudelliselta pohjalta. Siksi laki ei velvoita osakeyhtiöitä tavoittelemaan voittoa, mutta toisaalta se pitää sitä niiden toiminnan perustarkoituksena. Liiketaloudelliselta pohjalta toimivat osakeyhtiöt, esimerkiksi liikepankit, eivät siten ole yleistä hyvää tavoittelevia yhteenliittymiä vaan, niin kuin Lari Laine toteaa, "määritelmällisesti itsekkäitä", omaa etuaan ajavia toimijoita. Entinen, I970-luvulta peräisin ollut osakeyhtiölaki ei sisältänyt edellä mainitun pykälän kaltaista kohtaa. Sen sijasta se kuvasi lähinnä osakeyhtiöiden järjestysmuotoa ja hallintatapaa. Vuonna 2006 uusitun osakeyhtiölain taustana oli uusliberalismin nousun myötä tapahtunut ajatustavan muutos. Tutkimuksessaan Huipputuloiset Anu Kantola ja Hanna Kuusela (2019, 57) huomauttavat, että 
valtaosan I900-lukua yritykset kyllä kasvoivat, mutta se ei välttämättä vaurastuttanut omistajia. Tuolloin ei nimittäin jaettu muhkeita osinkoja, ja lisäksi verotus tasasi tehokkaasti mahdollisia osinkotuloja. Siksi moni suuromistaja on saattanut rikastua henkilökohtaisesti vasta I9०o-luvun lopusta lähtien, jolloin yritykset ja osakeyhtiöt on alettu nähdä ennen kaikkea omistajiensa vaurastumisen välineiksi.

Tästä näkökulmasta ei ole yllättävää, että voittoa tavoittelevat liikeyritykset esitetään Paholaisen haarukassa toimijoiksi, jotka laittavat liiketaloudelliset näkökohdat muiden, esimerkiksi moraalisten tai yhteisöllisten, näkökohtien edelle. Romaani esittää niiden toimivan tässä mielessä indifferentillä tavalla. Indifferenssi-motiivi esiintyy Paholaisen haarukassa selvimmin niissä kohdissa, joissa Lari Laine kuvailee työtään varallisuudenhoitajana ja sijoitusneuvojana. Näissä hän toteaa, että työssään hän ei voi kertoa koko totuutta pankkinsa tarjoamista sijoituspalveluista ja niiden tarkoitusperistä, sillä tällainen tieto karkottaisi sijoituspalveluja ostavat asiakkaat. Olennaista sijoituspalveluissa on se, että niissä riskit, kulut ja mahdolliset tappiot jäävät asiakkaiden kontolle, heidän maksettavakseen, kun taas pankki pääsee aina voitolle esimerkiksi laskuttamalla tarjoamistaan neuvontapalveluista ja ottamalla osansa sijoitustoiminnan mahdollisesta tuotosta. Pankkien ja finanssipääoman toiminta perustuu siten osittain tietojen salaamiseen ja asiakkaiden harhauttamiseen. Arvioidessaan pankkien toimintaa yleisemmin moraalisesta näkökulmasta Lari Laine toteaa, että

me etsimme aluetta jossa tiesimme tekevämme moraalisesti väärin mutta emme tehneet mitään rikollista. Me esimerkiksi sanoimme yhdistävämme yksityissäästäjille tärkeän tasaisen tuottokehityksen ja korkeamman tuottopotentiaalin sekä hallitun riskinoton. (PH, 229.)

Näiden kolmen asian lupaaminen on siitä syystä moraalisesti väärin, että käytännössä niitä ei ole aina mahdollista yhdistää toisiinsa ja ne voivat myös sulkea toisensa pois. Annettuaan lisää esimerkkejä pankkitoiminnasta Lari Laine toteaa lakonisesti: "Me huijasimme" (PH, 230). Yhtiökumppaneiden Peten tavoin hän on sisäistänyt kyynisen toimintatavan 
eli hän katsoo, että yksikkönsä menestymisen vuoksi hänen on pakko toimia tavalla, jota niin hän kuin muutkin ihmiset pitävät moraalisesti arveluttavana. (Ks. myös ibid., 3I, 37-42, 9I-92, I52-I56.)

Edellä mainittuja jaksoja täydentävät mantelitumakkeeseen viittaavat tekstikohdat. Laajimmin mantelitumakkeesta puhuu jakso, jossa taksikuski Klaus saapuu kelloseppä Lauri Laineen liikkeeseen (PH, 95-IO०). Katsellessaan ja ihaillessaan Lauri Laineen rauhallista, järjestelmällistä ja päättäväistä työskentelyä Klaus pohtii, "oliko tuon miehen aivojen etulohkossa tunnemuistia ja tunnereaktioita ohjaavaa mantelitumaketta" (ibid., 97). Klaus on siis perillä siitä, että nykyisen neurologisen tietämyksen mukaan aivojen ohimolohkoissa sijaitsevat kaksi mantelinmuotoista neuronien ryhmää toimivat tunnereaktioiden ja niihin liittyvien merkitysten prosessoimisen keskuksena. Ja edelleen, ilman mantelitumaketta ihminen olisi avuton arvo- ja merkityskysymysten käsittelemisessä:

Jos asioiden tunnearvo katosi, niiden käsitteleminen kävi mahdottomaksi. Ihmiset, joilta oli syystä tai toisesta poistettu mantelitumake, ajattelevat äärimmäisen loogisesti mutta eivät pysty vertailemaan rationaalisen päättelyn pohjalta syntyneitä vaihtoehtoja keskenään. Kaikki vaihtoehdot ovat samanarvoisia, yhtä tärkeitä tai merkityksettömiä. (PH, 97.)

Puhujana tässä on joko tarinamaailman ulkopuolinen, anonyymi kertoja tai Klaus - ilmeisesti jälkimmäinen, sillä katkelman jälkeen teksti jatkuu taas selvemmin Klausin pohdiskeluilla. Paholaisen haarukassa viittaus aivoihin, joista on poistettu mantelitumake, toimii metaforana nyky-yhteiskunnasta. Se viittaa siihen, että markkinavoimien hallitsema nyky-yhteiskunta toimii muodollisesti ajatellen yhä rationaalisemmin tehokkaammin ja tuottavammin -, mutta tällaisen kehityksen hintana on se, että yhteiskunta on vaarassa ajautua arvorationaalisessa tai substantiaalisessa mielessä mielivaltaisilta ja järjettömiltä vaikuttaviin toimintatapoihin. Tämä kehitys on myös päästänyt yhteiskunnassa irti irrationaaliset voimat, joita ruumiillistaa romaanissa selvimmin Jumalan Kyyneleen kaltainen, sisäisesti rikkonainen ja aggressiivisesti käyttäytyvä 
henkilöhahmo. ${ }^{94}$ Näin kapitalismi on usein ymmärretty myös weberiläis-habermasilaisessa traditiossa, jossa kapitalistisen rationalisaation paradoksina pidetään sitä, että myöhäismodernissa muodossaan se uhkaa kääntyä vastakohdakseen, tuottaa maailmaan patologioita ja irrationaalisia ilmiöitä (Zima 200I, 47-I23). ${ }^{95}$

\section{Kaikkialle ulottuva markkinadominanssi}

Paholaisen haarukka eroaa Yhtiökumppaneista siinä, että ensiksi mainitun maailmassa eletään lähes täydellisessä markkinadominanssin tilanteessa. Markkinoiden ylivalta yhteiskunnassa tulee ilmi jo heti Paholaisen haarukan alussa, jossa kuvataan Jumalan Kyyneleen sotkuista elämää:

Hän seisoi ikkunan ääressä ja katseli alas aukiolle, jonka suuria lehmuksia tuuli riepotteli. Ihmiset puskivat kävellen tuulta vastaan. Ukkonen jyrähti pari kertaa etäämpänä.

Hän seisoi korkealla ja oli Jumala.

Depzac, Fontex, Seronil.

Purkkeja lojui hänen yksiönsä komeron hyllyillä puoliksi syötyinä, irrallisia pillereitä oli siellä täällä tiskipöydällä ja lattialla.

Pahan olon poistamiseksi hänelle oli tarjottu samoja asioita, jotka olivat aiheuttaneet sen. Järjestelmä, joka oli tehnyt hänet sairaaksi, lupasi poistaa hänen sairautensa. Epäilemättä joku teki hänen ahdistuksellaan rahaa.

Fevarin, Seroxat, Zoloft.

Minä en saa nukuttua. (PH, 9. Kursivointi alkuperäisen tekstin. Tekstissä esiintyvät vieraskieliset nimet ovat uni- ja masennuslääkkeiden nimiä.)

Katkelma on pääosin tarinamaailman ulkopuolisen anonyymin kertojan esittämä. Hän rinnastaa kuvaamansa henkilön hetkellisesti Jumalaan, ja hieman myöhemmin Lari ja Laura Laine kutsuvat omissa kerrontajaksoissaan kyseistä mieshahmoa Jumalan Kyyneleeksi. Miehen oikeaa 
nimeä ei romaanissa mainita, mikä alleviivaa sitä, että tällaiset syrjäytyneet ihmiset eivät tavallisesti pääse itse määrittelemään itseään. Pikemminkin he ovat muiden, lähinnä poliitikkojen, sosiaalityöntekijöiden ja terveysviranomaisten määrittelyvallan alaisia. Vain lyhyt kursivoitu kohta katkelmassa on Jumalan Kyyneleen omaa, suoraa sisäistä puhetta.

Oheinen katkelma viittaa myös siihen, että markkinakapitalistisesta järjestyksestä ei ole ulospääsyä. Tuo järjestys tuottaa pahaa oloa, mutta siinä pahan olon lievittäminenkin on markkinallistettu, muutettu lääketeollisuuden pyörittämäksi liiketoiminnaksi, mikä puolestaan voimistaa markkinakapitalismia ja tuottaa yhteiskuntaan lisää pahaa oloa: "Pahan olon poistamiseksi hänelle oli tarjottu samoja asioita, jotka olivat aiheuttaneet sen. Järjestelmä, joka oli tehnyt hänet sairaaksi, lupasi poistaa hänen sairautensa. Epäilemättä joku teki hänen ahdistuksellaan rahaa.” Yhteiskunta kieltäytyy siis kajoamasta pahan olon syihin, markkinoiden valta-asemaan yhteiskunnassa; sen sijasta yhteiskunta siirtää nuo ongelmat yksilötasolle ja muuntaa ne lääkkeillä hoidettaviksi yksilöpsykologisiksi ongelmiksi. Tässä mielessä Paholaisen haarukan kuvaama fiktiivinen yhteiskunta edustaa täysin "yksiulotteista" maailmaa, totaalista markkinadominanssia.

Ilmaisu "yksiulotteinen yhteiskunta" on peräisin Frankfurtin koulua edustavan Herbert Marcusen teoksesta One-Dimensional Man (I964). Hän kritisoi sen avulla teknologisessa mielessä pitkälle rationalisoitunutta modernia teollisuusyhteiskuntaa, josta yhdysvaltalainen kapitalismi oli hänen mukaansa kehittänyt oman versionsa ja neuvostoliittolainen reaalisosialismi omansa. Marcuse katsoi, että nuo molemmat yhteiskunnat pakottivat ihmiset elämään ja työskentelemään yksilöitä, yhteiskuntaa ja ympäristöä tuhoavan teollisen suurtuotannon ja massiivisen kulutuksen järjestelmässä. Paholaisen haarukka ei sisällä suoria viittauksia Marcuseen, mutta sen tapa käsitellä nykykapitalismia ei ole kaukana Marcusen esittämästä rationaalisuuskritiikistä.

Paholaisen haarukassa Lari Laine esittää laajoja pohdiskeluja älymystön muuttuneesta roolista yhteiskunnassa (s. I74-I77). Nämä pohdiskelut ovat kyynisen finanssipääoman edustajan näkemyksiä, mutta myös niissä toistuu epäsuorasti ajatus siitä, että arvorationaalisuuden alue on katoamassa yhteiskunnasta. Pohdiskeluissaan Lari Laine tekee eron 
"todellisen älymystön" ja "lehmänhenkiälymystön" välille. Hänen mukaansa hänen sisarensa, elokuvaohjaaja Laura Laine kuuluu "epäilemättä” jälkimmäiseen ryhmään. Tämä ryhmä on perinteisesti muodostunut kirjailijoista, taiteilijoista, tutkijoista ja yhteiskunnallisten liikkeiden edustajista. Julkisuudessa se on käynyt kriittistä keskustelua yhteiskunnallisista ongelmista - romaanin maailmassa Laura Laine tekeekin elokuvaa syrjäytymisestä ja vieraantumisesta, aiheista, joita on perinteisesti pidetty tärkeinä kapitalismikriittisissä liikkeissä ja kulttuuripiireissä. "Todellinen älymystö" ei kuitenkaan toimi enää näin. Se on valinnut toisenlaisen linjan:

Jos todellisen älymystön edustaja oli käynyt teatterikoulun, hän oli ajoissa etsiytynyt töihin Nokialle, perustanut oman tuotantoyhtiön tai sumeilematta laskuttavan ajatuspajan. Muutamia muita ajattelevia ihmisiä, jotka pystyivät kovaan, analyyttiseen ajatteluun (käsittämätöntä oli, että muutamat heistä yhä pystyivät toimimaan akateemisella statuksella) pidettiin kavahduttavina kylähulluina. (PH, I74.)

"Todellinen älymystö" toimii talouselämää hyödyttävissä tehtävissä akateemisen kapitalismin ja luovan talouden piirissä, osa-alueilla, joissa se keskittyy tuottamaan innovaatioita eli kaupallisesti hyödynnettävissä olevia tutkimuksia ja niiden teknologisia sovelluksia. Se on täysin välttämätön osatekijä nykyisessä taloudellisessa arvonmuodostusprosessissa. "Lehmänhenkiälymystön" tilanne on ristiriitaisempi. Vaikka myös se on joutunut mukautumaan markkinallistumiskehitykseen, se on pitänyt toisella kädellään kiinni vanhasta roolistaan ja saavuttamistaan eduista. Siksi sen julkinen esiintyminen on usein todellista sisältöä vailla olevien, näennäiskriittisten eleiden toistamista: "Lehmänhenkiälymystöön kuuluvat eivät edustaneet muuta kuin opiskelijaromantiikkaa, poliittista laululiikettä tai hyväntekeväisyysrokkia. Lehmänhenkeä nostattavat eivät halunneet luopua mistään, saavutetuista eduista, julkisuudesta, älykön statuksestaan" (PH, I74). Lari Laine luonnehtii tätä kerrostumaa älyllisesti epärehelliseksi: se on olevinaan kriittinen taloutta ja poliittista järjestelmää kohtaan, mutta samalla se on siitä miltei täysin riippuvainen. 
Vaikka Lari Laineen puheet ilmentävät halveksuntaa perinteistä älymystöä kohtaan, niissä on tietty järkevä ydin. Jos nimittäin sosiologit, hallinnon asiantuntijat ja taiteilijat osallistuivat Suomessa laajan hyvinvointivaltion kaudella (I965-1990) aktiivisesti erilaisten palvelujen ja järjestelmien kehittämiseen, niin nykyiseen, markkinaperustaiseen yhteiskuntaan siirryttäessä he ovat paljolti menettäneet tämän asiantuntijavaltansa suuryritysten johtajille, ekonomisteille, managereille ja taloudellisten innovaatioiden kehittäjille. Juuri tällä ryhmällä on nykyisin sellaista asiantuntijavaltaa, joka ennen kuului perinteiselle älymystölle. Lari Lainekin pitää ongelmana sitä, että tämä uusi älymystö elää liiaksi teknisen ja välineellisen rationaalisuuden maailmassa: "Moraalista tai etiikasta en ole puhunut sanaakaan. Toivoisin, että todellisella älymystöllä olisi sitä nykyistä enemmän. Olemmeko tulleet kehityksessä vaiheeseen, jossa moraali ja äly sulkevat toisensa pois? Kieltämättä vähän pelkään, että niin on” (PH, I77). Tämän tutkimuksen käyttämän käsitteistön kielellä kyse on siitä, että tuo uusi älymystö on luomassa maailmaa, jossa ei ehkä ole enää sijaa arvorationaalisuudelle.

Sama ajatusmotiivi, arvorationaalisuuden katoaminen maailmasta kapitalismin edetessä, toistuu Paholaisen haarukan lopussa. Siinä Lari Laine esittää näkemyksiään nykyisestä globaalista "verkostoyhteiskunnasta", jossa digitaaliseen teknologiaan perustuvan, tietokoneistetun talouselämän pyörät pyörivät taukoamatta. Tuo globaali verkostoyhteiskunta on "maailma vailla mantelitumaketta. Siinä maailmassa Jumalan Kyynel eli." (PH, 228.) Nykyinen maailmanjärjestys toimii siis ilman kykyä tehdä johdonmukaisesti laadullisia tai substantiaalisia arvoerotteluja; sen rationaalisuus on tässä mielessä kyseenalaista. Paholaisen haarukassa tämän suuntainen arvio ei tule esiin ainoastaan Lari Laineen pohdiskeluissa, vaan se on myös romaanin sisäistekijän ja kokonaisrakenteen välittämä käsitys nykykapitalismista.

Kuvatessaan yhteiskunnan ajautumista lähes täydelliseen markkinoiden ja välineellisen järjen dominoimaan tilaan Paholaisen haarukka ei ole nykykirjallisuudessamme yksin. Sen välittämä näkemys nyky-yhteiskunnasta muistuttaa tietyiltä osin läheisesti sitä kuvaa "myöhäismodernista yhteiskunnasta", jonka G. H. von Wrightin filosofista esseistiikkaa edustava Myten om framsteget (I993) esittää. Kirjassaan von Wright 
(I993, 47-60, 68-82, II4-II6, I22-I23, I46-I49) puhuu Habermasiin tukeutuen "teknosysteemistä", joka muodostuu kapitalistisesta taloudesta ja siihen kiinni kasvaneesta teknologiasta ja tieteestä. Tämän järjestelmän kehitystä ohjaa pyrkimys jatkuvaan taloudelliseen kasvuun ja kansalaisten kulutusmahdollisuuksien lisäämiseen, minkä takia siitä on tullut vakava uhka sekä ympäristön kestokyvylle että mielekkäiden elämänmuotojen säilymiselle. Von Wrightin mukaan se, että kyseinen globaalisti toimiva teknosysteemi dominoi yhteiskuntaa ja sen kehitystä, kertoo yleisemmin siitä, että hallitseva järjen muoto ja moraaliset arvot ovat lopullisesti erkaantuneet toisistaan (ks. myös Söndergaard Christensen 2020, I90-I9I).

Romaanin alueella Paholaisen haarukan sukulaisteoksia ovat Tommi Melenderin Ranskalainen ystävä (2009) ja Arto Salmisen romaanit. Ranskalaisessa ystävässä päähenkilö, "mielikuvateollisuuden" palveluksessa oleva ja Flaubertin tuotantoa ihaileva Joel pakenee tympeäksi kokemaansa työtään Ranskaan, jota hän on pitänyt eurooppalaisen hengenelämän keskuksena. Surukseen hän kohtaa sielläkin markkinavoimien hallitseman maan, joka kärsii myös maahanmuuton mukanaan tuomista ristiriidoista, ammattimaisista rikollisliigoista ja ihmiskaupasta ja jossa kutistunut julkinen sektori ja poliisivoimat ovat menettämässä kykynsä ylläpitää yhteiskuntarauhaa (ks. Melender 2009, 228-238). Salmisen romaaneissa Paskateoria (2001), Ei-kuori (2003) ja Kalavale (2005) markkinallistuminen ei ole näin selvästi romuttanut järjestäytynyttä yhteiskuntaa, vaikka niissäkin esiintyy puolirikollisia sivuhenkilöitä. Niitä yhdistää Melenderin romaaniin se, että niidenkin kuvaamassa markkinaperustaisessa maailmassa ihmisten on tultava toimeen omin avuin: yrittämällä kaupata markkinoilla työvoimaansa, mahdollista erityisosaamistaan tai seksuaalisuuttaan - tai, jos tämä ei ole mahdollista, antautumalla Big Brother -tyyppisen viihdebisneksen käyteaineeksi, niin kuin Kalavaleessa tapahtuu. (Ks. myös Ojajärvi 20I6; Sevänen 20I4b.)

Rationalisaatiokriittisessä nykykirjallisuudessa Michel Houellebecqin romaanit Alkeishiukkaset (2000, ranskankielinen alkuperäisteos ilmestyi I998) ja Oikeus nautintoon (200I, ranskankielinen alkuperäisteos ilmestyi 2000) ja Don DeLillon Cosmopolis (2003, englanninkielinen alkuperäisteos ilmestyi 2003) kuvaavat nykyistä yhteiskuntaa siinä mielessä 
samalla tavalla kuin edellä mainitut Seppälän, Melenderin ja Salmisen romaanit, että niidenkin mukaan markkinoiden valta yhteiskunnassa on käymässä totaaliseksi. Houellebecqin romaanit eivät tosin aihepiirinsä osalta ole lähellä edellä mainittuja romaaneja, sillä ne käsittelevät markkinakäyttäytymisen leviämistä avioliiton, perhe-elämän, ihmissuhteiden ja seksuaalisuuden alueelle - "primitiivisen kommunismin viimeiselle saarekkeelle" (Houellebecq 2000, I24). Ne jakavat silti Seppälän, Melenderin ja Salmisen romaanien kanssa näkemyksen, jonka mukaan elämme nykyisin markkinavoimien lähes täysin dominoimassa maailmassa. Siinä, missä Paholaisen haarukassa lääketeollisuus toimii kapitalismin yksiulotteisuuden ilmentäjänä, Houellebecqin romaaneissa vastaavanlaisessa asemassa ovat, niin kuin Hanna Meretoja (2008b; 2008c) toteaa, porno ja seksiteollisuus: ne lupaavat markkinavoimien vieraannuttamille yksilöille, erityisesti miehille, hetkellistä poispääsyä kapitalistisen välinerationaalisuuden maailmasta, mutta koska ne ovat itsekin osa tuota maailmaa, ne pohjimmiltaan vain vahvistavat sitä ja lisäävät yksilöiden vieraantumista toisistaan (ks. myös David 20I3).

DeLillon Cosmopoliksessa ajatus siitä, että nyky-yhteiskunnassa kapitalististen markkinoiden ulkopuolinen alue on katomassa, tuodaan esiin toisin. Siinä tätä motiivia ilmentää kohtaus, jossa finanssialalla toimiva monimiljonääri Eric Packer ja hänen "teoriapäällikkönsä" Vilja Kinski istuvat New Yorkin liikenneruuhkassa edellisen loistoauton takapenkillä ja kommentoivat ympärillään marssivia, kapitalismia vastustavia mielenosoittajia:

"Sinä tiedät, mitä porvariluokka tuottaa. Marxin ja Engelsin mukaan."

"Omat haudankaivajansa", Eric sanoi.

"Mutta nämä eivät ole haudankaivajia. Tämä on itse markkinatalous. Nämä ihmiset ovat markkinoiden luoma fantasia. Heitä ei ole olemassa markkinoiden ulkopuolella. Sen ulkopuolella heillä ei ole paikkaa minne mennä. Ulkopuolta ei ole olemassa."

Kamera seurasi poliisia, joka ajoi takaa nuorta miestä väkijoukossa, ja kuva tuntui olevan jonkin löysän välimatkan päässä hetkestä. 
"Markkinakulttuuri on totaalista. Se synnyttää nämä miehet ja naiset. He ovat välttämättömiä järjestelmälle, jota he halveksivat. He antavat sille energiaa ja merkityksen. He saavat käyttövoimansa markkinoista. Heitä kaupataan maailmanmarkkinoilla. Juuri siksi he ovat olemassa, virkistääkseen ja vahvistaakseen järjestelmää. (DeLillo 2003, I06-I07.) ${ }^{96}$

Sitaatissa esiintyvä ajatus siitä, että kapitalismi tuottaa ennen pitkää omat haudankaivajansa, vallankumouksellisen proletaariluokan, on peräisin Marxin ja Engelsin Kommunistisen puolueen manifestista (ks. Marx \& Engels I978, 348; saksankielinen alkuperäisteos ilmestyi I848). DeLillon romaanissa työväenluokka ja mielenosoittajat nähdään kuitenkin toisessa valossa kuin Marx ja Engels ne näkivät. Mielenosoittajien toiminta ei ole lakkauttamassa tai heikentämässä kapitalismia vaan, niin kuin Vilja Kinski toteaa, pikemminkin he pohjimmiltaan vain virkistävät ja vahvistavat sitä järjestelmää, jota vastaan he ajattelevat marssivansa (DeLillo 2003, I07). Tässä mielessä aito vastarinta kapitalismia kohtaan on DeLillon romaanin kuvaamassa maailmassa käynyt mahdottomaksi.

Paholaisen haarukkaa ja edellä mainittuja Melenderin, Salmisen, Houellebecqin ja DeLillon romaaneja voidaan pitää rationalisaatiokriittisinä teoksina, jotka sisältävät aikalaistodellisuutta käsittelevälle spekulatiiviselle fiktiolle ominaisen ulottuvuuden. Ne kuvaavat siis yhtäältä oman aikansa yhteiskuntaa, mutta sen ohella ne sisältävät myös hahmotelman siitä, millainen läpikotaisin markkinallistunut yhteiskunta olisi nykytietämyksen valossa. Näin sanoessani oletan, ettei edes Cosmopolis ole ole mimeettisen tarkka kuvaus markkinavoimien asemasta Yhdysvalloissa, vaan sekin kiinnittyy markkinallistumiskehityksen kielteisiin puoliin ja niihin liittyviin uhkakuviin, joita se käsittelee romaanilogiikkansa mukaisesti liioitellen. (Vrt. Hall \& Soskice 200I; Harvey 2008.)

Vaikka Paholaisen haarukan fiktiivinen maailma rakentuu markkinoiden tukahduttavan ylivallan varaan, vastarinta ei siinä kaikesta huolimatta ole kokonaan kadonnut. Romaanin tarinamaailmassa sitä edustavat lähinnä Jumalan Kyynel ja Laura Laine. Jumalan Kyyneleen osoittama vastarinta on luonteeltaan summittaista ja viime kädessä absurdia. Se ei horjuta ollenkaan sitä järjestelmää, joka on vastuussa hänen syrjäyty- 
misestään ja jota vastaan hänen aggressiivinen käyttäytymisensä suuntautuu. Se johtaa vain viattoman sivullisen, kelloseppä Lauri Laineen kuolemaan. Sen sijaan Laura Laineen osoittama vastarinta on luonteeltaan toisenlaista. Hän käyttää kritiikkinsä ja vastarintansa välineenä elokuvantekoa, taidetta, jonka avulla hän tematisoi tarkastelun kohteeksi yhteiskunnassa esiintyvän vieraantumisen ja syrjäytymisen. Tähän problematiikkaan palataan lähemmin luvun lopussa.

Paholaisen haarukan narratiivisessa rakenteessa henkilökertojien yläpuolella ovat ekstradiegeettinen heterodiegeettinen kertoja ja sisäistekijä. Romaanissa esiintyvä ekstradiegeettinen heterodiegeettinen kertoja on asenteiden ja arvostelmien ilmaisemisen suhteen pidättyväinen. Hänen välttelee suorien luonnehdintojen ja arvostelmien esittämistä henkilöistä, ja tavallisesti hän rajoittuu heidän ulkoisen käyttäytymisensä niukkasanaiseen kuvaamiseen. Toisaalta romaanin sisäistekijä harjoittaa ankaraa kapitalismikritiikkiä. Sen hän tekee tapahtumien järjestämisen ja niiden etenemissuunnan avulla. Niiden kautta hän näyttää, millaisiin tuhoisiin seurauksiin (vieraantuneisuus, syrjäytyminen, absurdi väkivalta) markkinoiden valta-asema yhteiskunnassa johtaa.

Rationalisaatio-teemaan keskittyvän kapitalismikriittisen romaanin traditiossa on tietty kehityssuunta. Siinä, missä Balzacin romaaneissa provinssit toimivat markkinoiden valtaaman pariisilaisen elämänmuodon vastakohtana, I900-luvulla arvorationaalisuuden alue alkaa tendenssinomaisesti kutistua rationalisaatiokriittisten romaanien kuvaamassa maailmassa. Niin kuin aiemmin on todettu, jo H. G. Wellsin tulevaisuus-dystopiassa Kun nukkuja herää (200I, alkuperäisteos ilmestyi I899), samoin kuin tämän lajin toisessa klassikossa eli Aldous Huxleyn romaanissa Uusi uljas maailma (I984, alkuperäisteos ilmestyi I932), modernin kapitalismin, (luonnon)tieteen ja teknologian välinen liitto on johtanut autoritaariseen yhteiskuntaan, joka pyrkii lakkauttamaan kokonaan kriittisen ajattelun, sen mukana myös kirjallisuuden ja taiteen siinä mielessä kuin moderni länsimainen kulttuuri on ne käsittänyt. Toisaalta vielä Toivo Pekkasen romaanissa Tehtaan varjossa (I93I) perhe, ystävät, rakkaussuhde, kirjat, lukeminen ja yksinäisyyskin edustavat Samuel Oinolle vapauden aluetta, jonka vastakohtana on teolliskapitalistiselle yhteiskunnalle ominainen vierasmääritteinen työ ja 
koneiden säätelemä elämänrytmi. Pentti Haanpään Noitaympyrässä (kirjoitettu I93I, julkaistu I955) Pate Teikalle tällaista vapautta edustaa luonto ja - niin kuin hän romaanin loppuratkaisussa järkeilee - mahdollisesti myös Neuvostoliitossa meneillään ollut sosialistinen yhteiskuntakokeilu. Näihin verrattuna uudemmissa rationalisaatiokritiikeissä on yleistynyt nyky-yhteiskunnan esittäminen muodostumaksi, jonka markkinalogiikka on alistanut ja tukahduttanut miltei täysin valtansa alle. Tällaisille romaaneille on usein ominaista motiivi, jota voidaan Anthony Giddensiin (200I, 9) tukeutuen kutsua eksistentiaaliseksi isolaatioksi. Siinä ei ole Giddensin mukaan kyse pelkästään siitä, että yksilöt olisivat vieraantuneet omasta itsestään ja toisistaan, vaan yleisemmin siitä, että nyky-yhteiskunnassa yksilöt ovat etääntyneet sellaisista välineistä ja "moraalisista resursseista", jotka mahdollistaisivat tyydyttävän ja arvokkaaksi koetun elämän. Paholaisen haarukan henkilöt näyttävät Melenderin ja Salmisen romaanien henkilöiden tavoin kärsivän juuri tällaisesta vieraantumisesta.

Edellä mainittua lajihistoriallista kehityssuuntaa voidaan selittää yhtäältä sillä, että ı8oo-luvulta lähtien kapitalismi ja markkinat ovat ohjanneet yhä laajemmin yksilöiden ja yhteiskuntien elämää, ja toisaalta sillä, että tämä reaalihistoriallinen kehitys on herättänyt yhteiskunnassa, erityisesti älymystön ja kirjailijoiden piirissä, kasvavaa huolta siitä, millaiseen maailmaan olemme matkalla. Nykyistä tai tulevaa yhteiskuntaa kuvaavan rationalisaatiokriittisen romaanin kehityksessä kuvastuvat nämä molemmat puolet. Koska tällaiset romaanit sisältävät usein spekulatiiviselle fiktiolle ominaisia piirteitä, ne eivät välttämättä toimi oman aikansa reaalisen yhteiskunnan tarkkoina representaatioina. Siksi esimerkiksi Kari Hotakaisen Luonnon laki (2013) näyttää tavoittavan Paholaisen haarukkaa osuvammin sen tilanteen, jossa suomalainen hyvinvointivaltio on viime vuosina ollut.

Siinä, missä hyvinvointivaltio ei juurikaan tule esiin Paholaisen haarukan maailmassa, Hotakaisen romaanin keskushenkilö, maalämpöyrittäjä Jussi Rautala, toipuu vaikeasta autokolarista juuri sen ansiosta, että valtio maksaa suuren osan hänen hoitokuluistaan. Hotakaisen romaanissa hyvinvointivaltio ei silti ole nykyisessä muodossaankaan mikään itsestäänselvyys, sillä romaani käsittelee samalla siihen liittyviä uhka- 
kuvia. Erityisesti se pohtii hyvinvointivaltion tulevaisuutta, sitä, onko nykyisen hyvinvointivaltion rahoitus realistisella pohjalla ja millaisia uusia leikkauksia siihen saatetaan tehdä. (Vrt. Ojajärvi 20ı6.) Tässä suhteessa Luonnon laki ei turvaudu yhteiskunnallisten ongelmien kärjistävään käsittelytapaan, ja hyvinvointivaltion säilymiseen liittyvän problematiikan osalta se toimii Paholaisen haarukkaa selvemmin Suomessa viime vuosikymmeninä vallinneen tilanteen analyyttisenä kuvauksena. Sitä vastoin Paholaisen haarukka luo fiktiivisen yhteiskunnan, jossa hyvinvointivaltio on käytännössä jo paljolti menettänyt toimintakykynsä.

\section{Riskiyhteiskunta ja ekologiset näkökohdat}

Paholaisen haarukassa eletään yhteiskunnassa, josta puuttuu vakaus ja turvallisuus ja jossa ihmisten tulevaisuusperspektiivi on lyhyt. Henkilöillä ei ole juurikaan suunnitelmia tulevaisuuden varalle, eikä romaanin kerronta anna lukijalle laajalti tietoa heidän - lukuun ottamatta Jumalan Kyyneltä ja Saija Lehtosta - menneisyydestään. Muutoin kaikki tuntuu romaanissa tapahtuvan tässä ja nyt, romaanin nykyhetkessä. Tällaiset kerronnalliset ratkaisut alleviivaavat nykykapitalismin nopeatempoisuutta. Globaalin digitalisoidun talouden aikakaudella ratkaisevaa finanssimarkkinoiden kannalta on pääoma- ja valuuttasiirtojen, transaktioiden nopeus, finanssialan toimijoiden kyky siirtää varallisuutta ja resursseja aina nopeasti sinne, missä mahdollisuudet taloudelliseen arvonmuodostukseen ja lisäarvon tuottamiseen ovat optimaaliset. Kun tällainen "kvartaalitaloudelle" ominainen toimintatapa leviää yhteiskuntaan, tuloksena on elämänmuoto, jossa yksilöiden on vaikea rakentaa pitkäkestoisia elämänprojekteja lyhytkestoisten työprojektien ja toimintamuotojen varaan.

Tätä nykykapitalismin aiheuttamaa elämäntapaan liittyvää muutosta yhdysvaltalainen sosiologi Richard Sennett on eritellyt lähemmin kirjoissaan Työn uusi järjestys. Miten uusi kapitalismi kuluttaa ihmisen luonnetta (2002, englanninkielinen alkuperäisteos ilmestyi I998) ja Uuden kapitalismin kulttuuri (2007, englanninkielinen alkuperäisteos ilmestyi 2006). Niissä hän esittää, että klassisen laissez-faire-kapitalismin kaudel- 
la yhteiskunnalle olivat ominaisia rajut taloudelliset kriisit ja suhdannevaihtelut, joiden edessä alemmat luokat olivat paljolti suojattomia. Tähän kauteen verrattuna I9०o-luvun jälkipuoli, laajan hyvinvointivaltion kausi, kykeni tuomaan yhteiskuntaan ennakoitavuutta, järjestystä ja pitkäkestoisuutta - rakenteellisia ominaispiirteitä, joita uusliberalistinen nykykapitalismi on taas uudelleen korvannut lyhytkestoisilla ja ennakoimattomilla toimintamuodoilla. Näin ajateltaessa nykykapitalismi pakottaa yksilöt elämään epävarmuudessa ja vailla selkeitä tulevaisuusperspektiivejä.

Vakaiden rakenteiden purkautuminen ja siirtyminen "joustaviin" toimintatapoihin tuottaa myös yhteiskunnan ja elämäntavan, jota luonnehtivat erilaiset riskit. Paholaisen haarukassa sijoitusneuvoja ja varallisuudenhoitaja Lari Laine toteaakin, että

Yhteiskunta koostuu riskeistä ja riskinotosta: ruoan alkuperä ja puhtaus, terrorismi, ennakoimaton väkivalta, sairaudet, sairaalabakteerit, virukset, liikenneonnettomuudet, osakekurssien volatiliteetti. Toisia riskejä on kontrolloitava, toisten ottamiseen kannustetaan. Vähiten riskejä ottavat ne, joilla on varaa olla ottamatta.

Me valitsemme erilaisten riskien välillä ja asetamme niitä järjestykseen. (PH, 88.)

Ammattinsa puolesta Lari Laine on itsekin tekemisissä taloudellisten riskien kanssa - tai hän opettaa asiakkaansa olemaan tekemisissä niiden kanssa -, sillä sijoitustoiminnan perustana oleva tieto osakekurssien ja markkinoiden tulevasta kehityksestä on enemmän tai vähemmän epävarmaa. Vielä pidemmälle riskejä hyödyntää romaanin Mr. Smith keskushenkilö Smith, jonka ammattina on riskienhallinta. Talouden osa-alueena riskienhallinta kuvastaa tietyssä määrin nykykapitalismin kehämäistä luonnetta, osittain samaan tapaan kuin talouden rakenteiden tuottaman masentuneisuuden hoitaminen pelkillä lääketeollisuuden tuotteilla tai vieraantuneisuuden hoitaminen pornon ja seksiteollisuuden palveluksilla. Globaali kapitalistinen talousjärjestys sekä siihen liittyvä massiivinen kulutuskulttuuri ja liikkuvuuden lisääntyminen tuottavat erilaisia kollektiivisia ja yksilöllisiä riskejä, joita tämä järjestel- 
mä pyrkii sääntelemään antamalla niiden käsittelemisen liiketaloudelliselta pohjalta toimivien yritysten tehtäväksi. Niklas Luhmannin (I997a, 60-9I) teoriassa tällaiset ilmiöt edustavat sosiaalisten järjestelmien rekursiivista ja autopoieettista toimintatapaa. "Rekursiivisuus" merkitsee tässä sitä, että talous käyttää aiempia operaatioitaan ja tuotoksiaan (aiheuttamiaan riskejä) hyväksi uusissa operaatioissaan (riskienhallinta). "Autopoieettisuudessa" on puolestaan kyse siitä, että talous käsittelee työstämäänsä materiaalia (riskit) omien, erityislaatuisten (liiketaloudellisten) toimintatapojensa mukaisesti (ks. myös Sevänen 200I; 2006).

Paholaisen haarukka esittää kielteisessä valossa Jumalan Kyyneltä vaivaavan masentuneisuuden hoitamisen lääkkeillä. Ongelmana romaanin mukaan tässä tapauksessa on se, että lääketeollisuuden tuotteet eivät puutu itse ongelmien syihin, talouden rakenteisiin, minkä vuoksi masentuneisuuden hoitaminen pelkillä lääkkeillä pohjimmiltaan vain voimistaa tätä järjestelmää ja tuottaa sitä kautta yhteiskuntaan lisää vieraantuneisuutta. Liiketoimintana harjoitettua riskienhallintaa Seppälän romaanit eivät aseta aivan samalle viivalle lääketeollisuuden ja pornon tai seksiteollisuuden kanssa. Silti se, mitä Paholaisen haarukka sanoo Jumalan Kyyneleestä, ilmastonmuutoksesta ja ekologisista riskeistä, vihjaa siihen, etteivät nämä ilmiöt ole sen mukaan kovin kaukana toisistaan.

Paholaisen haarukkaan sisältyvä näkemys nyky-yhteiskunnasta epävakaana riskiyhteiskuntana on velkaa sosiologi Ulrich Beckille, jonka romaani avoimesti mainitseekin eräässä yhteydessä (ks. PH, 205). Riskiyhteiskunnan käsitteen Beck toi yleiseen tietoisuuteen kirjallaan Risikogesellschaft - auf dem Weg in eine andere Moderne (I986). Se kuvaa siirtymistä klassisen teollisuusyhteiskunnan tai yksinkertaisen moderniteetin kaudesta nykyiseen yhteiskuntakehityksen vaiheeseen, "refleksiiviseen moderniteettiin". Tässä uudessa vaiheessa yhteiskunnan instituutiot ja yksilöt asettavat modernin yhteiskunnan lähtöasettamukset entistä tietoisemman, refleksiivisemmän arvioinnin kohteeksi, mutta samalla kyseinen vaihe merkitsee siirtymistä teollisen yhteiskunnan vakaista rakenteista ja turvajärjestelyistä riskien ja epävarmuuksien leimaamaan maailmaan. Refleksiivisessä moderniteetissa riskien, esimerkiksi ympäristökatastrofien, estäminen tai niiden rajoittaminen paikallisiksi onnettomuuksiksi käy vaikeaksi. Samoin refleksiivinen moderniteetti murtaa 
maaperää entisten kollektiivisten instituutioiden (kansakunta, luokka, poliittinen ryhmä) ja niihin liittyvien identiteettipositioiden alta, ja se työntää ihmisiä maailmaan, jossa he ovat "tuomitut yksilöitymään" tai "tuomitut vapauteen" ja tulemaan yhä enemmän toimeen omin voimin.

Puhuessaan siitä, että nyky-yhteiskunnassa ihmiset on "tuomittu yksilöitymään”, Beck käyttää hyväksi Sartren tekstejä, joiden mukaan ihminen on maailmassa "tuomittu vapauteen". Sartre (I973; 2007) luonnehti tällä ilmaisulla ihmisen osaa universumissa. Sitä käyttäessään hän viittasi siihen, että pyrkiessään antamaan elämälleen ja olemassaololleen merkitystä ihmiset eivät voi turvautua kosmiseen järjestykseen ja jumaliin. Päinvastoin he ovat periaatteessa vapaita tekemään elämästään sellaisen kuin he itse haluavat. Tämän, ihmisen eksistentiaalisen tilanteen tajuaminen herättää heissä kuitenkin helposti myös ahdistusta, sillä sen mukaan he ovat itse vastuussa siitä, millaisen merkityksen he löytävät tai eivät löydä omalle elämälleen. Näin Sartre kuvasi ihmisen eksistentiaalista tilannetta maailmassa. Beckillä (I99I; I995) ilmaisu "tuomittu yksilöytymään" kuvaa ensi sijassa sitä, että yhteiskuntakehityksen nykyinen vaihe hajottaa entiset kollektiiviset turvajärjestelyt ja pakottaa ihmiset ottamaan itse vastuun elämästään. Tällainen tilanne on hänen mukaansa tehnyt eksistentiaaliset kysymykset viime vuosikymmeninä uudelleen ajankohtaisiksi ihmisten arkielämässä.

Leimallista Beckin ajattelulle on myös se, että käsitellessään siirtymistä moderniteetin kehityksen nykyiseen vaiheeseen hän ei anna kapitalistiselle taloudelle erityisasemaa eikä hän palauta tuota siirtymää pelkäksi kapitalistisen talouden kehityslogiikan ilmentymäksi. Pikemminkin talous on hänelle vain yksi ulottuvuus ja vain yksi yhteiskuntaa liikuttava tekijä refleksiivisen moderniteetin ilmaantumisessa. Tähän verrattuna Seppälän romaanin välittämä kuva riskiyhteiskunnasta kiinnittyy selvemmin talouteen.

Jumalan Kyyneleen elämäntilanteen, hänen syrjäytymisensä, Paholaisen haarukka selittää taloudessa tapahtuneiden rakennemuutosten seuraukseksi. Jumalan Kyyneleen elämäntilanteen sidosta talouteen korostaa romaanissa myös se, että hänen masennustaan hoidetaan lääkkeillä eikä terapialla, kuntoutuksella tai laitoshoidolla. Kulkiessaan vapaana ihmisten keskuudessa tämä uhkaavasti ja aggressiivisesti käyttäytyvä 
mies merkitsee siksi riskiä muille. Hän edustaa juuri sellaista yllättävää väkivaltaa, jonka kohteeksi ihmiset voivat arkielämässään joutua. Romaanin maailmassa hän iskeekin olutpullon rikki erään nuorukaisen päähän kadulla ja myöhemmin hän päätyy kelloseppä Lauri Laineen liikkeeseen ja ruhjoo tämän aivokuolleeksi:

Olennaista on tietenkin tietää, huomata, että isäni valikoitui Jumalan Kyyneleen uhriksi sattumalta, vahingossa, mielijohteesta, siksi että hänellä oli isästäni muistijälki, signaali joka laukaisi hänen aivoissaan jotakin, askelten kääntymisen kohti ovea ja oven avaamisen, väkivallanteon. ( $\mathrm{PH}, 238$.)

Kertojana tässä on sijoitusneuvoja Lari Laine. Sitaatissa tulee esiin hänen kaksoisluonteensa. Yhtäältä hän välittää lukijalle informaatiota romaanin maailmasta, mutta samalla hän osoittautuu välillä kertojana epäluotettavaksi. Tässä tapauksessa hän tulkitsee sitaatissa kuvattua väkivallantekoa puutteellisesti, ja hänen tulkintansa on ristiriidassa sen näkemyksen kanssa, jonka romaanin kokonaisuus kyseisestä tapahtumasta välittää. (Vrt. Phelan 2005, 49-52.) Kelloseppä Lauri Laineen päätyminen Jumalan Kyyneleen harjoittaman väkivallan uhriksi on toki sikäli satunnaista, että Lauri Laineen sijasta uhriksi olisi tässä tapauksessa voinut valikoitua joku toinen henkilö - mikäli Jumalan Kyynel vain olisi kaupungilla harhaillessaan kulkenut toisenlaisia reittejä. Mutta romaanin maailmassa se, että Jumalan Kyynel ylipäänsä käyttäytyy väkivaltaisesti, ei ole satunnainen ja selittämätön ilmiö, vaan romaani kuvaa sen markkinallistumiskehityksen väistämättömäksi seuraukseksi. Satunnaista romaanin maailmassa on lähinnä vain se, mihin tuo väkivaltaisuus kulloinkin kohdistuu.

Paholaisen haarukka käsittelee myös ekologisten riskien ja katastrofien mahdollisuutta suhteessa talouteen. Romaanissa esiintyvät tämän suuntaiset, lähinnä ilmastonmuutosta koskevat pohdiskelut ovat sijoitusneuvoja Lari Laineen ja verkkotuottaja Kari Lehtosen esittämiä. Yhteistä näille pohdiskeluille on ajatus, että nykyinen elämämuoto on rakennettu taloudellisen kasvun varaan ja tätä kasvua on puolestaan ylläpidetty uusiutumattomilla energiavaroilla, erityisesti öljyllä ja kivihiilellä. 
Tämä asetelma on Lari Laineen ja Kari Lehtosen mukaan aiheuttanut nykyisen ilmastonmuutoksen ja sen seurannaisvaikutukset. (PH, I22I24, 259-260.) Niiden ratkaisemiseksi he molemmat esittävät siirtymistä talouteen, joka käyttää uusiutuvia energiavaroja ja jossa on luovuttu alati kasvavien kulutusmahdollisuuksien vaatimuksesta. Ongelmana on kuitenkin se, että ihmiset eivät ole valmiita tällaiseen muutokseen. "Minä en luovu mistään. Minä syön ja ostan lisää. Me ostamme lisää. Meidän kirkkomme ei luovu ihokkaastaan, se sijoittaa", toteaa Lari Laine pohdiskelujensa lopuksi (ibid., I24). Samoin blogikirjoituksissaan Kari Lehtonen huomauttaa, että "meidän elämämme on rakennettu taloudellisen kasvun idean varaan, me tiedämme sen emmekä todellisuudessa ole valmiita luopumaan yhtään mistään henkilökohtaisessa elämässä saavutetusta. Meidän sormemme ovat selän takana ristissä” (ibid., 259).

Mihin ilmaisu "me" näissä yhteyksissä viittaa? On hedelmällistä ajatella, että se ei luo viestinnällistä yhteyttä pelkästään Lari Laineen ja tekstinsisäisten, fiktiivisten lukijoiden välille tai Kari Lehtosen ja hänen bloginsa lukijoiden välille. "Me" voidaan näissä yhteyksissä ymmärtää myös yleisemmällä tasolla. Tällöin kyseiset kohdat kääntyvät todellisten lukijoiden puoleen ja muistuttavat heitä siitä, että "meidän" kulutuskäyttäytymisemme ja elämäntapamme on sisäisesti ristiriitainen: vaikka me tiedämme, että elämänmuotomme sisältää vakavia ekologisia riskejä, me emme ole yksilötasolla valmiita muuttamaan sitä. Nykyiset yhteiskunnat pitävät siis yllä laajaa massakulutusta siitäkin huolimatta, että ne tietävät kulutuksen olevan ekologisesti kestämätöntä. Näin konsumeristishedonistinen asenne, "mielihyväperiaate", on saanut niissä yliotteen tiedollisista argumenteista tai tietoon perustuvasta, substantiaalisesti rationaalisemmasta luontosuhteesta.

Edellä mainituissa ekologisissa pohdiskeluissa tulee jälleen esiin sijoitusneuvoja Lari Laineen ajattelun ja toiminnan kaksijakoisuus. Hän on tietoinen siitä, että talouskasvun ideologia on ekologisesti kestämätön, mutta samalla hän on valinnut sijoitustoimintansa kohteiksi erilaisia "uudistuvien energialähteiden" ja "kestävän kehityksen" hankkeita, joiden hän toivoo olevan rahallisesti tuottoisia. Samassa yhteydessä hän huomauttaa yleisemmällä tasolla, että nykymaailmassa taloudellisen ja poliittisen eliitin intressit "olivat yhteiset: taloudelliseen kasvuun ja pää- 
omien vapaaseen liikkumiseen oli poliittisesti sitouduttu, sääntely oli purettu" (PH, 2I4). Nykykapitalismiin on siis sisäänrakennettu kasvun ja laajenemisen pakko, kun taas politiikan mainitseminen viittaa tässä lähinnä siihen, että varmistaakseen itselleen riittävän kannatuksen vaaleissa poliitikkojen on luvattava kansalaisille alati kasvavia kulutusmahdollisuuksia. Tämä asetelma tuottaa talous- ja yhteiskuntapolitiikkaa, jossa vallitseviin ekologisiin ongelmiin puututaan vain siinä määrin kuin se on mahdollista nykyisten taloudellisten ja poliittisten valtarakenteiden ja nykyisen kasvuideologian puitteissa. Paholaisen haarukan tarjoama näkemys tulevaisuudesta on näiltä osin pessimistinen. ${ }^{97}$

Romaani ennustaakin, että perustava muutos yhteiskunnassa tulee tapahtumaan vasta sitten, kun vallitseva talous- ja yhteiskuntapolitiikka on johtanut maailman syviin sosiaalisiin ja ekologisiin katastrofeihin. Niiden jälkeen yhteiskunta on pakko organisoida uudella tavalla:

Ei, me emme tee mitään ennen kuin on pakko.

Ennen kuin suurkaupunkien slummit tyhjenevät ihmisistä, jotka lähtevät etsimään syötävää ja juotavaa ja jotka saavat tarpeekseen siitä että heidän nälkäänsä käytetään taloudellisen spekulaation välineenä.

Me emme luovu mistään.

Ennen kuin kansat vaeltavat Venäjältä tulleiden tappajamehiläisten parvien lailla, mehiläisten joiden keskinäinen viestintä on pahasti häiriintynyt.

Me emme luovu mistään, ennen kuin meiltä otetaan.

Ennen kuin vesi Afrikasta loppuu ja ennen kuin antilooppien, norsujen ja seeprojen ikiaikaiset vaellusreitit haihtuvat kuumaan tuuleen ja suurlaumat pirstoutuvat kaikkeen maailmaan.

Ennen kuin maailmasta loppuu ruoka.

Ennen kuin suursateet saapuvat Etelä-Amerikan länsirannikolle ja alueen jyrsijäkanta lisääntyy räjähdysmaisesti ja alkaa levittää ruttobakteeri yersinia pestistä sitä kantavissa kirpuissa. (PH, I23I24. Kursivointi alkuperäisen tekstin.) 
Kertojana sitaatissa on sijoitusneuvoja Lari Laine, joka on - niin kuin edellä todettiin - tietoinen siitä, että nykyinen taloudellis-poliittinen maailmanjärjestys on ekologisesti kestämätön. Silti hän jatkaa työtään kyseisessä järjestyksessä tai "systeemissä" sen määrittämin ehdoin.

Paholaisen haarukka sisältää siten ekologisen dystopian aineksia. Se ei kuitenkaan lähde kehittelemään niitä pidemmälle vaan tyytyy lähinnä viittaamaan niiden avulla ekologisten katastrofien mahdollisuuteen. Se ei myöskään juuri astu ihmiskeskeisen, antroposentrisen maailmankuvan ulkopuolelle - alueelle, jota on käsitelty runsaasti viime vuosikymmeninä lisääntyvää mielenkiintoa herättäneessä posthumanistisessa ajattelussa. Seppälän romaanissa selvimmin tälle alueelle menee verkkotuottaja Kari Lehtonen eräässä blogikirjoituksessaan:

Eikö sekin, että me ajattelisimme maapallon nimenomaisesti ihmiselle jätettäväksi, edusta pikemminkin hybristä kuin järkeä? Onko ollut jotenkin järkevää saattaa maapallo tähän kuntoon?

Miksi ihmisen pitäisi olla viimeinen luomakunnan olento, joka patsastelisi maan päällä? Mehän tiedämme sitä paitsi, että monet eliölajit - jopa nisäkkäisiin kuuluvat, kuten mustarotat - voivat varsin hyvin vielä tilanteessa, jossa ihmisen ei enää hyödytä edes rukoilla luojan armoa. Mistä se filosofinen varmuus ja itsestäänselvyys, että maapallon pitäisi säilyä iäti? (PH, 259-260. Kursivointi alkuperäisen tekstin.)

Kari Lehtonen tarkastelee siis hetkittäin maailmaa ihmisyhteiskunnan ulkopuolisesta näkökulmasta. Hänelläkin tällaisten pohdiskelujen lähtökohta on silti ihmiskeskeinen, sillä blogikirjoituksissaan hän on ensi sijassa huolestunut siitä, millaisia mahdollisia tuhoisia seurauksia massakulutukseen perustuvalla talousjärjestyksellä on ihmislajille ja ihmisyhteiskunnalle. 


\section{Teosten ihmissuhteet, naishahmot ja seksuaalisuuden alueen tavaroituminen}

Paholaisen haarukassa toistuu kaksi kertaa ilmaisu "Sano hintasi". Ensimmäisellä kerralla sen esittää tarinamaailman ulkopuolinen anonyymi kertoja ja toisella kerralla sijoitusneuvoja Lari Laine. (Ks. PH, 2I, 23I.) Ilmaisu painottaa sitä, että markkinakapitalismin valtaamassa yhteiskunnassa miltei kaikelle on mahdollista määrittää vaihto- tai myyntiarvo. Tällaisessa yhteiskunnassa myös ihmisen kyvyistä ja ominaisuuksista on tullut tavaroita, kaupankäynnin kohteita. Lari Laine jatkaa, että elokuvaohjaaja Laura Laine - niin älymystöön kuin hän kuuluukin - ei ole oivaltanut kunnolla tätä puolta yhteiskunnasta:

Hän ei tiedä, että ihminen on tavara jolle määrätään hinta. Thomas Hobbes sanoi että ihmisen arvo on se hinta, jonka kuka vain joutuisi markkinoilla maksamaan oikeudesta käyttää tämän kykyjä ja avuja omana mahtinaan.

Ihmiset eivät tiedä, siksi eivät pelkää. (PH, I34.)

Ensi sijassa ihmisten kykyjen ja avujen tavaroituminen koskee Paholaisen haarukassa sitä, miten kapitalistinen talous käsittelee ihmisiä. Mutta romaani esittää, että tällainen suhtautumistapa on kasvavassa määrin levinnyt myös ihmisten elämismaailmoihin, erityisesti ihmissuhteiden ja seksuaalisuuden alueelle.

Seppälän kapitalismikriittisen kauden romaaneista ainoastaan Paholaisen haarukka tematisoi laajemmin tarkastelun kohteeksi edellä mainitun ilmiön, markkinalogiikan leviämisen ihmisten välisiin suhteisiin ja seksuaalisuuden alueelle. Yhtiökumppaneista ja Mr. Smithistä tällainen tarkastelu puuttuu paljolti, jos kohta niistä edellinen kiinnittää huomiota siihen, millaisia ongelmia korostunut kapitalistinen eetos sekä työn kuormittavuuden ja kilpailullisuuden lisääntyminen tuottaa ihmissuhteiden ja yksityisyyden piirissä. Kyseinen tematiikka ei myöskään nouse keskeiseen asemaan Seppälän vuosina 2000-20I2 julkaisemissa novellikokoelmissa. Lähinnä vain novelli "Bisnesenkeli" on tässä suhteessa rinnastettavissa Paholaisen haarukkaan. Koska se tarkastelee ihmissuh- 
teiden välineellistymistä osittain eri näkökulmasta kuin Paholaisen haarukka, seuraavaksi on syytä käsitellä sitä lyhyesti.

"Bisnesenkeli" (Seppälä 2004b) ilmestyi alun perin novellikokoelmassa Mitä sähkö on? (Seppälä 2004a). Se on kertomus finanssialalla työskentelevästä nuoresta miehestä ja hänen naissuhteistaan. Miehen oikeaa nimeä ei kertomuksessa mainita, mutta hän käyttää itsestään nimitystä "Bisnesenkeli". Nimitys kuvastaa hänen kohonnutta itsetuntoaan, joka perustuu siihen, että hän on runsaan 30 vuoden ikäisenä onnistunut kohoamaan monimiljonäärien joukkoon. Novelli ei silti keskity hänen ammatillisen uransa kuvaamiseen, vaan pääteemana siinä on ihmissuhteiden välineellistyminen. Päähenkilön kohdalla novelli kuvaa välineellistymisen olevan seurausta hänen työstään talouselämässä, jossa hän on tottunut käsittelemään asiakkaitaan pelkkinä taloudellisen tuloksenteon välikappaleina.

Sanaa "bisnesenkeli" käytetään myös nykyisessä talouselämässä. Se on käännös englanninkielisestä ilmaisusta angel investor, joka viittaa siihen, että bisnesenkelit ensi sijassa sijoittavat yrityksiin tai järjestävät niille rahoituksen. Bisnesenkelit ovat tavallisesti aktiivisesti mukana uusien yritysten perustamisessa, niiden toimintojen käynnistämisessä ja liiketoiminnan nostamisessa menestykselliseksi, mutta viimeksi mainitussa vaiheessa he myyvät usein yrityksensä tai osuutensa siitä pois ja saavat siten huomattavan rahallisen tuoton. Tällä tavalla bisnesenkelit ovat luomassa yritykselleen taloudellista arvoa, ja kun sen arvo nousee tietyn rajan yli, he realisoivat oman osuutensa siitä. Näin siis menestyneet bisnesenkelit toimivat, mutta toisaalta "enkelisijoittaminen" on riskialtista toimintaa, jossa sijoittaja voi myös menettää huomattavia summia ja jossa hänen yrityksensä saattaa ajautua konkurssiin..$^{8}$

"Bisnesenkeli" etenee päähenkilön minäkerronnan varassa. Hän on myös novellin tärkein fokalisoija, minkä ohella novelli antaa informaatiota hänen naisystävänsä Marikan tunteista ja ajatuksista. Muita fokalisoijia novellissa ei käytännössä juurikaan ole. Marikan jälkeen päähenkilö seurustelee lyhyen aikaa kansainvälisten organisaatioiden palveluksessa olevan vanhemman, noin 45-vuotiaan naisen kanssa, mutta tämän naisen, ammatiltaan sairaanhoitajan, ajatuksista ja tunteista novelli ei anna paljoakaan informaatiota. Novelli ei myöskään mainitse hänen ni- 
meään, mikä korostaa sitä, että pohjimmiltaan hän jää tuntemattomaksi sekä päähenkilölle että lukijalle. Nainen nähdään miltei pelkästään ulkoapäin, tiettyjen tekojen suorittajana, ja samalla tavalla ulkokohtaisesti hän kohtelee päähenkilöä, tuntematta mielenkiintoa tämän persoonallisuutta ja sisäistä maailmaa kohtaan.

Novelli alkaa tilanteesta, jossa päähenkilön ja Marikan välinen suhde on päättynyt. Suhdetta muisteleva päähenkilö tuijottaa mietteissään vaatekomeron hyllylle jäänyttä, Marikalle kuulunutta dildoa, jonka päähenkilö oli postimyynnistä tilannut tälle lahjaksi. Hetken kuluttua hän toteaa "Tarvitsin naisen" (BE, I37) käyttäen siten ilmaisua, johon on helppo liittää esineellistävä ja välineellistävä merkitysvivahde." Jatkossa se, mitä päähenkilö kertoo työstään finanssialalla ja suhteestaan Marikaan, vahvistaa tämän suuntaista tulkintaa.

Aloittaessaan aikoinaan työuransa "vähittäispankin omaisuudenhoitopalvelussa" päähenkilö oli ihmetellyt sitä, miten "tyhmillä ihmisillä" saattoi olla niin paljon rahaa:

Sitä oli peritty, kerätty, varmasti varastettukin. Tyhmiä ne olivat siksi, että ne toivat rahansa meille. Palveluiden maksut, eli meidän näkökulmastamme palkkiot, olivat kiinteät; emme me hirveästi ponnistelleet löytääksemme asiakkaiden omaisuuksille parasta mahdollista tuottoa. Sijoitimme rahaa sinne minne ne olisivat voineet itsekin sijoittaa. Ne eivät käsittäneet, että sijoitusrahastot olivat rikos sekä taloudellista järkeä että ihmisyyttä vastaan. Palkkiot söivät osinkotuoton, jos sitä oli, ja kaikki omistukseen liittyvä riski oli asiakkaalla. (BE, I37-I38.)

Bisnesenkeli on Paholaisen haarukan keskushenkilön, sijoitusneuvojavarallisuudenhoitaja Lari Laineen sukulaishahmo. He molemmat kuvaavat varallisuudenhoidon alaksi, jossa pankit harhauttavat ihmisiä asiakkaikseen ja jossa kaikki riskit on sen jälkeen jätetty asiakkaille. Silti pankit tarvitsevat näitä "tyhmiä asiakkaita" liiketoimintansa väli-

* Käytän tässä alaluvussa "Bisnesenkeli"-novellista lyhennettä BE silloin, kun siteeraan sitä tai viittaan siihen muuten sivunumeroiden tarkkuudella. 
kappaleiksi. Näin menetellessään Bisnesenkeli on menestynyt ammatissaan, ja finanssialakin on noteerannut hänen kyvykkyytensä. Nopeassa tahdissa hän jätti ensin työpaikkansa vähittäispankissa, siirtyi sitten varallisuudenhoitoon ja sijoitustoimintaan erikoistuneeseen pankkiin ja ensimmäiset miljoonansa ansaittuaan perusti oman sijoitusyhtiön. Menestyksen myötä myös Marika kiinnostui hänestä, "voittajasta" (BE, I42).

"Bisnesenkelin" päähenkilön habitus tai mentaliteetti on taloudellisen voitontavoittelun ja välineellisen ajattelun läpitunkema. Samalla tavalla välineellisesti hän käyttäytyy ihmissuhteidensa alueella. Tutustuessaan Marikaan hän pyrki tekemään tälle selväksi, ettei hän kaipaa syvempää sitoutumista:

Sanoin että kaikki aikaisemmat naissuhteeni olivat olleet eräänlaista harjoitusta tätä varten; tiesin että tämä oli joskus tulossa. Hän kysyi, mikä; mikä tässä olisi niin erityistä. Se, että me emme esitä mitään vaatimuksia toisiimme nähden, sanoin. Hänen mielestään siinä ei ollut mitään kovin erikoista. (BE, I4I.)

Ihmissuhteet ovat Bisnesenkelille vaihdantasuhteita, joissa suhteen osapuolet tavoittelevat erilaisia hyötyjä ja joissa he ovat valmiita irtautumaan suhteesta, mikäli se ei palvele heidän tarpeitaan. Tässäkin mielessä Bisnesenkeli muistuttaa läheisesti Lari Lainetta, joka - kuten hetken kuluttua käy ilmi - kuvaa niin ikään ihmissuhteita vaihdantasuhteiksi. Marikaan tutustuessaan Bisnesenkeli etsi lähinnä seksiä, mutta Marikalle se ei riittänyt. Kun Marika lopulta tajusi, ettei Bisnesenkelillä ollut halua jakaa syvemmin elämäänsä hänen kanssaan, hän pettyi tähän ja lähti suhteesta.

Suurin piirtein novellin puolivälissä Bisnesenkeli tapaa aiemmin mainitun, kansainvälisissä organisaatioissa työskentelevän naisen, jonka kanssa hän ryhtyy suhteeseen. Heidän keskinäinen suhteensa muodostuu alusta lähtien lähinnä yhteisistä seksiakteista, sillä päähenkilön hämmästykseksi nainen ei näytä olevan valmis tutustumaan häneen syvemmin. Novelli antaa naisen käyttäytymiselle selitykseksi hänen liikkuvan elämäntapansa, sen, että kansainvälisissä organisaatioissa toimiessaan hän on tottunut siirtymään nopeasti paikasta ja tehtävästä toiseen 
eikä hän siksi halua kiinnittyä pitkäksi aikaa yhteen paikkaan ja siellä kohtaamiinsa ihmisiin. Tämän tajutessaan Bisnesenkeli kokee, ilmeisesti ensi kerran ihmissuhteissaan, olevansa hyväksi käytetty osapuoli: "Hän ohjasi minua kuin lasta: hitaammin, rauhallisemmin, tule vähän ylemmäs. Minä olin kivikova, porsaan värinen, muovia ja metallia. Minä surisin, minussa oli paristo” (BE, I52). Heidän keskinäisissä akteissaan Bisnesenkeli rinnastaa siis itsensä paristokäyttöiseen dildoon, mikä viittaa siihen, että hän kokee naisen käyttäytymisen vahvasti esineellistäväksi. Bisnesenkeliä loukkaa se, että "minä en merkinnyt hänelle mitään" (ibid., I55), että nainen ei halua heidän keskinäisestä suhteestaan muuta kuin ruumiillista kanssakäymistä. Lopussa nainen pakkaa äkkiä laukkunsa, lähtee ilman jäähyväisrituaaleja uuteen työkohteeseensa ja jättää masentuneen Bisnesenkelin murehtimaan omaa tilaansa. "Kukaan ei vastaa vahingoista, joita ihmiset toisilleen aiheuttavat", Bisnesenkeli toteaa novellin päätteeksi (ibid., I56).

"Bisnesenkeliä" voi tiettyyn rajaan asti lukea kertomuksena kapitalistisesta välinerationaalisuudesta ja sen aiheuttamasta vieraantuneisuudesta. Tämä koskee lähinnä Bisnesenkelin käyttäytymistä sijoitusneuvojana ja hänen suhdettaan Marikaan. Sitä vastoin kansainvälisissä organisaatioissa työskentelevän naisen käyttäytyminen ei novellissa selity tästä käsin, vaan novelli antaa sille selitykseksi naisen työtehtävien luonteen, sen, että hänet voidaan milloin tahansa määrätä väliaikaisiin tai määräaikaisiin työtehtäviin ulkomaille. Hänen yhteydessään mainitut paikannimet - Beirut, Dubrovnik, Split, Zadir, Slovenia, Kroatia, Bosnia, Makedonia, Kosovo, Geneve, Palestiina (BE,I48, I53, I55) - viittaavat siihen, että hän toimii maailman katastrofi- ja kriisialueilla humanitaarisissa tehtävissä. Siksi lukijasta saattaa jopa tuntua epäuskottavalta, että hän antautuu tekemisiin Bisnesenkelin kaltaisen, kapitalistisen talouden vieraannuttaman bisnesmiehen kanssa. Toisaalta äskeisen oletuksen vastaisesti lukija voi myös ajatella, että ihmissuhteissaan syvempää sitoutumista tähän asti vältellyt Bisnesenkeli sopiikin tälle tilapäisiin suhteisiin tyytyvälle naiselle hyvin lyhytaikaiseksi rakastajaksi.

"Bisnesenkelin" tavoin Paholaisen haarukka kuvaa ihmissuhteiden ja seksuaalisuuden alueen välineellistymistä, mutta se käsittelee tätä tematiikka paljolti vain nykytaloudesta käsin eli selvästi kapeammin kuin ky- 
seinen novelli. Niin kuin edellä todettiin, "Bisnesenkeli" selittää ihmissuhteiden välineellistymistä yhtäältä nykytaloudesta käsin (Bisnesenkeli), mutta toisaalta se tuo esiin myös sen, että nyky-yhteiskunnassa työskenteleminen ja menestyminen ei aina mahdollista kiinteiden tai pysyvien ihmissuhteiden muodostamista (kansainvälisessä organisaatiossa työskentelevä nainen). Zygmunt Bauman (2000) on kuvannut tätä elämäntavallista muutosta puhumalla siitä, että klassisen moderniteetin vakaiden instituutioiden ja rakenteiden kauden jälkeen länsimaissa on siirrytty "notkeaan moderniteettiin", joka ylistää joustavuutta, liikkuvuutta ja valmiutta muutoksiin. Tästä syystä ihmissuhteita leimaa siinä lyhytkestoisuus, nautinnonhakuisuus ja sitoumusten vältteleminen.

"Bisnesenkeli" käsittelee nykytaloutta ja ihmissuhteiden välineellistymistä ensi sijassa miesten kokemusmaailmasta käsin. Samanlainen käsittelytapa on ominainen Paholaisen haarukalle, samoin kuin Yhtiökumppaneille ja Mr. Smithille. Niiden kaikkien päähenkilöt ovat miehiä, minkä lisäksi niiden kiinnittymistä miehiseen kokemistapaan vahvistaa se, että Paholaisen haarukassa ja Mr. Smithissä päähenkilöiden ja tarinamaailman ulkopuolisen kertojan välinen etäisyys vaikuttaa lyhyeltä. Varsinkin Paholaisen haarukassa päähenkilön, Lari Laineen, ja tarinamaailman ulkopuolisen kertojan ääniä tai kerrontajaksoja on usein vaikea erottaa toisistaan, sillä ne muistuttavat sävyjensä osalta läheisesti toisiaan. Henkilökertojien varaan rakentuvasta Yhtiökumppaneista puuttuu tarinamaailman ulkopuolinen kertoja, mutta siinä kiinnittyminen miehiseen kokemistapaan toteutuu sitä kautta, että romaania hallitsee Peten, kapitalismin eetoksen sisäistäneen mainosgraafikon ja sijoittajan, ääni ja kokemistapa.

Yhtiökumppaneiden, Paholaisen haarukan ja Mr. Smithin keskushenkilöt ovat ensi sijassa ylimpiä yhteiskuntaluokkia edustavia miehiä, jotka ovat sitoutuneet nykykapitalismissa yleistyneiden taloudellisten käytäntöjen mukaiseen toimintaan. Romaanit osoittavat kukin omalla tavallaan sen, että tämän sitoumuksen takia keskushenkilöt ajautuvat lopulta vakaviin sosiaalisiin, mentaalisiin ja eksistentiaalisiin ongelmiin. Näissä romaaneissa nykykapitalismi kohtelee huonosti myös työväenluokkaisia henkilöitä ja ajaa osan heistäkin tällaisiin ongelmiin, mutta he kärsivät lisäksi taloudellis-sosiaalisesta turvattomuudesta ja epävarmuudesta. 
Naishahmot jäävät kyseisissä romaaneissa päähenkilöiden varjoon. Osa heistä on täysin sivuhenkilöitä, kuten esimerkiksi Peten vaimo erikoishammashoitaja Terhi Yhtiökumppaneissa ja Lari Laineen vaimo kirjastonhoitaja Johanna Paholaisen haarukassa. Kumpikaan heistä ei esiinny kertojanroolissa, eikä näiden romaanien maailmaa juurikaan fokalisoida heidän näkökulmastaan. Lukijan on siksi vaikea päätellä, miten he konkreettisesti kokevat nykyisen talouselämän ja siinä keskeisessä asemassa toimivan puolisonsa. Naishahmoista näkyvämmän roolin näissä Seppälän romaaneissa saavat toimistosihteeri Kirsi (Yhtiökumppanit), sosiaalipsykologi Saija Lehtonen ja elokuvaohjaaja Laura Laine (Paholaisen haarukka) ja erinäisissä työväenluokkaisissa ammateissa työskentelevä Briscilla (Mr. Smith).

Nämä henkilöhahmot eivät tarjoa edustavaa pienoiskuvaa naisten luokka-asemasta Suomessa. Sivulla 89 olevasta taulukosta ilmenee, että työelämässä ja koulutusjärjestelmässä tapahtuneiden muutosten myötä naisten osuus ylemmissä luokissa on kasvanut Suomessa voimakkaasti, minkä seurauksena naisista $5 \%$ edustaa nykyisin yläluokkaa (luokka I) ja 22 \% ylempää keskiluokkaa (luokka II). Samalla työväenluokan osuus väestöstä on kutistunut, mutta edelleenkin $48 \%$ naisista ja miehistä kuuluu siihen. Seppälän romaaneissa naispuoliset henkilöt kiinnittyvät lähinnä keskiluokkaisiin ammatteihin (luokat II ja III), kun taas näiden romaanien miespuoliset päähenkilöt ja osa miespuolisista sivuhenkilöistä edustavat yläluokkaa (luokka I) tai ylempää keskiluokkaa (luokka II). Näistä romaaneista puuttuvat siis ylimpään luokkaan kuuluvat naiset ja työväenluokkaa niiden naishahmoista edustaa vain Mr. Smithissä esiintyvä Briscilla.

Seppälän romaanien naishahmoista keskiluokkaan kuuluu selvimmin Yhtiökumppaneissa esiintyvä toimistosihteeri Kirsi, joka toimii tyypillisessä alemman keskiluokan (luokka III) ammatissa. Sitä vastoin Paholaisen haarukassa esiintyvien elokuvaohjaaja Laura Laineen ja sosiaalipsykologi Saija Lehtosen luokka-asema on epämääräisempi, mutta lähinnä he häilyvät ylemmän keskiluokan (luokka II) ja alemman keskiluokan (luokka III) välillä. He ovat molemmat korkeasti koulutettuja, ja aiemmin heidän kaltaisensa koulutetut naiset saivat työelämässä toimia suhteellisen itsenäisissä, ylemmälle keskiluokalle tyypillisissä tehtävissä. 
Seppälän romaanien kuvaamassa yhteiskunnassa tällaisten naisten itsenäisyyteen kohdistuu kuitenkin uudenlaisia rajoituksia ja uhkakuvia.

Markkinallistuneessa kulttuurielämässä Laura Laineen vapautta rajoittaa periaatteessa se, että hänen on järjestettävä elokuvahankkeilleen rahoitus. Paholaisen haarukassa annetun informaation perusteella hän on onnistunut tässä tehtävässä ja taiteellisen vapautensa säilyttämisessä suhteellisen hyvin, joten hän kuuluu lähinnä ylempään keskiluokkaan. Saija Lehtonen kuvataan puolestaan akateemiseksi pätkätyöläiseksi tai akateemisen prekariaatin edustajaksi, joka kärsii yliopistomaailmassa nykyisin noudatettavasta, markkinakapitalismia jäljittelevästä toimintatavasta. Tämän seurauksena hän elättää itsensä lyhytaikaisilla työsuhteilla. Saija Lehtosen kautta Paholaisen haarukka käsittelee siten, tosin vain lyhyesti, korkeamman koulutuksen kapitalisoitumista sekä nuoren tutkijapolven taloudellis-sosiaalisen aseman romahtamista ja sen ajautumista lähemmäs alempia luokkia.

Merkittävä piirre Seppälän romaanien naishahmoissa on myös se, että monet heistä on sijoitettu uhripositioihin. Tämä pätee Kirsiin (Yhtiökumppanit), Saija Lehtoseen (Paholaisen haarukka) ja Briscillaan (Mr. Smith), jotka jäävät kaikki ahdistavien kokemustensa vangeiksi ja joiden on siksi vaikea saavuttaa sisäistä ja/tai ulkoista elämänhallintaa. Seppälän yhteiskunnallisissa romaaneissa esiintyvistä naishahmoista aktiivista subjektiutta ja elämänhallintaa edustaa vain Laura Laine, perinteisen älymystön jäsen, jota käsitellään vielä tämän pääluvun lopussa.

Kuvatessaan naisten asemaa nyky-yhteiskunnassa Seppälän romaanit kiinnittävät huomiota lähinnä vain negatiivisiin ilmiöihin, niihin tekijöihin, jotka ovat huonontaneet naisten asemaa nyky-yhteiskunnassa. Sen sijaan ne sivuuttavat sen, että nykyinen, "feminisoitunut" talouselämä on tietyssä mielessä tarjonnut naisille lisää toimintamahdollisuuksia. Painottaessaan työntekijöidensä affektiivisia, kommunikatiivisia ja sosiaalisia taitoja sekä heidän kykyään toimia joustavasti nykyinen talouselämä kiinnittyy juuri sellaisiin ominaisuuksiin, joissa naiset ovat perinteisesti olleet vahvoja ja miehiä etevämpiä. Osaltaan tästä syystä ei ole yllättävää, että tutkimuksessaan Sukupuolen järjestykset ja tasa-arvon paradoksit (20IO) Raija Julkunen päätyy yleistykseen, että monista uhkakuvista huolimatta uusliberalistinen yhteiskuntapolitiikka ei ole, aina- 
kaan Suomessa ja muissa Pohjoismaissa, yleisesti huonontanut naisten asemaa.

Näin sanottaessa on samalla pidettävä mielessä se, että Seppälän romaanit eivät ole tieteellisiä tutkimuksia naisten asemasta nyky-yhteiskunnassa. Ne noudattavat siksi ensi sijassa kaunokirjallisen esityksen eivätkä tieteellisen tutkimuksen logiikkaa. Tässä mielessä ne jatkavat jo I8oo-luvun realistis-naturalistiselle kirjallisuudelle ominaista tapaa kuvata yhteiskuntaa ensi sijassa sen epäkohtien ja ongelmien kautta. Epäkohdat ja ongelmat ovat yhteiskunnallisissa romaaneissa olleet niin keskeisiä, että "yhteiskunnallisen" tai "sosiaalisen romaanin" synonyyminä on usein, varsinkin I8oo-luvulla, käytetty "ongelmaromaania".

Palataan Paholaisen haarukan naishahmoihin. Ehkä moniulotteisin Seppälän luomista naishahmoista on siinä esiintyvä Saija Lehtonen.99 Hänet kuvataan monenlaisten, osittain sukupuolittuneiden ja eriarvoistavien käytäntöjen kohteeksi. Hänestä annettu informaatio painottaa sitä, että hän ei ole halunnut omaksua perinteistä aviopuolison ja perheenäidin roolia, jonka hän kokee omaa henkistä vapauttaan ja toimintamahdollisuuksiaan rajoittavaksi. Sen sijasta hän on haveillut laajemman itsetoteutuksen mahdollistavasta subjektiasemasta. Tähän asemaan kuuluu periaatteessa parisuhde tai aviopuoliso, mutta Saija ja Kari Lehtosen seitsemän vuotta kestänyt liitto hajoaa romaanissa puolisoiden keskinäisen vieraantumisen vuoksi - ja osittain myös siitä syystä, että miehensä pettymykseksi Saija Lehtonen kieltäytyy äitiydestä, lasten hankkimisesta. Työmarkkinoilla hänen tilanteensa on niin ikään vaikea eikä hän saa sielläkään kunnolla mahdollisuutta toimia itsenäisessä subjektiasemassa.

Paholaisen haarukka kommentoi eri yhteyksissä Saija Lehtosen ammatinvalintaa ja yhteiskuntatieteiden tilannetta. Se kuvaa yhteiskuntatieteet laskevaksi oppineisuuden alaksi, jonka markkinallistumiskehitys on marginalisoinut:

Saija Lehtonen on sosiologi, oikeammin sosiaalipsykologi, joka tutkii sitä miten ihmiset voivat elää maailmassa, jossa ekonomistit ovat tehneet sosiologit tarpeettomiksi ja jossa uutisen saattoi muuttaa rahaksi, jos se pysyi hengissä kolme päivää. (PH, 49-50.) 
Tässä äänessä on tarinamaailman ulkopuolinen kertoja. Hän luonnehtii Saija Lehtosen ja yhteiskuntatieteilijöiden tilannetta paljolti samalla tavalla kuin sijoitusneuvoja Lari Laine luonnehtii sisarensa Laura Laineen ja perinteisen älymystön roolia nyky-yhteiskunnassa. Näiden luonnehdintojen sisältönä on ajatus, että markkinallistuneessa nyky-yhteiskunnassa talouselämän asiantuntijat ja suuryritysten johtajat ovat paljolti syrjäyttäneet sosiologit ja perinteisen älymystön yhteiskuntaa koskevien "oikeanlaisten" tai "relevanttien" kuvausten, tulkintojen ja selitysten tuottajina.

Paholaisen haarukka vihjaa siihen, etteivät yhteiskuntatieteilijät osaa nykyisin aina reagoida tähän tilanteeseen mielekkäällä tavalla. He eivät ole ryhtyneet laajemmin selvittämään marginalisoitumisensa syitä ja markkinallistumiskehityksen vaikutuksia yhteiskunnassa. Sen sijasta he ovat usein valinneet toimintatavan, jossa he tuottavat abstraktin kielen avulla vaikeaselkoista puhetta kulttuurista ja yhteiskunnasta:

Saija Lehtonen oli tehnyt pitkän matkan ja myös kovan työn istuakseen tutkijana sosiaalipsykologian laitoksella ja pyrkiäkseen sisäistämään kulttuurisen diversiteetin ja transmodernin mielikuvayhteiskunnan käsitteitä. Sumea logiikka oli jo mennyttä aikaa. Mikään ei viitannut siihen, että 34-vuotias nainen oli lähtöisin maalta, vieläpä melko syrjäisestä pitäjästä, tosin kirkonkylästä, mutta niin pienestä että siellä ei ollut lukiota. Hänet koulutettiin ylioppilaaksi naapuripitäjässä. (PH, 83.)

Vaikka tässä tarinamaailman ulkopuolisen kertojan esittämässä katkelmassa pääasiana on Saija Lehtosen kulttuuristen lähtökohtien ja hänen nykyisen tilanteensa - maaseutumaisen pienelämän ja urbaanin akateemisen kulttuurin - vertaileminen toisiinsa, sitaattia voi myös lukea ironisena kommenttina yhteiskuntatieteiden nykytilasta. Se näyttää sanovan, että nykymuodossaan yhteiskuntatieteet eivät välttämättä auta meitä ymmärtämään syvemmin sitä, mitä maailmassa tapahtuu. Pikemminkin yhteiskuntatieteilijöiden nykyiset aiheenvalinnat ja heidän käyttämänsä abstrakti kieli toimivat esteenä maailman syvemmälle ymmärtämiselle (ks. myös PH, 83-86). Tätä ei kuitenkaan pidä käsittää 
niin, että Seppälän romaanit torjuisivat sinänsä yhteiskuntatieteet. Ne käyttävät markkinallistumiskehityksen kuvaamisessa ja arvioimisessa hyväksi yhteiskuntatieteiden klassista teoriaperintöä, niin kutsuttua "grand theory" -perinnettä, jota muun muassa Marx, Weber, Polanyi, Habermas ja Castells edustavat. Romaanien esittämä kritiikki kohdistuu lähinnä sellaiseen yhteiskuntatieteeseen, joka on mukautunut markkinoiden ja talouselämän logiikan tunkeutumiseen yliopistomaailmaan.

Palataan Saija Lehtosen henkilöhahmoon. Paholaisen haarukassa hän määrittyy siis naiseksi, joka ei ole työssään pystynyt kunnolla saavuttamaan kaavailemaansa itsenäistä subjektipositiota ja joka on jäänyt myös avioliitossaan onnettomaksi. Näiden ominaisuuksien lisäksi romaani liittää hänen hahmoonsa vielä kolmannen yhteiskunnallisesti merkittävän seikan, naisruumiin seksualisoimisen ja esineellistämisen. Tämä tulee selkeimmin ilmi kohtauksessa (PH, 6I-63), jossa Saija Lehtonen masturboi yksin kotonaan paristokäyttöisen dildonsa avulla ja samaan aikaan hänestä tuntuu, että yksi hänen lemmikkirotistaan katsoo häntä herkeämättä. Romaani kuvaa Saija Lehtosta tavalla, joka tuo paikoitellen mieleen pornografian käyttämät maneerit:

Rotan mustat silmät pureutuivat häneen.

Itsepintainen värinä voitelee hänen pillunsuutaan, hellittämättä, jauhaa paikallaan ja yrittää vääntää hänen alaraajojaan liikkeeseen. Hän pitää ne paikallaan ja sauvan kärjen myös, kunnes hän muutaman sekunnin ajaksi muuttuu heinäsirkaksi, täysin liikkumattomaksi, jäykäksi, haihtuvaksi ja olemattomaksi. Sitten hänen reitensä kohoavat vastustamaan värinää ja tavoittamaan jalkovälistä lantioon ja rintoihin asti leviävää hekumaa, kunnes nautinto alkaa hipoa kipua. Saija laukeaa nykien ja vähän voihkien, lopuksi muutaman kerran syvään huokaisten ja huultaan purren ja menee suihkuun.

Rotta katsoo. (PH, 63.)

Tätä samaa, tarinamaailman ulkopuolisen kertojan esittämää kohtausta Sanna Karkulehto on analysoinut artikkelissaan "Sukupuoli, seksuaalisuus ja valta" (20I3), joka sisältyy hänen sekä Mika Hallilan, Yrjö 
Hosiaisluoman, Leena Kirstinän ja Jussi Ojajärven toimittamaan teokseen Suomen nykykirjallisuus 2. Kirjallinen elämä ja yhteiskunta (2013b). Artikkelissaan Karkulehto huomauttaa, että irvokkuutta tavoitteleva liioitteleminen on ollut tavanomaista "seppäläläiselle estetiikalle" (Karkulehto 2OI3, I2O-I2I). Huomautus on osuva, sillä vastaavanlaista liioittelemista Seppälä on käyttänyt muussakin tuotannossaan, varsinkin kertomuskokoelmissaan Super Market (I991a) ja Suomen historia (I998). Edellä mainitussa kohtauksessa, jossa kertoja käsittelee Saija Lehtosta paljolti samalla tavalla kuin heteroseksuaalisille mieslukijoille suunnatut pornolehdet kuvaavat naisen seksuaalisuutta, tällainen liioitteleminen on kuitenkin vaarassa kääntyä itseään vasten. Osa Paholaisen haarukan lukijoista saattaa pitää siinä käytettyjä ilmaisutapoja ja tehokeinoja enemmän tai vähemmän tietoisina naisvihamielisyyden ilmentyminä. Tämän suuntaiseen tulkintamahdollisuuteen myös Karkulehto (2013, I20) viittaa kirjoituksessaan. Näin ajateltaessa Paholaisen haarukka olisi itsekin osa sitä naisia alentavaa diskurssia, jota se toisaalta esittää analysoivansa kriittisesti.

Myös Seppälän teoksista kirjoitetuissa arvosteluissa on toisinaan kriittisessä mielessä esitetty, että ne kuvaavat naispuolisia henkilöhahmoja miehisen katseen avulla: esineellistävästi, seksualisoivasti ja osaamatta eläytyä kunnolla naishahmojen sisäiseen maailmaan. ${ }^{\text {1oo }}$ Antamissaan haastatteluissa Seppälä on tavallisesti ihmetellyt tällaista näkemystä ja pitänyt sitä perusteettomana. ${ }^{\text {Ior }}$ Siksi onkin syytä kysyä, päteekö arvostelijoiden esittämä kritiikki edellä mainittuun kohtaukseen. Tähän kysymykseen voi vastata, että kyseisessä kohtauksessa kertojan kuvaustapa on kieltämättä paljolti esineellistävä ja objektivoiva, ja siksi kohtaus vaikuttaa pornografiasta otetulta lainaukselta tai sitaatilta. Kyseistä kohtausta on silti mahdollista tulkita myös toisesta näkökulmasta. Tällöin se toimii enemmänkin pornografian kritiikkinä kuin pornografiana, vaikka, niin kuin tuonnempana ilmenee, tällainenkaan tulkinta ei ole ongelmaton.

Paholaisen haarukan kokonaisrakenteen ja pääteeman näkökulmasta edellä mainittu kohtaus palvelee sukupuolittuneiden valtasuhteiden esiintuomista. Se näyttää havainnollisesti, miten nyky-yhteiskunta esineellistää ja seksualisoi naisia järjestelmällisesti. Karkulehto (20I3, I2I) huomauttaa, että näin ei tee ainoastaan tarinamaailman ulkopuolinen 
kertoja, vaan romaani asettaa lukijankin hetkellisesti tirkistelijän rooliin. Tämän tehtävän romaani toteuttaa täysin epäsentimentaalisella tavalla, osoittamatta minkäänlaista myötätuntoa onnetonta naishahmoaan kohtaan. Näin ajateltaessa kyseisessä kohtauksessa sekoittuvat toisiinsa pornografinen diskurssi sekä porno- ja yhteiskuntakriittinen diskurssi - kuitenkin tavalla, jossa ensiksi mainittu on alisteinen romaanin sisäistekijän ohjaamille kriittisille tarkoitusperille.

Rotan, arkielämässä tavallisesti vastenmielisenä pidetyn jyrsijän, katseesta puhutaan edellä mainitussa kohtauksessa kaikkiaan viisi kertaa ja siteeratussa katkelmassa kaksi kertaa. Tällä tavalla Paholaisen haarukka etäännyttää tai vieraannuttaa kyseistä kohtausta pornografiasta ja estää lukijaa ottamasta sen yhteydessä liian eläytyvää lukutapaa, vaikka tuo kohtaus tietyiltä osin vaikuttaa pornosivuilta otetulta lainaukselta. Samaa etäännyttävää tarkoitusta palvelee se, että kohtausta seuraa lyhyt jakso (ks. PH, 64-65), jossa sijoitusneuvoja Lari Laine kommentoi sitä. Siinä Lari Laine siirtyy hetkeksi tiedoiltaan rajoittuneen henkilökertojan roolista ulkopuolisen tai "kaikkitietävän" kertojan roolin - siis asetelmaan, joka merkitsee poikkeamista romaanilajissa pitkään vallalla olleista kerronnan konventioista, mutta joka tulee lukijaa usein vastaan postmodernistisessa kirjallisuudessa (ks. lähemmin McHale I987). Jakso pysäyttää hetkeksi romaanin etenemisen, mikä tarjoaa mahdollisuuden reflektoida kyseistä kohtausta: "Saija Lehtonen ei olisi nähnyt itseään näin. Edes elokuvaa käsikirjoittava ja ohjaava sisareni ei olisi nähnyt häntä näin. Tuo on kertojan tekstiä, joku voisi sanoa, että miehen katse, mutta kertoja voi vetäytyä sukupuolettomuutensa taakse” (PH, 64). Sivuutan tässä yhteydessä oheiseen sitaattiin sisältyvän oletuksen siitä, että romaanikertoja voisi olla sukupuoleton olento. Sitaatin tarkoitus on nimittäin se, että siinä Lari Laine pyytää lukijoita ajattelemaan kyseistä kohtausta jonakin muuna kuin pelkkänä miehisen diskurssin tai katseen ilmentymänä. Hän ei suoraan sano, mikä tuo muu yhteys on, mutta Paholaisen haarukka esittää ihmissuhteiden ja seksuaalisuuden alueiden olevan nykyisin riippuvaisia sekä arkielämän sukupuolittuneista valtasuhteista että kapitalistisen talouden toimintatavoista.

Levittäytyessään perinteisten rajojensa ulkopuolelle kapitalistinen talous on kasvavassa määrin kaapannut haltuunsa ihmisten välisten suh- 
teiden ja seksuaalisuuden alueen. Näin on tapahtunut siitäkin huolimatta, että valtiot ovat lainsäädännön avulla pyrkineet kontrolloimaan tätä ilmiökenttää ja kriminalisoimaan räikeimmät seksuaalisuuden riiston ja hyväksikäytön muodot. Kyseiseen ilmiökenttään kuuluu (I) ensinnäkin seksikauppa, joka sulkee sisäänsä prostituution, seksiturismin ja paljolti myös ihmiskaupan. Samoin sitä edustaa (2) pornoteollisuus ja (3) seksuaalisuuden alueen hyödyntäminen tavaroiden markkinoinnissa. Jälkimmäiseen alueeseen liittyy läheisesti kapitalismin harjoittama naisruumiin ja nuoruuden palvominen. Vietellessään ihmiset kuluttajiksi naisruumista esineellistävillä kuvilla kapitalismi vihjaa siihen, että tavaroiden kuluttamisen ja eroottisen tai seksuaalisen mielihyvän välillä vallitsee läheinen sukulaisuussuhde. Nykykapitalismi käyttää näin seksuaalisuuden aluetta järjestelmällisesti hyväkseen ylläpitäessään ihmisissä massatuotannon edellyttämää individualistis-hedonistista asennoitumista. (4) Nyky-yhteiskunnassa tällainen asennoituminen on aiempaa laajemmassa mittakaavassa vallannut myös ihmissuhteiden ja elämismaailmojen alueen, minkä seurauksena ihmiset käyttäytyvät kyseisellä alueella yhä useammin välineellisesti, lähinnä vain omaa hyötyään ja nautintoaan tavoitellen. ${ }^{\text {Io2 }}$

Seppälän romaaneista ainoastaan Paholaisen haarukka tematisoi pohdiskelun kohteeksi kapitalismin ja seksuaalisuuden välisen suhteen, mutta siinäkään nämä pohdiskelut eivät nouse pääteeman asemaan. Siksi Seppälää ei voi pitää samassa mielessä nykykapitalismin ja seksuaalisuuden alueen välisten suhteiden analysoijana kuin esimerkiksi Michel Houellebecqia, jonka tuotannossa nykykapitalismin hallitsevaksi piirteeksi määrittyy se, että konsumeristinen ja individualistis-hedonistinen asennoitumistapa on saanut yhteiskunnan valtaansa, mukaan lukien ihmissuhteiden ja seksuaalisuuden alueen (ks. Meretoja

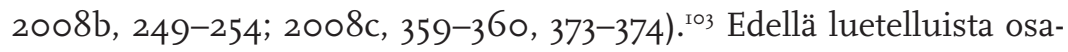
alueista Houellebecqin romaanit kuvaavat erityisesti (I) seksikauppaa ja (4) ihmissuhteiden tavaroitumista, mutta myös osa-alueet (2) ja (3) tulevat niissä mukaan kuvaukseen. Niinpä Alkeishiukkaset (2000, ranskankielinen alkuperäisteos ilmestyi I998) esittää länsimaisen elämäntavan hedonistis-individualistisen asenteen turmelemaksi muodostumaksi. Romaanissa Oikeus nautintoon (2002, ranskankielinen alkuperäisteos 
ilmestyi 200I) länsimaisen kapitalismin tunnusomaiseksi kehitysnäkymäksi määrittyy puolestaan se, että matkailuteollisuuden kasvun myötä se on sulautumassa yhteen seksibisneksen ja seksiturismin kanssa.

Saija Lehtosta käsittelevissä jaksoissa (ks. PH, 85-86) sijoitusneuvoja Lari Laine puhuu siitä, että nykyisin naisen seksuaalisuudesta on tullut taloudellinen hyödyke, jonka vaihtokurssi on korkeimmillaan naisen nuoruudessa. Pohdintojensa lopuksi hän huomauttaa, että Saija Lehtonen ei itse käytä hyväksi tätä seikkaa, vaikka se olisi "taloudellisesti mielekkäämpää kuin raataa työssä koko elämänsä” (ibid., 86). Lari Laine ei anna vihjeitä siitä, miten tämä sinänsä monimielinen huomautus tulisi ymmärtää. Tässä kohden on silti paikallaan todeta, että varsinkin osa-alueet (I) - (3) eli seksikauppa, pornoteollisuus ja tavaroiden markkinointi tarjoavat nyky-yhteiskunnassa naisille sellaisia positioita, joissa heidän on tehtävä omasta seksuaalisuudestaan tai seksuaalisuutensa esittämisestä kauppatavara tai kapitalistisen tavaratuotannon ja lisäarvon kasaamisen edellyttämä myynninedistämisväline.

Paholaisen haarukka ei käsittele konkreettisesti osa-alueita (I) - (3), vaikka Lari Laineen esittämät havainnot koskevat välillisesti myös niitä. Sitä vastoin osa-alueen (4) eli ihmissuhteiden ja elämismaailmojen tavaroitumisen se ottaa avoimesti esille jaksossa, jossa kertojana toimii jälleen Lari Laine (ks. PH, I03-IIO). Jakso osoittaa, että Lari Laine soveltaa ihmissuhteiden ja yksityisyyden alueella paljolti samanlaista ajatustapaa tai logiikkaa kuin työssään kapitalistisen talouden pyörittäjänä:

Sen verran olin avioliitossani oppinut, että pillulla oli vaihtoarvo, mutta sen todellisesta markkina-arvosta en tiennyt mitään. Olin mukautunut tarjonnan niukkuuteen, sillä - vaikka en juurikaan asiaa miettinyt - ymmärsin että Johannan [Lari Laineen vaimo] ja minun välisessä seksissä oli kysymys enemmän sosiaalisesta kuin taloudellisesta vaihdosta. Siitä, etteikö sitoutuminen ja rakkaus käytännössä tarkoittanut samaa kuin investointi, minulla ei ollut missään vaiheessa harhakäsitystä. Riskin, tappion, häviämisen vaaraa minulla ei ollut, toisin kuin sekä Saija että Kari Lehtosella, jotka olivat toisilleen pelkkiä riskejä, hajauttamattomia kohteita, joiden arvonkehitys oli voimakkaassa keskinäisessä riippuvuussuhteessa. (PH, ro8.) 
Lari Laineelle ihmissuhteet ovat vaihdantasuhteita, joihin "investoidessaan" ihmiset odottavat saavansa niistä erilaisia hyötyjä, esimerkiksi rakkautta, kiintymystä, seksuaalista mielihyvää tai puhtaasti aineellisia etuja, ja joissa toisen ihmisen arvoa mitataan sillä, millaisia hyötyjä hän tarjoaa arvioijalle. Tällaiset näkökohdat voivat olla jossakin määrin mukana myös "terveissä ihmissuhteissa", mutta olennaista tässä yhteydessä on se, että Lari Laineen ajatustavasta puuttuu näkemys, että toinen ihminen voisi olla arvokas myös omana itsenään - riippumatta siitä, millaisia hyötyjä hän pystyy tarjoamaan muille ihmisille. Niinpä Lari Laine kuvaa suhdettaan vaimoonsa käytännölliseksi järjestelyksi, jossa ei ole sijaa tunteille ja rakkaudelle (ks. PH, I05). Lähinnä vain kouluikäisten lastensa kevätjuhlissa tämä arvorationaalisen tajuntansa köyhdyttänyt pankkimies kykenee vielä tuntemaan aitoa ja syvempää liikutusta (ks. ibid., 77-79).

Seksuaalisuuden historian ensimmäisessä osassa (I998, ranskankielinen alkuperäisteos ilmestyi I976) Michel Foucault käyttää käsitettä strategisesti integroiva valta, joka on Paholaisen haarukan yhteydessä relevantti. Siinä on kyse sellaisista tekniikoista, käytännöistä ja prosesseista, joissa yksilöt sisäistävät yhteiskunnassa vallitsevat normit ja pakot ja joissa he muokkautuvat yhteiskunnassa vallitsevan normaaliuden mittapuun mukaisiksi. Kun yksilöt ovat sisäistäneet normit, he osallistuvat itse yhteiskunnassa vallalla olevien normaaliuden ja rationaalisuuden mittapuiden ylläpitämiseen. Paholaisen haarukassa kapitalismi on juurtunut tällä tavalla Lari Laineen mielen sisälle, siellä vaikuttavaksi maailman käsittelytavaksi. Sen, että juuri tämä markkinahenkistä diskurssia edustava pankkimies esittää Paholaisen haarukassa näkemyksiään seksuaalisuudesta tavarana tai vaihdannan välineenä, voi tulkita viittaavan myös siihen, että tämän romaanin mukaan markkinahenkisen yhteiskuntapolitiikan valtaantulo on avannut ihmissuhteet ja subjektien elämismaailmat välineelliselle ja seksuaalisuutta tavaroittavalle asenteelle ja käyttäytymiselle. Kyseisessä romaanissa näin ymmärretyn patriarkaaliskapitalistisen valtamekanismin uhreja ovat erityisesti naiset, jos kohta keskeisistä naishahmoista elokuvaohjaaja Laura Laine pystyy paljolti elämään ja toimimaan sen vaikutuspiirin ulkopuolella.

Suomalaisessa nykykirjallisuudessa seksuaalisuuden ja talouden välistä suhdetta ei ole aina nähty aivan edellä kuvatulla tavalla. Yhteisessä 
artikkelissaan ”Työtä töiden joukossa? Seksuaalisuus, kaupallisuus ja toimeentulon pakko kotimaisessa nykykirjallisuudessa" (20I8) Sanna Karkulehto ja Ilmari Leppihalme analysoivat seksityön, lähinnä prostituoitujen, kuvauksia nykykirjallisuudessamme. Analyysin kohteena ovat Pirkko Lindbergin Berenikes hår (2000), Sofi Oksasen Baby Jane (2004), Essi Henrikssonin Ilmestys (2007), Pasi Lampelan novelli "Motelli" saman tekijän kokoelmassa Hellekausi (2007), Elina Tiilikan Punainen mekko (20I0), Laura Gustafssonin Huorasatu (20II) ja Jari Tervon Layla (20II). Karkulehto ja Leppihalme toteavat, että Lindbergin, Gustafssonin ja Tervon teoksissa seksityö näyttäytyy lähes kauttaaltaan kielteisessä valossa, naisiin kohdistuvana taloudellisena ja sukupuolisena sortona. Oksasen, Henrikssonin, Lampelan ja Tiilikan teokset kuvaavat toisenlaisia naishahmoja, jotka ainakin aluksi kokevat, että he ovat itse, "omasta vapaasta tahdostaan", valinneet seksityön ammatikseen ja että he voivat sen avulla lisätä toimintamahdollisuuksiaan. Oksasen Baby Janessa ja Henrikssonin Ilmestyksessä tämä uskomus osoittautuu lopulta illuusioksi, kun niiden päähenkilöt uupuvat työssään ja joutuvat rajujen väkivallantekojen kohteeksi. Samoin Lampelan novellissa seksikauppaa harjoittavan naisen, bordellinpitäjän, hyväuskoisuus kokee haaksirikon: hän päätyy vankilaan, kun viranomaisille ja osittain myös hänelle itselleen paljastuu, että huumediilerit ja ihmiskauppaa pyörittävät venäläiset rikollisliigat ovat sekaantuneet hänen liiketoimiinsa. (Karkulehto \& Leppihalme 20I8.)

Osa edellä mainituista teoksista testaa oletusta, että seksityö voisi lisätä naisten mahdollisuuksia toimia itsenäisinä ja täysivaltaisina subjekteina nyky-yhteiskunnassa. Pääosin nuo teokset päätyvät tässä testaamisessa kielteiseen tai varaukselliseen lopputulokseen. Paholaisen haarukasta puuttuu tällainen testaamisen ulottuvuus. Siinä seksuaalisuuden alue on mukautettu patriarkaalis-kapitalistisen järjestyksen käyteaineeksi, ja tämä asiantila näyttäytyy siinä johdonmukaisesti kielteisessä ja naisia alentavassa valossa, ilman vihjausta siitä, että se voisi edistää heidän "voimaantumistaan" yhteiskunnassa. Tällainen näkemys sivuuttaa sen, että kaikkia naisia ei tarvitse suoranaisesti pakottaa oman seksuaalisuutensa taloudelliseen hyödyntämiseen. Osa heistä todellakin kokee valitsevansa sen vapaaehtoisesti eli tässä mielessä he eivät ole uhreja. ${ }^{104}$ Sen sijaan uhreja he ovat siinä mielessä, että yhteiskunnassa ei ole välttä- 
mättä tarjolla heille muita sellaisia ammatillisia positioita, joiden avulla he voisivat mielekkääksi kokemallaan tavalla hankkia toimeentulonsa ja elättää itsensä. Tämä asetelma ajaa tai ohjaa heidät oman seksuaalisuutensa tavaroittamiseen.

Paholaisen haarukassa historiallinen näkökulma yhteiskuntaan tulee ensi sijassa esiin Jumalan Kyyneltä ja hänen lapsuuttaan kuvaavissa jaksoissa, jos kohta romaani asettaa myös Saija Lehtosen elämänkulun ohuesti sosiaalihistorialliseen yhteyteen. Se sivuuttaa kuitenkin kysymyksen siitä, millaisia ihmisten elämismaailmat olivat ennen uusliberalistisen kapitalismin valtaantuloa. Omassa yhteiskuntateoriassaan myös Habermas jättää paljolti huomioimatta kysymyksen siitä, millaisia subjektien elämismaailmat olivat ennen kuin myöhäismoderni "rahan ja vallan systeemi" alkoi "kolonialisoida" niitä. Habermasin teoriaa analysoinut yhdysvaltalainen yhteiskuntafilosofi Nancy Fraser (2013, 25-29, 38) toteaakin, että todellisuudessa elämismaailmat olivat jo aiemminkin hierarkkisesti ja valtapoliittisesti järjestäytyneitä sosiaalisen toiminnan alueita. Monissa maissa, muun muassa Yhdysvalloissa, ne olivat I950luvulle asti alueita, joissa naiset oli rakenteellisesti pakotettu tai alistettu toimimaan kodin piirissä elämän ylläpitämiseen ja uuden sukupolven kasvattamiseen liittyvissä tehtävissä. Tässä mielessä Habermasin teoria on, Fraser päättelee, sukupuolisokea, sillä se ei juurikaan kiinnitä huomiota elämismaailmoissa aiemmin vallalla olleisiin valtarakenteisiin, joista erityisesti naiset joutuivat kärsimään. Samoin Fraser pitää Habermasin "sosiaalivaltioon" eli laajaan hyvinvointivaltioon suuntaamaa kritiikkiä osittain perusteettomana. Vaikka "sosiaalivaltio" harjoitti laajasti muuhun yhteiskuntaan kohdistunutta sääntelyä, Fraserin mukaan sen kehittämät palvelut ja järjestelmät irrottivat toisaalta osan naisista kotityön piiristä ja avasivat heille aiempaa monipuolisemmat koulutusväylät ja työmahdollisuudet.

Mikäli Paholaisen haarukka ajatellaan yleisluontoiseksi representaatioksi uusliberalistisesta kapitalismista, sitäkin voi arvostella ohuesta historiantajusta. Se ei ota esille sitä, että uusliberalistinen kapitalismi ei suinkaan aloittanut arkielämän sukupuolittuneiden valtarakenteiden ylläpitämistä. Pikemminkin uusliberalistinen kapitalismi on muunnellut vanhoja sukupuolittuneita rakenteita, lakkauttanut osan niistä ja luonut 
niiden rinnalle uusia sukupuolisen alistamisen ja alentamisen muotoja. Fraserin mukaan näin on tapahtunut esimerkiksi Yhdysvalloissa, jossa naiset ovat samalla edelleenkin tiukemmin sidoksissa kotitöihin, lastenhoitoon ja uuden sukupolven kasvattamiseen kuin pohjoismaiset naiset.

Laajan hyvinvointivaltion kaudella (I965-1990) suoritetun uudistustyön ansiosta Suomessa luotiin, niin kuin Raija Julkunen (20I0) toteaa, ennen uusliberalistisen kapitalismin valtaantuloa tilanne, jossa erilaiset koulutusväylät, työmarkkinat ja yhteiskunnan tarjoamat itsetoteutuksen mahdollisuudet avattiin laajasti myös naisille - myös Saija Lehtosen ja Laura Laineen sukupolvelle. Vaikka Paholaisen haarukka kiinnittää oikeutetusti huomiota siihen, että markkinalogiikan yleistyminen yhteiskunnassa on sittemmin vaarantanut tämän myönteisen kehityskulun, sen esittämä nykyisen sukupuolijärjestyksen kritiikki ei ole ongelmaton. Tuota järjestystä kritisoidessaan se nimittäin tulee paikoitellen antaneeksi vaikutelman, että edeltävä yhteiskuntakehityksen vaihe, laajan hyvinvointivaltion kausi, olisi paljolti poistanut päiväjärjestyksestä sukupuolijärjestykseen sisältyneet vääristymät.

\section{Vieraantuminen, syrjäytyminen ja eksistentiaaliset motiivit}

Paholaisen haarukassa kuvatun yhteiskunnallisen tilanteen taustaksi tai edeltäjäksi romaani hahmottaa teollisuuskapitalismin ja laajan hyvinvointivaltion kauden. Romaani alkaa jaksolla (PH, 9-13), jossa kuvataan työttömän ja syrjäytyneen asemaan joutuneen Jumalan Kyyneleen elämäntilannetta. Hänen työttömyytensä ja syrjäytymisensä on aiheuttanut yhteiskunnassa tapahtunut rakenteellinen muutos, siirtyminen kansallisissa puitteissa toimineesta teollisuuskapitalismista avoimempaan maailmantalouteen, jossa määräävään asemaan on noussut finanssipääoma. Muutoksen myötä Jumalan Kyyneleen työpaikka, konepaja, siirrettiin ulkomaille ja perinteinen teollisuustyöväestö putosi vaatimattomaan asemaan yhteiskunnassa. Tuo muutos on tapahtunut i990-luvun alussa, sillä romaanin mukaan Jumalan Kyyneleen asema työelämässä romahti siirryttäessä "sääntelytaloudesta avoimeen markkinatalouteen" (ibid., 68 ja 67-76). Uudessa tilanteessa hän elätti itsensä erilaisilla alemmalle 
työväenluokalle ominaisilla lyhytaikaisilla työsuhteilla ja työttömille tarkoitetuilla määräaikaistöillä, kunnes hän putosi kokonaan työelämän ulkopuolelle. Romaanimaailman nykyisyydessä hän pystyy kestämään elämäntilannettaan vain vahvan uni- ja masennuslääkityksen avulla.

Tässäkin suhteessa Paholaisen haarukka näyttäisi esittävän nykytilannetta edeltävän vanhan teollisuuskapitalismin ja laajan hyvinvointivaltion kauden suhteellisen myönteisessä valossa. Silti tuo kuva ei ole kauttaaltaan valoisa. Jumalan Kyynel eli jo lapsuudessaan köyhän ja osittain syrjäytyneen ihmisen elämää, varsinkin sen jälkeen, kun hänen yksinhuoltajaäitinsä hylkäsi hänet ja hän varttui sijaisperheissä ja nuorisokodissa (PH, I63-I65). Tämä tapahtui laajan hyvinvointivaltion kaudella, joka ei pystynyt tarjoamaan hänelle riittävän vakaata kasvuympäristöä. Aikuistuttuaan hän sai aineellista ja emotionaalista tukea Eero ja Rauha Raiviolta, joista edellinen järjesti hänet töihin konepajalle ja työnjohtajana turvasi pitkään hänen töidensä jatkumisen siellä. Romaanin nykyisyydessä Raiviot eivät enää ole elossa. Heidän voi tulkita edustavan perinteiselle työväenliikkeelle ominaisia ihanteita: keskinäisen solidaarisuuden ja huolenpidon eetosta. Näiltä osin romaani todellakin arvioi myönteisesti nykykapitalismia edeltävää vaihetta, mutta tähän on syytä lisätä, että se esittää tuon vaiheen kätkeneen sisälleen myös taloudellis-sosiaalista ja henkistä turvattomuutta ja luokkapohjaista eriarvoisuutta. Jumalan Kyyneleen muistoissa aika konepajalla ja sen levyhallissa muodostaa silti kaipuun kohteen (ks. ibid., I44-I47).

Jumalan Kyynel on mahdollista käsittää syvästä masennuksesta kärsiväksi henkilöksi. Masennuksen syynä on hänen putoamisensa syrjäytyneen työläisen asemaan. Toisaalta häntä voidaan pitää myös traumatisoituneena henkilönä. Tavallisesti trauman käsitteellä viitataan ihmisen kohtaamaan ylivoimaiseen katastrofiin, jollaisena voi toimia esimerkiksi väkivaltainen kohtelu tai jääminen sodan tai ympäristökatastrofin jalkoihin. Axel Honneth (I997) ja Laurie Vickroy (20I4, ix-xi; 20I5, I32-I33) huomauttavat, että trauman voi lisäksi aiheuttaa ihmisen kokema sorto yhteiskuntaluokkansa, sukupuolensa, seksuaalisen suuntautumisensa, etnisen taustansa tai kansallisuutensa vuoksi. Samanlainen vaikutus voi Vickroyn (20I4, xiii) mukaan olla sillä, että lapsi jää vaille vanhempien ja yhteisön antamaa huolenpitoa, tai sillä, että ihminen joutuu esineel- 
listävän ja välineellistävän kohtelun alaiseksi. Epäilemättä Jumalan Kyyneleen lapsuudenkokemukset ja hänen syrjäytymisensä aikuisena ovat riittävä syy hänen traumatisoitumiselleen. Tätä kokemustaan hän ei pysty lainkaan ilmaisemaan verbaalisesti, vaan hän oireilee ainoastaan aggressiivisen uhon ja väkivaltaisen käyttäytymisen avulla.

Vaikka Jumalan Kyyneleen traumatisoitumisen alkusyyt löytyvät hänen lapsuudestaan, laajan hyvinvointivaltion kaudelta, tuo yhteiskuntakehityksen vaihe näyttäytyy Paholaisen haarukassa suhteellisen myönteisessä valossa. Tämä tulee näkyviin myös anonyymin kertojan äänellä kerrotussa jaksossa (PH, 95-IOO), jossa taksikuski-opiskelija Klaus saapuu asioimaan kelloseppä Lauri Laineen liikkeeseen. Fokalisoijana jaksossa on pääosin Klaus, jonka tajunnansisällöt ja kokemistavan anonyymi kertoja välittää lukijalle. Jakson alussa kertoja toteaa, miten aina kyseiseen liikkeeseen saapuessaan Klausista "tuntui että hän astui modernin maailman ja talousteorian ulkopuolelle, ajattomuuteen. Kun Klaus astui liikkeeseen, hän ei puhkaissut 'asiakasrajapintaa', vaan ajan rajan" (ibid., 95). Termi "asiakasrajapinta" kuuluu nykyisessä talouselämässä käytettyyn puheenparteen, jossa sillä viitataan yrityksen ja asiakkaiden väliseen kanssakäymiseen. Klaus ei koe käyntiään Lauri Laineen liikkeessä pelkäksi taloudelliseksi vaihdoksi. Hänelle kyseinen liike näyttäytyy laadullisesti toisenlaisen, nykykapitalismista poikkeavan aikakauden ja maailman ilmentymänä. Katsellessaan kellojensa parissa rauhallisesti, järjestelmällisesti ja määrätietoisesti työskentelevää Lauri Lainetta Klaus ajatteli, että "hänen [Lauri Laineen] toimintansa ei perustunut missään määrin ahneudelle. Ahneus ei toiminut, ei ohjannut eikä sumentanut hänen ajatteluaan. Hänen työllään ei selvästikään ollut mitään tekemistä niin banaalin asian kuin rahan kanssa” (ibid., 98). Pelkän rahan ansaitsemishimon sijasta Lauri Laine teki työtä, jonka hän koki henkisesti palkitsevaksi ja jonka ääressä hän saattoi toteuttaa itseään. Siksi "Klaus kadehti häntä. Vaikka mies oli tuomittu häviämään, hänen elämällään oli tarkoitus, joka ilmaisi itsensä viisareilla tai digitaalisilla näytöillä, liikkeellä ja pysähtyneisyydellä, niiden keskeytymättömällä vuorovaikutuksella” (ibid., 99).

Yhtiökumppaneissa kuvauksen kohteena on nykyinen informationaalinen talous ja sen tapa muokata työntekijöidensä elämää ja menta- 
liteettia. Paholaisen haarukka välittää laajemman näkemyksen yhteiskunnasta, sillä se kiinnittää huomiota paitsi talouteen, työelämään ja yksityisyyden piiriin myös julkiseen sektoriin, terveydenhoitoon sekä kulttuurin ja kirjallisuuden tuotantoon. Yhtäältä kapitalistinen välinerationaalisuus ja sille ominainen indifferentti toimintatapa sekä toisaalta niiden yhdessä tuottama vieraantuneisuus eri muodoissaan ovat Paholaisen haarukan kuvaamassa maailmassa hallitsevia yhteiskunnallisen todellisuuden tunnuspiirteitä. Sen maailmassa vieraantuneisuus koskee myös niitä sosiaalisia tiloja, joissa ihmiset kohtaavat toisensa.

Paholaisen haarukka sisältää useita sellaisia kohtia tai tekstikatkelmia, jotka nostavat etualalle sosiaalisiin tiloihin ja ihmisten välisiin suhteisiin liittyvän vieraantuneisuuden. Näistä katkelmista laajin sijaitsee romaanin alussa, jaksossa, jossa tarinamaailman ulkopuolinen anonyymi kertoja kuvaa taksikuski-opiskelija Klausin tekemiä havaintoja kaupunkitilasta. Vaikka katkelmassa puhutaan linnuista, pulua saalistavasta haukasta, katkelman on tarkoitus toimia myös arviona ja tulkintana nyky-yhteiskunnan tilasta:

Edellisenä kesänä hän [Klaus] oli nähnyt, miten pieni haukka raateli pulua keskellä toria ohi kävelevistä ihmisistä hiukkaakaan piittaamatta.

Tappaminen oli projekti; pulu raahautui pölyisellä mukulakiveyksellä haukan pitäessä sitä koko ajan toisen jalan kynsillään otteessaan ja hypellen toisella perässä kepeästi, vaivattomasti, kuin osoittaen että se tulisi mainiosti toimeen yhdelläkin.

Haukka ei tiennyt, että sen kynsissä rimpuilevalla rauhoittamattomalla linnulla oli lainsuoja pesimisaikana heinäkuun loppuun asti eikä sitä, että pulun kahdesta munasta ei koskaan kuoriutuisi poikasia. Ne mätänivät suuren kivitalon vinttikaaveliin, alkoivat haista, homehtuivat ja haihtuivat.

Pulun mustissa silmissä oli seisahtunut kauhu, ja välillä näytti siltä että se käänsi päätään satakahdeksankymmentä astetta katsoakseen haukan kellertäviin silmiin, pyrkiäkseen vaikuttamaan, vedotakseen siihen. Yhtä vähän ihmiset välittäisivät tapahtumasta, ja luultavasti tilanne olisi ollut sama vaikka pulun tilalla olisi ollut 
kuka tahansa heistä. Pulun päälaki ja selkä oli vereslihalla, se räpiköi haukan otteessa, mutta kukaan ei edes pysähtynyt, ei aika, ei hän itsekään. (PH, 23-24.)

Katkelman aloituskappaleessa kertoja selostaa Klausin aiemmin tekemiä havaintoja pulua tappavasta haukasta. Katkelman jatko jättää epäselväksi sen, missä määrin aloitusvirkettä seuraavat havainnot, rinnastukset ja yleistykset kuuluvat Klausin diskurssiin tai ajatusmaailmaan ja missä määrin ne edustavat kertojan diskurssia. Tällaiset nopeat ja epämääräiset siirtymiset diskurssista tai näkökulmasta toiseen toistuvat usein Paholaisen haarukan eri luvuissa tai kerrontajaksoissa. Tästä epämääräisyydestä huolimatta yllä siteerattua katkelmaa voi pitää upotuksena tai mise en abyme -rakenteena, joka ilmaisee romaanin perusnäkemyksen markkinoiden hallitsemasta yhteiskunnasta.

Paholaisen haarukassa kehiteltyjen yhteiskunnallisten teemojen näkökulmasta katkelmassa olennaista on se, että haukka toimii suunnitelmallisesti ja tuloshakuisesti. Se on kuuro pulun ilmentämälle hädälle ja kärsimykselle, joista piittaamatta se vie "projektinsa" kylmäverisesti loppuun asti. Samat ominaisuudet eli päämäärärationaalisuus, tuloshakuisuus ja indifferenssi ovat romaanin mukaan ominaisia markkinallistuneelle yhteiskunnalle. Näin ajateltaessa kyseinen katkelma kuvaa sitä, että markkinayhteiskunnassa ovat vallalla kapitalismin julmat ja vieraantuneisuutta tuottavat lait, jotka rapauttavat ihmisten väliltä elintärkeät keskinäisen luottamuksen ja solidaarisuuden muodot.

Sama teema, solidaarisuuden rapautuminen, tulee esiin jaksossa (PH, 67-73), jossa ulkopuolinen anonyymi kertoja valottaa Jumalan Kyyneleen tilannetta. Jakso alkaa lyhyellä kesäisen aamuyön kuvauksella, minkä jälkeen kertoja ennustaa, että "tunnin kuluttua" kaupungin kadut alkaisivat täyttyä eri suuntiin kiirehtivistä ihmisistä: "Itseohjautuva kaupunkikulttuuri purkaisi sisälmyksensä kaduille kuin oksennuksen työnnettyään sormet kurkkuunsa, ja hän [Jumalan Kyynel] näkisi aivan selvästi: ei ollut mitään yhteiskuntaa, oli vain toisiaan pelkääviä, uhkaavia ja vältteleviä ihmisiä" (PH, 67; kursivointi alkuperäisen tekstin). Kohta viittaa ironisesti uusliberalistiseen diskurssiin, joka on pitänyt ihanteenaan sitä, että yksilöt ja yhteiskunnan eri osa-alueet toimivat kasvavassa 
määrin itseohjautuvasti ja markkinaperustaisesti, ilman julkisen sektorin tukea (vrt. Petersen 20II; Schmidt, Vivien Ann \& Thatcher 20I3b). Kursivoitu ilmaisu itseohjautuva kaupunkikulttuuri on kertojan diskurssiin kuuluva käsite. Jumalan Kyyneleellä ei ole edellytyksiä tällaiseen käsitteelliseen ajatteluun, mutta katkelman jatkossa kertoja selostaa sitä, mitä Jumalan Kyynel tulisi väistämättä näkemään ja kokemaan, kun hän herää seitsemännessä kerroksessa sijaitsevassa yksiössään ja katselee aamukahvia juoden alas kadulle: että yhteiskuntaa koossa pitäneet keskinäisen luottamuksen ja solidaarisuuden siteet ovat kadonneet ja sen myötä itse yhteiskuntakin on rapautunut.

Jumalan Kyyneleen oma käyttäytyminen on tietenkin romaanin maailmassa yksi osoitus solidaarisuuden ja yhteisöllisyyden murenemisesta. Erityisesti kohtaukset, joissa hän iskee olutpullon rikki erään nuorukaisen päähän, joutuu sen jälkeen poliisien pidättämäksi ( $\mathrm{PH}$, IO9-IIO) ja murskaa romaanin lopussa kelloseppä Lauri Laineen kallon (ibid., 235-240), osoittavat, ettei hän enää piittaa yhteiskunnassa vallalla olevista kirjoittamattomista ja kirjoitetuista säännöistä. Niiden sijasta hän ilmentää ahdistuneisuuttaan pidäkkeettömän väkivaltaisesti. Juridisessa mielessä Jumalan Kyynel joutuu Paholaisen haarukassa vastuuseen teoistaan, mutta romaani ei pidä häntä moraalis-yhteiskunnallisessa mielessä syypäänä edellä mainittuihin väkivaltaisuuksiin. Näin voi päätellä romaanin loppupuolelle sijoittuvasta katkelmasta, jossa anonyymi kertoja kuvailee Jumalan Kyyneleen ja tämän lähiympäristön välisiä suhteita. Katkelma vihjaa siihen, että solidaarisuudesta ja yhteisöllisyydestä tyhjentynyt yhteiskunta luo Jumalan Kyyneleen kaltaisia yksilöitä:

Kello on yksitoista aamupäivällä.

Pyöräilijöitä ja jalankulkijoita menee ohi molempiin suuntiin. He pelkäävät häntä.

Kokeessa rotta ripustetaan valjaisiin roikkumaan, niin että sen käpälät sätkivät ilmassa. Se vikisee ja yrittää riuhtoa itsensä vapaaksi. Toinen rotta havaitsee häkkitoverinsa ahdingon, hermostuu itsekin ja onnistuu pelastamaan uhrin painamalla vipua, joka laskee valjaissa roikkuvan maahan. (PH, I97.) 
Tämäkin katkelma kuvaa solidaarisuuden ja yhteisöllisyyden rapautumista eläinmaailmasta otetun esimerkin avulla. Katkelmaan sisältyvä, rottien keskinäistä solidaarisuutta kuvaava pienoiskertomus toimii epäsuorasti huomautuksena siitä, että ihmisyhteiskunnasta puuttuu nykyisin keskinäinen huolenpito. Sen sijaan, että kanssaihmiset auttaisivat Jumalan Kyyneltä, he pelkäävät ja hyljeksivät häntä ja lisäävät hänen pahaa oloaan. Markkinayhteiskunta toimii toisella tavalla kuin keskinäisen huolenpidon yhteen sitoma rottayhteisö.

Paholaisen haarukassa on kaksi masennuksesta ja syvästä mielekkyyskriisistä tai merkityskadosta kärsivää henkilöhahmoa: Jumalan Kyynel ja Saija Lehtonen. Jukka Tontti (2005, 388-389) huomauttaa, että masennuksen ilmeneminen yksilöiden käyttäytymisessä on sukupuolittunutta. Masentuneet naiset kääntyvät usein sisäänpäin, omaan itseensä, kun taas miehillä masentuneisuus voi ilmetä enemmänkin häpeän ja arvottomuuden tunteiden kieltämisenä ja ne tukahduttamaan pyrkivänä raivona ja uhoamisena.

Jumalan Kyyneleen masennus on alussa sisäänpäin kääntynyttä; tässä vaiheessa hän välttelee sosiaalisia kontakteja. Esimerkiksi sivulla 89 Lari Laine toteaa, että Jumalan Kyynel on nyt "liian hajalla, rikki, levällään, uupunut, jotta hän voisi toimia riittävän määrätietoisesti ja fokusoidusti. Hänet on revitty irti ympäristöstään ja pakotettu kääntymään itseensä, sisäänpäin, eikä hän joka hetki tiedä mihin hän on kulkemassa”. Jumalan Kyyneleen sisäisestä maailmasta Paholaisen haarukka antaa niukasti tietoa. Eräissä jaksoissa hänen oma äänensä tai kokemistapansa tulee tosin esiin (ks. PH, 9-I3, 67-73), mutta tavallisesti häntä tarkastellaan muiden silmin, lähinnä anonyymin kertojan, Lari Laineen tai Laura Laineen näkökulmasta. Jo romaanin kolmannesta osasta, sivulta I03 lähtien - tässä 267 sivua pitkässä romaanissa on kaikkiaan kuusi osaa - kuvataan usein Jumalan Kyyneleen kuljeskelemista kaupungilla ja näytetään samalla, miten muut ihmiset häneen suhtautuvat. Näissä jaksoissa (ks. ibid., II8-II9, I5O-I5I, I97, 235-240) hän näyttäytyy uhmakkaana ja aggressiiviseen käyttäytymiseen taipuvaisena romuluisena laitapuolen kulkijana, joka herättää muissa pelkoa.

Jumalan Kyyneleen kaltaisten syrjäytyneiden ja päihderiippuvaisten ihmisten käsitteleminen on suomalaisessa nykykirjallisuudessa harvi- 
naista. Paholaisen haarukka ei silti ole tässä suhteessa täysin ainutlaatuinen teos, sillä syrjäytyneitä ihmisiä, esimerkiksi köyhiä narkomaaneja, esiintyy myös Rosa Liksomin I980- ja I990-luvulla ilmestyneissä teoksissa (ks. Sandbacka 20I7, I3-I6). Samoin Hanna Marjut Marttila on käsitellyt toimeentulotukien ja sosiaaliavustusten varassa eläviä alkoholisoituneita ihmisiä romaanissaan Kertoi tulleensa petetyksi (2002), ja Pasi Lampelan näytelmä Nolla neljä viisi (2006) kuvaa huumeriippuvaisia nuoria ja heidän perheitään. Marttilan romaanissa kuvatuille kolmelle henkilölle - kahdelle naiselle ja yhdelle miehelle - ominaista on se, että he kärsivät arvottomuuden ja tarkoituksettomuuden tunteesta, jota he pystyvät sietämään vain alkoholin ja psyykenlääkkeiden avulla (ks. Marttila 2002, I03, II4, II6). Toinen keskeinen piirre heissä on heidän sosiaalisten suhteidensa kapeus ja lyhytaikaisuus. Osittain kokemansa häpeäntunteen vuoksi ja osittain aineellisten voimavarojensa niukkuuden vuoksi he eivät kykene luomaan ympärilleen vakaata ja toimivaa sosiaalista verkostoa, joka tukisi heitä heidän vaikeassa tilanteessaan.

Vuonna 2006 järjestetyn omaelämäkerrallisen kirjoituskilpailun Arkipäivän kokemuksia köyhyydestä puitteissa kerättyä laajaa aineistoa analysoidessaan Kati Launis, Harley Bergroth ja Anu-Hanna Anttila toteavat, että nykypäivän Suomessa köyhien ihmisten elämää leimaa tavallisesti tunne omasta arvottomuudesta ja merkityksettömyydestä. Menetettyään ansiotyönsä nämä ihmiset katsovat, että he eivät pysty toteuttamaan "kunnon kansalaisen" normia, johon kuuluu osallistuminen työelämään ja mahdollisuus laajaan kuluttamiseen. Tämä vertailuasetelma tuottaa heissä usein voimakasta häpeän tunnetta ja halua jättäytyä syrjään sosiaalisesta kanssakäymisestä. Siksi heidän on vaikea kehittää sellaisia yhteistoiminnan muotoja, joilla he voisivat puolustaa etujaan, eivätkä he liioin samaistu vahvasti olemassa oleviin etujärjestöihin ja yhteiskuntaluokkiin. (Launis, Bergroth \& Anttila 20I6, I43, I58-165.) Käsillä olevan tutkimuksen näkökulmasta heitä voidaan luonnehtia vieraantuneiksi ihmisiksi, joille on ominaista irrallisuus yhteiskunnassa. Jumalan Kyynel on tällaisten ihmisten kärjistetty representaatio, jossa irrallisuus ja epäsosiaalisuus korostuvat; sen jälkeen kun hänelle huolenpitoa antaneet Eero ja Rauha Raivio ovat kuolleet, hänelle ei ole jäänyt elämässään muita kiintopisteitä kuin uni- ja masennuslääkkeet. 
Sosiaalipsykologi Saija Lehtosen kokema masennus perustuu hieman toisenlaisiin tekijöihin. Hän kokee tilanteensa epämielekkääksi ensinnäkin siitä syystä, ettei hänen asemansa työelämässä tarjoa hänelle mahdollisuutta toimia itsenäisenä ja täysivaltaisena, itseään toteuttavana subjektina. Sen sijasta hän joutuu elämään pätkätöiden varassa, minkä ohella romaani viittaa siihen, että akateemisen kapitalismin juurtuminen yhä syvemmin yliopistomaailmaan uhkaa tulevaisuudessa viedä kokonaan häneltä työpaikan:

Saija Lehtonen kannattaisi ajatusta huippuyliopistosta, ellei aavistaisi että sen myötä hän saattaisi menettää pätkätutkimusmahdollisuutensa. Hän luonnostelee aikakauslehteen tilattua artikkelia nykynaisen dilemmasta. Hän ei kirjoita itsestään, hän kirjoittaa vanhenevasta naisesta. ( $\mathrm{PH}, 83$.)

Romaani jättää auki sen, miksi Saija Lehtonen ei ole hankkinut miehensä kanssa lapsia, mutta ilmeisesti syynä tähän on ollut se, että hän on pitänyt lapsia ja lastenhoitamiseen liittyvää elämäntapaa itsenäisyytensä esteenä. "Lapset veisivät häneltä elämän. Lapset tulisivat hänen ja hänen itsensä kehittämisen ja toteuttamisen väliin", arvioi Lari Laine (PH, 208) ykskantaan.

Ehkä osittain tästä syystä Saija ja Kari Lehtonen vieraantuvat seitsemän vuotta kestäneessä avioliitossaan toisistaan. Toisena syynä heidän keskinäiseen vieraantuneisuuteensa on heidän arvomaailmojensa erilaisuus. Tämä tulee ilmi jaksossa, jossa anonyymi kertoja luonnehtii verkkotuottaja Kari Lehtosta ilmaisulla "kauppalasielu, tsehovilainen tavallinen ihminen, joka joutui lukemaan Hesarista mitä kirjaa nyt kuului lukea ja mitä näytelmiä ja elokuvia piti katsoa" (PH, 59). Kohta on sikäli poikkeuksellinen, että tavallisesti Paholaisen haarukan anonyymi kertoja pidättäytyy näin suorasta tavasta arvioida henkilöitään. Hänen esittämänsä luonnehdinta on varsin kriittinen - ottaen huomioon sen, että Kari Lehtonen työskentelee romaanin maailmassa juuri kulttuurin alueella. Luonnehdinnan jälkeen kertoja toteaa, että kerran Saija Lehtonen antoi miehelleen joululahjaksi No logon, jonka tämä tunnin, parin selailemisen jälkeen laski käsistään pois. Kyseessä on ilmeisesti kanada- 
laisen intellektuellin Naomi Kleinin kirja No logo: tähtäimessä brändivaltiaat (200I, englanninkielinen alkuperäisteos ilmestyi 2000), joka arvostelee voimakkain sanankääntein nykyistä maailmanjärjestystä. Kari ja Saija Lehtonen ovat siis osittain "eri puolilla": Kari Lehtonen on työssään sitoutunut kulttuurielämän tavaroittamiseen ja kulttuurituotteiden brändäämiseen, kun taas hänen vaimonsa kärsii konkreettisesti kapitalismin logiikan tunkeutumisesta kulttuurin alueelle, yliopistoihin.

Saija Lehtosen ajautumista eksistentiaaliseen kriisiin Paholaisen haarukka ei tuo esiin vain häntä koskevan fragmentaarisen tarinalinjan avulla. Romaani puhuu siitä myös eksplisiittisesti, kielellisellä tasolla. Jo romaanin alkupuolella Lari Laine luonnehtii hänen mielentilaansa näin:

Saija Lehtosen iho oli kananlihalla vilusta, yksinäisyydestä, aamuisesta itkusta, ikuisesta ikävästä. Kari Lehtonen käveli häntä kohti lumipyryssä, mustassa illassa, josta saattoi ilmestyä näkyviin mitä tahansa. Saija Lehtonen kuoletti itsessään tuota näkyä, kipua, joka sykki jossain kuin pakottava tunne hänen klitoriksessaan, veren tahtiin, ja lohduttominta oli ajatella ettei se koskaan lakkaisi. (PH, 65.)

Sitaatti antaa informaatiota Saija ja Kari Lehtosen välisen suhteen tilasta, siitä, että osittain juuri heidän etääntymisensä toisistaan tekee Saija Lehtosen itkuiseksi ja onnettomaksi. Mutta hänen mielialansa taustalla on myös jotakin muuta; tuota muuta ainesta Lari Laine luonnehtii "ikuiseksi ikäväksi" ja "kivuksi - - joka ei koskaan lakkaisi". Paholaisen haarukan yhteydessä näitä ilmaisuja on luontevaa tulkita eksistentiaalifilosofisessa viitekehyksessä, varsinkin sillä perusteella, että romaanin myöhempiin lukuihin sisältyy sellaisia katkelmia, jotka kehittelevät oheiseen sitaattiin sisältyviä ideoita. Näiden myöhempien jaksojen avaamasta näkökulmasta oheinen sitaatti tuntuu sanovan, että inhimilliseen olemassaoloon liittyy perustava huoli, murhe ja turvattomuuden tunne. Siksi ihmisen osana on "ikuinen ikävä", kaipuu turvalliselta tuntuvaan ja ahdistuksesta vapaaseen olotilaan. ${ }^{\text {105 }}$

Seuraavan kerran kyseinen, eksistentiaalisesta turvattomuudesta puhuva motiivi esiintyy kelloseppä Lauri Lainetta kuvaavassa jaksossa. 
Siinä anonyymi kertoja kuvaa vapaan epäsuoran esityksen keinoin Lauri Laineen tajuntaa ja hänen muistikuviaan omasta lapsuudestaan:

Miksi kelloseppä Lauri Laine muisti tapauksen lapsuudestaan tultuaan ikään, jolloin jo tietää, että ihminen itkee syntyessään ja kuollessaan. Hän muisti äitinsä kertoneen omasta lapsuudestaan, miten kylältä oli kantautunut vanhusten päätöntä tuskanhuutoa, ulinaa ja voihketta, aikana jolloin ei ollut kroonikko-osastoja, morfiinijohdannaisia ja perushoitajia. Lasten naurua ja kirkunaa kuului samanaikaisesti. (PH I48.)

Sitaatti liittää edellä mainittuun motiiviin lisäulottuvuuden, kuoleman arvoituksen. Inhimillistä olemassaoloa ei luonnehdi vain eksistentiaalisten turvakehikoiden hauraus, vaan ihmiset joutuvat elämään myös sen tosiasian kanssa, että he eivät tiedä, mitä heille tapahtuu heidän elämänsä päättymisen jälkeen. Osaltaan näistä syistä ja myös puhtaasti fyysisistä syistä elämän ääripisteisiin, syntymään ja kuolemaan, liittyy kipuja ja tuskanhuutoja. Paholaisen haarukkaa lukiessa yllättävältä saattaa tuntua se, että kyseinen motiivi esiintyy kelloseppä Lauri Laineen yhteydessä; romaani ei nimittäin muutoin juurikaan välitä informaatiota siitä, miten hän kokee maailman. Kyseinen jakso ennakoi kuitenkin romaanin myöhempiä tapahtumia, Lauri Laineen oman elämän päättymistä. Samaisen jakson kautta romaani tuo painotetummin esiin myös sen, että eksistentiaaliset kriisit eivät ole vain tämän (Jumalan Kyynel) tai tuon (Saija Lehtonen) ihmisen kokemusta, vaan ne määrittävät yleisemmin inhimillistä olemassaoloa.

Kaikkein selvimmin edellä mainittu eksistentiaalinen motiivi tulee esiin romaanin lopussa, jaksossa, jossa kerrotaan Saija ja Kari Lehtosen avioliiton päättymisestä. Kertojana jaksossa on sijoitusneuvoja Lari Laine:

Saija Lehtonen on jättänyt avioerohakemuksensa raastuvanoikeuteen eikä hänen miehensä vastusta sitä. Hetki on lopulta niin ohimenevä, pari vuotta, eikä sylin kaipuu silti ihmisestä poistu. Me etsimme syliä loppuun asti, emmekä vähiten sen jälkeen kun opimme tietämään sen minkä isänikin oppi tietämään: että syn- 
tyessämme meillä on hätä, samoin kuollessamme, sylittömiltä. Sieltä, missä synnytään, kuuluu itkua ja tuskanhuutoja, samoin sieltä missä kuollaan. Monesti myös muualta, noiden ääripäiden väliltä, matkan varrelta. Syliä me etsimme, muodotonta, mittaamatonta, ääretöntä, joka ei lisäänny jos siihen jotain lisää ja jota ei voi jakaa osiin. Lämmintä elokuista iltaa me etsimme, sellaista kuin on juuri nyt, kun ensimmäiset räkättirastaat syöksähtelevät aroniapensaissa tummien, mehevien marjojen houkuttelemina, joukossa pari mustarastasta. Kostea, turvonnut sää, ruohon syvä vihreä, julma keltainen mustarastaiden nokassa. (PH, 238-239.)

Sitaatti kokoaa yhteen Paholaisen haarukassa esiintyviä aineksia. Se on yhtäältä jatkoa romaanissa aiemmin esiintyneelle puheelle "ikuisesta ikävästä" ja "koskaan lakkaamattomasta kivusta". "Ikuista ikävää" lähellä on "sylin kaipuu" tai rakkauden ja läheisyyden kaipaaminen; rakkaus ja läheisyys näyttäytyvät tällöin asioina, joiden avulla ihminen voi paremmin kestää turvattomuuden tunnettaan ja tietoisuutta kuolemansa väistämättömyydestä. Kuva "lämpimästä elokuisesta illasta" on Seppälän varhaistuotannossakin, esimerkiksi Kuun nousussa ja laskussa (I999), esiintyvä trooppi, eräänlainen eksistentiaalinen utopia, joka antaa ilmaisun kokemukselle olemassaolon täyteydestä. Luonteenomaista Seppälän teoksille on se, että ne sijoittavat tuon utooppisen ulottuvuuden luontoon ja vuodenaikojen kiertoon. Lopussa oleva ilmaisu "julma keltainen mustarastaiden nokassa" toimii muistutuksena siitä, että tällaiset utopiat eivät silti kanna ihmiselämää loppuun asti, vaan ne voivat tarjota ihmiselle vain tilapäistä lohdutusta.

Paholaisen haarukassa henkilöiden kokemat eksistentiaaliset kriisit saavat osittain tai ensi sijassa selityksensä heidän sosiaalisista suhteistaan ja heidän asemastaan yhteiskunnassa. Tämän piirteen voi nähdä poikkeamana klassisesta eksistentialismista, jonka tapa tarkastella inhimillistä olemassaoloa koskevia teemoja on abstrakti. Paholaisen haarukka ei silti torju kokonaan eksistentialismia, vaan se esittää, että eksistentiaalinen ahdistus on jossakin määrin myös sisäänrakennettu piirre inhimillisessä olemassaolossa. Romaanin mukaan tämä seikka liittyy lähinnä siihen, että mitkään kulttuuriset merkitysjärjestykset ja sosiaaliset siteet 
eivät pysty tarjoamaan ihmiselle aukotonta turvallisuuden tunnetta eivätkä poistamaan hänestä elämän rajallisuuteen liittyvää murhetta ja ahdistusta. Ajatus kosmisista merkitysjärjestyksistä ei liioin riitä ihmisille lohdutukseksi, sillä heillä ei ole mitään takeita tai varmuutta sellaisten olemassaolosta. Siksi "sylin kaipuu" määrittää pysyvästi ihmisen osaa maailmassa.

Yhtiökumppaneiden tavoin Paholaisen haarukkaa voidaan pitää yhteiskunnallisena romaanina, joka sisältää eksistentiaalisen ulottuvuuden. Samoin edellä siteeratuissa kohdissa tulee esiin eksistentialismin sukuinen näkemys inhimillisestä elämästä ja olemassaolosta. Tuo näkemys tai merkitysjuonne ei kuitenkaan ole Paholaisen haarukassa niin keskeisessä asemassa, että tämä romaani olisi syytä määrittää myös eksistentialistisen romaanigenren edustajaksi. Eksistentialistinen ulottuvuus liittyy siinä selvimmin kelloseppä Lauri Lainetta käsitteleviin jaksoihin sekä Saija ja Kari Lehtosesta kertovaan tarinalinjaan, joka päättyy heidän seksuaalisen yksinäisyytensä ja turhautumisensa kuvauksiin. Edellisellä sivulla oleva katkelma jatkuu Lari Laineen toteamuksella siitä, että "Saija Lehtosen tuleva elämä tulee olemaan yksinäistä, yksinäistä ja seksuaalisesti yksinäistä” (PH, 239). Kari Lehtonen pärjää kenties vielä huonommin oman seksuaalisuutensa kanssa:

Jos vilkaisemme Kari Lehtosta juuri nyt: hän joutuu haikeana katselemaan postia noutavan naapurin rouvan lanteiden keinuntaa. Hän saattaa saada erektion jonka nöyryyttävästi laukaisee vessan lavuaariin tai luultavasti sängyssään selällään maaten, sellaista on elämä. Koska se ei kulje niin kuin haluaisimme sen kulkevan, meidän osaksemme jää vetäytyminen syrjään ja toteuttaa eläintä itsessämme. (PH, 240.)

Tällainen näkemys seksuaalisuudesta esiintyi jo Seppälän varhaistuotannossa, esimerkiksi pienoisromaanissa Silta (I988), joka kuvaa murrosikäisen pojan kehitystä hänelle uudessa ja oudossa, urbaanissa ympäristössä. Mainittu näkemys muistuttaa eksistentialismin klassikkojen, esimerkiksi Beauvoirin ja Sartren, käsitystä siitä, että seksuaalisuus on ihmiselle risti tai taakka, josta ihminen ei pääse eroon, mutta 
jonka kanssa hänen on yritettävä tulla toimeen (Cooper 2008, II9-I20, I85-I86). Samaan tapaan Seppälän teoksissa ihminen on seksuaalisuuttaan toteuttaessaan tavallisesti mahdollisimman epävapaa, tahdostaan riippumattoman voiman ohjaama olento. Tuskin koskaan nuo teokset kuvaavat seksuaalisuutta myönteiseen sävyyn.

Paholaisen haarukassa eksistentiaalisia ja eksistentialistisia ulottuvuuksia tukevat monet intertekstuaaliset viittaukset. Esimerkiksi sivulla 53 anonyymi kertoja siteeraa suoraan Camus'n postuumisti ilmestynyttä, paljolti omaelämäkerrallista romaania Ensimmäinen ihminen (I995, ranskankielinen alkuperäisteos ilmestyi I994), jossa Camus kuvaa köyhää lapsuuttaan ja nuoruuttaan Algeriassa. Paholaisen haarukan myöhemmät luvut sisältävät puolestaan epäsuoria viittauksia myös Heideggeriin ja Sartreen. ${ }^{\text {I06 }}$ Romaanin eksistentiaalisia ja eksistentialistisia ulottuvuuksia vahvistavat niin ikään sivulla 27 olevat viittaukset Sofokleen tragediaan Kuningas Oidipus (429 eKr.), Dostojevskin romaaniin Idiootti (I929, venäjänkielinen alkuperäisteos ilmestyi I869) ja Alfred Döblinin romaaniin Berlin Alexanderplatz (I98I, saksankielinen alkuperäisteos ilmestyi I929). Tällaiset viittaukset, romaanissa kuvatut tarinalinjat ja siinä esitetyt pohdiskelut tuottavat yhdessä näkemyksen, jonka mukaan markkinakapitalismin valta-aseman vuoksi mielekkään elämän edellytykset ovat kaventuneet yhteiskunnassa merkittävästi (eksistentiaalinen ulottuvuus). Tätä voi pitää Paholaisen haarukan välittämänä pääväittämänä aikalaistodellisuudesta. Se lieventää tuohon pääväittämään sisältyvää yhteiskuntakritiikkiä eräissä kohdissa toistuvalla eksistentialistisella motiivilla, jonka mukaan inhimilliseen olemassaoloon liittyy jo sinänsä perustavanlaatuinen huoli, ahdistus ja vierauden kokemus - riippumatta siitä, millaisessa yhteiskunnassa ihmiset sattuvat kulloinkin elämään.

\section{Yhteiskunnallisen todellisuuden representoimisen ongelma}

Yhteiskunnallisena moraliteettina Paholaisen haarukka poikkeaa sikäli Yhtiökumppaneista, että siitä puuttuu jälkimmäiselle ominainen "absoluutin kaipuu", viittaus tilanteeseen, jossa bisneksenteon sokaisema 
yhteiskunta saisi rangaistuksensa jossakin kosmisessa, ehdottomien arvojen maailmassa. Sen sijaan markkinakapitalistinen yhteiskunta saa Paholaisen haarukassa rangaistuksensa siten, että ihmiset ja yhteisöt ajautuvat siinä vieraantuneisuuden ja eksistentiaalisten kriisien tilaan tai, niin kuin Giddens (200I, 9) sanoisi, "eksistentiaaliseen isolaatioon", jossa ihmisiltä on viety arvokkaan ja mielekkään elämän edellytykset. Näin ei tapahdu pelkästään Jumalan Kyyneleen, kelloseppä Lauri Laineen ja sosiaalipsykologi Saija Lehtosen kaltaisille, markkinallistumiskehityksessä häviäjien joukkoon joutuneille ihmisille. Edellä sanottu koskee myös sijoitusneuvoja Lari Lainetta, sillä "systeemissä, jossa tehtiin strategisia päätöksiä instrumentaalisen järjen ohjaamina", kukaan ei ole turvassa, vaan tällaisessa systeemissä "voittajiksi selviytyneistäkin tiristettiin elämänvoima pikkuhiljaa, tasaisesti puristamalla" (PH, IO). Paholaisen haarukassa "väärien jumalien" palvomisen seurauksena on todellisuuden muuttuminen painajaismaiseksi tilaksi.

Paholaisen haarukka sisältää joukon mise en abyme -tyyppisiä upotuksia, jotka ilmaisevat tiivistetyssä muodossa sen välittämän perusnäkemyksen nykykapitalismista. Niihin kuuluu muun muassa jo mainittu katkelma, jossa haukka raatelee pulua torilla ja ihmiset seuraavat tapahtumaa välinpitämättöminä (ks. PH, 23-24). Tämän katkelman voi tulkita puhuvan kapitalismille ominaisesta indifferenssistä ja sosiaalisen solidaarisuuden rapautumisesta. Sisällöltään varsin samanlainen on katkelma, jossa kuvataan ensin sitä, miten yhteiskunta ja muut ihmiset kohtelevat Jumalan Kyyneltä, ja sen jälkeen siirrytään puhumaan rottayhteisössä vallitsevasta keskinäisestä huolenpidosta (ibid., I97). Tämäkin trooppi viittaa siihen, että ihmisten ylläpitämästä yhteiskunnasta on kadonnut keskinäinen solidaarisuus.

Laajin metakirjallinen kokonaisuus romaanissa on Laura Laineen elokuvakäsikirjoitus ja sen filmaaminen. Elokuvaa ei tuoda esiin yhtenäisessä muodossa vaan katkelmallisesti, tavalla, joka sopii yhteen romaanin muutoinkin fragmentaarisen etenemistavan kanssa. Paholaisen haarukan 77 luvusta kaikkiaan I3 lukua muodostuu kyseiseen käsikirjoitukseen ja sen filmaamiseen kuuluvista katkelmista, minkä lisäksi sivuilla I29-I3I on luku, jossa muun kerronnan lomaan on sijoitettu lyhyt jakso käsikirjoituksesta. Laura Laineen elokuvaa ei voi pitää aivan 
samanlaisena mise en abyme -rakenteena kuin edellisessä kappaleessa mainittuja eläinaiheisia trooppeja. Siihen sisältyy kyllä tällainen itsensä tiedostaville romaaneille ominainen metakirjallinen ulottuvuus, sillä kuvaahan se Jumalan Kyyneleeksi nimetyn keski-ikäisen miehen syrjäytymistä sekä Saija ja Kari Lehtosen keskinäistä vieraantumista toisistaan - ja siten yleisemmin teemoja, jotka ovat romaanin muissakin luvuissa keskeisiä. Mutta tämän ohella käsikirjoituksen yhteydessä pohditaan sitä, millainen suhde vallitsee todellisuuden ja todellisuutta esittävän representaation välillä.

Kysymys todellisuuden ja todellisuutta esittävän representaation välisestä suhteesta jakautuu Paholaisen haarukassa kahteen osakysymykseen. (I) Niistä ensimmäinen koskee sitä, ovatko representaatiot ja niiden kohteet sulautuneet toisiinsa pitkälle medioituneessa nyky-yhteiskunnassa. Tämä osakysymys on luonteeltaan ontologinen, sillä epäsuorasti siinä pohditaan sitä, onko medioituminen muuttanut perustavasti yhteiskunnallisen todellisuuden luonnetta. (2) Toista osakysymystä voisi luonnehtia epistemologiseksi ja tiedonsosiologiseksi. Siinä pohdiskelun kohteeksi asettuu se, miten representaatioiden laatijoiden sosiaalinen asema vaikuttaa siihen, millaisen representaation he yhteiskunnasta luovat.

(I) Jo I970- ja I980-luvulla julkaisemissaan kirjoituksissa Jean Baudrillard (I98I, I47-I52) esitti, että markkinaperustaisen ja mediavälitteisen toiminnan yleistymisen myötä sosiaalis-kulttuurinen todellisuus on länsimaissa sulautumassa yhteen erilaisista merkeistä, representaatioista ja esteettisistä objekteista muodostuvan simuloidun keinotodellisuuden kanssa. Tätä ilmiötä, jossa todellisuus on yhä enemmän erilaisia merkkejä ja representaatioita, Baudrillard piti vieraantuneisuuden erityismuotona. Hänen mukaansa siinä perinteisen sosiaaliskulttuurisen todellisuuden päälle kerrostuu sitä peittävä, medioiden välittämä merkkien, mielikuvien ja representaatioiden kudelma.

Paholaisen haarukan kohdalla voidaan periaatteessa erottaa toisistaan romaanin oma todellisuus ja sitä käsittelevät representaatiot. Missä määrin romaanin oma todellisuus on tässä tapauksessa, Baudrillardin sanontaa käyttääksemme, sekoittunut mielikuvansa kanssa? Monet Paholaisen haarukan lukeneet kirjallisuuden harrastajat vastaisivat ehkä 
näin asetettuun kysymykseen toteamuksella, että kyseistä romaania lukiessaan heidän on paikoitellen ollut vaikea tietää, milloin siinä puhutaan romaanin omasta todellisuudesta ja milloin taas sitä käsittelevistä representaatioista. Tämä epämääräisyys koskee erityisesti Kari ja Saija Lehtosen keskinäistä suhdetta käsitteleviä jaksoja. Osa tämän suhteen käänteistä kerrotaan romaanissa elokuvan avulla, ja vastaavasti Kari ja Saija Lehtosen käyttäytyminen romaanin omassa todellisuudessa kuvataan toisinaan ikään kuin vain pohjustuksena sille, mitä heistä kerrotaan elokuvassa. Näistä syistä lukijan mielessä saattaa helposti syntyä vaikutelma, että elokuva seuraa reaaliajassa heidän avioliittonsa kehitystä tai että elokuvantekijät ovat aina silloin paikalla, kun heidän keskinäisessä suhteessaan tapahtuu jotakin merkittävää. ${ }^{107}$

Kari ja Saija Lehtosen keskinäistä suhdetta kuvaavissa jaksoissa romaanin todellisuus sekoittuu siis välillä tästä todellisuudesta tehtyihin representaatioihin. Kokonaan ne eivät kuitenkaan sulaudu toisiinsa, sillä kyseistä suhdetta käsitellään romaanissa myös elokuvanteon ulkopuolella. Muutoin Paholaisen haarukkaan sisältyvä ontologinen tematiikka muistuttaa läheisesti Hannu Raittilan Pamisoksen purkauksen (2005) käsittelemää tematiikkaa. Raittilan romaanin alussa poliisin kerrotaan saaneen haltuunsa nauhakeloja, jotka sisältävät aiemmin tuntemattoman dokumentin laivasta nimeltä Pamisos. Sen jälkeen kertojien puheenvuoroista saa käsityksen, että mukavuuslippulaiva Pamisos yritti vuonna I99I saapua Helsingin satamaan, mutta se pysäytettiin kaupungin edustalle, sillä sen lastina oli mädäntynyttä lampaanlihaa. Tämän jälkeen alkoi markkinakilpailu laivan tyhjentämisestä. Mukana kisassa oli epätoivoisia yrittäjiä, joilta lama-Suomi oli vienyt toimeentulon. Tuolloin Suomessa elettiin lähes ryöstökapitalismin vaihetta, jolloin markkinakilpailua eivät ohjanneet selkeät säännöt.

Raittilan romaanin alkuosaa voi lukea dokumentaarisesti, jolloin lukija olettaa sen kertomien asioiden todella tapahtuneen i990-luvun alussa. Toisessa osassa paljastuu kuitenkin, että alkuosa on romaanin keskushenkilön, Leena-nimisen kirjailijan laatimaa käsikirjoitusta, jota hän on tarjonnut kustantajalle. Myöhemmin kerrotaan, että Pamisos-laiva todella kävi Suomessa I990-luvun alussa, mutta se saapui Turun edustalle silakkalastissa, joka uhkasi pilaantua ja joka purettiin siksi merellä 
proomuihin; tosin tämänkin kertomuksen totuusarvo jää romaanissa lopulta epäselväksi. Lisäksi käy ilmi, että Leena on liittänyt käsikirjoitukseensa aineksia omasta ja läheistensä elämästä ja muunnellut niitä todellisuutta dramaattisempaan suuntaan.

Sekä Paholaisen haarukka että Pamisoksen purkaus pohtivat sitä, millä tavalla entistä immateriaalisemmaksi muuttunut nykykapitalismi tulisi kirjallisuudessa esittää. Ne molemmat lähtevät siitä, että markkinakäyttäytymisen ja mediavälitteisyyden yleistymisen myötä nykykapitalismi on monin eri tavoin kytkeytynyt merkkien, mielikuvien ja representaatioiden tuotantoon. Samalla tällaiset immateriaaliset tuotteet ovat nykyisin erottamaton osa yhteiskunnallista todellisuutta. Yhteistä kyseisille romaaneille on myös se, että ne käsittelevät tätä problematiikkaa metaleptisen romaanin keinoin. Metaleptisissä romaaneissa ontologisten tasojen väliset rajat hämärtyvät, jolloin lukijan on vaikea tietää, milloin romaani viittaa reaalimaailmaan ja milloin taas fiktion maailmaan tai fiktion sisään upotettuihin pienoismaailmoihin. Raittilan romaani tarkastelee tämän ohella sitä, missä määrin mediavälitteisyyden lisääntyminen peittää yhteiskunnallisen todellisuuden muut puolet ja estää kirjallisuutta pääsemästä niihin käsiksi. Se tuntuu epäilevän kirjallisuuden mahdollisuuksia kuvata näitä puolia todenmukaisesti. (Ojajärvi 20ıза, 296-297; Sevänen 2013c, 6I-62.)

(2) Paholaisen haarukassa tietoa ja totuutta koskevat kysymykset ovat esillä hieman toisella tavalla kuin Raittilan romaanissa. Jumalan Kyyneltä käsittelevien elokuvakohtausten yhteydessä romaani pohtii ensi sijassa sitä, missä määrin älymystöön tai ylempiin luokkiin kuuluvat taiteilijat tuntevat riittävästi Jumalan Kyyneleen kaltaisen syrjäytyneen ihmisen elämäntodellisuutta ja missä määrin he kykenevät kuvaamaan hänen elämäänsä pätevällä tavalla. Tämä kysymys saa romaanissa lisää painoarvoa sitä kautta, että Jumalan Kyyneltä kuvaavat jaksot ohjaaja Laura Laine tekee näyttelijöiden avulla, kun taas Kari ja Saija Lehtonen esittävät hänen elokuvassaan itseään. Siten elokuvadramaturgisten valintojen tekemisen ulottuvuus korostuu Jumalan Kyyneltä kuvaavien jaksojen yhteydessä. Pohjimmiltaan edellä mainittu kysymys on silti tiedonsosiologinen, sillä siinä käsitellään kognitiivisen toiminnan yhteiskunnallista sidonnaisuutta ja tuon sidonnaisuuden vaikutusta kognitioiden 
sisältöön. Epistemologiseen kysymykseen siitä, onko ihmisen ylipäänsä mahdollista saada pätevää tietoa yhteiskunnallisesta todellisuudesta, Paholaisen haarukka näyttäisi vastaavan myöntävästi.

Laura Laine on itsekin hyvin tietoinen luokkaerosta itsensä ja Jumalan Kyyneleen välillä. Hän tunnustaa avoimesti kuuluvansa ylempiin luokkiin:

Minä, joka teen elokuvia, olen etuoikeutettu. Minun vanhemmillani on huomattava nettovarallisuus. Kellosepät ovat rikkaita miehiä, heillä on kultaa. Myös ne, jotka parlamentaarisessa järjestelmässä ajavat köyhien etuja, ovat rikkaita, valtuutettuja, hallintoneuvoston jäseniä, osuusliikkeiden johtokunnassa istuvia ammattipoliitikkoja, kansanedustajia, myös menestyviä taiteilijoita. He puolustavat työpaikkoja, eivät työntekijöitä saati ihmisiä köyhistä puhumattakaan. Köyhän etua ajavalla köyhällä ei ole ääntä eikä kasvoja, pelkät kädet, joilla hän tekee mitä sattuu, usein virheitä. Minä olen etuoikeutettu ihminen. Minä valehtelen, mutta en ole valheellinen. Ihmisenä minä kuulun omistavaan, huolettomaan luokkaan. Taiteilijana minä annan ihmisille elämän, riisun itseni paljaaksi ja teen itsestäni haavoittuvan muiden edessä. Se on rooli, jonka läpi viemiseen vaaditaan riittävästi rahaa. En huijaa, en yritä pysytellä emotionaalisen totuuden alapuolella. Niin minä tämän itseni selitän, kielipelillä. Kun olen saanut ihmisistäni kokonaisia, ne lähtevät omille teilleen. (PH, 205-206.)

Menestyvänä taiteilijana Laura Laine edustaa lähinnä ylempää keskiluokkaa, jota Jani Erolan (20I0a) johtama luokkatutkimuksen projekti kutsuu myös "alemmaksi professioluokaksi". Luokkahierarkiassa se sijaitsee heti ylemmän professioluokan (tuomarit, lääkärit, johtavat poliitikot, yritysten omistajat ja toimitusjohtajat) alapuolella. Perhetaustansa kautta Laura Laineella on juuret myös perinteisessä pienyrittäjien kerrostumassa, sen vauraassa osakulttuurissa, sillä hänen vanhempansa ovat omistaneet taloudellisesti tuottoisan kellosepänliikkeen. Poliittisesti ja ideologisesti häntä voi pitää vasemmistopuolueiden ja Vihreän liiton kannattajana, sillä hän katsoo elokuvillaan ajavansa köyhien ihmisten 
asiaa ja hän on kouluvuosistaan lähtien kuulunut eläinten oikeuksia ajavaan Animalia-yhdistykseen. Pankkimaailmaa ja sitä edustavaa veljeään Lari Lainetta hänen on aina ollut vaikea sietää. Lari on puolestaan pilkallisesti nimittänyt mielessään sisartaan "lehmänhenkiälymystön" jäseneksi - erottaen hänet siten "todellisesta älymystöstä", joka on sitoutunut innovaatiopolitiikan ja luovan talouden edistämiseen. (Ks. PH, I25-I27, I74-I77.)

Laura Laine ajattelee, että taiteilijana hän toimii julkisuudessa tietynlaisessa sosiaalisessa roolissa tai, wittgensteinilaisittain, "kielipelissä". Siihen kuuluu ensinnäkin se, että taiteilijana hän käsittelee yhteiskunnallisia ongelmia ja epäkohtia. Tämä ulottuvuus on I700-luvulta lähtien ollut kiinteästi mukana länsimaisessa kirjallisuuskäsityksessä. Sen mukaan kirjailijalla tai taiteilijalla tulee olla laaja riippumattomuus taloudellisista ja poliittisista valtakeskuksista, jotta hän voisi harjoittaa yhteiskunnan arvopäämäärien ja epäkohtien kriittistä tarkastelemisesta. Katkelmaan sisältyvä ajatus siitä, että "taiteilijana minä annan ihmisille elämän, riisun itseni paljaaksi ja teen itsestäni haavoittuvan muiden edessä” on puolestaan monitulkintainen. Yhtäältä sen voi tulkita puhuvan modernille taiteelle ominaisesta ekspressiivisyydestä, siitä, että modernissa taiteessa on aina jossain määrin kyse taiteilijan itseilmaisusta, hänen oman subjektiutensa ilmaisemisesta. Toisaalta kyseisen lausuman voi suhteuttaa myös markkinaehtoisesti toimivaan nykykulttuuriin, jossa taiteilijalta odotetaan yhä enemmän oman elämänsä ja persoonallisuutensa asettamista näytteille yleisön eteen.

Oheisessa katkelmassa Laura Laine tunnustaa "valehtelevansa". Ilmeisesti hän tarkoittaa tällä sitä, että hän tietää kuuluvansa perhetaustansa ja sosiaalisen asemansa osalta ylempiin luokkiin, mutta taiteessaan hän haluaa esiintyä alempien luokkien puolustajana ja samalla myös, vähintäänkin epäsuorasti, ylempien luokkien kriitikkona. "Valehteleminen" viittaa tähän ristiriitaan hänen sosiaalisen taustansa ja hänen omaksumansa taiteilijanroolin välillä. Se ei siten tarkoita sitä, että hän katsoisi, että luokkataustansa vaikutuksen vuoksi hän ei voisi kuvata alempien luokkien elämää totuudenmukaisesti. "Minun on tehtävä ihmiseni siitä rajallisesta savesta mikä minulla on, eikä yksikään heistä sano huonosti nukuttuaan että 'minä vain itsekseni kiukuttelin'. Veljeni on tästä var- 
masti eri mieltä, mutta kyllä minä tiedän, mitä elämä on ja millaisia ihmiset” (PH, 92. Ks. myös s. 9I, 93, I87-I90, 206-207). Myöskään elokuvantekoon liittyvä luova ulottuvuus, käsillä olevan "saven" tai aineksen (tarinankerronta, näyttelijäntyö, kuvamateriaali) muokkaaminen "elämää" tai todellisuutta esittäväksi teokseksi, ei Laura Laineen mukaan tee mahdottomaksi sitä, että hän voisi ohjaajana välittää katsojilleen suhteellisen todenmukaisia representaatioita yhteiskunnallisesta todellisuudesta.

Paholaisen haarukassa elokuvanteko - ja yleisemmin todellisuuden representoiminen taiteen avulla - nähdään erilaisten valintojen tekemisenä, aidosti luovana toimintana. Tämä painotus ei tule esiin vain Laura Laineen puheissa vaan myös hänen veljensä Lari Laineen kerrontajaksoissa. Sisarensa elokuvantekoa aktiivisesti seuraava Lari Laine toteaa monessa eri yhteydessä olevansa tyytymätön sisarensa valintoihin, esimerkiksi siihen, miten tämä aikoo esittää Jumalan Kyyneleen ja yhteiskunnan välisen suhteen:

Laura pohtii Jumalan Kyyneltä, jota hän mielessään kutsuu välillä myös Robsoniksi. Sisareni tietää jossain vaiheessa hahmottelevansa hänet vastuuttomaksi ja vapaaksi, koska tällä ei ole enää mitään velvoitetta yhteiskuntaa kohtaan, pelkkä katkeruus. Kyyneltä ei kuitenkaan saisi esittää vain tyypillisenä ja puhdaspiirteisenä sosiaalipatologisena formulana, keissinä.

Jumalan Kyynel oli ihminen. (PH, 75.)

Lari Lainetta kiinnostaa siis se, tuleeko hänen sisarensa esittämään Jumalan Kyyneleen sosiaalisena tyyppinä, tiettyjen yhteiskunnallisten kehitystendenssien ilmentymänä vai pikemminkin ainutkertaisena ja erityislaatuisena yksilönä. Muissa yhteyksissä hän on vaivannut mieltään myös sillä, millaista genre-formulaa Laura Laine aikoo elokuvassaan hyödyntää ja millaisen lopun tämä tulee elokuvalleen sommittelemaan (PH, 74-76, II3-II4, I22, I54-I55, I63-I66, 229-23I, 267). Vaikka Lari Laine suhtautuu kriittisesti sisarensa valintoihin ja poliittisiin näkemyksiin, hänkään ei kiistä sitä, että elokuvan avulla on mahdollista esittää yhteiskunnallista todellisuutta suhteellisen totuudenmukaisesti. 
Entä mikä on Paholaisen haarukan oma kanta edellä esiteltyyn tiedonsosiologiseen ja epistemologiseen problematiikkaan? Mitä se itse esittää representaatioiden tiedollisesta arvosta? Tähän on hieman hankala antaa yksiselitteistä vastausta, mutta romaaniin sisältyvä elokuvantekoa käsittelevä tarinalinja alleviivaa sitä, että yhteiskunnallisen todellisuuden esittäminen taiteessa ja kirjallisuudessa on itsekin yhteiskunta- ja välinesidonnaista. Erilaisista yhteiskunnallisista asemista käsin tarkasteltaessa ja erilaisia välineitä (romaani, elokuva, teatteri) käytettäessä yhteiskunnallinen todellisuus näyttäytyy aina hieman eri valossa. Silloin kun kirjailijat ja taiteilijat kuvaavat alempia luokkia, representaatioiden suhteellisuus vain korostuu, sillä tavallisesti kirjailijat ja taiteilijat kuuluvat koulutuksensa ja asemansa osalta ylempiin luokkiin. Tätä representaatioiden relationaalisuutta, niiden tiedollisen arvon suhteellisuutta, ei pidä sekoittaa relativismiin eikä radikaaliin konstruktivismiin - siis käsityksiin, että kaikki representaatiot ovat tiedollisesti yhtä arvokkaita tai arvottomia tai että representaatiot ovat pelkkiä konstruktioita, joilla ei ole mitään tiedollista arvoa. Paholaisen haarukka ja siihen sisältyvät elokuvantekoa koskevat jaksot näyttävät siten sanovan, että representaatiot, mukaan lukien Paholaisen haarukka, ovat aina joistakin tietyistä näkökulmista laadittuja esityksiä todellisuudesta, mutta tästä sidonnaisuudesta huolimatta ne kykenevät ainakin periaatteessa lisäämään tietoamme ja ymmärrystämme maailmasta.

Näiltä osin Paholaisen haarukka ei eroa suuresti Hannu Salaman Finlandia-sarjassa (1976-I983) esitetystä tietokäsityksestä, vaikka Paholaisen haarukka, toisin kuin Salaman romaani, käyttääkin yhtenä kertojana tarinamaailman ulkopuolista anonyymia kertojaa eli ekstradiegeettistä heterodiegeettistä kertojaa. Milla Peltonen (2008, 29-59, 73-75, 85-88, 97) toteaa, että perinteistä, "kaikkitietävää" kerrontaa arvostellessaan Salama rakensi sarjaansa kertojanmallin, jossa kaikki kertojat, myös henkilöitä yksikön kolmannen persoonan pronominin eli hän-kerronnan avulla kuvaavat kertojat, ovat osa romaanin maailmaa ja samalla tasolla sen henkilöiden kanssa. Tällaisella kerrontastrategialla Salama torjui "totalisoivat" ja itseään erehtymättöminä pitävät maailmanselitysmallit.

Metatason jaksoissaan Paholaisen haarukka näyttää siis jakavan relationaalisen käsityksen representaatioiden tiedollisesta arvosta, mutta se 
tuo tämän käsityksen esiin metanarratiivisin keinoin - eikä, niin kuin Salaman romaanisarja, luopumalla tarinamaailman ulkopuolisista kertojista. Paholaisen haarukka kertoo yhdellä tasolla tarinaa Jumalan Kyyneleestä, ja toisella tasolla se käsittelee häntä koskevan elokuvan tekemistä ja kertoo samalla tarinaa myös siitä. Jälkimmäisellä tasolla se näyttää sanovan, että Jumalan Kyyneleen tarina on mahdollista kertoa monella eri tavalla, monesta eri näkökulmasta ja erilaisin painotuksin, eikä mitään niistä voi pitää kaikenkattavana tai ehdottomana totuutena hänestä.

Näiltä osin Paholaisen haarukka näyttää jakavan relationaalisen ajatustavan. Romaanin ilmestymisajankohdan yhteiskunnallisen tilanteen takia siinä on kuitenkin myös toisenlaisia, tuolle tietokäsitykselle vastakkaisia sävyjä. Vuonna 2008, jolloin teos ilmestyi, perinteinen realistinen, kaikkitietävää kertojaa käyttävä yhteiskunnallinen romaani oli suomalaisessa kirjallisuudessa menettänyt valta-asemansa ja sen tilalle oli tullut erityppisiä kertojia käyttävä ja uusia kerronnallisia ratkaisuja kokeileva romaanityyppi. Sydänmaasta (I994a) lähtien Seppälän omat romaanitkin ovat kuuluneet tämän uudenlaisen romaanityypin piiriin. Näistä syistä hänellä ei ilmeisesti ollut tarvetta käydä polemiikkia perinteistä realistista romaanimuotoa vastaan. Sitä vastoin Seppälä koki vuosina 2000-20I2 vastustajakseen uusliberalistisen politiikan, joka oli I990-luvulla noussut Suomessa hegemoniseen asemaan. Erityisesti Yhtiökumppanit (2002), Routavuosi (2004e) ja Paholaisen haarukka (2008) on syytä nähdä tätä taustaa vasten. Niissä sisäistekijän ote romaanin tapahtumista ja ekstradiegeettisen heterodiegeettisen kertojan puhetapa ovat usein sävyltään ehdottomia ja lakonisen toteavia, sillä niiden vastustajana ollut uusliberalistinen politiikka on, ideologiselle diskurssille luonteenomaisella tavalla, ollut taipuvainen pitämään itseään "lopullisena totuutena" siitä, miten yhteiskunta pitäisi järjestää (vrt. Kiander 20I3, I9-2I). Tällaiset ehdottomilta vaikuttavat näkemykset eivät sinällään sovi yhteen relationaalisen ajattelun kanssa, jollaista Seppälän varhaisemmat teokset paikoitellen edustivat ja jonka suuntaan hänen teoksensa ovat taas olleet selvemmin kallellaan vuoden 20 I2 jälkeen.

Paholaisen haarukan on paikoitellen vaikea sovittaa yhteen relationaalista ajattelua ja kapitalismikritiikkiä. Mitä ankarampaa kapitalismikri- 
tiikkiä jokin jakso edustaa, sitä kauempana jakso näyttää olevan teoksen relationaalisesta tietokäsityksestä. Ja toisaalta representaatioiden tiedollista arvoa pohtivissa jaksoissa romaani etääntyy kapitalismikritiikin harjoittamisesta. Vuoden 20 I2 jälkeen ilmestyneihin Seppälän romaaneihin ei sisälly tämän suuntaista jännitettä. Niiden kallistumista yksiselitteisemmin relationaalisen tietokäsityksen suuntaan ilmentää muun muassa se, että romaanin Matka aurinkoon (2014) mottona on Michel Foucault'n Tiedon arkeologiasta (2005, ranskankielinen alkuperäisteos ilmestyi I969) otettu virke, ja esimerkiksi Kuoppakaupungissa (2016) ekstradiegeettinen heterodiegeettinen kertoja kuvailee kirjailija Ilmo Halssin paluuta opiskeluajan jälkeen kotikaupunkiinsa näin:

Kun hän lähti, hän ei tuntenut olevansa tiedon haltija. Vasta paljon myöhemmin hän oivalsi, että mitään riippumatonta tietoa ei ollut olemassa: oli vain laskematon määrä merkitysten leikkiä, taistelua: fiktiota, jolla ei ollut perustaa, kohdetta eikä sisältöä. Tietoyhteiskunnalla ei liioin ollut mitään tekemistä varsinaisen tiedon kanssa. Typerykset käyttelemässä kehittynyttä teknologiaa. (Seppälä 20ı6, I6o.)

Tosin tämä anonyymin kertojan esittämä näkemys on monitulkintainen. Sen voi myös tulkita edustavan relationaalista tietokäsitystä radikaalimpaa - relativistista tai konstruktionistista - tietokäsitystä, jonka edustajana myös Foucault'ta on usein pidetty. Vaikka Kuoppakaupunki ei kehittele pidemmälle tätä tieto-opillista motiivia, katkelma osoittaa, että olisi väärin pitää Seppälän romaaneja perinteisen realistisen tai objektivistisen tietokäsityksen edustajina. Paholaisen haarukkakin on lähellä relationaalista käsitystä representaatioiden tiedollisesta arvosta, mutta sen kapitalismikriittisissä jaksoissa tämä ei aina tule painotetusti esiin.

Irmtraud Huber (20I4, 32-34) toteaa, että nykykirjallisuus on etääntynyt postmodernismille ja jälkistrukturalismille ominaisesta konstruktionistisesta ja relativistisesta ajattelusta. Tämä ei silti tarkoita sitä, että nykykirjallisuus olisi siirtynyt laajasti kannattamaan perinteistä realistista tietokäsitystä. Päinvastoin, Huber jatkaa, se korostaa tiedon suhteellisuutta ja epävarmuutta, muttei silti torju sitä mahdollisuutta, että 
kirjallisuus pystyy lisäämään tietoamme maailmasta. Seppälän kapitalismikriittiset romaanit näyttävät edustavan paljolti juuri tällaista käsitystä kirjallisuuden tiedollisesta arvosta.

\section{Kirjallisuuden asema nykykapitalismissa}

Paholaisen haarukka on metakirjallinen romaani siinäkin mielessä, että se pohtii sitä, miten kirjallisuuden asema on markkinallistumiskehityksen myötä muuttunut. Tässä suhteessa se ei ole ainutlaatuinen teos suomalaisessa nykykirjallisuudessa. Elina Arminen (2015; 2018) huomauttaa, että Kari Hotakaisen Klassikko-romaanista (I997) lähtien Suomessa on ilmestynyt joukko romaaneja, jotka kuvaavat, tavallisesti satiirin ja absurdin komiikan keinoin, kustannusmaailman, kirjailijantyön ja julkisuuden kaupallistumista. Hotakaisen Klassikon ohella tähän yhteyteen kuuluvat Jari Tervon Minun sukuni tarina (1999), Tuomas Vimman Toinen (2005), Hotakaisen Ihmisen osa (2009), Antero Viinikaisen Orgo (2009), Juha Itkosen Seitsemäntoista (2010), Kreetta Onkelin Kutsumus (20I0), Jussi Siirilän Historia on minut vapauttava (2010) ja Anja Snellmanin Ivana B. (20I2). Miltei kaikissa niissä kaupallistuminen nähdään vaaratekijäksi, joka uhkaa riistää tai viedä kirjallisuudelta henkisen liikkumisvapauden ja latistaa kirjailijantyön markkinatrendien myötäilemiseksi.

Armisen mainitsemia satiireja voi pitää nykyisen kirjallisuusinstituution kritiikkeinä. Ne eivät kuitenkaan ole pelkkää kritiikkiä, vaan niihin liittyy samalla voimakkaita kaupallisia ja viihteellisiä tarkoitusperiä. Arminen (2018) jatkaa, että näin ne itse asiassa näyttävät osaltaan todentavan Boltanskin ja Chiapellon käsityksen kapitalismikritiikin funktiosta kapitalistisessa yhteiskunnassa. Näiden kahden sosiologin esittämä käsitys painottaa sitä, että demokraattisesti hallitussa yhteiskunnassa kapitalismi ei suinkaan torju itseensä kohdistuvaa kritiikkiä, vaan pikemminkin se tarvitsee sitä. Varsinkin nykyisin se kykenee myös hämmästyttävän hyvin tuotteistamaan itseensä kohdistuvaa kritiikkiä ja käyttämään sitä itsensä vahvistamiseen. Tästä ilmiöstä Boltanski ja Chiapello käyttävät nimitystä récupération de la critique, jota on hankala 
suomentaa, mutta joka viittaa juuri kapitalismin kykyyn neutralisoida kritiikki ja käyttää sitä kapitalistisen järjestyksen vahvistamiseen. Mikäli tämä käsite, "rekuperaatio"ı88, on sovellettavissa Armisen mainitsemiin satiireihin, nekin tukisivat ja vahvistaisivat loppujen lopuksi kirjallisuusinstituution kaupallistumiskehitystä.

Kirjallisuusinstituution kritiikkinä Paholaisen haarukka eroaa edellä mainituista, enemmän tai vähemmän satiirisista romaaneista siinä, että se ei rajoitu kirjallisuusinstituution tarkastelemiseen, vaan se käsittelee eksplisiittisesti nykyistä kirjallista ja kulttuurista elämää yhtenä markkinakapitalistisen talousjärjestyksen osa-alueena. Armisen mainitsemissa romaaneissa tällainen kytkentä kirjallisuusinstituution ja muun talouselämän tai muun yhteiskunnan välillä on ohut, ja esimerkiksi Snellmanin romaanista se puuttuu miltei kokonaan. Tämä ei tosin estä sitä, etteikö lukija voisi lukea kyseisiä satiireja metonyymisesti, jolloin hän mieltää niihin sisältyvän kirjallisuusinstituution kritiikin myös yleisemmin kuvaukseksi markkinallistuneesta nyky-yhteiskunnasta.

Paholaisen haarukassa kirjallisuusinstituution markkinallistumisesta puhuvat verkkotuottaja Kari Lehtonen ja sijoitusneuvoja Lari Laine, jotka esittävät omissa kerrontajaksoissaan näkemyksiään kustannustoiminnan, elokuva-alan ja medioiden suhteesta kapitalismiin (ks. PH 2008, 43-48, 5I-56, II2-II9, I9I-I92, 2I4-2I6). Määrällisesti nämä jaksot eivät muodosta laajaa kokonaisuutta, mutta niiden vahvuus piileekin siinä, että niissä tulee esiin tietynlainen visio kirjallisuuden ja kulttuurituotannon kehityksestä kapitalismissa.

Omissa jaksoissaan Lari Laine puhuu siitä, että elokuvat ja kirjallisuus ovat muuttumassa tai ne ovat jo muuttuneet kapitalistisen viihdeteollisuuden osa-alueiksi:

Elokuva taidemuotona kuolee, on kuollut jo, muuttunut pelkäksi rahan funktioksi, enkä minä sure sen perään. Se on sosiaali- ja taloushistoriaa, joka jäi teknologian jalkoihin. Se on kuoleva myös taloudellisesti, koska kotiteatterit, netti ja kuva kännykässä tappavat sen. Elokuva oli pelkkä välivaihe nopeutettuna sarjana esitetyistä valokuvista matkalla kohti yksityistä kuvan katsomisen kokemusta. (PH, 46.) 
Katkelma ei selitä perinteisen taide-elokuvan osakulttuurin kuihtumista vain sillä, että elokuvateko on muuttunut pelkäksi rahan ansaitsemiskeinoksi, "pelkäksi rahan funktioksi". Toinen tärkeä nykyiseen visuaaliseen kulttuuriin vaikuttava tekijä on teknologia, joka mahdollistaa aiempaa yksityisemmän kuvavirran vastaanottokokemuksen ja joka etäännyttää visuaalista kulttuuria kollektiiviseen vastaanottoon tarkoitetuista perinteisistä taide-elokuvista. Näiden kahden tekijän vaikutuksesta eletään tilanteessa, jossa "kehnoimmat elokuvat myivät joka tapauksessa parhaiten. Sosiaalipornoa, kansakunnan historiaa, huolekasta epookin rakentamista, pukunäyttelyitä, julkkiskuvaelmia” (PH, 48). Silti Lari Laine suhtautuu kulttuurituotannon tavaroitumiskehitykseen sinänsä myönteisesti - samoin kuin Kari Lehtonen, jonka mielestä "kirjailijan mediakäyttäytymisessä ei ole mitään tuomittavaa. Hän vastaa täysin adekvaatisti markkinoiden kysyntään uusviihdeteollisuuden palvelusektorilla tai tietoviihteen telesektorilla, miten asia nyt halutaankin ilmaista" (ibid., 5I).

Lari Laine spekuloi myös sillä, miten kirjallisuuden tuotannon muuttuminen entistä jäännöksettömämmin kapitalistisen kulttuurituotannon osa-alueeksi mahdollisesti muuttaa kirjallisuuden luonnetta:

Kaksisataa vuotta vanha porvarillinen romaani pystyi aikaisemmin käsittelemään yhteiskunnallisen todellisuuden kahta tai kolmea keskeistä teemaa synteesinä, ja vaikka tämän fundamentalismin opit ovat vaikeasti murrettavissa siihen liittyvien taloudellisten kytkösten vuoksi, se tapahtuu. Tulossa on murros, sekatyylien aika, kirjallinen hellenismi. (PH, 47.)

Tähän Lari Laineen esittämään yleistykseen voidaan täsmennyksenä lisätä se, että porvarillisen romaanin alkuperä voidaan itse asiassa sijoittaa jo I700-luvulle, 300 vuoden taakse, jolloin se kehittyi ja kukoisti erityisesti Englannissa. Toisaalta kapitalismikriittisen romaanityypin syntyajankohtana voidaan pitää ı8oo-luvun alkupuolta, jolloin markkinakapitalismista tuli Englannissa ja Ranskassa hallitseva taloudellisen toiminnan muoto. Nykyiselle tilanteelle, jossa kirjallisuuden tuotanto ja välitys ovat yhdentymässä kapitalistisen talouden kanssa, leimallista on se, että kirjallisuudessa yhteiskuntakritiikki on enää mahdollista vain, 
mikäli "sen ympärille oli rakennettavissa hype, markkinoitava tuote" (PH, II6). Näin ajateltaessa nykykapitalismi olisi edennyt kritiikin tuotteistamisessa vielä pidemmälle kuin Boltanski ja Chiapello ajattelivat. Siinä, missä he puhuivat kapitalismin kyvystä tuotteistaa jälkikäteen itseensä kohdistunutta kritiikkiä, Lari Laine tuntuu olettavan, että tällainen kytkentä kritiikin ja tuotteistamisen välille luodaan jo prosessin alkupäässä. Tällöin julkaistavaksi valikoituu vain sellaisia kriittisiä teoksia, jolla uskotaan olevan kaupallista potentiaalia.

Lari Laineen näkemyksiä kirjallisuuden ja elokuvan tuotannon sulautumisesta markkinakapitalismiin voi pitää liioiteltuina. Niiden taustalla on yhteiskunnassa tapahtunut markkinallistumiskehitys, mutta niiden esiintymistä Paholaisen haarukassa selittää myös tämän romaanin oma logiikka, se, että Paholaisen haarukka käsittelee reaalisesta yhteiskunnasta poimimiansa ilmiöitä kärjistäen. Tämän logiikan mukaisesti se esittää yhteiskunnallisen todellisuuden johdonmukaisesti muodostumana, jonka eri osa-alueet markkinakapitalismi on miltei täydellisesti alistanut ja tukahduttanut valtansa alle. Samoihin aikoihin kirjoittamissaan lehti- ja blogiteksteissä Seppälä ei kuvannut markkinakapitalismin valtaa näin totaaliseksi ja tukahduttavaksi, vaan teksteissään hän puhui siitä, että Suomessa valtiollinen kulttuuripolitiikka on tukimuotojensa avulla edelleen taannut kirjailijoille ja taiteilijoille tietyn riippumattomuuden markkinoista. Samalla hän oli teksteissään huolissaan siitä, että valtiovallan piirissä on esitetty kaavailuja kulttuurisektorin muuttamisesta aiempaa markkinaehtoisemmaksi. ${ }^{109}$ Paholaisen haarukkaan sisältyvät Lari Laineen pohdiskelut toimivat siten varoittavina visioina siitä, mitä kirjallisuuden ja taiteen kriittisille potentiaaleille tapahtuisi läpikotaisin markkinallistuneessa maailmassa.

Paholaisen haarukan kuvaamassa todellisuudessa lähinnä vain ohjaaja Laura Laine toimii vielä suhteellisen itsenäisesti, tavalla, joka tuo hänet lähelle perinteistä taiteilijaa. Hänkään ei silti ole riippumaton taloudellisista pakoista, sillä hänen on aina kyettävä järjestämään elokuvilleen rahoitus. Näissä rajoissa hän pyrkii tekemään yhteiskunnallisesti merkittävää taidetta. Romaanin eräässä luvussa, jossa hän kertoo taiteenteossa noudattamistaan periaatteista, toistuu moneen kertaan ilmaisu "punaista ja mustaa", esimerkiksi näin: "Minun on tehtävä tilanne. Minun 
on tunkeuduttava tilanteeseen kuin noita. Punaista ja mustaa, äkkiä" (PH, 93). Laura Laine rinnastaa siten taiteilijana toimimisensa Stendhalin romaanin Punainen ja musta (I969, ranskankielinen alkuperäisteos ilmestyi ı830) poliittiseen asetelmaan. Kyseinen romaani kritisoi Napoleonin kukistumisen jälkeistä ranskalaista yhteiskuntaa, jolle oli samanaikaisesti ominaista kuningasvallan palauttaminen ja suurporvariston voimistuminen. Stendhalin romaanissa tämä asetelma estää alhaista syntyperää olevan Julien Sorelin, romaanin päähenkilön, nousun korkeampiin sosiaalisiin asemiin (ks. Dubois 2007). Laura Laine katsoo syrjäytymistä ja vieraantumista käsittelevällä elokuvallaan jatkavansa tällaista kriittisen kyseenalaistamisen perinnettä.

Erityistä huomiota Laura ja Lari Laine kiinnittävät elokuvan loppukohtaukseen. Useissa luvuissa Lari Laine pohdiskelee, aikooko hänen sisarensa viitata lopussa Jumalan Kyyneleen valvojaan Eero Raivioon ja tämän Rauha-vaimoon, joita esittäisivät näyttelijät:

Vanhan miehen ruskea kämmenselkä auringossa on inhimillisen lämmön vertauskuva. Konjakkiryyppy vatsanpohjassa.

Eero Raivion kaltaisella ikääntyneellä miehellä olisi jo tilaa sydämelle, armolle. Hän olisi auttanut Jumalan Kyyneleen kaltaista nuorta poikaa, antanut mahdollisuuden, ottanut kuhmuraisten, suonikkaiden, nikotiinin keltaisiksi värjäämien kättensä suojiin.

Semmoisesta suunnasta hohkaa lämpö ja kiireettömyys, sieltä kuuluu köhää, pesän virittelemisen ääniä, sieltä kantautuu meidät rakkauden tavoin ympäröivän savun tuoksua, lapsuudesta joka meidän kaikkien olisi kuulunut kokea. Eero-vaari on totta. (PH, I64-I65.)

Taiteen vaikutusten kannalta kyse on siitä, valitseeko Laura Laine elokuvalleen tällaisen ristiriitoja sovittavan ja katsojia rauhoittavan, terapeuttista lohdutusta tarjoavan lopun - niin kun viihteellisissä elokuvissa usein tapahtuu - vai pakottaako hän katsojansa kohtaamaan todellisuuden. Sen jälkeen kun Jumalan Kyynel on kostanut kärsimänsä yhteiskunnalliset vääryydet absurdilla tavalla, iskemällä tarkkuuskellon kello- 
seppä Lauri Laineen takaraivoon, sovittava loppu ei ole mahdollinen. Romaani päättyy kohtaan, jossa Lari Laine kommentoi sisarensa valitsemaa loppukohtausta: "Laura teki oikean ratkaisun. Viimeinen kuva ei ole Eero ja Rauha Raivio keinussa eikä Eero Raivion ruskeat kädet" (PH, 267).

Tällainen lopetus tuo samalla paljolti tiivistetysti esiin sen, mitä Seppälän vuosina 2000-20I2 ilmestyneet teokset esittävät kirjallisuuden yhteiskunnallisesta tehtävästä. Erityisesti Yhtiökumppanit (2002), Routavuosi (2004e) ja Paholaisen haarukka (2008) näyttävät sisältävän epäsuorasti ajatuksen, että kirjallisuuden tulee pakottaa lukija kohtamaan markkinakapitalismin tuottama yhteiskunnallinen todellisuus ja siihen liittyvät uhkakuvat - paljolti riippumatta siitä, miten rujo tuo todellisuus on.

Jyrkimmässä muodossaan tämä vaatimus esiintyy Routavuoden päähenkilön Kaarlen puheissa siitä, mitä hän odottaa taiteelta: "Iines [Kaarlen naisystävä] kuunteli epäuskoisen näköisenä, kun selitin pitäväni ainoana rehellisenä taiteena sellaista taidetta, joka pisti hyvinvoinnin illuusioon turtunutta, velttoa keskiluokkaista ihmistä epämukavasti kylkiluiden väliin kuin vuodesohvasta irti ponnahtanut vieteri” (Seppälä 2004e, 6o). Tällainen taide poikkeaa Kaarlen mukaan nykytaiteen valtasuunnista, jotka ovat kaupallista menestystä tavoitteleva taide ja poliittisia vallanpitäjiä mielistelevä, konformistinen taide. Nykytaiteesta Kaarleen on myönteisen vaikutuksen tehnyt vain "eräs poliittinen vastalause, jonkun itävaltalaisen taiteilijan performanssi, jossa tämä alaston ruumis yltä päältä paskassa, koko ajan masturboiden lauloi maansa kansallishymniä. Hän sai aktion vuoksi puolen vuoden vankeusrangaistuksen" (ibid., 6I). Kyseinen taiteilija on Wienin aktionisteihin kuulunut Günther Brus (syntynyt I938), joka piti Kaarlen mainitseman performanssin vuonna I968 järjestetyssä tapahtumassa "Taide ja vallankumous". ${ }^{\text {Iı }}$ Kaarle ihannoi siten aktivistista ja avantgardistista poliittista taidetta.

Romaanihenkilö Kaarlen esittämiä näkemyksiä ei kuitenkaan ole syytä pitää Seppälän omina mielipiteinä. Antamissaan haastatteluissa Seppälä on itsekin korostanut tätä seikkaa, jos kohta hän on samalla lisännyt, että hän ei silti usko taiteeseen, joka ryhtyy yhteistyöhön vallitsevan taloudellisen ja poliittisen järjestyksen kanssa. ${ }^{\text {III }}$ Tämän perusteella ei 
ole yllättävää, että edellä mainitut kolme romaania sisältävät epäsuorasti saman ajatuksen: kirjallisuuden on niiden mukaan kuvattava ilman sovittavia elementtejä sitä, millaisia kielteisiä vaikutuksia markkinahenkisellä politiikalla on yksilöiden ja yhteisöjen elämään.

\section{Yhteenvetoa}

Paholaisen haarukan kuvaamassa fiktiivisessä maailmassa markkinakapitalismi on levinnyt miltei kaikkialle yhteiskuntaan ja tukahduttanut sen osa-alueet valtansa alle. Miten tällainen yhteiskuntakuva suhteutuu kyseisen romaanin kontekstiin? Kontekstin käsitteellähän on tässä tutkimuksessa viitattu (a) Seppälän vuosina 2000-20I2 ilmestyneiden teosten historiallis-yhteiskunnalliseen taustaan, (b) kapitalismiteorian traditioon, (c) rationalisaatiokriittisen romaanityypin traditioon ja (d) Seppälän aiempaan tuotantoon. Sivuutan tässä Seppälän aiemman tuotannon eli kontekstin (d) ja tarkastelen seuraavaksi Paholaisen haarukan suhdetta konteksteihin (a), (b) ja (c).

Paholaisen haarukka on ottanut kontekstista (a) mukaan monia aineksia. Niitä ovat erityisesti uusliberalismin nousu hallitsevaksi yhteiskuntapoliittiseksi strategiaksi, talouden avaaminen globaaleille markkinavoimille, finanssipääoman keskeisyys nykykapitalismissa, ekologisten riskien ja uhkakuvien ajankohtaistuminen ja markkinakapitalismin toimintatapojen leviäminen yhteiskunnan eri osa-alueille, lähinnä terveydenhoidon, yliopistolaitoksen, kulttuurituotannon, kirjallisuusinstituution, yksilöiden elämismaailmojen ja seksuaalisuuden piiriin. Paholaisen haarukan kuvaama maailma rakentuu tällaisista aineksista. Kuvauksen ulkopuolelle romaani jättää muun muassa sen, että kaikesta huolimatta hyvinvointivaltiota ja sen tuottamia palveluja ei ole kokonaan lakkautettu vaan lähinnä supistettu. Lisäksi yhteiskunnassa esiintyy edelleen arvorationaalisuutta painottavia liikkeitä, esimerkiksi naisliike ja ympäristöliike. Suhteessa kontekstiin (a) Paholaisen haarukka on siten erittäin valikoiva. Se ottaa siitä kuvaukseensa mukaan lähinnä vain markkinallistumiskehitystä edustavia aineksia, joiden kielteisiä puolia se korostaa. Tässä suhteessa Paholaisen haarukka muistuttaa perinteisiä naturalistisia 
romaaneja. I80o-luvun naturalismille oli niin ikään ominaista kuvata yhteiskunnan kielteisiä ilmiöitä ja räikeitä epäkohtia, joiden tuhoisia vaikutuksia alleviivaamalla se pyrki herättämään lukijoissa moraalisen shokkivaikutuksen. (Rossi 2009, I94, 225-252.) Samanlainen kärjistämisen logiikka on paljolti ominainen Paholaisen haarukalle, joka sisältää kuitenkin myös spekulatiivisille fiktioille ominaisia piirteitä. Se ei kuvaa pelkästään oman aikansa yhteiskuntaa, vaan jatkuvan ja johdonmukaisen valikoimisen ja kärjistämisen kautta se laajenee myös hahmotelmaksi siitä, millainen lähes läpikotaisin markkinallistunut yhteiskunta olisi nykytietämyksen valossa.

Paholaisen haarukkaa ei siten ole kokonaisuudessaan syytä pitää pelkkänä kuvauksena aikalaistodellisuudesta eli kontekstista (a). Sen kuvaama maailma rakentuu kahden yläperiaatteen varaan. Yhtäältä tuossa fiktiivisessä maailmassa miltei kaikki tapahtumat kuvastavat markkinakapitalismille ominaista systeemirationaalisuutta, "välineellistä järkeä", tai, jos näin ei ole asianlaita, ne ilmentävät tuon systeemirationaalisuuden tuhoisia vaikutuksia yksilöiden ja yhteisöjen elämään. Muunlaista, arvorationaalista todellisuutta Paholaisen haarukan kuvaamassa maailmassa edustavat vain Eero ja Rauha Raivio, kelloseppä Lauri Laine ja ohjaaja Laura Laine, mutta heistäkään Raiviot eivät ole elossa romaanin nykyhetkessä ja Lauri Laineenkin Jumalan Kyynel murjoo lopussa aivokuolleeseen tilaan.

Näin voimakkaasti kärjistetty yhteiskuntakuva on riippuvainen paitsi reaalisesta markkinallistumiskehityksestä (konteksti a) ja kirjallisista traditioista (konteksti c) myös kapitalismiteorian traditiosta (konteksti b). Kapitalismiteorian traditiosta Paholaisen haarukka nojautuu erityisesti Habermasin tuotantoon sisältyvään ajatukseen myöhäismodernista talouden ja politiikan järjestelmästä, joka toimii yksipuolisesti kognitiivis-instrumentaalisen rationaalisuuden pohjalta. Mutta siinä, missä Habermasilla tällaiseen välineelliseen rationaalisuuteen perustuva toiminta muodostaa vain yhden, tosin keskeisen myöhäismodernin yhteiskunnan osa-alueen, Paholaisen haarukan kuvaama fiktiivinen nykyyhteiskunta rakentuu miltei kokonaan sen varaan. Samoin kyseinen romaani sivuuttaa paljolti sen, ettei nykyinen talousjärjestelmäkään noudata pelkästään välineellistä rationaalisuutta, vaan siinä on myös 
arvorationaalisia, affektiivisia ja perittyihin tapoihin perustuvia toimintamuotoja. Näin Paholaisen haarukka koodaa sekä reaalisesta yhteiskunnasta ottamansa aineksen että siihen lisäämänsä fiktiivisen aineksen välineellisen systeemirationaalisuuden ilmentymiksi tai tuon systeemirationaalisuuden kielteisiksi vaikutuksiksi.

Habermasin Theorie des kommunikativen Handelns on Paholaisen haarukan keskeisin yhteiskuntateoreettinen interteksti, jota se hyödyntää valikoivasti ja joka ohjaa sen tapaa käsitellä reaalisesta yhteiskunnasta ottamaansa ainesta. Toisaalta Paholaisen haarukalle on vaikea nimetä sellaista yksittäistä rationalisaatiokriittistä romaania, joka toimisi sen kirjallisena intertekstinä. Siksi onkin parempi ajatella, että yksittäisten romaanien sijasta sen pohjatekstinä toimii koko rationalisaatiokriittisen romaanin traditio, jonka edustajat ovat usein käsitelleet kapitalismin toimintatapoja voimakkaiden kärjistysten avulla, esimerkiksi käyttämällä hyväksi satiirista ja groteskia kuvaustapaa. Rationalisaatiokriittisen romaanin traditiota voidaan pitää kulttuurisena arkkitekstinä, joka ilmentää lähinnä länsimaisen kriittisen älymystön maailmankuvaa, sen kehittämää ja työstämää kuvaa kapitalismista. Paholaisen haarukka on osa tätä traditiota, mutta sille ominainen kärjistämisen logiikka vie sitä samalla aikalaistodellisuutta käsittelevän spekulatiivisen fiktion suuntaan.

Entä missä suhteissa siinä esitetty yhteiskuntakuva vastaa kirjailija Juha Seppälän maailmankuvaa, hänen omaa käsitystään nyky-yhteiskunnasta? Tämä kysymys on syytä ottaa lyhyesti esille siitä syystä, että Seppälä on haastatteluissaan ja kolumneissaan käsitellyt kapitalismia ja markkinallistumiskehitystä. Paholaisen haarukassa esitettyä käsitystä voidaan siksi verrata siihen kuvaan, jonka nuo haastattelut ja kolumnit tarjoavat.

Oheiseen kysymykseen vastattaessa on syytä pitää mielessä se, että retorisessa kertomusteoriassa kirjailijan ääni liitetään kiinteästi ekstradiegeettiseen heterodiegeettiseen kertojaan ja sisäistekijään. Niinpä Richard Walshin $(2007,84)$ tutkimuksissa ekstradiegeettistä heterodiegeettistä kertojaa ei voida erottaa kirjailijasta, sillä Walshin mukaan tällainen kertoja edustaa kertomuksessa kirjailijan ääntä. Ekstradiegeettinen heterodiegeettinen kertoja on siis sellainen henkilöiden yläpuolella oleva kertoja, joka ei osallistu tarinamaailman tapahtumiin. Tällaista 
kertojaa on usein myös luonnehdittu kaikkitietäväksi, mutta hän voi myös olla "asenteeton tarkkailija", joka kuvailee vain henkilöiden ulkoista käyttäytymistä. Ehkä tavallisimmin kirjailijan ääni on kuitenkin liitetty sisäistekijään, kertomuksen ylimpään tiedolliseen ja moraaliseen auktoriteettiin, jota James Phelan $(2005,45)$ on taipuvainen pitämään "virtaviivaistettuna" versiona kirjailijan omasta ajatustavasta ja arvomaailmasta.

Walshin ja Phelanin tavoin ajateltaessa Seppälän oma ajatustapa ja arvomaailma tulisi Paholaisen haarukassa selvimmin esiin sisäistekijän ja ekstradiegeettisen heterodiegeettisen kertojan puheessa. Romaanissa jälkimmäinen esittää muun muassa alussa olevan kertomuksen Jumalan Kyyneleen työhistoriasta ja hänen jäämisestään työttömäksi sekä heti niiden perässä olevan habermasilaisen kuvauksen nykytaloudesta tai nyky-yhteiskunnasta systeeminä, jota hallitsee välineellinen järki (ks. PH, 9-I3). Sijoitusneuvoja Lari Laine toimii romaanin eräissä jaksoissa ekstradiegeettisenä homodiegeettisenä kertojana - siis sellaisena henkilöiden yläpuolella olevana kertojana, joka osallistuu romaanissa kerrotun maailman tapahtumiin. Hänen esittäminään tällaiset kuvaukset ja kertomukset eivät olisi yhtä uskottavia, sillä hän on sitoutunut markkinakapitalismin edistämiseen.

Paholaisen haarukassa sisäistekijä ja ekstradiegeettinen heterodiegeettinen kertoja ovat maailmankatsomuksellisesti epäilemättä lähellä kirjailija Juha Seppälää, joka on myös haastatteluissaan ja lehtikirjoituksissaan puhunut välineellisen järjen ja markkinoiden hallitsemasta nykyyhteiskunnasta. Silti noiden kahden narratiivisen toimijan esittämää yhteiskuntakuvaa ei voida kaikilta osin samaistaa Seppälän omaan yhteiskuntakäsitykseen. I990-luvulla ja 2000-luvun alussa julkaisemissaan lehtikirjoituksissa Seppälä ei esittänyt markkinakapitalismin valta-asemaa yhteiskunnassa niin totaaliseksi kuin Paholaisen haarukka sen esittää, kuten tässä pääluvussa on käynyt ilmi.

Phelanin ja Walshin esittämä ajatus siitä, että kirjailijan arvomaailma ja ääni tulevat kertomuksessa esiin sisäistekijän ja ekstradiegeettisen heterodiegeettisen kertojan toiminnassa, on siksi sellaisenaan epätarkka. Konkreettisen tutkimuksen ei ole syytä soveltaa sitä suoraan aineistoonsa, vaan olisi kysyttävä aina tapauskohtaisesti, missä mielessä nuo 
narratiiviset toimijat mahdollisesti ilmentävät kulloinkin kirjailijan omaa arvomaailmaa ja ääntä. Tähän kysymykseen annetun vastauksen uskottavuutta lisää se, että tutkimuksella on käytettävissään kirjallisesta teoksesta riippumatonta vertailumateriaalia, esimerkiksi kirjailijahaastatteluja. Tällainen tapa selvittää kirjailijan ja sisäistekijän välistä suhdetta on dialogisen ja diskursiivisen kirjallisuuskäsityksen ja kirjallisuussosiologian kannalta hedelmällisempi kuin Seymour Chatmanin (I978; I990) ja Ansgar Nünningin (I997) tapa depersonalisoida sisäistekijä. Heillä sisäistekijän käsite ei viittaa lainkaan reaaliseen kirjailijaan vaan pelkästään teosta hallitsevaan normistoon ja konstruktioperiaatteeseen.

Routavuoden (2004e) ilmestymisen yhteydessä Ilta Sanomat Plussa -lehdessä julkaistussa haastattelussa Seppälä puhui siitä, että Suomessa viime vuosikymmeninä harjoitettu yhteiskuntapolitiikka on käsitellyt kansalaisia pelkkinä talouskasvun ja tuloksenteon välikappaleina. Siksi hänen mukaansa kansalaisista on alkanut tuntua siltä, että nykyisin "ihmisen ainoa arvo on välineellinen arvo". Tästä arviosta tai otaksumasta on lyhyt matka Paholaisen haarukan ihmiskuvaan. Ohjaaja Laura Lainetta, kelloseppä Lauri Lainetta sekä Eero ja Rauha Raiviota lukuun ottamatta sen henkilöhahmot ilmentävät kukin omalla tavallaan näkemystä tai visiota siitä, millaista typistettyä subjektiutta ja habitusta välinerationaalisen toiminnan radikaali yleistyminen tuottaa tai tuottaisi yksilötasolla.

Samantyyppistä valikoivaa ja kärjistävää käsittelytapaa Paholaisen haarukka soveltaa yhteiskunnan eri osa-alueisiin. Sen kuvaamassa maailmassa terveydenhoitojärjestelmä toimii pitkälle lääketeollisuuden asettamin ehdoin, yliopistolaitos on muuttumassa vallitsevan talousjärjestyksen aputieteeksi, kirjallisuuden ja taiteen tuotanto palautuu viihdeteollisuuden osa-alueeksi, "rahan funktioksi", sosiaalisesta elämästä ja ihmisten keskinäisistä suhteista on kadonnut solidaarisuus, eikä yksityisyyden sfäärikään kykene enää toimimaan vastavoimana talouden alueelta huokuvalle välineelliselle käyttäytymistavalle. Näin Paholaisen haarukassa muodostuu fiktiivinen markkinayhteiskunta, joka ei kaikilta osin enää vastaa reaalista yhteiskuntaa. Tätä ominaisuutta on käsillä olevassa pääluvussa luonnehdittu kyseiseen romaaniin sisältyväksi spekulatiiviseksi ulottuvuudeksi. Paholaisen haarukka ei siten kuvaa ja 
arvioi pelkästään oman aikansa markkinallistumiskehitystä, vaan siihen on myös upotettu näkemys siitä, millaiselta läpikotaisin markkinallistunut yhteiskunta näyttäisi nykyistä yhteiskuntaa koskevan tietämyksen pohjalta. Koska tuo romaani kiinnittyy samalla realistisen yhteiskuntaromaanin tavoin monilta osin vankasti omaan aikaansa, se viestii epäsuorasti myös siitä, että läpikotaisin markkinallistuneen yhteiskunnan peruspiirteet tai puitteet ovat paljolti jo olemassa valmiina nykytodellisuudessa. 


\section{Luku V Mr. Smith ja kritiikin suhteellistuminen}

\section{Henkilöt, rakenne ja geneeriset ainekset}

Vaikka Mr. Smith jatkaa Seppälän kapitalismikriittisten romaanien sarjaa, se poikkeaa tietyissä suhteissa merkittävästi Yhtiökumppaneista ja Paholaisen haarukasta. Näitä kahta jälkimmäistä romaania voidaan lukea moderneina yhteiskunnallisina moraliteetteina, jotka osoittavat, millaisiin tuhoisiin seurauksiin markkinavoimien ylivalta yhteiskunnassa johtaa. Niissä molemmissa sisäistekijä kuljettaa tapahtumia kohti eräiden henkilöhahmojen henkistä ja/tai fyysistä tuhoutumista, katastrofia, mitä voidaan pitää niissä selvänä temporaalisena aineksena. Mr. Smith ei jäsenny moraliteetiksi. Pikemminkin se yhdistää toisiinsa arvoitustarinan ja yhteiskunnallisen romaanin tematiikan.

Jo Paholaisen haarukan ilmestymisen aikoihin Seppälä alkoi pohtia sitä, mitä kapitalismikritiikki on ja miten se vaikuttaa kohteeseensa, kapitalismiin. Riitta Kylänpäälle Suomen Kuvalehteen vuoden 2008 lopussa antamassaan haastattelussa hän totesi, että "markkinapsykologia on sellaista, että kun kapitalismi kohtaa kritiikkiä tai vastustusta, se vain virkistyy, keksii uusia selviytymiskeinoja. Sille kasvaa sata uutta päätä katkotun tilalle” (ks. Kylänpää 2008, 62). Samanlaista pohdiskelua hän jatkoi vuonna 20I4 Parnasso-lehdessä Ville Hännisen tekemässä haastattelussa: "Kapitalismi ei ole ideologiaa. Se muistuttaa enemmän kaasun asettamista tyhjiöön. Kellään ei ole tarvetta uskoa kapitalismiin 
sen kummemmin, mutta se on realismia, jonka mukaan on elettävä” (ks. Hänninen 20I4, 24). Toteamus viittaa siihen, että markkinakapitalismista eli siitä, mikä vielä I990-luvulla ja 2000-luvun alussa näyttäytyi dramaattisena muutoksena, on parissa vuosikymmenessä tullut uusi normaalitila, joka määrää samalla puitteet yksilöiden elämälle yhteiskunnassa.

Suomen Kuvalehdessä ilmestyneessä haastattelussa Seppälä katsoi siis kritiikin parantavan kapitalismin toimintakykyä. Tätä samaa asiaa myös Luc Boltanski ja Éve Chiapello ovat käsitelleet tutkimuksissaan. Heidän mukaansa läntisissä demokratioissa kapitalismikritiikillä on ollut siinä mielessä kapitalismia vahvistava vaikutus, että se on auttanut kapitalismia tiedostamaan omat heikot kohtansa ja puutteensa, minkä jälkeen tuo järjestelmä on voinut muuttaa toimintatapojaan sekä tehdä tarpeellisia reformeja tai ainakin kosmeettisia muutoksia. Tavallista on ollut myös se, että kapitalismi kykenee tuotteistamaan itseensä kohdistuvaa kritiikkiä ja integroimaan sitä tässäkin mielessä itseensä. (Boltanski \& Chiapello I999, 35-90. Ks. myös Ratiu 20ı8; Sevänen 20I4a.) Onko kapitalismikritiikin esittäminen sitten turhaa? Boltanski ja Chiapello eivät ajattele niin, vaikka he puhuvat kritiikin ongelmista. Boltanski (2OII) on myöhemmin korostanut sitä, että kaikesta huolimatta yhteiskuntakritiikki on läntisissä demokratioissa tarpeellinen instituutio, sillä kansalaisten näkökulmasta se toimii suojana valtakoneistojen mahdollisesti harjoittamaa mielivaltaista vallankäyttöä kohtaan. Mr. Smithkään ei luovu nykykapitalismin arvostelemisesta, mutta Seppälän edellisiin romaaneihin verrattuna kritiikin sävy on siinä huomattavasti maltillisempi.

Mr. Smithin keskushenkilönä toimii "Smithiksi" itseään kutsuva mies, ammatiltaan konsultti ja riskienhallinnan ammattilainen, joka harjoittaa omistamansa yrityksen kautta myös tuottoisaa sijoitustoimintaa ja joka edustaa ylintä yhteiskuntaluokkaa. Kerrontajaksoissaan hän välittää lukijalle informaatiota nykykapitalismin toimintatavoista. Osittain samanlainen tehtävä romaanissa on niillä jaksoilla, joissa ekstradiegeettinen kertoja tarkastelee Smithiä ulkoapäin. Konsulttina Smith tarjoaa ihmisille ja yrityksille maksua vastaan palveluja erilaisten ongelmien ratkaisemiseen. Romaanin alussa hän toteaa kuitenkin, että hänen suurin ongelmansa on hän itse. Hän ei tiedä, millainen ihminen hänen 
isoisänsä oli, ja tätä kautta hänelle on jäänyt epäselväksi myös se, mitä hän itse oikeastaan on. Isoisästään hän tietää sen, että tämä saksalaissukuisen pikkukauppiaan poika syntyi Pietarissa vuonna I893, toimi I9oo-luvun alkuvuosikymmeninä vakuutusasiamiehenä ja liikemiehenä Pietarissa ja Viipurissa, muutti vaimonsa ja lapsensa jätettyään Turkuun ja kuoli siellä vuonna I939. Juuri muuta Smithin perhe ei ole isoisästä kertonut, sillä perheen ja suvun piirissä tämä vaimonsa ja lapsensa jättänyt mies oli "tabu, vaiettu salaisuus" (MRS, I09). "Smith pyrkii siksi hankkimaan hänestä lisää tietoja erilaisten tietolähteiden, esimerkiksi arkistojen ja virallisten asiakirjojen, avulla.

Isältään Smith on aikoinaan saanut isoisälle alun perin kuuluneen sikarilaatikon, "johon mahtui kaikki isoisään liittyvä: muutama valokuva, todistus tutkinnon suorittamisesta Viipurin kaupungin kauppakoulussa, ajalle harvinainen rannekello sekä kustannusliikkeestä tullut romaanikäsikirjoituksen palautekirje” (MRS, 40). Kustannusliikkeen, WSOY:n, lähettämässä palautekirjeessä tai hylkäämiskirjeessä kyseisen, isoisän kirjoittaman romaanikäsikirjoituksen todetaan kuvaavaan isoisoisän elämää ja hänen liiketoimiaan. Käsikirjoituksen nimeksi isoisä oli antanut "Mustaa ja punaista", joka sisältää monimielisen viittauksen Stendhalin romaaniin Punainen ja musta (I969, ranskakielinen alkuperäisteos ilmestyi I830). WSOY:n lähettämä palautekirje on siis Smithin hallussa, mutta itse käsikirjoitus on kadonnut. Smith uskoo käsikirjoituksen sisältävän totuuden isoisästä, joka - näin hän olettaa - Viipurissa asuessaan ilmeisesti antoi sen naapureilta saamansa lainan pantiksi. Romaanin lopussa käsikirjoitus löytyykin viimein noiden naapurien jälkeläisen, eläkkeellä olevan päätoimittajan Orvo Mannisen saunarakennuksen seinähirsien välistä. Romaanin alussa Smith on siten tilanteessa, jossa hänellä ei ole vielä hallussaan isoisänsä romaanikäsikirjoitusta. "Koska käsikirjoitus oli kadonnut, minun oli kuviteltava se kuin mennyt maailma”, hän toteaa (MRS, 26). Mr. Smithissä Smith konstruoi siis isoisälleen elämäkerran ja välittää sen avulla informaatiota kapitalismin varhaisvaiheista Suomessa. Tutkimukselle tämä menettely antaa aiheen

* Käytän luvuissa V ja VI Mr. Smithistä lyhennettä MRS silloin, kun siteeraan sitä tai viittaan siihen muuten sivunumeroiden tarkkuudella. 
pohtia sitä, missä määrin hän on kyseisen elämäkerran laatijana luotettava. Astetta yleisemmällä tasolla tuon elämäkerran laatimiseen liittyvät kysymykset liittyvät Mr. Smithissä identiteetin teemaan ja metanarratiivisiin kysymyksiin.

Romaanin kerronta rakentuu ulkopuolisen kertojan, Smithin ja "herra Schmidtin" kerrontajaksojen varaan. Herra Schmidtin eli Smithin isoisän mukaan nimetyt jaksot ovat "oikeasti", romaanin todellisuudessa, Smithin kirjoittamia, vaikka muodollisesti ottaen niissä kertojana toimii herra Schmidt. Tässä mielessä Smith ja ulkopuolinen kertoja hallitsevat romaanin kerrontaa. Romaanin tematiikkaa mutkistaa vielä se, että jo romaanin alussa Smith ilmoittaa, ettei "Smith" ole hänen oikea sukunimensä; samoin eräissä "herra Schmidtin" mukaan nimetyissä jaksoissa todetaan, että heidän sukunsa "oli muuttanut vieraskielisen nimensä suomalaiseksi Snellmanin syntymän satavuotispäivänä toukokuussa I906" (MRS, 233). Mikä tämä suomenkielinen nimi voisi olla? Todennäköisin vaihtoehto on "Seppä" tai "Seppälä" - ottaen huomioon sen, että "Smith" ja Schmidt" merkitsevät molemmat 'seppää', ja sen, että Smith kertoo isoäitinsä isän olleen läkkiseppä (MRS, 94-95). Näin ajateltaessa Mr. Smith sisältää autofiktiivisiä aineksia. Esimerkiksi Suomen historiassa (I998) Juha Seppälä kertoo, että hänen omat sukujuurensa ovat sekä isän että äidin puolelta suomalaiset ja suomenkieliset ja että nimen "Seppälä" otti I8oo-luvun jälkipuolella käyttöön hänen pappansa isoisä, ammatiltaan seppä. Näiltä osin Mr. Smith muuntelee kirjailija Juha Seppälää koskevia tietoja, mutta samalla romaaniin jää viitteitä siitä, että nimet "Smith" ja "Schmidt" on mahdollista yhdistää kirjailija Juha Seppälään.

Smith on siis henkilöhahmona ainakin kolmiulotteinen. Hän on kapitalismin elinvoimaisuuteen uskova yrittäjä ja sijoittaja, tarinankertoja ja autofiktiivinen versio kirjailija Juha Seppälästä. Tässä mielessä Mr. Smith (20I2) on välittäjänasemassa Seppälän tuotannossa. Se on jatkoa hänen aiemmille kapitalismi-teemaa käsitteleville romaaneilleen, mutta samalla siihen on upotettu uusia teemoja, jotka yhdistävät sitä romaaneihin Matka aurinkoon (20I4) ja Kuoppakaupunki (20I6). Nämä uudet teemat liittyvät kysymykseen siitä, mitä ja miten kirjailijan tai kertojan tulisi kertoa omasta itsestään ja elämästään. 
Sivuhenkilöinä Mr. Smithissä toimivat eläkkeellä oleva päätoimittaja Orvo Manninen ja hänen poikansa Erno Manninen. Jälkimmäinen on ICT-alalla työskentelevä teatteritieteen maisteri. Romaanissa tämä luovan talouden ja sisällöntuotannon edustaja on matkoilla Yhdysvalloissa testaamassa yhtiönsä uuden älypuhelimen toimintaa. Erno Mannisen ja viihdekirjailija Erkka Torron hahmojen kautta Mr. Smith käsittelee luovan työn kapitalisoitumista nyky-yhteiskunnassa; samanlainen funktio liittyy osittain Smithiin. Työväenluokkaa tai alaluokkaa romaanissa edustavat Briscilla, Rane ja Equity, yhdysvaltalaisen mustan työväenluokan köyhtynyt jäsen, jonka oikea nimi on Donald Southbrook ja joka on menettänyt kotinsa vuonna 2007 Yhdysvalloissa puhjenneen pankki- ja finanssialan kriisin seurauksena. Orvo Mannisen luona hanttihommissa ollut Rane löytää romaanin lopussa Smithin isoisän käsikirjoituksen, joka toimitetaan sen jälkeen Smithille. Muutaman päivän asiaa mietittyään Smith ei ryhdy lukemaan käsikirjoitusta, vaan hän polttaa sen. Identiteetin teeman näkökulmasta tässä teossa on kyse siitä, että hän ei loppujen lopuksi uskalla tutustua omiin juuriinsa. Tätä teemaa ja sitä, miten se mahdollisesti liittyy romaanin muuhun tematiikkaan, tarkastellaan lähemmin myöhemmissä luvuissa.

Pituudeltaan 279 sivun laajuinen $M r$. Smith muodostuu kaikkiaan 5I luvusta, joiden muodollisina kertojina ovat tarinamaailman ulkopuolinen anonyymi kertoja (I8 lukua), Smith (Io lukua), herra Schmidt (I7 lukua), kuvitteellinen Jalmari Jäntti ( $\mathrm{l}$ luku) ja viidessä luvussa kertojina vuorottelevat anonyymi kertoja, Smith ja herra Schmidt. Lisäksi romaaniin on sijoitettu seitsemän sivun pituinen loppuviiteosasto. Sen eräät kohdat tuovat lisävalaistusta romaanin teemoihin, mutta sen pääfunktio on lähinnä parodioida historiallisissa romaaneissa nykyisin yleistynyttä tapaa sijoittaa romaanin loppuun lähteitä selvittävä osasto.

Yhtiökumppaneihin ja Paholaisen haarukkaan verrattuna Mr. Smith on moniaineksisempi ja vaikeatulkintaisempi romaani. Se ei silti jätä tutkijaa täysin neuvottomaksi, sillä teoksen luonnetta koskeva tärkeä vihje annetaan luvussa, joka muodostuu WSOY:n johtajan Jalmari Jäntin lähettämästä kuvitteellisesta palautuskirjeestä herra Schmidtille, Smithin isoisälle. Kirjeessä Jäntti luonnehtii isoisän laatiman omaelämäkerralli- 
sen romaanin "Mustaa ja punaista" käsikirjoitusta turhan hajanaiseksi ja moniaineksiseksi:

Työmäärä, jonka olette romaaninne "Mustaa ja punaista" eteen tehnyt, on valtava.

Olette koonnut yhteen aineksia, joita voi pitää aikaan sidottuina uutisina, sosiaalisena ja poliittisena raportointina, historiallisena seikkailuna, mieskohtaisina muisteluina, lainauksina maailmankirjallisuudesta ja ihmismielen salaisia onkaloita tutkivana psykologiana.

Myrskyjä merellä ja maalla Teillä on käsikirjoituksessanne myös, samoin sirkusta, fantasiaa ja hokkus-pokkusta, jolle kaikelle on vaikea löytää vertailukohtaa. Tulevan ennustaminenkin on kiinnittänyt mieltänne, vaikka aivan Nostradamuksen kanssa ette ryhdy kilpailemaan.

Kirjoititte käsikirjoituksenne sisältävän kootun viisauden, voiman ja tiedon sukunne ja elämänne vaiheista. Kuitenkin romaaninne käsittää runsaasti ainesta, jota on pidettävä silkkana ajanvietteenä. (MRS, 24.)

Yhteenvetona Jäntti toteaa, että kaiken kaikkiaan käsikirjoitusta vaivaa keskittämisen puute, minkä vuoksi se on julkaisukelvoton: "Suururakkanne on tuottanut koostumattoman aineskokoelman, jolle on vaikea edes ankaran keskittämisen kautta nähdä kehittämisen suuntaa” (MRS, 25). Tämä arvio koskee siis käsikirjoituksen koostumusta ja rakennetta. Sisällön tasolla Jäntti pitää ongelmana sitä, että käsikirjoituksessa "on piirteitä ulkomaalaisen kirjallisuuden ja hengenelämän rappiosta, pessimismistä ja kyynillisyydestä, mikä ei suinkaan ole omiaan lisäämään kustantamomme mielenkiintoa romaanianne kohtaan" (ibid., 25).

Jäntin arvion Smithin isoisän käsikirjoituksesta voi ymmärtää metafiktiiviseksi kuvaukseksi siitä, millaisista geneerisistä aineksista Mr. Smith itse muodostuu. Tuossa kuvauksessa Mr. Smith näyttäytyy lajihybridinä, jossa on aineksia aikalaisromaanista ja yhteiskunnallisesta romaanista ("aikaan sidottuja uutisia, sosiaalista ja poliittista raportointia"), historiallisesta romaanista ("historiallista seikkailua"), omaelämä- 
kerrasta ("mieskohtaista muistelua") sekä autenttisuuden ja identiteetin problematiikkaa käsittelevästä romaanista ("ihmismielen salaisia onkaloita tutkivaa psykologiaa”). Samoin siinä on aineksia sukuromaanista ("koottu viisaus, voima ja tieto sukunne ja elämänne vaiheista") ja autofiktiosta ("sirkusta, fantasiaa ja hokkus-pokkusta").

Koska Mr. Smith on moniaineksinen romaani, se ei ole kapitalismin ja rationalisaation teemojen kannalta yhtä otollinen tutkimuskohde kuin Yhtiökumppanit ja Paholaisen haarukka. Siinä on mukana enemmän sellaista ainesta, joka on suhteellisen riippumatonta näistä teemoista. Lajiteorian kielellä kyse on siis siitä, että geneerisessä mielessä se on näitä kahta edeltäjäänsä selvästi avoimempi ja hybridisempi romaani.

Kapitalismi-teeman ja eksistentiaalisten teemojen ohella Mr. Smith sisältää hajanaisen joukon aineksia muista romaanilajeista. Tyypillistä näille muille aineksille on se, että niiden kehitteleminen jää paljolti kesken. Tämä koskee esimerkiksi Mr. Smithiin sisältyviä historiallisen romaanin, elämäkertaromaanin ja sukuromaanin piirteitä. Herra Schmidtin (klassinen vapaan kilpailun kapitalismi), Orvo Mannisen (laajan hyvinvointivaltion kausi) sekä Smithin, Erno Mannisen, Briscillan, Ranen ja Donald Southbrookin (nykykapitalismi) henkilöhahmojen kautta romaani luo kuvaa kapitalismin kolmesta eri kehitysvaiheesta, mutta tämä kuva jää kovin luonnosmaiseksi ja laajan hyvinvointivaltion kaudesta se antaa informaatiota niukasti. Romaanin välittämän kapitalismikuvan kannalta tärkeää tässä luonnoksessa on ehkä se, että siinä korostuu ensimmäisen ja kolmannen vaiheen välinen osittainen analogia. Näissä molemmissa vaiheissa eletään vapaan markkinatalouden oloissa, mutta ensimmäinen vaihe eroaa kolmannesta vaiheesta siinä, että silloin ihmisten, pääomien ja tavaroiden liikkumisella oli erinäisiä valtiollisia ja poliittis-ideologisia esteitä. Romaaniin sisältyy myös Suomen tilannetta kommentoiva huomautus, joka on sijoitettu herra Schmidtin nimenmuutosseikan yhteyteen; sen mukaan ensimmäisen maailmansodan tapahtumissa oli Suomen näkökulmasta kyse siitä, että "Suomi oli aloittanut vaivalloisen matkansa idästä kohti länttä, kivuliaan muodonmuutoksensa herra Schmidtistä Mr. Smithiksi” (MRS, 73). Historiallisesta näkökulmasta tämä arvio pitää paikkansa, sillä ensimmäinen maailmansota ja Venäjällä tapahtunut bolsevikkivallankumous 
edistivät Suomen irtautumista Venäjästä. Mr. Smithiin ei ole kuitenkaan rakennettu kertomusta siitä, miten Suomen irtautuminen ensin itäisestä ja sen jälkeen saksalaisesta vaikutuspiiristä toteutui jatkossa. ı900-luvun alun tilanteesta romaani hyppää suoraan 2000-luvulle, jolloin ICT-talouden palveluksessa oleva Erno Manninen matkustelee työasioissa Suomen ja Yhdysvaltain välillä.

Sivuhuomautuksena on syytä todeta, että edellä sanotun perusteella herra Schmidtin ja Smithin henkilöhahmot on mahdollista ymmärtää sepiksi myös siinä mielessä kuin sepän hahmo esiintyy Kalevalassa. Siinä "seppo Ilmarinen" on yhteisönsä tuotannollisen toiminnan keskipiste, jonka tekemä työ, metalliesineiden valmistaminen luonnon tarjoamista materiaaleista, on yhteisön vaurauden ja hyvinvoinnin lähde. Hänen käsistään lähtöisin on myös sampo, joka symboloi kalevalaisessa mytologiassa juuri vaurautta ja hyvinvointia, niiden tuottamisen välineitä (ks. Anttonen 2002 ja 20I2; Hakamies 20I2; Tarkka, Lotte 20I2).

Mr. Smithissä yhteys kalevalaiseen mytologiaan rakentuu sitä kautta, että Mr. Smithin mukaan suomalainen hyvinvointi luotiin tai "taottiin" ensin hyvien idänsuhteiden ja saksalaisen kulttuurin vaikutuksen avulla, mutta myöhemmin niiden tilalle tärkeimmäksi vaurauden lähteeksi tuli Suomen integroituminen läntiseen maailmaan, erityisesti angloamerikkalaisiin maihin. Tämän merkitysjuonteen kehittäminen jää kuitenkin Mr. Smithissä melko irralliseksi motiiviksi. Romaani ei rakenna sen varaan tarinalinjaa, jos kohta eräät romaaniin sisältyvät ainekset tukevat kyseistä merkitysjuonnetta. Näihin aineksiin kuuluu erityisesti se, että liiketoimiaan harjoittaessaan Smithin isoisä liikkui ı9oo-luvun alkuvuosikymmeninä usein Karjalan maisemissa ja Erno Manninen puolestaan oleskelee romaanin nykyisyydessä lähinnä Yhdysvalloissa, missä hän on testaamassa kehittämiään uusia älypuhelinsovelluksia. Osittain samaan tapaan Väinämöinen ja Ilmarinen matkustavat Kalevalassa toistuvasti Kalevalan ja Pohjolan välillä sammon valmistamiseen ja hallintaan liittyvissä asioissa, ja lopussa myös Lemminkäinen lähtee heidän mukaansa Pohjolaan Ilmarisen takomaa sampoa anastamaan. Mr. Smithissä korostuu kuitenkin se, että nykytaloudessa tuotannollinen toiminta on etääntynyt perinteisistä vaurauden ja hyvinvoinnin lähteistä, joita Kalevalassa edustavat maanviljely ja raudan valmistaminen - niin 
kuin sen toisessa ja yhdeksännessä runossa kerrotaan (ks. Kalevala I947, I3-24, 96-II3). Smith ilmaisee tämän muutoksen kategorisesti: "Rahaa ei tehdä työllä, vaan rahalla. On annettava rahan tehdä työ." (MRS, Io6.) Tällä hän tarkoittaa sitä, että nykykapitalismissa sijoitustoiminnasta eli spekulatiivisesta taloudesta on tullut merkittävä vaurastumisen lähde. ${ }^{\text {II2 }}$ Samassa yhteydessä hän toteaa, että nykyisin valtaosa ihmisistä on kuitenkin sidottu palkkatyöhön tai "palkkaorjuuteen", minkä vuoksi vain pienilukuinen yläluokka hyödyntää käytännössä sijoitustoimintaan liittyviä rikastumisen mahdollisuuksia.

Edellä kuvattu merkitysjuonne ei nouse Mr. Smithissä koko romaania läpäiseväksi temaattiseksi ainekseksi. Samanlainen keskeneräisyys tai luonnosmaisuus leimaa Mr. Smithiin sisältyviä elämäkertaromaanin ja sukuromaanin piirteitä. Ne liittyvät Smithin pyrkimykseen määrittää itsensä ja identiteettinsä; nämä molemmat tavoitteet hän aikoo toteuttaa esittämällä kertomuksen isoisänsä elämästä ja suhteuttamalla samalla isoisänsä ja itsensä osiksi yhteiseen sukulaisuuden ketjuun. Isoisää koskevat luvut muodostavat romaanista noin kolmasosan, mutta sellaisinakin ne kertovat lähinnä vain pääkohdat hänen elämästään ja liiketoimistaan. Koska Smithillä ei ole romaanin lopussa uskallusta tutustua isoisänsä oikeaan käsikirjoitukseen ja tarkistaa, missä määrin hänen laatimansa elämäkerta vastaa isoisän omaa käsikirjoitusta, hänen identiteettiprojektinsa raukeaa ja hän tuntee jäävänsä määrittelemättömään tilaan, epäautenttiseen olemassaoloon. Tämä ulottuvuus ei ole irrallaan kapitalismi-teemasta, sillä osittain romaani selittää Smithin käyttäytymistä hänen ammatillisesta ja yläluokkaisesta habituksestaan käsin.

Ominaista Mr. Smithille on siis se, että siinä esiintyy aineksia useista eri lajirepertoaareista, joita se hyödyntää tietyissä rajoissa viemättä niitä kuitenkaan pitkälle tai "loppuun asti”. Näin tapahtuu siihen sisältyville historiallisen romaanin, elämäkerran, sukuromaanin ja autofiktion aineksille. Lajeihin liittyvä keskeneräisyys on romaanissa analoginen sen kanssa, että myös romaanin henkilöiden elämä on tietyiltä osin epätäydellistä, keskeneräistä ja vajaata tai se jää sellaiseksi. Tämä koskee miltei kaikkia romaanin keskeisiä henkilöitä: elämää ja omaa itseään pelkäävää Smithiä, ennenaikaisesti kuolevia herra Schmidtiä ja Ranea, itseään alati etsivää Briscillaa, finanssikriisin runtelemaa Donald Southbrookia, 
itsensä ICT-talouteen kadottamassa olevaa Erno Mannista ja entistä päätoimittajaa Orvo Mannista, jolle nykymaailma on käymässä tympeäksi ja käsittämättömäksi paikaksi. Mr. Smith ei silti hajoa heterogeenisten lajipiirteiden mosaiikiksi, sillä henkilöiden elämälle ja toiminnalle yleiset puitteet antaa kapitalistinen talousjärjestys, joka määrää varsinkin alaluokkaisten henkilöiden elämänkaarta. Geneerisellä tasolla Mr. Smith jäsentyy siksi ensi sijassa kapitalismi-teemaa ja eksistentiaalista tai elämänfilosofista tematiikkaa (vieraantuneisuus, epäautenttisuus, elämän epätäydellisyys) käsitteleväksi romaaniksi.

Näistä syistä Mr. Smith eroaa Yhtiökumppaneista, Routavuodesta ja Paholaisen haarukasta, jotka ovat vahvassa mielessä teleologisia romaaneja ja joiden rakenne tai kompositio on keskitetty. Niissä sisäistekijä kuljettaa romaanin tapahtumia kohti tiettyä loppuratkaisua, telosta, ja samalla sisäistekijä on karsinut niistä pois sivupolut; siksi kaikki tarinalinjat suuntautuvat niissä keskitetysti kohti loppuratkaisuja. Sartre suhtautui kriittisesti vahvasti teleologisiin romaaneihin, jotka eivät hänen mukaansa ilmennä oikein elämän mielivaltaisuutta ja sattumanvaraisuutta. Siksi hänen Inho-romaaninsa päähenkilö, elämäkertaansa suunnitteleva Roquentin alkaa ajatella, että elämästä kertominen on samalla elämän väärentämistä: tämä johtuu hänen mielestään siitä, että kertomusmuoto projisoi tapahtumien välille järjestyksen, jota ei oikeasti ole olemassa. Valheellista kertomuksissa on myös niiden teleologisuus, se, että tapahtumat esitetään tiettyä loppuratkaisua kohti suuntautuneena ketjuna. Kertomuksissa

loppu antaa kaikelle aivan toisen sävyn. Meille kertoja on jo kertomuksensa sankari. Hänen ärtymyksensä ja rahahuolensa ovat jotakin paljon erikoisempaa kuin omamme, niitä kultaa jo tulevien intohimojen hehku. Ja niin jatkuu kertomus takaperoisena: tuokiot eivät enää sattumanvaraisesti lataudu toistensa päälle, vaan ne ovat takertuneet toisiinsa hakeutuen kohti kertomuksen loppua. Se vetää puoleensa niitä kutakin ja ne vuorostaan kukin edeltäjäänsä. (Sartre 1964, 62-63.) I13 $^{\mathrm{I3}}$ 
Sartren muotoilema problematiikka on nähty tärkeäksi myös nykyisessä kertomusteoriassa ja elämäkertatutkimuksessa. Näiden tutkimussuuntausten edustajat ovat taipuvaisia ajattelemaan, että kertomusmuodon vaikutuksesta ihmisen oikea tai todellinen elämä poikkeaa aina jossain määrin siitä, mitä ihminen kertoo omasta elämästään tai mitä muut hänen elämästään kertovat (Leskelä-Kärki 20I7, 224-226; Saunders 20IO, 5IO-5I2, 528). Mr. Smith ei kuitenkaan aseta kyseenalaiseksi itse elämäkertamuotoa, vaan pikemminkin se epäilee vahvasti teleologisen kertomustyypin tai romaanitypin mahdollisuuksia kuvata elämää totuudenmukaisesti. ${ }^{\text {II4 }}$ Siksi sitä voidaan luonnehtia heikosti teleologiseksi romaaniksi, joka pohjustaa tietyssä määrin loppuratkaisujaan (Smithin päätös olla lukematta isoisänsä käsikirjoitusta, Ranen kuoleminen asbestoosiin, Briscillan hakeutuminen joogan harrastajaksi, Erno Mannisen vetäytyminen ICT-alalta), mutta joka sisältää samalla puolitiehen jätettyjä tarinalinjoja ja tarina-aineksia.

Koska Mr. Smith etääntyy vahvasti teleologisesta romaanityypistä, sitä voidaan myös lukea Seppälän aiempien yhteiskunnallisten romaanien epäsuorana kritiikkinä. Se merkitsee varovaista irtiottoa Seppälän vuosina 2002-2008 toteuttamasta vahvasti teleologisesta ja keskitetystä romaanipoetiikasta, vaikka siihen sisältyvä näkemys kapitalismista on monilta osin samanlainen kuin Yhtiökumppaneiden ja Paholaisen haarukan esittämä näkemys.

Teleologisen romaanipoetiikan kritiikki ei yhdistä Mr. Smithiä ainoastaan Sartreen ja eksistentialismiin vaan myös yleisemmin modernistiseen kirjallisuuteen. Edeltäviin kirjallisiin traditioihin verrattuna modernismi supisti juoni- ja tarina-aineksen osuutta romaanissa ja korvasi ne episodimaisemmalla rakenteella, jonka yhtenäisyys on enemmänkin temaattista kuin kausaalisiin tapahtumasarjoihin perustuvaa. Tällaisen, usein "fragmentaariseksi" luonnehditun modernistisen romaanityypin perustana on ajatus, että vain näin kirjallisuus pystyy tavoittamaan elämän kaoottisen luonteen sekä sattuman ja mielivaltaisuuden roolin siinä. Hanna Meretoja (2007, I85-I87; 2010, 86-88, II5, I7I) toteaa, että edellä hahmoteltu romaanipoetiikka ja elämänfilosofia jatkuivat ı900-luvun ranskalaisessa kirjallisuudessa vielä eksistentialismin jälkeenkin, sillä i950-luvulla esiin murtautuneet "uusromaanin" edustajat 
- Alain Robbe-Grillet, Nathalie Sarraute, Claude Simon - kehittivät siitä oman versionsa. Näin tehdessään he luopuivat lineaarisesti etenevistä juonirakenteista, psykologisesti moniulotteisista henkilöhahmoista ja yhtenäisen fiktiivisen maailman rakentamisesta, joiden vastapainoksi he pyrkivät teoksissaan ilmaisemaan elämän kaoottisuutta ja mielivaltaisuutta. Näihin teoksiin Seppälän romaanit eivät juurikaan viittaa. Sitä vastoin eksistentialismilla on ollut konstitutiivinen vaikutus hänen tuotantonsa ominaisluonteeseen.

\section{Kapitalismin dialektiikka}

Mr. Smith poikkeaa sikäli Yhtiökumppaneista ja Paholaisen haarukasta, että se ei metaforisesti rinnasta nykytaloutta vääränlaiseen uskontoon tai väärien jumalien valtaanpääsyyn. Silti siinäkin on mukana arvokriittinen näkökulma. Se sisältää myös Smithin, romaanin keskushenkilön, esittämiä rahan luonnetta koskevia pohdiskeluja, mutta toisin kuin Yhtiökumppaneiden Pete ja hänen sukunsa Smith ei mystifioi rahaa eikä hän näe siinä salaperäistä lumoa. Hänen käsityksensä rahasta on varsin realistinen.

Mr. Smith välittää kapitalismista huomattavasti dialektisemman näkemyksen kuin Yhtiökumppanit ja Paholaisen haarukka. Siinä, missä Yhtiökumppanit ja Paholaisen haarukka esittävät kapitalismin paljolti vain tuhoa ympärilleen kylvävänä yhteiskunnallisena järjestelynä, $M r$. Smithin mukaan kapitalismi on samanaikaisesti tuhoava ja uutta luova, orjuuttava ja vapauttava, sivilisoiva ja pinnallistava muodostuma. ${ }^{\text {I5 }}$ Tämä kapitalismin dialektinen puoli tulee hyvin esiin Smithin esittämissä rahan luonnetta koskevissa pohdiskeluissa. Niissä hän toteaa ensiksi elävänsä "synnissä". Jatkossa paljastuu, että tuo "synti" liittyy siihen, että hän on liiaksi kiinnittynyt kapitalistiseen rahatalouteen ja sen avaamiin toiminnan ja elämisen näkymiin. Kapitalistinen rahatalous on sinänsä pitkälle amoraalinen tai indifferentti ilmiö, joka ei tunnista laadullisia eroja eri ilmiöiden välillä. Sen avulla voi siksi tehdä sekä hyvää että pahaa: 
Minä rakastan kapitalismia. Minä rakastan rahaa. Minä rakastan sitä että se ei koskaan kuole, että se elää ikuisesti, muuttaa muotoaan mutta ei katoa, kuin energia. Jos sitä ei olisi, minua ei olisi. Ongelmia ei olisi. Mikään ei ole niin oikeudenmukaista, demokraattista kuin kapitalismi. Se antaa köyhällekin mahdollisuuden rikastua. Se antaa jokaiselle sen, mihin hänellä on oikeus. Kapitalismi on hirveä. Se eläimelliset vaistot eivät kuihdu koskaan. Se on hirveä, mutta Jumala on ikuisempi. Raha ei petä. Se on suvereeni, itsenäinen, riippumaton, kuin kissa autiotalon nurkissa, kuin dvornokki kuolleessa Kannaksen huvilakaupungissa. Sillä ei ole isänmaata, uskollisuusvelvoitetta eikä yhteiskuntavastuuta. Siksi siihen voi luottaa. Se ei lupaa mitään. Se ei etsi kotia eikä aatetta. Se ei tarvitse ketään. Se on arvokas minulle. Se on arvokas sinulle. Se on arvokas meistä riippumatta, kukaan ei pääse siltä karkuun. Se on kaikkialla kuin ilma, mittaa ja arvottaa kaiken. Se riisuu kaikelta muuhun suhteutumattomuuden, mutta on itse suhteutumaton. Se on puhdas, viaton, täydellinen, se on mitä tahansa, koska sillä saa mitä tahansa. Koska se on absoluuttinen väline, se on absoluuttinen päämäärä. Kaikki elävät vain hankkiakseen rahaa. Joka lopulta haihtuu, kuin viimeinen näky elämästä. Raha antaa vapauden. (MRS, I45-I46.)

Smithille, menestyvälle yrittäjälle ja sijoittajalle, kapitalismi on samanaikaisesti rakkauden ("Minä rakastan kapitalismia") ja kauhistuksen ("Kapitalismi on hirveä") kohde. Sen myönteiset puolet liittyvät siihen, että se on avannut ihmisille uudenlaisia toimintamahdollisuuksia ja luonut köyhiinkin olosuhteisiin syntyneille ihmisille mahdollisuuksia sosiaaliseen nousuun. Sen kielteiset puolet liittyvät puolestaan siihen, että kapitalistisen rahatalouden logiikka on paljolti kuuro laadullisille arvoerotteluille: "Sillä ei ole isänmaata, uskollisuusvelvoitetta eikä yhteiskuntavastuuta. Siksi siihen voi luottaa. Se ei lupaa mitään. Se ei etsi kotia eikä aatetta. Se ei tarvitse ketään. Se on arvokas minulle.” Se on tässä mielessä amoraalinen yhteiskunnallinen järjestely, joka pyrkii rientämään aina sinne, missä se saa parhaan tuoton tai liikevoiton - välittämättä paljoakaan siitä, millaisia seurauksia tästä logiikasta on ihmi- 
sille ja muulle yhteiskunnalle. Smithin "synti" piilee lähinnä siinä, että kapitalistisen talouden pyörittäjänä hän on itse ylläpitämässä tällaista järjestelmää, joka tarjoaa hänelle ja monille muille ihmisille runsain mitoin uudenlaisia toimintamahdollisuuksia ja aineellisia palkkioita, mutta joka kykenee samalla aiheuttamaan tuhoa yhteiskuntaan.

Mr. Smith kuvaa nykykapitalismin amoraalisuutta, sen kyvyttömyyttä sitoutua laadullisiin arvoerotteluihin osittain samalla tavalla kuin Paavo Haavikon Murtuva keskiluokka. Aikalaiskirjoitus (I992). Myöskään Haavikon (I992, I9) pamfletin mukaan kapitalistisella yrityksellä "ei ole isänmaata. Se on isänmaa itse, raha on sen äidinkieli, jota se ikänsä opettelee”. Kapitalismin amoraalisuudesta puhuessaan Haavikkokin viittaa siten siihen, että kansalliset sidonnaisuudet eivät loppujen lopuksi ole kapitalismille tärkeitä. Niiden sijasta "markkinavoimat ovat valon ja vapauden voima, joiden kotimaa on maailma ja jotka ovat joka päivä kotimaata valitsemassa. Raha äänestää aina isänmaastaan. Se on aina lojaali, niin kauan kuin siihen on syytä” (Haavikko I992, I2).

Vaikka Mr. Smith ei metaforisesti rinnasta nykykapitalismia uskontoon, myös edellä lainatussa sitaatissa tulee esiin ajatus siitä, että nykyyhteiskunnassa raha - yleisemmin: yksipuolisesti ymmärretyt taloudelliset arvot - ovat saavuttaneet absoluutin aseman, ylivallan muihin arvopäämääriin nähden: "Koska se on absoluuttinen väline, se on absoluuttinen päämäärä. Kaikki elävät vain hankkiakseen rahaa." Nykyisin eletään markkinafundamentalistista aikakautta, jolloin yhteiskunnan arvopohjassa ratkaisevan sananvallan ovat saaneet liiketaloudelliset arvot ja kapitalistinen tulostehtailu.

Edellä oleva laaja sitaatti ei liity pelkästään kapitalistisen rahatalouden luonnetta koskevaan tematiikkaan. Siinä tullaan myös yleisemmällä tasolla nykytalouden toimintalogiikkaa koskevien kysymysten pariin. Tällä tasolla Mr. Smith kuvaa nykykapitalismia tavalla, joka muistuttaa läheisesti Yhtiökumppaneiden kuvausta nykyisestä talousjärjestyksestä. Siinä, missä jälkimmäinen romaani rinnastaa metaforisesti nykyaikaisen yrityksen toiminnan metsästykseen, $M r$. Smith käyttää vastaavanlaisena rinnastuksena tai vertauksena kuvausta susilaumasta ja sen toimintatavoista: 
En voi sanoa, että toimintani sisältäisi varsinaisia arvoja, missiota tai strategiaa. Olen kuin raha, minulla ei ole isänmaata. Toiminimeni kutsuminen peitefirmaksi olisi vääristelyä. Visioni on se, että ihminen voisi jatkaa elämäänsä kunnes kokee luonnollisen kuoleman. Kokemukseni on osoittanut, että ihmisten yhteydessä on syytä puhua pidättyvästi arvoista.

Luontodokumenteissa näitä kysymyksiä tai moraalisia ongelmia ei esiintynyt: kaikki toiminta tähtäsi lajin säilymiseen, ravinnon ja paritteluoikeuden hankkimiseen, reviirin ja jälkeläisten suojelemiseen. Vuosi susipoikueen elämässä Pyreneillä oli yksi suosikeistani, vain yksi pennuista menehtyi pudottuaan rotkoon. Ravinto, lepo, suvun jatkaminen, syntymä ja kuolema; koodi oli valmis toteutettavaksi sellaisenaan, ja vain satunnaistekijät vaikuttivat toteutuksen kulkuun. Lauman hierarkia ja säännöt olivat kaikille selvät, eikä niistä ollut mahdollista yrittää poiketa. Joku olisi voinut pitää näitä ohjelmia ja niiden toistamista yksitoikkoisena, mutta minun maailmassani ne edustivat selkeyttä, varmuutta ja pysyvyyttä. Niissä esitetyssä maailman toimintamallissa ei ollut ristiriitaa eikä ongelmaa. (MRS, 93-94.)

Sitaatin ydinsisältönä on ajatus, että kapitalismiin sitoutuneena yrittäjänä Smith sulkee pitkälle arvokysymykset pois toiminnastaan ("Olen kuin raha, minulla ei ole isänmaata"). Niiden sijasta hän keskittyy siihen, mitä hän pitää tärkeänä yrityksensä taloudellisen menestymisen, sen tuloksen kannalta. Näin tehdessään hän ajattelee menettelevänsä kuin susilauma, joka lähtee omassa toiminnassaan lauman toimintakyvyn ja menestyksen varmistamisesta ja edistämisestä. ${ }^{\text {I16 }}$ Nykykapitalismin rinnastaminen susilaumaan tai luonnontilaan on kuitenkin tietyssä mielessä ongelmallista. Eläinyhteisöissä yksilöiden välillä esiintyy nimittäin alistussuhteiden ohella hoivasuhteita, eikä myöskään nykyaikainen talouselämä toimi pelkästään muodollisten organisaatioiden pohjalta; tällaisten organisaatioiden lisäksi sen toimintapohjaan kuuluvat epäviralliset verkostot ja henkilökohtaiset lojaliteettisiteet ("hyvä veli" -verkostot). Näissä molemmissa yhteisöissä toimijoiden käyttäytyminen on enemmän tai vähemmän selvästi hoivarationaalisuuden tai substantiaa- 
lisen rationaalisuuden läpitunkemaa, jolloin toimijat keskittyvät huolehtimaan yhteisön muiden jäsenten tarpeista tai ainakin antavat niille tärkeän sijan omissa tekemisissään. (Vrt. Aspers 20II, 59-60, I7I-I72; Wherry 20I2, I3, I29-I30.) Viekö tämä tieto pohjan Mr. Smithiin sisältyvältä rinnastukselta, jossa kapitalistinen yritys ja susilauma näyttävät noudattavan samanlaista toimintatapaa?

Ei välttämättä. Esittäessään susilauman tai kapitalistisen yrityksen päämäärärationaaliseksi tai, habermasilaisesti ymmärrettynä, "menestyssuuntautuneeksi" yksiköksi Mr. Smith kiinnittää ensi sijassa huomiota näiden yksiköiden ympäristösuhteeseen, siihen, että ne tarkastelevat ja arvioivat toimintaympäristöään yksikön edun ja menestyksen näkökulmasta. Susilauman sisällä vallitseviin suhteisiin edellä esitetty rinnastus kiinnittää huomiota siinä määrin kuin niiden tunteminen on tarpeen lauman ympäristösuhteen ja toimintatavan ymmärtämisen kannalta - tai tämän vertauksen toimivuuden kannalta.

Mr. Smith tuo eräitä uusia sävyjä ja vivahteita indifferenssin motiiviin tai teemaan. Nämä sävyt liittyvät yhtäältä Smithin henkilöhahmoon ja toisaalta siihen kertomukseen, jonka hän laatii isoisästään herra Schmidtistä. Romaani ei tarjoa runsaasti informaatiota Smithin työstä ja liiketoimista, kun taas hänen isoisänsä liiketoimista rakentuu värikäs kuva. Tosin romaanin alussa Smith kuvaa omia toimintatapojaan tähän tapaan:

Minun on oltava kova, vaativakin. Anteeksiantamaton en ole. Minun on kärjistettävä ja karrikoitava, jotta asiakkaalleni kirkastuisi hänen tilanteensa. Joskus minun on vaikutettava tapahtumien kulkuun jälkikäteen, kirjoitettava historiaa uusiksi, varsinkin jos pidän tapahtunutta kohtuuttomana. Jos tarvitaan Kekkosen avioton poika, teen sellaisen. (MRS, I6.)

Toimeksiantoja hankkiessaan ja suorittaessaan Smith on tarvittaessa valmis valehtelemaan tai poikkeamaan totuudesta, mikäli se edistää hänen liiketoimiaan. Hän ei itse ole aivan varma siitä, miten hänen toimintansa tätä ulottuvuutta pitäisi arvioida ja luonnehtia. "En tiedä, olenko moraaliton ihminen, mutta olen kohdannut liikaa sellaisia", hän jatkaa 
hetken kuluttua pohdiskelujaan (MRS, I7). Toteamuksen voi tulkita viittaavan siihen, että asiakaskuntansa ja toimialansa (konsultointi ja riskienhallinta) piirissä hän on tavannut monia sellaisia ihmisiä, joiden toimia hän ei pidä moraalisesti hyväksyttävinä. Yllä olevan sisennetyn sitaatin perusteella romaanin lukija voi kuitenkin päätellä, että Smith toimii toisinaan itsekin moraalisesti kyseenalaisella tavalla eivätkä hänen toimintatapansa ehkä poikkea paljoa siitä, mikä on hänen alallaan yleinen käytäntö.

Smith ei ole kertojana täysin luotettava. Vaikka hän pyrkii olemaan avoin, hän tuo asioita esiin valikoiden ja käyttäen sellaisia ilmaisutapoja, jotka vähättelevät hänen omien toimiensa moraalisesti arveluttavia piirteitä. Narratologian näkökulmasta Smithiä voidaan siten luonnehtia kertojaksi, jonka tapa kertoa omasta itsestään, isoisästään ja muistakin asioista on "aliarvioiva" (underregarding) ja "aliraportoiva" (underreporting). Phelanin $(2005$, 49-52, 219) laatimassa typologiassa ne molemmat ovat epäluotettavan kerronnan alalajeja. Yhtäältä Smith siis antaa lukijalle vain niukasti tietoa omasta elämästään ja sisäisestä maailmastaan, mutta toisaalta romaanin etenemistapa ja Smithin oma puhetapa vihjaavat siihen, että hän ei halua arvioida ja paljastaa itseään syvemmin tai että joku toinen, häntä avoimempi kertoja voisi puhua noista asioista enemmänkin. Samoin laatiessaan isoisänsä elämäkertaa Smith on lähdetietojen suhteen hyvin valikoiva ja, niin kuin aiemmin todettiin, romaanin lopussa hän torjuu itselleen tarjoutuneen mahdollisuuden lukea isoisän kauan kadoksissa ollut omaelämäkerrallinen romaanikäsikirjoitus "Mustaa ja punaista".

Mitä Mr. Smithin lukijan on siksi ajateltava siitä kertomuksesta, jonka Smith niukkojen faktatietojen, sukunsa piirissä liikkuneen perimätiedon sekä päättelykykynsä ja mielikuvituksensa avulla laatii isoisästään? Niin kuin tulen seuraavissa alaluvuissa osoittamaan, romaani sisältää selviä viitteitä siitä, että lukija voi edellä sanotusta huolimatta pitää tuota pienoiselämäkertaa suhteellisen luotettavana kertomuksena Smithin isoisän elämän pääpiirteistä ja hänen liiketoimistaan I9IO-I930-lukujen Venäjällä ja Suomessa. Tuossa pienoiselämäkerrassa Smith näyttää tavoittaneen isoisänsä tavan kertoa elämästään ja liiketoimistaan, vaikka hän kieltäytyy tutustumasta isoisänsä omaan käsikirjoitukseen. Siksi 
seuraavassa kappaleessa oleva informaatio isoisästä on ilmeisesti totta Mr. Smithin maailmassa.

Kyseisen elämäkerran useissa eri kohdissa toistuu tilanne, jossa isoisä on liiketoimiaan harjoittaessaan laittanut taloudelliset hyötynäkökohdat kaiken muun, esimerkiksi juridisten, moraalisten ja inhimillisten seikkojen, edelle. Hän oli esimerkiksi jo vuonna I9I8 aloittanut taloudellisesti tuottoisan ihmisten salakuljetuksen Neuvostoliitosta länsimaihin ja länsimaista Neuvostoliittoon, ja vakuutusasiamiehenä toimiessaan hän oli kiinni jäämättä syyllistynyt vakuutuspetoksiin. Yleisemmin Smith luonnehtii isoisäänsä kahden tälle aikoinaan kuuluneen valokuvan perusteella. Niistä toinen esittää kahta kenttätykkiä, ja toisessa isoisä seisoo koivun alla: "Isoisä saattoi olla kuvassa kolmissakymmenissä. Hän ei näyttänyt mieheltä, joka olisi taistellut tykkien takana. Hän näytti mieheltä, joka oli myynyt ne" (MRS, I26. Ks. myös s. 37, 42-43, IOI-IO3, I08, IIO-II3).

Edellisessä kappaleessa mainitut, Smithin isoisään liittyvät näkökohdat ilmentävät romaanissa kapitalismin indifferenttiä toimintatapaa. Merkille pantavaa tässä yhteydessä on se, että niissä ei ajallisesti liikuta nykyisen uusliberalistisen kapitalismin piirissä vaan lähinnä klassisen liberaalikapitalismin loppuvaiheessa. Romaanina Mr. Smith pyrkii siksi kuvaamaan ja arvioimaan kapitalismin toimintatapoja yleisemmästä näkökulmasta, ei vain uusliberalistisen vaiheen perspektiivistä. Toinen, tästä tulkintavaihtoehdosta poikkeava tulkintavaihtoehto on se, että herra Schmidtin hahmossa Mr. Smith pyrkii tavoittamaan kapitalismin synty- ja alkuvaiheelle ominaisen omaisuuksien ja pääomien hankkimistavan, sen, että tuolloin kapitalistisen yritystoiminnan edellyttämä alkupääoma ja varallisuus hankittiin usein huijaamisen ja väkivallan avulla. ${ }^{\text {II7 }}$ Tämä tulkintavaihtoehto ei ole kuitenkaan kovin uskottava. Suomessa kyseinen vaihe ajoittuu lähinnä I80o-luvun jälkipuolelle eikä I9ıoI930-luvuille, minkä lisäksi on syytä ottaa huomioon se, että $M r$. Smithin etenemistapa ja kompositio eivät tue jälkimmäistä tulkintavaihtoehtoa. Romaanista puuttuvat jaksot ja pohdiskelut, joissa käsiteltäisiin siirtymistä traditionaalisesta yhteiskunnasta moderniin kapitalismiin. ${ }^{\mathrm{I}}{ }^{\mathrm{I} 8}$

Mr. Smith ei siis käsittele kapitalismin syntyvaiheita, mutta toisaalta se esittää vapaan markkinatalouden ja vakavien talouskriisien liittyvän 
erottamattomasti toisiinsa. "Vapaus" on tässä yhteydessä vapautta poliittisesta ohjailusta ja valtion harjoittamasta kontrollista. Tällaisen vapauden pääoma ja kapitalismi saavuttivat ensimmäisen kerran I8oo-luvulla, mikä itse asiassa vei yhteiskunnat kohti katastrofia ja tuhoa:

Mannermaalla käytiin sotaa, miksi?

Siksikö, että joku tasapainoton ylioppilas ampui arkkiherttuan? Ei tietenkään.

I870-luvulta lähtien yritettiin luoda kultakantajärjestelmä, jonka kauniina ideana oli saattaa maailma yhdeksi markkinaksi. Haluttiin, että maailma ei kilpailisi sodassa, vaan taloudessa. Kultakanta supisti kaikkialla taloudet, laski palkkoja ja kulutusta. Konkursseja, kurjuutta. Vapaakaupan oli määrä tehdä sodat mahdottomiksi, mutta pian tapeltiin koko maailman resursseista. Työläisten piti tuhota kapitalismi, mutta heidät usutettiin toistensa kimppuun. (MRS, 98.)

Kertojana tässä on herra Schmidt. Vaikka hän on sitoutunut markkinakapitalismiin ja sen toimintatapoihin, oheisessa sitaatissa hän itse asiassa kritisoi klassisen liberaalikapitalismin ja uusliberalistisen kapitalismin puolustukseksi esitettyä argumentaatiota - ajatusta, että vapaaseen markkinatalouteen perustuva maailmanjärjestelmä ohjaisi valtioiden välisen kilpailun taloudellisiin uomiin ja poistaisi siten sotilaalliset konfliktit valtioiden väliltä. Herra Schmidtin mukaan klassisen liberaalikapitalismin vaiheessa kävi juuri päinvastoin: valtioiden välinen hillitön kilpailu johti ensin kilpavarusteluun ja sotilasliittojen muodostamiseen ja lopulta myös ensimmäiseen maailmansotaan, jonka seurauksena maailma jaettiin uudelleen etupiireihin johtavien länsimaiden kesken.

Tämä herra Schmidtin suuhun laitettu käsitys klassisesta liberaalikapitalismista muistuttaa taloushistorioitsija Karl Polanyin näkemystä siitä, että I80o-luvulla ja I900-luvun alussa poliitikkojen ja suuryritysten pyrkimys luoda itseään sääntelevä markkinayhteiskunta ja maailmanjärjestelmä oli luonteeltaan tuhoava. Se johti Polanyin (2009, 369-384) mukaan valtioiden välisten ristiriitojen kärjistymiseen, ensimmäiseen maailmansotaan, Wall Streetin suureen pörssiromahdukseen 
(I929) ja sitä seuranneeseen yleismaailmalliseen lamakauteen (I929I933) sekä yhteiskunnalliseen kuohuntaan varsinkin Saksassa. Tämän jälkeen kapitalismin kehityksessä siirryttiin rajoitetumman markkinatalouden vaiheeseen, jossa poliitikot asettivat talouden demokraattisen sääntelyn alaisuuteen. ${ }^{\text {I9 }}$

Polanyin kapitalismikäsitystä Mr. Smithissä muistuttavat myös pohdiskelut siitä, että rajoittamaton markkinayhteiskunta on itsessään toteuttamiskelvoton visio, joka pitää sisällään yhteiskunnallisen katastrofin ainekset. Pyrkimys rakentaa yhteiskunta rajoittamattomien markkinoiden varaan on, Smith esittää, seurauksiltaan lopulta aina tuhoisa:

Hyväksykää totuus olevaisen luonteesta: elämän suuri tie kulkee vääjäämättömästi toistuvista talouskatastrofeista toiseen. Rajoittamaton markkinayhteiskunta romahtaa aina omaan mahdottomuuteensa, mylly pyörii, värit ja kuviot vaihtuvat tuossa kauniissa, helvetillisessä kaleidoskoopissa. Mutta samalla järkähtämättömällä varmuudella kuin maailma romahtaa, se syntyy aina uudelleen, ja samalla varmuudella palaa kapitalismi maailmaan, veressä ja tulessa kylpien. (MRS, Io8.)

Smith uskoo siis siihen, että rajoittamattomassa markkinayhteiskunnassa taloudelliset kriisit ja katastrofit seuraisivat väistämättä toisiaan. Menestyvänä yrittäjänä ja sijoitustoiminnan harjoittajana hän katsoo silti olevansa itse turvassa niiltä, ja siksi hän ajattelee, että hän voi jatkaa rauhassa liiketoimiaan. Tietyt sitaatissa esiintyvät ilmaisut kuten "rajoittamaton markkinayhteiskunta" ja kapitalismin kuvaaminen "myllyksi" ovat melko suoraa lainaa Polanyiltä, jos kohta I80o-luvun laissezfaire-teollisuuskapitalismia luonnehtiessaan Polanyi käyttää usein pelkän "myllyn" sijasta runoilija William Blakelta peräisin olevaa ilmaisua "saatanallinen mylly" (ks. Polanyi 2009, 79, 88, ı37; Heiskala 2009, I6).

Polanyin mukaan pyrkimys luoda rajoittamaton markkinayhteiskunta tai itseään sääntelevät markkinat tuottaa aina myös vastavoiman, "yhteiskunnan itsepuolustuksen". I80o-luvun Isossa-Britanniassa sellaisena toimi interventionistinen liike, joka halusi alistaa talouden laajemman yhteisöllisen ja valtiollisen sääntelyn alaisuuteen ja jota monet 
brittiläiset kirjailijat, muun muassa Thomas Carlyle, Charles Dickens ja Elizabeth Gaskell, tukivat. Tällainen ajatusjuonne ei Mr. Smithissä korostu, jos kohta se ei siitä täysin puutukaan. Mr. Smith hyödyntää Polanyin tutkimusta itsenäisesti. Sen maailmassa markkinakapitalismi on alistanut yhteiskunnan keskeiset osa-alueet valtaansa eikä tälle asetelmalle löydy siinä juurikaan vaihtoehtoja. Päinvastoin Smith ennustaa, että markkinakapitalismin aiheuttamista katastrofeista huolimatta tämä järjestelmä pystytetään aina uudelleen.

Mr. Smith on romaanina valikoiva. Se sivuuttaa osittain sen, että I990-luvun jälkipuolelta lähtien eri puolilla maailmaa on syntynyt yhtäältä uusliberalismia vastustavia ja globaalia oikeudenmukaisuutta vaativia liikkeitä, esimerkiksi ATTAC-liike ja Maailman sosiaalifoorumi, sekä toisaalta populistisia ja vanhakantaiseen nationalismiin tukeutuvia äärioikeistolaisia liikkeitä, joiden suomalaisena muunnoksena Perussuomalaiset-puoluetta voidaan nykyisin pitää. Seppälän vuosina 2000-20I2 julkaisemissa teoksissa vastarinnan ulottuvuus tulee laajasti esiin vain Routavuodessa (2004e), joka kuvaa terroristisen mielenlaadun syntymistä nykyiseen maailmanjärjestykseen tyytymättömässä yksilössä.

Polanyin ajattelusta Mr. Smith poikkeaa toisessakin suhteessa. Polanyi käsitti kapitalismin vahvasti historialliseksi ilmiöksi. Vaikka voitontavoitteluun ja lisäarvon tuotantoon tähtäävää taloudellista toimintaa on hänen mukaansa esiintynyt jossain määrin myös aiemmissa sivilisaatioissa, vasta modernissa läntisessä sivilisaatiossa siitä tuli hallitseva taloudellisen toiminnan muoto, joka on painanut leimansa koko yhteiskuntaan ja ohjaillut sen kehitystä. (Polanyi 2009, 34, 73-74, 93, IIO-III.) Mr. Smithin keskushenkilö Smith käsittää puolestaan markkinakapitalismin lähes luonnonvoimaiseksi muodostumaksi, joka kerran synnyttyään ajautuu aina välillä syviin katastrofeihin ja kriiseihin, mutta joka kykenee hämmästyttävällä tavalla toipumaan vakavista toimintahäiriöistään ja saavuttamaan taas uuden kukoistusvaiheen. Mr. Smithin komposition ja etenemistavan perusteella on vaikea sanoa, onko tämä myös romaanin sisäistekijän ja anonyymin kertojan näkemys kapitalismista. Joka tapauksessa on syytä todeta, että kapitalismin ja sen lakien näkeminen luonnonlakien kaltaisiksi voimiksi on ollut tyypillistä kapitalismia puolustaville ideologioille ja ajatustavoille, esimerkiksi uusklassiselle 
talousteorialle. Kapitalismikritiikissä sen suuntainen ajatusjuonne on esiintynyt harvemmin. Tosin sellainen sisältyy esimerkiksi Marxin Pääoman ensimmäisen osan alkuun, joka kuvaa kapitalistisen yhteiskuntamuodon kehityksen "luonnonhistorialliseksi prosessiksi" (Marx I979, I7-I8). Tällä Marx (I979, I6) korosti lähinnä sitä, että kapitalistisen talousjärjestelmän lait, nuo "rautaisen välttämättömästi vaikuttavat ja toteutuvat tendenssit", ovat kokonaisyhteiskunnallisen kehitysprosessin tuloksia, joiden voimassaolosta kukaan yksittäinen ihminen ei ole yksin vastuussa ja joita yhden ihmisen on vaikea tai miltei mahdotonta mennä muuttamaan. Marx ei siis samaistanut kapitalismin lakeja luonnonlakeihin. Polanyin tavoin hänkin oli sitä mieltä, että vakaan yhteiskuntakehityksen turvaaminen edellyttää välttämättä markkinavoimien vallan rajoittamista yhteiskunnassa ja talouden saattamista laajasti yhteisöllisen sääntelyn piiriin. (Ks. myös Dale 2010, I-45, 207-250.)

\section{Työväenluokkaiset henkilöhahmot}

Markkinakapitalismi näyttäytyy Yhtiökumppaneissa, Paholaisen haarukassa ja Mr. Smithissä vieraantuneisuutta ja merkityksettömyyttä ympärilleen levittävänä yhteiskunnallisena järjestelmänä. Tästä tuhoavasta järjestelmästä taloudellisen hyödyn korjaavat ylimmät yhteiskuntaluokat. Mr. Smithissä herra Schmidt muotoilee ajatuksen kyseisen järjestelmän luokkaluonteesta kategorisella tavalla: "Kun Neuvostoliitto romahti, herrat saivat meilläkin luvan panna kansan polvilleen. Kun rahoitusmarkkinat romahtivat, herrat saivat luvan panna kansan makaamaan" (MRS, 220). Toteamus sisältää kaksi väittämää: yhtäältä sen, että Neuvostoliiton romahtaminen aiheutti perustavaa laatua olevan muutoksen luokkavoimasuhteissa niin kansallisella kuin globaalillakin tasolla, ja toisaalta sen, että tätä kautta voimistunut finanssipääoma on pystynyt maksattamaan toiminnastaan aiheutuneet vahingot alempien luokkien kärsimyksellä.

Ajatus siitä, että uusliberalismi on merkinnyt osittaista paluuta I80o-luvulla ja I900-luvun alussa vallinneeseen luokkavoimasuhteiden tilaan, on ollut tavallinen nykyisessä kapitalismikriittisessä ajattelussa. Se esiintyy muun muassa David Harveyn (2008), Heikki Patomäen 
(2007) ja Thomas Pikettyn (2016) tutkimuksissa, joissa uusliberalismi nähdään pyrkimyksenä saattaa uudelleen voimaan sääntelemätön, valtion poliittisesta ohjauksesta vapaa kapitalismi ja yläluokan perinteinen valta-asema. Seppälän laajat yhteiskunnalliset romaanit voi nähdä osana tätä nykykapitalismin kritisoimisen perinnettä. Silti ne poikkeavat tietyissä suhteissa esimerkiksi tyypillisestä marxilaisesta kapitalismikritiikistä.

Marxilainen tarkastelutapa ei tavallisesti tyydy vain kapitalismin arvostelemiseen sekä riiston ja alistussuhteiden osoittamiseen, vaan se etsii yhteiskunnasta myös vaihtoehtoisen tietoisuuden ja poliittisen vastarinnan aineksia, elementtejä, jotka voisivat johtaa laadulliseen muutokseen yhteiskunnassa. Tällaista tarkastelutapaa edustaa muun muassa Heikki Patomäen ja Teivo Teivaisen Globaali demokratia (2003). Se kuvaa ensin kriittisesti uusliberalistista maailmanjärjestelmää ja sille ominaisia hallitsemisen keinoja, minkä jälkeen se ryhtyy selvittämään ja arvioimaan mahdollisuuksia korvata uusliberalistiset instituutiot demokraattisemmilla instituutioilla. Fredric Jameson soveltaa periaatteessa samanlaista tarkastelutapaa omassa tuotannossaan. Esimerkiksi kuvatessaan kulttuurin alueen syvenevää tavaroitumiskehitystä nykykapitalismissa Jameson tuo johdonmukaisesti esiin markkinoiden lujan otteen muusta yhteiskunnasta, niiden toimintatapojen läsnäolon miltei kaikkialla yhteiskunnassa. Tällaisen kuvauksen täydennykseksi hän etsii nyky-yhteiskunnasta kuitenkin myös aukkopaikkoja ja halkeamia - eli sellaisia alueita ja saarekkeita, joissa kapitalismin ote ei ole ehdoton ja jotka voisivat siksi toimia radikaalin tietoisuuden ja toiminnan pohjana. Samanlaista "dialektista" tarkastelutapaa hän hyödyntää kirjallisia tekstejä koskevissa analyyseissaan, joissa hän siis tavallisesti pohtii kirjallisten tekstien mahdollisuuksia avata tietä kapitalismikriittiselle tietoisuudelle ja sen mukaiselle yhteiskunnalliselle toiminnalle. ${ }^{\text {I2o }}$

Seppälän vuosina 2000-20I2 ilmestyneet teokset sisältävät aineksia kapitalismikriittisen tietoisuuden kehittymiselle. Tässä suhteessa hänellä on yhtymäkohtia edellä mainittujen tutkijoiden kanssa. Hänen romaaneissaan nykykapitalismille ei kuitenkaan esitetä vaihtoehtoa; niistä ei ole hahmotettavissa utopistista, toisenlaiseen yhteiskuntaan viittaavaa perspektiiviä. Näiltä osin hän poikkeaa edellä mainituista tutkijoista. 
Luonteenomaista Seppälän romaaneille on se, että ne esittävät alemmat luokat nykykapitalismin maksumiehinä, sen passiivisina uhreina. Tällaisia henkilöhahmoja ovat sekä Jumalan Kyynel Paholaisen haarukassa että Briscilla, Rane ja osittain myös Donald Southbrook Mr. Smithissä. Heidän passiivisuuttaan tai jopa tiedottomuuttaan nuo romaanit alleviivaavat siten, että yksikään heistä ei toimi kertojan roolissa. Heidät nähdään lähinnä anonyymien kertojien ja yläluokkaisten henkilökertojien silmin, vaikka romaaneissa kuvatut tapahtumat fokalisoidaan välillä heidän näkökulmastaan.

Paholaisen haarukassa Jumalan Kyynel tajuaa vain välittömässä elinpiirissään tapahtuneet muutokset, mutta hänellä ei ole käsitystä niistä rakenteellisista tekijöistä, jotka ovat aiheuttaneet hänen syrjäytymisensä: "Hän ei tiennyt siirtyneensä sääntelytaloudesta avoimeen markkinatalouteen eikä sitä, että sivuun siirrettynä hänkin omalta vaatimattomalta osaltaan oli kilpailukykytekijä", toteaa Paholaisen haarukan anonyymi kertoja (PH, 68). Siirtyminen laajan hyvinvointivaltion kaudesta markkinakapitalismiin on vienyt pohjan Jumalan Kyyneleen elämältä. Hänellä ei ole edellytyksiä pärjätä avoimilla työmarkkinoilla ja digitaalisessa taloudessa, joilla hänen pitäisi kaupata teollisuuskapitalismin vaiheessa hankkimiaan, sittemmin vanhentuneiksi käyneitä työmiehentaitojaan. Hän ei myöskään ole tajunnut asemaansa eikä rooliansa yhteiskuntakokonaisuudessa. Työttömäksi jäätyään hän ei siksi tiedä, mihin hänen pitäisi katkeruutensa kohdistaa. Toisaalta tarinamaailman ulkopuolisella kertojalla on siitä selkeä käsitys: "Aina kun finanssikriisi puhkesi, kapitalistien halveksiman valtion oli kuitenkin tultava apuun ja maksatettava lasku tavallisilla ihmisillä, veronmaksajilla, ja myös Jumalan Kyyneleen kaltaisten riskialttiiden yksilöiden kohtalolla” (PH, 72). ${ }^{\text {I2I }}$ Tässä kertoja viittaa siihen, että talouskriisien yhteydessä kapitalismi luopuu herkästi vapaan markkinatalouden ideologiasta ja maksattaa aiheuttamansa vahingot valtion varoista, mikä merkitsee tulonsiirtoja veronmaksajilta talouselämälle ja yläluokalle. Sitaatti jättää epäselväksi sen, missä mielessä Jumalan Kyyneleen kaltaiset ihmiset joutuvat näissä yhteyksissä maksumiehen rooliin. Ilmeisesti ajatus sitaatin takana on se, että kriisien yhteydessä valtiot ovat usein karsineet sosiaalimenojaan ja heikentäneet näin turvattomien ihmisten asemaa. 
Sama ajatusmotiivi - se, että kapitalismi maksattaa kriisinsä julkisista varoista - esiintyy Mr. Smithissä. Sen keskeinen kertoja Smith esittää eri yhteyksissä, että talouskriisien puhjetessa valtio pelastaa kyllä finanssimarkkinat, sillä niiden romahtaminen merkitsisi koko markkinakapitalistisen talousjärjestyksen toimintakyvyn menettämistä:

Koska en voi tietää, onko julkisia palveluita ja hyvinvointivaltiota kymmenen vuoden kuluttua, olen hakeutunut ainoalle saarekkeelle, joka kaiken luhistuessa, pimeyden langetessa, pelastetaan ilman ehtoja. Suuri tuntematon, globaalien rahoitusmarkkinoiden romahdus, uhkaa meitä koska tahansa, ja Jumala on vain siinä, että hänet, joka viisaasti ja vanhurskaasti sijoittaa varojaan, pelastetaan. Kun markkinat romahtavat, raivostuneet ihmiset lähtevät liikkeelle, he eivät suostu enää kriisien maksumiehiksi. He riehuvat kaduilla, särkevät ikkunoita, ryöstävät kauppoja ja polttavat taloja. Arvopaperistettu julkinen velka tulee tiensä päähän, koneet syytävät uutta rahaa, vaikka sen arvo ei enää perustu mihinkään. Sitä saa ilmaiseksi, mutta sillä ei tee mitään.

Minä aion silloinkin olla turvassa.

'Silloin' tulee vääjäämättä. Koskaan ei ole toisin kuin ennen. Romahdus tulee aina. (MRS, Io6-IO7.)

Toisin kuin Paholaisen haarukan kuvaamassa yhteiskunnassa Mr. Smithissä hyvinvointivaltio on yhä olemassa, mutta sen tulevaisuus on muuttunut epävarmaksi. Siksi Smith päättelee, että tulevaisuudessa hän voi olla turvassa vain rahoitusmarkkinoiden toimijana, sillä, näin hän uskoo, rahoitusmarkkinoita - ja itse kapitalismia - valtio ei päästä romahtamaan. Mr. Smith ei konkretisoi lähemmin tätä päättelyketjua, mutta esimerkiksi Suomessa I990-luvun alkupuolella valtiovaltaa ja sen toimenpiteitä, erityisesti pankkitukia, tarvittiin pelastamaan pankkijärjestelmä. Yhdysvalloissa vuoden 2007 lopussa puhjenneen kriisin jälkiseuraukset rantautuivat myös Eurooppaan, missä ne ilmenivät niin sanottuina euroalueen kriisinä ja velkakriisinä. Kriiseissä oli kyse siitä, että rahoitusmarkkinoille levinnyt luottamuskato vaikeutti huomattavasti taloudellisesti heikompien maiden (Baltian maat, Espanja, Islanti, Kreikka, 
Portugali) mahdollisuuksia saada ulkomaista lainaa. Näistä syistä - ja uusliberalistisen ideologian vastaisesti - globaaleja rahoitusmarkkinoita ryhdyttiin tuolloin pelastamaan laajoilla valtioiden ja keskuspankkien toimenpiteillä tai väliintuloilla. ${ }^{\mathrm{I} 22}$ Seppälän muista yhteiskunnallisista romaaneista $M r$. Smith poikkeaa siinä, että se sisältää viittauksen myös kansanjoukkojen radikalisoitumiseen finanssikriisien yhteydessä: "Kun markkinat romahtavat, raivostuneet ihmiset lähtevät liikkeelle, he eivät enää suostu kriisien maksumiehiksi." Vaikka romaani ei mainitse nimeltä yksittäisiä maita, valtion ja finanssimarkkinoiden toimintatapoja vastustaneita liikkeitä syntyi vuoden 2007 jälkeen muun muassa Yhdysvalloissa, Islannissa, Espanjassa, Kreikassa ja Portugalissa. (Kiander 20I3, I9-22.) Lähinnä tämä tapahtumaketju muodostaa kyseisessä sitaatissa esitettyjen ajatuskulkujen kontekstin.

Mr. Smithissä Briscilla, Rane ja Donald Southbrook eivät edusta raivostuneita tai radikalisoituneita kansanjoukkoja. He ovat Jumalan Kyyneleen kaltaisia henkilöhahmoja siinä suhteessa, että heidätkin esitetään vallitsevan talousjärjestyksen passiivisina uhreina. Briscillalla ja Ranella ei liioin ole käsitystä siitä, mitä heidän ympärillään yhteiskunnassa tapahtuu: "Rane ei tiennyt, mitä tapahtui, kun idänkauppa romahti. Hänellä oli yhä rahaa olueen ja lätkämatseihin, mutta väkeä vähennettiin kiihtyvään tahtiin” (MRS, I98). Pian tämän jälkeen se tehdasyksikkö, jossa Rane on käynyt töissä, tuhoutuu tulipalossa, minkä seurauksena Rane jää työttömäksi ja hän alkaa alkoholisoitua. Missään vaiheessa hän ei alkuunkaan osoita ymmärtävänsä asemaansa yhteiskuntakokonaisuudessa. Sama pätee Briscillaan. Ranen tavoin hän on joutunut lähtemään työelämään suoraan peruskoulun penkiltä, ensin kampaajaksi ja sen jälkeen työläiseksi säkkitehtaan kokoonpanolinjalle. Briscilla avioituu nuorena, vain I9-vuotiaana, mutta muutaman vuoden kuluttua hän jättää miehensä ja pienen tyttärensä. Sen jälkeen kauniiksi kuvattu Briscilla alkaa etsiä merkitysköyhään elämäänsä sisältöä viihde- ja unelmateollisuuden tuotteista, vaihtuvista työpaikoista ja ravintolailloista - sekä miessuhteista, joissa hän joutuu yleensä huonosti kohdelluksi. Ranesta ja Briscillasta poiketen Donald Southbrook tiedostaa asemansa amerikkalaisen yhteiskunnan luokkarakenteessa, mutta hänen kohdallaan tämä tietoisuus ei kanavoidu aktiiviseksi yhteiskunnalliseksi toiminnaksi. 
Paholaisen haarukassa ja Mr. Smithissä kuvatut työläiset edustavat työväenluokan alinta kerrostumaa, jonka ammattitaito on heikko ja joka horjuu työelämän ja syrjäytymisen välillä. Miksi Seppälä on valinnut romaaneihinsa tällaiset henkilöhahmot edustamaan työväenluokkaa? Miksei hän ole ottanut niihin mukaan luokkatietoisempia ja työmarkkinoilla paremmin pärjääviä työläishahmoja? Osittain Seppälän valintoja selittää se, että kyseisistä romaaneista Paholaisen haarukka noudattaa johdonmukaisesti kriittisen kärjistämisen logiikkaa, eikä Mr. Smithkään ole siitä kaukana työväenluokkaa käsittelevissä jaksoissaan. Paholaisen haarukka ja Mr. Smithin työväenluokkaa kuvaavat jaksot nojautuvat negatiivisten yksityiskohtien kasaamisen menetelmään eli ne tuovat kohteistaan esiin lähinnä vain kielteisiä, kritiikille alttiita puolia. Tällainen menetelmä on ollut varsin tavallinen naturalistisessa kirjallisuudessa. (Vrt. Isomaa 20I2a, 20I2b ja 20I3; Rossi 2009.)

Silti Seppälän romaanien tapa kuvata työväenluokkaa on syytä suhteuttaa myös siihen, että I980-luvulta lähtien puhe yhteiskuntaluokista hiipui läntisissä maissa. Luokista tuli jopa tabu, vaiettu ja epävirallisesti kielletty aihe niin kirjallisuudessa kuin yhteiskuntatieteissäkin. Paholaisen haarukkaa ja Mr. Smithiä voidaan pitää tämän vaikenemisen kritiikkinä.

Tutkimuksensa Le nouvel esprit du capitalisme (I999) englanninkielisen version (2007) esipuheessa Boltanski ja Chiapello tematisoivat tarkastelun kohteeksi luokkapuheen hiipumisen läntisissä maissa, erityisesti Ranskassa. He toteavat, että I980-luvulle tultaessa sellaiset käsitteet kuin "kapitalismi" ja "yhteiskuntaluokka" katosivat yllättävän nopeasti ranskalaisen älymystön ja taiteilijakunnan kielenkäytöstä. Vielä toisen maailmansodan jälkeisinä vuosikymmeninä ne olivat itsestään selvästi kuuluneet Ranskassa intellektuaaliseen kielenkäyttöön, varsinkin vasemmistolaiseen diskurssiin, mutta I980-luvulla yhtäältä uusliberalistisen ideologian ja yhteiskuntapolitiikan voitokas esiinmarssi sekä toisaalta itäeurooppalaisen valtiososialismin kriisiytyminen murensivat ranskalaisen älymystön piirissä uskoa perinteisen, ensi sijassa marxismin pohjalta harjoitetun kapitalismikritiikin ja luokkapuheen mielekkyyteen. Samalla myös itse ajatus kapitalismin kritisoimisesta alkoi monista näyttää historialliselta anakronismilta. (Boltanski \& Chiapello 2007, ix-xiii.) 
Suomessa vallinnut tilanne poikkeaa eräissä suhteissa Boltanskin ja Chiapellon kuvauksesta. Luokkatutkija Harri Melin (20IO, 2I2-2I5) huomauttaa, että Suomessa yhteiskuntaluokista puhumista pidettiin jo ennen I980-lukua melko sopimattomana. Kansalaissodan jälkeensä jättämät traumat olivat pitkään läsnä suomalaisessa kulttuurissa, minkä vuoksi luokkapuhe liitettiin täällä helposti politiikkaan, vasemmistolaisuuteen ja kumouksellisuuteen, eikä se juurtunut kunnolla myöskään täkäläiseen älymystökulttuuriin. Uusliberalistisen politiikan voittokulku sekä itäeurooppalaisen valtiososialismin kriisiytyminen ja romahtaminen vahvistivat entisestään tätä torjuntaa tai kulttuuris-poliittista asetelmaa. Melin jatkaa, että niinpä I980-luvulla meillä todisteltiin pääministeriä myöten, että luokkajakojen aika oli ohi ja että kaikki suomalaiset kuuluvat suureen keskiluokkaan. Samoihin aikoihin, I980- ja I990luvulla, akateemisessa tutkimuksessa toistui suoremmin tai epäsuoremmin kanta, että luokkajaon sijasta sukupuoleen, sukupolveen ja etnisyyteen perustuvat jaottelut - niihin liittyvät "identiteettipolitiikat" - ovat keskeisiä nykyisissä yhteiskunnissa.

Näistä syistä Tampereen yliopistossa vaikuttaneiden, lähinnä marxilaisten tutkijoiden laatima Suomalaiset luokkakuvassa (I984) jäi pitkäksi aikaa viimeiseksi suomalaisen yhteiskunnan luokkarakennetta koskevaksi esitykseksi. Siinä toteutettu kokonaisvaltaisen analyysin ihanne sai jatkoa vasta Jani Erolan (20I0a) toimittaman artikkelikokoelman Luokaton Suomi? Yhteiskuntaluokat 2000-luvun Suomessa (2010) myötä. Siihen kirjoittamassaan johdannossa Erola (2010d, 20) huomauttaa, että muutama vuosi ennen kyseistä teosta oli toki ilmestynyt Katriina Järvisen ja Laura Kolben yhteinen kirja Luokkaretkellä hyvinvointiyhteiskunnassa (2007), joka sai julkisuudessa innostuneen vastaanoton ja jonka ansiosta yhteiskuntaluokista oli Erolan mukaan "suorastaan tullut kuuma aihe". Erolan toimittamassa, empiirisiin yleistyksiin pyrkivässä kirjassa luokkajaon pääkriteereinä käytetään ihmisen ammattia sekä työtehtävien itsenäisyyden astetta ja niiden edellyttämää erityisosaamista. Luokkajaon kokemuksellisesta puolesta, siitä, miten ihmiset kokevat luokka-asemansa ja miten he mieltävät suhteensa yhteiskuntaan, tietoa tarjoavat Anu-Hanna Anttilan, Ralf Kaurasen, Kati Launiksen ja Jussi Ojajärven toimittama Luokan ääni ja hiljaisuus. Yhteiskunnallinen luokka- 
järjestys 2000-luvun alun Suomessa (2016) sekä Anu Kantolan ja Hanna Kuuselan Huipputuloiset. Suomen rikkain promille (2019).

Paholaisen haarukka (2008) ja Mr. Smith (20I2) ilmestyivät siis tilanteessa, jossa puhe luokista oli vasta palaamassa takaisin suomalaiseen julkisuuteen ja akateemiseen tutkimukseen. Seppälä näyttää olleen tietoinen tästä tilanteesta, sillä kuvatessaan Ranen elämänkaarta tarinamaailman ulkopuolinen kertojaa toteaa, että "Ranen kohtalon ratkaisi luokka, sosiaalinen tausta, minkäänlaista pääomaa perheellä ei ollut. Tämä tapahtui aikana, jolloin luokista oli vielä lupa puhua” (MRS, 8485). Mr. Smithissä annettujen tietojen perusteella Rane ja Briscilla ovat syntyneet I950- ja I960-luvun taitteessa, joten heidän lapsuutensa ja nuoruutensa ajoittuu I960- ja I970-luvulle, ajankohtaan, jolloin puhe luokista oli yleisempää kuin I980- ja I990-luvulla. Jumalan Kyyneleen, Briscillan ja Ranen hahmoissa Seppälän romaanit kuvaavat niin kutsuttua sosiaalisesti periytyvää köyhyyttä, sillä nämä henkilöt ovat lähtöisin vaatimattomista olosuhteista: varhaislapsuudessaan käytännössä orvoksi jäänyt Jumalan Kyynel on varttunut sijaiskodeissa ja nuorisokodissa, Rane on työläistaustaisen yksinhuoltajaäidin kasvattama poika ja myös Briscilla on menettänyt lapsuudessaan isänsä ja päätynyt sen jälkeen äitinsä kanssa huonomaineiseen lähiöön. Kaikissa näissä tapauksissa Seppälän romaanit tuovat esiin luokkadeterminaation periaatteen, näkemyksen, jonka mukaan alempien luokkien kohdalla vanhempien luokkaasema saattaa yhä määrätä ratkaisevasti ja negatiivisella tavalla heidän lastensa elämänkulun ja tulevan aseman yhteiskunnassa. ${ }^{123}$ Nykyisessä luokkatutkimuksessa on huomautettu myös siitä, että päätyessään yksinhuoltajaksi naiset joutuvat usein kokemaan taloudellis-sosiaalisen asemansa romahtamisen, sillä avioliitossaan he ovat tavallisesti olleet miehistään taloudellisesti riippuvaisia (Launis, Bergroth \& Anttila 20I6, I40). Se kuva, jonka Seppälän romaanit välittävät työläistaustaisista henkilöistään, on sopusoinnussa luokkatutkimusten tulosten kanssa.

Jumalan Kyyneleelle, Briscillalle ja Ranelle lapsuudenaikainen luokkaympäristö ja alemman työväenluokan habitus ovat "kohtalo", josta he eivät pääse eroon. Mr. Smithin Ranesta antama informaatio korostaa tätä puolta. Ranella oli sinänsä edellytyksiä nousta luokkahierarkiassa ylöspäin, sillä kouluaikoina hän oli monissa aineissa (matematiikka, 
laulu, urheilu) lahjakas ja lisäksi hän oli fyysisesti komea. Aineellisesti ja henkisesti köyhässä kasvuympäristössään hänellä ei kuitenkaan ollut mahdollisuuksia kehittää lahjojaan, minkä seurauksena hän jämähti sosiaalisiin lähtökohtiinsa: "Ranen identiteetti oli se, että hän joutui suoraan koulunpenkiltä palkkatyöhön, ensiksi mopolähetiksi ja sen jälkeen konepajalle laitosmiesharjoittelijaksi” (MRS, 85). Tämän jälkeen Ranen myöhempi elämänkulku oli paljolti sinetöity. Hän päätyi jatkossakin toistuvasti vähempiarvoisiin töihin, joihin katkoja aiheuttivat lähinnä vain eripituiset työttömyysjaksot.

Jumalan Kyyneleen, Briscillan, Ranen ja Donald Southbrookin hahmoja voi lukea uusliberalistisen diskurssin kritiikkinä. Tuossa diskurssissa laajan hyvinvointivaltion alasajo ja talouselämään kohdistuneen poliittisen sääntelyn keventäminen on esitetty sosiaalisten toimijoiden (yritykset, työntekijät) vapauden lisääntymisenä ja niille avautuneena mahdollisuutena laajempaan itsetoteutukseen. Ideaalisessa tilanteessa tällaiset "itseohjaukseen" kykenevät toimijat hyödyntävät markkinoilla esiintyvää kysyntää ja tarjontaa ja rakentavat niiden avulla itselleen sopivan työ- ja toimintaprofilin, joka on tuottoisa myös talousjärjestelmän ja kansallisen kilpailukyvyn näkökulmasta. (Vrt. Boltanski \& Chiapello I999, 9I-238.) Katariina Mäkinen (20I6, 25I-252) toteaa, että tässä asetelmassa työttömyyden ja syrjäytymisen syyt on alettu esittää uudella tavalla. Enää niitä ei nähdä niinkään talouselämän toimintatapoihin ja suhdannevaihteluihin liittyvänä rakenteellisena ilmiönä, vaan pikemminkin ne ymmärretään yksilötason ongelmiksi, yksilön kyvyttömyydeksi tai haluttomuudeksi ottaa itse vastuu työllistymisestään. Tämän ajatustavan ideologisuus paljastuu siinä, että samaan aikaan eurooppalaiset yhteiskunnat ovat jo pitkään kärsineet korkeista työttömyysluvuista.

Seppälän romaanit suhtautuvat ironisesti uusliberalistisen ihannekansalaisen normiin. Esimerkiksi Paholaisen haarukan eräässä jaksossa opiskelija-taksikuski Klaus nappaa lukemistaan tenttikirjoista ajatuksen "On oltava itseohjautuva ja kyettävä poimimaan tuotteistettavaksi ajassaan liikkuvia asioita, ideoita, konsepteja" (PH, 57). Klaus ei kuitenkaan itse pyri toteuttamaan tätä normia, vaan pikemminkin hän välttelee sitä ja ylipäänsäkin yliopistolaitoksessa nykyisin vallitsevaa tuloshakuista logiikkaa, akateemista kapitalismia. Jumalan Kyyneleen, Briscillan ja 
Ranen tilanne on vaikeampi suhteessa uusliberalismin ihannenormeihin. Lähtökohtiensa vuoksi heillä ei ole juuri minkäänlaisia edellytyksiä täyttää niitä. Lisäksi näiden kolmen, varsinkin Briscillan ja Ranen habituksessa, heidän ruumiillisuudessaan kuvastuu yhteiskunnallinen eriarvoisuus.

Mr. Smith kuvaa vanhenevan Ranen huonohampaiseksi terveysriskiksi, joka saattoi polttaa jopa 40 sätkää päivässä ja jonka viikset ikääntyminen ja sätkänpoltto olivat värjänneet harmahtaviksi. Mutta vielä tämä korvikealkoholeja aikoinaan käyttänyt ja pari haimatulehdusta sairastunut mies "silloin tällöin nousi pubin korokkeelle ja antoi tulla karhealla äänellä: oo mami, oo mami mami bluu, o mami bluu, mä vielä vielä vielä - " (MRS, 202). Briscillan kohdalla alemmalle työväenluokalle ominainen ruumiillinen habitus tulee ilmi toisella tavalla. Hänen elämäntapansa, jota raskas työ, ravintolaillat ja lukuisat lyhytaikaiset miessuhteet kuormittavat, kuluttaa häntä ja kuihduttaa hänen luontaisen kauneutensa, eikä hän vähävaraisena pysty hidastamaan sitä maksullisilla hoidoilla. Vasta Ranen kuoltua asbestoosiin hän löytää joogan ja kääntyy sisäistyneempään elämäntapaan. Jooga "tähtäsi ihmisen henkiseen kasvuun ja hyvinvointiin, siitä löytyisi tasapaino, rauha ja oma tie, joka oli aina ollut hakusessa", toteaa tarinamaailman ulkopuolinen kertoja lempeän ironisesti (MRS, 272). ${ }^{\mathrm{I} 4}$

Perinteisessä luokkatutkimuksessa Jumalan Kyyneleen, Briscillan ja Ranen kaltaisia ihmisiä on luonnehdittu toteamuksella, että objektiivisesti katsoen heillä on tietty asema yhteiskunnan luokkarakenteessa, mutta heiltä puuttuu sitä vastaava luokkatietoisuus. Objektiivisen taloudellis-sosiaalisen asemansa perusteella tällaiset ihmiset kuuluvat siis alempaan työväenluokkaan, mutta subjektiivisella tasolla he eivät samaistu kunnolla mihinkään luokkaan eivätkä he myöskään muodosta keskenään erityistä yhteenliittymää, jonka sisällä vallitsisi yhteenkuuluvuuden tunne ja joka olisi kehittänyt oman luokkaideologiansa. Siten kyseinen luokka on olemassa samanlaisessa asemassa olevien erillisten yksilöiden tasolla, mutta sillä ei ole omaa kollektiivista luokkaideologiaa.

Olen tässä tutkimuksessa itsekin noudattanut paljolti tällaista perinteiselle luokkatutkimukselle ominaista kuvaustapaa. Harley Bergroth (2016, I99-200) huomauttaa, että sen ongelmana on kuitenkin se, että 
siinä luokat ymmärretään vain suhteessa tuotantoelämään ja ihmisen luokka-asema määritetään hänen tuotantoelämässä saavuttamansa aseman perusteella. Juuri tällaiset, tuotantoelämän sisäpuolella olevat ihmiset pystyvät suhteellisen helposti järjestäytymään yhteen ja muodostamaan etujaan ilmentävän luokkaideologian. Sitä vastoin ne, joiden suhde tuotantoelämään on epäsäännöllinen tai jotka ovat jääneet sen ulkopuolelle esimerkiksi syrjäytymisen vuoksi, ovat toisenlaisessa tilanteessa; heidän välilleen ei synny helposti yhteisyyden tunnetta eivätkä he tavallisesti myöskään tunne halua muodostaa yhteistä ideologiaa. Siksi heidän tilanteensa eri puolia ei välttämättä pystytä kuvaamaan nykyisten luokkateorioiden avulla. Niiden täydennykseksi tarvittaisiin monipuolisempaa näkemystä yhteiskunnassa vallitsevasta taloudellis-sosiaalisesta eriarvoisuudesta.

Myös Paholaisen haarukassa Jumalan Kyyneleen kaltaiset ihmiset esitetään lähinnä alemman työväenluokan jäseniksi, joita sortaa sekä kapitalismi että työväenluokan ylempi kerrostuma. Jälkimmäinen sorron muoto tulee ilmi muun muassa kohtauksessa, jossa kovapalkkaiset ammattimiehet osoittavat avoimesti halveksuntaa Jumalan Kyyneltä, "tehtaan paariaa" edustavaa työläistä kohtaan (PH, I46). Vaikka kyseinen kohta on suppea, vain yhden kappaleen pituinen, se riittää tuomaan esiin sen, että Jumalan Kyyneleen suhde työväenluokkaan on ristiriitainen. Toisaalta romaani esittää hänen olevan osa sitä, mutta toisaalta esiin tuodaan myös syitä siihen, ettei hän voi täysin samaistua siihen. Näihin syihin kuuluvat muun muassa työväenluokan sisällä vallitsevat hierarkkiset asetelmat ja se, että elämässään ja työurallaan Jumalan Kyynel ei saa juuri minkäänlaista konkreettista tukea muilta työläisiltä. Hänen ainoaksi tukijakseen jää hänen valvojansa, työnjohtaja Eero Raivio eli "Eero-vaari”, jonka kuoltua hän menettää tämänkin avun muodon. ${ }^{\mathrm{I} 25}$

Mr. Smith käsittelee tai sivuaa lyhyesti myös nykyisten luokkasuhteiden ylirajaista tai globaalia luonnetta. Näin tapahtuu lähinnä jaksoissa, joissa kuvataan Erno Mannisen (ylempi keskiluokka) ja Donald Southbrookin (Erno Manniselle vuokratun työsuhdeasunnon huoltomies) välistä kanssakäymistä Yhdysvalloissa. Näiden kahden välinen sanallinen viestintä ei romaanissa etene yhdentekevää small talkia pidemmälle, sillä Donald Southbrook on haluton vastaamaan Erno Mannisen 
tekemiin aloitteisiin. "Erno ymmärsi, että hänen omien, tyhjänpäiväisten sanojensa tarkoitus oli pyrkiä peittämään heidän välillään vallitsevien taloudellisten suhteiden väkivaltaisuus”, toteaa tarinamaailman ulkopuolinen kertoja (MRS, 2I6). Siksi myös Erno vaikenee lopulta ja kääntyy omaan maailmaansa. Todellisessa globaalissa maailmanjärjestelmässä tällainen asetelma, jossa ylempien luokkien edustaja on lähtöisin järjestelmän valtakeskusten ulkopuolelta ja alempien luokkien edustaja valtakeskusten sisäpuolelta, ei ole epätavallinen. Silti globaalia yläluokkaa tai kapitalistien luokkaa, jota edustavat varsinkin suuryritysten omistajat ja johtajat, on uusliberalismin kaudella hallinnut ensi sijassa amerikkalainen bisneseliitti. (Ks. lähemmin Ten Brink 20II.)

\section{Autenttisuuden problematiikka}

Autenttisuuden problematiikka on suorasti tai epäsuorasti esillä monissa Seppälän vuosina 2000-20I2 julkaisemissa teoksissa. Hänen tuolloin ilmestyneistä romaaneistaan se liittyy laajimmin Mr. Smithiin, jonka tapaa käsitellä autenttisuuden teemaa eritellään tässä ja erityisesti seuraavissa alaluvuissa. Koska kyseinen tematiikka liittyy myös Seppälän muihin teoksiin, on syytä tarkastella lähemmin itse autenttisuuden käsitettä.

Autenttisuuden käsite liittyy läheisesti vieraantumisen käsitteeseen. Niiden välistä suhdetta voidaan valottaa toteamuksella, että vieraantuneiden yksilöiden ja yhteiskuntien elämä on epäautenttista. Tällöin yksilöt eivät pääse kehittämään itseensä sisältyviä mahdollisuuksia ja potentiaalejaan, vaan he joutuvat mukautumaan ulkoisiin pakkoihin eivätkä he kiinnity kunnolla toisiinsa ja ympäröivään yhteiskuntaan. Autenttisuudessa on kyse vieraantumattomasta tilasta, jossa ihminen on yhtä itsensä ja ympäristönsä kanssa. Tällaisessa tilassa ihmisellä on mahdollisuus toteuttaa ja ilmaista itseään tavalla, jossa hän kokee todellisen minuutensa pääsevän esiin. (Lindholm 2008, I-2; Taylor I995, 48, 7I-73; Taylor I996, 370.)

Seppälän tuotannossa autenttisen tilan kuvaukset ovat harvinaisia, mutta kokonaan ne eivät siitä puutu. Miltei säännöllisesti tällaiset har- 
vat kuvaukset liittyvät luontoon ja maaseutuun. Esimerkiksi romaanissa Silta (I988) päähenkilö, kaupunkiin muuttanut murrosikäinen poika, kokee autenttisuuden hetkiä päästessään viikonlopuiksi maalle isovanhempiensa luokse, ja Kuun nousussa ja laskussa (I999) kaupunkisosiologi saavuttaa vastaavanlaisen kokemuksellisen tilan niin ikään maaseutuympäristössä seuratessaan viljan kypsymistä ja korjaamista ja kuunnellessaan samalla "kuivureiden huminaa". Tätä samaa, autenttisuuden ja maaseutumaisen elämänmuodon yhteen liittävää kertomustyyppiä edustaa myös novelli "Mustalla saarella" (Seppälä 200ob), joka sisältyy novellikokoelmaan Suuret kertomukset (Seppälä 200oa). Se kuuluu siis Seppälän kapitalismikriittiseen kauteen, ja itse asiassa sen voi sanoa aloittaneen tuon kauden. Autenttisuuden ideaali esiintyy siinä selkeässä ja Seppälän tuotannolle melko luonteenomaisessa muodossa.

Kyseisen novellin päähenkilöinä on kaksi nuorta miestä: kehonrakentaja Sulevi ja hänen valmentajansa, jonka nimeä ei novellissa mainita, mutta joka esittää novellin tapahtumat minämuodossa. Ilmeisesti minäkertoja on Sulevin veli, sillä kertoja ja hänen äitinsä asuvat samassa taloudessa Sulevin kanssa, mutta selvät maininnat heidän keskinäisestä sukulaisuussuhteestaan puuttuvat. Nämä kaksi henkilöä ovat novellin keskeiset fokalisoijat, minkä lisäksi novelli antaa informaatiota eräiden sivuhenkilöiden ajatuksista ja tunteista. Minäkertojan esityksessä hyvin toimivan maaseutuyhteisön ja kansainvälisen kilpaurheilun maailmat asettuvat vastakkain. Novellin keskushenkilöt ovat lähtöisin maaseudulta. Matkustaessaan Islantiin kehonrakennuksen pohjoismaisiin mestaruuskisoihin he kohtaavat kansainvälisen urheiluviihteen maailman, jossa he kokevat menettävänsä minuutensa ja identiteettinsä ja joka näyttäytyy novellissa epäautenttisena sosiaalisena tilana.

Keskushenkilöiden kotipitäjä sijaitsee syrjässä suurista asutuskeskuksista, ja ihmiset elävät siellä maaseutuyhteisön kiireetöntä elämää. Heidän välillään vallitsevat tuttavalliset naapuruussuhteet, ja heillä on tapana auttaa toisiaan arkisissa askareissa, esimerkiksi perunannostossa. Kotipitäjänsä asukkaista puhuessaan kertoja käyttääkin sellaisia ilmaisuja kuin "naapurin Antti" (MUSA, Io) ja "Rahkosen Liisa" (ibid., 30).*

* Käytän tässä pääluvussa "Mustalla saarella" -novellista lyhennettä MUSA silloin, kun siteeraan sitä. 
Tällaisia epämuodollisen tuntuisia ilmaisuja ihmiset käyttävät toisistaan lähinnä silloin, kun heidän sukujensa välille on muodostunut pitkäaikaisia tuttavuussuhteita sen takia, että he ovat vuosikymmeniä asuneet lähellä toisiaan. Nyky-yhteiskunnassa ihmissuhteet ovat usein toisenlaisia, sillä niitä leimaa yhä enemmän tilapäisyys ja lyhytkestoisuus (ks. Bauman 2000).

Kansainvälistä kaupallistunutta ja viihteellistynyttä urheilumaailmaa "Mustalla saarella" arvostelee kuvaamalla sen liian monimutkaiseksi muodostelmaksi Sulevin kaltaiselle nuorelle miehelle, joka on henkisessä kehityksessään jäänyt lievästi lapsenomaiselle tasolle ja jonka käyttäytymistä minäkertoja pystyy siksi helposti ohjailemaan. Sulevin lapsenomaisuutta kuvastaa minäkertojan mainitsema tieto siitä, että muutamaa viikkoa ennen Islannin-matkaa uutinen Elvis Presleyn kuolemasta oli tavoittanut Sulevin. Idolinsa kuolemasta syvästi järkyttynyt Sulevi oli ensireaktionaan vetäytynyt huoneeseensa ja lopettanut valmistautumisensa pohjoismaisiin mestaruuskilpailuihin. Vasta minäkertojan maanittelujen ja suostuttelujen jälkeen Sulevi oli vihdoin kuuden päivän suremisen jälkeen palannut harjoittelemisen pariin, tosin tästä lähtien musta surunauha oikeassa ranteessaan.

Elvis Presley kuoli vuonna I977. Vaikka novellin tapahtumat ajoittuvat markkinahenkistä käännettä edeltävään aikaan, novellia ei tarvitse ymmärtää pelkäksi historialliseksi kuvaukseksi tuosta edeltävästä aikakaudesta. Tapahtumien sijoittumisen menneisyyteen voi ajatella toimivan novellissa vieraannuttavana kognitiivisena elementtinä. Siinä, missä historiallisilla romaaneilla on tapana kuvata oman aikansa ongelmia sijoittamalla ne historiallisesti ja maantieteellisestikin etäisiin ympäristöihin, novellissa "Mustalla saarella" kaupallistunut ja viihteellistynyt kehonrakennuskisojen maailma on mahdollista käsittää nyky-yhteiskunnan toimintatapojen metonyymiseksi ilmentäjäksi. Novellissa kokonaisuuden (nyky-yhteiskunta) ominaisluonnetta määritetään siis epäsuorasti sen yhden osa-alueen (kehonrakennuskisat) avulla. Sijoittaessaan tuon osa-alueen samalle aikajanalle hyvin toimivan maaseutuyhteisön kanssa novelli korostaa niiden vastakohtaisuutta ja I980- ja I990-luvulla käynnistyneen reaalisen yhteiskunnallisen murroksen syvyyttä. 
Hieman ristiriitaiselta autenttisuus-teeman kannalta saattaa kuitenkin tuntua se, että novellissa Sulevi ilmaisee itseään ja identiteettiään juuri Elvis Presleyn, angloamerikkalaisen populaarikulttuurin tai kulttuuriteollisuuden ikonisen hahmon avulla. I950-I970-lukuja voidaan pitää nykyisen luovan talouden tai kulttuurikapitalismin edeltäjänä, vaiheena, jolloin kulttuurikapitalismi ei ollut vielä noussut kapitalismin hallitsevien sektorien joukkoon ja jolloin siihen liittyi runsaasti nuorison kapinointia vallitsevaa tapakulttuuria vastaan. Elvis Presleyn ura sijoittuu tuohon vaiheeseen. Sulevi siis käyttää identiteettinsä ja minuutensa ilmaisussa hyväkseen amerikkalaisen kulttuurikapitalismin tarjoamia välineitä. Hän ei siten ole elänyt missään täysin suljetussa maaseutuyhteisössä. Novellissa kuvatussa maailmassa hän on omaksunut toisessakin mielessä vaikutteita luovasta taloudesta. Hänen harrastuksensa, kilpailuun tähtäävä kehonrakennus, voidaan sijoittaa pitkälle kaupallistuneen urheiluviihteen piiriin, jossa urheiluun aiemmin liitetyt yhteisölliset ja aatteelliset merkitykset ovat korvautuneet yksilökeskeisemmillä merkityksillä.

Kansainvälisissä kehonrakennuskisoissa päähenkilöiden ei ole aina mahdollista käyttäytyä tavalla, joka olisi heille luontainen. Sen sijasta he joutuvat usein mukautumaan niihin rooleihin, jotka heille tuossa maailmassa tarjoutuvat. Esimerkiksi ennen kilpailuja kertoja sivelee Sulevin vaalealle iholle ruskehtavaa väriainetta, jotta tämän lihakset näkyisivät paremmin. "Niinkun Pekka ja Pätkä neekereinä. Enhän minä tunne itteeni”, Sulevi huomauttaa (MUSA, 2I) - tavalla, joka tuo esiin sekä hänen lapsenomaisen puolensa ja kulttuurisen tietämyksensä rajoittuneisuuden että hänen tunteensa oman minuutensa ja identiteettinsä menettämisestä. Samanlaisia voiteita kilpailuissa käyttävät muutkin osallistujat.

Novelli kuvaa kansainväliset kehonrakennuskisat äärimmäisen kilpailuhenkiseksi urheiluviihteen ja showelämän alueeksi, jossa monet kehonrakentajat pyrkivät menestymisen toivossa ottamaan itsestään kaiken irti, usein lihaksia kasvattavia aineita väärinkäyttämällä. Kertoja on kiinnittänyt jo ennen varsinaista kilpailutapahtumaa huomiota erääseen ruotsalaiseen kilpailijaan, joka "oli vetänyt itsensä niin kuivaan kuntoon, 
että sen selkä koostui muutaman millin vahvuisista lihassäikeistä ja kaikki pintasuonet taatusti näkyivät kuin partti narua olisi sullottu sukkahousuihin. Tälle oli sitten varsinaisessa kisassa käyvä niin että se jäi toiseksi, muutama kuukausi kisojen jälkeen se hirtti itsensä” (MUSA, 22). Varsinaisessa kilpailussa myös Sulevi, joka osallistuu raskaaseen sarjaan, jää toiseksi, mutta se ei suista häntä kriisiin vaan aiheuttaa hänessä korkeintaan vain harmituksen tunteen.

Kilpailutapahtuman jälkeen islantilaiset järjestäjät ovat vielä valmistelleet illaksi show-tapahtuman, joka on minäkertojan mukaan luonteeltaan huomattavasti kaupallisempi kuin varsinainen kilpailu: "Katsojia varten oli järjestetty lisää paikkoja ja mainoksiakin oli levitelty aulan seinustoille enemmän kuin niitä iltapäivällä oli ollut. Väkeä oli paljon. Ennen kuin ohjelma alkoi, ymmärsin tuulikaapin tapahtumista, että liput oli myyty loppuun" (MUSA, 27). Kertojan kuvauksen perusteella tuota show-tapahtumaa voi luonnehtia spektaakkeliksi, jossa öljytyt kehonrakentajaryhmät ilmaantuvat vuoron perään esiintymislavalle diskomusiikin melun saattelemana ja samaan aikaan heihin suunnatut valonheittimet välillä kirkastuvat ja välillä taas himmenevät.

Istuessaan esiintymislavan edessä innostuneen katsojajoukon, korvia huumaavan musiikin ja valonheittimien vaihtuvien valokaarien ympäröimänä minäkertojaan iskee paniikki, tunne oman olemassaolon kiinnekohtien menettämisestä: "Minusta tuntui että olin äkkiä tullut aivan itsettömäksi, ei keneksikään, että minut oli heitetty oman onneni nojaan enkä minä ollut kukaan” (MUSA, 27-28). Tässä kertoja kuvailee kokemaansa tunnetta oman minuutensa ja identiteettinsä menettämisestä ("olin äkkiä tullut aivan itsettömäksi", "enkä minä ollut kukaan"), ja tähän kokemukseen liittyy myös hänen turvallisuuden tunteensa horjuminen ("minut oli heitetty oman onneni nojaan"). Sama motiivi, epäautenttisen tilanteen aiheuttama vierauden kokemus, tulee esiin jaksossa, jossa minäkertoja kuvaa hetkeä myöhemmin Sulevin ja muiden raskaaseen sarjaan osallistuneiden kilpailijoiden saapumista esiintymislavalle:

Musiikki puhkesi uudestaan vastenmielisen kovaksi. Viisi satakiloista öljyttyä miestä käveli kuin hidastetussa filmissä lavalle savun ja valon sekaan. Ne eivät olleet miehiä, ihmisiä, ne olivat maan alta 
nousseita jättiläisiä, saaren hirviöitä ja taruolentoja, joiden armoilla me olimme ja jotka saivat aikaan korvia huumaavan metelin. (MUSA, 29.)

Yksi näistä hirviöiltä näyttävistä olennoista on kuitenkin Sulevi, joka esittelee lavalla eri asennoissa lihaksiaan. Paikalla olijoista vain minäkertoja tietää, että tuo luonnottomalla tavalla vääntelehtivä olento ei ole oikea Sulevi:

Seurasin Sulevin liikehtimistä ja näin että se pystyi tekemään suorituksensa kuin kone, mitään ajattelematta ja tuntematta. Tajusin olevani ainoa joka tunsi sen; ne jotka näkivät sen nyt lavalla näkivät sata kiloa kiusattua lihaa, eivät sitä poikasta joka pyysi minua kanssaan ostamaan moottorisahaa ettei häntä kaupoissa petettäisi ja joka ei pakkien pelossa uskaltanut lavalla hakea Rahkosen Liisaa tanssimaan. Sulevi se oli, uimahousuissaan, savun ja värivalojen seassa, keskellä valtamerta ja sen kivistä, mustaa saarta, kuun pintaa. (MUSA, 29-30.)

Oikea, todellinen Sulevi on varttunut maaseutuyhteisössä. Tuon yhteisön verkkaisempi elämänrytmi ihmisineen, tapoineen ja töineen on muodostanut sen kulttuurisen kontekstin tai, Habermasin käsitteistöä käyttääksemme, elämismaailman, jossa Sulevi ja minäkertoja kokevat olevansa omia itsejään. Kansainvälisissä kehonrakennuskisoissa ja yleisemmin nyky-yhteiskunnassa he tuntevat ajautuneensa vieraaseen ympäristöön, joka käyttää heitä välikappaleina omien kaupallisten tavoitteidensa toteuttamisessa.

Tämä vuonna 2000 ilmestynyt novelli ei siten esitä koko yhteiskunnallista todellisuutta sellaisena yksiulotteisena ja vieraantuneena tilana, jollaisena tuo todellisuus näyttäytyy kahdeksan vuotta myöhemmin ilmestyneessä Paholaisen haarukassa. Sulevilla ja minäkertojalla on vielä mahdollisuus aitoihin valintoihin. Show-illan päätyttyä he käyvät kylpemässä kuumassa lähteessä, jossa Sulevi pääsee eroon iholleen levitetystä väriaineesta. Uimisen ja sukeltamisen jälkeenkin "näin sen vasempaan olkavarteen vielä jääneen ruskeaa värivoidetta ja huomautin asiasta. Sen 
oli hierottava väriä aika kauan ennen kuin se lähti." (MUSA, 33.) Tämän jälkeen he voivat palata maaseutuyhteisöönsä, omaan elinpiiriinsä. Esimerkiksi Paholaisen haarukasta tällaisia autenttisen olemassaolon mahdollistavia saarekkeita ei juurikaan löydy; niiden viimeisten jäänteiden, esimerkiksi Lauri Laineen kellosepänliikkeen, on kadottava markkinallistumiskehityksen ja uudenlaisen kapitalismin tieltä. Autenttisen elämäntavan mahdollistava maalaisyhteisö ja kulttuurikapitalismin nimeen vannova epäautenttinen markkinayhteiskunta eivät silti ole "Mustalla saarella" -novellin kuvaamassa maailmassakaan totaalisesti toistensa vastakohtia. Niiden väliset rajat ovat liukuvat, ja vaikutteita jälkimmäisestä on jo päässyt vuotamaan maaseudun ihmisten elämään. Näitä vaikutteita novelli ei kuitenkaan tematisoi ongelmaksi, vaan se ottaa ne paljolti annettuina.

"Mustalla saarella" tavoittaa monien I990-luvulla eläneiden suomalaisten aikalaiskokemuksen. Suomalaisen yhteiskunnan kehityksessä tuo vuosikymmen oli aikaa, jolloin täällä siirryttiin täydessä mitassa uusliberalistisen politiikan vaiheeseen. Juuri tuon vuosikymmenen kuluessa suomalainen yhteiskunta avattiin laajemmassa mittakaavassa markkinavoimille, yksityiskapitalistiselle yritystoiminnalle ja kaupallisille tv- ja radioyhtiöille ja samaan aikaan kilpailun periaate juurrutettiin siihen entistä syvemmin. (Alasuutari 2006, 43-44; Heiskala 2006, 30, 34, 39-40; Patomäki 2007, IO-I2.) Seppälän novellissa nämä piirteet ovat muunnellussa muodossa siirtyneet kansainvälisen kehonrakennusmaailman ominaisuuksiksi.

Kehonrakennusta käsitellessään "Mustalla saarella" korostaa sen spektaakkelimaista tai mahtipontisen irvokasta luonnetta. Tämä tehostus tuo kyseisen novellin lähelle groteskin kirjallisuuden perinnettä, jossa liioittelun, kärjistysten ja muuntelun kautta kuvauskohteet esitetään mittasuhteiltaan vääristyneinä tai epäinhimillisinä (ks. Alanko \& Kuisma 2000). Siten groteski voi toimia joustavasti yhteiskuntakritiikin välineenä. Kun "Mustalla saarella" ymmärretään arvioksi ı ९९०-luvulla esiin murtautuneen uudenlaisen yhteiskunnan toimintatavoista, se käsittelee tuota yhteiskuntaa niiden ihmisten näkökulmasta, jotka kokivat sen itselleen kulttuurisesti vieraaksi. Novellissa tällaisia ihmisiä edustavat maaseudun pieneläjät, mutta laajemmassa katsonnassa heihin kuu- 
luisivat myös syrjäytyneet, työttömät ja I990-luvun alkupuolen laman runtelemat ihmiset, joille I990-luvun suuret rakenteelliset muutokset näyttäytyivät koko omaa elämänmuotoa uhkaavana murroksena.

Kyseiseen novelliin verrattuna Yhtiökumppanit ja varsinkin Paholaisen haarukka kuvaavat maailmaa, josta puuttuvat paljolti autenttisen elämänmuodon ja itsetoteutuksen mahdollisuudet. Tuossa maailmassa markkinallistumiskehitys on perustavalla tavalla murskannut tällaiset mahdollisuudet. Yhtiökumppanit (2002) kuvaa Peten ja Ollin ja heidän yhtiönsä henkilökunnan kasvavaa vieraantumista omasta itsestään, toisistaan ja itsetoteutuksesta. Vapaan itsetoteutuksen sijasta he joutuvat yhä enemmän mukautumaan kiristyvään kilpailutilanteeseen ICT-markkinoilla ja ottamaan toimintamuodokseen alan, tietokonepelit, jonka he kokevat pohjimmiltaan valheelliseksi. Romaanin neljännessä osassa, erityisesti näytelmämuotoon kirjoitetussa jaksossa (YK, I67-I77) tämä jännite henkilöiden todellisen tilanteen ja autenttisuuden ihanteen välillä käy sietämättömäksi, mitä ilmentää se, että humalainen Olli alkaa osoitella muita aseella herättääkseen heissä tietokonesimulaatioiden sijasta todellisia tunteita. Samanlainen tehtävä näytelmäjaksossa on Peten epätoivoisella purkauksella (ibid., I73): "[J]onkin asian pitää jumalauta olla totta ja oikeeta. Oikee sisältö, saatana, ei tyhjä kuva väsyneestä miehestä, joka roikkuu silmät ummessa ja on saatanan väsynyt kaikkeen! Ei peliä perkele!"

Paholaisen haarukassa (2008) autenttisuuden teemalla on paljolti samanlainen asema kuin Yhtiökumppaneissa. Siinäkään henkilöillä ei ole mahdollisuuksia elää ja toimia autenttisuuden ihanteen mukaisesti. Selvimmin tämä piirre tulee esiin sosiaalipsykologi Saija Lehtosessa, joka on tavoitellut laajemman itsetoteutuksen mahdollistavaa elämäntapaa, ja sijoitusneuvoja Lari Laineessa, joka on samalla tavalla tietoinen elämäntapansa vinoutumista. Puhuessaan avioliitostaan Lari Laine kuvailee näitä vinoutumia raamatullisin termein:

Jos olisin tiennyt enemmän seksistä, olisin tiennyt että meidän seksimme oli huonoa. En tiennyt että me elimme helvetissä, synnissä; en voinut pohtia sitäkään mihin sitten kuoltuamme saattaisimme joutua. 
Synti tarkoitti sitä että me olimme joutuneet itseltämme kadoksiin. Kaikki oli hyvin.

Koska ihminen oli tarkoitettu olemaan yksin, meistä tuntui että kaikki oli hyvin, koska toinen asui samassa asunnossa ja nukkui samassa sängyssä. Me tiesimme milloin toinen ulosti, vaimoni illalla, minä aamulla. Rakkautta se ei ollut, niin kuin ei ollut Klausin ja Hennan välilläkään. (PH, I05.)

Epätavallista katkelmassa on se, että Lari Laine näyttää ilmaisevan osan ajatuksistaan kontrafaktuaalisen ehtolauseen muodossa ("Jos olisin tiennyt enemmän seksistä, olisin tiennyt että meidän seksimme oli huonoa”), minkä jälkeen hän kiistää tietävänsä sen, minkä hän tietää ("En tiennyt että me elimme helvetissä, synnissä; en voinut pohtia sitäkään mihin sitten kuoltuamme saattaisimme joutua”). Katkelman ensimmäinen kappale vaikuttaa siksi paradoksilta, sisäisesti ristiriitaiselta tai mahdottomalta ilmaisulta. Paradoksi kuitenkin ratkeaa, kun otetaan huomioon se, että Lari Laineen puheessa sekoittuu toisiinsa kaksi erilaista ajallista ja kerronnallista näkökulmaa. Katkelma sisältyy jaksoon (PH, IO3-IIO), jossa Lari Laine kertoo "puolitoista vuotta sitten" tapahtuneista asioista. Katkelman voi siksi ajatella ilmaisevan sekä hänen entistä, rajoittunutta tietämystään seksistä ja elämästä että hänen nykyistä, laajentunutta tietämystään niistä. Toisaalta on mahdollista ajatella, että Lari Laine toimii katkelmassa kahdessa eri roolissa: yhtäl̈ltä tarinamaailman henkilönä, jonka tietomäärä on rajallinen, ja toisaalta tarinamaailman ulkopuolisena, kaikkitietävänä kertojana, joka arvioi tarinamaailman henkilöiden rajoituksia, myös omia rajoituksiaan. Monissa muissakin Paholaisen haarukan jaksoissa ja luvuissa Lari Laineelle on ominaista tällainen joustava kerronnallisten ja ontologisten rajojen ylittäminen ja niiden kanssa leikitteleminen.

Kristillisessä teologiassa "synti" merkitsee etääntymistä ja luopumista Jumalasta ja hänen säätämästään maailmanjärjestyksestä. Lari Laine ei puhu synnistä tässä merkityksessä. Hän käyttää synti-sanaa lähinnä samalla tavalla kuin eksistentialistit puhuivat epäautenttisuudesta. Eksistentialistisessa filosofiassa, esimerkiksi Heideggerilla, Sartella ja Beauvoirilla, ihminen etääntyy autenttisuuden ihanteesta, mikäli hän 
samaistuu liiaksi sosiaalisiin rooleihinsa ja rutiineihinsa tai mikäli hän elää liiaksi yhteiskunnassa vallalla olevien tapojen ja sovinnaissääntöjen mukaisesti, konformistisesti. (Cooper 2008, 33-34, II6-I22.) Juuri tällaista Lari Laineen elämä on, yhtäältä aineellisesti rikasta, mutta toisaalta rutinoitunutta ja henkisesti köyhtynyttä. ${ }^{126}$

Yhtiökumppaneissa ja Paholaisen haarukassa epäautenttisuuden ja kapitalismin välinen yhteys on siis selkeä. Vaikka Seppälän tuotannossa ihmisten mahdollisuudet elää autenttista elämää ovat olleet alusta lähtien niukat, markkinallistumiskehitys merkitsee näiden kahden romaanin mukaan tällaisten mahdollisuuksien radikaalia kaventumista. Saman suuntainen näkemys sisältyy Mr. Smithiin. Ennen kuin me otamme tuon näkemyksen lähemmän tarkastelun kohteeksi, on syytä kysyä, miten kapitalismin ja autenttisuuden välinen suhde on yleisemmin nähty modernissa länsimaisessa kulttuurissa. Missä mielessä ne sopivat sen mukaan yhteen tai sulkevat toisensa pois?

Teoksessaan Culture and Authenticity (2008) amerikkalainen kulttuuriantropologi Charles Lindholm kirjoittaa, että modernin länsimaisen autenttisuuden idean keksijänä voidaan pitää ennen kaikkea Jean-Jacques Rousseau'ta. Erityisen tärkeä sija autenttisuuden idean synnyssä ja yleistymisessä on ollut Rousseau'n teoksella Les confessions (I782, Tunnustukset). Siinä hän tekee eron julkisen ja todellisen minuutensa välille ja pyrkiessään häpeämättömällä tavalla jälkimmäisen ilmaisemiseen hän osoittautuu muun muassa pelkuriksi, masokistiksi ja seksuaalisesti poikkeavaksi. Autenttisuuden idean myöhemmän kehityksen kannalta tärkeää on myös ollut Rousseau'n esittämä ajatus siitä, että moderni sivilisaatio korruptoi ihmisen todellisen olemuksen ja siksi autenttisuutta voi nykyisin löytää selvimmin primitiivisistä kulttuureista ja lapsista. (Lindholm 2008, I-2, 8-9. Ks. myös Taylor I996, 368-390.)

Rousseau'n teoksen ilmestymisen jälkeen oman, todellisen minuuden ilmaisemisesta tuli länsimaissa kulttuurinen hyve taiteilijoiden ja ylempien luokkien piirissä, ja myöhemmin, ı9o0-luvulla, tämä kulttuurinen ihannenormi tavoitti myös alemmat luokat. Charles Taylor (I995, 44-45) toteaa, että Yhdysvalloissa ja muissa länsimaissa "itsensä toteuttamisen individualismi" on I96o-luvulta lähtien toiminut keskeisenä kulttuurisena arvosuuntauksena. Taylor ilmoittautuu itsekin sen kan- 
nattajaksi, mutta samalla hän lisää, että "autenttisuuden etiikan" jyrkimmät, egoistiset ja narsistiset, ilmenemismuodot eivät ole hyväksyttäviä. Vaikka egoistinen ja narsistinen käyttäytyminen on Taylorin (I995, 48, 83,88 ) mukaan yleistynyt länsimaissa, hyvin toimivassa yhteiskunnassa itsensä toteuttamiselle täytyy asettaa tietyt rajat; muussa tapauksessa se vaikuttaa yhteiskuntaan hajottavasti, sosiaalisuutta ja yhteisöllisyyttä rapauttaen (Taylor I995, 7I-72). Lari Laine edustaa Paholaisen haarukassa potentiaalisesti tällaista tuhoavaa arvosuuntausta. Eräässä luvussa hän toteaa: "Olet vastuussa itsestäsi, et muista. Etiikka on sitä, että juuri sinä toteutat itseäsi" (PH, III). Lausuma sisältää viittauksen Taylorin teokseen Autenttisuuden etiikka (I995, englanninkielinen alkuperäisteos ilmestyi I99I), jossa Taylor kuvaa autenttisuuden etiikan vahingollisia muotoja paljolti samalla tavalla kuin Lari Laine ilmaisee omaa arvomaailmaansa.

Lindholm ja Taylor eivät tutkimuksissaan tarkastele laajasti autenttisuuden teemaa suhteessa kapitalismiin ja kapitalismikritiikkiin. Boltanskin ja Chiapellon "Kapitalismin uudessa hengessä" tällainen tarkastelu on systemaattisesti mukana. Siinä he erottavat toisistaan kapitalismin ja kapitalismin hengen. Kapitalismin Boltanski ja Chiapello määrittävät yhteiskunnalliseksi järjestelyksi, jota ajaa eteenpäin "imperatiivi kasata rajoittamattomasti pääomaa muodollisesti rauhanomaisin keinoin". ${ }^{27}$ Ilmaisu "muodollisesti rauhanomaisin keinoin" paljastaa, että kapitalismista puhuessaan he ajattelevat demokraattis-kapitalistisia yhteiskuntia, jotka yhdistävät toisiinsa liberaalis-demokraattisen poliittisen järjestyksen ja kapitalistisen talouden. Kapitalismin autoritaariset ja totalitaariset versiot he sulkevat tarkastelunsa ulkopuolelle.

Kapitalismin luonteeseen kuuluvaa pääoman kasaamispakkoa Boltanski ja Chiapello pitävät sinänsä absurdina ja amoraalisena asiana, jonka hyväksi ihmiset eivät ole luonnostaan valmiita työskentelemään. Sitä yhteiskunnallista järjestelyä, jonka avulla kapitalismi saa ihmiset hyväksymään tämän järjestelmän ja työskentelemään sen eteen, he kutsuvat kapitalismin hengeksi tai eetokseksi. Siinä on kyse siitä, miten kapitalismi esittää itsensä ihmisille ja legitimoi itsensä näiden silmissä. Historiallisesti Boltanski ja Chiapello erottavat toisistaan kolme erilaista kapitalismin henkeä. 
(I) Aina I700-luvulta I900-luvun alkuun asti kapitalismia ja sen henkeä edusti herooinen porvarillinen yrittäjä, joka oli valmis riskeihin ja kokeiluihin ja jonka toiminnan esitettiin koituvan koko kansakunnan ja yhteiskunnan hyväksi. Kolonialismia harjoittaneissa maissa tällainen yrittäjä oli usein myös seikkailija ja valloittaja. (2) Ensimmäisen maailmansodan jälkeen, klassisen yksityisyrittäjyyden aikakauden päätyttyä, kapitalismia ei ollut enää järkevää esittää tällä tavalla. I930-luvulta lähtien sitä edusti siksi suuri rationaalisesti organisoitu teollisuuslaitos, jota johtivat teknisen koulutuksen saaneet insinöörit sekä talouden, hallinnon ja yhdyskuntasuunnittelun asiantuntijat. Kun tähän malliin yhdistettiin hyvinvointivaltion rakentaminen ja tuloerojen tasaaminen, sen taakse oli helppo saada väestön enemmistö. I960-luvulta lähtien sen legitimaatio alkoi silti horjua, sillä nuoret ikäpolvet kokivat rationaalis-byrokraattiset tehdasympäristöt ahdistaviksi ja yksilöllisyyttään tukahduttaviksi eivätkä he enää viihtyneet haisevissa tehdasrakennuksissa ja mekaanisten liukuhihnojen ääressä. (3) I980-luvulla ilmaantui kapitalismin kolmas henki, jota voidaan pitää ratkaisuyrityksenä näihin ongelmiin ja joka tiivistyy managerien ja projektityöntekijöiden hahmoissa. Avainsanoja siinä ovat olleet "autonomia", "luovuus" ja "joustavuus". Murtautuessaan esiin tämä uusliberalistisen kapitalismin henki lupasi yrityksille ja työntekijöille vapautumista byrokraattisista rakenteista ja valtion harjoittamasta sääntelystä, joiden vastapainoksi se painotti mahdollisuutta tehdä itsenäistä, luovaa ja mielenkiintoista työtä. Sitä vastoin solidaarisuuden ja oikeudenmukaisuuden ihanteiden toteuttamisesta tämä itsensä vapaasta toteuttamisesta puhuva henki ei ole ollut kiinnostunut. (Boltanski \& Chiapello I999, 54-58. Ks. myös Ratiu 20I8; Sevänen 20I4a, 6-8.)

Edellä sanotun perusteella kapitalismi olisi siis vasta vaiheessa (3), ı980-luvulta lähtien, kaapannut itselleen autenttisuuspuheen ja käyttänyt sitä omiin ideologisiin ja kaupallisiin tarkoituksiinsa. Tässä kohdassa on kuitenkin syytä huomata se, että "Kapitalismin uusi henki” on osittain tarkoitettu jatkoksi Weberin "Protestanttiselle etiikalle ja kapitalismin hengelle", joka kuvaa modernin kapitalismin hengen tai eetoksen syntyä ja sen yleistymistä uuden ajan alussa. Weberin (I980, 36-56) mukaanhan modernin kapitalismin hengessä oli alun perin kyse järjestelmällisen ammattimaisesta pyrkimyksestä rahan ansaitsemiseen 
muodollisesti laillisin keinoin. Koska tätä henkeä toteuttaneet protestantit katsoivat näin toimiessaan toteuttavansa "omaa kutsumustaan", Jumalan heille asettamaa tehtävää maailmassa, modernin kapitalismin alkuperäinen henki sisälsi epäsuorasti autenttisuuden kategorian. Se yhdisti toisiinsa kristillisen ihmiskäsityksen, taloudellisen voitontavoittelun ja autenttisuuden ihanteen.

Niin kuin kolmannessa pääluvussa kävi ilmi, Yhtiökumppaneiden keskeinen interdiskursiivinen pohjateksti on edellä mainittu Weberin tutkimus. Sitä ja Yhtiökumppaneita yhdistää ajatus, että hillitön tai ammattimainen pyrkimys rahan ansaitsemiseen on luonteenomaista kapitalismin hengelle tai eetokselle. Tässä eetoksessa Yhtiökumppanit erottaa kaksi eri kehitysvaihetta: uskonnollisesti motivoidun pyrkimyksen rahan ansaitsemiseen ja maallisesti tai liiketaloudellisesti motivoidun pyrkimyksen siihen. Edellistä edustavat romaanissa Peten esivanhemmat, kun taas Pete itse toimii lähinnä abstraktin rahanhimon ohjaamana ilman uskonnollista motivaatiopohjaa.

Mr. Smithissä kuvatut kolme sukupolvea liittyvät melko suoraan Boltanskin ja Chiapellon mainitsemiin kapitalismin hengen eri vaiheisiin. Smithin isoisä herra Schmidt, hovioikeudenneuvos Paavo Manninen ja taiteilija Erik Torro vaikuttivat aktiivisesti vaiheen (I) lopussa, Smithin oma isä sekä maakuntalehden päätoimittaja Orvo Manninen sijoittuvat ensi sijassa vaiheeseen (2), kun taas Smith, teatteritaiteen maisteri Erno Manninen, kirjailija Erkka Torro, Rane ja Briscilla sekä Donald Southbrook elävät ja toimivat vaiheessa (3), romaanin nykyisyydessä. Kapitalismin historiallisen kehityksen näkökulmasta vaihe (I) ajoittuu klassiseen vapaan kilpailun kauteen (I800-I930), vaihe (2) "organisoidun", "säännellyn" tai "hyvinvointivaltiollisen" kapitalismin kauteen (I930-I980/I990) ja vaihe (3) nykyisen, uusliberalistisen kapitalismin kauteen (1980/ı990-). Romaanissa Mr. Smith vaiheen (2) hahmottaminen jää niukkojen kuvausten varaan, ja lähinnä tästä vaiheesta puhutaan Smithin isän ja Orvo Mannisen yhteydessä. Pääpaino romaanissa on vaiheissa (I) ja (3). Niitä käsitellessään romaani kuljettaa mukanaan autenttisuuden teemaa. Tämän romaani tekee hieman eri tavalla kuin "Kapitalismin uusi henki", joka tarkastelee autenttisuuden teemaa lähinnä siitä käsin, miten se on tullut esiin kapitalismikritiikissä. 
Vaiheessa (I) autenttisuuden teema tuli kapitalismikritiikissä esiin ennen kaikkea boheemitaiteilijan hahmossa, jonka tyypillisenä edustajana Boltanski ja Chiapello pitävät Charles Baudelairea. Boheemitaiteilijat pyrkivät elämään kapitalistisen tuotannon ja markkinalogiikan ulkopuolella. He kokivat ne epäautenttiseksi järjestelmäksi, jossa heidän ei ollut mahdollista toteuttaa itseään. Niiden sijasta he valitsivat aineellisesti niukan elämäntavan, joka tarjosi heille laajemman henkisen liikkumatilan ja ilmaisuvapauden. Vaiheessa (2) autenttisuuden teema liittyi massayhteiskunnan ja byrokraattisten rakenteiden kritiikkiin. Tällaista kritiikkiä esittivät yhtäältä eksistentialistit, esimerkiksi Heidegger ja Sartre, jotka puhuivat siitä, että yksilö ei saa hukata eksistentiaalista vapauttaan banaalin arkielämän ja sosiaalisen yhdenmukaisuuden vaatimuksiin. Konkreettisemmin autenttisuudesta puhuivat tuolloin Frankfurtin koulun edustajat Adorno, Horkheimer ja Marcuse. He pitivät pitkälle kehittyneen teollis-kapitalistisen yhteiskunnan ongelmana sitä, että sille ominainen massiivinen tuotanto ja kulutus sekä elämäntapojen standardisoituminen ja tavaroituminen uhkaavat lakkauttaa maailmasta aidon yksilöllisyyden. (Boltanski \& Chiapello I999, 84, 53I-532.)

Länsimaisessa intellektuaalisessa kulttuurissa esiintyi ı960-luvun jälkipuolella ja I970-luvulla myös pyrkimyksiä hylätä autenttisuuden käsite. Tällaisen pyrkimyksen edustajiksi Boltanski ja Chiapello (I999, 549552) mainitsevat Pierre Bourdieun, Jacques Derridan, Gilles Deleuzin ja Roland Barthes'n, jotka suhtautuivat epäillen tai torjuvasti erotteluihin autenttinen/epäautenttinen ja aito/epäaito. Osittain juuri jälkistrukturalismin ja Wittgensteinin myöhäisfilosofian vaikutuksesta länsimaiseen akateemiseen kulttuuriin alkoikin tuolloin levitä essentialismin, olemusajattelun kritiikki, jonka erääksi kohteeksi autenttisuuspuhekin usein joutui. Boltanski ja Chiapello (ibid., 89-90) jatkavat, että uusliberalistinen politiikka ei ole mennyt mukaan tällaiseen puheeseen. Se on pikemminkin käyttänyt hyväksi autenttisuus- ja vieraantuneisuuspuhetta, kun se on esittänyt, että juuri markkinoiden pohjalta toimivassa yhteiskunnassa ja vapaina valtion harjoittamasta ohjauksesta yksilöt ja yritykset pystyvät parhaiten ottamaan käyttöönsä omat potentiaalinsa ja toteuttamaan siten itseään. Samoin uusliberalistinen talous on kiinnittänyt suurta huomiota kulutuksen alueeseen. Siinä se on halunnut saada 
kuluttajat kokemaan, että juuri tällä alueella, erilaisten kulutusvalintojen kautta, he voivat toteuttaa omia yksilöllisiä tarpeitaan ja toiveitaan. Näin uusliberalismi on tuotteistanut ja tavaroittanut autenttisuuspuhetta ja kapitalismikritiikkiä ja valjastanut niitä omaan käyttöönsä.

Tämä ei silti ole koko totuus uusliberalismin ja autenttisuuspuheen välisestä suhteesta. "Kapitalismin uusi henki" sisältää myös kuvauksen siitä, missä mielessä nykykapitalismi on torjunut entisenlaisen autenttisuuspuheen. Tuo kuvaus painottaa sitä, että kapitalismin muodonmuutos on tehnyt epätarkoituksenmukaiseksi sellaisen autenttisuuspuheen, joka korostaa tarvetta suojata yksilöitä "massayhteiskunnalta". Tällainen autenttisuuspuhe tuntuu helposti vanhentuneelta siksi, että nykyyhteiskunnassa menestymisen ehtona on se, miten hyvin yksilöt pystyvät verkostoitumaan ja käyttämään noita verkostoja hyväkseen. Samalla nyky-yhteiskunnalle ominainen dynaamisuus ja joustavuus on tehnyt myös "luottamuksesta", "sitoutumisesta" ja vilpittömyydestä" tavoiteltavissa olevia hyveitä, joita on vaikea saavuttaa nykyisessä elämänmuodossa, mutta joita ilman pitkäkestoiset ihmissuhteet ja asiakassuhteet eivät ole mahdollisia. Tässä jälkimmäisessä mielessä autenttisuus on yhä tärkeä ihanne yhteiskunnassa. (Boltanski \& Chiapellon I999, 552-555.)

Muutaman vuosikymmenen epäilyn jälkeen autenttisuuden ihanne on palannut takaisin kirjallisuuteenkin. Siinä, missä postmodernistinen kirjallisuus ja jälkistrukturalistinen älymystökulttuuri suhtautuivat usein ironisesti autenttisuuspyrkimyksiin, nykykirjallisuus on suhtautunut niihin huomattavasti vakavammin. Kirjassaan Literature after Postmodernism Irmtraud Huber (20I4, 26-28, 33-34, 42-43) esittää, että nykykirjallisuus käsittelee usein subjektien itsetoteutuspyrkimyksiä ja näiden pyrkimysten yhteiskunnallisia ja kulttuurisia esteitä ja edellytyksiä. Näin tehdessään se ei kyselemättä jaa uusliberalismin ylläpitämää käsitystä autenttisuudesta, vaan pikemminkin nykykirjallisuus tarkastelee tuota käsitystä kriittisesti ja kiinnittää huomiota sen heikkouksiin.

Autenttisuuden ihanteen kannattajien mukaan suotuisissa olosuhteissa ihminen pystyy toteuttamaan itseään. Tätä mahdollisuutta voidaan pitää sosiokulttuurisen evoluution myönteisenä saavutuksena ihmislajin kannalta. Se ei kuitenkaan tarkoita sitä, että itseään toteuttavat ihmiset pääsisivät muissakin suhteissa laajalti osallisiksi jonkinlaisesta ylihisto- 
riallisesta tai ylikulttuurisesta "ihmisolemuksesta". Pikemminkin ihmiset ovat aina paljolti historiallisesti, kulttuurisesti ja yhteiskunnallisesti muuttuvien olosuhteiden tuotteita. Autenttisuudesta puhuttaessa ei liioin välttämättä ajatella, että itseään toteuttavan subjektin identiteetti pysyisi vakaana ja muuttumattomana. Taylor (I995, I09-IIO) toteaa, että autenttisuuden ihanne painottaa vain subjektien itsemääräämisoikeutta, sitä, että yksilöiden ja yhteisöjen tulee saada valita sellainen elämänmuoto, jota ne pitävät itselleen sopivana ja jossa ne katsovat voivansa toteuttaa itseään.

Taylorin lailla kriittinen teoria nojaa autenttisuuden ihanteeseen. Rainer Winterin ja Peter V. Ziman toimittamaan kirjaan Kritische Theorie heute (2007) kirjoittamassaan artikkelissa Hans-Herbert Kögler (2007, 79) huomauttaa, että kriittinen teoria tarkastelee subjekteja aina suhteessa näiden yhteiskunnalliseen ja kulttuuriseen tilanteeseen ja arvioi samalla sitä, millaisia mahdollisuuksia itsetoteutukseen subjekteilla kulloinkin on. Tällaiseen tarkasteluun kuuluu sen selvittäminen, miten erilaiset historialliset edellytykset muokkaavat subjektien ajattelua ja kokemusmaailmaa. Kriittisen teorian näkökulmasta uusliberalistisessa autenttisuuspuheessa ongelmana on se, että uusliberalistisen järjestyksen myötä kapitalismin lait ja toimintatavat määräävät yhä enemmän subjektien elämää ja rajoittavat heidän mahdollisuuksiaan tehdä elämässään aitoja valintoja. (Ks. myös Schweppenhäuser 2007, I65.)

I980-luvulle ja osittain myös I990-luvulle ajoittuneen hiljaiselon jälkeen autenttisuuden, epäautenttisuuden ja vieraantuneisuuden käsitteet ovat siis palanneet filosofiaan ja ihmistieteisiin, joissa näitä käsitteitä käytetään nyt hieman eri tavalla kuin I960- ja I970-luvulla. Keskeinen eroavaisuus on siinä, että nykytutkimus ei kiinnity "yleisen ihmisluonnon" tai "ihmisen lajiolemuksen" käsitteisiin, vaan sen lähtökohta on yksilökeskeisempi. Tietyin, hetken kuluttua esitettävin varauksin voidaan sanoa, että nykytutkimuksen mukaan yksilöt elävät autenttisessa tai vieraantumattomassa tilassa, mikäli he kokevat, että he voivat toteuttaa itseään ja heissä itsessään olevia mahdollisuuksia. Siten nykyinen autenttisuuden käsite on pitkälle subjektivoitu, kiinnitetty subjektin omaan kokemistapaan. Tekevätkö nämä muutokset autenttisuuden ja vieraantuneisuuden käsitteistä ongelmattomia tai ideologisesti neutraaleja? 
Eivät tee. Vaikka autenttisuuden käsite on palannut nykytutkimukseen subjektivoidussa muodossa, tutkimuksen ei tulisi ottaa sosiaalisten toimijoiden itsemäärityksiä annettuina, kyseenalaistamatta niitä mitenkään. Kuten aiemmin todettiin, kaikki itsetoteutuksen muodot eivät välttämättä ole juridisesti, moraalisesti, sosiaalisesti tai ekologisesti hyväksyttäviä, sillä osa niistä saattaa vahingoittaa muita yksilöitä, yhteisöjä ja luontoa. Toiseksi on huomattava se, että sosiaalisten toimijoiden tavat mieltää ja määrittää oma tilanteensa eivät aina perustu riittävään tai oikeanlaiseen tietopohjaan. Kun toimijat katsovat jonkin tietyn sosiaalisen järjestelyn tai toimintamuodon mahdollistavan autenttisen itsetoteutuksen, he voivat myös erehtyä, jos he eivät esimerkiksi ole tietoisia tuon järjestelyn tai toimintamuodon haittavaikutuksista pitkällä aikavälillä. Tässä mielessä toimijat saattavat omaa tilannettaan arvioidessaan olla väärän tietoisuuden vallassa.

Kolmanneksi on vielä syytä todeta, että autenttisuuden ja vieraantuneisuuden käsitteitä on vaikea käyttää ilman arvositoumuksia. Edellinen käsitehän viittaa ihannetilaan ja jälkimmäinen käsite ei-toivottuun asiantilaan. Samalla tavalla suuri osa yhteiskuntatieteiden ja humanististen oppiaineiden käyttämistä käsitteistä on kuitenkin arvofilosofisesti tai ideologisesti latautuneita. Tämä koskee esimerkiksi sellaisia käsitteitä kuin "kapitalismi", "vapaa markkinatalous", "kansakunta", "kansallinen", "tasa-arvo" ja "oikeudenmukaisuus", joita käyttävät myös yhteiskunnalliset liikkeet ja niiden ideologit. Mikäli tällaiset käsitteet integroidaan tutkimuksen käsitekieleen, tutkijoiden on reflektoitava niitä ja niiden erilaisia käyttöyhteyksiä sekä määriteltävä ne riittävän täsmällisesti ja oltava valmiita käymään niistä avointa keskustelua tiedeyhteisössä. (Vrt. Zima I989, IO-I4, 43-45, 56, I85.) Näin käytettynä tieteellinen puhe voidaan erottaa ideologisesta diskurssista, vaikka ero tieteen ja ideologian välillä ei ole filosofiassa ja ihmistieteissä mitenkään yksiselitteisen selkeä.

Charles Lindholmin ja Charles Taylorin ohella autenttisuuden ja vieraantumisen käsitteitä ja niiden lähikäsitteitä ovat viime vuosikymmeninä tutkimuksen käyttöön kehitelleet Ulrich Beck (I986; I99I; I995), Anthony Giddens (2000; 200I) sekä Jerome Braun ja Lauren Langman. Jälkimmäisen kaksikon toimittama Alienation and the Carnivalization of Society (20I2) pitää nyky-yhteiskuntaa analysoidessaan lähtökohtanaan 
Marxin ja Weberin teorioita. Oman tutkimusperinteensä muodostaa Edward L. Decin ja Richard M. Ryanin I980-luvulta lähtien yhdessä kehittämä itsemääräämisteoria (self-determination theory), joka kuuluu motivaatio- ja sosiaalipsykologian alaan. Decin ja Ryanin teorian mukaan ihmisen tunteman elämäntyytyväisyyden ja elämänmielekkyyden perustana on se, että ihminen kokee toimivansa omaehtoisesti ja olevansa vapaa päättämään asioistaan. Ihmisten halujen, pyrkimysten ja toiveiden muodostumista määräävät tai ohjaavat tietenkin pohjimmiltaan monet ihmisen ulkopuoliset biologiset ja kulttuuris-yhteiskunnalliset tekijät, mutta se ei välttämättä heikennä ihmisen kokemaa elämäntyytyväisyyttä - olennaista tässä tyytyväisyydessä on nimittäin se, että ihminen kokee elävänsä sellaista elämää kuin hän itse haluaa. Decin ja Ryanin teoriassa autenttinen itsetoteutus on siten edellytys sille, että subjekti tuntee elämänsä mielekkääksi (ks. Ryan \& Deci 20I7, 382-400, 59I-6I5).

Autenttisuuden käsitteestä käydään siis nykytutkimuksessa keskustelua, jossa osa tutkijoista kehittelee tuota käsitettä ja osa suhtautuu siihen skeptisesti. Autenttisuuden ihanteesta käydään puolestaan nykykulttuurissa kamppailua, jossa erilaiset ryhmittymät esittävät käsityksiään siitä, millainen autenttisen itsetoteutuksen mahdollistama yhteiskunta on. Mr. Smith käsittelee autenttisuuden teemaa suhteessa kapitalistiseen talouteen ja siinä toimiviin ihmisiin. Se voidaan pitkälle käsittää uusliberalistisen autenttisuusdiskurssin kritiikiksi, sillä se epäilee, voiko välinerationaalisuuteen perustuva kapitalistinen talous tuottaa aidossa mielessä autenttisia elämän ja toiminnan muotoja. Toisaalta se ei torju sinänsä autenttisuuden ihannetta. Pohdiskeluissaan Mr. Smith päätyy näkemykseen, jonka mukaan ihmisten välisissä suhteissa autenttisuus on syvemmin mahdollista vain välinerationaalisen käyttäytymisen ulkopuolella.

\section{Epäautenttinen elämä ja olemassaolo}

Mr. Smithin lähtökohtana on arvoitus, joka liittyy kiinteästi identiteetin ja autenttisuuden teemaan. Jo heti romaanin alussa Smith toteaa, että 
[m]inulla on yhä yksi ratkaisematon kysymys, joka on niin suuri, että se tuntuu olevan elämäni kantava voima, keskusplaneetta jonka ympärillä kaikki pyörii. Se on kasvanut arvoitukseksi minusta itsestäni ja se tiivistyy yhteen koneella kirjoitettuun, kellastuneeseen arkkiin. (MRS, 23.)

Tuo ratkaisematon kysymys koskee sitä, millainen ihminen hänen isoisänsä oli. Pohjimmiltaan tämä arvoitus liittyy samalla siihen, millainen ihminen Smith itse on. Hän näet uskoo, että saadessaan vastauksen edelliseen kysymykseen hän pystyy myös pääsemään paremmin selville omasta itsestään. Sitaatissa esiintyvä maininta "koneella kirjoitetusta, kellastuneesta arkista" viittaa Smithin hallussa olevaan, isoisälle lähetettyyn kirjeeseen, jossa WSOY:n silloinen johtaja Jalmari Jäntti ilmoittaa isoisälle, että yhtiö ei voi julkaista hänen omaelämäkerrallista romaaniaan "Mustaa ja punaista". Tuo sivuilla 24-25 oleva kirje on päivätty "Helsingissä 20. toukokuuta I938", noin vuosi ennen isoisän kuolemaa. Mr. Smithin maailmassa kyseinen kirje on totta, kun taas reaalimaailman näkökulmasta sitä voidaan pitää kuvitteellisena aineksena, jonka Seppälä on sepittänyt romaaninsa tarpeita varten.

Isoisästään Smith tietää varmuudella vain sen, että hän oli Pietarissa vuonna I893 syntynyt saksalaissukuisen pienkauppiaan poika, joka suoritti tutkinnon Viipurin kauppaopistossa ja toimi sittemmin liikemiehenä ja vakuutusasiamiehenä Pietarissa ja Viipurissa. Tuolloin hän avioitui Irene-nimisen naisen kanssa, joka on Smithin isoäiti. Viipurissa isoisällä oli kuitenkin ilmeisesti myös kirjailija Erkka Torron isoäidin kanssa lyhytaikainen suhde, josta syntyi poika, kirjailija Erkka Torron isä. Smithillä ja Erkka Torrolla olisi siten yhteinen isoisä. Pian suhteen jälkeen isoisä otti vaimostaan eron, jätti "häpeällisesti" tämän ja poikansa vaille elatusta ja muutti Turkuun, missä hän kuoli vuonna I939. ${ }^{\text {I28 }}$ Näiden tietojen, sukunsa piirissä liikkuneiden tarinoiden, päättelykykynsä ja mielikuvituksensa avulla Smith rakentaa isoisälleen elämäkerran, jonka tarkoituksena on toimia samalla vastauksena hänen omaan identiteettiinsä liittyvään problematiikkaan. Sen avulla Smithin on tarkoitus määritellä itsensä, muodostaa itselleen aiempaa totuudenmukaisempi minäkuva tai identiteetti. 
Mr. Smithin alkuasetelma on tavallinen nykykirjallisuudessa, jossa henkilöiden identiteetti rakentuu usein sitä kautta, että muistelun välityksellä he arvioivat erilaisten asioiden merkitystä itselleen ja suhteuttavat samalla itsensä merkityksellisinä pitämiinsä toisiin ihmisiin, erityisesti perheeseensä ja sukuunsa (Taylor I996, 33-34, 48-5I). Näin myös Smith menettelee, jos kohta varsinaisen muistelun sijasta hän tukeutuu perheensä ja sukunsa piirissä liikkuneeseen, isoisää koskeneeseen niukkaan kertomusperinteeseen. I900-luvun alusta lähtien länsimaisessa kirjallisuudessa tavallisia ovat myös olleet kuvaukset subjektien identiteettien hauraudesta ja heidän identiteettiprojektiensa kariutumisesta. Näin Mr. Smithissäkin lopulta tapahtuu. Kun isoisän omaelämäkerrallinen käsikirjoitus "Mustaa ja punaista" löytyy Mr. Smithin lopussa ja Smithille tarjoutuu tilaisuus tutustua siihen, lyhyen empimisen jälkeen hän torjuu lukumahdollisuuden ja jättää minäkuvansa epämääräiseen tilaan. Näissä suhteissa romaani on kuvaus identiteettiprojektin raukeamisesta. Sen alussa asetettu arvoitus ei ratkea.

Mr. Smithissä ei ainoastaan keskushenkilö epäonnistu pyrkimyksissään. Epäonnistumisen tai keskenjäämisen motiivi toistuu siinä niin usein, että sitä voi pitää teoksen keskeisenä teemana. Smithillä on ollut menestystä konsulttineuvontaan ja riskienhallintaan erikoistuneen liikeyrityksen omistajana ja johtajana sekä sijoitustoiminnan harjoittajana, mutta identiteettityössä, eksistentiaalisella alueella, hänen pyrkimyksensä jäävät puolitiehen. Smithin isoisän vastoinkäymiset olivat toisenlaisia. Isoisän liiketoimet eivät aikoinaan sujuneet toivotulla tavalla, ja siksi hän menetti pankkinsa silmissä luottokelpoisuutensa. Kyetäkseen jatkamaan hankkeitaan hän lainasi hovioikeudenneuvos Paavo Manniselta rahaa ja antoi tälle romaanikäsikirjoituksensa saamansa lainan pantiksi. Kummallakaan alueella, liiketoimissa ja kirjallisuudessa, hänen hankkeensa eivät tuottaneet toivottua tulosta, minkä lisäksi hän pettyi avioliittoonsa ja erosi vaimostaan. Briscillan ja Ranen välille syttyvä rakkaus on romaanin ainoita myönteisiä tapahtumia, mutta heidänkin onnensa jää lyhyeksi, kun Rane kuolee asbestoosiin, jonka hän on saanut siistiessään I990-luvun alussa erään roskapankin omistamia kiinteistöjä (MRS, 200-20I). Hyvin ei ole käynyt Donald Southbrookillekaan, sillä amerikkalaisen finanssipääoman harjoittaman asuntoluottokeinottelun 
vuoksi hän on menettänyt romaanissa kotinsa ja perheensä ja jäänyt elämään yksin aineellisesti niukkaa elämää.

Mr. Smithiä koskevissa arvosteluissa romaania pidettiin usein ku-

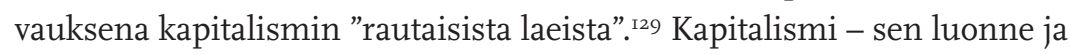
toimintatavat sekä sen vaikutus ihmisten elämään - onkin romaanissa etualalla, mutta sen vanavedessä romaani kehittelee tavoitteiden epäonnistumisen, keskenjäämisen ja raukeamisen teemaa. Arvosteluissa tähän ulottuvuuteen kiinnitti huomiota Hannu Waarala (20I2) Savon Sanomissa. Waarala toteaa, että kyseinen ulottuvuus luo yhtymäkohdan Mr. Smithin ja Sartren välille. Sartren myöhäisfilosofiassa ihmistä ei määritä pelkästään hänen eksistentiaalinen vapautensa vaan myös se, että ihmiset joutuvat toteuttamaan projektejaan maailmassa, jossa vallitsee niukkuus ja kilpailu erilaisten projektien toteuttamisen välineistä. Osaltaan siksi puute, keskeneräisyys ja projektien raukeaminen sekä ylipäänsäkin epäautenttisuus luonnehtivat lopulta ihmisten elämää. (Sartre I960, 220-224, 26I-276.) Mr. Smith sisältää epäilemättä tämän suuntaisen ajatusmotiivin, mutta romaani sitoo sen Sartrea kiinteämmin kapitalismin ja yhteiskunnallisen determinismin problematiikkaan.

Kaikki ei Mr. Smithin maailmassa silti tapahdu "kapitalismin rautaisten tai raudanlujien lakien" vaikutuksesta. Romaanissa kapitalismi asettaa yleiset puitteet tai kehykset ihmisten elämälle ja toiminnalle, mutta nämä puitteet eivät tyhjentävästi määrää heitä, vaan heillä on tietty itsenäisyytensä niihin nähden. Näihin puitteisiin kuuluu erityisesti se, että kapitalistinen talous perustuu liikevoitto-motiiviin ja välineelliseen rationaalisuuteen ja se on suhteellisen indifferentti muiden arvopäämäärien suhteen. Samoin siinä toistuvat tietyin väliajoin kriisit ja romahdukset, joiden kustannukset se yleensä maksattaa verovaroilla ja tavallisten ihmisten uurastuksella. Tällaiset puitteet määräävät romaanissa ennen kaikkea alempiin luokkiin kuuluvien ihmisten elämää, sitä, mitä romaanissa tapahtuu Briscillalle, Ranelle ja Donald Southbrookille. Näillä kolmella ei ole juurikaan ollut mahdollisuuksia välttää kapitalismiin liittyviä "mykkiä pakkoja" ja suhdannevaihtelujen tuottamia katastrofeja, mutta silti sattumalla on osuutensa heidänkin elämässään. Esimerkiksi Briscillan ja Ranen alhainen luokka-asema on pitkälle määrännyt heidän myöhemmän elämänkulkunsa ja elinpiirinsä, mutta se, että juuri he 
kaksi sattuvat tapaamaan ja vielä rakastumaan toisiinsa, ei ole samalla tavalla kapitalismin lakien ja toimintatapojen ehdottomasti määräämää. Oma osuutensa siinä on myös ollut sattumilla.

Romaanin maailmassa yläluokkaiset henkilöt pystyvät paremmin välttelemään kapitalismiin liittyviä pakkoja ja katastrofeja. Esimerkiksi Smith puhuu siitä, että mahdollisten kriisien ja romahdusten sattuessa hän on itse turvassa niiden haittavaikutuksilta. Samoin hän esittää, että juuri luokka-asema ja siihen liittyvä varallisuus tuovat hänelle laajemman vapauden elämässä:

Ainoa vapauden mahdollisuus sisältyy pääomaan, rahaan, aivan kuten Jean Baudrillard sanoo: Vapautta on vain pääomassa, pääoma tuottaa ja laajentaa vapautta. Siksi rikkaita inhotaan, ei heidän rahojaan, vaan heidän riippumattomuuttaan, mahdollisuutta kääntää kylkeä, välttää pakko.

Raha on sitä, että sinun ei ole pakko. (MRS, 38.)

Siinä, missä köyhät elävät paljolti "välttämättömyyden valtakunnassa", vailla laajoja valinnanmahdollisuuksia, yläluokkaiset ihmiset pystyvät tekemään enemmän valintoja elämässään. Heillä on myös paremmat edellytykset itsetoteutukseen, autenttiseen toimintaan, mutta Mr. Smithin päähenkilö jättää osittain käyttämättä tämän laajemman mahdollisuuden.

Aloittaessaan isoisänsä elämäkerran laatimisen Smith tuo useissa eri yhteyksissä esiin näkemyksensä siitä, että hän on isoisänsä kaltainen. Isäänsä kohtaan hän ei tunne voimakasta hengenheimolaisuutta, mutta isoisäänsä hän näyttää samaistuvan miltei ehdoitta: "Tiedän olevani isoisäni kaltainen, hänet oli pantu kokoon saksalaisen säntillisyyden ja kannakselaisen levottomuuden ristiriidasta." (MRS, 94. Ks. myös s. 38 4I.) Se, mitä romaani paljastaa Smithin elämästä ja luonteesta, näyttää kuitenkin olevan ristiriidassa tämän näkemyksen kanssa. Itsestään kertoessaan Smith paljastaa pikemminkin olevansa varovainen ihminen, joka elelee mieluiten yksikseen ja karttaa kontakteja muihin ihmisiin, erityisesti naisiin. Romaanin alussa hän luonnehti itseään näin: 
Asun yksin. Se on ainut vaihtoehto. Kaltaistani ihmistä ei yksikään nainen voisi sietää kovin pitkään. Enää minulla ei ole tarvetta jakaa vuodettani kenenkään kanssa, ei leikkiä kotia, ei hankkia parvekkeelle infrapunalämmitintä jonka loimussa käpertyä nautiskelemaan iltateetä sateen ropinaa kuunnellen. En kaivannut parvekkeen pöydälle krysanteemeja, tädykkeitä tai koristekaaleja. Orastavia eturauhasvaivoja, tihentynyttä virtsaamistarvetta, nainen ei ollut ensimmäisenä mielessäni. Kaksi avioliittoa, muutama avosuhde, epälukuinen määrä hoitoja - ei siis kovin epätavallinen ikäiseni miehen naishistoria. Ei jälkeläisiä, mistä saatoin olla vilpittömästi tyytyväinen. Yksi naisista oli halunnut lasta kanssani. Olin ehdottanut koiraa, mutta se ei käynyt, koska se olisi ollut liian ilmeinen lapsen korvike. Ellei kaikkea toimintaani leimannutkaan kohtuuton vastuullisuus, saatoin katsoa jossakin sentään onnistuneeni. (MRS, I6-I7.)

Sitaatin perusteella Smithiä voi pitää sovinnaisena ihmisenä, joka välttelee viimeiseen asti tunneperäistä sitoutumista toisiin ihmisiin sekä tällaiseen sitoutumiseen liittyviä riskejä. Hän vaikuttaa henkilöltä, jonka habitukseen hänen ammattinsa - konsulttineuvonta, riskienhallinta, sijoitustoiminta - on lähtemättömästi painanut leimansa. Hänen kauttaan Mr. Smith kuvaa nykytalouden toimintamuotojen typistämää tai yksipuolistamaa ihmistyyppiä.

Smithin laatimassa elämäkerrassa hänen isoisänsä harjoittaa Pietarin ja Viipurin seuduilla liiketoimiaan ja kokeilee menestymistään erilaisilla aloilla. Isoisä toimi kapitalismin hengen kehitysvaiheessa (I), klassisen markkinakapitalismin kaudella, jolloin kapitalismia edusti ennen kaikkea herooinen porvarillinen yksityisyrittäjä. Tämä ihmistyyppi tai taloudellisen toimijan tyyppi oli seikkailunhaluinen ja valmis riskeihin ja kokeiluihin. Vaikka hänen toimintansa saattoi perustua puhtaasti taloudelliseen egoismiin, liberalistinen ideologia esitti sen vastaavan yhteiskunnallisen edistyksen vaatimuksia. Smithin laatimassa isoisän elämäkerrassa korostuu se, että liiketoimiaan harjoittaessaan hänen isoisänsä toteutti samalla itseään ja loi oman identiteettinsä tai autenttisen minuutensa: 
Uskoin ihmisten ja pääoman vapaaseen liikkumiseen, kapitalismin ruumiillistuneeseen kaaokseen. Kuljin mustaa ja punaista tietä, halusin luoda oman yksilöllisen identiteettini ja loin sen, kutsuttakoon sitä sitten egotismiksi tai miksi hyvänsä. (MRS, 70.)

Merkille pantavaa tässä Smithin kirjoittamassa katkelmassa on se, että sen mukaan hänen isoisänsä kytki yhteen vapaan markkinatalouden ideologian ja autenttisuuden ihanteen. Esittäähän isoisä siinä käsityksen, että juuri vapaan markkinatalouden oloissa hän kykeni toteuttamaan itseään. Katkelmassa esiintyvä ilmaisu "mustaa ja punaista" viittaa Stendhalin romaaniin Punainen ja musta. "Egotismi" on puolestaan käsite, jolla Stendhal luonnehti suhtautumistapaansa maailmaan.

Stendhalin romaani kuvaa restauraation, kuningasvallan palauttamisen jälkeistä aikaa (I8I4-I830) Ranskan historiassa. Tuo aika näyttäytyy romaanissa pysähtyneisyyden tilana, jolloin vanhoilliset voimat ottivat taas valtaansa yhteiskunnan avainpositiot. Romaanin nimen on tulkittu viittaavaan siihen, että tuolloin köyhistä oloista, esimerkiksi alemmasta porvarisluokasta lähtenyt nuorukainen saattoi menestyä yhteiskunnassa vain pääsemällä sotilasammattiin (punainen) tai papinammattiin (musta). Tällainen henkilö Stendhalin romaanin päähenkilö, pappiskoulutukseen romaanin alussa päässyt Julien Sorel epäilemättä on, sillä romaanissa hänen isänsä kerrotaan olevan puutavarakauppaa harjoittava "äveriäs" sahamyllyn omistaja (Stendhal I969, 7, I6-I9). Toisaalta Stendhalin romaanin nimessä "punaisen" on myös tulkittu viittaavan kumoukseen ja "mustan" yhteiskuntaa säilyttäviin voimiin, ja kolmannessa tulkintamahdollisuudessa punainen edustaa intohimoa ja musta sille käänteistä mielentilaa eli rauhallisuutta ja tyyneyttä. (Dubois 2000, I90-206; Dubois 2007, 24, 27, 29-3I, 40-4I, 238-240, 246; Saariluoma 1989, I40.)

Eri tavoin toisiinsa kytkeytyneinä "musta" ja "punainen" esiintyvät Mr. Smithissä useissa eri kohdissa, tavallisesti juuri tässä järjestyksessä. Isoisän itsensä aikoinaan kirjoittaman romaanikäsikirjoituksen nimenä on "Mustaa ja punaista", ja samannimisen romaanin hänen toinen pojanpoikansa Erkka Torro on julkaissut Mr. Smithin nykyisyydessä. Samoin Smith aloittaa isoisästään kirjoittamansa elämäkerran otsikolla 
"Mustaa ja punaista". Lisäksi musta ja punainen liitetään romaanissa muun muassa "Karjalan väreihin" sekä tuskaan ja riemuun. (Ks. MRS, 24-25, 29, 70, I27, I29-I30, I34, 259-260.) Se, että nämä värit esiintyvät isoisän omassa käsikirjoituksessa ja Smithin kirjoittamassa elämäkerrassa toisessa järjestyksessä kuin Stendhalin romaanissa, tarjoaa mahdollisuuden makrohistorialliseen tulkintaan. Tällöin tuon käänteisen järjestyksen voi ymmärtää viittaukseksi porvariston historiallisessa roolissa tapahtuneeseen muutokseen. Stendhalin kuvaamassa tilanteessa porvaristo joutui vielä kamppailemaan poliittisista valta-asemista aristokraatteja ja rojalisteja vastaan, kun taas Smithin ja hänen isoisänsä aikana porvaristosta on tullut sekä taloudellisesti että poliittisesti yhteiskunnan johtava luokka. Seppälän romaanissa se ei ole enää samalla tavalla edistyksellinen voima kuin Stendhalin aikana. Pikemminkin se asettaa olosuhteiden säilyttämisen (musta) niiden radikaalin muuttamisen (punainen) edelle.

Liisa Saariluoma (1989, I32-I33, I36) toteaa, että "egotismi" ei Stendhalilla merkinnyt egoismia ja narsismia, joihin egotismi helposti sekoitetaan ja joihin sen äärimuodot johtavat. Egotismissa on kyse tietynlaisesta maailmansuhteesta. Siinä subjekti ei pyri tarkastelemaan maailmaa sellaisena kuin se hänestä riippumatta on, vaan subjekti suhteuttaa maailman itseensä ja arvioi sitä siltä kannalta, mitä se hänelle itselleen merkitsee. Tätä siis egotismi oli Stendhalilla, mutta Smithin huikentelevaisuuteen taipuvaisen isoisän kohdalla se muuttuu usein egoismiksi, itsekkääksi oman edun, hyödyn tai onnen tavoittelemiseksi. Egotismia ilmentää romaanissa muun muassa se, että sotien välillä isoisä harjoitti ihmissalakuljetusta bisneksenä ja syyllistyi vakuutuspetoksiin, joista hän ei jäänyt kiinni. Samoin hän osoittautuu romaanissa uskottomaksi aviopuolisoksi, joka jätettyään perheensä suisti sen taloudelliseen ahdinkoon. Stendhalin romaanin ja Smithin isoisän välinen eroavuus korostuu myös sitä kautta, että siinä, missä Julien Sorel joutuu yläluokkaisissa piireissä liikkuessaan tavallisesti kätkemään todellisen minänsä - erityisesti voimakkaan kaunan tunteensa etuoikeutettua yläluokkaa kohtaan -, Smithin isoisän toimintatapa on huomattavasti avoimempi ja se ilmaisee peittelemättömästi hänen omaa subjektiuttaan. 
Smithin ja hänen isoisänsä kautta $M r$. Smith käsittelee kapitalismin ja autenttisuuden ihanteen välistä suhdetta eri näkökulmista. Isoisän hahmon kautta romaani näyttää, että yhdistyessään kapitalismin toimintatapoihin autenttisuuden ihanne tuottaa helposti kyseenalaisia tuloksia. Liiketoimissaan ja siviilielämässään isoisä toteutti tai loi omaa identiteettiään, mutta hän teki sen usein moraalista, laista ja yhteisöllisistä siteistä piittaamatta. Hänen pyrkimyksensä autenttiseen itsetoteutukseen oli siksi luonteeltaan osittain tuhoava, destruktiivinen. Nykytalouden kontekstissa Smithin henkilöhahmon voi puolestaan ymmärtää kapitalismin toimintakäytäntöjen typistämäksi persoonallisuustyypiksi, joka tarrautuu omiin ammatillisiin ja elämäntavallisiin rutiineihinsa ja joka on menettänyt kykynsä laajempaan itsetoteutukseen. Näissä suhteissa häntä voi pitää sijoitusneuvoja Lari Laineen, Paholaisen haarukan keskushenkilön, sukulaishahmona.

Mr. Smithin lopussa Rane on palkattu purkamaan Orvo Mannisen saunamökkiä. Sen seinähirsien välistä hän löytää paperipinkan, joka osoittautuu myöhemmin Smithin isoisän kirjoittamaksi, kauan kadoksissa olleeksi käsikirjoitukseksi. Tässä tarinamaailman ulkopuolisen kertojan esittämässä jaksossa Rane ryhtyy lukemaan isoisän tekstiä:

Aivan nuoresta pitäen kävin kauppaa Pietarissa. Se oli kappale outoa maailmaa. Iso kappale, metropoli jonka pulssi sykki tiheästi ja jossa elettiin samalla tavalla kuin se oli rakennettukin, kiihkeästi, ihmisuhreista piittaamatta. Kaupunki maallisen ja kosmisen, Euroopan ja Aasian rajalla. Siellä saattoi tapahtua ihan mitä tahansa. Se oli silloin Euroopan neljänneksi suurin kaupunki ja uskomattoman lähellä. Kuljin siellä isäni mukana jo poikasena, opin tuntemaan paikkoja ja ihmisiä. (MRS, 248-249.)

Katkelmassa äänessä on siis oikeasti Smithin isoisä. Käsikirjoitus toimitetaan Smithille, jolla olisi nyt tilaisuus jatkaa identiteettityötään, selvittää, miten hän itse asettuu osaksi sukupolvien ketjua ja missä määrin hän on isoisänsä kaltainen. Tässä vaiheessa tarkkaavaiselle lukijalle, mutta ei Smithille itselleen, on selvinnyt, että Smithin laatima kertomus isoisän elämästä vastaa ilmeisesti pääpiirteittäin isoisän omaa 
kertomusta. Romaanin alussa Smith nimittäin on ryhtynyt kertomaan isoisänsä elämästä tähän tapaan:

Nuoresta pitäen kävin kauppaa Pietarissa.

Se oli kappale outoa maailmaa, iso kappale, metropoli jonka pulssi sykki tiheästi ja jossa elettiin samalla tavalla kuin se oli rakennettu, kiihkeästi, ihmisuhreista piittaamatta. Kaupunki maallisen ja kosmisen, lännen ja idän rajalla. Siellä saattoi tapahtua mitä tahansa. Se oli Euroopan neljänneksi suurin kaupunki ja uskomattoman lähellä.

Kuljin siellä isäni mukana jo poikasena, opin tuntemaan paikkoja ja ihmisiä. (MRS, 3I.)

Näissä versioissa on vain pieniä eroja sanavalinnoissa, mutta muutoin Smith näyttää tavoittaneen isoisänsä tavan kertoa itsestään. Smithin laatima pienoiselämäkerta isoisästä on siten ilmeisesti pääkohdissa todenmukainen, mutta hän ei voi olla varma siitä, mitä muuta isoisän itsensä laatima elämäkerta mahdollisesti toisi hänen tietoonsa. Päättäessään jättää tutustumatta siihen hän rinnastaa tilanteensa Oscar Wilden romaanin Dorian Grayn muotokuva (I906, englanninkielinen alkuperäisteos ilmestyi ı89o) päähenkilön tilanteeseen: "Jos näkisin oman kuvani, kävisikö sille kuin Dorian Grayn muotokuvalle" (MRS, 262). Wilden romaanissa Dorian Grayn todellinen minä, hänen "sielunsa" tulee esiin vain hänestä maalatussa muotokuvassa, jonka hän pitää salassa muiden katseilta ja joka muuttuu sitä hirveämmäksi, mitä enemmän hän saavuttaa seurapiireissä nautintoja ja menestystä. Smith pelkää, että hänen isoisänsä omaelämäkerta tuo esiin myös sellaisia asioita, joita hän ei pysty hyväksymään minäkuvansa rakennusaineiksi.

Kun Smith on polttanut isoisän käsikirjoituksen, ulkopuolinen kertoja kuvaa hänen tilannettaan eksistentialistisesta filosofiasta lainatuilla ajatuskuvioilla:

Käsikirjoitusta ei ollut enää olemassa. Se ei tarkoittanut, etteikö Smith olisi toisinaan ajatellut sitä. Hän koki perääntyneensä, jättäneensä ottamatta haastetta vastaan ja itsensä ikään kuin määritte- 
lemättömäksi, tyhjäksi tauluksi. Hän ei ollut kääntänyt viimeistä korttia. (MRS, 269.)

Sartren ja Beauvoirin käsittein ilmaistuna Smith on siis tilanteessa, jossa hänellä olisi mahdollisuus määritellä tai kohdata itsensä, mutta hän ei käytä tätä vapauttaan hyväksi. Sen sijasta hän pakenee rutiineihinsa ja tottumuksiinsa - lyhyesti sanoen "epäautenttiseen olemassaoloon", jota eksistentialistit pitivät vieraantuneisuuden keskeisenä ilmenemismuotona.

Autenttisuuden teema ei liity Mr. Smithissä ainoastaan Smithiin ja hänen isoisäänsä vaan myös teatteritieteen maisteriin Erno Manniseen ja romaaniin työväenluokkaisiin henkilöihin eli Briscillaan, Raneen ja Donald Southbrookiin. ICT-teollisuuden palveluksessa olevan Erno Mannisen kautta romaani hahmottaa nykykapitalismin globaalisti toimivaksi taloudellis-teknologiseksi muodostumaksi, joka asettaa yleiset reunaehdot ihmisten elämälle ja toiminnalle ja muokkaa samalla heidän subjektiuttaan ja aistimellisuuttaan. Erno Manninen kokee ICT-alan vaikutukset itseensä psykofyysisesti:

Hänen oli koettava omassa ruumiissaan metamorfoosi matkapuhelinyhtiön muuttumisessa mediayhtiöksi. Hänen oli mukautettava elämänsä ja tajuntansa monikosketusnäytön, kahden sormen zoomauksen ja sovelluksia sujuvasti pyörittävän gigahertsin prosessorin vaatimuksiin.

Joskus hänestä tuntui, että hänen elämänsä oli sekin eräänlainen käyttöliittymä tai -järjestelmä, jonka oikeutuksesta oli kaiken aika taisteltava samaan tapaan kuin hänen oma ja muut suuryhtiöt tekivät älypuhelinmarkkinoilla, ja silti tabletit ja iPadit tunkivat ohi. (MRS, 53.)

Erno Manninen katsoo, että nämä vaikutukset rajoittavat hänen itsemääräämisoikeuttaan ja mahdollisuuksiaan elää autenttista elämää. Romaanin lopussa hän on siksi tullut tilanteeseen, jossa "hän ei voinut enää kauan jatkaa työssään. Hän oli kenties onnistunut siinä [uusien 
teknisten sovellusten kehittämisessä] mitä häneltä odotettiin, mutta hän kaipasi jotakin todellisempaa ja pelkistetympää” (MRS, 27I).

Mr. Smith toimii suoremmin ja epäsuoremmin uusliberalistisen autenttisuuspuheen kritiikkinä. Siihen sisältyvä kritiikki on luonteeltaan maltillisempaa kuin Yhtiökumppaneissa ja Paholaisen haarukassa esitetty kritiikki, eikä se esitä sitä niin dramaattisella tavalla kuin nämä edeltäjänsä. Briscillan, Ranen ja Donald Southbrookin kautta Mr. Smithiin sisältyy myös myönteinen ulottuvuus, näkymä siitä, millaisia kapitalistisesta välinerationaalisuudesta ja hyötynäkökohdista vapaat ihmissuhteet ja habitukset tai mielenlaadut voivat olla. Tätä piirrettä voidaan jamesonilaisittain pitää kyseiseen romaaniin upotettuna "utooppisena impulssina", hahmotelmana kapitalismin toimintalogiikan ylittävästä tai siitä poikkeavasta sosiaalisen elämän ja toiminnan mahdollisuudesta (vrt. Jameson I979; Ojajärvi 20I8, 330-340).

Silti noiden kolmen työväenluokkaisen henkilöhahmon elämä on paljolti kapitalismin lakien ja toimintatapojen määräysvallan alainen, minkä lisäksi Briscillan luonnekuvaa rakennetaan romaanissa autenttisuusproblematiikan näkökulmasta. "Hän ei tuntenut koskaan olevansa oikeassa kohdassa elämää, hän näki että muilla oli kaikkea enemmän kuin hänellä: rahaa, onnea, rakkautta. Hän kohtasi ihmisiä, jotka eivät antaneet hänelle niistä mitään", toteaa tarinamaailman ulkopuolinen anonyymi kertoja (MRS, I69). Pyrkiessään löytämään itsensä ja paikkansa elämässä Briscilla ajautuu siksi halpahintaisten kauneus-, viihdeja autenttisuusteollisuuden tuotteiden kuluttajaksi.

Tarinamaailman ulkopuolinen anonyymi kertoja toteaa, että Briscilla käy "reiki- ja shiatsu-hoidoissa" (MRS, I73) ja soittelee "kaukoparantajille, selvännäkijöille, astrologeille ja kehonkielen tulkitsijoille, joiden hän odotti tuovan ratkaisun ongelmiinsa" (ibid., ı88). Autenttisuuden problematiikkaa koskevassa tutkimuksessa on kiinnitetty huomiota siihen, että nykykapitalismi on kehittänyt erityisen taloudellisen tuotannon ja liiketoiminnan alan, joka pyrkii vastaamaan kasvaneeseen autenttisuuden tarpeeseen tai "kysyntään". Tähän alaan kuuluvat muun muassa erilaiset itsehoito-oppaat ja itsensä löytämisen autuutta julistavat tuotteet. (Ks. Braun 20I2; Langman 20I2; Lindholm 2008.) Mr. Smithissä Briscilla kuvataan otolliseksi kohteeksi tällaiselle tarjonnalle. Näin hän 
ei pääse itseään etsiessäänkään eroon siitä positiosta, johon kapitalismin lait ja hänen luokka-asemansa ovat hänet heittäneet. Kapitalismin lakien ulkopuolelle hän pystyy osittain pääsemään vasta suhteessaan Raneen, sillä romaani kuvaa heidän rakastavan toisiaan ehdoitta, vailla hyötynäkökohtia. Samoin Donald Southbrook pitää kiinni omasta arvokkuuden tunteestaan, kunniallisuudestaan ja rehellisyydestään, joista hän ei suostu luopumaan edes taloudellisessa ahdingossaan.

Mr. Smithissä alempaan työväenluokkaan kuuluvat henkilöt joutuvat paljolti mukautumaan kapitalistisen talousjärjestyksen asettamiin ehtoihin, mutta se ei silti määrää totaalisesti heidän elämäänsä ja toimintaansa. Tietyissä rajoissa se jättää tilaa heidän vapaalle, omaehtoiselle toiminnalleen, minkä ohella sattumalla on osuutensa heidän elämänkulussaan. Mr. Smithin mukaan juuri näillä kapitalistisen välinerationaalisuuden ulkopuolisilla saarekkeilla subjektit kykenevät parhaiten autenttiseen itsetoteutukseen. Sitä vastoin kapitalismin ja autenttisuuden välinen suhde on ristiriitainen ja osittain ne sulkevat toisensa pois. Vaikka kapitalistisen yrittäjän, romaanissa esiintyvän herra Schmidtin, toimintaan liittyy itsetoteutuksen ulottuvuus, ongelmana hänen tapauksessaan on se, että pidäkkeettömässä muodossaan hänen toimintansa vahingoittaa yhteisöjen ja muiden subjektien mahdollisuuksia itsetoteutukseen. Päästessään hallitsemaan subjektien mieliä ja mentaliteettia kapitalistinen välinerationaalisuus tuottaa puolestaan typistettyä subjektiutta, eikä Mr. Smithin mukaan unohtaa sovi sitäkään, että kapitalismi tuotteistaa laajamittaisesti autenttisuuden ihannetta. Tällaisten markkinallistettujen autenttisuuslupausten kohteena ovat erityisesti Briscillan kaltaiset alaluokkaiset naiset.

\section{Autofiktiivinen ja metanarratiivinen ulottuvuus}

Mr. Smithiin sisältyvän autofiktiivisen ulottuvuuden tunnistaa siitä, että eräissä yhteyksissä Smith esittää, että heidän sukunsa oli jo Snellmanin satavuotispäivänä vuonna I906 muuttanut saksalaisperäisen nimensä "Schmidt" suomalaiseksi ja että hänen isoäitinsä isä oli ammatiltaan läkkiseppä (MRS, I3, 94-95, 233). Koska saksankielinen "Schmidt" ja 
englanninkielinen "Smith" merkitsevät molemmat 'seppää', niin romaanin todellisuudessa Smithin oikea nimi lienee "Seppälä". Tätä kytköstä kirjailija Juha Seppälään vahvistaa se, että Seppälän teksteissä esitettyjen tietojen perusteella hänen suvussaan nimen "Seppälä" otti ı80o-luvun jälkipuolella käyttöön hänen isoisänsä isoisä, ammatiltaan seppä. Mr. Smith tarjoaa siten riittävästi muodollisia tunnusmerkkejä nähdä tässä romaanissa myös autofiktiivinen ulottuvuus.

Autofiktiota voi pitää kahden perinteisen lajin, omaelämäkerran ja fiktion/romaanin, risteytymänä, tai pikemminkin se häilyy omaelämäkerran ja fiktion/romaanin välimaastossa, niistä jompaankumpaan suuntaan painottuen. Autofiktiivisille romaaneille on tyypillistä, että niissä esiintyy henkilöhahmo, jolla on sama nimi kuin teoksen kirjoittajalla, tai kirjailija on sijoittanut teokseensa henkilöhahmon, joka muistuttaa häntä itseään. Systemaattisesti suomalaista autofiktiota analysoineen Päivi Koiviston (20II, 25, 49; 20I3a, 99-I00) tutkimuksissa muun muassa Kari Hotakaisen Klassikko (I997), Pentti Holapan Ystävän muotokuva (I998) ja Pirkko Saision trilogia Pienin yhteinen jaettava (I998), Vastavalo (2000) ja Punainen erokirja (2003) täyttävät edellisen tunnusmerkin eli niissä päähenkilöllä on sama nimi kuin kirjailijalla. Toisaalta Christer Kihlmanin autofiktiivisessä romaanissa På drift i förlustens landskap (I986) päähenkilö-kirjailijan nimeä ei mainita, mutta hänestä annetun informaation perusteella lukija kykenee yhdistämään hänet kirjailija Christer Kihlmaniin (Carlson 20I4, I49-I82. Ks. myös McGill 2013, 72-73). Vaikkei Mr. Smith mainitse suoraan kirjailija Juha Seppälän nimeä, se on lähempänä ensiksi mainittua autofiktion tyyppiä.

Yhteistä autofiktiivisille teoksille on myös metafiktiivisyys. Niissä kirjailija tavallisesti tarkastelee autofiktiivisin keinoin omaa tuotantoaan ja/ tai yleisemmin kirjallista instituutiota ja kulttuuria. Mr. Smithin autofiktiiviset piirteet ovat yhteydessä metafiktiivisiin ja metanarratiivisiin teemoihin, sillä niiden avulla se reflektoi itseään ja pohtii elämästä kertomisen problematiikkaa. Samoin se tarkastelee kriittisesti nykyistä markkinaehtoisesti toimivaa kirjallisuusinstituutiota. Näin tapahtuu esimerkiksi romaanin loppuviitteessä 4. Se liittyy lukuihin, joissa Smith selvittää kirjailija Erkka Torrolle, miten tämä voisi menestyä paremmin kaupallistuneessa kirjallisuusinstituutiossa (MRS, I25-I4O, I43-I48). 
Loppuviitteessä 4 tarinamaailman ulkopuolinen kertoja jatkaa sitten tätä selvitystyötä:

Maailma on muuttunut sellaiseksi, että sitä kiinnostaa enemmän kirjan tekeminen kuin kirja. Vakavasti, kunnianhimoisin tarkoitusperin kirjoitettu kirja on ylellisyystuote, joka ei enää oikeastaan kuulu tähän aikaan. Se on kuriositeetti, relikti, joka kenties ansaitsisi kuolla. Suunnaton määrä eri eläinlajeja ja pieniä kieliä kuolee joka päivä. Mieluiten reaaliaikaisesti etenevä kertomus kirja synnystä on mielenkiintoisempi kuin kirja. Syntyhistoriaa tulisi esitellä pitkin matkaa sosiaalisessa mediassa. (MRS, 276.)

Tämä kritiikki on luonteeltaan samanlaista kuin Paholaisen haarukassa esitetyt kommentit kulttuurituotannon markkinallistumiskehityksestä. Molemmissa tulee esiin ajatus, että perinteisen taidekirjallisuuden ja aidosti yhteiskuntakriittisen taiteen aikakausi olisi päättymässä kapitalismin ekspansion myötä. Pian edellä siteeratun katkelman jälkeen teksti jatkuu monitulkintaisella tavalla:

Esimerkiksi tämän kirjan synnyn mittaan olisi ollut syytä esitellä ja tarjota kommentointimahdollisuutta teoksen juonenkulusta, henkilöistä, esittelyteksteistä. Ja tietenkin vaihtoehtoisia loppuja; kannattaa unohtaa se marginaalinen joukko lukijoita, jotka haluavat tsaarin, suurinkvisiittorin, päättämään, milloin kirja loppuu ja millä tavalla. (MRS, 276.)

Ilmaisu "tämä kirja" viittaa Juha Seppälän kirjoittamaan romaaniin Mr. Smith. Mikäli Seppälä siis olisi sitä kirjoittaessaan toiminut kaupallisen logiikan mukaisesti, hänen olisi tuolloin kannattanut olla runsaasti esillä julkisuudessa ja hankkia näin kirjalleen ennakkomainontaa.

Jälkimmäistä sitaattia on myös mahdollista tulkita metaleptisesti. Tällöin se näyttäytyy tilanteena, jossa Mr. Smithissä esiintyvä tarinamaailman ulkopuolinen kertoja tulee hetkeksi ulos omalta narratiiviselta tasoltaan ja kommentoi sen romaanin syntyprosessia, jossa hän toimii kertojana. Toisen tulkintamahdollisuuden mukaan siteeratussa kohdas- 
sa puhuu itse kirjailija Juha Seppälä, joka on siinä hetkeksi omaksunut kertojan roolin voidakseen tällä tavalla kritisoida kustannustoiminnan kaupallistumista.

Mr. Smithissä merkille pantavaa on se, että muodollisesti tai kertomusteknisesti ajatellen Juha Seppälän suhde tähän romaaniin on samanlainen kuin Smithin suhde "herra Schmidtin" nimissä esitettyihin kerrontajaksoihin. Siinä, missä Juha Seppälä tai "hänen virtaviivaistettu versionsa" on Mr. Smithin sisäistekijä, Smithillä on romaanissa vastaavanlainen suhde "herra Schmidtin" nimissä esitettyihin kerrontajaksoihin: isoisää koskevien kerrontajaksojen sisäistekijänä Smith siis kirjoittaa, ohjaa, järjestää ja valikoi näitä jaksoja, vaikka muodollisesti niissä minäkertojana esiintyy hänen isoisänsä herra Schmidt. Tätä analogiaa on mahdollista jatkaa pidemmälle. Siinä, missä Juha Seppälän oma ääni tulee Mr. Smithissä esiin myös tietyissä tarinamaailman ulkopuolisen kertojan esittämissä jaksoissa, "herra Schmidtin" nimissä kerrotuissa jaksoissa tulee toistuvasti ilmi se, että nämä jaksot eivät voi oikeasti olla Smithin isoisän eli herra Schmidtin kirjoittamia. Niissä on nimittäin runsaasti viittauksia Smithin isoisän kuoleman (vuosi I939) jälkeisiin tapahtumiin, joten näissä viittauksissa Smith tuo esiin myös omaa näkökulmaansa ja ajallista tarkastelupistettään.

Tällainen metanarratiivinen asetelma vaikuttaa niin artistiselta ja kokeelliselta ratkaisulta, että se on tuskin pelkkää spontaanin kirjoitustyön tulosta. Pikemminkin on syytä olettaa, että Mr. Smithin kirjoittaja on rakentanut sen romaaniinsa tietoisesti. Tuo asetelma toimii romaanissa lukijalle osoitettuna vihjeenä tai muistutuksena siitä, miten Juha Seppälän tai hänen virtaviivaistetun versionsa ääni on läsnä $M r$. Smithissä. Siitä huolimatta tämä informaatio ei jätä tulkitsijalle paljoakaan käteen. Ilman biografis-psykologisen menetelmän ja Seppälästä tehtyjen teemahaastattelujen käyttämistä tulkitsija ei voi tietää paljoakaan siitä, mikä Mr. Smithissä, erityisesti Smithin henkilöhahmossa, on omaelämäkerrallista ainesta, Seppälää itseään, ja mikä puolestaan fiktiivistä ainesta, sepitettä. Ehkä kuitenkin se, että isoisästään pienoiselämäkerran laatinut Smith päättää lopussa olla lukematta isoisänsä käsikirjoitusta oikeuttaa tulkitsijaa esittämään seuraavanlaisen kysymyksen $M r$. Smithin kirjoittajasta. Vihjaako kyseinen kohta siihen, että kirjailijana Seppälä olisi 
itsekin kieltäytynyt paljastamasta sisimpäänsä syvemmin lukijoille, että hänen oma tuotantonsa olisi siten ollut etäällä autenttisesta itseilmaisusta?

Päivi Koivisto (20II, 49) toteaa, että vahvoja omaelämäkerrallisia aineksia sisältävät autofiktiot ovat tavallisesti kirjailijan itseanalyysia. Tällaisissa teoksissa kirjailija käy usein läpi merkittäviä elämänkokemuksiaan ja valottaa samalla teostensa biografis-psykologista taustaa, niin kuin esimerkiksi Pirkko Saision romaanitrilogia tekee. Mr. Smith ei ole kuitenkaan tässä mielessä moniulotteisesti valaistu "näkymä Juha Seppälän mielenmaisemaan". Jos sitä halutaan pitää itseanalyysina tai itsereflektiona, se on sitä varsin yleisluontoisella tavalla. Sellaisena se samanaikaisesti sekä paljastaa että peittää. Yhtäältä se siis voisi vihjata siihen, että Juha Seppälä pitää puutteellista itseilmaisukykyä kirjailijantyönsä heikkona kohtana, mutta toisaalta se jättää kertomatta sen, minkä ilmaisemista tai kertomista hän olisi vältellyt. Sen sijasta se näyttää enemmänkin kokeilevan tai jopa leikittelevän autofiktion idealla. Siksi on mahdollista myös ajatella, että Mr. Smithiin upotetun autofiktiivisen problematiikan yhtenä tehtävänä on toimia nykyisen kirjallisen kulttuurin kritiikkinä - siis sellaisen kirjallisen kulttuurin, jossa kirjailijan odotetaan tuovan itsensä ja elämänsä lukijoiden ulottuville ja jossa autofiktiivisyydestä on tullut suosittu laji. Niin kuin edellä todettiin, eräissä yhteyksissä Mr. Smithin kertoja puhuukin ironisesti siitä, että nykyisin lukijat ovat kirjojen sijasta enemmän kiinnostuneita "kirjojen synnystä" (MRS, 276). Autofiktiivisyyden kritiikkiä edustaisi Mr. Smithissä myös se, ettei siihen sisältyvä autofiktiivinen ulottuvuus tavallaan johda mihinkään - kuten hetki sitten kävi ilmi. Toisaalta tämä tulkintalinja ei saa tukea Seppälän myöhemmistä romaaneista, sillä esimerkiksi Kuoppakaupungin (20I6) keskushenkilönä on jälleen fiktiivinen kirjailija, joka pitää riittämätöntä itseilmaisukykyä kirjailijantyönsä vakavana puutteena. Tähän problematiikkaan palataan vielä tämän pääluvun lopussa.

Kirjallisena henkilönä Smithin henkilöhahmo aukeaa eri suuntiin. (I) Hän on yhtäältä kapitalismiin sitoutunut yrittäjä ja sijoittaja, joka esittää näkemyksiään nykytaloudesta, mutta toisaalta hän on myös (2) isoisästään elämäkertaa laativa tarinankertoja ja (3) autofiktiivinen versio kirjailija Juha Seppälästä. Robert McGillin (2OI3, I53) mukaan 
autofiktioita tai "omaelämäkerrallisia fiktioita" luonnehtii referentiaalinen monimielisyys, joka on samalla potentiaalisesti eettistä monimielisyyttä. Lukijan on vaikea tietää, missä määrin autofiktio viittaa kirjailijan omaan elämään ja hänen omiin näkemyksiinsä, ja samalla autofiktio saattaa vältellä ottamasta yksiselitteisiä kantoja moraalisiin kysymyksiin. McGill jatkaa, että monimielisenä teoksena se luo epävarmuuden tilan, jossa mitään ei lyödä lukkoon ja kaikesta voidaan käydä keskustelua.

Mr. Smith ei ehkä aivan täytä McGillin kuvausta autofiktion avoimuudesta, vaikka se on selvästi Yhtiökumppaneita ja Paholaisen haarukkaa arvoituksellisempi romaani. Kuinka onnistuneesti se pystyy sovittamaan yhteen Smithin henkilöhahmoon liittyvät funktiot (I) - (3)? Onko Smith uskottava ja hyvin toimiva figuuri tällaisena kolmiulotteisena henkilöhahmona? Tietyissä rajoissa Smithin ajatukset ja toiminta ilmentävät samanaikaisesti näitä kaikkia kolmea ulottuvuutta, mutta monasti nuo ulottuvuudet sulkevat myös toisensa pois. Niinpä kaikkea sitä, mitä Smith ajattelee ja tekee (I) yrittäjän ja sijoittajan roolissa, ei voida samalla luontevasti liittää autofiktiiviseen tai todelliseen Juha Seppälään. Tässä suhteessa Mr. Smith on merkityspotentiaaleiltaan heterogeeninen ja paikoitellen jopa ristiriitainen teos.

(I) Näkemyksensä kapitalismista $M r$. Smith esittää osittain juuri Smithin henkilöhahmon kautta. Omissa kerrontajaksoissaan Smith luonnehtii, osin epäsuorasti ja tahattomasti, kapitalismia välineelliseen rationaalisuuteen ja indifferenttiin toimintatapaan perustuvaksi järjestelmäksi, joka ajautuu aina tietyin väliajoin kriisiin markkinavoimille ominaisten suhdannevaihteluiden takia; kriisiensä kustannukset se pystyy kuitenkin tavallisesti maksattamaan valtion ja veronmaksajien rahoilla. (Ks. MRS, IO6-IO7, I45-I46.) Tällainen näkemys on pitkälle samanlainen kuin Yhtiökumppaneissa ja varsinkin Paholaisen haarukassa esitetty näkemys, joten sen voisi olettaa olevan hyvin lähellä kirjailija Juha Seppälän omaa käsitystä kapitalismista. Kapitalismikäsitysten suhteen Smithin ja Seppälän välillä on kuitenkin myös jännitteitä, sillä Mr. Smith ja romaanin sisäistekijä osoittavat, millaisia kielteisiä ja tuhoisia vaikutuksia kapitalismin laeilla ja toimintatavoilla, siis epäsuorasti myös Smithin omilla liiketoimilla, on ihmisten elämään. Samoin näihin kielteisiin vaikutuksiin kuuluu se, että Smithissä itsessään kapitalismi 
tuottaa typistynyttä subjektiutta. Näistä syistä osa siitä, mitä Smith tekee kapitalistina, näyttää sopivan huonosti yhteen funktion (3) kanssa.

(2) Smith esiintyy romaanissa myös tarinankertojana ja kirjallisen elämän toimijana. Jälkimmäisellä alueella hän antaa konsulttina kirjailija Erkka Torrolle neuvoja siitä, miten kaupallista menestystä tavoittelevan kirjailijan tulisi kirjoittaa:

Jos ei ole rikosta, on oltava juoni. Mieluiten molemmat. Ei ole merkitystä, mikä rikosjuoni on. Vain sen puuttuminen on ongelma. Juoni ei ole rikos, sen puuttuminen on. Muuten lukija ei tiedä mitä lukee, taluttava käsi puuttuu, lukija ei pääse perille, vaan jää roikkumaan yksin, epätietoisuuteen ja neuvottomuuteen, tyydyttämättömään tilaan. Jos se puuttuu, kirjan takakanteen täytyy painaa varoitus: "HUOM! Tässä romaanissa ei ole rikosjuonta." On ilmoitettava selkeästi, että rikosjuonen puuttumisesta aiheutuvaa mielipahaa ei korvata lukijalle. Jos et tyydy kuljettamaan rikosjuonta, saarnaat. Ellei kirjassa ole rikosjuonta, sen on edustettava jotakin lajityyppiä, niin kuin Clint Eastwoodin elokuvien. Muuten ei tule myyntiä eikä Oscaria. Jos ihmiset eivät tiedä, mikä kirja on, se ei ole mikään. Hyvien on oltava hyviä, mustan mustaa. Moralismia, ei moraalisuutta. Hyvät vastaan demonisoidut, hyvä vastaan ulkoistettu paha. Selkeä tarina, jossa on sankari, alku ja loppu. Keskushenkilö. Caulfield tai Salminen, Sorel tai vaikka Mr. Smith, kuten tässä kirjassa, jonka ympärillä lukijat kiertävät kuin planeetat. (MRS, I34.)

Tässäkin katkelmassa, sen lopussa, esiintyy viittaus "tähän kirjaan", Mr. Smithiin. Katkelma on siten luonteeltaan metaleptinen. Aiemmin esillä olleen kohdan tavoin sekin ylittää romaaneissa perinteisesti käytetyt ontologiset, epistemologiset ja narratiiviset kehykset, sillä siinä fiktiivinen henkilöhahmo Smith tulee kehyksistään ulos ja kommentoi sitä romaania, jonka fiktiivinen henkilöhahmo hän on. Perinteisesti vain romaanin kirjoittajan ja ehkä myös kaikkitietävän kertojan on oletettu voivan toimia tällaisessa roolissa. Näin ajateltaessa Smith esiintyy katkelman lopussa roolissa, joka kuuluisi luontevammin todelliselle tai auto- 
fiktiiviselle Juha Seppälälle. Muutoin katkelma sopii yhteen sen kanssa, että Smith esiintyy romaanissa kapitalismin edusmiehenä, joka hyväksyy markkinallistumiskehityksen. Romaanin sisäistekijä suhtautuu puolestaan siihen monin varauksin, ja romaanin omassa kontekstissa kyseistä katkelmaa voikin pitää parodiana markkinahenkisestä kirjallisuuspuheesta.

(3) Kapitalistina ja tarinankertojana Smithillä on omat syynsä siihen, että hän jättää tutustumatta isoisänsä oikeaan käsikirjoitukseen tai omaelämäkertaan. Romaani selittää hänen ratkaisuaan yhtäältä sillä, että kapitalismi on köyhdyttänyt hänen subjektiuttaan ja tehnyt hänestä ihmisen, joka pelkää astua ulos epäautenttisesta elämäntavastaan. Toisaalta hänen ratkaisunsa yhteydessä anonyymi kertoja tuo esiin myös sen, että maailma on paljon enemmän kiinnostunut itse tarinoista kuin totuudesta:

Käsikirjoitukset palavat, kun ne poltetaan.

Tarina teki ajan voimattomaksi. Tarina oli yhtä totta kuin kivija teräsbetonikolossit tai kahvilat, kampaamot ja vanhat lehmukset hänen ympärillään ja taivas kaupungin yllä - - Maailma oli tarina, pelkkiä tarinoita jotka oli upotettu toisiin tarinoihin. (MRS, 269-270.)

Myöhemmin kertoja toistaa vielä ajatuksen siitä, että "maailma tarvitsee myyttejä, legendoja, eläviä ja kuolleita" (MRS, 276). Molemmat katkelmat näyttävät sanovan, että identiteettimme tai minäkuvamme ei perustu ainoastaan koeteltuun tietoon vaan aina lisäksi kuvitelmiin ja oletuksiin, joiden pohjalta voimme järjestää myös käytännön elämäämme. Tämä yleistys pitää paikkansa, mutta se tuskin tarjoaa meille syvempää vastausta siihen, miksi Juha Seppälä on ilmeisesti vältellyt teoksissaan autenttista itseilmaisua. Yllä mainitut selitysperusteet tekevät kyllä ymmärrettäväksi kapitalisti-Smithin ja tarinankertoja-Smithin tekemän ratkaisun, mutta mikäli me pidämme Smithiä myös autofiktiivisenä versiona Juha Seppälästä, niin tällöin nuo perusteet eivät vaikuta informatiivisilta. Tässäkin mielessä Mr. Smith päättyy siihen, mistä se alkoi: arvoitukseen. 
Koska Mr. Smith on avoin, moniaineksinen ja ristiriitainenkin romaani, on syytä kysyä, lähestyykö se lajiltaan traumakirjallisuutta ja löytyisikö tästä suunnasta selitys siihen, että Smith jättää tutustumatta isoisänsä käsikirjoitukseen. Traumallahan tarkoitetaan tavallisesti ihmisen kokemaa ylivoimaista katastrofia tai onnettomuutta tai, kuten Judith Herman (I992, 33-34) kirjoittaa, ihmistä järkyttänyttä kokemusta, jonka ihminen pyrkii torjumaan tietoisuudestaan, mutta joka palaa hänen mieleensä vahvoina tunnemuistoina, jälkikuvina, näkyinä ja häiritsevinä ajatuksina. Traumaattinen mieli toimii pakonomaisesti. Trauman vallassa ollessaan subjekti palaa kerta kerran jälkeen traumaattiseen kokemukseensa ja hänen on vaikea keskittyä normaaliin elämään ja viedä siellä asioita päätökseen. Kirjassaan Trauma Fiction (2004, 4, 83-84) Anne Whitehead toteaa, että traumaattisen mielen tuottama kerronta on vastaavasti polveilevaa ja tiettyjä aineksia pakonomaisesti toistavaa ja siinä subjektin on vaikea päättää kertomuksiaan narratiivisella sulkeumalla.

Mr. Smith sisältää sivujuonteena traumakirjallisuuden piirteitä. Niihin kuuluu ensinnäkin se, että Smith palaa jatkuvasti ja miltei pakonomaisesti isoisänsä elämään ja liiketoimiin, joita hän yrittää hahmottaa kertomusmuodon keinoin. Romaani antaa ainakin yhden selityksen siihen, miksi hän näin tekee. Romaanin lopussa on Smithin tuottama kuvitteellinen dialogijakso, jossa hän keskustelee vuonna I939 kuolleen isoisänsä kanssa:

- [Smith] Miksi jätit perheesi?

Osui.

- [Herra Schmidt, isoisä] Se ei kuulu Teille.

- Sen vaikutukset ovat tuntuneet elämässäni. Isäni oli isätön, eikä sellainen mene ohi jälkeä jättämättä.

- Elämä jättää aina jälkensä.

- Moni on vihannut sinua. Sinua ei muisteta hyvällä.

- Olen pahoillani.

- Oletko?

- Niin tavataan sanoa. (MRS, 252-253.) 
Hylätessään perheensä isoisä on tehnyt teon, joka on traumatisoinut Smithin isän ja jonka vaikutukset ulottuvat tätä kautta, ylisukupolvisena kokemuksena ja muistona, myös Smithiin itseensä. Kuvitteellisen dialogijakson päätteeksi Smith huomauttaakin isoisälleen: "Sinä välitit ihmisistä yhtä vähän kuin lumi, niin kuin Tsehov sanoo" (MRS, 253). Hänen isoisänsä, epävakaa liikemies, on jättänyt jälkeläisensä vaille sitä rakkautta ja huolenpitoa, joka näille luontaisesti kuuluisi. Traumakirjallisuudelle luonteenomaisella tavalla Smith on yhtäältä pakonomaisesti kiinnostunut isoisästään, traumansa aiheuttajasta, ja samanaikaisesti hän lopulta torjuu itselleen tarjoutuneen mahdollisuuden tutustua yksityiskohtaisemmin isoisän elämänvaiheisiin.

Edellä siteerattu kohta selittää sitä, miksi kapitalisti ja tarinankertoja Smith on estynyt ja traumatisoinut, mutta jää avoimeksi, soveltuuko tuo kohta myös autofiktiiviseen versioon Juha Seppälästä. Toisaalta kyseinen kohta toimii romaanissa vihjeenä siitä, että trauman kategoria on relevantti Mr. Smithin yhteydessä. On mahdollista ajatella, että tälle romaanille ominainen tapa välttää narratiivisia sulkeumia, sen tapa käyttää hyväksi erilaisia lajirepertoaareja ja jättää niiden hyödyntäminen kesken jäljittelee myös traumaattisen mielen toimintatapaa - eikä, niin kuin aiemmin esitettiin, pelkästään elämän epätäydellisyyttä ja kaoottisuutta. Samaa tarkoitusta palvelee se, että Smith esiintyy romaanissa vähintäänkin kolmiulotteisena henkilöhahmona tai vähintäänkin kolmessa eri roolissa. Siten Mr. Smithin narratiivinen rakenne ja kompositio ovat samalla tavalla polveilevia, eri suuntiin kurkottavia ja päättämättömiä aineksia sisältäviä kuin millainen on traumaattisen mielen tapa käsitellä asioita. Näin ajateltaessa Mr. Smithissä on mukana kokeellinen ulottuvuus. Se testaa, miten romaani voi tuottaa vaikutelman traumaattisen mielen esittämisestä tai representoimisesta. Toisaalta Mr. Smithiä ei kannata psykologisoida, sillä sitä ei ole syytä pitää todellisen tai aktuaalisen traumakokemuksen ilmaisuna. Sen rakenne vaikuttaa niin huolellisesti suunnitellulta ja artistiselta, että se on enemmänkin tietoisen suunnittelutyön kuin spontaanin ilmaisun tuotetta. 


\section{Yhteenvetoa}

Mr. Smithissä esitetty näkemys kapitalismista on tietyiltä osin samanlainen kuin Yhtiökumppaneiden ja Paholaisen haarukan näkemys. Näiden kaikkien romaanien mukaan kapitalismi noudattaa välineellistä rationaalisuutta ja indifferenttiä toimintatapaa, mutta siinä, missä Paholaisen haarukan maailmassa nämä periaatteet ovat saaneet valtaansa koko yhteiskunnan, Mr. Smithin maailmankuva ei ole yhtä deterministinen. Mr. Smithin mukaan ihmiset eivät ole pitkälle markkinallistuneessa nyky-yhteiskunnassakaan täysin talouden lakien määräysvallan alaisia, vaan tietyssä määrin he kykenevät edelleen aitoihin valintoihin.

Romaanipoetiikan ${ }^{130}$ tasolla Yhtiökumppanit ja Paholaisen haarukka ovat vahvasti keskitettyjä ja teleologisia romaaneja, joissa sisäistekijä ja kertojat vievät tapahtumia kohti kärsimyksiä ja katastrofeja. Mr. Smithissä useiden henkilöiden elämä osoittautuu niin ikään epätäydelliseksi ja epäautenttiseksi ja monet heistä kärsivät kapitalismin aiheuttamasta vieraantuneisuudesta. Toisaalta kaikki ei tämän romaanin maailmassa selity taloudesta käsin. Esimerkiksi Briscilla ja Rane kuvataan romaanissa syrjäytymisvaarassa oleviksi henkilöiksi, joiden elämänkulun heidän työväenluokkainen kotitaustansa pitkälle määrää ja joilla ei ole edellytyksiä menestyä nykyisessä markkinaperustaisessa kilpailuyhteiskunnassa. Silti keskinäisessä rakkaussuhteessaan nämä kaksi näyttävät toimivan vailla hyötynäkökohtia. Myöskään tähän romaaniin sisältyvä autofiktiivinen ulottuvuus ei ole kaikilta osin läheisesti yhteydessä kapitalismi-teemaan.

Ensimmäisessä ja toisessa pääluvussa Seppälän tuotanto jaettiin yksilökeskeiseen (I980-luku), kansalliseen (I990-luku) ja kapitalismikriittiseen (vuodet 2000-20I2) kauteen sekä vuoden 20I2 jälkeiseen tuotantoon. Näiden kausien väliset rajat eivät ole jyrkkiä, sillä kyseinen jaottelu tuo esiin lähinnä sen, millaisin aiheisiin ja teemoihin Seppälän teokset eri aikoina ovat keskittyneet. Niinpä Mr. Smithillä on yhtymäkohtia Seppälän seuraavaksi ilmestyneiden romaanien Matka aurinkoon (20I4) ja Kuoppakaupunki (20I6) kanssa. Nämä kaksi romaania keskittyvät metanarratiivisiin teemoihin. Ne käsittelevät siis kertomusmuodon avulla kertomuksiin liittyviä teoreettisia kysymyksiä, minkä ohella 
Kuoppakaupunki sisältää itsensä tiedostavalle metafiktiolle, autofiktiolle ja traumakirjallisuudelle ominaisia piirteitä.

Kuoppakaupunki kuvaa fiktiivistä kirjailijahahmoa Ilmo Halssia, joka on valintojen edessä. Tämä historian sijaisopettajana aiemmin toiminut, mutta sittemmin vapaaksi kirjailijaksi antautunut sanankäytön ammattilainen on kyseisessä romaanissa tullut tunnetuksi menneisyyteen huolellisesti ankkuroituneiden historiallisten romaanien tekijänä, mutta Halssista tuntuu, ettei hän voi enää jatkaa samalla linjalla. Seuraavassa romaanissaan "Kartanpiirtäjä" hänen olisi myös kerrottava jotakin omasta itsestään ja paljastettava siinä sisäistä maailmaansa. Tämä tehtävä on kuitenkin vaikea kirjailijalle, joka on tottunut kätkemään itsensä tuotantonsa taakse:

Romaanini olivat rationaalisesti rakennettuja, omalla tavallaan täydellisiä, vammattomia. En antanut niihin mitään itsestäni (naiiviudessani kuvittelin, että voisin jotenkin säännöstellä itseni paljastamisen astetta!). Saatoin pysytellä turvassa tuon keinotekoisen poetiikan takana. En kirjoittanut selittääkseni vaan karttaakseni itseäni. Kirjoitin historiasta samalla tavalla kuin olisin kuvannut matkaa enkä matkustanut. Illuusion luominen ei ollut vaikeaa, koska juuri se oli sitä mihin lukijat halusivat uskoa. (Seppälä 20ı6, 82.)

Ankarassa itsekritiikissään Halssi rinnastaa itsensä Thomas Mannin romaanin Huijari Felix Krullin tunnustukset (I980, saksankielinen alkuperäisteos ilmestyi I954) päähenkilöön, taiteilija Felix Krulliin, joka näyttäytyy Mannin romaanissa samanaikaisesti myös illuusioiden luojana, tempuntekijänä ja huijarina. ${ }^{131}$ Näin ajateltaessa taiteilijaa voisi pitää moraalisesti arveluttavana olentona, mutta Halssi ei tällaista päätelmää tee, jos kohta hänen mielestään aidot kirjailijat ja taiteilijat ovat, toisinaan demonisuuteen saakka, sosiaalisesti eriskummallisia olentoja. Heillä esimerkiksi on tiettyjä erioikeuksia, sillä menneisyyttä käsitellessään he voivat muunnella historiallisia tosiasioita ja tässä mielessä - Halssi järkeilee - "valehteleminen" kuuluu erottamattomasti historiallisia aiheita käsittelevään kirjallisuuteen ja taiteeseen. 
Halssin pyrkimys kääntää kirjailijanuransa tunnustuksellisempaan suuntaan ei onnistu. Kun hän joutuu jo romaanin alussa pitkäaikaisen naisystävänsä jättämäksi, hänen omasta elämästään katoaa johtotähti tai kompassi, jonka mukaisesti hän voisi suunnistaa arkitodellisuudessa. Sen jälkeen hän ajelehtii tapahtumista ja sattumuksista toisiin ja menettää vähitellen kykynsä hahmottaa elämäntilanteensa ja sisäisen maailmansa kertomusmuodon keinoin. Jo ennen kuin Halssi romaanin lopussa päätyy psykoottisena laitoshoitoon, hän joutuu tunnustamaan, että hän ei yksinkertaisesti kykene kirjoittamaan romaania kartanpiirtäjästä, todellisuuden kartoittajasta. Näin Kuoppakaupunki on kuvaus henkilökohtaiseen kriisiin sekä taiteelliseen ja maailmankuvalliseen umpikujaan ajautuneesta kirjailijasta. ${ }^{132}$

Mielenkiintoista romaanissa on se, että Halssi suhtautuu vähättelevästi aiempaan tuotantoonsa eikä hän pidä sitä oikeanlaisena, henkilökohtaisesta sisäisestä ilmaisuntarpeesta kumpuavana kirjallisuutena. Mikäli me pidämme Ilmo Halssia kirjailija Juha Seppälän alter egona, sellaisena Seppälä näyttäisi edellä siteeratussa kohdassa arvostelevan aiempaa tuotantoaan, mukaan lukien vuosina 2000-20I2 ilmestyneitä yhteiskunnallisia teoksiaan. Hän luonnehtii niitä rationaalisesti rakennetuiksi konstruktioiksi, joista puuttuu niiden kirjoittajan omaa, sisäistä maailmaa syvemmin ilmaiseva tai luotaava aines. Tässä mielessä Seppälä reflektoisi Kuoppakaupungissa Ilmo Halssin henkilöhahmon avulla kriittisesti omaa kirjailijuuttaan. Samanlaista itsereflektiota hän ilmeisesti harjoitti jo Mr. Smithissä, mutta huomattavasti peitellymmin ja varovaisemmin kuin Kuoppakaupungissa, minkä vuoksi edelliseen romaaniin sisältyvät autofiktion ja traumafiktion piirteet tarjoavat tutkijalle vain niukasti aineksia tulkintojen muodostamiseen. Kuoppakaupungissa huomiota kiinnittää lisäksi kuvaus siitä, että Halssi ei enää kykene hahmottamaan todellisuutta kertomusmuodon keinoin. On mahdollista, että näin tehdessään Kuoppakaupunki ottaa kriittistä etäisyyttä myös Yhtiökumppaneissa, Paholaisen haarukassa ja Mr. Smithissä ilmenevään käsitykseen kapitalismista, mutta avoimet viittaukset tähän problematiikkaan puuttuvat siitä.

Mr. Smith sisältää varovaisia ensiaskeleita myös "rationaalisen romaanipoetiikan" kritisoimisen suuntaan. Tästä näkökulmasta Yhtiökumppa- 
neiden ja Paholaisen haarukan ongelmana on, että ne nojautuvat siihen samaan rationaalisuuden muotoon, josta ne arvostelevat kapitalismia. Näyttäessään, millaisia henkisiä ja fyysisiä vaurioita markkinallistuminen aiheuttaa yhteiskunnassa, ne kuljettavat tapahtumia vääjäämättömästi kohti tiettyä suuntaa ja päämäärää. Tällöin niihin sisältyvät tarinalinjat ovat luonteeltaan välineellisiä eli ne on alistettu palvelemaan tuota päämäärää ja tarkoitusta. Niissä kuvatusta fiktiivisestä maailmasta pyrkii siksi katoamaan tietoisuus todellisuuden moniäänisyydestä sekä kriittisen ajattelun ja vastarinnan mahdollisuudesta.

Tämän tutkimuksen toisessa pääluvussa esiteltiin käsityksiä siitä, miten kirjallisuus on edustanut modernin länsimaisen rationaalisuuden päämuodosta poikkeavaa rationaalisuuden muotoa. Habermasin esteettisekspressiivinen rationaalisuus, Luhmannin kontingenssi-tietoisuus, Meretojan mahdollisuuksien taju ja Nussbaumin aristoteliseen käytännöllisen viisauden käsitteeseen perustuvat tutkimukset ovat kaikki yrityksiä tavoittaa ja käsitteellistää modernille kirjallisuudelle ominainen erityislaatuinen rationaalisuus. Vaikka Yhtiökumppaneiden ja Paholaisen haarukan kuvaamassa maailmassa esiintyy arvorationaalisesti toimivia henkilöitä (Peten vaimo ja lapset edellisessä romaanissa, Eero ja Rauha Raivio sekä elokuvaohjaaja Laura Laine jälkimmäisessä romaanissa), varsinkin Paholaisen haarukassa välineellisen järjen mukainen toiminta on paljolti ottanut valtaansa yhteiskunnan eri osa-alueet ja tukahduttanut niiden erityislaadun. Koska kyseinen romaani noudattaa myös rakenteensa tasolla välineellis-teleologista etenemistapaa, sen mahdollisuudet ylläpitää tietoisuutta vaihtoehtoisista rationaalisuuden muodoista ovat rajalliset. Näiltä osin sen maailmankuva tai yhteiskuntakuva sisältää ilmeisiä reifioituneita aineksia. Tämä Georg Lukácsin ja Fredric Jamesonin teorioissa keskeisessä asemassa oleva käsite, reifikaatio, viittaa tilanteeseen, jossa olemassa oleva todellisuus koetaan tai esitetään ainoaksi mahdolliseksi todellisuudeksi ja jossa katoaa tietoisuus siitä, että kulttuurisyhteiskunnallinen todellisuus on inhimillisen toiminnan tuote ja sellaisena se on myös muutettavissa inhimillisen toiminnan avulla. ${ }^{133}$ Paholaisen haarukan välittämä kuva nykykapitalismista ei ole kaukana tällaisesta tilanteesta. 
Toisaalta juuri kyseinen seikka, Paholaisen haarukan tietynasteinen "yksiulotteisuus", vahvistaa siihen sisältyvää spekulatiivisen fiktion ulottuvuutta. Voimakkaita dystooppisia sävyjä sisältävät spekulatiiviset fiktiot muistuttavat tätä romaania siinä, että niidenkin kuvaamaa maailmaa hallitsee usein jokin tuhoava voima tai tapahtuma, joka tekee elämän tuossa maailmassa painajaismaisen ahdistavaksi ja vaihtoehdottomaksi. Kyse voi olla esimerkiksi autoritaarisesta hallitsemistavasta, teknologian ylivallasta, ydinsodasta tai ympäristökatastrofista. Paholaisen haarukan tavoin tällaiset teokset toimivat kulttuurissamme enemmän tai vähemmän tehokkaina varoitustarinoina tai shokki-iskuina, jotka muistuttavat lukijoita siitä, millaisia riskejä ja uhkakuvia elämänmuotomme kantaa mukanaan.

Trauman ja hajoavan tai murtuvan mielen kategoriat yhdistävät Seppälän 20ıo-luvulla ilmestyneitä teoksia myös hänen varhaistuotantoonsa, lähinnä romaaneihin Hyppynaru (I990a) ja Luru (I992a). Niissä keskushenkilöt - edellisessä työtön perheenisä ja jälkimmäisessä aikuisikää lähenevä nuorukainen - päättävät vapaaehtoisesti elämänsä, lähinnä siitä syystä, että heidän lapsuutensa aikaiset kasvuolosuhteet ovat olleet äärimmäisen rikkonaiset ja traumatisoivat. ${ }^{134}$ Seppälän tuotannossa nämä kaksi romaania edeltävät tässä mielessä $M r$. Smithiä ja varsinkin Kuoppakaupunkia, jotka tosin käsittelevät traumaattisia kokemuksia hieman erilaisesta näkökulmasta. Vaikka tämä Seppälän tuotantoon sisältyvä temaattinen linja joudutaan käsillä olevassa tutkimuksessa jättämään vaille lähempää tarkastelua, on syytä pitää mielessä se, että kansallisen, eksistentiaalisen ja yhteiskunnallisen kerrostuman ohella hänen tuotantonsa sisältää selvästi tunnistettavissa olevan psykologisen kerrostuman. Tuo kerrostuma ei kuitenkaan ole kaikilta osiltaan läheisesti yhteydessä kapitalistisen rationalisaation kritiikkiin. 


\section{Luku VI Päätäntä}

\section{Kritiikin näkökulma ja arvolähtökohta}

Rakenteensa, kompositionsa ja kerrontatapansa osalta tutkimuksen kohteena olevat Seppälän romaanit ovat kompleksisia. Ne perustuvat epäjatkuvan etenemistavan ja rinnakkaiskerronnan varaan. Ne kuljettavat siis eteenpäin useita eri tarinalinjoja, joiden välille syntyy kerronnan edetessä yhtymäkohtia ja leikkauspisteitä. Kustakin tarinalinjasta romaanit esittävät kerrallaan vain lyhyen jakson, sen jälkeen ne siirtyvät kehittelemään muita tarinalinjoja ja palaavat sitten takaisin aiemmin esillä olleisiin tarinalinjoihin. Elokuvateorian näkökulmasta keskeinen kirjallinen keino Seppälän romaaneissa on leikkaus, montaasi. Elokuvateoriassa leikkauksilla tarkoitetaan tavallisesti elokuvakameran tallentamien otosten väliin jääviä merkkejä siitä, että otos katkeaa ja elokuvassa siirrytään seuraavaan otokseen. ${ }^{35}$ Seppälän romaaneihin sisältyvät luvut tai kerrontajaksot voidaan siten rinnastaa otoksiin. Näille romaaneille ovat ominaisia lyhyet otokset ja nopeat siirtymät otoksesta toiseen, ja samalla tavalla näkökulmat esitettyyn todellisuuteen vaihtuvat niissä joutuisaan tahtiin. Selvimmin tällainen tekniikka on käytössä Yhtiökumppaneissa ja Paholaisen haarukassa, jotka muodostuvat nopeasti vaihtuvista näkymistä niissä esitettyyn todellisuuteen.

Seppälän romaaneissa leikkauksen tai montaasin periaate toimii usein samalla tavalla kuin tuo periaate esiintyy Sergei Eisensteinin 
I920- ja I930-luvulla ohjaamissa elokuvissa. Eisensteinin elokuvat luovat leikkauksen ja kuvasarjojen yhteen liittämisen avulla rinnastuksia sellaisten todellisuuden osa-alueiden ja kokemusmaailmojen välille, jotka eivät esiinny normaalissa, arkisessa havaintomaailmassa yhdessä. Samoin Yhtiökumppanit ja Paholaisen haarukka synnyttävät erilaisia tarinalinjoja eteenpäin kuljettamalla ja niitä toisiinsa rinnastamalla yhtymäkohtia yhtäältä markkinakilpailun ja sodankäynnin välille ja toisaalta epäjumalien palvomisen ja markkinafundamentalismin välille.

Yhtiökumppanit, Paholaisen haarukka ja Mr. Smith osallistuvat nyky-yhteiskunnan luonnetta koskevaan diskursiiviseen kamppailuun esittämällä representaatioita ja arvioita nyky-yhteiskunnan toimintatavoista ja niiden vaikutuksista yksilöiden ja yhteisöjen elämään. Tässä mielessä näihin romaaneihin liittyy realistinen intentio. Yhteiskunnallista todellisuutta representoidessaan ne ovat silti osittain etääntyneet pelkän jäljittelemisen, mimesiksen periaatteesta. Niihin on kyllä otettu tunnistettavia piirteitä nykyisestä yhteiskunnallisesta todellisuudesta, mutta Seppälä on sovittanut nuo piirteet romaaniensa rakenteen, komposition ja etenemistavan logiikkaan ja samalla hän on muunnellut ja kärjistänyt yhteiskunnallisesta todellisuudesta valikoimiansa aineksia. Näistä syistä nuo romaanit poikkeavat osittain todellisuuden realistis-mimeettisestä esittämistavasta eikä niitä kannata kaikilta osin yrittää lukea pelkkinä nykyyhteiskuntaa koskevina representaatioina.

Seppälän kapitalismikriittisissä romaaneissa rakenne, kompositio ja kerrontatapa toimivat vieraannuttavina aineksina siinä mielessä kuin jo venäläiset formalistit puhuivat vieraannuttamisesta. Formalisteilla kirjallinen teos ottaa etäisyyttä siitä, mikä on käynyt ihmisille arkiseksi ja tavanomaiseksi; tämän teos tekee siten, että se sijoittaa tuttuutta edustavat ainekset teoksen muodollisen rakenteen yhteyteen ja käyttää samalla artistisia tai keinotekoisia ilmaisukeinoja, joihin esimerkiksi proosassa kuuluu kerrontarakenne. Vieraannuttaminen ei kuitenkaan ole itsetarkoitus. Formalisteilla vieraannuttamisen funktio on osittain kognitiivinen: se etäännyttää lukijan totunnaisista ajattelu-, havainto- ja tuntemistavoista, jotta tämä voisi sitten nähdä todellisuuden uusin silmin ja keskittyä siihen, mikä todellisuudessa teoksen mukaan on olennaista. Vieraannuttavien ainesten käyttäminen ei siksi ole ristiriidassa 
realististen tavoitteiden kanssa, vaan se voi olla kiinteä osa todellisuuden syvempään tuntemiseen tähtäävän teoksen rakentumistapaa. ${ }^{136}$

Seppälän romaaneihin sisältyy siis realistinen intentio, pyrkimys tavoittaa nyky-yhteiskunnan toimintatapa, mutta vieraannuttavien ainestensa, erityisesti kerrontatapansa vuoksi nuo romaanit poikkeavat selvästi perinteisestä lineaarisesti tai kronologisesti etenevästä ja kerronnallisesti yksinkertaisesta realistisesta romaanityypistä. ${ }^{137}$ Entä mistä näkökulmasta käsin Yhtiökumppanit, Paholaisen haarukka ja Mr. Smith harjoittavat markkinallistuneen nyky-yhteiskunnan kritiikkiä? Ja missä määrin ne tuovat esiin sen arvohorisontin, josta käsin ne yhteiskuntaa tarkastelevat? Mikäli yhteiskuntaa kuvaava romaani kätkee lähtökohtansa ja sitoumuksensa ja mikäli se esittää itsensä itsestään selvänä tai ainoana oikeana maailman jäsennystapana, se täyttää vahvasti ideologisen diskurssin tunnuspiirteet (ks. Zima I989, 56, 235). Tällöin se nojautuu paljolti doksaan, kulttuurissa itsestään selvinä pidettyihin arvostuksiin ja uskomuksiin.

Doksan käsite on tärkeä Pierre Bourdieun tutkimuksissa. Ihmisten arkitietoisuus tai arkitajunta koostuu Bourdieun (1979, 59, 464, 499, 539, 54I, 547, 549) mukaan paljolti juuri doksasta: arvoista, asenteista, käsityksistä ja uskomuksista, joita ihmiset pitävät itsestään selvinä totuuksina. Tällaiset ainekset muodostavat perustan heidän tavalleen suuntautua ja toimia maailmassa. Ne eivät ole välttämättä epätosia, sillä ihmisten muodollisen koulutustason noustua heidän arkitajuntansa sisältää nykyisin yhä enemmän myös koululaitoksen, tieteen ja joukkoviestimien välittämiä uskomuksia maailmasta. Siksi leimallista ihmisten arkitajunnalle on pikemminkin se, että sen sisältämä kuva maailmasta on hajanainen ja epäsystemaattinen ja siinä on runsaasti mukana vanhentuneita ja huonosti perusteltuja asenteita ja uskomuksia.

Ihmisten elämismaailmoja kuvaava kirjallisuus sisältää miltei väistämättä doksa-tason aineksia, käsityksiä, jotka jonkin tietyn yhteisön ja aikakauden jäsenet ovat hyväksyneet itsestään selvinä totuuksina. Siten kirjallisuudella on aina kulttuurihistoriallisen dokumentin arvoa; se tarjoaa meille tietoa siitä, mitä eri aikoina ja erilaisissa yhteisöissä on pidetty totena ja oikeana. (Vrt. Peltonen 2008, 75; Sevänen 20I8c, 63-67.) Kirjallisuuden tiedollisen arvon kannalta tärkeä kysymys liittyy siihen, 
missä määrin kirjallisuus problematisoi tuon common sense -maailmankuvan eli arkijärjen maailmankuvan.

Seppälän kapitalismikriittisissä romaaneissa tulee esiin kaksi erilaista arkijärkeen liittyvää maailmankuvaa. Niistä ensimmäistä edustaa uusliberalistinen yhteiskuntakäsitys, joka nousi jo I980- ja I990-luvulla suomalaisen poliittisen eliitin ja suomalaisten tiedotusvälineiden piirissä hegemoniseen asemaan, itsestään selvänä pidetyksi totuudeksi ja josta alettiin Suomessa käydä laajemmin kriittistä julkista keskustelua vasta vuosituhannen vaihduttua. (Alasuutari 2006, 42-55.) Ilmestymiskontekstissaan Seppälän romaanit olivat osa tuota kriittistä keskustelua. Toista arkijärkeen liittyvää maailmankuvaa edustaa tiettyjen ryhmien (pätkätyöläiset, työttömät, syrjäytyneet, perinteinen älymystö, aiempaa laajemmin myös keskiluokka) piirissä syntynyt kriittinen kokemus uusliberalistisen mallin pohjalta toteutetusta yhteiskunnasta ja sen vääristymistä. Tämän kokemuksen Seppälän romaanit paljolti jakavat, vaikka niiden päähenkilöt edustavat ensi sijassa ylempiä luokkia. Hänen romaaninsa asettavat kyseisen kokemuksen laajempiin yhteiskunnallisiin ja yhteiskuntateoreettisiin yhteyksiin.

Kokonaisuutena Seppälän romaaneille on siksi ominaista korkea reflektoimisen aste, mikä tulee näkyviin siinä, että niissä kapitalismin käsittelemisen yhteyteen on upotettu erilaisia metatasoja. Kehitellessään kriittistä kuvaa ja arviota nykykapitalismista ne hyödyntävät erityisesti sosiologian ja poliittisen taloustieteen klassista teoriaperinnettä, josta niihin on kulkeutunut tai josta ne ovat sulattaneet itseensä runsaasti aineksia. Toisen keskeisen metatason Yhtiökumppaneissa, Paholaisen haarukassa ja Mr. Smithissä muodostavat tekstijaksot ja rakenteet, jotka pohtivat kirjallisuuden ja taiteen asemaa nyky-yhteiskunnassa. Nämä jaksot ja rakenteet tematisoivat pohdiskelun kohteeksi myös sen, miten kirjallisuus ja taide, mukaan lukien Seppälän omat romaanit, representoivat yhteiskuntaa.

Korkeasta itsetietoisuuden asteestaan huolimatta edellä mainitut romaanit ovat myös valikoivia, ja ne ottavat osan lähtökohdistaan annettuina. Tämä tutkimus on tarkastellut niitä osana sellaista kirjallista traditiota, joka kuvaa kriittisesti kapitalistista rationaalisuutta ja sen aiheuttamia sosiaalisia ja henkisiä vaurioita. Länsimaisessa kirjallisuudessa kapita- 
lismin toimintatapojen reflektoiminen alkoi Daniel Defoen romaaneista I700-luvun alussa, mutta vasta I830-luvulta lähtien, Honoré de Balzacin ja Charles Dickensin teosten myötä, kirjallisuus alkoi tuottaa kriittisiä esityksiä ja arvioita kapitalismista. Suomessa merkkipaaluja kapitalistisen toimintarationaalisuuden kriittisessä käsittelemisessä ovat Maiju Lassilan ja Maria Jotunin I9ıo-luvulla julkaisemat teokset sekä varsinkin Pentti Haanpään ja Toivo Pekkasen I930-luvulla kirjoittamat romaanit. Tämän kulttuurisen arkkitekstin reflektoiminen ei nouse Seppälän romaaneissa etualalle. Paholaisen haarukkaan ja Mr. Smithiin sisältyvät Stendhalviittaukset osoittavat silti lukijalle sen, että Seppälän romaanit liittyvät myös yleisemmällä tasolla länsimaisen kriittisen yhteiskuntakuvauksen traditioon. Balzac ja Stendhal edustavat molemmat länsimaista kriittistä yhteiskuntaromaania, mutta heistä nimenomaan Balzac tarkasteli teoksissaan markkinakäyttäytymisen etenemistä yhteiskunnassa. Jacques Dubois (2000, 170-206; 2007, 22-39, 238-246) toteaa, että Balzaciin verrattuna Stendhal on ensi sijassa "politiikan sosiologi" eli kirjailija, joka mielsi yhteiskunnan ennen kaikkea poliittisten valtasuhteiden ja luokkaerojen muodostamaksi kokonaisuudeksi. Poliittiseen ulottuvuuteen Seppälän vuosina 2000-20I2 julkaisemista romaaneista keskittyy vain Routavuosi, joka ei kuulu tämä tutkimuksen varsinaiseen aineistoon.

Seppälän romaanit ovat valikoivia myös suhteessa kuvauksensa pääkohteeseen, nykykapitalismiin. Tietyt nykytalouden piirteet eivät tule niissä esiin. Yhtiökumppaneiden Pete ja Olli, Paholaisen haarukan Lari Laine ja Mr. Smithin nimihenkilö edustavat pieniä ja keskisuuria yrittäjiä tai nykytalouden käyttöönsä palkkaamaa "huippuammattilaisten" kerrostumaa - eivät suuryrityksiä, jotka hallitsevat talouselämää ja joiden menestymisestä globaalissa talouskilpailussa valtiovalta on ollut erityisen huolestunut. Viime vuosikymmeninä harjoitettu "kansallisen kilpailukyvyn politiikka" on ensi sijassa tukenut suuryrityksiä eikä Seppälän teoksissa kuvattua "pienkapitalismia". Seppälän teoksissa ei myöskään käy laajasti ilmi talouselämän kansainvälistyminen, se, että pääosa suomalaisista suuryrityksistä on nykyisin lähinnä ulkomaisten tai globaalien sijoitusrahastojen ja eläkerahastojen omistuksessa.

Nykyisessä maailmanjärjestyksessä vallitsevat globaalit valtasuhteet Seppälän kapitalismikriittiset romaanit ottavat esille lähinnä viitteen- 
omaisesti. Tällaisena viittauksena voi pitää esimerkiksi Yhtiökumppaneihin sisältyvää mainintaa siitä, että liiketoimiansa aloitellessaan Pete ja Olli kävivät hakemassa oppia Yhdysvalloista, uusliberalistisen maailmanjärjestyksen ja luovan talouden keskuksesta. Mr. Smithissä älypuhelinteollisuuden palveluksessa oleva Erno Manninen matkustelee niin ikään ahkerasti Suomen ja Yhdysvaltain väliä, ja Donald Southbrookin hahmo toimii romaanissa muistutuksena siitä, että nykyisessä maailmanjärjestyksessä luokka- ja alistussuhteet ovat yhä useammin luonteeltaan ylirajaisia.

Yhtiökumppaneiden, Paholaisen haarukan ja Mr. Smithin välittämä kuva nyky-yhteiskunnasta on siis monessakin mielessä rajallinen. Mutta sen, mitä nämä romaanit laajuudessa menettävät, ne korvaavat kuvauksen syvyydellä. Ne eivät kuvaa nyky-yhteiskuntaa sen koko monimuotoisuudessa, vaan ne keskittyvät käsittelemään markkinallistuneen nyky-yhteiskunnan toimintalogiikkaa ja sen vaikutuksia yksilöiden ja yhteisöjen elämään. Tässä suhteessa romaaneja voidaan verrata tieteissä kehiteltyihin esittäviin tai representatiivisiin malleihin. Representatiivisen mallin tarkoituksena ei ole kuvata kohteen kaikkea moni-ilmeisyyttä ja yksilöllisyyttä, vaan sen tavoitteena on tuoda esiin kohteen yleinen rakenne ja toimintatapa. Ihmistieteissä kehitellyt teoriat ovat usein juuri faktoista, oletuksista ja arvoista koostuvia teoreettisia malleja, jotka kuvaavat jostakin tietystä arvonäkökulmasta käsin kohteidensa yleisiä rakenteellisia ja funktionaalisia ominaispiirteitä. (Vrt. Niiniluoto I984, 206-207.) Seppälän vuonna 20I4 Parnasso-lehdessä ${ }^{138}$ esittämää toteamusta siitä, että hänen omat kirjansa "ovat kehittyneet artefaktimaisempaan suuntaan", ettei hän nykyisin niinkään "pyri jäljittelemään maailmaa vaan luomaan kokonaisvaltaisia vaikutelmia lähes kubistiseen malliin, piittaamatta juonellisuuteen tai uskottavuuteen liittyvistä kysymyksistä”, voidaan tulkita tässä valossa. Kyse on siis siitä, että romaanejaan kirjoittaessaan, esimerkiksi niiden henkilöhahmoja ja tarinalinjoja luodessaan, Seppälä on harjoittanut abstrahointia voidakseen siten tavoittaa paremmin kohteensa kokonaiskuvan tai sen yleiset tunnuspiirteet. Tässä mielessä hän on, niin kuin semioottisessa kirjallisuudentutkimuksessa sanotaan, "mallintanut maailmaa", luonut fiktion keinoin esityksen siitä, miltä nykykapitalismin toimintaperiaatteet 
näyttävät, kun niitä tarkastellaan kriittisesti tietystä arvonäkökulmasta ja kokemusmaailmasta käsin. ${ }^{139}$

Selvimmin edellisessä kappaleessa esitetty käsitys sopii Paholaisen haarukkaan ja Mr. Smithiin, jotka kapitalismia ja sen toimintalogiikkaa mallintaessaan käyttävät laajasti hyväksi länsimaisen yhteiskuntateorian traditioita. Niihin verrattuna Yhtiökumppanit nojautuu enemmän erilaisten juonellisten tarinalinjojen kehittelemiseen, jos kohta nuo tarinalinjat eivät ole kaikilta osin kovin uskottavia. Toisaalta nyky-yhteiskuntaa mallintaessaan Paholaisen haarukka abstrahoi yhteiskuntakuvastaan johdonmukaisesti pois sellaiset piirteet, jotka eivät ilmennä kapitalismille ominaista systeemirationaalisuutta ja "välineellistä järkeä". Näin sen välittämästä yhteiskuntakuvasta häviää tietoisuus maailman moninaisuudesta ja vaihtoehtoisen ajattelun ja toiminnan mahdollisuudesta, kun kaikki teoksen tapahtumat pelkistyvät kapitalismin systeemilogiikan ilmentymiksi tai tuon logiikan aiheuttamiksi vaurioiksi yksilöille ja yhteisöille.

Seppälän teoksiin sisältyvän kapitalismikritiikin ominaisluonnetta määritettäessä voidaan myös nojautua Boltanskin ja Chiapellon tapaan ymmärtää kritiikki. He puhuvat erikseen "reformistisesta" ja "radikaalista" kritiikistä, joista edellinen pyrkii kehittämään yhteiskuntaa korjaamalla sen epäkohtia ja jälkimmäinen tähtää yhteiskunnan kokonaisvaltaiseen uudistamiseen. Heidän omat sympatiansa ovat reformistisen kritiikin puolella, sillä he tekevät pesäeroa marxilaiseen teoriaan ja sosialistisiin liikkeisiin ja katsovat itse jatkavansa Weberin ja Habermasin edustamaa traditiota kapitalismitutkimuksessa. Tältä pohjalta on mahdollista erottaa toisistaan neljä erityyppistä kritiikkiä.

Taulukossa 2 esitettyjä erotteluja voidaan havainnollistaa Leena Krohnin dystopian Unelmakuolema (2004) avulla. Krohnin romaani on markkinallistumisen ja liiketaloudellisten arvojen ylikorostamisen kritiikkiä. Se ei kehitä tätä kritiikkiään niinkään nyky-yhteiskunnasta poimituilla konkreettisilla aineksilla, vaan se luo tieteisfantasian keinoin läpikotaisin markkinallistuneen tulevaisuuden maailman, jossa kuolemastakin on tehty bisnestä ja jossa Unelmakuolema-yhtiö myy ihmisille sellaisen kuoleman kuin nämä haluavat. Kriittisenä romaanina Unelmakuolema toimii siten lähinnä tasoilla (a) ja (c). Toisaalta monet suomalaiset työ- 
Taulukko 2. Neljä erilaista kritiikin tyyppiä kapitalismi-teeman näkökulmasta

(a) Kulttuurinen kritiikki kohdistuu yhteiskunnassa esiintyviin asenteisiin, arvoihin ja maailmankuviin.

(b) Osittainen reformistinen kritiikki kiinnittää huomiota yksittäisiin sosiaalisiin epäkohtiin ja ongelmiin, esimerkiksi sosiaaliturvan puutteisiin, työelämän rasittavuuteen ja sukupuoliseen tai etniseen syrjintään työelämässä.

(c) Kokonaisvaltainen reformistinen kritiikki haluaa rajoittaa merkittävästi markkinoiden ja yksityiskapitalistisen yrityssektorin valta-asemaa yhteiskunnassa ja maailmassa ja korvata sen "pehmeämmällä tai rajoitetummalla kapitalismilla".

(d) Radikaalis-konstitutiiviselle kritiikille eivät (a), (b) ja (c) riitä, vaan se pyrkii ei-kapitalistiseen yhteiskuntaan.

Lähde: Boltanski \& Chiapello I999, 77; Sevänen 20I4a, I2.

elämän rasittavuuden kuvaukset, esimerkiksi Anna Krogeruksen julkisella sektorilla tehtävää hoitotyötä käsittelevä näytelmä Kuin ensimmäistä päivää (2007), toimivat ensi sijassa tasolla (b) eli ne puuttuvat nyky-yhteiskunnassa esiintyviin konkreettisiin epäkohtiin. Taso (d) on harvinainen suomalaisessa nykykirjallisuudessa. Tosin Juhani Niemen (20I3) mukaan Hannu Salaman romaaneihin Elämän opetuslapsia I-IV (I997-2005) ja Sydän paikallaan (20I0) sisältyy selviä antikapitalistisia juonteita, ja Jussi Ojajärvi (20I5; 20I6) on tulkinnut Arto Salmisen upottaneen romaaneihinsa vastaavanlaisia, tosin kätketympiä aineksia. Samaan yhteyteen kuuluu Tommi Melender, joka on teoksissaan asettanut nykykapitalismin vaihtoehdoksi esimodernin länsimaisen kulttuurin (ks. Sevänen 20I4C).

Nykyinen kriittinen yhteiskuntatiede on kiinnittynyt lähinnä tyyppeihin (a), (b) ja (c) eikä niinkään tyyppiin (d). Esimerkiksi Habermas on puhunut siitä, että vaikka uusliberalistisen maailmanjärjestyksen legitimiteetti on vuoden 2007 jälkeen heikentynyt ihmisten mielissä, kapitalismille itsessään ei näytä lähitulevaisuudessa olevan toteuttamiskelpoista vaihtoehtoa. Siksi vallankumouksen sijasta ainoa jäljelle jäävä vaihtoehto tällä hetkellä on "kapitalismin kesyttäminen sisältäpäin", sen asettaminen järkeviin rajoihin (Habermas 20I2, I06). Habermas 
ei ole itse kehittänyt rajoitetun kapitalismin mallia, mutta viime vuosikymmeninä poliittisessa taloustieteessä tällaisia malleja ovat laatineet muun muassa yhdysvaltalaiset taloustieteilijät Paul Krugman (2009) ja Joseph Stiglitz (20IO). Sosiologeista voidaan mainita brittiläiset Anthony Giddens (2009) ja John Urry (20I3), ja myös ranskalainen taloustieteilijä Thomas Piketty (20I6) on puhunut tarpeesta rajoittaa nykykapitalismia.

Vuonna 20I3 Oxford University Press julkaisi Paul du Gayn ja Glenn Morganin toimittaman artikkelikokoelman New Spirits of Capitalism? Crises, Justifications, and Dynamics. Sen kirjoittajat pyrkivät yhtäältä arvioimaan Boltanskin ja Chiapellon I4 vuotta aiemmin ilmestynyttä "Kapitalismin uutta henkeä” ja toisaalta tarkastelemaan myöhempää yhteiskuntakehitystä, erityisesti vuonna 2007 alkaneen talouskriisin vaikutuksia Boltanskin ja Chiapellon kirjan avaamista perspektiiveistä käsin. Chiapello (2013) on kirjoittanut kokoelmaan kapitalismikritiikin erilaisia muotoja käsittelevän artikkelin. Siinä hän toteaa, että I990-luvun jälkipuolelta lähtien esitetty kritiikki ja yhteiskunnallinen liikehdintä ovat johtaneet siihen, että kapitalismi on 2000-luvulle tultaessa uudistamassa henkeään ja eetostaan. Kun uusliberalistinen kapitalismi nousi I970- ja I980-luvun vaihteessa valtaan lupaamalla yksilöille ja yrityksille vapautta valtioiden harjoittamasta sääntelystä ja mahdollisuutta itsetoteutukseen, kapitalismin seuraava henki tulee Chiapellon mukaan ilmeisesti painottamaan ekologisia ja moraalis-yhteiskunnallisia näkökohtia. Nykykapitalismi onkin jo jonkin aikaa tavaroittanut ja tuotteistanut tämän suuntaista kritiikkiä, mikä näkyy siinä, että valtiot käyvät nykyisin kauppaa päästörajoituksista ja monet yritykset pyrkivät luomaan itsestään julkisuudessa kuvaa eettisesti vastuullisina toimijoina. (Ks. myös Ratiu 20I8, I94-I95.) Nähtäväksi jää, muuttaako ekologinen ja moraalis-yhteiskunnallinen kritiikki syvällisemmin kapitalismin toimintatapoja vai tuleeko kapitalismi taas kerran osoittautumaan hämmästyttävän kyvykkääksi käyttämään kritiikkiä itsensä voimistamisen lähteenä ja välikappaleena.

Chiapello jatkaa, että kapitalismin rajoittamisesta ovat viime vuosikymmeninä puhuneet myös populistiset ja äärioikeistolaiset liikkeet. Tämä puhe on hänen mukaansa ollut toisenlaista kuin kriittisessä yhteiskuntatieteessä esiintynyt keskustelu. Populistiset ja äärioikeistolaiset 
liikkeet kiinnittyvät kansallisiin yhteiskuntiin ja vaatimukseen niiden suvereniteetin palauttamisesta. Ne ovat halunneet purkaa nykyisessä maailmanjärjestyksessä vallitsevat valtapoliittiset asetelmat, kun taas kansallisten yksiköiden sisällä ne ovat usein ajaneet markkinahenkistä politiikkaa. Tavallisesti niiden poliittista linjaa on luonnehdittu protektionistiseksi. Monet tutkijat ovat olettaneet, että Kiinan, Intian, Brasilian ja Venäjän voimistumisen myötä uusliberalismin jälkeinen maailmanjärjestys tulee joka tapauksessa painottamaan protektionistisia arvoja ja toimintatapoja. Oletus perustuu siihen, että nuo maat ovat perinteisesti antaneet valtiolle yhteiskuntakehityksen ohjaamisessa huomattavasti keskeisemmän aseman kuin markkinoiden ensisijaisuutta painottavat angloamerikkalaiset maat.

Yhtiökumppaneiden, Paholaisen haarukan ja Mr. Smithin esittämä kritiikki kiinnittyy lähinnä tyyppeihin (a), (b) ja (c). Nämä romaanit arvostelevat markkinallistumiskehitystä siitä, että se on johtanut (a) kulttuurin pinnallistumiseen ja banalisoitumiseen, (b) vieraantumisen, syrjäytymisen ja mielekkyyskriisien lisääntymiseen sekä (c) ylipäänsäkin kapitalismin toimintalogiikan tunkeutumiseen alueille, joille se ei sovi ja joilla se aiheuttaa vain vahinkoa. Mitä kapitalismin eri vaiheisiin tulee, niin kyseisissä romaaneissa esitetyn kritiikin kohteena ovat lähinnä perinteinen vapaan kilpailun kapitalismi ja nykyinen uusliberalistinen kapitalismi. Tarkastelemani teokset esittävät, että juuri näissä kahdessa vaiheessa talouden toimintatapaa luonnehtii välineellinen rationaalisuus ja indifferentti asenne perustavia arvoerotteluja kohtaan. Sitä vastoin laajan hyvinvointivaltion kausi ei joudu yhtä voimakkaan kritiikin kohteeksi. Tosin Seppälän romaanit eivät esitä sitäkään ongelmattomaksi vaiheeksi. Paholaisen haarukka ja Mr. Smith kiinnittävät huomiota siihen, että laaja hyvinvointivaltio ei kyennyt nostamaan alempaan työväenluokkaan kuuluvia ihmisiä (Jumalan Kyynel, Briscilla, Rane) syrjäytymisvaarasta ja tarjoamaan heille edellytyksiä kunnolliseen elämänhallintaan. Edellä mainituista romaaneista ekologiset kysymykset ottaa esille ainoastaan Paholaisen haarukka, joka puhuu yhtäältä siitä, että nykykapitalismi käyttää taloudellisesti hyväksi ympäristöhuolta, ja toisaalta siitä, että kuluttajina kaikkien kansalaisten tulisi ottaa suurempi vastuu ympäristön säilymisestä elinkelpoisena. Populistisen nationalismin nousua Seppälä 
käsittelee tai sivuaa vasta Sankariajassa (20ı8a), joka on tässä tutkimuksessa jäänyt tarkastelun ulkopuolelle.

Jussi Ojajärvi (20ı6, 92-93) toteaa, että suomalaisessa nykykirjallisuudessa useimmat kapitalismi-teemaa käsittelevistä kirjailijoista ovat syntyneet I950-I970-luvuilla. He ovat siis pääosin varttuneet aikuisiksi tilanteessa, jossa markkinoiden valta yhteiskunnassa oli nykyistä huomattavasti rajoitetumpi ja jossa poliittinen hallitsemistapa nojautui enemmän yhteisvastuun ja keskinäisen solidaarisuuden periaatteille. Siksi ei ole yllättävää, että tällaiset kirjailijat tarkastelevat markkinallistumiskehitystä yleensä laajan hyvinvointivaltion arvomaailmasta käsin, niin kuin esimerkiksi Kari Hotakaisen Luonnon laki (2013) ja Miika Nousiaisen Metsäjätti (20II) sekä edellä mainitut Krohnin ja Krogeruksen teokset tekevät. Laajan hyvinvointivaltion kauden arvomaailma on myös Arto Salmisen romaanien taustalla, vaikka ne esittävätkin markkinakapitalismin jo lakkauttaneen hyvinvointivaltion. Seppälän vuosina 2000-20I2 ilmestyneet teokset kuuluvat tähän samaan ryhmään. Niissäkin tulee esiin huoli siitä, mitä markkinallistumiskehitys tekee hyvinvointivaltiolle ja siinä harjoitetulle politiikalle. ${ }^{\text {I40 }}$ Tämä selittää osaltaan sen, ettei niistä voi johtaa tyypin (d) mukaista arvolähtökohtaa, visiota siitä, miten yhteiskunta voitaisiin organisoida ei-kapitalistiselta pohjalta.

Haastatteluissaan Seppälä on toistuvasti todennut, että hän lähtee romaaneissaan yksilöllisestä kokemuksesta. Esimerkiksi vuonna 2003 Seppälä antoi Seppo Puttoselle ja Joni Pyysalolle Parnassoon haastattelun, jossa hän asetti Väinö Linnan edustaman perinteisen suomalaisen realistisen kirjallisuuden yksilöllisen kokemuksen vastakohdaksi: "Linna on aika hegeliläinen kirjailija, joka loi laajan kaaren tällaisesta teleologisoivasta historiakäsityksestä käsin, mitä minä vierastan jossain

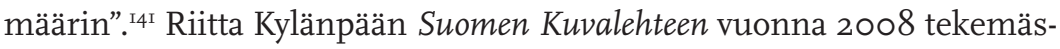
sä haastattelussa Seppälä piti yksityisen kokemuksen vastakohtana teoreettista pohdiskelua, jollaista esimerkiksi sosiologit hänen mukaansa harjoittavat. ${ }^{142}$ Miten osuvasti nämä haastattelut kuvaavat Seppälän laajoja yhteiskunnallisia romaaneja?

Linnasta puhuessaan Seppälällä on ilmeisesti ollut mielessään se, että Täällä Pohjantähden alla (I959-I962) edustaa kansallista realismia. Linnan romaani kuvaa yhden kyläyhteisön kautta kokonaisen kansakunnan 
kehitystä, ja siinä henkilöiden kokemien historiallisten tapahtumien, sosiaalisten konfliktien ja henkilökohtaisten tragedioiden implisiittisenä teloksena on kansakunnan eheytyminen ja yhteisen hyvinvointivaltioprojektin aloittaminen. Seppälän vuosina 2000-20I2 julkaisemissa romaaneissa sidos suomalaiseen kansakuntaan ja yhteiskuntaan on heikompi, mutta kokonaan se ei niistä puutu.

Seppälän vuosina 2000-20I2 ilmestyneet romaanit ovat reagointia maailmalla ja Suomessa I980- ja I990-luvulla valtaan noussutta uusliberalistista kapitalismia vastaan. Näissä romaaneissa hän ei siten kuvaa pelkästään "suomalaista nykykapitalismia". Paholaisen haarukka on myös yleisemmällä tasolla toimiva kirjallinen malli siitä, millainen läpikotaisin markkinallistunut yhteiskunta on tai voisi olla. Tätä realistisen yhteiskuntaromaanin ja spekulatiivisen fiktion keinovalikoimaa yhdistelevää romaania ei siksi kannata tarkastella pelkkänä tulkintana ja arviona suomalaisen yhteiskunnan tilasta ja kehityssuunnasta. Peten ja Ollin pyörittämän ICT-alan yrityksen ja Peten isän sotakokemusten kautta Yhtiökumppanit kiinnittyy selkeästi suomalaiseen todellisuuteen. Silti sekin näyttää yleisemmällä tasolla sen, millaista fyysistä ja mentaalista tuhoa nykytalous voi aiheuttaa yksilöiden ja yhteisöjen elämässä. Mr. Smith sijoittuu näiden kahden romaanin välimaastoon. Sen sidosta suomalaiseen yhteiskuntaan heikentää se, että se kuvaa kapitalismin lakeja ja toimintatapoja usein yleisluonteisesta näkökulmasta ja samalla Seppälä on tehnyt Smithistä myös autofiktiivisen hahmon, jonka avulla hän reflektoi omaa kirjailijuuttaan.

Entä missä määrin Seppälän romaanit laittavat nykykapitalismia käsitellessään yksilöiden kokemuksen etusijalle sosiologiseen teoretisointiin nähden? Tarkastelemani romaanit pitävät siinä mielessä yksilöiden kokemusta lähtökohtanaan, että niiden keskushenkilöt ovat nykykapitalismin edusmiehiä, jotka reflektoivat omaa toimintatapaansa ja joiden ajatusmaailma tuo esiin nykykapitalismin itseymmärrystä, kyseisen luokan kehittämää kuvaa kapitalismista. Nykyisen talous- ja yhteiskuntajärjestyksen tuottamaa vieraantuneisuutta Seppälän romaanit käsittelevät osittain juuri näiden yläluokkaisten henkilöhahmojen kautta sekä osittain myös keskiluokkaisten prekariaatti-työntekijöiden (sosiaalipsykologi Saija Lehtonen) ja syrjäytymisvaarassa olevien työläisten (Jumalan Kyynel, 
Briscilla, Rane, Donald Southbrook) kautta. Muodostaessaan arviota nykykapitalismista Seppälän romaanit eivät silti rajoitu näiden henkilöiden kokemukseen ja tietoisuuteen. Tilannetta hieman yksinkertaistaen voi sanoa, että hänen romaaneissaan tarinamaailman ulkopuoliset anonyymit kertojat - eli ekstradiegeettiset heterodiegeettiset kertojat - asettavat alaluokkaisten henkilöiden elämän ja toiminnan laajempiin yhteiskunnallisiin yhteyksiin ja sisäistekijät puolestaan kyseenalaistavat yläluokkaisten keskushenkilöiden arvomaailman ja yhteiskuntakäsityksen.

Näin tapahtuu esimerkiksi Paholaisen haarukassa, jossa tarinamaailman ulkopuolista anonyymiä kertojaa tarvitaan selittämään lukijalle syitä Jumalan Kyyneleen pahaan oloon: "Pahan olon poistamiseksi hänelle oli tarjottu samoja asioita, jotka olivat aiheuttaneet sen. Järjestelmä, joka oli tehnyt hänet sairaaksi, lupasi poistaa hänen sairautensa. Epäilemättä joku teki hänen ahdistuksellaan rahaa.” (PH, 9.) Tässä tarinamaailman ulkopuolinen kertoja edustaa järjestelmän näkökulmaa, kykyä tarkastella nykykapitalismia erityislaatuisena taloudellisena toimintatapana ja valtasuhteiden muodostumana, joka tuotteistaa Jumalan Kyyneleen vieraantumisenkin. Samalla tavalla tarinamaailman ulkopuolinen anonyymi kertoja asettaa Mr. Smithissä Briscillan ja Ranen elämän laajempiin yhteyksiin. Yläluokkaisten keskushenkilöidensä tietoisuuden rajoittuneisuuden Seppälän romaanit osoittavat ennen kaikkea etenemistapansa ja sisäistekijänsä arvomaailman kautta. Ne paljastavat, millaisia tuhoisia seurauksia nykyisellä talousjärjestyksellä on sekä yläluokan että alempien luokkien kannalta. Seppälän romaanit kiinnittyvät näin yksilöiden kokemusmaailmaan, mutta toisaalta ne ylittävät sen ja osoittavat sen rajoittuneisuuden.

Merkille pantavaa Seppälän romaaneissa, varsinkin Paholaisen haarukassa ja Mr. Smithissä, on se, että niissä tarinamaailman ulkopuoliset kertojat ja osaksi myös henkilökertojat käyttävät yhteiskuntateorian käsitteitä ja selitysmalleja. Ilman niitä kyseisiin romaaneihin sisältyvät pohdiskelut kapitalismista jäisivät ohuiksi. Tässä mielessä Seppälän haastatteluissa esittämä toteamus, jonka mukaan hänen omat romaaninsa lähtevät yksilöiden kokemuksista ja sosiologit puolestaan yleistyksistä, vaatii täsmennystä. Yksilöiden kokemusta nykykapitalismista täydentävät hänen romaaneissaan kuvaukset kapitalismista erityislaatui- 
sena järjestelmänä, joka noudattaa omaa toimintatapaansa tai systeemirationaalisuuttansa. Tällaiset kuvaukset eivät ole niinkään osa yksilöiden arkikokemusta, vaan ne ovat enemmänkin lähtöisin kapitalismin teoreettista reflektoimista harjoittaneesta älymystökulttuurista.

\section{Yhteenveto tutkimuskohteena olevista teoksista}

Tämä tutkimus on tarkastellut Seppälän vuosina 2000-20I2 ilmestyneitä teoksia dialogisen ja diskursiivisen kirjallisuuskäsityksen pohjalta. Tutkimus on siis lähtenyt siitä, että Seppälän teokset ottavat temaattisen käsittelyn kohteeksi sellaisia aiheita, jotka kulttuurin ja yhteiskunnan kehitys on tehnyt ajankohtaisiksi. Niitä ovat markkinavoimien eteneminen sekä vieraantuneisuuden, syrjäytymisen ja merkityksettömyyden kokemusten lisääntyminen yhteiskunnassa. Edellinen prosessi eli markkinoiden ja yksityiskapitalistisen yritystoiminnan toimintalogiikan leviäminen yhteiskunnan muille osa-alueille selittää hänen romaaneissaan paljolti muiden mainittujen ilmiöiden yleistymisen.

Tutkimuskohteena olevat romaanit on siten mahdollista käsitteellistää nykyaikaisiksi kertomuksiksi kapitalistisesta välinerationaalisuudesta ja sen aiheuttamista vaurioista yksilöille ja yhteisöille. Tältä pohjalta voidaan lopuksi laatia niistä yhteenvedonomainen kuvaus:

(I) Yhtiökumppanit, Paholaisen haarukka ja Mr. Smith ovat kirjallisuuden keinoin toteutettua reagointia yhteiskuntapolitiikassa I980- ja I990-luvulla tapahtuneeseen käänteeseen, jonka myötä yksityiskapitalistisen yritystoiminnan ja markkinavoimien toimintaedellytyksiä on merkittävästi parannettu. Samaan aikaan hyvinvointivaltiota on purettu ja markkinakapitalismin toimintatavat ovat levinneet yhteiskunnan muille osa-alueille, perinteisen talouden ulkopuolelle. Tämä murros muodostaa kyseisten romaanien historiallisen ja yhteiskunnallisen kontekstin.

(2) Edellä mainitut kolme romaania eivät ilmennä passiivisesti kohdassa (I) kuvattua yhteiskuntakehitystä. Niistä varsinkin Yhtiö- 
kumppanit ja Paholaisen haarukka voidaan käsittää sen ankaraksi kritiikiksi. Sama pätee Routavuoteen, jos kohta siinä kritiikin kohteena ei ole niinkään talous vaan poliittisella alueella tapahtunut muutos: kansallisten järjestelmien ja valtioyksikköjen suvereenisuuden väheneminen ja valtiota suurempien poliittisten yksikköjen (Euroopan unioni) merkityksen kasvaminen nykyisessä maailmanjärjestyksessä. Yhtiökumppanit, Routavuosi ja Paholaisen haarukka ovat siten osallistuneet aktiivisesti nykyistä yhteiskunnallista todellisuutta koskeviin diskursiivisiin kamppailuihin. Mr. Smithissä tällainen ulottuvuus on heikompi, mutta sekin kuuluu kriittisten kapitalismikuvausten piiriin.

(3) Kapitalismikuvausten alalajina rationalisaatiokriittiset romaanit käsittelevät kapitalistisen talousjärjestyksen toimintatapoja ja niiden aiheuttamia vaurioita yksilöille, yhteisöille ja yhteiskunnalle. Tämän I80o-luvun alkupuolella syntyneen romaanitradition edustajina Yhtiökumppanit, Paholaisen haarukka ja Mr. Smith painottavat sitä, että nykytalouden toimintatavat tuottavat yhteiskunnassa syrjäytymistä, vieraantuneisuutta, eksistentiaalisia kriisejä ja patologisia ilmiöitä. Yhtiökumppanit ja Paholaisen haarukka ovat tämän ohella moraliteetteja, kertomuksia siitä, millaista tuhoa yksilöille ja yhteisöille aiheutuu, kun yhteiskunnassa lähdetään seuraamaan "vääriä arvoja" tai kun kapitalistinen tulosajattelu nostetaan hallitsevaan asemaan yhteiskunnan arvopohjassa. Mr. Smith ei ole tässä mielessä moraliteetti, mutta se pyrkii osoittamaan, miten markkinoiden valta-asema aiheuttaa yhteiskunnassa erilaisia epäautenttisia elämisen ja käyttäytymisen muotoja. Lisäksi Paholaisen haarukka ja Mr. Smith sisältävät luokkakriittisen ulottuvuuden, näkemyksen siitä, miten nykykapitalismi tekee keskiluokasta prekariaatin (Saija Lehtonen) ja kurjistaa alemman työväenluokan (Jumalan Kyynel, Briscilla, Rane, Donald Southbrook).

(4) Toinen tutkimuskohteena olevien romaanien kannalta keskeinen traditio on eksistentiaalisia teemoja käsittelevä kirjallisuus. Se pohdiskelee, miten ihminen voisi merkityksellistää elämänsä, ole- 
massaolonsa ja asemansa maailmassa positiivisella tavalla. Seppälän romaaneissa kapitalismin toimintatavat aiheuttavat yksilöissä perustavanlaatuista eksistentiaalista turvattomuutta ja merkityskatoa. Tämä piirre on mukana kaikissa kolmessa tutkimuskohteena olevassa romaanissa. Teosten eksistentiaalinen tematiikka yhdistää niitä Seppälän varhaistuotantoon, varsinkin romaaneihin Silta (I988) ja Kuun nousu ja lasku (I999), joissa tätä tematiikkaa ei tosin käsitellä suhteessa kapitalismiin, vaan niissä sen yhteiskunnallisena kontekstina on lähinnä maaseudun rakennemuutos.

(5) Lisäksi Paholaisen haarukassa on mukana eksistentialistinen sivumotiivi, näkemys, jonka mukaan eksistentiaalista ahdistusta ja turvattomuuden tunnetta ei voida kokonaan poistaa edes yhteiskunnallisilla uudistuksilla, vaan tietyssä määrin ne kuuluvat inhimillisen olemassaolon luonteeseen. Tällainen motiivi ontologisoi eksistentiaalisen ahdistuksen ja vierauden kokemuksen. Se sisältyy myös Seppälän varhaistuotantoon, erityisesti novelliin "Taivaanranta" (I987b) ja romaaniin Sydänmaa (I994a), joissa se on keskeisemmässä asemassa kuin Paholaisen haarukassa.

(6) Nykykapitalismia kuvatessaan ja arvioidessaan tutkimuskohteena olevat romaanit nojautuvat länsimaisen yhteiskuntateorian traditioon, erityisesti Max Weberin ja Jürgen Habermasin näkemyksiin siitä, millainen modernille kapitalismille ominainen rationaliteetti on luonteeltaan. Näitä näkemyksiä Paholaisen haarukka täydentää Manuel Castellsin verkostoyhteiskunnan idealla ja Ulrich Beckin riskiyhteiskunnan teorialla, joiden avulla se kykenee ottamaan monipuolisemmin haltuun sen, mikä nyky-yhteiskunnassa on erityistä kapitalismin edeltäviin vaiheisiin nähden. Mr. Smithissä weberiläis-habermasilaista kapitalismikäsitystä täydentää puolestaan Karl Polanyin näkemys, jonka mukaan pyrkimys rajoittamattoman markkinayhteiskunnan toteuttamiseen johtaa yhteiskunnan lopulta aina vakaviin toimintahäiriöihin. Näin tutkimuskohteena olevat romaanit ovat vahvasti interdiskursiivisessa suhteessa länsimaisen yhteiskuntateorian traditioihin. Tätä ulottu- 
vuutta teoksissa tukee se, että monissa eri yhteyksissä ne kommentoivat kriittisesti uusliberalistista diskurssia ja yhteiskuntamallia tai asettavat ne ironian ja parodian kohteeksi.

(7) Metakirjallisella tasolla tutkimuskohteena olevat romaanit reflektoivat toistuvasti itseään erilaisten upotusten tai mise en abyme -rakenteiden avulla, ja samoin ne pohtivat kysymystä siitä, miten kirjallisuuden ja kulttuurituotannon asema on muuttunut yhteiskunnassa markkinallistumiskehityksen etenemisen myötä. Paholaisen haarukan metatasot käsittelevät lisäksi kysymystä siitä, miten kirjailijan tai taiteilijan luokka-asema ja hänen käyttämänsä ilmaisuvälineet vaikuttavat siihen, millaisen kuvan tai representaation yhteiskunnasta hän tuottaa. Mr. Smith sisältää puolestaan autofiktiivisen ulottuvuuden, jossa Juha Seppälä reflektoi varovaisella, monitulkintaisella ja ristiriitaisellakin tavalla omaa kirjailijuuttaan.

(8) Lajiteoriassaan Alastair Fowler (I997, I23-I29) puhuu "kvasigeneerisistä" kirjallisista ilmiöistä, jotka muistuttavat lajeja, mutta jotka eivät täytä kaikkia lajeille tyypillisiä piirteitä. Näihin ilmiöihin hän sijoittaa muun muassa kirjallisille virtauksille (klassismi, romantiikka, realismi, modernismi) ominaiset sisällölliset ja muodolliset tunnuspiirteet, "virtausten koodit". Tutkimuskohteena oleviin romaaneihin sisältyy realistinen tarkoitusperä, pyrkimys sanoa nykykapitalismista jotakin tärkeää ja paikkansapitävää, mutta ne eivät toteuta tätä pyrkimystä pelkästään perinteisen realistis-naturalistisen romaanin keinoin. Ne nojautuvat vahvasti myös modernismin ja postmodernismin kehittämiin ilmaisukeinoihin sekä erilaisiin kokeellisiin ratkaisuihin ja uudistuksiin. Tässä mielessä ne voidaan sijoittaa "modernin" tai "avantgardistisen" realismin piiriin - ja hieman yleisemmällä tasolla postmodernismista etääntyneeseen nykykirjallisuuteen, jossa ontologiset ja tieto-opilliset kysymykset ovat antaneet tilaa arvoja, kommunikaatiota ja subjektien itsetoteutuksen esteitä ja edellytyksiä koskeville teemoille. 
(9) Komposition ja etenemistavan näkökulmasta Yhtiökumppaneissa ja Paholaisen haarukassa on vahvasti teleologinen ja keskitetty rakenne. Vaikka näissä romaaneissa on useita eri tarinalinjoja, romaanien sisäistekijät kuljettavat keskeisiä tarinalinjoja määrätietoisesti kohti tiettyjen henkilöiden fyysistä tuhoutumista ja/tai psyykkistä romahtamista. Näin sisäistekijä, "virtaviivainen versio kirjailija Juha Seppälästä", näyttää, että markkinakapitalismin valtaanpääsy yhteiskunnassa aiheuttaa yksilöiden ja yhteisöjen elämässä tuhoa ja hävitystä. Tässä mielessä Yhtiökumppanit ja Paholaisen haarukka edustavat suhteellisen suljettua muotoa.

(Io) Kompositionsa ja etenemistapansa osalta Mr. Smith poikkeaa Yhtiökumppaneista ja Paholaisen haarukasta. Sen näkemys nykykapitalismista on sinänsä osittain samanlainen kuin näiden kahden romaanin eli senkin mukaan nykykapitalismi perustuu välineelliseen rationaalisuuteen ja suhteellisen indifferenttiin toimintatapaan. Edeltäjistään - lähinnä Paholaisen haarukasta - Mr. Smith poikkeaa kuitenkin siinä, että se ei esitä nykyistä markkinakapitalismia totaaliseksi koneistoksi, joka hallitsee raudanlujin ottein kaikkia yhteiskunnan osa-alueita sekä yksilöiden elämismaailmoja ja mieliä. Mr. Smithin mukaan yksilöillä on tietty riippumattomuutensa ja itsenäisyytensä kapitalismin lakeihin nähden, vaikka heidän yhteiskunnallinen asemansa määrääkin heidän elämänsä suuret linjat. Siksi ankarasti teleologinen ja keskitetty kompositio ja etenemistapa antaisivat väärän kuvan yksilöiden toimintamahdollisuuksista nyky-yhteiskunnassa. Lisäksi Mr. Smithin komposition väljyyttä ja sen etenemistavan polveilevuutta voi selittää sillä, että näiden piirteiden tehtävänä on ilmentää eksistentialistista filosofiaa lähellä olevaa ja modernistiselle kirjallisuudelle ominaista näkemystä elämän epätäydellisyydestä ja keskeneräisyydestä. Näissä suhteissa Mr. Smithin muoto on avoimempi kuin Seppälän muiden kapitalismia kritisoivien romaanien. Seppälän tuotannossa Mr. Smith on myös sikäli välittäjän asemassa, että kirjailijasubjektin itseilmaisua ja tekijyyttä koskevat teemat yhdistävät sitä romaaneihin Matka aurinkoon (20I4) ja Kuoppakaupunki (2016). 
(II) Kapitalismin asema ja vaikutusala ei ole tutkimuskohteena olevissa romaaneissa vakioinen. Paholaisen haarukka luo oman aikansa yhteiskunnasta poimimiensa ainesten ja spekulatiivisille fiktiolle ominaisen kärjistämislogiikan keinoin dystooppisesti sävyttyneen kuvan siitä, millaista nykytietämyksen valossa on tai olisi elämä läpikotaisin markkinallistuneessa yhteiskunnassa. Mr. Smith etääntyy tällaisista dystooppisista sävyistä, mutta sekään ei esitä visiota siitä, miten yhteiskunta pitäisi järjestää. Seppälän romaanit ovat siten kapitalismikritiikkiä vailla eksplisiittistä utopistista perspektiiviä, kapitalismikritiikkiä vailla kuvaa siitä, millainen nykykapitalismin korvaava yhteiskuntajärjestys olisi. Silti Seppälän tuotannolle on ominaista kaipuu sellaiseen elämänmuotoon, jossa markkinakapitalismin vaikutusalaa yhteiskunnassa on huomattavasti rajoitettu. Niinpä muun muassa novellissa "Mustalla saarella" (2000b) perinteinen maaseutumainen elämänmuoto näyttäytyy autenttisen elämäntavan mahdollistajana. Briscillan ja Ranen välisen rakkaussuhteen ja Donald Southbrookin henkilöhahmon käsitteleminen Mr. Smithissä viittaa niin ikään asetelmaan, jossa autenttisuuden saavuttaminen on mahdollista vain silloin, kun ihmisten keskinäiset suhteet eivät perustu toisen osapuolen välineellistämiseen.

(I2) Lajiteoriassaan Fowler (I997, I23-I29) sijoittaa myös kirjailijalle ominaisen "koodin" kvasi-geneeristen ilmiöiden piiriin. Kirjailijalle ominaisen koodin muodostavat hänen tuotannossaan toistuvat muodolliset ja sisällölliset ratkaisut. Muodollisessa mielessä Seppälän romaanit ovat I990-luvun puolivälistä, Sydänmaasta (I994a) lähtien rakentuneet samanlaisen poetiikan varaan. Se perustuu käsitykseen, että myöhäismodernissa yhteiskunnassa ei ole enää mahdollista kirjoittaa kokoavia kansallisia romaaneja, "suuria kertomuksia", sillä yhteisesti jaetun kokemismaailman sijaan kokemusmaailmat ovat nykyisin eriytyneet erilaisiin osakulttuureihin ja yksilöllisiin kokemistapoihin. Tämän käsityksensä Seppälä on tuonut esiin myös lehtikirjoituksissaan. Hänen romaaneilleen on siten ominaista kertojien, fokalisoijien, tarinalinjojen ja aikatasojen 
moninaisuus. Näin hän tarjoaa lukijoilleen erilaisista tarkastelupisteistä laadittuja, lähes kaleidoskooppisia näkymiä romaaneissa kuvattuihin maailmoihin. Seppälän rationalisaatiokriittiset romaanit eivät siten kuvaa yhteistä kansallista kokemusta nykykapitalismista vaan erilaisissa yhteiskunnallisissa asemissa olevien ihmisten tapaa kokea se. Näitä kaikkia kokemistapoja muokkaa silti markkinakapitalismille ominainen välinerationaalisuus ja sille ominainen suhteellisen indifferentti toimintatapa, jotka tuottavat henkilöissä erilaisia epäautenttisuuden ja vieraantuneisuuden muotoja. Toisaalta Seppälän romaanien välittämä kuva erilaisista maailman kokemistavoista on sikäli kapea, että romaaneista puuttuvat paljolti menestyvät ja hyvin elämäänsä hallitsevat henkilöt.

(I3) Kapitalismille ominaisen välinerationaalisuuden kritiikki on tässä tutkimuksessa käsitetty kulttuuriseksi arkkitekstiksi. Sellaisena se ei ole pelkästään kirjallisuuden laji, vaan se ilmentää myös länsimaisen kulttuurin maailmankuvaa, siihen pesiytynyttä epäluuloa kapitalismia ja markkinavoimia kohtaan. I8oo-luvun alkupuolelta lähtien tämän kulttuurisen arkkitekstin sisältämää näkemystä kapitalismista ovat ensi sijassa kehittäneet kapitalismikriittiset yhteiskunnalliset liikkeet ja erilaiset kirjailijoista, taiteilijoista ja yhteiskuntateoreetikoista koostuvat älymystökulttuurit. Kyseinen käsitys ei siis ole ollut työväenliikkeen ja poliittisen vasemmiston yksinoikeutta, vaan sitä ovat Karl Marxin, Alan Tourainen, Theodor W. Adornon, Max Horkheimerin, Herbert Marcusen ja Jürgen Habermasin ohella kehittäneet myös muista yhteiskunnallisista ryhmistä lähtöisin olevat ajattelijat, esimerkiksi Max Weberin, Daniel Bellin, Amitai Etzionin, G. H. von Wrightin ja Martha C. Nussbaumin kaltaiset "porvarilliset" sosiologit ja filosofit. Siinä, missä poliittinen vasemmisto on perinteisesti pyrkinyt pohjaamaan yhteiskunnan moraalis-sosiaalisten arvojen (solidaarisuus, yhteisvastuu) varaan, kapitalismiin kriittisesti suhtautuvat kristillis-fundamentalistiset ja kansallis-fundamentalistiset liikkeet ovat halunneet antaa yhteiskunnan arvopohjassa keskeisen sijan kristillisille ja äärikansallisille arvoille. Jälkimmäisistä, funda- 
mentalistisista ryhmistä Seppälän romaanit (Routavuosi, Sankariaika) sanoutuvat selvästi irti.

(I4) Tämän laajan kapitalismikriittisen muodostuman edustajista työväenliike kiinnitti perinteisesti ensi sijassa huomiota kapitalismin aiheuttamaan sortoon ja eriarvoisuuteen. Nämä samat teemat ovat olleet esillä kirjailijoiden ja yhteiskuntateoreetikkojen kehittämissä näkemyksissä, joissa on pidetty esillä myös kapitalismiin liittyviä epäautenttisuuden ja merkityksettömyyden kokemuksia. Tämän nojalla Seppälää voi pitää ensi sijassa älymystöläisenä kapitalismikriitikkona, jonka romaanit keskittyvät ylempien luokkien kuvaamiseen ja merkityskysymyksiin. Nykykapitalismissa tilanne on kuitenkin muuttunut perinteisen kapitalismikritiikin ajoista. Nykykapitalismiin liittyvä epävakaus, erilaisten turvainstituutioiden rapautuminen ja kapitalismin toimintatapojen leviäminen yhteiskunnan eri osa-alueille ovat tehneet merkitystä ja mielekkyyttä koskevat teemat yhteiskunnassa laajalti ajankohtaisiksi. Seppälän romaanit eivät näin ajatellen ole pelkkää älymystöläistä itsetutkiskelua, vaan ne koskettavat muitakin luokkia ja ryhmiä nyky-yhteiskunnassa. Silti näissä romaaneissa nykykapitalismin pääongelma ei ole niinkään siinä, että se tuottaa sortoa ja eriarvoisuutta, vaan pikemminkin siinä, että se levittää yhteiskuntaan merkityksettömyyttä, epäautenttisuutta ja henkistä kurjuutta.

(I5) Seppälän yksilölliseen kirjailijakoodiin kuuluvat myös hänen tapansa käyttää kieltä ja hänen teoksilleen ominaiset tyylilajit ja sävyt. Vaikka olen tutkimuksessani toisinaan puhunut Seppälän romaaneille ominaisesta minimalistisesta ja lakonisen toteavasta kielenkäytöstä ja hänen teoksiaan hallitsevista synkistä sävyistä, ovat nämä tyyliseikat jääneet järjestelmällisen tarkastelun ulkopuolelle. Niiden selvittämisessä tarvitaan metodiikkaa, joka poikkeaa monilta osin tässä tutkimuksessa käytetystä metodiikasta. 
Siinä, missä Yhtiökumppanit esittää informationaalisen nykytalouden välineellisen järjen läpäisemäksi ja työntekijöidensä kannalta tuhoisaksi muodostumaksi, Paholaisen haarukan kärjistyksiin perustuvassa fiktiivisessä maailmassa välinerationaalinen toiminta ja sen kielteiset seuraukset ovat levinneet lähes kaikkialle yhteiskuntaan. Toteuttamansa avoimemman ja väljemmän romaanimuodon avulla $\mathrm{Mr}$. Smith onnistuu välttämään jälkimmäiseen romaaniin sisältyvät maailmankuvalliset ja romaanipoeettiset ongelmat. Tämän uuden käsityksen mukaan nykykapitalismi määrää yksilöiden elämän yleiset puitteet, mutta sellaisenakin se jättää jonkin verran tilaa heidän aidolle, omaehtoiselle toiminnalleen. Se ei siten sulje kokonaan pois yksilöiden autenttista ja moraalisessa mielessä hyväksyttävissä olevaa itsetoteutusta.

Kyseiset romaanit, lähinnä Yhtiökumppanit ja Paholaisen haarukka, yhdistävät toisiinsa länsimaisessa älymystökulttuurissa kehitetyn kapitalismikäsityksen ja diskursiivisen kirjallisuuskäsityksen. Yhdistäminen antaa tulokseksi kirjallisuutta, joka ottaa aktiivisesti kantaa markkinallistumiskehitykseen ja osoittaa erilaisten kärjistysten avulla sen, millaisia ongelmia ja riskejä tuo kehitys sisältää. Tässä yhteydessä on syytä huomauttaa siitä, että vaikka teoriaa kapitalistisesta rationalisaatiosta on työstetty erityisesti Frankfurtin koulun piirissä, koulun edustajat torjuivat tavallisesti vaatimuksen, että taiteen tulisi heittäytyä aktiivisesti mukaan yhteiskunnassa käytäviin kamppailuihin. Tämän sijasta Adorno, Marcuse ja Habermas painottivat taiteen autonomiaa ja erityislaatua. Niinpä Adorno asetti poliittisen taiteen, esimerkiksi brechtiläisen teatterin, vastapainoksi autonomisen taideteoksen idean, sillä "kaikkein sublimoiduimmissakin taideteoksissa piilee epäsuorasti vaatimus 'Asioiden täytyy olla toisin'” (Adorno I980a, I34-I35). Omia esteettisiä ja kompositionaalisia periaatteitaan noudattava autonominen taideteos on vapaa tendensseistä ja riippumaton ulkoisesta poliittisesta ja taloudellisesta ohjailusta. Siihen sitoutumista Adorno piti epäsuorana yhteiskunnallisena valintana, sillä jo pelkällä olemassaolollaan taideteos osoittaa, että inhimillinen maailma on mahdollista järjestää toisin kuin vallitseva yhteiskuntajärjestys sen tekee. Siksi taideteoksen ei tarvitse sisältää mitään poliittista sanomaa tai konkreettista utopistista visiota siitä, miten yhteiskunta tulisi järjestää. Poliittisen ja utopistisen taiteen ongelma on 
Adornon (I966, 356) mukaan siinä, että se välineellistää maailman eli alistaa erilaiset asiat ja omat osatekijänsä omaksumansa poliittisen tai utopistisen vision toteuttamisen välikappaleiksi. ${ }^{\mathrm{I} 3}$

Yhtiökumppaneiden ja Paholaisen haarukan teleologinen rakenne ja etenemistapa noudattavat paljolti juuri sellaista välineellistävää romaanilogiikkaa, jota Adorno vierasti. Niiden kummankin etenemistapa palvelee sen osoittamista, että markkinallistumiskehitys johtaa yksilöt ja yhteisöt vääjäämättä kriiseihin ja katastrofeihin. Ne edustavat siten tässä mielessä yhteiskunnallisesti aktiivista ja "osallistuvaa" kirjallisuutta. Tämän suuntainen näkemys kirjallisuuden tehtävästä yhteiskunnassa oli myös ı960-luvun jälkipuoliskon ja I970-luvun suomalaisessa kirjallisuudessa tavallinen ilmiö, josta monet tuolloin toimineet kirjailijat kehittivät oman versionsa. (Ks. Arminen 2009; Peltonen 20I0; Söderling 2008.) Tässä suhteessa Yhtiökumppanit ja Paholaisen haarukka ovat tukevasti ankkuroituneet edeltävään suomalaiseen kirjallisuuteen. Seppälän tapauksessa on lisäksi syytä tuoda esiin se, että kirjassaan Qu'est-ce que la littérature? (I948) Sartre, omaksumansa julkisen intellektuellin roolin mukaisesti, oli niin ikään puolustanut kirjailijan sitoutumista yhteiskunnallisen oikeudenmukaisuuden edistämiseen. Sartren näkemykset ihmisen eksistentiaalisesta vapaudesta ja kirjailijan yhteiskunnallisesta vastuusta herättivätkin toisen maailmansodan jälkeisinä vuosikymmeninä laajalti mielenkiintoa suomalaisten kirjailijoiden keskuudessa. Sartren myöhäistuotannolle ja Seppälän kapitalismikriittisen kauden teoksille yhteistä on myös pyrkimys arvioida sitä, millaisia autenttisen itsetoteutuksen edellytyksiä yhteiskunnan rakenteet, normit ja toimintatavat kulloinkin subjekteille tarjoavat.

Vuoden 20 I2 jälkeen ilmestyneissä Seppälän teoksissa kapitalismin ja rationalisaation teemat eivät ole näkyvästi esillä, vaikka Matka aurinkoon (20I4), Kuoppakaupunki (20I6) ja Sankariaika (20I8a) sisältävät viittauksia niihin. Matka aurinkoon (20I4) tuokin hieman lisävalaistusta rationaalisuuden teemaan Seppälän tuotannossa. Sen eräissä yhteyksissä tarinamaailman ulkopuolinen kertoja pohtii syitä siihen, miksi Eurooppa on nykyisin "kriisissä". Hänen mukaansa kriisin syyt eivät ole ensi sijassa luonteeltaan taloudellisia: 
Eivät ilmastonmuutos, Euroopan unioni, globalisaatio, ahneet pankkiirit ja finanssikonsernit, maahanmuuttajat, muslimit, terroristit, järjestäytyneet rikollisryhmät, persut, tuloerot, työttömät tai syrjäytyneet nuoret - - ole suurin uhka kansakunnalle. Eurooppa on ollut kriisissä I700-luvulta lähtien, jo Rousseaun Emile julisti Euroopan astuneen "kriisin aikakauteen", merkitysten kadottamisen aikaan; ei, eurooppalaisen kriisin juuret oli johdettu jo Galilein ja Descartesin ajattelun yksipuolisuuteen, maailman typistämiseen teknisen ja matemaattisen tutkimuksen kohteeksi. (Seppälä 20I4, IIO.)

Katkelmassa kertoja esittää epäsuorasti rationalisaatiokritiikkiä, mutta hän ymmärtää rationalisaation yleisemmällä tavalla kuin se ymmärretään Seppälän vuosina 2000-20I2 ilmestyneissä teoksissa. Kertojalle rationalisaatiota on maailman kvantifioiminen, sen muuntaminen numeerisesti ilmaistavissa oleviksi suureiksi ja suhteiksi ja näin saadun tiedon soveltaminen teknologiaan ja yhteiskunnallisiin käytäntöihin. Juuri tällainen rationaalisuuden muoto on kertojan mukaan hallinnut modernia sivilisaatiota. "Moderni oli marssia vankilaan, aloimme olla perillä" (Seppälä 20I4, I80), hän toteaa eräässä yhteydessä tavalla, joka tuo mieleen jälkistrukturalistien esittämän rationalisaatio- ja modernisaatiokritiikin. Yhteyttä jälkistrukturalismiin vahvistaa se, että romaanin mottona on monimielinen lausuma Michel Foucault'n teoksesta Tiedon arkeologia (2005, ranskankielinen alkuperäisteos ilmestyi I969).'144

Matka aurinkoon ymmärtää siis rationaalisuuden laajemmin kuin Yhtiökumppanit, Paholaisen haarukka ja Mr. Smith. Kolmessa jälkimmäisessä romaanissa kritiikin kohteena on lähinnä markkinakapitalistinen toimintarationaalisuus, kun taas Matka aurinkoon pitää modernia tiedettä, teknologiaa ja kapitalistista taloutta yhden ja saman rationalisaatioprosessin ja siihen liittyvän maailmankatsomuksen ilmentyminä. Kirjassaan Myten om framsteget (I993) G. H. von Wright puhuu niin ikään siitä, että modernin tieteen, teknologian ja talouden muodostamaa "teknosysteemiä" hallitsee välineellinen järki ja paljolti juuri se on syypää nykyisiin yhteiskunnallisiin ja ekologisiin ongelmiin. Matka aurinkoon -romaani tulee hyvin lähelle myös tällaista, wrightiläistä rationalisaa- 
tiokritiikkiä. Sen suuntainen rationalisaation konseptio on kyseisen romaanin mukaan juurtunut niin syvästi länsimaiseen kulttuuriin, että sitä eivät välttämättä horjuta edes poliittisella tasolla tapahtuvat muutokset. "Käytännössä vallankumous kesti tätä nykyä pari viikkoa, sen ajan kun nuoret miehet ajelivat ympäri kaupunkia ilmaan ampuen ennen kuin vanhat miehet jatkoivat vallassa entiseen malliin, korkeintaan eri nimisinä, yksikään vallankumous ei ollut kumonnut valtaa”, toteaa Matka aurinkoon -romaanin kertoja (Seppälä 20I4, I9O). Konkreettisesti oheinen sitaatti viittaa lähinnä arabikevään (20IO-20II) tapahtumiin, mutta laajemmin ajatellen se ilmentää kertojan omaksumaa epäuskoa siihen, että nykyisiä yhteiskuntia voitaisiin muuttaa ratkaisevalla tavalla poliittisten vallankumousten kautta. Tällaiset kumoukset eivät välttämättä koskettaisi lainkaan yhteiskunnan perustaa ja siihen lujasti juurtunutta rationaalisuuden konseptiota.

Sankariajassa yhteys Seppälän kapitalismikriittisen kauden teoksiin löytyy sitä kautta, että siinä Seppälä palasi osittain takaisin yhteiskunnassa käynnissä olevien diskursiivisten kamppailujen äärelle. ${ }^{\mathrm{I} 5}$ Sen pääteema - kysymys siitä, miten kansallinen arvo- ja symbolimaailma on Suomessa muotoutunut ja keillä on nykyisin oikeus esiintyä tuon perinteen jatkajana - ei ole tosin suoraan yhteydessä rationalisaatio-teemaan, mutta toisaalta se ei myöskään ole irrallinen kapitalismia koskevista kysymyksistä. Boltanski ja Chiapello (I999, 6I9-620) toteavat kapitalismikritiikin yhdeksi ongelmaksi sen, että nykytilanteen sijasta kritiikki kohdistuu usein kapitalismin ohitettuihin vaiheisiin tai sen aiempiin muotoihin. Tällaista kritiikkiä Boltanski ja Chiapello luonnehtivat anakronistiseksi. Se on heidän mukaansa ongelmallista siksi, että se kohdistuu osittain väärään kohteeseen ja siksi sentyyppinen kritiikki saattaa vaikeuttaa kapitalismin nykymuotojen ymmärtämistä. Chiapello (20I3) on lisäksi puhunut siitä, että äärioikeiston ja populistisen nationalismin voimistuminen tulee ympäristökysymyksen ohella olemaan yksi keskeinen aihe lähitulevaisuuden yhteiskunnallisissa keskusteluissa. 2020-luvun kynnyksellä uusliberalistinen maailmanjärjestys onkin saanut varteen otettavan vastustajan liikkeistä, jotka nojaavat vanhakantaiseen nationalismiin ja (puoli)autoritaarisen hallitsemistavan ideoihin. Niiden analysoiminen on haaste sekä yhteiskuntatieteille että kirjalli- 
suudelle. Nähtäväksi jää, tulevatko Seppälän kaunokirjalliset teokset osallistumaan tulevaisuudessa laajemmin näihin keskusteluihin ja kamppailuihin.

\section{Yksilölliset ja henkilökohtaiset utopiat}

Kuten edellä todettiin, Seppälän kapitalismikriittisistä romaaneista ei ole mahdollista johtaa konkreettista visiota siitä, miten yhteiskunta tulisi järjestää, vaikka ne viittaavatkin siihen, että markkinoiden valtaa yhteiskunnassa tulee rajoittaa. Silti hänen vuosina 2000-20I2 ilmestyneihin teoksiinsa sisältyy yksilöllisempiä ja henkilökohtaisempia ihannetilan kuvauksia. Tässä suhteessa avainasemassa ovat kokoelmaan Mitä sähkö on? (2004a) sisältyvät kertomukset "Mitä sähkö on?" (2004C) ja "Kimalaisen hunajaa" (2004d), joissa molemmissa kertojat esittävät maaseutumaisen elämänmuodon autenttisena tilana. Samoin nuo kertomukset kuljettavat mukanaan uskontoon liittyviä teemoja ja motiiveja. Seppälän tuotannossa ne ovat sikäli poikkeuksellisia tekstejä, että niiden kertojat näyttäisivät - ainakin tekstin pintatasolla - saavuttaneen yhteyden siihen mysteeriin tai kosmiseen järjestykseen, jonka olemassaolon Seppälän muut teokset toistuvasti kieltävät.

Kokoelman Mitä sähkö on? alaotsikkona on "Novelleja". Se soveltuu luonnehtimaan pääosaa kokoelman kuudesta tekstistä, mutta kertomusten "Mitä sähkö on?" ja "Kimalaisen hunajaa" ominaisluonnetta se ei tavoita. Kertomuksesta "Mitä sähkö on?" puuttuvat henkilöt ja juonellinen toiminta. Se muodostuu kokonaan anonyymin minäkertojan pohdiskeluista. Konkreettisella tasolla nuo pohdiskelut koskevat kysymystä siitä, mitä sähkö on, mutta abstraktimmassa mielessä niissä määritetään armoa. "Me luulemme tietävämme koko ajan, mitä sähkö on. Me käytämme sitä koko ajan. Me emme tiedä siitä paljon. Suurin osa meistä ei käsitä elävänsä täysin sähkön varassa. Me emme käsitä, että se merkitsee samaa kuin armo.” (MSO, I76.)* Vaikkei kertomus sisällä suo-

* Käytän tässä pääluvussa novellista "Mitä sähkö on?" lyhennettä MSO silloin, kun siteeraan sitä tai viittaan siihen muuten sivunumeroiden tarkkuudella. 
ria lainauksia kristillisestä teologiasta, tässä kohden voidaan todeta, että kristillisessä teologiassa armon ajatellaan mahdollistavan ihmisen persoonallisen eheytymisen. Nöyrtyessään vastaanottamaan Jumalan rakkauden, syntien anteeksiannon ja lupauksen kuoleman jälkeisestä elämästä armontilassa oleva ihminen vapautuu häpeän ja syyllisyyden taakasta ja kykenee ottamaan paremmin käyttöönsä omat henkiset ja hengelliset voimavaransa. ${ }^{146}$ Siksi ihmiset voivat tosiasiassa elää vain armon varassa. "Meidän elämässämme kaikki perustuu sähköön, emmekä me tiedä mitä se on. Joskus ajattelen, että se on vain yksi Jumalan tapa ilmaista itseään", toteaa kertoja (MSO, I77). Kyseisen kertomuksen yhtenäisyys on siten lähinnä temaattista.

Sivujuonteena "Mitä sähkö on?" sisältää näkemyksen siitä, että perinteisen agraarisen elämänmuodon hiipumisen myötä ihmiset ovat etääntyneet yhteydestään armoon:

Kun aloitin, varsinkin maaseudulla sähkö oli ihmisille itsestään selvä asia. Ne tunsivat sen omalla kohdallaan. Vanhat naisetkin osasivat tehdä sähkötöitä. Pienissä pitäjissä oli pieniä sähköyhtiöitä, joku maanviljelijä hoiti muuntoasemaa oman työnsä lomassa. Niillä ihmisillä oli mutkaton suhde sähköön, ne eivät miettineet mitä se oli. (MSO, I6r.)

Samanlainen suhde linnuilla on "korkeampaan voimaan". Uskonsa perusteella ne tietävät sen, milloin ne voivat turvallisesti istahtaa sähkölangoille: "Linnut ovat autuaita, ne uskaltavat koska uskovat. - - Ne tietävät paikkansa kaikkeuden järjestyksessä. Ne ovat turvassa niin kauan kuin ne elävät sen mukaan. Ihmiset eivät osaa.” (MSO, ı6ı.) Ihmisiltä tällainen välitön suhde korkeampaan järjestykseen on kadonnut. Kertojan mukaan tämä on seurausta siitä, että entisestä maaseutuyhteiskunnasta on siirrytty nykyiseen kilpailuyhteiskuntaan: "Meidät häpäistään sillä, että me emme enää kunnioita mitään, että meidät on alistettu osaksi tätä kasvotonta ja aivotonta tuloksentekokoneistoa" (ibid., I66). ”Mitä sähkö on?" sisältää siten ohuen markkinakriittisen ulottuvuuden, mutta kertoja ei kehittele sitä pidemmälle. Sen sijaan hän antaa ymmärtää, että myös hänen oma suhteensa Jumalaan on jossain määrin ambivalentti: 
"Suurta voimaa pelkään aina, mutta samalla se vetää minua puoleensa, ja tiedän että minulla ei ole vaihtoehtoja. Minun on lähestyttävä sitä elämäni loppuun asti” (ibid., I63-164).

Tässä kertomuksessa maaseutumainen elämäntapa näyttäytyy kulttuurimuotona, jossa ihminen saattoi olla luonnollisella tavalla yhteydessä korkeampaan järjestykseen. Kertoja ei kuitenkaan esitä sitä minään ratkaisuna nykyisiin yhteiskunnallisiin ongelmiin. Vielä henkilökohtaisempi sävy on kertomuksella "Kimalaisen hunajaa". Sitä voidaan lukea joko omaelämäkerrallisena tai autofiktiivisenä tekstinä - tai pikemminkin näitä kahta lukutapaa yhdistellen. Omaelämäkerrallisia tekstejä koskevan "autobiografisen sopimuksen" mukaan omaelämäkerrallisissa teksteissä kirjailija, kertoja ja päähenkilö ovat yksi sama henkilö, ja tavallisesti tällainen teksti kertoo retrospektiivisesti sen, miten päähenkilö kehittyi sellaiseksi ihmiseksi kuin hän tekstin kirjoittamishetkellä on. Siten ero kertovan ja kokevan minän välillä on omaelämäkerroissa tärkeä, sillä niissä nykyisyydessä elävä kertoja pyrkii luomaan vaikutelman, että hän tavoittaa oman kokemusmaailmansa osapuilleen sellaisena kuin se oli hänen varhaisemmissa elämänvaiheissaan. Silti omaelämäkerrallisen tekstin kirjoittaja ei tule teksteissään esiin sellaisenaan, "arkiminuudessaan", vaan pikemminkin omaelämäkerrallinen minä on tyylitelty versio kirjoittajan "todellisesta" tai empiirisestä minästä. Autofiktiivinen teksti sisältää puolestaan vihjeen siitä, että kirjailija puhuu siinä itsestään, mutta ilman kirjailijaa koskevia taustatietoja lukija ei voi tietää, mikä kaikki tekstissä tarkkaan ottaen on omaelämäkerrallista ainesta ja mikä fiktiivistä. ${ }^{\text {I47 }}$

"Kimalaisen hunajaa" häilyy näiden kahden kertomustyypin välillä. Sen päähenkilö ja minäkertoja voidaan käsittää kirjailija Juha Seppäläksi, vaikka minäkertoja ei esittele ja nimeä siinä itseään. Kuitenkin se informaatio, jonka kertoja itsestään ja suvustaan antaa, vastaa pääkohdissa sitä, mitä Seppälä on kertonut itsestään ja suvustaan muissa teksteissään (ks. Seppälä ı99od; I998, 6-Io). Toisaalta kyseinen kertomus tarjoaa näistä asioista niin yksityiskohtaisia tietoja, että niiden todenperäisyyden tarkistaminen edellyttäisi usein esimerkiksi teemahaastattelujen tekemistä Seppälästä. Koska se ei ole käytännössä mahdollista tässä tutkimuksessa, käsittelen "Kimalaisen hunajaa" -tekstiä kertomuksena, joka häilyy omaelämäkerrallisen ja autofiktiivisen tekstin välillä. 
"Kimalaisen hunajassa" minäkertoja liikkuu isovanhempiensa entisillä mailla. Maiden sijaintia ei mainita, mutta Seppälää koskevien elämäkertatietojen perusteella kyseessä olisi Karvian kunta, joka sijaitsee Pohjois-Satakunnan itäisessä kolkassa lähellä Etelä-Pohjanmaan ja Hämeen maakuntien rajoja. Ilmeisesti kertomuksen konkreettisena lähtökohtana on tilanne, jossa Seppälä on aikeissa myydä isovanhemmilleen aikoinaan kuuluneen maapalstan. Tähän viittaa kertojan toteamus "minä myyn tämän maan enkä tiedä mitä minulle tapahtuu. Siitä mikä on tärkeää on päästettävä irti” (KH, 2OI). " Luopuminen koskee kuitenkin vain kyseistä maapalstaa. Sitä vastoin isovanhempiinsa liittyvistä muistoista kertoja ei halua eikä voi päästä eroon, sillä ne ovat erottamaton osa hänen identiteettiään.

Seppälä asui vuodesta I962 vuoteen I970 asti isovanhempiensa naapurissa. Noina vuosina hänen ja isoisän välille muodostui läheinen side: "Sinun tehtäväsi oli olla isoisä. Se oli rakennettu sisääsi. Sinua ei ole ollut kolmeenkymmeneen vuoteen ja silti se mitä välillämme oli on ainut asia mitä ihmiset elämässään etsivät. Osaanko minä näyttää lapsenlapsilleni miten nokkosta vedetään sen polttamatta, tiedänkö missä on siilin koti?” (KH, I96.) Seppälä muistaa isoisänsä ihmisenä, joka välitti hänelle oman, maaseutuyhteiskunnassa tarvittavan kulttuurisen ja kädentaidollisen tietämyksensä ja jonka rakkaus häntä kohtaan oli varauksetonta. Osaltaan tästä syystä hän koki saavuttaneensa tuolloin persoonallisen eheyden tunteen:

Isoisän huoneet, pihan puut, pellot, perunamaa. Niissä minä olin ehjä ja täydellinen, haavoittumaton. Se ei ole mikään lattea sosiologinen kannanotto maalaisuuden puolesta kaupunkilaisuutta vastaan, vaan jotakin väistämätöntä, jotakin mistä ihminen on pääsemättömissä. Kuin aurinko joka on kaikkialla ja jonka säde on kerran lävistänyt sinut pohjaan asti, hetkellä jota et voi valita. Siksi on lähdettävä. (KH, 2OI.)

* Käytän tässä pääluvussa kertomuksesta "Kimalaisen hunajaa" lyhennettä KH silloin, kun siteeraan sitä tai viittaan siihen muuten sivunumeroiden tarkkuudella. 
Isoisä ja lapsuuden elämismaailma maaseudulla muodostavat kuitenkin vain yhden, tosin keskeisen ulottuvuuden "Kimalaisen hunajan" maailmassa. Toisen ulottuvuuden muodostaa kertojan tietoisuus siitä, että "jotakin minussa särkyi" kaupunkiin muuttamisen jälkeen (KH, I94). Myöhemmin aikuisiässä tätä eheyden tunteen menettämistä syvensi tietoisuus siitä, että "olen hukannut itseni rahatalouteen, kasvuun, riippumattomuuteni varjelun illuusioon" (ibid., I95). Näin "Kimalaisen hunajakin" toistaa Seppälän tuotannossa I980-luvun jälkipuolelta lähtien tietyin väliajoin esiintyvän motiivin, temaattisen vastakohdan perinteisen maaseutumaisen elämänmuodon ja nykyisen kaupunkikeskeisen, muodollista koulutusta painottavan ja markkinasuuntautuneen elämäntavan välillä. Edellinen ei aina edusta hänen teoksissaan autenttista elämämuotoa, sillä esimerkiksi Sydänmaan (I994a) välittämä kuva köyhien ihmisten elämästä I800- ja I900-luvun Suomessa on lohduton ja lievemmässä muodossa myös Kuun nousu ja lasku (I999) sisältää samansuuntaisia, synkkiä piirteitä. Mutta toisaalta Seppälän teoksiin sijoittuvat harvat autenttisen olotilan kuvat sijoittuvat juuri maaseutuympäristöön. Se edustaa hänen teoksissaan usein menetettyä autenttista elämänmuotoa, jonka vastakohtana on vieraantuneisuutta huokuva urbaani elämäntapa.

Keskeiset intertekstit "Kimalaisen hunajassa" ovat Albert Camus'n postuumisti ilmestynyt romaani Ensimmäinen ihminen (I995, alkuperäisteos ilmestyi vuonna I994) ja Raamattu. Camus'n vahvasti omaelämäkerrallinen teos kertoo algerianranskalaisesta Jacques Comerystä, joka eli lapsuutensa Algerin köyhälistökortteleissa, mutta jonka lahjakkuuden hänen kansakoulunopettajansa huomasi ja järjesti hänet lukioon. Tätä kautta Jacquesille avautui tie kirjojen ja sivistyksen maailmaan. "Kimalaisen hunajan" kertoja samaistuu voimakkaasti Camus'n romaanin kuvaamaan asetelmaan: "Camus'n aurinko hehkuu Algerian taivaalla, mutta se on kirja isoisästä ja minusta" (KH, I93). Yksi "Kimalaisen hunajaa" ja Ensimmäistä ihmistä yhdistävistä tekijöistä on vieraantuminen lapsuuden aikaisesta sukuyhteydestä. Siirtyessään tiedon, koulutuksen ja korkeakulttuurisen sivistyksen pariin molempien teosten päähenkilöt ovat joutuneet etääntymään lähisukulaistensa muodostamasta yhteisöstä, johon he ovat olleet syvästi kiintyneitä. Etääntymistä on voimistanut 
vielä se, että luokkaulottuvuudella he ovat siirtyneet maailmaan, joka on paljolti vieras heidän suvulleen. Siksi he kärsivät vielä aikuisiässäkin perustavasta juurettomuuden ja menetyksen tunteesta.

"Kimalaisen hunajaa" ei silti ole synkkä kertomus. Pikemminkin se on sävyltään intiimi ja nostalginen ja tyylilajiltaan lyyrinen. Sen toiveikas lopetus toistaa miltei sanatarkasti Luukkaan evankeliumin loppujakeet, joissa Jeesus ilmestyy ylösnousemuksensa jälkeen opetuslapsilleen, puhuu heille ja siirtyy sen jälkeen taivaaseen. "Kimalaisen hunajan" teksti perustuu vuonna I776 käyttöön otettuun Raamatun suomennokseen:

Ja hän sanoi meille: mitä te pelkäätte? Ja miksi senkaltaiset ajatukset tulevat teidän sydämiinne? Katsokaat minun käsiäni ja jalkojani, että minä itse olen: ruvetkaat minuun, ja katsokaat: sillä ei hengellä ole lihaa eikä luita, niin kuin te näette minulla olevan. Ja kuin hän nämä sanonut oli, osoitti hän heille kätensä ja jalkansa. Mutta koska ei he vielä uskoneet ilon tähden, vaan ihmettelivät, sanoi hän heille: onko teillä tässä mitään syötävää? Niin me panimme hänen eteensä kappaleen paistettua kalaa, ja vähän kimalaisen hunajaa. Ja minä otan sen ja syön teidän nähtenne. Sen jälkeen pilvi saa viedä minut mukanaan. (KH, 202-203. Lihavoinnit tutkimuksen tekijän.)

Kertomukselle nimen antanut ilmaisu "Kimalaisen hunajaa" esiintyy tässä vuonna I776 käyttöön otetussa suomennoksessa, mutta ei myöhemmissä, vuosina 1938 ja I992 käyttöön otetuissa versioissa. ${ }^{\mathrm{I} 4^{8}}$ Olen lihavoinut tässä siteeratussa katkelmassa ilmaisut "meille" ja "me" siitä syystä, että alkuperäisessä Raamatun suomennoksessa niiden tilalla ovat ilmaisut "heille" ja "he". Tämän voisi tulkita merkitsevän sitä, että kertomuksen pääasiallinen minäkertoja, Juha Seppälä, esittää siinä kuuluvansa Jeesukseen uskovien opetuslasten joukkoon, "meihin". Siten katkelmassa limittyisivät toisiinsa opetuslasten, mukaan luettuna pääasiallisen minäkertojan, ja Jeesuksen (siteeratussa katkelmassa esiintyvän "hänen" ja "minän") diskurssit. Viimeinen lause "Sen jälkeen pilvi saa viedä minut mukanaan" ei esiinny sellaisenaan Raamatussa, mutta siteeratussa katkelmassa se tiivistää vapaassa muodossa Luukkaan evankeliumin 
lopussa ja Apostolien teoissa (г:9) kuvatun tapahtuman, Jeesuksen siirtymisen taivaaseen.

Pitäisikö "Kimalaisen hunajan" lopetus siis ymmärtää Seppälän henkilökohtaiseksi credoksi, osoitukseksi siitä, että elämänsä aikana hän on ainakin hetkellisesti kokenut olevansa osallinen kristillisestä uskosta ja armosta? Niin kuin hetki sitten kävi ilmi, tämän suuntainen kirjaimellinen tai kyseisen kertomuksen pintatasoon kiinnittyvä tulkinta saa tukea samassa kokoelmassa ilmestyneestä toisesta kertomuksesta "Mitä sähkö on?", joka suhtautuu uskontoon niin ikään myönteisesti. Kyseinen tulkinta sopii kuitenkin huonosti yhteen Seppälän muun - sekä aiemman että myöhemmän - tuotannon kanssa. Siksi mainittu "uskontunnustus" voidaan myös käsittää "Kimalaisen hunajaan" liitetyksi fiktiiviseksi ainekseksi. Kolmannen tulkintavaihtoehdon mukaan edellä siteeratussa kohdassa ei ole pohjimmiltaan lainkaan kyse uskonnosta vaan syvätason merkityksellisyyden kokemuksesta.

Viimeisen tulkinnan perusteella "Kimalaisen hunajan" lopetus ei siis toimi niinkään Seppälän henkilökohtaisena uskontunnustuksena. Pikemminkin se pyrkii ilmaisemaan, kuinka merkityksellisiä isoisä ja hänen edustamansa elämänmuoto ovat Seppälälle olleet. Siksi kertomuksen lopetus rinnastaa ne pyhyyteen. Tämä ei tarkoita sitä, että Seppälä uskoisi persoonallisen Jumalan olemassaoloon. Siinä, että "Kimalaisen hunajaa" päättyy lainaukseen Luukkaan evankeliumista ja Apostolien teoista, on kyse lähinnä siitä, että meidän kulttuurissamme tällaista erityistä merkityksellisyyden kokemusta voidaan parhaiten ilmaista juuri uskonnon tarjoamien myyttien avulla. Merkityksellisyyden ja merkityksettömyyden kokemuksia käsitellessään Seppälän tuotanto turvautuu muissakin yhteyksissä Raamatun kuvakieleen. Näin tapahtuu varsinkin Yhtiökumppaneissa ja Paholaisen haarukassa, joissa markkinakapitalismi rinnastetaan metaforisesti väärien jumalien valtaanpääsyyn. Raamatun, sen pyhien tekstien retorinen hyödyntäminen on siten jokseenkin johdonmukainen piirre Seppälän tuotannossa (ks. myös Juntunen 20I2, I95-196).

Kaipuu lapsuuden aikaiseen maaseutumaiseen elämänmuotoon on Seppälän teoksissa pysyvä motiivi, joka esiintyy aina välillä enemmän tai vähemmän selvästi tunnistettavalla tavalla hänen teksteissään. Tässä 
mielessä hänen tuotantonsa sisältää eittämättä nostalgisen motiivin. Nostalgiaa (koti-ikävää, kaipuuta) koskevassa tutkimuksessa erotetaan toisistaan palauttava ja reflektivinen nostalgia (ks. Boym 20ıг; Sandbacka 20I7, 33-40). Palauttava nostalgia on naiivia ja välitöntä, ja siinä - toisin kuin reflektiivisessä nostalgiassa - nostalginen subjekti ei tajua, että hänen kaipuunsa kohde ei välttämättä ole ollut sellainen kuin hän sen mielessään kuvittelee olleen; hän ei siten myöskään ymmärrä, että hänen kaipuunsa ei ehkä voi saada täyttymystä. Reflektiivisessä nostalgiassa subjekti oivaltaa, että hän idealisoi kaipuunsa kohteen ja että siksi hän ei voi saavuttaa sitä sellaisenaan. Näistä syistä hän saattaa omaksua itseironisen asenteen, mikä ei niinkään lakkauta hänen kaipuutaan vaan lähinnä vain hillitsee sitä. Seppälän tuotannossa on aineksia näistä molemmista nostalgian muodoista. Ehkä "Kimalaisen hunajassa" hallitsevana on silti välitön tai palauttava nostalgia, sillä sen lopetus näyttää asettavan kertojan lapsuuden aikaisen maailman pyhyyden kokemisen yhteyteen. 


\section{Viitteet}

\section{LUKU I JOHDANTO}

$1 \quad$ Kapitalismi-teemasta suomalaisessa nykykirjallisuudessa ks. myös Malmio 2018; Ojajärvi, Sevänen \& Steinby 2018b; Pohjola-Skarp \& Suutela 2018; Sevänen 2013b; Suutela 2013.

2 Seppälän eksistentialismikäsityksestä ks. myös Seppälä $1990 b$.

3 Kirkkoa Seppälä on käsitellyt kriittisesti mm. blogiteksteissään Seppälä 2006h, 2007e ja $2007 \mathrm{~g}$.

4 Kristillisestä armon käsitteestä ks. lähemmin Iso Raamatun Tietosanakirja. Osa 1 (1988), 117-120; Novum. Uusi Testamentti Selityksin. Osa 5 (1984), 767-769.

5 Ks. esim. Antti Majanderin (1992) ja Maija Alftanin (2001) Helsingin Sanomiin tekemiä haastatteluja Seppälästä.

6 Ks. Antti Majanderin (1992) Helsingin Sanomiin tekemää haastattelua Seppälästä.

7 Ks. Seppo Puttosen ja Joni Pyysalon (2003) Parnassoon tekemää haastattelua Seppälästä.

8 Seppälä on käsitellyt kirjallisuudentutkimusta kriittisesti myös kirjoituksessaan Seppälä 1990c ja romaanissaan Matka aurinkoon (2014).

9 Habermas on esitellyt käsitystään ihmistieteiden metodologiasta erityisesti teoksissaan Erkenntnis und Intresse (1968), Zur Logik der Sozialwissenschaften (1973, erityisesti s. $260-263,275-276,283-292,305)$ ja Theorie des kommunikativen Handelns (1987a, 158-191). Ks. myös hänen kirjoitustaan "Zu Gadamers 'Wahrheit und Methode'" (1975, 46-50, 52-55).

10 Ks. esim. Panu Rädyn (2001) Helsingin Sanomien Kuukausiliitteeseen tekemää kirjoitusta ja haastattelua Seppälästä.

11 Ks. esim. Suvi Aholan (1991) Helsingin Sanomiin ja Seppo Heiskasen (1991) Demariin kirjoittamia arvosteluja Super Marketista.

12 Arto Miettinen on viime vuosina kirjoittanut monografiaväitöskirjaa kansallisuusteemasta Seppälän tuotannossa. Valmistuttuaan se tulee täydentämään Seppälätutkimusta. Kapitalismi-teeman ja kansallisuus-teeman ohella Seppälän tuotannosta kirjoittaneita tutkijoita ovat kiinnostaneet hänen teostensa kieli ja tyyli ja niiden henkilöhahmojen tapa käydä dialogia keskenään. Tästä näkökulmasta hänen teoksiaan ovat artikkeleissaan käsitelleet Tuomas Juntunen (2013) ja Tuula Piikkilä (2004; 2007).

13 Suomalaista nyky-yhteiskuntaa on käsitelty erityisesti teoksissa Heiskala \& Luhtakallio 2006, Kuisma 2013, Patomäki 2007, Pietikäinen 2010 ja Rantala \& Sulkunen 2006. Ne tarjoavat taloudellisesta ja poliittisesta näkökulmasta laaditun kuvan siitä, miten suomalaisen yhteiskunnan rakenteet ovat muuttuneet 1980- ja 1990-luvulta lähtien. Suomalaisen nyky-yhteiskunnan luokka- ja/tai sukupuolirakennetta on puolestaan tarkasteltu teoksissa Julkunen 2010, Erola 2010a, Anttila, Kauranen, Launis \& Ojajärvi 2016 sekä Kantola \& Kuusela 2019. Nykyistä kapitalistista maailmanjärjestystä koskevista tutkimuksista on syytä mainita Castells 2000 ja 2004, Gilpin 2001, Harvey 2008, 
Krugman 2009 ja 2012, Patomäki \& Teivainen 2003, Piketty 2016 ja 2019, Stiglitz 2010 ja Ten Brink 2011. Nykykapitalismin vaikutuksia kulttuuriin ja elämäntapoihin ovat käsitelleet McGuigan 2009 sekä Sennett 2002 ja 2007. Nykykapitalismin eri tyyppejä ja ilmenemismuotoja on analysoitu tutkimuksissa Hall \& Soskice 2001, Schmidt, Vivien Ann 2002 ja Schmidt, Vivien Ann \& Thatcher 2013a. Valtion roolin muuttumista ovat käsitelleet Cerny 1990 ja 2010 sekä Jessop 2002 ja 2016.

14 Ks. esim. Antti Majanderin (1992) Helsingin Sanomiin ja Merja Ylösen (2006) Aamulehteen tekemiä haastatteluja Seppälästä.

15 Ks. Antti Majanderin (1992) Helsingin Sanomiin ja Ville Hännisen Parnassoon (2014) tekemiä haastatteluja Seppälästä.

16 Ks. myös Christa Bürgerin teosta Der Ursprung der bürgerlichen Institution Kunst im höfischen Weimar (1977) ja Peter Bürgerin teosta Aktualität und Geschichtlichkeit. Studien zum gesellschaftlichen Funktionswandel der Literatur (1977), joissa molemmissa liikutaan historiallis-yhteiskunnallisen kontekstin, tutkimuskohteena olevien teosten ja niiden tekijöiden sekä kirjallisuusinstituution tai yleisemmin taideinstituution tasoilla.

17 Cooperin (2008) käsitys eksistentialismista on muutoinkin suppea. Hän on esimerkiksi taipuvainen sulkemaan Camus'n pois eksistentialistien joukosta sillä perusteella, että tämä on enemmänkin kirjailija kuin (systemaattinen) filosofi. Näin tehdessään hän sivuuttaa sen, että monien eksistentialisteina pidettyjen filosofien ja kirjailijoiden mukaan eksistentialismin perusideoiden ilmaisemiseen tarvitaan juuri sellaista kieltä, joka käyttää hyväksi sekä filosofista argumentaatiota että kaunokirjallista esitystapaa.

18 Ks. Seppälä 1990b; 1994b. Ks. myös Maija Alftanin (2001) Helsingin Sanomiin tekemää haastattelua Seppälästä.

\section{LUKU II AINEISTO, KÄSITTEET JA TEORIAT}

19 Ks. Panu Rädyn (2001) Helsingin Sanomien Kuukausiliitteeseen tekemää kirjoitusta ja haastattelua Seppälästä.

20 Karvian maalaiskunta on Satakunnan pohjoisosan eli Ylä-Satakunnan pohjoisin ja itäisin kunta. Sen pohjoispuolella alkaa Etelä-Pohjanmaan maakunta ja itäpuolella Hämeen makkunta. Tämän raja-alueen kunnat ovat yhteiskunnan rakennemuutosten seurauksena kokeneet viime vuosikymmeninä voimakasta muuttotappiota - riippumatta siitä, sijaitsevatko ne Satakunnassa (Honkajoki, Kankaanpää, Karvia), Hämeessä (Kihniö, Parkano, Virrat) vai Etelä-Pohjanmaalla (Jalasjärvi, Kauhajoki). Niinpä vuosina 1980-2012 Karvian väestö väheni 3782 asukkaasta 2545 asukkaaseen, jolloin vähennys oli 32,7\%. Vuosina 1980-2017 vähennys Karvian väestömäärässä oli 3782 asukkaasta 2403 asukkaaseen (36,5\%). Ks. Tilastokeskuksen Px-Web-tietokannat internetissä, taulukko "Väestö kielen mukaan sekä ulkomaan kansalaisten määrä ja pinta-ala alueittain", vuodet 1980-2017. Luettu 3.-4.9.2018.

21 Camus'n kirjanen Le mythe de Sisyphe (1942) sisältyy suomennettuna teokseen Camus 1971.

22 Tieto, jonka mukaan Seppälän isän kaksi setää osallistuivat vuonna 1918 Tampereen valtaukseen valkoisten puolella, on peräisin Seppälän Aamulehteen (1993b) kirjoitta- 
masta kolumnista. Suomen historiassa $(1998,8)$ hän täydentää tätä kuvaa sukutaustastaan: "Lähimmillään vanhempieni suvut olivat toisiaan jo vuonna 1918, jolloin valtion postinkantajana toiminut, valkoisista joukoista sen johdosta vapautettu isänisäni vei hevosella kahdelle nuoremmalle veljelleen ruokaa Ylöjärvelle. Nämä osallistuivat Tampereen valtaukseen ja toinen haavoittuikin. Piiritetyssä kaupungissa ajoi ruumiskuormia 14-vuotias äidinisäni, joka sekasorron yhteydessä vangittiin ja muutaman viikon kuluttua alaikäisenä vapautettiin". Ks. myös Seppälä 1990d ja Panu Rädyn (2001) Helsingin Sanomien Kuukausiliitteeseen laatimaa kirjoitusta ja haastattelua Seppälästä.

23 Sydänmaan kerrontajaksoista ei aina käy selvästi ilmi se, kuka niissä toimii kulloinkin kertojana. Tämän epävarmuuden huomioon ottaen voisi sanoa, että romaanin minäkerrontaa hyödyntävissä jaksoissa äänessä ovat pääasiassa tai pelkästään Vesa ja hänen äitinsä.

24 Seppälä on myös kirjoittanut Rintalasta esseen "Maatyöläisen helvetti ja taivas", joka on julkaistu Juhani Salokanteleen toimittamassa teoksessa Kirjojen Suomi (1996). Essee käsittelee Rintalan romaania Maatyömies ja kuu (1983). Ks. Seppälä 1996b.

25 Ks. esim. Ruohola 1994, Kulmala 1994, Mäkinen 1994 ja Toiviainen 1994.

26 Kritiikissä Sydänmaata koskevat arvostelut olivat pääosin myönteiset. Merkittävän poikkeuksen muodosti kuitenkin Helsingin Sanomissa ilmestynyt Pekka Tarkan (1994) arvostelu, jossa hän piti tätä romaania taitavasti sommiteltuna, mutta puhui samalla myös "Seppälän jurottavasta synkkyydestä", päähenkilöiden "lohduttomuudesta" ja romaanin "hautajaistunnelmasta". Samassa lehdessä kolme päivää myöhemmin julkaistussa vastineessaan Seppälä (1994b) katsoi Tarkan käyttävän arvostelussaan "vanhoihin konventioihin" perustuvia arviointikriteerejä. Yleensä Seppälä ei silti ole reagoinut julkisesti teostensa saamiin arvosteluihin.

27 Kirjallisuuden välittämää maailmankuvaa ja arvomaailmaa rekonstruoitaessa on syytä olla tietoinen siitä, että kirjallisten teosten sisältöä ei voida ilmaista tyhjentävästi käsitteellisten abstraktioiden avulla. Peter V. Zima (1999) huomauttaa osuvasti, että kirjalliset teokset sisältävät tavallisesti epämääräisiä, ristiriitaisia ja esikäsitteellisiä aineksia, minkä vuoksi niiden ja tieteen abstraktin käsitekielen välillä vallitsee aina jonkinasteinen epäsuhta. Toisin sanoen tieteen käsitekielen avulla esitetty kuvaus teosten merkityssisällöstä on aina enemmän tai vähemmän karkea yksinkertaistus. Siksi se, mitä tässä tutkimuksessa esitetään Seppälän teosten maailmankuvasta ja arvomaailmasta, ei pyri olemaan kattava kuvaus niiden kaikista ulottuvuuksista.

28 Ks. esim. Seija Lappalaisen (1993), Helena Ruuskan (1993) ja Stina Haason (1999) arvosteluja.

29 Ks. esim. Seppälä 1989e; 1992b; 1992C.

30 Ks. Koskela 1986; Rintanen 2004.

31 Vaikka Seppälän varhaistuotanto on sävyiltään pääosin synkkä, se sisältää myös muutaman myönteisesti päättyvän teoksen. Tämä pätee lähinnä hänen novelleihinsa "Riikinkukon sulka" (1989b), "Pääsiäinen" (1989c) ja "Kasvukausi" (1989d), joissa päähenkilöt tempautuvat irti ahtaasta elämäntilanteestaan ja saavuttavat jonkinlaisen ulkoisen ja sisäisen elämänhallinnan. Romaani Jumala oli mies. Romaani rakkaudesta (1996a) on puolestaan sikäli harvinainen teos Seppälän tuotannossa, että se kuvaa myönteisesti miehen ja naisen välistä suhdetta. 
32 Ks. Kimmo Rintasen (2004) Ilta-Sanomat Plussa -lehteen tekemää esittelyä ja haastattelua Seppälästä.

33 Selvimmän poikkeuksen tästä yleistyksestä muodostaa Jyrki Kataisen (kokoomus) johtama laajapohjainen hallitus (2011-2014), jossa olivat alun perin mukana kokoomus, SDP, vihreät, vasemmistoliitto, ruotsalainen kansanpuolue ja kristillisdemokraatit. Tämä koalitio tasapainoili kahden erisuuntaisen tavoitteen kanssa: yhtäältä se pyrki jatkamaan markkinoiden toimintaedellytyksiä parantavaa politiikkaa, mutta samalla se halusi turvata hyvinvointipalvelujen säilymisen. Ks. lähemmin Kauranen \& Lamberg 2016. Sanna Marinin johdolla toimiva nykyinen hallitus (2019-) on koronapandemian takia joutunut työskentelemään niin epävakaissa ja poikkeuksellisissa olosuhteissa, että tällä hetkellä on ennenaikaista ryhtyä esittämään yleisarviointia sen harjoittamasta politiikasta.

34 Ks. lähemmin Erola 2010b, 90, 92; Erola 2010c, 238; Kantola \& Kuusela 2019, 15-17; Melin 2010, 225; Sevänen 2013a, 26-30.

35 Hallin \& Soskicen (2001) ohella koordinoidun markkinakapitalismin käsitettä ovat kehitelleet muun muassa Crouch 2005, Heiskala 2006 ja Lechevalier 2014.

36 Vivien Ann Schmidtin (2002) ohella valtiojohtoista kapitalismia ovat analysoineet Schmidt, Vivien Ann \& Thatcher 2013a, Jackson \& Deeg 2006 ja Ebenau \& Liberatore 2013.

37 Ks. lähemmin Castells 2000, 137-142; Gilpin 2001, 379-384; Patomäki \& Teivainen 2003, 25, 29, 58, 75, 116-117; Schmidt, Vivien Ann \& Thatcher 2013b, 13; Thatcher \& Schmidt, Vivien Ann 2013, 418-421.

38 Seppälä on kiinnittänyt myös blogikirjoituksissaan huomiota puolueiden välisten erojen hämärtymiseen. Erityisesti hän on tällöin arvostellut Suomen Sosialidemokraattista Puoluetta oikeistolaistumisesta ja sitoutumisesta uusliberalistisen politiikan toteuttamiseen. Ks. esim. Seppälä 2007d.

39 Routavuoden ilmestymisvuonna Seppälä pohti terrorismin teemaa myös Eugen Schaumania käsittelevässä kuunnelmassaan Ruma ankanpoikanen - Eugen Schauman ja terroristin luomiskertomus, jonka ensiesitys oli 15.4.2004 Yle:n Radio 1 -kanavalla. Siinä piirretty kuva terroristista on jonkin verran kriittisempi kuin Routavuodessa.

40 Suomalaisen yhteiskunnan luokkarakenteen historiallista kehitystä ovat tarkastelleet Heikki Waris (1948), Erik Allardt (1976) ja Risto Alapuro (1985). Eri ammattien asema luokkarakenteessa voi muuttua. Niinpä Waris sijoitti vielä kaikki akateemisen loppututkinnon suorittaneet yläluokkaan, mutta nyky-yhteiskunnassa suuri osa tällaisista ihmisistä sijoittuu pikemminkin ylempään keskiluokkaan tai keskiluokkaan.

41 Mr. Smithissä (s. 224-227) pääkertojana toimiva Mr. Smith luonnehtii isoisäänsä luokkien väliin sijoittuneeksi epämääräiseksi henkilöksi, joka ei kuulunut työväkeen eikä herrasväkeen, hädin tuskin kansaankaan. Samassa yhteydessä Mr. Smith tuo esiin myös alemman keskiluokan käsitteen, mutta toteaa heti perään, että tällaista käsitettä ei juurikaan käytetty vielä maailmansotien välillä.

42 Kirjallisuutta ja taidetta koskevassa sosiologisessa tutkimuksessa kirjailijat ja taiteilijat on usein sijoitettu keskikerrostumiin, "keskiluokkaan". Olen leipätekstissä menetellyt tämän perinteen mukaisesti Laura Laineen ja Erkka Torron kohdalla. On kuitenkin syytä huomata, että todellisuudessa osa kirjailijoista ja taiteilijoista toimii myös yrittäjinä. 
Sellaisina he saattavat työskennellä oman toiminimen alla tai he voivat olla osakkaina taidealan yrityksessä. Tällöin kysymys heidän luokka-asemastaan on moniselitteisempi kuin leipätekstistä käy ilmi. Leipätekstissä tämä problematiikka sivuutetaan, sillä Seppälän romaanit eivät tematisoi sitä tarkastelun kohteeksi. Niinpä Paholaisen haarukka on siinä mielessä perinteisillä linjoilla, että se tarkastelee ohjaaja Laura Lainetta älymystön edustajana, joka kuuluu taloudellis-sosiaalisessa mielessä lähinnä ylempään keskiluokkaan, mutta joka esiintyy taiteessaan alempien luokkien puolustajana.

43 Bourdieu on esitellyt luokkateoriaansa mm. massiivisessa, lähes 700-sivuisessa tutkimuksessaan La distinction. Critique sociale du jugement (1979).

44 Suomalaista älymystöä käsittelevät mm. Risto Alapuron Suomalainen älymystö Venäjän varjossa (1997), Pertti Karkaman ja Hanne Koiviston toimittama Älymystön jäljillä. Kirjoituksia suomalaisesta sivistyneistöstä ja älymystöstä (1997) ja Hanne Koiviston toimittama Politiikkaa, erotiikkaa ja kulttuuritaistelua. Kirjoituksia suomalaisesta vasemmistoälymystöstä 1930-luvulta (2011). Teoreettisempaa lähestymistapaa älymystön problematiikkaan edustavat Niilo Kaupin ja Pekka Sulkusen toimittama Vanguards of Modernity. Society, Intellectuals and the University (1992) ja Johan Strangin ja Thomas Wallgrenin toimittama Georg Henrik von Wright. Modernin ajan ajattelija (2020, ruotsinkielinen alkuperäisteos ilmestyi 2016).

45 Tämä ei tarkoita sitä, että von Wrightin esittämä rationalisaatiokritiikki olisi saanut Suomessa tuolloin kaikkien ryhmittymien jakamattoman hyväksynnän. Kirjansa Myten om framsteget alussa von Wright toteaa itse, että hänen omat aiemmat rationalisaatiokriittiset kirjansa olivat saaneet osakseen kritiikkiä lähinnä elinkeinoelämän ja sosialidemokraattien piirissä, sillä niissä arvostellaan teollista tuotantotapaa, talouskasvun ideologiaa ja kulutuskeskeistä elämäntapaa. Samalla von Wright arvioi, että erityisesti kulttuurikonservatiivit ja vasemmistointellektuellit ovat suhtautuneet hänen esittämäänsä kritiikkiin myönteisesti. Ks. von Wright 1993, 8-10. Mikko Salmelan tutkimuksesta Suomalaisen kulttuurifilosofian vuosisata (1998) käy ilmi, että rationaalisuuden eri lajeja käsiteltiin jonkin verran myös von Wrightiä edeltäneessä suomalaisessa filosofiassa, erityisesti Erik Ahlmanin ja Sven Krohnin teoksissa, joiden sävy ei kuitenkaan ole samalla tavalla ankaran kriittinen kuin von Wrightin teosten sävy.

46 Seppälä on myös blogikirjoituksissaan kommentoinut Habermasin ajattelua. Ks. Seppälä 2006i.

47 Lehdistökritiikissä Paholaisen haarukan saamat arvostelut olivat valtaosin myönteisiä, ja arvosteluissa sitä luonnehdittiin muun muassa mestarilliseksi taidonnäytteeksi (ks. esim. Korhonen 2008; Sihvonen 2008). Romaani valittiin myös Finlandia-palkintoehdokkaaksi, ja siitä otettiin jo sen ilmestymisvuonna useita uusintapainoksia.

48 Ks. Kimmo Rintasen (2004) tekemää haastattelua Ilta-Sanomat Plussa -lehdessä 28.2.2004 ja Merja Ylösen (2006) tekemää haastattelua Aamulehdessä 20.1.2006.

49 Seppälän yhteydessä modernista realismista on puhunut Leena Kirstinä (2007), joka on soveltanut tätä käsitettä Sydänmaa-romaaniin. Jussi Ojajärvi (2013a) on puolestaan soveltanut avantgardistisen realismin käsitettä Hannu Raittilan Pamisoksen purkaukseen, joka muistuttaa rakenteellisesti Seppälän laajoja yhteiskunnallisia romaaneja. Näitä käsitteitä lähellä ovat uuden realismin ja modernistisen realismin käsitteet, joilla Sari Salin (2013) on luonnehtinut Sofi Oksasen tuotantoa. Salin toteaa, että Oksanen 
hallitsee erilaiset romaanikerronnan tekniikat, kuten aikatasojen limittämisen toisiinsa, sisäisen elämän kuvaamisen fokalisaatio-tekniikan ja tajunnanvirran avulla sekä kertojaposition notkeat vaihdokset minäkertojasta ulkopuoliseen kertojaan. Oksasella tällaiset tekniikat palvelevat Salinin mukaan (suomalaisen) todellisuuden esittämistä uudella tavalla ja uusista näkökulmista. Se, mitä Salin sanoo Oksasesta, pätee moneen muuhunkin nykyiseen kotimaiseen yhteiskunnallisen romaanin edustajaan, muun muassa Kari Hotakaiseen, Hannu Raittilaan, Arto Salmiseen ja Juha Seppälään. Sekä sisällön että ilmaisukeinojen, muodon ja rakenteiden tasolla nykyinen kotimainen yhteiskunnallinen romaani on siten ollut erittäin kekseliäs ja uusiutumiskykyinen. Ks. lähemmin Seppälä 1995b sekä Seppo Puttosen ja Joni Pyysalon Parnasso-lehteen $1 / 2003$ tekemää haastattelua Seppälästä.

51 Manuel Castells on tarkastellut systemaattisesti tällaisia liikkeitä tutkimuksissaan The Information Age. Economy, Society and Culture. Volume II. The Power of Identity (2004) ja Networks of Outrage and Hope. Social Movements in the Internet Age (2012).

52 Ks. esim. Antti Majanderin (2002), Hannu Marttilan (2004), Jukka Koskelaisen (2006) ja Ville Miettisen (2007) kirjoittamia arvosteluja Seppälän teoksista.

53 Ks. Seppo Puttosen ja Joni Pyysalon (2003) Parnassoon tekemää haastattelua Seppälästä.

54 Klassiselle moderniteetille ominaista funktionaalisen eriytymisen periaatetta on tarkasteltu lähemmin myös teoksissa Sevänen 2001, 79-87; 2008b, 38-80; 2018a, 10-16.

55 Tässä kappaleessa esitetty kuvaus kapitalismin nykyvaiheeseen liittyvistä yhteiskunnallisista ongelmista ja riskeistä perustuu Tore Fougnerin (2006, 169, 172), Robert Gilpinin (2001, 262-277, 315-316), Pauli Kettusen (2008, 43-47, 209-210), Seppo Tiihosen $(2006,100)$ ja John Urryn (2013) tutkimuksiin.

56 Ekologisiin näkökohtiin perustuvan kapitalismikritiikin tunnetuimpia edustajia on John Urry (1946-2016), jonka teos Climate Change and Society (2011) ilmestyi vuonna 2013 suomeksi nimellä "Ilmastonmuutos ja yhteiskunta" (ks. Urry 2013).

57 Myös Odile Heynders kuvaa kirjassaan Writers as Public Intellectuals. Literature, Celebrity, Democracy (2005) sitä, miten vaikeaa julkisuutta on hallita ja miten julkisuus usein toimii siellä esiintyvien henkilöiden toiveiden ja aikomusten vastaisesti.

58 Käsikirjaan The Oxford Handbook of Rationality (2004a) kirjoittamassaan johdannossa Alfred R. Mele ja Piers Rawling kiinnittävät huomiota uskomusrationaalisuuden ja toiminnallisen tai käytännöllisen rationaalisuuden välisiin yhtymäkohtiin. Heidän mukaansa niissä molemmissa keskeistä näyttäisi olevan perusteiden esittäminen - se, että ihminen esittää uskomustensa ja toimintansa pohjaksi argumentteja. Ks. Mele \& Rawling 2004b, 3-4. Toisaalta Habermasin mukaan perusteltavuuden vaatimus sisältyy kyllä kognitiivis-instrumentaaliseen rationaalisuuteen ja eräisiin kommunikatiivisen rationaalisuuden muotoihin, mutta samalla hän on katsonut, että arvorationaalisuuden tai kommunikatiivisen rationaalisuuden muotona taide ei ole argumentteihin pohjautuvaa esitystä vaan ilmaisullista toiminta, jossa subjekti tuo sisäistä maailmaansa muiden koettavaksi. Silti Habermasin mukaan taiteella ja esteettisellä kokemuksella on oma paikkansa rationaalisten toimintatyyppien kokonaisuudessa.

59 Weberiläis-habermasilaisen tradition piirissä länsimaista rationalisaatiota ovat kriittisesti tarkastelleet myös Max Horkheimerin Välineellisen järjen kritiikki (2008, saksan- 
kielinen alkuperäisteos ilmestyi 1941-1947) sekä Max Horkeimerin ja Theodor W. Adornon Valistuksen dialektiikka (2008, saksankielinen alkuperäisteos ilmestyi 1944). Ne ovat filosofisempia kuin Weberin ja Habermasin teokset, ja niiden historiallinen näkökulma on laajempi. Myös Michel Foucault voidaan sijoittaa tähän perinteeseen, sillä tuotannossaan hän käsittelee modernien, rationaaliseen tietoon perustuvien hallintamenetelmien syntyä ja kehitystä (ks. Winter \& Zima 2007). Rationaalisuus-teemaa on viime vuosikymmeninä käsitelty myös analyyttisessä filosofiassa. Nicholas Rescherin tutkimuksen Rationality (1988) ohella tähän yhteyteen kuuluvat mm. Donald Davidsonin Problems of Rationality (2004), George Lakoffin ja Mark Johnsonin Philosophy in the Flesh. The Embodied Mind and its Challenge to Western Thought (1999), Emmanuel Chukwudi Leen On Reason. Rationality in a World of Cultural Conflicts and Racism (2008) ja John McDowellin Mind and the World (1996). Alfred R. Melen ja Piers Rawlingin The Oxford Handbook of Rationality (2004) pyrkii tarjoamaan kokonaiskuvan siitä, miten rationaalisuuden problematiikkaa on käsitelty analyyttisessä perinteessä. Tämä perinne poikkeaa monilta osin weberiläis-habermasilaisesta tarkastelutavasta, sillä siinä on pohdittu muun muassa sitä, mitä itse järki ja rationaalisuus ovat ja mihin ne perustuvat. Näistä, lähinnä tutkimusekonomisista syistä se sivuutetaan paljolti tässä tutkimuksessa. Toisaalta analyyttisen perinteen piirissä työskentelevän Martha C. Nussbaumin (1990; 2012) teokset kuuluvat kuitenkin tämän tutkimuksen teoriapohjaan.

60 Ilmaus "hyvän ja pahan tuolla puolen" toimii Nietzschen kirjoituksen "Jensseits von Gute und Böse" (1886) otsikkona. Siinä Nietzsche yhtäältä arvosteli aikansa kristillistä moraaliajattelua konformismista, mutta toisaalta myös vaati moraalisten arviointikriteerien roolin minimoimista tarkasteltaessa hänen kaavailemansa "uudenlaisen ihmisen" tai "yli-ihmisen" toimintaa.

61 1980- ja 1990-luvulla suosituksi tulleen konstruktionistisen ajatustavan myötä monet yhteiskuntateoreetikot katsoivat, että "ihmisen lajiolemuksesta" puhuessaan Marx syyllistyi essentialismiin. Marx olisi siis olettanut, että ihmisen olemus on jotakin kiinteää ja vakaata, jotakin sellaista, joka säilyy samana kulttuurista, yhteiskunnasta ja aikakaudesta toiseen siirryttäessä. Osittain tästä syystä vieraantumisen käsite marginalisoitui tuolloin eri oppiaineissa. Edellä esitettyä kritiikkiä arvioitaessa voidaan todeta, että Marxin mainitsema ominaisuus, vapauden ja itsensä toteuttamisen mahdollisuus, luonnehtii ihmistä varsin korkealla abstraktiotasolla. Siksi tämä luonnehdinta ei ole ristiriidassa sen ajatuksen kanssa, että monessa suhteessa ihminen on samanaikaisesti historiallisten, kulttuuristen ja yhteiskunnallisten olosuhteiden määräämä tai "konstruoima" olento.

62 Tässä esitettyä kuvaa merkityksen problematiikasta eksistentialismissa voidaan täydentää toteamuksella, että sekä Heidegger että Sartre erottavat toisistaan maailman sellaisena kuin se objektiivisesti, meistä riippumatta on ja maailman sellaisena kuin me ihmiset sen kohtaamme. Heidän mukaansa me kohtaamme maailman ja sen objektit tavallisesti tarpeidemme näkökulmasta, elämänkäytäntömme pohjalta. Suhteemme maailmaan ei siis tavallisesti ole puhtaasti objektivoiva, vaan kohdatessamme maailman me samalla merkityksellistämme sitä. Toisin sanoen me olemme taipuvaisia näkemään maailman objektit siltä kannalta, mitä ne merkitsevät meille 
esimerkiksi taloudellisesti, käytännöllisesti ja henkisesti. Ks. Cooper 2008, 57-78; Danto 1975.

63 Tässä yhteydessä Karkama (1998a, 31) viittaa myös Ulrich Beckin kirjoitukseen "Politiikan uudelleen keksiminen: kohti refleksiivisen modernisaation teoriaa". Siinä Beck (1995, 70) toteaa, että "nykyisessä riskiyhteiskunnassa" eksistentialistisen filosofian kysymyksistä tulee miltei päivänpolttavia ongelmia, joita ihmiset joutuvat käsittelemään ja ratkomaan arkielämässään. Beck siis katsoo, että eksistentialismin nykyisen suosion taustalla ovat yhteiskunnassa tapahtuneet suuret muutokset, siirtyminen yksinkertaisesta tai klassisesta modernisaatiosta nykyiseen riskiyhteiskuntaan ja refleksiiviseen modernisaatioon. Karkamasta poiketen Beck ei kuitenkaan selitä eksistentialismin suosiota ensi sijassa yhteiskunnan markkinallistumisesta käsin. Sen sijaan hän esittää, että yhteiskuntakehityksen nykyvaihe on murtanut klassiselle teollisuusyhteiskunnalle ominaiset varmuudet ja kiinteät rakenteet ja vienyt yhteiskunnan epävarmuuden ja riskien aikakauteen. Ks. myös Beck 1991.

64 Habermasilaista esteettis-ekspressiivisen rationaalisuuden käsitettä ovat tarkastelleet lähemmin Kotkavirta 1991, 218-219; Sevänen 1998, 189-199; Sevänen 2018a, 3-6, 10-16.

65 Luhmannin taidekäsityksestä ks. myös Sevänen 2008b, 50-65; 2013d, 241-259.

66 Habermasin käsitys on ollut saman suuntainen kuin Nussbaumin käsitys. Kommunikatiivisen toiminnan teoriassaan hän katsoo, että jopa eroottinen ja seksuaalinen kokemus voi lisätä subjektien itsereflektiokykyä ja heidän ymmärrystään elämästä ja maailmasta. Tämä ajatusmotiivi jää kuitenkin Habermasin teoriassa sivujuonteeksi, jota hän ei lähtenyt lähemmin kehittelemään. Vrt. McCarthy 1988.

67 Yhteiskuntaromaanin, sosiaalisen romaanin ja sosiaalisen tendenssiromaanin lajihistoriaa ovat käsitelleet mm. Adler 1990, Béroud \& Régin 2002, Biermann 1982, Cazamian 1973, Claybough 2007, Dubois 2000, Koc 1982 ja Sicotte, Poirson, Loncle \& Biet 2013.

68 Näitä kirjailijoita on käsitelty tutkimuksessa toistaiseksi melko vähän. Tryggve Söderling (2008) on kuitenkin väitöskirjassaan käsitellyt Alopaeuksen romaania ja Kihlmanin varhaistuotantoa, ja Mikko Carlson (2014) on puolestaan tarkastellut Kihlmanin tuotantoa seksuaalisen halun, sukupuolipolitiikan ja luokkaproblematiikan näkökulmasta. Lisäksi Milla Peltonen (2008; 2010) on analysoinut Salaman pääteoksia ja 1970-luvun suomalaista yhteiskunnallisesti suuntautunutta kirjallisuutta. Muista tutkimuksista on syytä mainita Voitto Ruohosen (1995) artikkeli Kihlmanin suomenruotsalaista yläluokkaa kritisoivista romaaneista ja Jussi Ojajärven (2015) kirjoitus luokkaproblematiikasta Arto Salmisen teoksissa.

69 Näitä romaaneja on käsitelty jonkin verran tutkimuksessa. Tuomas Juntunen (2012) on väitöskirjassaan eritellyt laajasti Seppälän Yhtiökumppaneita, ja Erkki Sevänen (2013C; 2014b) on artikkeleissaan tarkastellut Seppälän, Melenderin, Raittilan ja Salmisen romaanien välittämää kuvaa nykykapitalismista. Raittilan romaania Pamisoksen purkaus ovat lisäksi analysoineet Fredric Jameson (2018) ja Jussi Ojajärvi (2013a). Samoin Liisa Steinby ja Mikko Tirronen (2018) ovat eritelleet Hotakaisen Ihmisen osaa. Lisäksi Jussi Ojajärvi (2013a) on kirjoittanut yleiskatsauksen kapitalismi-teemasta suomalaisessa nykykirjallisuudessa, ja Kristina Malmio (2018) on puolestaan tarkastellut tätä tematiikkaa suomenruotsalaisessa nykykirjallisuudessa. Juha Raipola (2015) 
on tarkastellut Leena Krohnin tuotantoa ympäristökysymysten näkökulmasta, ja Pirjo Lyytikäinen (2018) on puolestaan käsitellyt Krohnin yhteiskunnallisesti kantaa ottavia satiireja.

70 Eksistentialismia käsittelevissä tutkimuksissaan niin Cooper (2008) kuin Möbusskin (2015a; 2015b) sivuuttavat käytännössä miltei kokonaan elämänfilosofian. Toisaalta Karkama (1998a, 33-45, 64-65) ymmärtää eksistentialistissävyisen elämänfilosofian laajasti, sillä hänen mukaansa sitä edustavat tai sitä lähellä ovat myös Sigmund Freud, Georges Bataille, Michel Foucault, Gilles Deleuze, Jacques Lacan, Julia Kristeva ja Charles Taylor. Karkama $(1998,35)$ toteaa, että yhteistä elämänfilosofeille on ajatus, että elämässä vaikuttaa kaikkialla kaoottinen ja jäsentymätön yleinen voima, elämän energia, esimerkiksi seksuaalienergia (Freud), halu (Deleuze), imaginaarinen (Lacan) tai semioottinen (Kristeva). Karkaman mainitsemat uudemmat "elämänfilosofit" ovat kuitenkin monessa suhteessa myös etäällä eksistentialismista, minkä vuoksi heidän ja eksistentialistien välille ei ole syytä vetää yhtäläisyysmerkkejä.

71 Tutkijat ovat nähneet eksistentialismia muistuttavia ajatusmotiiveja ja aineksia myös varhaisemmassa suomalaisessa kirjallisuudessa. Esimerkiksi Karkaman (1994, 161162) mukaan 1800 - ja 1900-luvun vaihteessa eksistentiaalisen ahdistuksen tunnot ja maailmankatsomuksellinen pessimismi olivat yleisiä niin suomalaiselle kirjallisuudelle kuin kulttuuriälymystöllekin. Eräs osoitus siitä on, Karkama jatkaa, Nietzschen filosofian nauttima arvostus suomalaisten kirjailijoiden, esimerkiksi Eino Leinon ja Joel Lehtosen, keskuudessa, eikä tässä yhteydessä myöskään sovi unohtaa V. A. Koskenniemen runoudelle ominaista jylhää kuoleman ja eksistentiaalisen yksinäisyyden teemojen käsittelemistä. Eksistentiaalisen tematiikan kehittelemistä on myös nähty Maria Jotunilla ja dagdrivare-sukupolven kirjailijoilla, joista jälkimmäiset joutuivat suomalaisuusliikkeen menestyksen myötä mukautumaan ruotsinkielisen yläluokan ja sivistyneistön hegemonia-aseman menetykseen ja sitä seuranneisiin jatkuvasti kapeneviin tulevaisuudennäkymiin (ks. lähemmin Mazzarella 1989 ja Rossi 2011).

72 Peter V. Zima (2001) soveltaa indifferenssi-termiä myös tähän ilmiöön - siis siihen, että postmodernistinen kirjallisuus välittää lukijalle ajatuksen tai tunnun siitä, että vallitsevat tai olemassa olevat sosiaalis-kulttuuriset järjestelyt ja erottelut ovat aina periaatteessa korvattavissa toisenlaisilla sosiaalis-kulttuurisilla järjestelyillä ja erotteluilla. Tällainen konstruktivistista sosiaali- ja kulttuurifilosofiaa myötäilevä näkemys tulee Ziman mukaan esiin muun muassa Italo Calvinon, Umberto Econ ja Alastair Fowlerin kirjallisissa teoksissa, samoin kuin jälkistrukturalistisessa älymystökulttuurissa. $\mathrm{Ne}$ molemmat ovat problematisoineet eräät moderniin länsimaiseen kulttuuriin liittyvät perustavat ontologiset ja epistemologiset erottelut. Zima toteaa, että tällainen indifferenssi eroaa kapitalistisen talouden toimintatapojen tuottamasta indifferenssistä. Edellisessä merkityksessä "indifferenssissä" on kyse sosiaalis-kulttuuristen arvojen, erottelujen ja järjestelyjen vaihdettavuudesta, kun taas jälkimmäisessä merkityksessä "indifferenssi" viittaa siihen, että kapitalistisella taloudella on taipumus sivuuttaa ei-liiketaloudelliset arvokysymykset. Kysymys siitä, millainen suhde näiden kahden erilaisen indifferenssin muodon välillä vallitsee, joudutaan tässä yhteydessä sivuuttamaan. Postmodernistisesta kirjallisuudesta ks. myös Hallila 2006, Hutcheon 1985 ja 1988 sekä Waugh 1984. 
73 Päivi Kososen, Hanna Meretojan ja Päivi Mäkirinnan toimittamasta kirjasta Tarinoiden paluu. Esseitä ranskalaisesta nykykirjallisuudesta (2008) käy ilmi, että 1970- ja 1980-luvulta lähtien ranskalaisessa kirjallisuudessa on niin ikään tapahtunut etääntymistä uusromaanin ja kokeellisen kirjallisuuden kaudesta, jolloin kirjallisuus vieroksui tarinoita ja yhteiskunnan kuvaamista. Sen vastapainoksi tarinat ovat palanneet ranskalaiseen nykykirjallisuuteen, minkä ohella monet kirjailijat ovat myös käsitelleet markkinakapitalismin lakien ja toimintatapojen tunkeutumista yhä syvemmälle yhteiskunnan ja yksilöiden elämään.

\section{LUKU III YHTIÖKUMPPANIT JA KAPITALISMIN EETOS}

74 Ks. lähemmin Bruun, Eskelinen, Kauppinen \& Kuusela 2009, 22-27.

75 Yhtiökumppaneissa on siis 91 lukua. Pete on kertojana 46 luvussa, Kirsi 23 luvussa ja Peten isä 16 luvussa; Lasse, Olli, Susanna ja anonyymi kertoja kertovat kukin yhden luvun tai jakson, ja kahdessa luvussa kertojan identiteetti on epämääräinen tai monitulkintainen.

76 Yhtiökumppaneita koskevassa arvostelussaan myös Antti Majander (2002) luonnehti Helsingin Sanomissa tätä romaania moraliteetiksi.

77 Yhtiökumppaneissa tämä katkelma on sulkeissa ja se on kursivoitu. Olen leipätekstissä jättänyt sulkeet ja kursivoinnin pois.

78 Ks. J. A. Guddonin toimittamaa hakuteosta A Dictionary of Literary Terms and Literary Theory (1998), s. 519-520.

79 Näitä eroja on lähemmin tarkastellut Richard Münch tutkimuksissaan Die Kultur der Moderne. Band 1. Ihre Entwicklung in England und Amerika (1986a) ja Die Kultur der Moderne. Band 2. Ihre Entwicklung in Frankreich und Deutschland (1986b). Ne ovat tosin siinä mielessä vanhentuneita, että ne eivät ota huomioon yhteiskuntakehityksessä 1980-luvulla alkanutta, uusliberalistisen ideologian ja politiikan hallitsemaa vaihetta.

80 Ks. lähemmin Bruun, Eskelinen, Kauppinen \& Kuusela 2009, 14-16, 22-28; Häyrynen 2018, 168-178.

81 Seppälä on arvostellut "sisällöntuotanto"-visioita myös lehtikirjoituksissaan. Esimerkiksi Aamulehteen 6.1.2001 kirjoittamassaan katsauksessa "Sisältö-Suomen huterat jalat" hän puhuu kriittiseen sävyyn Paavo Lipposen toisen hallituksen (1999-2003) ohjelmasta, joka sisälsi maininnan kulttuuriasioiden tärkeydestä ja joka tähtäsi kulttuurin tuotteistamiseen, "sisällöntuotantoon". Ks. Seppälä 2001 .

82 Myös Juhani Sipilä on analysoinut Raittilan romaania artikkelissaan "Vedenpaisumus ja Baabelin kieltensekoitus samana päivänä. Hannu Raittilan yhdenpäivänromaani $E i$ minulta mitään puutu" (2005). Tässä tutkimuksessa noudatetusta tarkastelutavasta se poikkeaa siinä, että se ei käsitteellistä Raittilan romaania yhteiskunnallisen romaanin lajitradition edustajaksi.

83 Yhteiskuntatieteissä tähän pinnallistumiseen ovat kiinnittäneet huomiota $\mathrm{mm}$. David Harvey (2008) ja Richard Sennett (2002; 2007).

84 J. A. Guddonin toimittama hakuteos A Dictionary of Literary Terms and Literary Theory (1998, 401-402) määrittelee hybriksen käsitteen juuri näin: siinä on kyse siitä, että 
antiikin Kreikan tragedioissa sankarit ylittivät sen rajan, jonka jumalat olivat ihmisille asettaneet.

85 Samansuuntainen näkemys tragediasta sisältyy George Steinerin tunnettuun tutkimukseen The Death of Tragedy (1961), joka käsittelee tragedian kehitystä antiikista 1900-luvulle saakka. Steinerin mukaan yhteiskunnan ja kulttuurin modernisoitumiseen liittyvä maailmankuvien maallistuminen sekä kapitalistisen talouden ja teknologian kehitys ovat paljolti hävittäneet ne ainekset, joiden pohjalta perinteinen tragedia oli mahdollinen.

\section{LUKU IV PAHOLAISEN HAARUKKA JA KRIITTISEN KÄRJISTÄMISEN LOGIIKKA}

86 Seppälä on käsitellyt pankki- ja sijoitustoimintaa kriittisesti myös blogiteksteissään: ks. esim. Seppälä 2006a; 2006b; 2006c. Niissä hän kirjoittaa, että sijoitustuotteita kehittämällä pankit ovat luoneet liiketoiminnan muodon, jossa mahdolliset riskit ja tappiot jäävät aina asiakkaiden kontolle, kun taas pankit säästyvät niiltä yleensä silloinkin, kun ne ovat ohjanneet asiakkaansa vääriin sijoituspäätöksiin.

87 Ks. esim. Kuisma Korhosen (2008) ja Lauri Sihvosen (2008) kirjoittamia arvosteluja Paholaisen haarukasta.

88 Lyhenteet "ext" ja "int" ovat elokuvakäsikirjoituksissa käytettyjä tavanomaisia lyhenteitä. Niissä "ext" viittaa siihen, että kohtaus tapahtuu ulkotiloissa, ja "int" siihen, että kohtaus tapahtuu sisätiloissa.

89 Paholaisen haarukka muodostuu siis 77 luvusta tai kerrontajaksosta. Ne jakautuvat kertojille seuraavalla tavalla: anonyymi kertoja 23 lukua, Lari Laine 27 lukua, Laura Laineen elokuvakäsikirjoitus 13 lukua, Kari Lehtosen blogitekstit 3 lukua, Laura Laine 1 luku, yhdessä luvussa kertojan identiteetti on monitulkintainen ja yhdeksässä luvussa on useita eri kertojia. Nämä laskelmani ovat tulkinnanvaraisia, sillä Lari Laine sukkuloi romaanissa erilaisissa rooleissa: välillä anonyymi ekstradiegeettinen kertoja tarkastelee häntä ulkoapäin, välillä hän on minäkertoja tai henkilökertoja ja välillä hän ottaa sellaisen ekstradiegeettisen kertojan roolin, joka osallistuu itse tarinan maailmaan. Sivuilla 19-21 anonyymi ekstradiegeettinen kertoja näyttäisi kertovan taksinkuljettaja Klausin ja erään asiakkaan välisestä väkivaltaisesta yhteenotosta, mutta hieman myöhemmin, sivuilla $25-26$, on Lari Laineen puhetta: "Se, mitä äsken kerroin taksinkuljettajan ja asiakkaan kesken tapahtuneesta välikohtauksesta, tapahtui edellisenä päivänä, eilen" (s. 25); tällä perusteella sivuilla 19-21 olevassa luvussa kertojana onkin Lari Laine, joten olen laskenut tämän luvun hänen kerrontajaksokseen. Osittain samantapainen epäselvyys aiheutuu siitä, että ensin sivuilla 61-63 anonyymi ekstradiegeettinen kertoja kuvaa Saija Lehtosta, ja sitten seuraavassa luvussa (s. 64-65) Lari Laine kommentoi kyseistä kuvausta: "Saija Lehtonen ei olisi nähnyt itseään näin. Edes elokuvaa käsikirjoittava ja ohjaava sisareni ei olisi nähnyt häntä näin. Tuo on kertojan tekstiä." Tässä jälkimmäisessä tapauksessa Lari Laine ei kuitenkaan luonnehdi itseään sivuilla 61-63 olevan luvun kertojaksi, joten olen laskenut sivuilla 61-63 olevan luvun anonyymin ekstradiegeettisen kertojan esittämäksi. Kolmas epäselvä luku on sivuilla 219-221. Siinä anonyymi ekstradiegeettinen kertoja näyttäisi puhuvan siitä, miten 
Laura Laine kuvaa Kari Lehtosta ja tämän isoisää, mutta jaksossa esiintyykin lausuma "Ei Laura näe Kari Lehtosen isoisää. Se kaikki on minun spekulaani" (s. 221), joka viittaakin Lari Laineeseen; Lari Laine oli nimittäin jo aiemmissa luvuissa (s. 64) puhunut Laura Lainetta koskevista "spekulaatioistaan". Näillä perusteilla lasken sivuilla 219-221 olevan luvun Lari Laineen kertomaksi.

90 Tätä seikkaa - sitä, että Lari Laine toimii Laura Laineen ohjaaman elokuvan tuottajana - ei Paholaisen haarukassa sanota suoraan, mutta Lari Laineen osoittama aktiivinen mielenkiinto sisarensa elokuvantekoa kohtaan ja hänen esittämänsä puheet elokuvatuotannosta viittaavat siihen suuntaan.

91 "Suomesta" ja sen eri osista puhutaan Paholaisen haarukassa vain muutaman kerran. Sivulla 128 Laura Laine puhuu veljensä Lari Laineen liiketoimista Suomessa, sivulla 235 Lari Laine käyttää ilmaisua "Suomen markka" ja sivuilla 261-262 Lari Laine kertoo matkastaan "Suomen eteläisimpään asuttuun paikkaan". Ks. myös sivuja 41, 43-44, 46, 84, 94, 161, 175 ja 176, joissa käytetään Suomeen liittyviä ilmaisuja.

92 Todettakoon, että ilmeisesti Seppälä on tutustunut Habermasin teoksiin alkukielellä. Omien sanojensa mukaan hän kuuluu vielä siihen ikäpolveen, joka luki oppikoulussa pitkän saksan oppimäärän. Ks. Ville Hännisen $(2014,22)$ Parnasso-lehteen tekemää haastattelua Seppälästä.

93 Ks. lakia osakeyhtiöistä 21.7.2006/624, pykälä 5 .

94 Mantelitumake-troopilla on siis Paholaisen haarukassa tärkeä tehtävä. Sen avulla romaani puhuu siitä, että nyky-yhteiskunta on menettämässä kykynsä käsitellä substantiaalisia merkityskysymyksiä. Mantelitumakkeesta voidaan todeta se, että ihmisen kummassakin aivopuoliskossa on yksi mantelitumake, joka sijaitsee ohimolohkon sisäsyrjässä. Neurolääketieteen mukaan mantelitumakkeen tehtävät liittyvät tunnereaktioiden sääntelemiseen ja aisti-informaation emotionaaliseen käsittelemiseen. Lääketieteelliset kokeet viittaavat siihen, että mantelitumakkeen vaurioituminen tai sen tuhoutuminen rapauttaa ihmisen "tunneälyn". 1930-luvulla toteutetussa klassisessa, nykyisen käsityksen mukaan epäeettisessä tutkimuksessa (Klüverin ja Bucyn apinatutkimus) apinoilta poistettiin molemmat mantelitumakkeet ja niitä ympäröivä aivokuori. Poiston takia niille kehittyi psyykkiseksi sokeudeksi kutsuttu oireyhtymä eli niistä tuli yliseksuaalisia ja ylioraalisia eivätkä ne enää kyenneet tekemään eroa uhkaavan ja ystävällismielisen käyttäytymisen välillä. Muun muassa tällä perusteella mantelitumakkeita on luonnehdittu tunnemuistin ja merkitysten keskusvarastoksi. Ilman sitä asioilla ei olisi ihmiselle henkilökohtaista merkitystä tai tunnemerkitystä. Ks. lähemmin Pitkänen 1998.

95 Ks. esim. Marcusen kirjoitusta "Industrialismus und Kapitalismus im Werk Max Webers" (1964). Siinä (s. 110-113) hän esittää, että kapitalistisen rationaalisuuden yleistyessä irrationaalisuus tulee yhteiskunnassa järjeksi. Kapitalistinen rationaalisuus ilmenee tuottavuuden kasvuna, luonnon valloittamisena ja tavararikkauden lisääntymisenä. Tämä on Marcusen mielestä sinänsä rationaalista. Irrationaalista se on kuitenkin siksi, että samalla se tuhoaa luonnonvaroja ja inhimillisiä voimavaroja, tuottaa yhteiskunnallisia ongelmia ja aiheuttaa aggressiivisuutta kansallisvaltioiden välille. Samoin se mahdollista nykyaikaisen joukkotuhoamisen. Max Horkheimerin ja Theodor W. Adornon Valistuksen dialektiikka (ilmestyi alun perin 1944) on niin ikään kuvaus 
siitä, miten järjen ja emansipaation nimissä sääty-yhteiskuntaa vastaan noussut valistus muuttui 1900-luvulle tultaessa vastakohdakseen, destruktiiviseksi voimaksi.

96 Alkuperäinen teksti on seuraavanlainen:

"You know what capitalism produces. According to Marx and Engels". [Vilja

Kinski's remark.]

"Its own grave-diggers", he said.

"But these [the demonstrators] are not the grave-diggers. This is the free market itself. These people are a fantasy generated by the market. They don't exist outside the market. There is nowhere they can go to be on the outside. There is no outside."

The camera tracked a cop chasing a young man through the crowd, an image that seemed to exist at some drifting distance from the moment.

"The market culture is total. It breeds these men and women. They are necessary to the system they despise. They give it energy and definition. They are market-driven. They are traded on the markets of the world. This is why they exist, to invigorate and perpetuate the system". (DeLillo 2004, 89-90.)

97 Kirjassaan Ilmastonmuutos ja yhteiskunta (2013) John Urry päätyy samansuuntaisiin johtopäätöksiin kuin Paholaisen haarukka. Pohtiessaan sitä, missä määrin yhteiskunnassa voitaisiin siirtyä vähähiiliseen talouteen tai "luonnonvarakapitalismiin", Urry toteaa, että öljyn ja hiilen varaan pohjatut elämänmallit ovat yhä voimissaan ja ne leviävät ympäri maailmaa. Yhteiskunnat eivät siten näytä olevan valmiita luopumaan vapaaehtoisesti runsashiilisistä energiamuodoista, ja ekologisiin ongelmiin ne haluavat ilmeisesti puuttua vain siinä määrin kuin se voi tapahtua nykyisiä taloudellisia, poliittisia ja ideologisia valtarakenteita vaarantamatta.

98 Tavallisesti enkelisijoittajat toimivat niin sanotuissa kasvuyrityksissä eli start up -yrityksissä, joiden toiminnan eri vaiheita on analysoinut Antti Hyrkäs tutkimuksessaan Startup Complexity. Tracing the Conceptual Shift behind the Spectacle (2017). Käytännön tietoa siitä, miten bisnesenkelit toimivat, tarjoavat Matti Laineman Enkeleitä, onko heitä? (2011) ja Sami Etulan Osaamista, verkostoja, rahaa. Opas enkelisijoituksen hakemiseen (2014). Suomalaiset enkelisijoittajat järjestäytyivät vuonna 2010, kun he perustivat oman yhdistyksensä Finnish Business Angels Network. Sen kotisivujen mukaan sillä oli kesäkuussa 2019 noin 650 jäsentä.

99 Ks. lähemmin Seppälä 2008, 35-36, 49-50, 57-59, 61-65, 83-86, 208-210, 238-241, 245-246, 252. Näissä jaksoissa Paholaisen haarukka kuvaa Saija Lehtosta ja hänen elämäntilannettaan.

100 Ks. esim. Aulikki Elon (1992) ja Helena Ruuskan (1993) kirjoittamia arvostelua Lurusta, Stina Haason (1999) kirjoittamaa arvostelua Kuun noususta ja laskusta, Antti Majanderin (2002) kirjoittamaa arvostelua Yhtiökumppaneista ja Vesa Karosen (2016) kirjoittamaa arvostelua Kuoppakaupungista.

101 Ks. esim. Seppo Puttosen ja Joni Pyysalon (2003, 73) Seppälästä tekemää haastattelua Parnasso-lehdessä.

102 Kapitalismin ja seksuaalisuuden välistä suhdetta ovat viime vuosina käsitelleet muun muassa Frida Beckmanin Between Desire and Pleasure. A Deleuzian Theory of Sexuality (2013) sekä Banu Bargun ja Chiara Botticin toimittama Feminism, Capitalism, and 
Critique. Essays in Honor of Nancy Fraser (2017). Suomessa tätä problematiikkaa ovat tarkastelleet Raija Julkunen (2010, 186-198) sekä yhteisessä artikkelissaan Sanna Karkulehto ja Ilmari Leppihalme (2018). Olen kehitellyt leipätekstissä mainitun nelijaottelun näiden lähteiden pohjalta.

103 Myös Houellebecqin romaanien julkisessa vastaanotossa on käyty keskustelua siitä, missä määrin hänen omat porno- ja seksiteollisuutta kritisoivat teoksensa ovat itse saaneet vaikutteita kritiikkinsä kohteesta. Kärjistetysti sanoen kyse on ollut siitä, missä määrin hänen omat romaaninsa syyllistyvät siihen, mistä ne kritisoivat nykykapitalismia. Ks. lähemmin Meretoja 2008b; 2008c.

104 Anna Kontula on analysoinut lähemmin tällaisten naisten tilannetta tutkimuksessaan Kontula 2008.

105 Ilmaisuna ja motiivina "ikuinen ikävä" oli tavanomainen perinteisissä karjalaisissa riitti-itkuissa. Sitä käytettiin esimerkiksi saatettaessa kuolleita haudanlepoon, jolloin eloonjääneet jäivät kaipaamaan heitä "ikuisen ikävän" vallassa; ks. lähemmin Konkka 1985. Tätä ilmaisua ja sitä lähellä olevia ilmaisuja on myöhemmin viljelty usein populaarimusiikissa, tosin ei välttämättä aivan samassa merkityksessä kuin karjalaisissa riitti-itkuissa.

106 Paholaisen haarukan kolmannessa osassa sijoitusneuvoja Lari Laineen diskurssiin on upotettu virke "Kun joskus katsoin kättäni, se toi mieleeni ranskalaisen sodanjälkeisen näytelmän nimen" (Seppälä 2008, 155). Virke sisältää viittauksen Sartren näytelmään Likaiset kädet (1995, ranskankielinen alkuperäisteos ilmestyi 1948), joka käsittelee syyllisyyden teemaa. Kolmannen osan sivuilla 191-192 on verkkotuottaja Kari Lehtosen blogiteksti, jonka lopussa olevat ilmaisut "oleminen (Dasein)" ja "ei-oleminen" ovat peräisin Heideggerin teoksista ja ilmaisu "essentia vai eksistenssi" viittaa puolestaan Heideggerin ja Sartren tunnettuun ajatukseen siitä, että olemassaolo edeltää olemusta. Kari Lehtonen käyttää näitä ilmaisuja tietoisen huolimattomasti jäljitellessään ja parodioidessaan lehdistölle nykyisin ominaista tapaa tiedustella ihmisten kulttuurisia mieltymyksiä. "Kulttuuri on nykyisin sitä, että kulttuurin vaikuttajilta kysytään, mikä on sinulle kaikkien aikojen rakkain kotimainen rock-biisi? Ei ainoastaan kulttuurin vaikuttajilta, vaan lukijoilta, katsojilta ja kuulijoilta kysytään: mikä on kaikkien aikojen paras elokuva? Suurin suomalainen? Kymmenen tärkeintä kirjaa? Maailman vahvin nalle? ... Jääkiekko vai jalkapallo? Ollako vai eikö olla? Mitä sanotte? Laskurini näyttää tällä hetkellä olemisen (Dasein) puolesta Ei-Olemista vastaan 67-33. Essentia vai eksistenssi? Oleminen on miinussummapeliä. Mikä on kautta aikojen paras kokemuksenne? Kyllä ja ei?” Ks. Seppälä 2008, 191-192 (kursivointi alkuperäisen tekstin). Jakson tehtävänä on ilmentää ja kritisoida kulttuurin pinnallistumista ja banalisoitumista.

107 Paholaisen haarukassa lähinnä seuraavat jaksot kuvaavat Kari ja Saija Lehtosen keskinäistä suhdetta: 57-59, 61-66, 94, 131, 184-186, 208, 222-223, 237-241, 245-246, 252.

108 Kirjassaan Kansainväliset situationistit (2005) Marko Pyhtilä osoittaa, että jo situationistien ryhmä kehitti 1950- ja 1960-luvulla rekuperaation ideaa. Pyhtilä ei varsinaisesti suomenna ilmaisua récupération, vaan hän muuntaa sen suomeksi muotoon "rekuperaatio".

109 Ks. lähemmin Seppälä 1992b; 1992C; 2001. Ks. myös Seppälästä tehtyä haastattelua Turun Sanomissa 6.2.2001 (Anonyymi 2001) ja Helsingin Sanomissa 1.9.2001 (Räty 
2001). Viihdekulttuuria Seppälä on käsitellyt muun muassa blogiteksteissään Seppälä 2006d; 2007b; 2007c; 2007f.

110 Wieniläisestä aktionismista ks. lähemmin Oliver Jahrhausin (2001) tutkimusta.

111 Ks. Kimmo Rintasen (2004) tekemää haastattelua Seppälästä Ilta-Sanomat Plussa -lehdessä 28.2.2004 ja Merja Ylösen (2006) tekemää haastattelua Seppälästä Aamulehdessä 20.1.2006.

\section{LUKU V MR. SMITH JA KRITIIKIN SUHTEELLISTUMINEN}

112 Saman asian toteavat Anu Kantola ja Hanna Kuusela Huipputuloiset-kirjassaan, jonka mukaan Suomen rikkaimman väestökerrostuman tulot ovat ensi sijassa pääomatuloja: vuokra-, korko- ja osinkotuloja, luovutusvoittoja ja yksityisiä eläkkeitä. Esimerkiksi vuonna 2016 Suomen rikkaimman promillen tuloista kaksi kolmasosaa oli pääomatuloja ja vain yksi neljäsosa palkkatuloja. Koska pääomatulojen verotus on maltillisempaa kuin palkkatulojen verotus, kyseinen kerrostuma on vaurastunut myös tätä kautta. Ks. Kantola \& Kuusela 2019, 21, 263-289.

113 Alkukielisessä muodossa tämä sitaatti kuuluu seuraavasti: "Mais la fin est là, qui transforme tout. Pour nous, le type est déjà le héros de l'histoire. Sa morosité, ses ennuis d'argent sont bien plus précieux que les nôtres, ils sont tout dorés par la lumière des passions futures. Et le récit se poursuit à l'envers: les instants ont cessé de s'empiler au petit Bonheur les uns sur les autres, ils sont happés par la fin de I'histoire qui les attire et chacun d'eux attire à son tour l'instant qui le précède." (Sartre 1938, 65.)

114 Toisaalta heti Mr. Smithin (2012) jälkeen ilmestynyt Matka aurinkoon (2014) käsittelee nimenomaan elämän ja kertomusmuodon välistä suhdetta. Sen keskushenkilö, eläkkeellä oleva 81-vuotias kirjallisuudenprofessori Irma suunnittelee omaelämäkertaansa. Hän kokee kuitenkin hankkeensa tietyssä suhteessa ongelmalliseksi. "Maailma haluaa ehjän tarinan, jossa kulkee jonkinlainen selityksen ja merkityksen lanka" (s. 15), kun taas Irmasta tuntuu, että hänen elämästään puuttuu tällainen kertomusmuodon edellyttämä yhtenäisyys ja sisäinen johdonmukaisuus (s. 16, 39). Silti hän ei luovu hankkeestaan. Hän katsoo, että juuri kertomalla itsestään hän ottaa vallan määritellä itsensä: "Minä kerron minän tarinan, te ette määrittele minua. Minä kerron itselleni, kuka minä olen" (s. 16). Kohta viittaa myös omaelämäkerran performatiiviseen luonteeseen, ajatukseen siitä, että kertoessaan itsestään subjekti tuottaa omaa identiteettiänsä ja minäkuvaansa. Vrt. Saunders 2010, 510-512, 528.

115 Fredric Jameson $(2011,8,12)$ on korostanut sitä, että myös Marxin näkemys kapitalismista oli dialektinen: Marxille kapitalismi oli samaan aikaan hyvä ja paha, luova ja tuhoava, sivilisoiva ja raaistava. Mr. Smithissä esitetty dialektinen näkemys kapitalismista ei kuitenkaan sisällä suoria viittauksia Marxiin.

116 Myös Yhtiökumppaneissa Pete rinnastaa (ks. Seppälä 2002, 132, 144) yhtiönsä henkilökunnan ja sen toiminnan susilaumaan, mutta romaani ei kehittele tätä rinnastusta niin pitkälle kuin Mr. Smith.

117 Klassinen kuvaus modernin kapitalismin väkivaltaisista synty- ja alkuvaiheista on 
Marxin (1979) Pääoman ensimmäiseen osaan sisältyvä luku alkuperäisestä kasautumisesta (s. 640-682). Myöhemmin tätä samaa ilmiötä on Englannin osalta käsitellyt Karl Polanyi (2009) ja maailmanjärjestelmän osalta Immanuel Wallerstein (2004).

Seppälä on käsitellyt indifferenssin problematiikkaa myös lehti- ja blogikirjoituksissaan. Esimerkiksi toukokuussa 2007 Satakunnan Kansan blogissaan hän totesi, että suomalaiset yritykset ovat viime vuosikymmeninä puhuneet usein eettisyydestään ja yhteiskuntavastuustaan. Seppälän (2007a) mukaan tällaisen puheen ei pidä antaa hämätä kuulijoita, sillä jo osakeyhtiöitä koskevan lain mukaan osakeyhtiöiden perustehtävänä on tuottaa arvoa, voittoa, omistajilleen. Yritykset ovat, hän jatkaa, valmiita tinkimään eettisyydestä, työpaikoista ja ympäristöasioista huolehtimisesta, mikäli ne katsovat sen vaarantavan tuon perustehtävän hoitamisen. Ks. myös Seppälä $2007 \mathrm{~g}$ ja $2018 \mathrm{~b}$.

119 Ks. Polanyi 2009, 34, 73-74, 324-334, 370-384. Polanyin ajattelua on suomeksi esitellyt Risto Heiskala artikkelissaan "Karl Polanyi, suuri murros ja substantivistinen talousantropologia" (2009). Ks. myös Gareth Dalen julkaisemaa monografiaa Karl Polanyi. The Limits of the Market (2010), joka käsittelee Polanyin talousteoreettisen ajattelun eri puolia ja sen yhteyksiä nykyiseen uusliberalismin kritiikkiin.

120 Ks. esim. Jamesonin (2018) analyysia Hannu Raittilan romaanista Pamisoksen purkaus (2005). Siinä hän pohtii Raittilan romaanin mahdollisuuksia toimia nykykapitalismia koskevana kriittisenä representaationa. Ks. myös Jussi Ojajärven (2018) esittelyä Jamesonin ajattelusta.

121 Tämä sitaatti on peräisin luvusta (ks. Seppälä 2008, 67-73), jossa äänessä näyttää pääosin olevan tarinamaailman ulkopuolinen kertoja ja jakson lopussa myös sijoitusneuvoja Lari Laine. Siteeraamassani kohdassa äänessä on mielestäni tarinamaailman ulkopuolinen kertoja, sillä juuri ennen sitä Lari Lainetta tarkastellaan tekstissä ulkoapäin.

122 Vuonna 2007 Yhdysvalloissa alkanutta ja eri puolille maailmaa levinnyttä finanssikriisiä ovat analysoineet mm. Patrik Aspers (2011, 62-63), Jaakko Kiander (2013) ja Paul Krugman (2009). Todettakoon, että odotusten vastaisesti valtiovalta ei Yhdysvalloissa kaikesta huolimatta pelastanut vuonna 1850 toimintansa aloittanutta Lehman Brothersia, jättimäistä rahoitusalan yritystä ja investointipankkia, joka ajautui vuonna 2008 selvitystilaan. Monien arvioiden mukaan tämä ratkaisu oli omiaan levittämään paniikkimielialaa niin amerikkalaisiin kuin globaaleihinkin rahoitusmarkkinoihin.

123 Ks. lähemmin Seppälä 2008, 67-73, 88-90, 144-147, 163-165; Seppälä 2012, 84-86, 139-140, 152-154, 165-174, 196-203, 208-210, 246-249. Näiden jaksojen perusteella lukija voi laatia itselleen kuvan Jumalan Kyyneleen, Briscillan ja Ranen elämän etenemisestä pääpiirteittäin.

124 Tässä kappaleessa esitetty analyysi perustuu osittain Harley Bergrothin artikkelissa "Luokan ruumiillisuus arjen kokemuksissa köyhyydestä" (2016) esitettyihin ajatuksiin. Kyseinen artikkeli käsittelee luokan, erityisesti köyhyden suhdetta ruumiillisuuteen. Se sisältyy Anttilan, Kaurasen, Launiksen ja Ojajärven toimittamaan teokseen Luokan ääni ja hiljaisuus (2016).

125 Seppälä on käsitellyt kriittisesti työväenliikkeen ja työväenluokan sisällä vallitsevia hierarkioita myös antamissaan haastatteluissa. Esimerkiksi Kimmo Rintaselle (2004, 32) 
Turun Sanomiin antamassaan haastattelussa hän totesi, että "Paperiliiton hyväpalkkaisia koneenhoitajia eivät ole kiinnostaneet edes saman liiton siivoojat, saati täysin kelkasta pudonneet”. Ks. myös Seppälä 2006f sekä Arttu Seppäsen (2018) Seppälästä tekemää haastattelua Helsingin Sanomissa 12.8.2018.

126 Ehkä tämä ulottuvuus tulee Paholaisen haarukassa selvimmin esiin kohdassa, jossa Lari Laine kertoo, millaista kokonaisvaltaista omistautumista hänen työnsä sijoitusneuvoja-varallisuudenhoitajana vaatii:

Me päivystimme, vertailimme ja analysoimme Q2:n raportteja heinäkuun kuumimmassa helteessä, jolloin olisi pitänyt kävellä loputonta rantaa silmät puoliummessa, aistia häikäisevän, välkehtivän valon tanssi sinivihertävän veden pinnalla, kulkea kohti aurinkoa. Sisareni Laura teki elokuvakäsikirjoitusta ja haki siihen henkeä ja elämää. Hän tiesi, että raamit tulivat ensin, muuten henki olisi jäänyt vetten päälle. Minä olin tekemässä elämälleni kehyksiä. Oliko minulla muuta, tulisivatko ne koskaan valmiiksi?

Me hikoilimme henkemme ja rahan edestä soveltaen sinisen meren strategiaa, etsien uusia asiakkaita, markkinoita ja toimintamalleja, ja sanoimme sitä työelämäksi.

Me asetimme sijoitusinstrumentit itsemme ja elämän väliin.

Joskus minusta tuntui että me olimme päästäisiä, jotka eivät elämänsä aikana ehtineet nukkua yhtään, joiden oli metsästettävä ja syötävä koko ajan. Muuten ne olisivat kuolleet, ja ne kuolivat silti." (Seppälä 2008, 29.)

127 Tämä toimii heillä kapitalismin minimimääritelmänä. Ranskankielisessä asussa määritelmä kuuluu seuraavasti: "Des différentes caractérisations du capitalisme (ou souvent aujourd-hui des capitalismes) depuis un siècle et demi nous retiendrons une formule minimale mettant l'accent sur une exigence d'accumulation illimitée du capital par des moyens formellement pacifiques" (Boltanski \& Chiapello 1999, 37, kursivointi alkuperäisen tekstin).

128 Ks. Seppälä 2012, 20-25, 56-57, 125-130, 175, 224-227, 234-235. Nämä jaksot antavat romaanissa tietoa Smithin isoisästä.

129 Ks. esim. Ville Hännisen (2013) Kiiltomatoon kirjoittamaa arvostelua Mr. Smithistä. Saman suuntaisen arvostelun julkaisi Juhani Karila (2012a) Helsingin Sanomissa.

130 Käytän tutkimuksessani termiä "romaanipoetiikka" väljässä merkityksessä. Usein sillä viitataan lähinnä kirjallisuuden ilmaisukeinojen järjestelmään ja sitä koskevaan tutkimukseen, mutta tässä tutkimuksessa se viittaa myös kirjallisten teosten kompositioon ja rakenteeseen ja niihin liittyvään kirjallisuuskäsitykseen ja maailmankuvaan.

131 Thomas Mann (1875-1955) kirjoitti Felix Krull -romaaniaan vuosina 1910-1913 ja 19501954. Se ilmestyi kolmiosaisena vuonna 1954, mutta Mannin tiedetään suunnitelleen sille jatkoa. Sitä pidetään usein Johann Wolfgang von Goethen Dichtung und Wahrheit -teoksen (1811) ja siinä esitetyn taiteilijakäsityksen parodiana. Yleisemmin Mannin romaani on kriittisessä suhteessa 1700 - ja 1800 -luvun vaihteessa syntyneeseen, romanttiseksi luonnehdittuun taiteilijakäsitykseen, joka piti taiteilijaa luovana ja nerokkaana poikkeusyksilönä sekä todellisuutta koskevan ylivertaisen tiedon haltijana ja ilmaisijana. Kuoppakaupungissa viittaus Felix Krullin hahmoon toimii hieman toisenlaisessa yhteydessä. Jos ajatellaan, että Ilmo Halssi on Juha Seppälän alter ego, rinnastus Felix 
Krulliin toimii Seppälän kapitalismikriittisen vaiheen kritiikkinä. Toisaalta on myös mahdollista ajatella, että tämä rinnastus pyrkii yleisemmin problematisoimaan kirjailijantyön.

Tässä mielessä Ilmo Halssi on lähellä Sari Salinin nimeämää kirjailijatyyppiä, "hylkiökirjailijaa", jonka hahmo on 1990-luvulta lähtien esiintynyt usein suomalaisessa kirjallisuudessa. Salin (2008) tarkastelee sen esiintymistä Pentti Holapan Ystävän muotokuvassa (1998), Jouko Turkan Häpeässä (1994), Helena Sinervon Runoilijan talossa (2004), Tomi Kontion Uumenessa (1995), Jussi Kylätaskun Akuabassa (2002) ja Torsti Lehtisen Kutsumushuorassa (2003). Niissä hylkiökirjailija on tavallisesti julkisuuskuvaansa armottomasti ruotiva mieskirjailija, joka muistuttaa joiltain osin oikeaa kirjailijaa.

Reifikaation käsitteen (saksaksi Verdinglichung, englanniksi reification) kannalta avainteos on Lukácsin Geschichte und Klassenbewusstsein (1977, ilmestyi alun perin 1919-1922), jota Jameson käyttää hyväksi muun muassa pääteoksessaan The Political Unconscious. Narrative as a Socially Symbolic Act (1986, ilmestyi alun perin 1981). Ks. myös Ojajärvi, Sevänen \& Steinby 2018b, 15-25.

Hyppynarun päähenkilönä ja kertojana on musiikkitiedettä opiskellut, mutta romaanin nykytodellisuudessa työttömäksi jäänyt mies, "humanististen tieteiden kandidaatti", joka asuu merkantti-vaimonsa Annan ja kouluikää lähenevän tyttärensä Marin kanssa lähiössä. Romaani on kuvaus päähenkilön elämänpiirin ja tulevaisuusnäkymien asteittaisesta kaventumisesta ja hänen mielensä murtumisesta. Syyt näihin romaani löytää päähenkilön läheisistä ihmissuhteista, kun taas hänen kokemansa työttömyys ja lähiöelämän ominaispiirteet eivät kohoa romaanissa etualalle. Isästään, rappiolle menneestä huikentelevaisesta surmanajajasta, Hyppynarun päähenkilö ei tiedä juuri mitään, ja hänen äitinsä on puolestaan lähtenyt aikoinaan Ruotsiin ja jättänyt hänet isovanhempien kasvatettavaksi. Romaanin nykyhetkessä päähenkilö on kirjeenvaihdossa äitinsä kanssa, mutta tämä suhde ei johda mihinkään, sillä päähenkilö ei kykene paljastamaan äidilleen todellisia, kielteisiä tunteitaan ja saamaan tältä tukea ongelmiinsa. Näin hänellä ei ole keinoja käsitellä traumaattisia kokemuksiaan, kaksinkertaista hylätyksi tulemisen tunnetta. Hänen ihmissuhteidensa toivottomuutta lisää vielä se, että heidän avioliittonsa onnellisten alkuvuosien jälkeen Anna on alkanut tuntea vastenmielisyyttä miestään kohtaan, joka ei täytä perinteisen miehen rooliodotuksia ja jota Anna siksi vähättelee. Siten päähenkilön elämässä on vain vähän sellaista, johon hän voisi liittää myönteisen tunnemerkityksen, mielekkyyden kokemuksen. Ainoaksi myönteiseksi asiaksi jää lopulta tytär Mari, johon hänellä on rakastava ja huolehtivainen suhde, mutta tämäkin sidos ohenee romaanin lopussa Marin aloittaessa koulunkäyntinsä ja irtautumisensa hänen huolenpidostaan. Romaani päättyy tuskaisesti ahdistuneen päähenkilön kokemaan henkiseen umpikujaan ja hänen psyykkiseen luhistumiseensa, minkä seurauksena hän kuristaa Marin kuoliaaksi tämän hyppynarulla ja ottaa itse sen jälkeen tappavan annoksen unilääkkeitä.

Luru kuvaa puolestaan yksinhuoltajaäitiä ja hänen poikaansa Teemua, jotka toimivat samalla romaanin kertojina. Romaania voi lukea kuin sairaskertomusta, sillä miltei alkutilanteesta lähtien Teemu käyttäytyy traumaattisesti ja tappaa lopulta itsensä sen jälkeen, kun hänet oli otettu sairaalaan pakkohoitoon psykoottisessa tilassa. Syyksi 
Teemun käyttäytymiseen romaani esittää lähinnä sen, että Teemun isä oli aikoinaan ollut henkisesti erityisen julma Teemun äitiä kohtaan, jolla ei myöhemmin ollut enää voimavaroja luoda Teemun ympärille turvallista kasvuympäristöä. Tosin romaani ei esitä tätä selitystä varmana tosiasiana, vaan sekä Teemun että hänen isänsä käyttäytymisen perusta jää romaanissa viime kädessä arvoitukseksi, eikä sitä jälkimmäisen osalta taustoiteta mitenkään. Teemun isällä ei liioin ole romaanissa omaa ääntä, vaan hän tulee esiin vain Teemun äidin kerrontajaksoissa, jotka ovat sävyltään katkeria ja joista ei rakennu kokonaiskuvaa Teemun isästä. Lurua voi siten pitää tyypillisenä avoimena romaanina, joka jättää tulkintojen muodostamisen lukijan tehtäväksi.

Näistä romaaneista Hyppynaru on herättänyt runsaasti mielenkiintoa kriitikoiden ja tutkijoiden keskuudessa. Kritiikissä (ks. esim. Anonyymi 1990 ja Koskela 1991) sen loppuratkaisua selitettiin muun muassa sillä, että päähenkilön toimintaa ohjaa paljolti tukahdutettu naisviha ja siksi kuristamalla tyttärensä hän estää tämän kasvamisen naiseksi. Vrt. Tuomas Juntusen (2012) tapaa tulkita Hyppynarua.

\section{LUKU VI PÄÄTÄNTÄ}

135 Montaasin käsitteestä ks. David Hermanin, Manfred Jahnin ja Marie-Laure Ryanin toimittamaa hakuteosta Routledge Encyklopedia of Narrative Theory (2005), sivut 321-322.

136 Vrt. David Hermanin, Manfred Jahnin ja Marie-Laure Ryanin toimittamaa hakuteosta Routledge Encyklopedia of Narrative Theory (2005), sivut 98 (hakusana "defamiliarisation") ja 486-491 (hakusana "realism").

137 Nykyisessä suomalaisessa yhteiskunnallisessa romaanissa perinteinen realismi on muutoinkin harvinainen ilmiö, mutta lähellä sitä ovat ainakin Matti Yrjänä Joensuun Harjunpää-romaanit ja Miika Nousiaisen Metsäjätti (2011), jos kohta niistä jälkimmäisessä perinteiselle realismille ominainen kaikkitietävä kertoja on korvattu kahdella romaania eteenpäin vievällä minäkertojalla. (Vrt. Ojajärvi 2016, 103-104; Ruohonen 2005, 117-122.)

138 Tästä haastattelusta ks. Hänninen 2014.

139 Harri Veivo (2011, 172-191) toteaa, että nykyisessä semioottisessa kirjallisuudentutkimuksessa kirjalliset tekstit ymmärretään todellisuutta esittäviksi malleiksi. Tämä implikoi ajatuksen, että mallin ja todellisuuden välillä vallitsee jonkinasteinen samankaltaisuus. Kirjallisten mallien tiedollista arvoa määritettäessä näitä malleja on Veivon mukaan syytä verrata tieteen ja arkikokemuksen tarjoamiin malleihin tai maailmankuviin, sillä muulla tavalla tuota arviointia on miltei mahdotonta suorittaa. Tähän on syytä lisätä se, että modernissa akateemisessa kulttuurissa tieteenalat ovat jatkuvassa käymistilassa ja tutkijat käyvät säännöllisesti keskustelua erilaisten todellisuutta koskevien mallien pätevyydestä, niiden ansioista ja heikkouksista. Kirjallisten mallien tavoin tieteelliset mallitkin on siten syytä ymmärtää intellektuaaliseen keskusteluun tarjotuiksi puheenvuoroiksi, ei lopullisiksi totuuksiksi siitä, millainen todellisuus on luonteeltaan.

140 Seppälän yhteiskunnallisista näkemyksistä ks. esim. Seppälä 1992c; 2001; 2006b; 2006c; 2006f; 2006g; 2007a. Ks. myös Seppälästä tehtyjä haastatteluja Turun Sano- 
missa 6.2.2001 (Anonyymi 2001) ja Helsingin Sanomissa 1.9.2001 (Räty 2001).

Ks. Seppo Puttosen ja Joni Pyysalon (2003, 62-63) Parnasso-lehteen 1/2003 tekemää haastattelua Seppälästä.

142 Ks. Riitta Kylänpään $(2008,58)$ Suomen Kuvalehden numeroon 44/2008 tekemää haastattelua Seppälästä.

143 Adornon taidekäsityksestä ks. myös Adorno 1980b ja Adorno 2006 sekä Fredric Jamesonin teosta Late Marxism: Adorno or the Persistence of the Dialectic (2007). Marcusen osalta ks. hänen teostaan The Aesthetic Dimension. Toward a Critique of Marxist Aesthetics (1986). Habermasin taidekäsityksen osalta ks. Kotkavirta 1991 ja Sevänen 1998.

144 Matka aurinkoon -romaanin mottona on seuraavanlainen Foucault-sitaatti: "Luuletteko, että näkisin niin paljon vaivaa, saisin niin paljon nautintoa kirjoittamisesta, ajatteletteko, että pysyisin niin peräänantamattomana tehtävieni edessä, jos en olisi valmistelemassa labyrinttia, johon voisin kadottaa itseni."

145 Eksplisiittisimmin Seppälä on Mr. Smithin jälkeen käsitellyt kapitalismia kolumnissaan "Pysyvä kriisi" (Satakunnan Viikko 19.9.2018). Siinä esitetty käsitys kapitalismista ei poikkea olennaisesti siitä, joka tulee esiin Mr. Smithissä.

Kyseinen kolumni liittyy laajemmin ottaen siihen, että elo-syyskuussa 2018 suomalainen lehdistö, muun muassa Helsingin Sanomat, julkaisi useita kirjoituksia, joissa käsitellään vuoden 2007 lopussa Yhdysvalloissa alkanutta ja vuonna 2008 yleiseen tietoisuuteen tullutta finanssikriisiä ja sen "erityislaatua". Seppälä mukaan vakavat taloudelliset kriisit eivät ole kapitalismissa mitään epätavallista tai erityistä, vaan ne toistuvat siinä suhteellisen säännöllisin väliajoin: "Suhdannevaihtelu ja kriisit kuuluvat kapitalismin luonteeseen. Markkinatalouteen halutaan lisää inhimillisyyttä ja vastuullisuutta, mutta ihmiset kaikkialla maailmassa ovat pääsemättömästi takertuneet vapaiden markkinoiden verkkoihin. Jatkossakin paljastuu velkojen ja riskien piilottamista, ahneutta ja vauhtisokeutta" (Seppälä 2018b). Sitaatti ei viittaa ainoastaan kapitalismin epävakauteen, vaan siinä tulee esiin myös ajatus kapitalismin indifferentistä luonteesta, sitä vaivaavasta "inhimillisyyden ja vastuullisuuden" puutteesta. Seppälän romaaneista tällaista näkemystä kapitalismista kehittelee erityisesti Paholaisen haarukka, jossa se on päämotiivin tai pääteeman asemassa, ja hieman maltillisemmassa muodossa se sisältyy Mr. Smithiin.

Seppälän kapitalismikriittisissä romaaneissa toistuu suoremmin tai epäsuoremmin näkemys, että rajoittamaton markkinayhteiskunta on tuhoisa järjestely yksilöiden ja yhteisöjen kannalta. Tämä näkemys sisältyy myös edellä mainittuun kolumniin. Siinä Seppälä jatkaa, että kapitalismi ei kaikesta huolimatta ole kokonaan kelvoton järjestelmä. Se pitää vain asettaa järkeviin ja mielekkäisiin rajoihin: "Evoluutiota ajatellen kapitalismi on elinkelpoinen tuotantotapa, mutta sitä pitää suitsia ja säädellä. Sen myöntää aina hädän tullen kapitalistikin, vaikka panee hanttiin samalla kun huutaa apua valtiolta eli meiltä, veronmaksajilta" (Seppälä 2018b). Eri tavoin ilmaistuina ja painotettuina nämä samat arviot ja johtopäätökset ovat paljolti löydettävissä varsinkin Mr. Smithistä, joka tuo ne esiin fiktiivisten tarinalinjojen ja kerronnan lomaan sijoitettujen pohdiskelujen avulla.

146 Ks. Iso Raamatun Tietosanakirja. Osa 1 (1988), 117-120; Novum. Uusi Testamentti Selityksin. Osa 5 (1984), 767-769. 
147 Ks. David Hermanin, Manfred Jahnin ja Marie-Laure Ryanin toimittamaa hakuteosta Routledge Encyclopedia of Narrative Theory, s. 34-37.

148 Erilaisiin Raamattu-suomennosten versioihin voi tutustua internet-osoitteessa http:// www.finbible.fi. Osoitteesta löytyvät vuosien 1548-1552, 1642, 1776, 1938 ja 1992 suomennokset. Luukkaan evankeliumin loppuluku (luku 24) löytyy seuraavasta alaosoitteesta: http://www.finbible.fi/jakeittain/UT/Luukas_24htm. Kyseinen tiedosto kantaa nimeä Finbible. Suomalaisia Raamatunkäännöksiä. Tämän lähteen käsittelyssä ja tulkinnassa olen saanut apua teologian tohtori Harri Koskelalta (Itä-Suomen yliopisto). Luettu 22.3.2018. 


\section{English Abstract}

Erkki Sevänen (D) https://orcid.org/0000-000I-5227-45II

Aberrations of Reason. Capitalist Rationality and its Critique in Juha Seppälä's Novels Yhtiökumppanit (The Partners, 2002), Paholaisen haarukka (Devil's Fork, 2008) and Mr. Smith (20I2)

Juha Seppälä's early literary works, published in the I980s and in the early I990s, usually described spiritually lonely men who suffered from an existential loss of meaning and serious alienation problems in the modern world. After this, Seppälä turned to deal with the transformation of the Finnish way of life and its cultural base, until after the turn of the new millennium he began to critically judge society's ongoing marketization process. This study analyses his capitalism-critical works, particularly his novels Yhtiökumppanit (The Partners, 2002), Paholaisen haarukka (Devil's Fork, 2008) and Mr. Smith (20I2). These works do not, primarily, consider contemporary market capitalism from a class perspective, although this sort of perspective is also included in them. They are, above all, critical of market capitalist rationality. According to Seppälä, the basic problem of modern economic profit-seeking lies in the fact that in its unchecked form it is largely indifferent with respect to existential, moral, social and ecological values and principles. Free market economy or market capitalism has, therefore, a destructive influence on individuals, communities and ecological systems. The novels at issue emphasize that due to this it is also, in a deeper sense, incapable of producing existentially meaningful ways of life. 


\section{Lähteet}

\section{TUTKIMUKSEN KOHDE}

BE: Juha Seppälä, Bisnesenkeli. Teoksessa Seppälä 2004a, 77-134.

KH: Juha Seppälä, Kimalaisen hunajaa. Teoksessa Seppälä 2004a, 185-203.

MRS: Juha Seppälä, Mr. Smith. Romaani. WSOY, Helsinki 2012.

MSO: Juha Seppälä, Mitä sähkö on? Teoksessa Seppälä 2004a, 157-183.

MUSA: Juha Seppälä, Mustalla saarella. Teoksessa Seppälä 2000a, 9-36.

PH: Juha Seppälä, Paholaisen haarukka. Romaani. Kolmas painos. WSOY, Helsinki 2008.

YK: Juha Seppälä, Yhtiökumppanit. WSOY, Helsinki 2002.

\section{TUTKIMUKSESSA KÄYTETTY SEPPÄLÄN TUOTANTO}

Seppälä, Juha 1986: Torni. Novelleja. WSOY, Porvoo-Helsinki-Juva.

Seppälä, Juha 1987a: Taivaanranta. Proosaa. WSOY, Porvoo-Helsinki-Juva.

Seppälä, Juha 1987b: Taivaanranta. Teoksessa Seppälä 1987a, 5-121.

Seppälä, Juha 1988: Silta. Pienoisromaani. WSOY, Porvoo-Helsinki-Juva.

Seppälä, Juha 1989a: Riikinkukon sulka. Novelleja. WSOY, Porvoo-Helsinki-Juva.

Seppälä, Juha 1989b: Riikinkukon sulka. Teoksessa Seppälä 1989a, 7-34.

Seppälä, Juha 1989c: Pääsiäinen. Teoksessa Seppälä 1989a, 56-84.

Seppälä, Juha 1989d: Kasvukausi. Teoksessa Seppälä 1989a, 141-164.

Seppälä, Juha 1989e: Henkilökohtainen on poliittista. Kolumni. Aamulehti 30.4.

Seppälä, Juha 1990a: Hyppynaru. Romaani. WSOY, Porvoo-Helsinki-Juva.

Seppälä, Juha 1990b: Elämää marginaalissa. Kolumni. Aamulehti 3.1.

Seppälä, Juha 1990c: Akateemista harmoniaa. Kolumni. Aamulehti 14.4.

Seppälä, Juha 1990d: Essee. Kotkan Sanomat 26.8.

Seppälä, Juha 1991a: Super Market. WSOY, Porvoo-Helsinki-Juva.

Seppälä, Juha 1991b: Supermarket. Teoksessa Seppälä 1991a, 71-72.

Seppälä, Juha 1991c: Äyräpää 1. Teoksessa Seppälä 1991a, 95-96.

Seppälä, Juha 1991d: Katujyrässä Viipurissa. Teoksessa Seppälä 1991a, 97-98.

Seppälä, Juha 1992a: Luru. WSOY, Porvoo-Helsinki-Juva.

Seppälä, Juha 1992b: Demokraattiset markkinavoimat. Kolumni. Aamulehti 26.4.

Seppälä, Juha 1992c: Apurahat ja taide. Kolumni. Aamulehti 9.8.

Seppälä, Juha 1993a: Lähtösavut. Novelleja. WSOY, Porvoo-Helsinki-Juva.

Seppälä, Juha 1993b: Tampere 1918. Kolumni. Aamulehti 19.3.

Seppälä, Juha 1994a: Sydänmaa. Romaani. WSOY, Porvoo-Helsinki-Juva.

Seppälä, Juha 1994b: Miksi arvostella? Helsingin Sanomat 31.8.

Seppälä, Juha 1994c: Kauneus on kauhua. Kolumni. Aamulehti 16.1.

Seppälä, Juha 1995a: Tunnetko typpin? Tapauksia, oikkuja, sattumuksia. WSOY, Porvoo-Helsinki-Juva.

Seppälä, Juha 1995b: Yhteiskunnallisen romaanin kohtalonhetki? Suomen Kuvalehti numero $25 / 26,60-61$. 
Seppälä, Juha 1996a: Jumala oli mies. Romaani rakkaudesta. WSOY, Porvoo-Helsinki-Juva. Seppälä, Juha 1996b: Maatyöläisen helvetti ja taivas. Paavo Rintala: Maatyömies ja kuu.

Teoksessa Juhani Salokannel (toim.), Kirjojen Suomi. Otava, Helsinki, 580-586.

Seppälä, Juha 1998: Suomen historia. WSOY, Porvoo-Helsinki-Juva.

Seppälä, Juha 1999: Kuun nousu ja lasku. Romaani. WSOY, Porvoo-Helsinki-Juva.

Seppälä, Juha 2000a: Suuret kertomukset. WSOY, Porvoo-Helsinki-Juva.

Seppälä, Juha 200ob: Mustalla saarella. Teoksessa Seppälä 2000a, 9-36.

Seppälä, Juha 2000c: Tikapuut. Teoksessa Seppälä 2000a, 111-150.

Seppälä, Juha 2001a: Sisältö-Suomen huterat jalat. Katsaus. Aamulehti 6.1.

Seppälä, Juha 2001b: In It We Trust. Suomen Kuvalehti numero 44, 59-62.

Seppälä, Juha 2002: Yhtiökumppanit. WSOY, Helsinki.

Seppälä, Juha 2004a: Mitä sähkö on? Novelleja. WSOY, Helsinki.

Seppälä, Juha 2004b: Bisnesenkeli. Teoksessa Seppälä 2004a, 77-134.

Seppälä, Juha 2004c: Mitä sähkö on? Teoksessa Seppälä 2004a, 157-183.

Seppälä, Juha 2004d: Kimalaisen hunajaa. Teoksessa Seppälä 2004a, 185-203.

Seppälä, Juha 2004e: Routavuosi. Romaani. WSOY, Helsinki.

Seppälä, Juha 2006a: Ei kenenkään maa. Romaani. WSOY, Helsinki.

Seppälä, Juha 2006b: Sijoituskatsaus. Blogikirjoitus Satakunnan Kansan verkkosivuilla 5.9.

Seppälä, Juha 2006c: Taloustiedon aakkoset. Blogikirjoitus Satakunnan Kansan verkko-

sivuilla 19.9.

Seppälä, Juha 2006d: Taidetta telkkarissa. Blogikirjoitus Satakunnan Kansan verkkosivuilla 18.10 .

Seppälä, Juha 2006e: Suuret sanat. Blogikirjoitus Satakunnan Kansan verkkosivuilla 30.10.

Seppälä, Juha 2006f: Työmiestä etsimässä. Blogikirjoitus Satakunnan Kansan verkkosivuilla 31.10.

Seppälä, Juha 2006g: Quo vadis, Finlandia? Blogikirjoitus Satakunnan Kansan verkkosivuilla 1.12 .

Seppälä, Juha 2006h: Uusi Jeesus, pysy poissa! Blogikirjoitus Satakunnan Kansan verkkosivuilla 21.12.

Seppälä, Juha 2006i: Vihreät kuulat on syöty. Blogikirjoitus Satakunnan Kansan verkkosivuilla 22.12.

Seppälä, Juha 2007a: Kenen yhteiskuntavastuu? Blogikirjoitus Satakunnan Kansan verkkosivuilla $5 \cdot 5$.

Seppälä, Juha 2007b: Seksiä ja väkivaltaa. Blogikirjoitus Satakunnan Kansan verkkosivuilla 1.6.

Seppälä, Juha 2007c: Nobel-äänestys. Blogikirjoitus Satakunnan Kansan verkkosivuilla 10.7.

Seppälä, Juha 2007d: Demokraatit ja demokraatit. Blogikirjoitus Satakunnan Kansan verkkosivuilla 21.8.

Seppälä, Juha 2007e: Kirkko vähällä auttaa hädänalaisia. Blogikirjoitus Satakunnan Kansan verkkosivuilla 4.9.

Seppälä, Juha 2007f: Kuka korvaa Tonyn? Blogikirjoitus Satakunnan Kansan verkkosivuilla 19.9.

Seppälä, Juha 2007g: Löytyykö Jumala pankista? Blogikirjoitus Satakunnan Kansan verkkosivuilla 3.10 . 
Seppälä, Juha 2008: Paholaisen haarukka. Romaani. Kolmas painos. WSOY, Helsinki.

Seppälä, Juha 2010a: Takla Makan. Kaksi kertomusta. WSOY, Helsinki.

Seppälä, Juha 2010b: Takla Makan. Teoksessa Seppälä 2010a, 7-91.

Seppälä, Juha 2010c: Ristin tie. Teoksessa Seppälä 2010a, 93-149.

Seppälä, Juha 2010d: Houellebecq karkaa. Teoksessa Timo Hännikäinen (toim.),

Mitä Houellebecq tarkoittaa? Savukeidas, Tallinna, 56-67.

Seppälä, Juha 2012: Mr. Smith. Romaani. WSOY, Helsinki.

Seppälä, Juha 2014: Matka aurinkoon. Romaani. WSOY, Helsinki.

Seppälä, Juha 2016: Kuoppakaupunki. Romaani. WSOY, Helsinki.

Seppälä, Juha 2018a: Sankariaika. Romaani. Siltala, Helsinki.

Seppälä, Juha 2018b: Pysyvä kriisi. Satakunnan Viikko 19.9.

Seppälä, Juha 2020: Syntymättömän testamentti. Romaani. Siltala, Helsinki.

\section{SEPPÄLÄN TEOKSIA KOSKEVAT ARVOSTELUT}

Ahola, Suvi 1987: Juha Seppälän mestarinovellit eivät ole selviytymistarinoita. Ihminen häviää aina. Arvostelu Juha Seppälän teoksesta Taivaanranta. Helsingin Sanomat 29.3.

Ahola, Suvi 1991: Miehen tahma ja uhma. Juha Seppälä parodioi kirjallisuuttamme, juuri sellaista kuin olemme ansainneetkin. Arvostelu Juha Seppälän teoksesta Super Market. Helsingin Sanomat 25.10.

Anonyymi 1990: Viha on jäinen tuli. Arvostelu Juha Seppälän romaanista Hyppynaru. Me Naiset 19.10., numero 43.

Elo, Aulikki 1992: Seppälä on Seppälä lainahameessakin. Arvostelu Juha Seppälän romaanista Luru. Savon Sanomat 29.10.

Haaso, Stina 1999: Kun kaksi miestä melkein kohtaa. Arvostelu Juha Seppälän romaanista Kuun nousu ja lasku. Koillis-Häme 18.2.

Hakala, Raija 1999: Kaksi kamppailua hevosesta ja karhusta. Juha Seppälä kirjoittaa tiukkaa proosaa sivullisuudesta. Arvostelu Juha Seppälän romaanista Kuun nousu ja lasku. Pohjolan Sanomat 26.9.

Heiskanen, Seppo 1991: Irtonaisesti iljettävyyksistä. Arvostelu Juha Seppälän teoksesta Super Market. Demari 28.11.

Hänninen, Ville 2013: Näetkö viisi sormea? Arvostelu Juha Seppälän romaanista Mr. Smith. Kiiltomato 16.1.2013.

Kantokorpi, Mervi 2004: Yhteiskunnan sydämen kammiovärinää. Juha Seppälän uudet novellit ovat nykynaturalismin voimannäyte. Arvostelu Juha Seppälän teoksesta Mitä sähkö on? Helsingin Sanomat 18.9.

Karila, Juhani 2012a: Raha nujertaa Euroopan ja ihmiset. Arvostelu Juha Seppälän romaanista Mr. Smith. Helsingin Sanomat 7.8.

Karila, Juhani 2012b: Valuutasta luonnonlaiksi. Kommentteja Juha Seppälän teoksesta Mr. Smith ja nykyisestä suomalaisesta kapitalismia käsittelevästä kirjallisuudesta. Helsingin Sanomat 7.8 .

Karonen, Vesa 2016: Kirjailija tavoittelee tavoittamatonta. Arvostelu Juha Seppälän romaanista Kuoppakaupunki. Helsingin Sanomat 18.9. 
Korhonen, Kuisma 2008: Jumalan kyynel talouden myrskyssä. Arvostelu Juha Seppälän teoksesta Paholaisen haarukka. Helsingin Sanomat 27.9.

Koskela, Lassi 1991: Huipennus, ääripää, umpikuja. Arvostelu Juha Seppälän romaanista Hyppynaru. Parnasso 2, 127-128.

Koskelainen, Jukka 2006: Älkää unohtako että kohta kuolette. Arvostelu Juha Seppälän teoksesta Ei kenenkään maa. Helsingin Sanomat 24.9.

Kulmala, Markku 1994: Uuden ajan torppariromaani. Arvostelu Juha Seppälän romaanista Sydänmaa. Satakunnan Kansa 11.9.

Lappalainen, Seija 1993: Hännättömän tarina. Arvostelu Juha Seppälän romaanista Luru. Lapin Kansa 26.1.

Majander, Antti 2002: Raha koituu kuolemaksi. Juha Seppälä näkee vain mustaa tietotekniikka-ajan kuvauksessa. Arvostelu Juha Seppälän romaanista Yhtiökumppanit. Helsingin Sanomat 7.9.

Martin, Margareta 1995: Review of Juha Seppälä's Sydänmaa (Heartland). World Literature Today. Summer 1995.

Marttila, Hannu 2004: Me olemme kaikki demareita. Juha Seppälän Routavuosi on edunvalvontayhteiskunnan ruoska ja mestarillinen romaani yksinäisestä terroristista. Arvostelu Juha Seppälän romaanista Routavuosi. Helsingin Sanomat 20.3.

Miettinen, Ville 2007: Maahan pitää sinun palaamaan. Arvostelu Juha Seppälän teoksesta Ei kenenkään maa. Kymen Sanomat 27.1.

Mäkinen, Kari 1989: Valoa joka ei lämmitä. Arvostelu Juha Seppälän teoksesta Riikinkukon sulka. Kotimaa 6.10.

Mäkinen, Kari 1994: Voima joka pitää elämää yllä. Arvostelu Juha Seppälän teoksesta Sydänmaa. Kotimaa 7.10 .

Ruohola, Kai 1994: Sadan vuoden moninaisuus. Juha Seppälän Sydänmaa on tämän syksyn kirjatapaus. Arvostelu Juha Seppälän romaanista Sydänmaa. Satakunnan Kansa 11.9.

Ruuska, Helena 1993: Minä tulen ja tuon mansikkajogurttia. Arvostelu Juha Seppälän romaanista Luru. Parnasso 2.

Sihvonen, Lauri 2008: Ei paholainenkaan niin paha ole. Arvostelu Juha Seppälän teoksesta Paholaisen haarukka. Parnasso 5, 75.

Tarkka, Pekka 1994: Kuoleman voittokulku. Juha Seppälän tuomiosaarna haudoilla. Arvostelu Juha Seppälän teoksesta Sydänmaa. Helsingin Sanomat 28.8.

Toiviainen, Kalervo 1994: Tällaista on elämäsi. Juha Seppälän Sydänmaalla eletään ja kuollaan yksin. Arvostelu Juha Seppälän romaanista Sydänmaa. Pohjolan Sanomat 2.9.

Waarala, Hannu 2012: Juha Seppälä: Mr. Smith. Arvostelu Juha Seppälän romaanista Mr. Smith. Savon Sanomat 6.8.

Wilhelmsson, Putte 2007: 'Kuolema on totta'. Juha Seppälä parhaimmillaan. Arvostelu Juha Seppälän teoksesta Ei kenenkään maa. Turun Sanomat 5.1.

\section{SEPPÄLÄSTÄ TEHDYT HAASTATTELUT}

Alftan, Maija 2001: Tylyn miehen maineessa. Maija Alftanin haastattelu Juha Seppälästä. Helsingin Sanomat 4.2. 
Anonyymi 2001: Runeberg-palkittu Juha Seppälä: kirjallisuus ja kirjailijat voivat hyvin. Juha Seppälästä tehty haastattelu Turun Sanomat 6.2.2001.

Grönholm, Jouko 1987: Juha Seppälä ja yksinäinen kirjoituskone. Kun huumori näkyy mustana. Jouko Grönholmin haastattelu Juha Seppälästä. Turun Sanomat 29.3.

Hänninen, Ville 2014: Jännitetty jousi. Rytmiä, hengitystä, verenkiertoa, motoriikkaa. Siinä Juha Seppälän teokset. Ville Hännisen haastattelu Juha Seppälästä. Parnasso 6-7, 21-28.

Karvala, Samu 2000: Seppälä ei ole saarnamies. Hyvä teksti vaikuttaa eri lukijoihin eri tavalla. Samu Karvalan haastattelu Juha Seppälästä. Uusimaa 28.12.

Koskela, Lasse 1986: Novelli on musta hanska vasten maailman naamaa. Lasse Koskelan kirjoitus ja haastattelu Juha Seppälästä. Nuori Voima 4, 17-18.

Kylänpää, Riitta 2008: Juha Seppälä: 'Isoja totuuksia laukova kirjailija on tollo', sanoo kirjailija, joka kuvaa yhteiskuntaa yksityisen kokemuksen kautta. Riitta Kylänpään haastattelu Juha Seppälästä. Suomen Kuvalehti 22, 58-62.

Levola, Lauri 2003: Kirjoittaa elääkseen. Lauri Levolan haastattelu Juha Seppälästä. Lukufilis 4, 4-6.

Lilja, Kimmo 2001: Juha Seppälä kirjoittaa vastavirran passiota. Vakavia iskuja, ironian viiltoja, etiikan pistoja. Kimmo Liljan kirjoitus ja haastattelu Juha Seppälästä. Turun Sanomat 7.1.

Majander, Antti 1992: Armottoman suurinta moralismia. Antti Majanderin haastattelu Juha Seppälästä. Helsingin Sanomat 2.2.

Majander, Antti 1998: Jos patsaat palaisivat elämään. Juha Seppälä kääntää Mannerheimin sekä muita merkkihahmoja nurin niskoin - ja he näyttävät jälleen ihmisiltä. Antti Majanderin haastattelu Juha Seppälästä. Helsingin Sanomat 21.2.

Puttonen, Seppo \& Joni Pyysalo 2003: Ammatti, totuudellisuus, kirjailija. Juha Seppälän haastattelu Porissa. Haastattelijoina Seppo Puttonen ja Joni Pyysalo. Parnasso 1, 62-76.

Rantanen, Kimmo 1988: Juha Seppälä: eleettömän tyylin taitaja. Kimmo Rintasen haastattelu Juha Seppälästä Turun Sanomat 19.3.

Rintanen, Kimmo 2004: Suoriutumisen pakko. Juha Seppälä kirjoitti romaanin nykyihmisen ahdingosta. Kimmo Rintasen haastattelu Juha Seppälästä. Ilta-Sanomat Plussa 28.2., 32-33.

Räty, Panu 2001: Porilainen ilman mausteita. Panu Rädyn kirjoitus ja haastattelu Juha Seppälästä. Helsingin Sanomien Kuukausiliite 1.9., 28-31.

Seppänen, Arttu 2018: Kirjailija Juha Seppälä haukkuu harvinaisessa haastattelussa Finlandian, ay-liikkeen, Suomi-Areenan ja Helsingin Sanomat - muun muassa. Arttu Seppäsen tekemä haastattelu Juha Seppälästä. Helsingin Sanomat 12.8 .

Ylönen, Merja 2006: Seppälässä on Jumalan mentävä reikä. Maija Ylösen haastattelu Juha Seppälästä. Aamulehti 20.1.

\section{ARKISTOAINEISTO}

Tutkimusta varten olen käynyt läpi Seppälää koskevan lehtileikeaineiston, jota WSOY:n Kirja-arkisto säilyttää Porvoon Kirjakeskuksessa. Se muodostuu lähinnä Seppälän teoksia koskevista arvosteluista sekä hänestä tehdyistä haastatteluista ja hänen kirjoittamistaan kolumneista. Arvosteluaineisto lienee suhteellisen kattava 1980- ja 1990-luvun osalta, 
mutta Seppälän 2000-luvulla ilmestyneiden teosten arvosteluja aineistoon sisältyy niukalti.

\section{VERKKOAINEISTO}

Finbible. Suomalaisia Raamatunkäännöksiä. Osoite: http://www.finbible.fi. Tiedosto sisältää vuosien 1548-1552, 1642, 1776, 1938 ja 1992 Raamattu-suomennokset.

Seppälän julkaisemat blogikirjoitukset Satakunnan Kansan verkkosivuilla vuosina 2006-2007. Osoite: http://www2.satakunnankansa.fi/blogit/juhaseppala. Olen printannut kirjoitukset internetistä 16.6.2010 ja säilytän näitä kopioita työhuoneessani Itä-Suomen yliopistossa.

\section{VERTAILUAINEISTO}

Balzac, Honoré de 1983a: Eugénie Grandet. Alkuperäisteos Eugénie Grandet (1833). Suomentanut Kalevi Nyytäjä. Karisto, Hämeenlinna.

Balzac, Honoré de 1983b: Kadonneet illuusiot. Alkuperäisteos Illusions perdues (1837-1843). Suomentanut Heikki Kaskimies. Love Kirjat, Helsinki.

Balzac, Honoré de 1985: Ukko Goriot. Alkuperäisteos Pére Goriot (1835). Suomentaneet Eino Voionmaa et al. Karisto, Hämeenlinna.

Brecht, Bertolt 1971: Kerjäläisromaani. Alkuperäisteos Drei Groschen Roman (1934). Tammi, Helsinki.

Broch, Hermann 1994: Unissakävelijät-romaanitrilogia. Osa III. Liikemies Huguenau eli asiallisuus 1918. Alkuperäisteos Die Schlafwandler. Band III (1931-1932). Suomentanut Oili Suominen. Tammi, Helsinki.

Camus, Albert 1969: Sivullinen. Alkuperäisteos L'Etranger (1942). Suomentanut Kalle Salo. Otava, Helsinki.

Camus, Albert 1971: Kapinoiva ihminen. Esseitä ja katkelmia. Valikoinut Maija Lehtonen. Suomentaneet Ulla-Kaarina Jokinen ja Maija Lehtonen. Otava, Helsinki.

Camus, Albert 1995: Ensimmäinen ihminen. Alkuperäisteos Le Premier homme (1994). Suomentanut Sirkka Suomi. Otava, Helsinki.

DeLillo, Don 2003: Cosmopolis. Alkuperäisteos Cosmopolis (2003). Suomentanut Helene Bützow. Tammi, Helsinki.

DeLillo, Don 2004: Cosmopolis. Picador, London. (Ilmestyi alun perin 2003.)

Ellis, Bret Easton 1991: American Psycho. Picador, London.

Haanpää, Pentti 1974: Noitaympyrä. Romaani pohjoisesta. Otava, Helsinki. (Ilmestyi 1956, kirjoitettu 1931.)

Haavikko, Paavo 1992: Murtuva keskiluokka. Aikalaiskirjoitus. Art House, Helsinki.

Hotakainen, Kari 2013: Luonnon laki. Siltala, Helsinki.

Houellebecq, Michel 2000: Alkeishiukkaset. Alkuperäisteos Les particules élémentaires (1998). Suomentanut Ville Keynäs. WSOY, Helsinki.

Houellebecq, Michel 2006: Mahdollinen saari. Alkuperäisteos La Possibilité d'une Île (2005). Suomentanut Ville Keynäs. WSOY, Helsinki. 
Houellebecq, Michel 2009: Halujen taistelukenttä. Alkuperäisteos Extension du domaine de la lutte (1994). Suomentanut Ville Keynäs. WSOY, Helsinki.

Huxley, Aldous 1984: Uusi uljas maailma. Alkuperäisteos Brave New World (1932). Suomentanut I. H. Orras. 9. painos. Tammi, Helsinki.

Hämäläinen, Karo 2011: Erottaja. Romaani. WSOY, Helsinki.

Hämäläinen, Karo 2012: Kolmikulma. Romaani. WSOY, Helsinki.

Jokela, Juha 2003: Mobile Horror. Näytelmä. WSOY, Helsinki.

Kalevala 1947. Koonnut Elias Lönnrot. Kuvittanut ja painatustyön suunnitellut Akseli GallenKallela. WSOY, Porvoo.

Kianto, Ilmari 1969: Punainen viiva. Otava, Helsinki. (Ilmestyi alun perin 1907.)

Kihlman, Christer 1976: Kallis prinssi. Alkuperäisteos Dyre prins (1974). Suomentanut Pentti Saaritsa. Tammi, Helsinki.

Krohn, Leena 2004: Unelmakuolema. Teos, Helsinki.

Kundera, Milan 1985: Olemisen sietämätön keveys. Alkuperäisteos Nesnesitelná lehkost bytí (1983). Suomentanut Kirsi Siraste. WSOY, Helsinki.

Kundera, Milan 1992: Kuolemattomuus. Alkuperäisteos Nesmrtelnost (1990). Suomentanut Kirsti Siraste. WSOY, Porvoo-Helsinki-Juva.

Kundera, Milan 2015: Merkityksettömyyden juhla. Alkuperäisteos La fête de insignificance

(2013). Suomentanut Ville Keynäs. Siltala, Helsinki.

Lampela, Pasi 2005: Westend. Näytelmä. Kirja kerrallaan, Helsinki.

Marttila, Hanna Marjut 2002: Kertoi tulleensa petetyksi. Otava, Helsinki.

Maupassant, Guy de 1987: Bel-Ami (Kaunis ystävä). Alkuperäisteos Bel-Ami (1885). Suomentanut Arvi Nuormaa. Tammi, Helsinki.

Melender, Tommi 2007: Kunnian mies. Romaani. WSOY, Helsinki.

Melender, Tommi 2009: Ranskalainen ystävä. Romaani. WSOY, Helsinki.

Pekkanen, Toivo 1967: Tehtaan varjossa. Romaani. WSOY, Porvoo-Helsinki. (Ilmestyi alun perin 1931.)

Raittila, Hannu 1998: Ei minulta mitään puutu. WSOY, Porvoo-Helsinki-Juva.

Raittila, Hannu 2005: Pamisoksen purkaus. Romaani. WSOY, Helsinki.

Salama, Hannu 1972: Siinä näkijä missä tekijä. Otava, Helsinki.

Salminen, Arto 2001: Paskateoria. Romaani. WSOY, Porvoo-Helsinki-Juva.

Salminen, Arto 2003: Ei-kuori. Romaani. WSOY, Helsinki.

Salminen, Arto 2005: Kalavale. Kansalliseepos. WSOY, Helsinki.

Sartre, Jean-Paul 1938: La nausée. Gallimard, Paris.

Sartre, Jean-Paul 1964: Inho. Alkuperäisteos La nausée (1938). Suomentanut Juha Mannerkorpi. 4. painos. Tammi, Helsinki.

Sinkkonen, Lassi 1968: Sumuruisku. Tammi, Helsinki.

Stendhal 1969: Punainen ja musta. Alkuperäisteos Le Rouge et le Noir. Chronique du XIXe siècle (1830). Toinen painos. Suomentanut J. A. Hollo. WSOY, Porvoo.

Wells, H. G. 2001: Kun nukkuja herää. Alkuperäisteos When the Sleeper Wakes (1899). Suomentanut Tero Valkonen. Desura, Jyväskylä.

Verronen, Maarit 2008: Karsintavaihe. Romaani. Tammi, Helsinki. 


\section{TUTKIMUSKIRJALLISUUS}

Adler, Hans (Hrsg.) 1990: Der Deutsche Sozialroman des 18. und 19. Jahrhunderts. Wissenschaftliche Buchgesellschaft, Darmstadt.

Adorno, Theodor 1966: Negative Dialektik. Suhrkamp, Frankfurt am Main.

Adorno, Theodor W. 1980a: Engagement (1962). Teoksessa Theodor W. Adorno, Noten zur Literatur III. Suhrkamp, Frankfurt am Main, 109-135.

Adorno, Theodor W. 1980b: Versuch, das Endspiel zu verstehen. Teoksessa Theodor W. Adorno, Noten zur Literatur II. Suhrkamp, Frankfurt am Main, 188-236.

Adorno, Theodor W. 2006: Esteettinen teoria. Alkuperäisteos Ästhetische Theorie (1970).

Suomentanut Arto Kuorikoski. Vastapaino, Tampere.

Airaksinen, Timo 1987: Moraalifilosofia. WSOY, Porvoo-Helsinki-Juva.

Alanko, Outi \& Oiva Kuisma (toim.) 2000: Subliimi, groteski, ironia. Suomalaisen Kirjallisuuden Seura, Helsinki.

Alapuro, Risto 1985: Yhteiskuntaluokat ja sosiaaliset kerrostumat 1870-luvulta toiseen maailmansotaan. Teoksessa Tapani Valkonen et al., Suomalaiset. Yhteiskunnan rakenne teollistumisen aikana. WSOY, Porvoo-Helsinki-Juva.

Alapuro, Risto 1997: Suomalainen älymystö Venäjän varjossa. Tammi, Helsinki.

Alasuutari, Pertti 2006: Suunnittelutaloudesta kilpailutalouteen: miten muutos oli ideologisesti mahdollinen? Teoksessa Heiskala \& Luhtakallio 2006, 43-64.

Alasuutari, Pertti \& Marjaana Lampinen 2006: OECD ja suomalaisen projektiyhteiskunnan synty. Teoksessa Rantala \& Sulkunen 2006, 56-68.

Alexander, Victoria D. 2018: Enterprise Culture and the Arts. Neoliberal Values and British Art Institutions. Teoksessa Alexander, Hägg, Häyrynen \& Sevänen 2018a, 43-66.

Alexander, Victoria D., Samuli Hägg, Simo Häyrynen \& Erkki Sevänen (eds.) 2018a: Art and the Challenge of Markets. National Cultural Politics and the Challenge of Marketization and Globalization. Palgrave Macmillan, Cham Switzerland.

Alexander, Victoria D., Samuli Hägg, Simo Häyrynen \& Erkki Sevänen (eds.) 2018b: Art and the Challenge of Markets. From Commodification of Art to Artistic Critiques of Capitalism. Palgrave Macmillan, Cham Switzerland.

Allardt, Erik 1976: Hyvinvoinnin ulottuvuuksia. WSOY, Porvoo.

Andersson, Clas 1986: Pahan ongelma uudessa proosassa. Helsingin Sanomat 7.10.

Anttila, Anu-Hanna, Ralf Kauranen, Kati Launis \& Jussi Ojajärvi (toim.) 2016: Luokan ääni ja hiljaisuus. Yhteiskunnallinen luokkajärjestys 20oo-luvun alun Suomessa. Vastapaino, Tampere.

Anttonen, Veikko 2002: Pyhän patsaan arvoitus - selitys sammolle? Teoksessa Pekka Laaksonen \& Sirkka-Liisa Mettomäki (toim.), Pyhän perintö. Kirjoituksia suomalaisesta pyhästä Kalevalassa, kansanperinteessä, luonnossa ja taiteessa. Kalevalaseuran vuosikirja 79-80. Suomalaisen Kirjallisuuden Seura, Helsinki, 123-143.

Anttonen, Veikko 2012: The Sampo as a Mental Representation of the Mythic Origins of Growth. Teoksessa Frog, Siikala \& Stepanova 2012.

Aristoteles 1967: Runousoppi. Suomentanut Pentti Saarikoski. Otava, Helsinki. (Alkuperäisteos ilmestyi 330-320 eKr.) 
Arminen, Elina 2009: Keskellä melua ja ääntä. Timo K. Mukan myöhäistuotanto, kirjallisuuskäsitys ja niiden suhde 1960-luvun yhteiskunnallis-kulttuuriseen keskusteluun. Suomalaisen Kirjallisuuden Seura, Helsinki.

Arminen, Elina 2015: Ostettuja, myytyjä ja varastettuja tarinoita. Teoksessa Elina Arminen, Mika Hallila, Samuli Hägg \& Risto Turunen (toim.), Taide ja maailma. University of Eastern Finland, Joensuu.

Arminen, Elina 2018: Jussi Siirilän 'Historia on minut vapauttava' ja satiirin vaikuttamiskeinot 2000-luvun kulttuurikapitalismissa. Teoksessa Ojajärvi, Sevänen \& Steinby 2018.

Aspers, Patrik 2011: Markets. Polity Press, Cambridge.

Bahtin, Mihail 1992: Dostojevskin poetiikan ongelmia. Alkuperäisteos Problemy poètiki Dostojevskogo (1963). Suomentaneet Paula Nieminen ja Tapani Laine. Orient Express. Bargu, Banu \& Chiara Bottici (eds.) 2017: Feminism, Capitalism, and Critique. Essays in Honor of Nancy Fraser. Palgrave Macmillan, London.

Baudrillard, Jan 1981: Simulations. Translated from the French by Paul Foss et al. Semiotexte, New York.

Bauman, Zygmunt 2000: Liquid Modernity. Polity Press, London.

Beck, Ulrich 1986: Risikogesellschaft - auf dem Weg in eine andere Moderne. Suhrkamp, Frankfurt am Main.

Beck, Ulrich 1991: Auf dem Weg in die industrielle Gesellschaft. Teoksessa Christian W. Thomsen (Hrsg.), Aufbruch in die Neunziger. Ideen, Entwicklungen, Perspektiven der achtiziger Jahre. Dumont, Köln, 27-41.

Beck, Ulrich 1995: Politiikan uudelleen keksiminen. Kohti refleksiivisen modernisaation teoriaa. Teoksessa Ulrich Beck, Anthony Giddens \& Scott Lash, Nykyajan jäljillä. Refleksiivinen modernisaatio. Alkuperäisteos Reflexive Modernization. Politics, Tradition and Aesthetics in Modern Social Order (1994). Suomentanut Leevi Lehto. Vastapaino, Tampere.

Beckman, Frida 2013: Between Desire and Pleasure. A Deleuzian Theory of Sexuality. Edinburgh University Press, Edinburgh.

Belina, Bernd 2011: Kapitalismus, Raum und Staatensystem in der kritischen Geographie. Teoksessa Ten Brink 2011, 87-104.

Bell, Daniel 1979: The Cultural Contradictions of Capitalism. Heineman, London. (Orig. pub. 1976.)

Bergroth, Harley 2016: Luokan ruumiillisuus arjen kokemuksissa köyhyydestä. Teoksessa Anttila, Kauranen, Launis \& Ojajärvi 2016, 166-204.

Béroud, Sophie \& Tania Régin (rédacteurs) 2002: Le roman social. Littérature, histoire et mouvement ouvrier. Les Éditions d'Atelier, Paris.

Biermann, Karlheinz 1982: Literarisch-politische Avantgarde in Frankreich 1830-1870. Hugo, Sand, Baudelaire und andere. Verlag V. Kohlhammer, Stuttgart, Berlin, Köln und Mainz.

Boltanski, Luc 2011: On Critique. A Sociology of Emancipation. Alkuperäisteos De la Critique (2009). Translated from the French by Gregory Elliott. Polity Press, Cambridge.

Boltanski, Luc \& Ève Chiapello 1999: Le nouvel esprit du capitalisme. Gallimard, Paris.

Boltanski, Luc \& Ève Chiapello 2007: The New Spirit of Capitalism. Translated from the French by Gregory Elliott. Verso, London and New York.

Boucher, Francois-Emmanuël 2013: Balzac, les espèces sociales et la representation du 
pouvoir économique au XIXe siècle. Teoksessa Sicotte, Poirson, Loncle \& Biet 2013,

$61-78$.

Bourdieu, Pierre 1979: La distinction. Critique sociale du jugement. Les Éditions de Minuit, Paris.

Boym, Svetlana 2011: The Future of Nostalgia. Basic Books, New York.

Braun, Jerome 2012: The Increasing Similarities between Post-Modernity and Pre-Moderni-

ty. Teoksessa Jerome Braun \& Lauren Langman (eds.) 2012: Alienation and the Carnivalization of Society. Routledge, New York and London.

Braun, Jerome \& Lauren Langman (eds.) 2012: Alienation and the Carnivalization of Society. Routledge, New York and London.

Bruun, Otto, Teppo Eskelinen, Ilkka Kauppinen \& Hanna Kuusela 2009: Immateriaalitalous. Kapitalismin uusin muoto. Gaudeamus, Helsinki.

Bürger, Christa 1977: Der Ursprung der bürgerlichen Institution Kunst im höfischen Weimar.

Suhrkamp, Frankfurt am Main.

Bürger, Peter 1977: Aktualität und Geschichtlichkeit. Studien zum gesellschaftlichen Funktionswandel der Literatur. Suhrkamp, Frankfurt am Main.

Bürger, Peter 2007: Sartre. Philosophie des als-ob. Suhrkamp, Frankfurt am Main.

Carlson, Mikko 2014: Paikantuneita haluja. Seksuaalisuus ja tila Christer Kihlmanin tuotannossa. Jyväskylän yliopiston nykykulttuurin tutkimuskeskuksen julkaisuja 144, Jyväskylä.

Cartwell, Brendan \& Ilkka Kauppinen (eds.) 2014: Academic Capitalism in the Age of Globalization. The Johns Hopkins Press, Baltimore.

Castells, Manuel 2000: The Information Age. Economy, Society ad Culture. Volume I. The Rise of the Network Society. Blackwell, Oxford UK and Malden USA. (Ilmestyi alun perin 1996.)

Castells, Manuel 2004: The Information Age. Economy, Society ad Culture. Volume II. The

Power of Identity. Blackwell, Oxford UK and Malden USA (Ilmestyi alun perin 1997.)

Castells, Manuel 2012: Networks of Outrage and Hope. Social Movements in the Internet Age.

Polity Press, Cambridge, MA.

Castells, Manuel \& Pekka Himanen 2002: The Information Society and the Welfare State.

The Finnish Model. Oxford University Press, Oxford.

Cazamian, Louis 1973: The Social Novel in England 1830-1850. Dickens, Disraeli, Mrs Gaskell, Kingsley. Orig. Le Roman social en Angleterre (1903). Translated by Martin Fido. Routledge, London and Boston.

Cerny, Philip G 1990: The Changing Architecture of Politics. Structure, Agency, and the Future of the State. Oxford University Press, New York.

Cerny, Philip G. 2010: Rethinking World Politics. A Theory of Transnational Pluralism. Oxford University Press, New York.

Chatman, Seymour 1978: Story and Discourse. Narrative Structure in Fiction and Film. Cornell University Press, Ithaca and London.

Chatman, Seymour 1990: Coming to Terms. The Rhetoric of Narrative in Fiction and Film.

Cornell University Press, Ithaca and London.

Cherry, Frederick W. 2012: The Culture of Markets. Polity Press, Cambridge UK and Malden USA.

Chiapello, Ève 2013: Capitalism and its Criticism. Teoksessa Paul du Gay \& Glenn Morgan (eds.), New Spirit of Capitalism. Crises, Justification, and Dynamics. Oxford University Press, Oxford, 60-80. 
Claybough, Amanda 2007: The Novel of Purpose. Literature and Social Reform in the AngloAmerican World. Cornell University Press, Ithaca.

Commelin, P. 1953: Kreikkalaisten ja roomalaisten mytologia. Alkuperäisteos Nouvelle mythologie grecque et romaine (1948). Suomentanut J. A. Hollo. WSOY, Helsinki.

Cooper, David E. 2008: Existentialism. An Introduction. Second Edition. Blackwell, Oxford.

Crouch, Colin 2005: Models of Capitalism. New Political Economy 10:4, 439-456.

Currie, Mark (ed.) 1995: Metafiction. Methuen, London and New York.

Dale, Gareth 2010: Karl Polanyi. The Limits of the Market. Polity, Cambridge UK and Malden USA.

Danto, Arthur C. 1975: Sartre. Fontana, Glasgow.

David, Sylvain 2013: Tristes topiques. Nature, culture et capitalism 'sauvage' chez Michel Houellebecq. Teoksessa Sicotte, Poirson, Loncle \& Biet 2013, 135-148.

Davidson, Donald 2004: Problems of Rationality. Oxford University Press, New York.

Dubois, Jacques 2000: Les romanciers du reel. De Balzac à Simenon. Ėditions de Seuil, Paris.

Dubois, Jacques 2007: Stendhal. Une sociologie romanesque. Ėditions de Découverte, Paris.

Eagleton, Terry 1976: Criticism and Ideology. A Study in Marxist Literary Theory. NLB, London.

Ebenau, Matthias \& Victoria Liberatore 2013: Neodevelopmentalist State Capitalism in

Brazil and Argentina. Changes, Limits and Restrictions. Zeitschrift für Public Policy, Recht und Management 6:1, 105-125.

Erola, Jani (toim.) 2010a: Luokaton Suomi? Yhteiskuntaluokat 2000-luvun Suomessa.

Gaudeamus, Helsinki.

Erola, Jani 2010b: Yhteiskuntaluokat, tulot ja lasten määrä. Teoksessa Erola 2010a, 89-106.

Erola, Jani 2010c: Yhteenveto: yhteiskuntaluokat 2000-luvun alun Suomessa. Teoksessa

Erola 2010a, 237-234.

Erola, Jani 2010d: Johdanto. Teoksessa Erola 2010a, 9-26.

Etula, Sami 2014: Osaamista, verkostoja, rahaa. Opas enkelisijoituksen hakemiseen. Finnish

Business Angels Network.

Etzioni, Amitai 1988: The Moral Dimension. Toward a New Economics. Free Press, New York.

Etzioni, Amitai 1996: The New Golden Rule. Community and Morality in a Democratic

Society. Basic Books, New York.

Fludernik. Monika 2002: Towards a "Natural" Narratology. Routledge, Lontoo and New York. (Ilmestyi alun perin 1996.)

Fludernik, Monika 2010: Luonnollinen narratologia ja kognitiiviset parametrit. (Ilmestyi alun perin 2003.) Suomentanut Sanna Katariina Bruun. Teoksessa Mari Hatavara, Markku Lehtimäki \& Pekka Tammi, Luonnolliset ja luonnottomat kertomukset. Jälkiklassisen narratologian suuntauksia. Gaudeamus, Helsinki, 17-43.

Foucault, Michel 1998: Seksuaalisuuden historia. Tiedontahto, Nautintojen käyttö, Huoli itsestä. Alkuperäisteos Histoire de la sexualité (1976-1984). Suomentanut Kaisa Sivenius. Gaudeamus, Helsinki.

Fougner, Tore 2006: The State, International Competitiveness and Neoliberal Globalization: Is there a Future beyond 'the Competition State'. Review of International Studies 32, 165-185.

Fowler, Alastair 1997: Kinds of Literature. An Introduction to the Theory of Genres and Modes. Clarendon Press, Oxford. (Ilmestyi alun perin 1982.) 
Fraser, Nancy 2013: Fortunes of Feminism. From State-Managed Capitalism to Neoliberal Crisis. Verso, London and New York.

Frog, Anna-Leena Siikala \& Eila Stepanova (eds.) 2012: Mythic Discourses. Studies in Uralic Traditions. Suomalaisen Kirjallisuuden Seura, Helsinki.

Gadamer, Hans-Georg 1986: Wahrheit und Methode. Grundzüge einer philosophischen Hermeneutik. 5. Auflage. J.C.B. Mohr (Paul Siebeck), Tübingen. (Ilmestyi alun perin 1960.)

Gay, Paul du \& Glenn Morgan (eds.) 2013: New Spirits of Capitalism. Crises, Justification, and Dynamics. Oxford University Press, Oxford.

Genette, Gérard 1980: Narrative Discourse. Orig. Discours du récit (1972). Translated by Jane E. Lewin. Basil Blackwell, Oxford.

Genette, Gérard 1992: The Architext. An Introduction. Orig. Introduction à l'architexte (1979). Translated by Jane E. Lewin. University of California Press, Berkeley, Los Angeles and London.

Gibson, Andrew 1996: Towards a Postmodern Theory of Narrative. Edinburgh University Press, Edinburgh.

Giddens, Anthony 1976: New Rules of Sociological Method. A Positive Critique of Interpretative Sociologies. Hutchinson, London.

Giddens, Anthony 2000: The Consequences of Modernity. Polity Press, Cambridge. (Ilmestyi alun perin 1990.)

Giddens, Anthony 2001: Modernity and Self-Identity. Self and Society in the Late Modern Age. Polity Press, Cambridge. (Ilmestyi alun perin 1991.)

Giddens, Anthony 2009: The Politics of Climate Change. Polity, Oxford.

Gilpin, Robert 2001: Global Political Economy. Understanding the International Economic Order. Princeton University Press, Princeton and Oxford.

Goldmann, Lucien 1975: Towards a Sociology of the Novel. Orig. Pour une sociologie du roman (1964). Translated by Alan Sheridan. Tavistock, London.

Goldmann, Lucien 1976: Cultural Creation in Modern Society. Orig. La creation culturelle dans la société moderne (1971). Translated by Bart Grahl. Telos Press, Saint Louis.

Gronow, Jukka 2013: Talous ja yhteiskunta. Teoksessa Niiniluoto, Vilkko \& Kuorikoski 2013, $35-53$.

Guddon, J. A. 1998: A Dictionary of Literary Terms and Literary Theory. Blackwell, Oxford UK and Malden, Massachusetts, USA.

Haapala, Pertti 2010: Vallan rakenteet ja yhteiskunnan muutos: mielikuvaharjoitus 1800-2000-lukujen Suomesta. Teoksessa Pietikäinen 2010, 21-33.

Haapala, Vesa \& Juhani Sipilä (toim.) 2013a: Kiviaholinna. Suomalainen romaani. Avain, Helsinki.

Habermas, Jürgen 1968: Erkenntnis und Intresse. Suhrkamp, Frankfurt am Main.

Habermas, Jürgen 1973: Zur Logik der Sozialwissenschaften. Suhrkamp, Frankfurt am Main. (Ilmestyi alun perin 1970.)

Habermas, Jürgen 1975: Zu Gadamers 'Wahrheit und Methode'. Teoksessa Hermeneutik und Ideologiekritik. Mit Beiträgen von Karl-Otto Apel, Claus v. Bormann, Rüdiger Bubner, Hans-Georg Gadamer, Hans Joachim Giegel und Jürgen Habermas. Suhrkamp, Frankfurt am Main, 45-56. 
Habermas, Jürgen 1983: Moralbewusstsein und kommunikatives Handeln. Suhrkamp, Frankfurt am Main.

Habermas, Jürgen 1987a: Theorie des kommunikativen Handelns. Band 1. Handlungsrationalität und gesellschaftliche Rationalisierung. Suhrkamp, Frankfurt am Main. (Ilmestyi alun perin 1981.)

Habermas, Jürgen 1987b: Theorie des kommunikativen handelns. Band 2. Zur Kritik der funktionalistischen Vernunft. Suhrkamp, Frankfurt am Main. (Ilmestyi alun perin 1981.) Habermas, Jürgen 2004: Julkisuuden rakennemuutos. Tutkimus yhdestä kansalaisyhteiskunnan kategoriasta. Alkuperäisteos Strukturwandel der Öffentlichkeit. Untersuchungen zu einer Kategorie der bürgerlichen Gesellschaft (1962). Suomentanut Veikko Pietilä. Vastapaino, Tampere.

Habermas, Jürgen 2012: The Crisis of the European Union. A Response. Orig. Zur Verfassung Europas. Ein Essay (2011). Translated by Ciaran Cronin. Polity Press, Cambridge.

Hakamies, Pekka 2012: Ilmarinen and Popular Techno-Utopian Conceptions. Teoksessa Frog, Siikala \& Stepanova 2012.

Hall, Peter A. \& David Soskice (eds.) 2001: Varieties of Capitalism. The Institutional Foundations of Comparative Advantage. Oxford University Press, Oxford.

Hallila, Mika 2006: Metafiktion käsite. Teoreettinen, kontekstuaalinen ja historiallinen tutkimus. Joensuun yliopisto, Joensuu.

Hallila, Mika 2013: Metafiktiivistä menoa. Teoksessa Hallila, Hosiaisluoma, Karkulehto, Kirstinä \& Ojajärvi 2013a, 85-94.

Hallila, Mika, Yrjö Hosiaisluoma, Sanna Karkulehto, Leena Kirstinä \& Jussi Ojajärvi (toim.) 2013a: Suomen nykykirjallisuus 1. Lajeja, poetiikkaa. Suomalaisen Kirjallisuuden Seura, Helsinki.

Hallila, Mika, Yrjö Hosiaisluoma, Sanna Karkulehto, Leena Kirstinä \& Jussi Ojajärvi (toim.) 2013b: Suomen nykykirjallisuus 2. Kirjallinen elämä ja yhteiskunta. Suomalaisen Kirjallisuuden Seura, Helsinki.

Harvey, David 2008: Uusliberalismi. Lyhyt historia. Alkuperäisteos A Brief History of Neoliberalism (2005). Suomentanut Kaisa Koskinen. Vastapaino, Tampere.

Hayek, Friedrich von 2005: The Road to Serfdom: with the Intellectuals and Socialism. Institute of Economic Affairs, London. (Ilmestyi alun perin 1944.)

Heiskala, Risto 2006: Kansainvälisen toimintaympäristön muutos ja Suomen yhteiskunnallinen murros. Teoksessa Heiskala \& Luhtakallio 2006, 14-42.

Heiskala, Risto 2009: Karl Polanyi, suuri murros ja substantivistinen talousantropologia. Teoksessa Polanyi 2009, 7-27.

Heiskala, Risto \& Akseli Virtanen (toim.) 2011a: Talous ja yhteiskuntateoria. Osa I. Vanhan maailman talous ja suuri murros. Gaudeamus ja Helsinki University Press, Helsinki.

Heiskala, Risto \& Akseli Virtanen 2011b: Talous yhteiskuntateorian ongelmana. Teoksessa Heiskala \& Virtanen 2011a, 15-50.

Heiskala, Risto \& Anu Kantola 2010: Vallan uudet ideat: hyvinvointivaltion huomasta valmentajavaltion valvontaan. Teoksessa Pietikäinen 2010, 124-148.

Heiskala, Risto \& Eeva Luhtakallio (toim.) 2006: Uusi jako. Miten Suomesta tuli kilpailukykyyhteiskunta? Gaudeamus, Helsinki. 
Herman, David, James Phelan, Peter J. Rabinowitz, Brian Richardson \& Robyn Warhol 2012: Narrative Theory. Core Concepts and Critical Debates. The Ohio State University Press, Columbus.

Herman, David, Manfred Jahn \& Marie-Laure Ryan (eds.) 2005: Routledge Encyklopedia of Narrative Theory. Routledge, London and New York.

Herman, Judith 1992: Trauma and Recovery. Basic Books, New York.

Heynders, Odile 2005: Writers as Public Intellectuals. Literature, Celebrity, Democracy.

Palgrave, London.

Honneth, Axel 1988: Kritik der Macht - Reflexionsstufen einer kritischen Gesellschaftstheorie. Suhrkamp, Frankfurt am Main.

Honneth, Axel 1997: Recognition and Moral Obligation. Social Research 64, 1(Spring), 16-35.

Horkheimer, Max 2008: Välineellisen järjen kritiikki. Alkuteokset The Eclipse of Reason (1941) ja The End of Reason (1947). Suomentaneet Olli-Pekka Moisio ja Veikko Pietilä. Vastapaino, Tampere.

Horkheimer, Max \& Theodor W. Adorno 2008: Valistuksen dialektiikka. Alkuperäisteos Dialektik der Aufklärung (1944). Suomentanut Veikko Pietilä. Vastapaino, Tampere.

Hosiaisluoma, Yrjö 1990: Järjestyksen kourista vapauden valtakuntaan. Samuli Parosen elämä, tuotanto ja yhteiskuntakritiikki. Suomalaisen Kirjallisuuden Seura, Helsinki.

Huber, Irmtraud 2014: Literature after Postmodernism. Reconstructive Fantasies. Palgrave Macmillan, London and New York.

Hutcheon, Linda 1985: Narcissistic Narrative. The Metafictional Paradox. Methuen, New York and London. (Ilmestyi alun perin 1980.)

Hutcheon, Linda 1988: The Poetics of Postmodernism. History, Theory, Fiction. Routledge, London.

Hyrkäs, Antti 2017: Startup Complexity. Tracing the Conceptual Shift behind the Spectacle. University of Helsinki, Helsinki.

Hägg, Samuli 2011: Kerrontakeinojen sosiologiaa. Teoksessa Ruohonen, Sevänen \& Turunen 2011, 428-456.

Hägg, Samuli, Erkki Sevänen \& Risto Turunen (eds.) 2008: Metaliterary Layers in Finnish Literature. The Finnish Literature Society, Helsinki.

Hänninen, Sakari 2011: Marxin talous. Teoksessa Heiskala ja Virtanen 2011a, 230-265. Häyrynen, Simo 2018: Renegotiating Cultural Welfare. The Adoption of Neoliberal Trends in Finnish Cultural Policy and How It Fits the Nordic Model of a Welfare State. Teoksessa Alexander, Hägg, Häyrynen \& Sevänen 2018a, 155-182.

Hökkä, Tuula 1999: Modernismi: uusi alku - vanhan valtaus. Teoksessa Pertti Lassila (toim.), Suomen kirjallisuuden historia 3. Rintamakirjeistä tietoverkkoihin. Suomalaisen Kirjallisuuden Seura, Helsinki, 68-89.

Ikonen, Sirkku 2005: Voiko elämästä puhua? Elämänfilosofia, Wienin piiri ja filosofian kahtiajako. Teoksessa Haukioja \& Räikkä 2005, 115-128.

Iser, Wolfgang 1993: The Fictive and the Imaginary. Charting Literary Anthropology. Johns Hopkins University Press, Baltimore.

Iso Raamatun Tietosanakirja. Osa 1. Raamatun Tietokirja, Eskilstuna 1984. 
Isomaa, Saija 2009: Heräämisten poetiikkaa. lajeja ja intetekstejä Arvid Järnefeltin romaaneissa 'Isänmaa', 'Maaemon lapsia' ja 'Veneh'ojalaiset'. Suomalaisen Kirjallisuuden Seura, Helsinki.

Isomaa, Saija 2012a: Mimesis and Purposeful Plays and Novels. 'Tendensroman' and 'Tendensdrama' in Nineteenth-Century Realism. Teoksessa Saija Isomaa et al. (eds.), Rethinking Mimesis. Concepts and Practices of Literary Representation. Cambridge Scholars Publishing, 139-160.

Isomaa, Saija 2012b: Kirjallisuus ja moraaliset emootiot. Tendenssikirjallisuuden 180o-lukulainen tausta. Avain 3, 5-19.

Isomaa, Saija 2013: Nykyajan Hannut ja Kertut. Kaltoinkohdeltu lapsi vuosituhannen vaihteen kotimaisessa kirjallisuudessa. Teoksessa Haapala \& Sipilä 2013a, 355-372.

Isomaa, Saija \& Toni Lahtinen 2017: "Kotimaisen nykydystopian monet muodot". Joutsen/ Svanen 4:7-17.

Israel, Joachim 1974: Vieraantuminen: Marxista nykysosiologiaan. Alkuperäisteos Alienation. Från Marx till modern sociologi (1971). Suomentanut Tuomas Takala. Tammi, Helsinki. Jackson, Gregory \& Richard Deeg 2006: How Many Varieties of Capitalism? Comparing the Comparative Institutional Analysis of Capitalist Diversity. Max Planck Institute for the Study of Societies, Discussion Paper 06/2, Cologne.

Jahrhaus, Oliver 2001: Die Aktion des Wiener Aktionismus. Subversion der Kultur und Dispositionierung des Bewusstseins. Wilhelm Fink, München.

Jameson, Fredric 1979: Reification and Utopia in Mass Culture. - Social Text 1 (Winter), 130-148.

Jameson, Fredric 1986: The Political Unconscious. Narrative as a Socially Symbolic Act. Methuen, London and New York. (Ilmestyi alun perin 1981.)

Jameson, Fredric 2007: Late Marxism: Adorno or the Persistence of the Dialectic. Verso, London.

Jameson, Fredric 2011: Representing Capitalism. A Commentary of Volume One. Verso, London.

Jameson, Fredric 2018: Representaation ongelmia. Hannu Raittilan Pamisoksen purkauksesta ja kognitiivisen kartoituksen mahdollisuuksista. Englannin kielestä suomentanut Jussi Ojajärvi. Teoksessa Ojajärvi, Sevänen \& Steinby 2018, 315-324.

Jauss, Hans Robert 1984: Ästhetische Erfahrung und literarische Hermeneutik. Suhrkamp, Frankfurt am Main. (Ilmestyi alun perin 1982.)

Jessop, Bob 2002: The Future of the Capitalist State. Polity, Cambridge. Jessop, Bob 2016: The State. Past, Present, Future. Polity, Cambridge. Julkunen, Raija 2005: Työelämän pitkä ja lyhyt historia. Yhteiskuntapoliitikka 70:1, 82-88. Julkunen, Raija 2010: Sukupuolen järjestykset ja tasa-arvon paradoksit. Vastapaino, Tampere. Juntunen, Tuomas 2012: Virsta väärää, vaaksa vaaraa. Intertekstuaalinen moniäänisyys Juha Seppälän proosassa. Helsingin yliopiston humanistinen tiedekunta, Helsinki.

Juntunen, Tuomas 2013: Kuuroille korville. Dialogi ja ohipuhumisen funktiot Juha Seppälän tuotannossa. Teoksessa Aino Koivisto \& Elise Nykänen (toim.), Dialogi kaunokirjallisuudessa. Suomalaisen Kirjallisuuden Seura, Helsinki, 99-121.

Järvinen, Katriina \& Laura Kolbe 2007: Luokkaretkellä hyvinvointiyhteiskunnassa. Kirjapaja, Helsinki. 
Kantola, Anu \& Hanna Kuusela 2019: Huipputuloiset. Suomen rikkain promille. Toinen, korjattu painos. Vastapaino, Tampere. (Ilmestyi alun perin 2018.)

Karisto, Antti, Pentti Takala \& Ilkka Haapola 1997: Matkalla nykyaikaan. Elintason, elämäntavan ja sosiaalipolitiikan muutos Suomessa. WSOY, Helsinki.

Karkama, Pertti 197: Sosiaalinen konfliktiromaani. Rakennetutkimus suomalaisen yhteiskunnallisen realismin pohjalta. Pohjoinen, Oulu.

Karkama, Pertti 1990: Modernismin haasteet. Teoksessa Tuija Takala \& Juha Hyvärinen (toim.), Tutkielmia suomalaisesta modernismista. Turun yliopisto, taiteiden tutkimuksen laitos, sarja A, n:o 21, Turku, 7-51.

Karkama, Pertti 1994: Kirjallisuus ja nykyaika. Suomalaisen sanataiteen teemoja ja tendenssejä. Suomalaisen Kirjallisuuden Seura, Helsinki.

Karkama, Pertti 1998a: Kulttuuri ja demokratia. Kirjoituksia kulttuurin nykytilasta. Suomalaisen Kirjallisuuden Seura, Helsinki.

Karkama, Pertti 1998b: Kontekstualisoinnin haasteet. Teoksessa Päivi Molarius (toim.), Konteksti - tutkimuksen avainsana. Suomalaisen Kirjallisuuden Seura, Helsinki, 78-83.

Karkama, Pertti \& Hanne Koivisto (toim.) 1997: Älymystön jäljillä. Kirjoituksia suomalaisesta sivistyneistöstä ja älymystöstä. Suomalaisen Kirjallisuuden Seura, Helsinki.

Karkulehto, Sanna 2013: Sukupuoli, seksuaalisuus ja valta. Teoksessa Hallila, Hosiaisluoma, Karkulehto, Kirstinä \& Ojajärvi 2013b, 109-123.

Karkulehto, Sanna \& Ilmari Leppihalme 2018: Työtä töiden joukossa? Seksuaalisuus, kaupallisuus ja toimeentulon pakko kotimaisessa nykykirjallisuudessa. Teoksessa Ojajärvi, Sevänen ja Steinby 2018.

Kauppi, Niilo \& Pekka Sulkunen (eds.) 1992: Vanguards of Modernity. Society, Intellectuals and the University. University of Jyväskylä, Jyväskylä.

Kauranen, Ralf \& Emma Lamberg 2016: Hyvinvointi, työ ja häivytetty luokka pääministeri Jyrki Kataisen puheissa. Teoksessa Anu-Hanna Anttila, Ralf Kauranen, Kati Launis \& Jussi Ojajärvi (toim.), Luokan ääni ja hiljaisuus. Yhteiskunnallinen luokkajärjestys 200o-luvun Suomessa. Vastapaino, Tampere, 205-246.

Kettunen, Pauli 2008: Globalisaatio ja kansallinen me. Kansallisen katseen historiallinen kritiikki. Vastapaino, Tampere.

Kiander, Jaakko 2013: Globaali finanssikriisi, talouspolitiikka ja taloustieteen todellisuuskäsitys. Teoksessa Niiniluoto, Vilkko \& Kuorikoski 2013, 19-35.

Kirstinä, Leena 2007: Kansallisia kertomuksia. Suomalaisuus 1990-luvun proosassa. Suomalaisen Kirjallisuuden Seura, Helsinki.

Kirstinä, Leena \& Risto Turunen 2013: Nykyproosan solmukohtia ja avauksia. Teoksessa Hallila, Hosiaisluoma, Karkulehto, Kirstinä ja Ojajärvi 2013a, 41-78.

Kivistö, Sari (toim.) 2007a: Satiiri: Johdatus lajin historiaan ja teoriaan. Yliopistopaino Kustannus ja Helsinki University Press, Helsinki.

Kivistö, Sari 2007b: Satiiri kirjallisuuden lajina. Teoksessa Kivistö 2007a, 9-27.

Koc, Richard A. 1982: The German Gesellschaftsroman at the Turn of the Century. A Comparison of the Works of Theodor Fontane und Eduard von Keyserling. Peter Lang, Berne und Frankfurt am Main.

Koivisto, Hanne (toim.) 2011: Politiikkaa, erotiikkaa ja kulttuuritaistelua. Kirjoituksia suoma- 
laisesta vasemmistoälymystöstä 1930-luvulta. Työväen historian ja perinteen tutkimuksen seura, Helsinki.

Koivisto, Päivi 2011: Elämästä autofiktioksi. Lajitradition jäljillä Pirkko Saision romaanisarjassa Pieni yhteinen jaettava, Vastavalo ja Punainen erokirja. Helsingin yliopisto, Helsinki.

Koivisto, Päivi 2013a: Oman romaaninsa sankari. Teoksessa Hallila, Hosiaisluoma, Karkulehto, Kirstinä \& Ojajärvi 2013a, 97-106.

Koivisto, Päivi 2013b: Katkelmien romaani vai hetkinä avautuva elämä. Petri Tammisen

'Muistelmat'. Teoksessa Haapala ja Sipilä 2013a, 333-354.

Komu, Eija 1995: Armon tүhjiössä. Kristillinen eksistentialismi eräissä Mika Waltarin, Helvi Hämäläisen ja Paavo Rintalan 1950-luvun teoksissa. Joensuun yliopisto, Joensuu.

Konkka, Unelma 1985: Ikuinen ikävä. Karjalaiset riitti-itkut. Suomalaisen Kirjallisuuden Seura, Helsinki.

Kontula, Anna 2008: Punainen eksodus. Tutkimus seksityöstä Suomessa. Like, Helsinki.

Kosonen, Päivi, Hanna Meretoja ja Päivi Mäkirinta (toim.) 2008: Tarinoiden paluu. Esseitä ranskalaisesta nykykirjallisuudesta. Avain, Tallinna.

Kotkavirta, Jussi 1991: Katkoksia ja jatkuvuuksia modernissa taideinstituutiossa. Teoksessa Erkki Sevänen, Liisa Saariluoma \& Risto Turunen (toim.), Taide modernissa maailmassa. Taiteensosiologiset teoriat Georg Lukácsista Fredric Jamesoniin. Gaudeamus, Helsinki, 205-230.

Kotkavirta, Jussi 2013: Tunteiden talous. Teoksessa Niiniluoto, Vilkko \& Kuorikoski 2013 , $71-88$.

Krugman, Paul 2009: Lama - talouskriisin syyt, seuraukset ja korjauskeinot. Alkuperäisteos The Return of Depression Economics and the Crises of 2008. Suomentanut Jyrki Raivio. Helsingin Sanomat, Helsinki.

Krugman, Paul 2012: Lopettakaa tämä lama nyt! Alkuperäisteos End This Depression Now! Suomentanut Anni Lassila. Helsingin Sanomat, Helsinki.

Kuisma, Markku 2013: Suomen poliittinen taloushistoria 1000-2000. Siltala, Helsinki.

Kylänpää, Riikka 2013: Romaani sairastaa. Yhdeksän syytä, miksi kotimainen proosa ei innosta. Suomen Kuvalehti 43, 28-36.

Kögler, Hans-Herbert 2007: Autonomie und Anerkennung: Kritische Theorie als Hermeneutik des Subjekts. Teoksessa Winter \& Zima 2007, 79-96.

Lagerspetz, Erik 2013: Tie orjuuteen. Kaksi näkökulmaa markkinakapitalismiin. Teoksessa Niiniluoto, Vilkko \& Kuorikoski 2013, 124-139.

Lainema, Matti 2011: Enkeleitä, onko heitä? Denali Oy.

Laitinen, Kai 1981: Suomen kirjallisuuden historia. Otava, Helsinki.

Laki osakeyhtiöistä 21.7.2006/624.

Lakoff, George \& Mark Johnson 1999: Philosophy in the Flesh. The Embodied Mind and its Challenge to Western Thought. Basic Books, New York 1999.

Langman, Lauren 2012: Alienation, Entrapment, and Inauthenticity. Teoksessa Braun \& Langman 2012, 53-75.

Lash, Scott 2010: Intensive Culture. Social Theory, Religion and Contemporary Capitalism. Sage, London.

Lash, Scott \& John Urry 1987: The End of Organized Capitalism. Polity Press, Cambridge. 
Launis, Kati, Harley Bergroth \& Anu-Hanna Anttila 2016: Luokattomuus ja eriarvoisuuden kokeminen köyhyyskirjoituskilpailun teksteissä. Teoksessa Anttila, Kauranen, Launis \& Ojajärvi 2016, 134-165.

Lechevalier, Sébastian 2014: The Great Transformation of Japanese Capitalism. Orig. La grande transformation du capitalisme Japonais (2013). Translated by J. A. A. Stockwin. Routledge, London and New York.

Lee, Emmanuel Chukwudi 2008: On Reason. Rationality in a World of Cultural Conflicts and Racism. Duke University Press, Durham and London 2008.

Lepenies, Wolf 1988: Drei Kulturen. Soziologie zwischen Literatur und Wissenschaft. Rowolt, Reinbeck bei Hamburg. (Ilmestyi alun perin 1985.)

Leskelä-Kärki, Maarit 2017: Toisten elämät. Kirjoituksia elämäkerroista. Avain, Helsinki.

Lindholm, Charles 2008: Culture and Authenticity. Blackwell, London.

Lindskog, Claes 1968: Kreikkalaisia jumalaistaruja ja satuja. Alkuperäisteos Grekiska myter och sagor (1928). Suomentanut I. K. Inha. WSOY, Porvoo ja Helsinki.

Luhmann, Niklas 1997a: Die Gesellschaft der Gesellschaft. Zwei Bände. Band 1. Suhrkamp, Frankfurt am Main.

Luhmann, Niklas 1997b: Die Kunst der Gesellschaft. Suhrkamp, Frankfurt am Main. (Ilmestyi alun perin 1995.)

Luhmann, Niklas 2008: Schriften zur Kunst und Literatur. Suhrkamp, Frankfurt am Main.

Lukács, Georg 1971a: Die Theorie des Romans. Ein geschichtsphilosophischer Versuch über die Formen der grossen Epik. Luchterhand, Darmstadt und Neuwied. (Ilmestyi alun perin 1914-1915.)

Lukács, Georg 1971b: Die Gegenswartsbedeutung des kritischen Realismus (1957). Teoksessa Georg Lukács, Werke. Band 4. Essays über Realismus. Luchterhand, Berlin und Neuwied. Lukács, Georg 1977: Geschichte und Klassenbewusstsein (1919-1922). Teoksessa Georg Lukács, Werke. Band 2. Frühschriften II. Geschichte und Klassenbewusstsein. Luchterhand, Darmstadt und Neuwied, 161-517.

Lyytikäinen, Pirjo 2018: Pilviä maailmanlopun taivaalla. Leena Krohnia lukiessa. Teos, Helsinki.

Maijala, Minna 2008: Passion vallassa. Hermostunut aika Minna Canthin tuotannossa. Suomalaisen Kirjallisuuden Seura, Helsinki.

Malmio, Kristina 2018: Wunderkammer? Suomenruotsalainen kirjallisuus ja uusliberalistinen talous. Teoksessa Ojajärvi, Sevänen \& Steinby 2018.

Malmio, Kristina 2019: Postmodernismi ja sen 'yli' kirjoittaminen 2000-luvun suomenruotsalaisissa romaaneissa. Teoksessa Elina Arminen ja Markku Lehtimäki (toim.), Muistikirja ja matkalaukku. Muotoja ja merkityksiä 200o-luvun suomalaisessa romaanissa. Suomalaisen Kirjallisuuden Seura, Helsinki, 177-210.

Marcuse, Herbert 1964: One-Dimensional Man. Studies in the Ideology of Advanced Industrial Society. Beacon Press, The United States.

Marcuse, Herbert 1980a: Existentialismus (1948). Teoksessa Herbert Marcuse, Kultur und Gesellschaft 2. Suhrkamp, Frankfurt am Main, 49-84.

Marcuse, Herbert 1980b: Industrialismus und Kapitalismus im Werk Max Webers (1964). Teoksessa Herbert Marcuse, Kultur und Gesellschaft 2. Suhrkamp, Frankfurt am Main, 107-129. 
Marcuse, Herbert 1986: The Aesthetic Dimension. Toward a Critique of Marxist Aesthetics. Macmillan, London. (Ilmestyi alun perin 1977.)

Marx, Karl 1978: Taloudellis-filosofiset käsikirjoitukset 1844. Teoksessa Karl Marx \& Friedrich Engels, Valitut teokset 1-G. Osa 1. Edistys, Moskova. (Saksankielinen alkuperäisteos ilmestyi 1844.)

Marx, Karl 1979: Pääoma. kansantaloustieteen arvostelua. Osa 1. Pääoman tuotantoprosessi. Edistys, Moskova. (Saksankielinen alkuperäisteos ilmestyi 1867.)

Marx, Karl \& Friedrich Engels 1978: Kommunistisen puolueen manifesti. Teoksessa Karl Marx \& Friedrich Engels, Valitut teokset 1-G. Osa 2. Edistys, Moskova. (Saksankielinen alkuperäisteos ilmestyi 1848.)

Mazzarella, Merete 1989: Det trånga rummet. En finlandssvensk romantradition. Söderström, Borgå.

McCarthy, Thomas 1988: Reflections on Rationalization in the Theory of Communicative Action. Teoksessa Richard J. Bernstein (ed.), Habermas and Modernity. Polity Press, Cambridge, 176-191.

McDowell, John 1996: Mind and World. Harvard University Press, Cambridge.

McGill, Robert 2013: The Treacherous Imagination. Intimacy, Ethics, and Autobiographical Fiction. The Ohio State University Press, Columbus.

McGuigan, Jim 2009: Cool Capitalism. Pluto Press, London.

McHale, Brian 1987: Postmodernist Fiction. Methuen, New York and London.

Mele, Alfred R. \& Piers Rawling 2004a: The Oxford Handbook of Rationality. Oxford University Press, New York.

Mele, Alfred R. \& Piers Rawling 2004b: Introduction: Aspects of Rationality. Teoksessa Mele \& Rawling 2004a, 3-13.

Melin, Harri 2010: Tarvitaanko vielä luokkatutkimusta? Teoksessa Erola 2010a, 211-226.

Meretoja, Hanna 2004: Tarinoiden hajottajista toisiin kertojiin. Kirjailijan yhteiskuntakriittisestä tehtävästä eksistentialismin jälkeisessä Ranskassa. Teoksessa Tuomo Lahdelma, Risto Niemi-Pynttäri, Outi Oja \& Keijo Virtanen (toim.), Laji, tekijä, instituutio. Kirjallisuudentutkijain Seuran vuosikirja 56(2003). Suomalaisen Kirjallisuuden Seura, Helsinki, 121-150.

Meretoja, Hanna 2007: Ranskalainen uusi romaani avantgardekirjallisuuden suuntauksena. Teoksessa Sakari Katajamäki \& Harri Veivo (toim.), Kirjallisuuden avantgarde ja kokeellisuus. Gaudeamus, Helsinki, 183-205.

Meretoja, Hanna 2008a: Suuruuden vuosisadasta tarinoiden kriisiin. Teoksessa Kosonen, Meretoja \& Mäkirinta 2008, 17-23.

Meretoja, Hanna 2008b: Michel Houellebecq - myöhäismodernin kulutusyhteiskunnan kuvaaja. Teoksessa Kosonen, Meretoja \& Mäkirinta 2008, 247-256.

Meretoja, Hanna 2008c: Ihmissuhteet kulutussuhteina Michel Houellebecqin romaanissa Oikeus nautintoon. Teoksessa Ojajärvi \& Steinby 2008, 356-386.

Meretoja, Hanna 2010: The French Narrative Turn. From the Problematization of Narrative Subjectivity in Alain Grillet's Dans le labyrinth to its Hermeneutical Rehabilitation in Michel Tournier's Le Roi des Aulnes. Annales Universitatis Turkuensis, ser. B, tom. 329, Turku. Meretoja, Hanna 2015: A Sense of History - A Sense of the Possible. Nussbaum and 
Hermeneutics of the Ethical Potential of Literature. Teoksessa Meretoja, Isomaa, Lyytikäinen \& Malmio 2015, 25-46.

Meretoja, Hanna 2018: The Ethics of Storytelling. Narrative Hermeneutics, History, and the Possible. Oxford University Press, Oxford.

Meretoja, Hanna, Saija Isomaa, Pirjo Lyytikäinen \& Kristina Malmio (eds.) 2015: Values of Literature. Brill Rodopi, Leiden and Boston.

Meretoja, Hanna \& Pirjo Lyytikäinen 2015: Why We Read. The Plural Values of Literature.

Teoksessa Meretoja, Isomaa, Lyytikäinen \& Malmio 2015, 1-22.

Miettinen, Arto 2008: Kansallisen uudet tulkinnat. Suurten kertomusten problematisoituminen Juha Seppälän tuotannossa. Joensuun yliopisto, Kirjallisuuden lisensiaattitutkimus. Painamaton.

Moulier-Boutang, Yann 2007: Le capitalisme cognitif. Le nouvelle grande transformation.

Editions Amsterdam.

Münch, Richard 1986a: Die Kultur der Moderne. Band 1. Ihre Entwicklung in England und Amerika. Suhrkamp, Frankfurt am Main.

Münch, Richard 1986b: Die Kultur der Moderne. Band 2. Ihre Entwicklung in Frankreich und Deutschland. Suhrkamp, Frankfurt am Main.

Mäkelä, Matti 1999: Suuren muutoksen kuvaukset. Teoksessa Pertti Lassila (toim.), Suomen kirjallisuuden historia 3. Rintamakirjeistä tietoverkkoihin. Suomalaisen Kirjallisuuden Seura, Helsinki, 227-235.

Mäkinen, Katariina 2016: Maahanmuuttovastainen internet-aktivismi, uusliberaali ideaalikansalainen ja ylijäämäihmiset. Teoksessa Anttila, Kauranen, Launis \& Ojajärvi 2016, 247-276.

Möbuss, Susanne 2015a: Existensphilosophie. Von Augustinus bis Nietzsche. Karl Alber, Freiburg/München.

Möbuss, Susanne 2015b: Existensphilosophie. Das 20. Jahrhundert. Karl Alber, Freiburg/ München.

Niemi, Juhani 2013: Veijo Meri poikineen ja tyttärineen. Teoksessa Hallila, Hosiaisluoma, Karkulehto, Kirstinä \& Ojajärvi 2013a, 20-33.

Niiniluoto, Ilkka 1994: Järki, arvot ja välineet. Kulttuurifilosofisia esseitä. Otava, Helsinki.

Niiniluoto, Ilkka, Risto Vilkko \& Jaakko Kuorikoski 2011 (toim.): Talous ja filosofia. Gaudeamus, Helsinki.

Nilsson, Magnus 2006: Arbetarlitteratur. Studentlitteratur. Printed in Denmark.

Novum. Uusi Testamentti Selityksin. Osa 5. Raamatun Tietokirja, Vantaa.

Nozick, Robert 1974: Anarchy, State, and Utopia. Basic Books, New York.

Nummi, Jyrki 1993: Jalon kansan parhaat voimat. Kansalliset kuvat ja Väinö Linnan romaanit Tuntematon sotilas ja Täällä Pohjantähden alla. WSOY, Porvoo-Helsinki-Juva.

Nussbaum, Martha C. 1990: Love's Knowledge. Essays on Philosophy and Literature. Oxford University Press, New York and Oxford.

Nussbaum, Martha C. 2012: Not for Profit. Why Democracy Needs the Humanities. With a New Afterword by the Author. Princeton University Press, Oxford.

Nygård, Stefan 2020: Filosofi ja julkinen keskustelu. Teoksessa Strang \& Wallgren 2020, 43-70. 
Nünning, Ansgar 1997: Deconstructing and Reconceptualizing the Implied Author. Anglistik 8.2., 95-116.

Nystrand, Marko 2012: Arvoja näkyvissä. Kaunokirjallisuuden etiikka Ludwig Wittgensteinin filosofian valossa. Helsingin yliopiston humanistinen tiedekunta, Helsinki.

Ojajärvi, Jussi 2006: Supermarketin valossa. Kapitalismi, subjekti ja minuus Mari Mörön romaanissa Kiltin yön lahjat ja Juha Seppälän novellissa "Supermarket". Suomalaisen Kirjallisuuden Seura, Helsinki.

Ojajärvi, Jussi 2013a: Realismin keksimisen velvoite. Lamanjälkeisen kapitalismin aikalaiskokemus tematiikan ja muodon ongelmana. Teoksessa Hanna Meretoja \& Aino Mäkikalli (toim.), Romaanin historian ja teorian kytköksiä. Suomalaisen Kirjallisuuden Seura, Helsinki, 28o-313.

Ojajärvi, Jussi 2013b: Kapitalismista tulee ongelma. Teoksessa Hallila, Hosiaisluoma, Karkulehto, Kirstinä \& Ojajärvi 2013b, 131-153.

Ojajärvi, Jussi 2015: The Dirty Class. The Re-Intensified Antagonism of Capital and Labor, and the Politics of Arto Salminen. Journal of Finnish Studies Volume 18, Number 2, 181-209.

Ojajärvi, Jussi 2016: Luokkakamppailusta ja sen piiloutumisesta kaunokirjallisuuden valossa. Teoksessa Anu-Hanna Anttila, Ralf Kauranen, Kati Launis \& Jussi Ojajärvi (toim.), Luokan ääni ja hiljaisuus. Yhteiskunnallinen luokkajärjestys 200o-luvun alun Suomessa. Vastapaino, Tampere, 88-133.

Ojajärvi, Jussi 2018: Poliittista poetiikkaa kapitalismin globaalissa tilassa. Kognitiivisen kartoituksen käsite Fredric Jamesonin ajattelussa. Teoksessa Ojajärvi, Sevänen \& Steinby 2018.

Ojajärvi, Jussi, Erkki Sevänen \& Liisa Steinby (toim.) 2018a: Kirjallisuus nykykapitalismissa. Suomalaisen kirjallisuuden ja kulttuurin näkökulma. Suomalaisen Kirjallisuuden Seura, Helsinki.

Ojajärvi, Jussi, Erkki Sevänen \& Liisa Steinby 2018b: Johdanto. Teoksessa Ojajärvi, Sevänen \& Steinby 2018a, 7-52.

Ojajärvi, Jussi \& Liisa Steinby (toim.) 2008: Minä ja markkinavoimat. Yksilö, kulttuuri ja yhteiskunta uusliberalismin aikakaudella. Avain, Helsinki.

Patomäki, Heikki 2007: Uusliberalismi Suomessa. WSOY, Helsinki.

Patomäki, Heikki \& Teivo Teivainen 2003: Globaali demokratia. Gaudeamus, Helsinki. Pavel, Thomas G. 1986: Fictional Worlds. Harvard University Press, Cambridge MA.

Peltonen, Milla 2008: Jälkirealismin ehdoilla. Hannu Salaman 'Siinä näkijä missä tekijä' ja 'Finlandia'-sarja. Turun yliopiston julkaisuja, sarja C, osa 272, Turku.

Peltonen, Milla 2010: Mainettaan monipuolisempi - 1970-luvun kotimaisen kirjallisuuden linjoja. Teoksessa Kaisa Hypén (toim.), 197o-luku suomalaisessa kirjallisuudessa. Poliittisen vuosikymmenen ilmiöitä. Avain, Helsinki.

Petersen, Anders 2011: Authentic Self-Realisation and Depression. International Sociology Volume 26, Number 1, January, 5-24.

Pettersson, Anders 2003: Traditional Genres, Communicational Genres, Classificatory Genres. Teoksessa Beate Agrell \& Ingela Nilsson (eds.), Genrer och genreproblem: teoretiska och historiska perspektiv / Genres and their Problems: Theoretical and Historical Perspectives. Daidalos, Göteborg, 33-43. 
Phelan, James 1996: Narrative as Rhetoric. Technique, Audience, Ethics, Ideology. Ohio State University Press, Columbus.

Phelan, James 2005: Living to Tell About It. A Rhetoric and Ethics of Character Narration. Cornell University Press, Ithaca and London.

Phelan, James \& Peter J. Rabinowitz 2012a: Narrative as Rhetoric. Teoksessa Herman, Phelan, Rabinowitz, Richardson \& Warhol 2012, 3-8.

Phelan, James \& Peter J. Rabinowitz 2012b: Kommenttipuheenvuoro teoksessa Herman, Phelan, Rabinowitz, Richardson \& Warhol 2012, 29-38.

Phelan, James \& Peter J. Rabinowitz 2012C: Kommenttipuheenvuoro teoksessa Herman, Phelan, Rabinowitz, Richardson \& Warhol 2012, 57-65.

Pietikäinen, Petteri (toim.) 2010: Valta Suomessa. Gaudeamus, Helsinki.

Piikkilä, Tuula 2004: 'Minua ei ole. Sinua ei ole'. Negaatio kerronnan vuorovaikutusta jäsentävänä periaatteena Juha Seppälän romaanissa Jumala oli mies. Teoksessa Tuomo Lahdelma, Risto Niemi-Pynttäri, Outi Oja \& Keijo Virtanen (toim.), Laji, tekijä, instituutio. Kirjallisuudentutkijain Seuran vuosikirja 56. Suomalaisen Kirjallisuuden Seura, Helsinki, 32-53.

Piikkilä, Tuula 2007: Proosallista elämää. Dialogi tekstin sokkeloissa ja sieltä ulos Juha Seppälän romaanissa Silta. Teoksessa Yrjö Hosiaisluoma, Maria Laakso, Hanna Suutela \& Pekka Tammi (toim.), Kirjallisia elämyksiä. Alkukivistä toiseen elämään. Suomalaisen Kirjallisuuden Seura, Helsinki, 252-276.

Piketty, Thomas 2016: Pääoma 200o-luvulla. Alkuperäisteos Le Capital au XXI siècle (2013). Suomentaneet Marja Ollila ja Maarit Tillman-Leino. Into, Turku.

Piketty, Thomas 2019: Capital et idéologie. Seuil, Paris.

Pitkänen, Asla 1998: Mantelitumake. Duodecim 114, numero 23.

Pohjola-Skarp, Riitta \& Hanna Suutela 2018: Suorittaa, esittää, murtua. Työn uusi kuva suomalaisessa nykynäytelmässä, esimerkkeinä Päällystakki ja Patukkaooppera. Teoksessa Ojajärvi, Sevänen \& Steinby 2018, 237-260.

Polanyi, Karl 1957: The Economy as Instituted Process. Teoksessa Karl Polanyi, Conrad M. Arensberg \& Harry W. Pearson (eds.), Trade and Markets in the Early Empires. Economies in History and Theory. The Free Press, Clencoe Illinois, 243-269.

Polanyi, Karl 2009: Suuri murros. Aikakautemme poliittiset ja taloudelliset juuret. Alkuperäisteos The Great Transformation. The Political and Economic Origins of Our Time (1944). Suomentanut Natasha Vilokkinen. Vastapaino, Tampere.

Pyhtilä, Marko 2005: Kansainväliset situationistit. Like, Helsinki.

Rahkonen, Keijo \& J. P. Roos 1992: The Field of Intellectuals. The Case of Finland. Teoksessa Kauppi \& Sulkunen 1992, 107-125.

Raipola, Juha 2015: Ihmisen rajoilla. Epävarma tulevaisuus ja ei-inhimilliset toimijat Leena Krohnin Pereat Munduksessa. Tampere University Press, Tampere.

Rantala, Kari \& Pekka Sulkunen (toim.) 2006: Projektiyhteiskunnan kääntöpuolia. Gaudeamus, Helsinki.

Ratiu, Dan Eugen 2018: Artistic Critique of Capitalism as a Theoretical and Practical

Problem. Teoksessa Alexander, Hägg, Häyrynen \& Sevänen 2018b, 173-212.

Rescher, Nicholas 1988: Rationality. Oxford University Press, Oxford. 
Richardson, Brian 2012: Kommenttipuheenvuoro teoksessa Herman, Phelan, Rabinowitz, Richardson \& Warhol 2012, 132-137.

Ricoeur, Paul 1984: Time and Narrative. Volume One. Orig. Temps et Récit (1983). Translated by Kathleen McLaughlin \& David Pallauer. The University of Chicago Press, Chicago and London.

Roche, Mark William 2004: Why Literature Matters in the 21th Century? Yale University Press, New Haven and London.

Rossi, Riikka 2005: 'Vaaralla' ja 'Elsa' naturalistisina romaaneina. Laji arkkitekstuaalisena mallina. Teoksessa Haapala ja Sipilä 2005, 104-127.

Rossi, Riikka 2009: Särkyvä arki. Naturalismin juuret suomalaisessa kirjallisuudessa. Helsinki University Press, Helsinki.

Rossi, Riikka 2011: Vapauden muunnelmia. Naturalismi ja eksistentialismi Maria Jotunin Arkielämää-kertomuksessa. Avain n:o 1/2011, 5-23.

Ruohonen, Voitto 1995: 'Sinä olet pahassa pulassa, Gerdt'. Christer Kihlmanin 'Gerdt Bladhin tuho' porvarillisen subjektin hajoamisen kuvauksena. Teoksessa Pirjo Ahokas, Otto Lappalainen \& Liisa Saariluoma (toim.), Proosan taiteesta. Leevi Valkaman juhlakirja. Turun yliopisto, Taiteiden tutkimuksen laitos, sarja A, n:o 32, Turku.

Ruohonen, Voitto 2005: Paha meidän kanssamme. Matti Yrjänä Joensuun romaanien yhteiskuntakuvasta. Otava, Helsinki.

Ruohonen, Voitto 2018: Kapitalismi, julkisuus, kirjallisuus ja web 2.o. Teoksessa Ojajärvi, Sevänen \& Steinby 2018.

Ruohonen, Voitto, Erkki Sevänen \& Risto Turunen (toim.) 2011: Paluu maailmaan. Kirjallisten tekstien sosiologiaa. Suomalaisen Kirjallisuuden Seura, Helsinki.

Ryan, Richard M. \& Edward L. Deci 2017: Self-Determination Theory. Basic Psychological Needs in Motivation, Development and Wellness. Guilford, New York.

Saariluoma, Liisa 1989: Muuttuva romaani. Johdatus individualistisen lajin historiaan. Karisto, Hämeenlinna.

Saariluoma, Liisa 1992: Postindividualistinen romaani. Suomalaisen Kirjallisuuden Seura, Helsinki.

Saariluoma, Liisa 1998: Kundera, Broch und die Tradition des modernen Romans. Poetica 20:1-2, 170-199.

Saariluoma, Liisa 2005: Milan Kundera - viimeinen modernisti. Faros, Turku.

Saastamoinen, Kari 2011: Adam Smith ja näkymätön käsi. Teoksessa Heiskala \& Virtanen 2011a, 176-202.

Salin, Sari 2008: Narri kertojana. Kultaisesta aasista suomalaiseen postmodernismiin. Suomalaisen Kirjallisuuden Seura, Helsinki.

Salin, Sari 2013: Prinsessaruttoa Sysi-Suomesta. Ruoka, rakkaus ja äidinkieli Sofi Oksasen romaanissa 'Stalinin lehmät'. Teoksessa Haapala \& Sipilä 2013a, 373-391.

Salmela, Mikko 1998: Suomalaisen kulttuurifilosofian vuosisata. Otava, Helsinki.

Sandbacka, Kasimir 2017: Utopia Derailed. Rosa Liksom's Retrospection of the Modern Project. University of Oulu Graduate School, B 154, Oulu.

Sartre 1960: Critique de la raison dialectique. Tome 1. Théorie des Ensembles Pratiques. Gallimard, Paris. 
Sartre 1973: L'être et le néant. Essai d'ontologie phénomenologique. Gallimard, Paris. (Ilmestyi alun perin 1943.)

Sartre, Jean-Paul 2007: Existentialism is a Humanism. Including a Commentary on 'The Stranger'. Orig. L'Existentialisme est un humanism (1945) ja Explication de l'Etranger (1947). Translated by Carol Macomber. Yale University Press, New Haven and London.

Saunders, Max 2010: Self-Impression. Life-Writing, Autobiografication, and the Forms of Modern Literature. Oxford University Press, New York.

Schmidt, Siegfried J. 1989: Die Selbstorganisation des Sozialsystems Literatur im 18. Jahrhundert. Suhrkamp, Frankfurt am Main.

Schmidt, Vivien Ann 2002: The Future of European Capitalism. Oxford University Press, Oxford.

Schmidt, Vivien Ann 2016: The Roots of Neo-Liberal Resilience. Explaining Continuity and Change in Background Ideas in Europe's Political Economy. British Journal of Politics $Q$ International Relations. Volume 18, no. 2, 318-334.

Schmidt, Vivien Ann \& Mark Thatcher (eds.) 2013a: Resilient Liberalism in Europe's Political Economy. Cambridge University Press, Cambridge.

Schmidt, Vivien Ann \& Mark Thatcher 2013b: Theorizing Ideational Continuity: The Resiliency of Neoliberal Ideas in Europe. Teoksessa Schmidt, Vivien Ann \& Thatcher 2013a, 1-50.

Schumpeter, Joseph 2010: Capitalism, Socialism and Democracy. With a new Introduction by Joseph E. Stiglitz. (Ilmestyi alun perin 1942.) Routledge, London.

Schweppenhäuser, Gerhard 2007: 'Ein Gemälde von Cézanne ist auch auf dem Klosett ein gemälde von Cézanne'. Kunst, Alltagskultur und ready-made bei Marcuse. Teoksessa Winter \& Zima 2007, 159-175.

Selzer, Mark 1984: Henry James and the Art of Power. Cornell University Press, Ithaca.

Sennett, Richard 2002: Työn uusi järjestys. Miten uusi kapitalismi kuluttaa ihmisen luonnetta. Alkuperäisteos The Corrosion of Character (1998). Suomentaneet Eeva Kivinen ja David Kivinen. Vastapaino, Jyväskylä.

Sennett, Richard 2007: Uuden kapitalismin kulttuuri. Alkuperäisteos The Culture of New Capitalism (2006). Suomentanut Kaisa Koskinen. Vastapaino, Tampere.

Sevänen, Erkki 1998: Taide instituutiona ja järjestelmänä. Modernin taide-elämän historiallis-sosiologiset mallit. Suomalaisen Kirjallisuuden Seura, Helsinki.

Sevänen, Erkki 2001: Art as an Autopoietic Sub-System of Modern Society. A Critical Analysis of the Concepts of Art and Autopoietic System in Luhmann's Late Production. Theory, Culture and Society 18:1, 75-103.

Sevänen, Erkki 2006: A Long-term Contrast in Systemic Sociology: Niklas Luhmann's Anti-Humanist System Theory and Actor-Centric Critical Theory. Cybernetics and Human Knowing 13:2, 64-93.

Sevänen, Erkki 2008a: Introduction: On the Study of Metafiction and Metaliterary Phenomena. Teoksessa Hägg, Sevänen \& Turunen 2008, 9-25.

Sevänen, Erkki 2008b: Towards a New Kind of System of Art. The Shift from Modern to Contemporary Sphere of Art from the Standpoint of System-Theoretical and Systemic Sociology. Dr. Müller, Saarbrücken Germany. 
Sevänen, Erkki 2011: Kirjallisuus maailman merkityksellistäjänä. Teoksessa Ruohonen, Sevänen \& Turunen 2011, 249-297.

Sevänen, Erkki 2013a: Nykykirjallisuuden yhteiskunnallinen kehys. Teoksessa Hallila, Hosiaisluoma, Karkulehto, Kirstinä \& Ojajärvi 2013b, 11-34.

Sevänen, Erkki 2013b: Nykykapitalismin kritiikki näytelmässä ja teattereissa. Teoksessa Hallila, Hosiaisluoma, Karkulehto, Kirstinä \& Ojajärvi 2013a, 119-120.

Sevänen, Erkki 2013c: Juha Seppälän 'Paholaisen haarukka' markkinakapitalismin representaationa. Teoksessa Hanna Meretoja \& Aino Mäkikalli (toim.), Romaanin historian ja teorian kytköksiä. Suomalaisen Kirjallisuuden Seura, Helsinki, 314-350.

Sevänen, Erkki 2013d: Taide Luhmannin järjestelmäteoriassa. Teoksessa Janne Jalava (toim.), Yhteiskunnan järjestelmät. Niklas Luhmannin ajattelu. Gaudeamus, Helsinki, 236-259.

Sevänen, Erkki 2014a: Luc Boltanskin ja Ève Chiapellon sosiologinen käsitys kapitalismikritiikistä ja kriittinen nykytaide. Kulttuurintutkimus 31:2, 3-14.

Sevänen, Erkki 2014b: Sosiaalinen romaani, yhteiskuntaromaani ja niiden lajisukulaiset kirjallisuushistorian ja nykykirjallisuuden kerrostumana. Joutsen/Svanen 1, 48-73.

Sevänen, Erkki 2018a: Capitalist Economy as a Precondition and Restraint of Modern and Contemporary Art Worlds. Teoksessa Alexander, Hägg, Häyrynen \& Sevänen 2018b, 3-33.

Sevänen, Erkki 2018b: Modernin taideautonomian synty ja sen kohtalo nykykapitalismissa. Teoksessa Ojajärvi, Sevänen \& Steinby 2018a, 84-125.

Sevänen, Erkki 2018c: Modern Literature as a Form of Discourse and Knowledge of Society. Sociologias 20, 48-85.

Sicotte, Geneviève, Martial Poirson, Stéphanie Loncle \& Christian Biet (sous la direction) 2013: Fiction et économie dans la littérature et les arts du spectacle, XIXe-XXIe siècles. Les Presses de l'Université Laval, Imprimé au Canada.

Siltala, Juha 2004: Työelämän huonontumisen lyhyt historia. Muutokset hyvinvointivaltion ajasta globaaliin hyperkilpailuun. Otava, Helsinki.

Sipilä, Juhani 2005: Vedenpaisumus ja Baabelin kieltensekoitus samana päivänä. Hannu Raittilan yhdenpäivänromaani 'Ei minulta mitään puutu'. Teoksessa Pirjo Lyytikäinen, Jyrki Nummi \& Päivi Koivisto, Lajit yli rajojen. Suomalaisen kirjallisuuden lajeja. Suomalaisen Kirjallisuuden Seura, Helsinki, 206-236.

Smitten, Jeffrey R. \& Anna Daghistany (eds.) 1981: Spatial Form in Narrative. With a Foreword by Joseph Frank. Cornell University Press, Ithaca and London.

Steinby, Liisa 2011: Sosiologinen näkökulma kirjallisuuden lajeihin. Teoksessa Ruohonen, Sevänen \& Turunen 2011, 365-394.

Steinby, Liisa 2013: Kirjallisuus ja kirjallisuudentutkimus. Teoksessa Liisa Steinby \& Aino Mäkikalli (toim.), Johdatus kirjallisuusanalyysiin. Helsinki. SKS, 15-56.

Steinby, Liisa \& Mikko Tirronen 2018: Kohti totaalikapitalismia. Liberaalikapitalismin kaventunut subjekti Kari Hotakaisen Ihmisen osassa ja Don DeLillon Cosmopoliksessa. Teoksessa Ojajärvi, Sevänen \& Steinby 2018, 201-236.

Steiner, George 1961: The Death of Tragedy. Faber and Faber, London.

Stiglitz, Joseph 2004: Globalisaation sivutuotteet. Alkuperäisteos Globalization and its Discontents (2002). Suomentanut Juhani Yli-Vakkuri. Like, Helsinki. 
Stiglitz, Joseph 2010: Freefall. America, Free Market Economy and the Sinking of the World Economy. Penguin, London.

Stockwell, Peter 2002: Cognitive Poetics. An Introduction. Routledge, New York.

Strang, Johan \& Thomas Wallgren (toim.) 2020: Georg Henrik von Wright. Modernin ajan ajattelija. Alkuperäisteos Tankens utåtvändhet. Georg Henrik von Wright som intellektuell (2016). Suomentanut Timo Soukola. Gaudeamus, Helsinki.

Sulkunen, Pekka 2006: Projektiyhteiskunta ja uusi yhteiskuntasopimus. Teoksessa Rantala \& Sulkunen 2006, 17-38.

Suomalaiset luokkakuvassa. Tekijöinä Raimo Blom ja joukko Tampereen yliopistossa vaikuttaneita yhteiskuntatieteilijöitä. Vastapaino, Tampere 1984.

Suomela, Johanna 2007: Oliver pyytää lisää. Charles Dickens ja satiiri. Teoksessa Kivistö 2007a, 135-151.

Suutela, Hanna 2013: Näytelmäkirjallisuus seuraa aikaansa. Teoksessa Hallila, Hosiaisluoma, Karkulehto, Kirstinä \& Ojajärvi 2013a, 110-118.

Söderling, Tryggve 2008: Drag på Parnassen: två sextiotalsstudier. Del 1. Medelklass med mänskligt ansikte: medelklassradikalism i fyra romaner av Christer Kihlman, Jarl Sjöblom, Marianne Alopaeus och Ulla-Lena Lundberg. Nordica, Helsingfors universitet, Helsingfors.

Söndergaard Christensen, Anna-Marie 2020: Georg Henrik von Wright Tanskassa. Teoksessa Strang \& Wallgren 2020, 179-195.

Tarkka, Lotte 2012: The Sampo. Myth as a Vernacular Imagination. Teoksessa Frog, Siikala \& Stepanova 2012.

Tarkka, Pekka 2000: Suomalaisia nykykirjailijoita. Kuvittanut Pekka Vuori. Kuudes laitos. Tammi, Helsinki.

Taylor, Charles 1995: Autenttisuuden etiikka. Alkuperäisteos The Ethics of Authenticity. The Malaise of Modernity (1991). Suomentanut Timo Soukola. Gaudeamus, Helsinki.

Taylor, Charles 1996: Sources of the Self. The Making of Modern Identity. Cambridge University Press.

Ten Brink, Tobias (Hrsg.) 2011: Globale Rivalitäten. Staat und Staatensystem im globalen Kapitalismus. Stuttgart.

Thaler, Richard H. 1994: Quasi-Rational Economics. Russell Sage Foundation, New York. Thaler, Richard H. 2015: Misbehaving. The Making of Behavioral Economics. Norton \& Company, New York.

Thatcher, Mark \& Vivien Ann Schmidt 2013: Conclusion: Explaining the Resiliency of Neo-Liberalism and Possible Pathways Out. Teoksessa Schmidt, Vivien Ann \& Thatcher 2013a, 403-432.

Tiihonen, Seppo 2006: Poliittisen hallinnan ja hallintopolitiikan muutoksia 1980- ja 1990-luvulla. Teoksessa Heiskala \& Luhtakallio 2006, 82-104.

Tontti, Jukka 2005: Masennus yhteiskunnallisena ja kulttuurisena ilmiönä. Teoksessa Anna-Maija Pirttilä-Backman, Marja Ahokas, Liisa Myyry \& Susanna Lähteenoja (toim.), Arvot, moraali ja yhteiskunta. Sosiaalipsykologisia näkökulmia yhteiskunnan muutokseen.

Gaudeamus, Helsinki, 385-398.

Touraine, Alain 1992: Critique de la modernité. Librairie Arthème Fayard, Paris.

Urry, John 2013: Ilmastonmuutos ja yhteiskunta. Alkuperäisteos Climate Change and Society (2011). Suomentanut Jyrki Vainonen. Vastapaino, Tampere. 
Wallerstein, Immanuel 2004: World-Systems Analysis. An Introduction. Temple University Press, Philadelphia.

Walsh, Richard 2007: The Rhetoric of Fictionality. Narrative Theory and the Idea of Fiction. The Ohio State University Press, Columbus.

Warhol, Robyn 2012: Kommenttipuheenvuoro teoksessa Herman, Phelan, Rabinowitz, Richardson \& Warhol 2012, 165-168.

Waris, Heikki 1948: Suomalaisen yhteiskunnan rakenne. Otava, Helsinki.

Watt, Ian 1987: The Rise of the Novel. Studies in Defoe, Richardson and Fielding. Hogarth Press, London. (Ilmestyi alun perin 1957.)

Waugh, Patricia 1984: The Theory and Practice of Self-Conscious Fiction. Methuen, London and New York.

Weber, Max 1956: Wirtschaft und Gesellschaft I-II. J.C.B. Mohr (Paul Siebeck), Tübingen. (Ilmestyi alun perin 1921-1922.)

Weber, Max 1980: Protestanttinen etiikka ja kapitalismin henki. Alkuperäisteos Die protestantische Ethik und der Geist des Kapitalismus (1904-1906). Suomentanut Timo Kyntäjä. WSOY, Porvoo-Helsinki-Juva.

Weber, Max 2009: Tiede ammattina ja kutsumuksena. Alkuperäisteos Wissenschaft als Beruf (1919). Teoksessa Max Weber, Tiede ja politiikka. Kutsumus ja ammatti. Suomentanut Tapani Hietaniemi. Vastapaino, Tampere.

Veivo, Harri 2010: Representaation muodot ja mahdollisuudet kirjallisuudessa. Teoksessa Tarja Knuuttila \& Aki Petteri Lehtinen (toim.), Representaatio. Tiedon kivijalasta tieteiden työkaluksi. Gaudeamus ja Helsinki University Press, Helsinki, 135-157.

Veivo, Harri 2011: Portti ja polku. Tutkimus kirjallisuuden semiotiikasta. Gaudeamus, Helsinki. Welsch, Wolfgang 1995: Vernunft. Die zeitgenössische Vernunftkritik und das Konzept der transversalen Vernunft. Suhrkamp, Frankfurt am Main.

Wherry, Frederick F: 2012: The Culture of Markets. Polity Press, Cambridge UK and Malden USA.

Whitehead, Anne 2004: Trauma Fiction. Edinburgh University Press, Edinburgh.

Vickroy, Laurie 2014: Reading Trauma Narratives. University of Virginia Press, Charlottesville and London.

Vickroy, Laurie 2015: Voices of Survivors in Contemporary Fiction. Teoksessa Michelle Balaev (ed.), Contemporary Approaches in Literary Trauma Theory, Palgrave Macmillan, London, 130-151.

Wienen, Mark W. van 2012: American Socialist Triptych: The Literary-Political Work of Charlotte Gilman, Upton Sinclair and W.E.B. Bois. University of Michigan Press.

Wilenius, Markku 2006: Yhteiskunta, tulevaisuus, ennakointi. Teoksessa Heiskala \& Luhtakallio $2006,218-237$.

Williams, Raymond 1988: Marxismi, kulttuuri ja kirjallisuus. Alkuperäisteos Marxism and Literature (1977). Suomentanut Mikko Lehtonen. Vastapaino, Tampere.

Winter, Rainer \& Peter V. Zima (Hrsg.) 2007: Kritische Theorie heute. Transcript Verlag, Bielefeld.

Wolff, Jonathan 1991: Robert Nozick. Anarchy, Justice, and the Minimal State. Stanford University Press. 
Wright, G. H. von 1985: Filosofisia tutkimuksia. Suomentaneet Heikki Nyman, Tauno Nyberg ja Jyrki Uusitalo. Kirjayhtymä, Helsinki.

Wright, G. H. von 1987: Tiede ja ihmisjärki. Suunnistusyritys. Suomentanut Anto Leikola. Otava, Helsinki.

Wright, G. H. von 1993: Myten om framsteget. Tankar 1987-1992 med en intellektuell självbiografi. Söderströms, Falun.

Zima, Peter V. 1980: Textsoziologie. Eine kritische Einführung. Metzler, Stuttgart.

Zima, Peter V. 1989: Ideologie und Theorie. Eine Diskurskritik. Francke Verlag.

Zima, Peter V. 1999: The Philosophy of Modern Literary Theory. Athlone Press, London and New Brunswick NJ.

Zima, Peter V. 2001: Moderne/Postmoderne. Gesellschaft, Philosophie, Literatur. Zweite, überarbeitete Auflage. A. Francke Verlag, Tübingen and Basel. (Ilmestyi alun perin 1997.) 


\section{Henkilöhakemisto}

A

Adorno, Theodor W. 32, 109, 194, 222, 361, 411, 413, 414

Aho, Esko 75, 76

Aho, Juhani 149

Alasuutari, Pertti 76

Alfvén, Erik (Hohenthal, Lennart) 82

Allardt, Erik 62

Alopaeus, Marianne 147

Althusser, Louis 18

Anttila, Anu-Hanna 91, 287, 343

Aristoteles 122, 203-205, 207-208

Arminen, Elina 34, 304

Atwood, Margaret 157

Aspers, Patrik 85

Augustinus 46

\section{B}

Bahtin, Mihail 34, 56, 110

Balzac, Honoré de 38, 43, 44, 100, 138, 139, 141-143, 213, 252, 396

Barthes, Roland 361

Baudelaire, Charles 361

Baudrillard, Jean 232, 295, 369

Bauman, Zygmunt 267, 350

Beauvoir, Simone de 20, 45, 46, 133, 153, 292, 356, 375

Beck, Ulrich 134, 256-257, 364, 407

Beckett, Samuel 153, 197-198

Beecher-Stowe, Harriet 140

Belina, Bernd 80

Bell, Daniel 31, 32, 209, 411

Berdjajev, Nikolai 45, 46

Bergroth, Harley 287, 346

Bergson, Henri 153

Biet, Christian 44

Blair, Tony 176

Blake, William 335

Bobrikov, Nikolai 82

Boltanski, Luc 113, 118-121, 304, 307, 317, $342-343,358-362,398,400,416$
Bourdieu, Pierre 95-96, 361, 394

Brecht, Bertolt 141, 144, 214

Broch, Hermann 141, 144, 214

Bürger, Christa 26

Bürger, Peter 26

C

Camus, Albert 16, 20, 45, 46, 50, 51, 54, 65, 133, 153, 154, 293, 421

Canth, Minna 15, 44, 145, 147, 149

Carlson, Mikko 44, 45

Carlyle, Thomas 336

Castells, Manuel 71, 80, 159, 233, 237,

272, 407

Cazamian, Louis 43

Cerny, Philip G. 80

Cervantes 152

Chatman, Seymour 314

Chiapello, Ève 113, 118-121, 304, 307, 317,

$342-343,358-362,398,400-401,416$

Claybough, Amanda 43, 139-140

Cooper, David 46

Coppola, Francis Ford 202

Currie, Mark 47

D

David, Sylvain 155

DeLillo, Don 141, 145, 223, 249- 251

Debord, Guy 232

Deci, Edward L. 365

Defoe, Daniel 137, 396

Deleuze, Gilles 361

Derrida, Jacques 46, 361

Descartes, René 415

Dickens, Charles 38, 43, 139, 143-144, 166, 336, 396

Dilthey, Wilhelm 153

Disraeli, Benjamin 43

Dostojevski, Fjodor 45, 46, 81, 293

Douglas, Michael 39

Dubois, Jacques 43, 396 
Dupin, Aurore (Sand, George) 139, 140

Döblin, Alfred 293

E

Eagleton, Terry 17-18

Eisenstein, Sergei 392-393

Eliot, George (Evans, Mary Ann) 139

Ellis, Bret Easton 141, 145, 214-215

Engels, Friedrich 129, 250-251

Erola, Jani 88-91, 96, 298, 343

Etzioni, Amitai 31-32, 411

Evans, Mary Ann (Eliot, George) 139

F

Fagerholm, Monika 157

Flaubert, Gustave 138, 249

Fludernik, Monika 17-18, 25

Fontane, Theodor 138

Foucault, Michel 277, 303, 415

Fougner, Tore 80

Fowler, Alastair 14, 36, 142, 408, 410

Franklin, Benjamin 170-17

Franzen, Jonathan 157

Fraser, Nancy 279-280

Friedman, Milton 223, 238-239

\section{G}

Gadamer, Hans-Georg 24-25, 34

Galilei, Galileo 415

Gaskell, Elizabeth 43, 139, 336

Gassett, Jose Ortega y 45, 46

Gay, Paul Du 400

Genette, Gérard 36-37, 229

Gibson, Andrew 94

Giddens, Anthony 33, 51, 63, 134, 152, 253,

294, 364, 400

Gilpin, Robert 73-74

Gogol, Nikolai 39

Goldmann, Lucien 43, 133-134

Goncourt, Edmond de 139

Goncourt, Jules de 139

Gorki, Maksim 141

Gustafsson, Laura 278
$\mathrm{H}$

Haanpää, Pentti 15, 146, 147, 150, 253, 396

Haavikko, Paavo 97, 329

Habermas, Jürgen 10, 18, 25-26, 32-34, 83, 97-98, 109, 113, 120-121, 123-128, 130-131, 135-137, 190, 211, 219, 236-237, $245,249,272,279,311-313,331,353,390$, 398-400, 407, 411, 413

Hall, Peter A. 78-79

Hallila, Mika 13, 272-273

Harvey, David 71, 77, 80, 337-338

Hayek, Friedrich von 116-117, 180

Hegel, G. W. F. 43

Heidegger, Martin 45, 46, 133, 153, 194, 293, 356,361

Heiskala, Risto 74, 78, 80

Henriksson, Essi 277

Herman, Judith 385

Himanen, Pekka 159

Hobbes, Thomas 262

Hohenthal, Lennart (Alfvén, Erik) 82

Holappa, Pentti 378

Holkeri, Harri 75, 76

Holmström, Johanna 157

Honneth, Axel 125, 281

Horkheimer, Max 32, 194, 361, 411

Hosiaisluoma, Yrjö13, 272-273

Hotakainen, Kari 149, 253, 304, 378, 402

Houellebecq, Michel 44, 111, 141-142, 145,

155-156, 249-251, 275

Huber, Irmtraud 47, 157, 303

Huovinen, Veikko 29

Husserl, Edmund 45

Hutcheon, Linda 46

Huxley, Aldous 144, 252

Hämäläinen, Helvi 153-154

Hämäläinen, Karo 149, 215-216

Hämäläinen, Simo 53

Hännikäinen, Liisa 53

Hänninen, Ville 41

Hökkä, Tuula 153 
I

Ionesco, Eugene 153

Iser, Wolfgang 105

Isomaa, Saija 35, 44, 225

Israel, Joachim 129

Itkonen, Juha 304

J

Jakobson, Max 97

Jameson, Fredric 26, 30, 100, 338, 390

Jaspers, Karl 45, 46

Jauss, Hans Robert 34, 69

Jessop, Bob 80

Jokela, Juha 160, 185

Jotuni, Maria 146, 396

Julkunen, Raija 269-270, 280

Juntunen, Tuomas 27, 56, 175, 189, 196

Jylhä, Yrjö 110

Jäntti, Jalmari 320, 366

Järnefelt, Arvid 44, 146

Järvinen, Katriina 343

K

Kafka, Franz 39, 153

Kailas, Uuno 110

Kalervo, Leo 53

Kant, Immanuel 122

Kantola, Anu 74, 80, 91, 99, 242-243, 344

Karkama, Pertti 44, 119, 134, 149-151

Karkulehto, Sanna 272-273, 277-278

Karvala, Samu 24

Kauranen, Anja (Snellman, Anja) 304-305

Kauranen, Ralf 91, 343

Keski-Vähälä, Sami 39

Kianto, Ilmari 150-151

Kierkegaard, Søren 45, 46

Kihlman, Christer 45, 147, 148, 378

Kirstinä, Leena 13-14, 29, 272-273

Kivelä, Malin 157

Kivi, Aleksis 38

Klages, Ludwig 153

Klein, Naomi 288-289

Koivisto, Päivi 378

Kolbe, Laura 343
Korpela, Jorma 153

Krogerus, Anna 398-399

Krohn, Leena 388-399

Krugman, Paul 400

Kundera, Milan 154-155

Kuusela, Hanna 91, 99, 175, 242-243, 344

Kylänpää, Riitta 17, 316, 402

Kögler, Hans-Herbert 363

L

Lahtinen, Toni 225

Laitinen, Kai 110

Lampela, Pasi 185

Langman, Lauren 364-365

Lash, Scott 113, 114

Lassila, Maiju 146, 147, 396

Launis, Kati 287

Lehtonen, Joel 150

Lepenies, Wolf 43

Leppihalme, Ilmari 278

Leskinen, Esa 39

Lévinas, Emmanuel 46

Lewis, Sinclair 140

Liksom, Rosa 29, 287

Lindberg, Pirkko 277

Lindholm, Charles 357-358, 364

Linna, Väinö 16, 34, 38, 56-57, 101-102, 147, 149, 402

Lipponen, Paavo 82

Lo-Johansson, Ivar 141-142

Loncle, Stéphanie 44

Luhmann, Niklas 135, 211, 256, 390

Lukács, Georg 43, 100-101, 113, 152, 390

Lyytikäinen, Pirjo 136

M

Macherey, Pierre 18

Maijala, Minna 44

Majander, Antti 208

Malmio, Kristina 157

Mann, Heinrich 138

Mann, Thomas 100, 138, 140, 388

Manner, Eeva-Liisa 153

Mannerheim, C. G. E. 29 
Mannerkorpi, Juha 153

Marcuse, Herbert 32, 109, 133, 246, 361, 411, 413

Martin, Margareta 55

Marttila, Hanna Marjut 286

Marx, Karl 31-32, 111-114, 128-129, 131, 161, 171, 206, 250-251, 337, 365, 411

Maupassant, Guy de 141, 144

McGill, Robert 381-382

McGuigan, Jim 72, 176

McHale, Brian 47

Melender, Tommi 149, 215-216, 249, 399

Melin, Harri 343

Meretoja, Hanna 135-136, 250, 326, 390

Meri, Veijo 29

Merleau-Ponty, Maurice 45-46

Miettinen, Arto 29

Munthe, Axel 189

Mäkinen, Kari 19

Mäkinen, Katariina 345

Möbuss, Susanne 46, 51

Mörö, Mari 27-28

N

Nietzsche, Friedrich 45-46, 128, 153

Niiniluoto, Ilkka 64, 127

Nousiainen, Miika 101

Nozick, Robert 117

Nummi, Jyrki 34, 57

Nussbaum, Martha C. 127, 136, 390, 411

Nünning, Ansgar 314

Nystrand, Marko 108

O

Ojajärvi, Jussi 13, 27-28, 100-101, 399, 402

Oksanen, Sofi 278

Onkeli, Kreetta 304

P

Pakkala, Teuvo 145, 147

Palmgren, Raoul 96

Paronen, Samuli 148

Patomäki, Heikki 75-76, 80

Pavel, Thomas G. 105-106
Peirce, Charles Sanders 105

Pekkanen, Toivo 15, 146-147, 252-253, 396

Peltola, Sirkku 83

Peltonen, Milla 44, 301

Petersen, Anders 131-132

Pettersson, Anders 39-40

Phelan, James 36, 42, 104, 313

Piketty, Thomas 77, 80, 98-99, 213-214,

337-338, 400

Pinter, Harold 153

Poirson, Martial 44

Polanyi, Karl 32, 334-335, 407

Presley, Elvis 349

Pulkkinen, Matti 53

Putin, Vladimir 79

Puttonen, Seppo 16

Pyysalo, Joni 16

Päätalo, Kalle 38, 53

$\mathbf{R}$

Rabinowitz, Peter J. 42, 108

Rahkonen, Keijo 97

Raittila, Hannu 100, 149, 177-178, 215, 296

Reagan, Ronald 71

Rescher, Nicholas 127

Richardson, Brian 104

Ricoeur, Paul 106, 151

Rintala, Paavo 24, 56, 153, 192, 202

Robbe-Grillet, Alain 327

Roche, Mark William 136-137

Roos, J. P. 97

Rossi, Riikka 44

Rousseau, Jean-Jacques 357

Runeberg, J. L. 38

Ryan, Richard M. 365

S

Saariluoma, Liisa (Steinby, Liisa) 155, 372

Saisio, Pirkko 147, 378, 381

Salama, Hannu 29, 44, 56, 147-148, 154, 301-302, 399

Salminen, Arto 147, 149, 227, 249, 399, 402

Salminen, Johannes 97

Salminen, Matti 186 
Sand, George (Dupin, Aurore) 140

Sariola, Esa 29

Sarraute, Nathalie 327

Sartre, Jean-Paul 16, 20, 45, 46, 50, 66-67, $96,133,153-154,194,257,292-293,325-$ $326,361,368,375,414$

Schauman, Eugen 82

Schmidt, Vivien Ann 71, 78-79

Schopenhauer, Arthur 153

Schulte-Sasse, Jochen 26

Schumpeter, Joseph 161

Scorsese, Martin 39

Selzer, Mark 94

Sennett, Richard 132, 254

Sevänen, Erkki 27, 45

Shaw, Bernard 139

Sicotte, Geneviève 44

Sihvonen, Lauri 223-224

Siirilä, Jussi 304

Siljo, Juhani 110

Siltala, Juha 97, 184-185

Sinclair, Upton 140-141

Sinkkonen, Lassi 147, 148

Simon, Claude 327

Smith, Adam 223, 238

Snellman, Anja (Kauranen, Anja) 304-305

Snellman, J. W. 96

Sofokles 203-205, 207-208, 293

Soskice, David 78-79

Spengler, Oswald 153

Stael, Germaine de 44

Steinbeck, John 140

Steinby, Liisa (Saariluoma, Liisa) 34, 45

Stendhal 138, 139, 308, 318, 371-372, 396

Stiglitz, Joseph 400

Stockwell, Peter 37

Stone, Oliver 39

Sue, Eugéne 139

Sund, Lars 157

Säisä, Eino 53

T

Taivassalo, Hannele Mikaela 157

Tapio, Marko 153
Tarkka, Pekka 49

Tavaststjerna, K. A. 145, 147

Taylor, Charles 357-358, 364

Teivainen, Teivo 338

Tervo, Jari 278, 304

Thackeray, William Makepeace 139

Thaler, Richard H. 220-221

Thatcher, Margaret

Thatcher, Mark 71, 78

Tiilikka, Elina 278

Tillich, Paul 45

Tolstoi, Leo 100, 138, 139

Tontti, Jukka 131-132, 286

Touraine, Alain 31, 32, 237, 411

Tšehov, Anton 386

Turgenev, Ivan 138

Turunen, Heikki 53

Turunen, Risto 13-14

Tuuri, Antti 29

U

Urry, John 114-115, 400

\section{V, W}

Waarala, Hannu 368

Wagner, Richard 202

Waltari, Mika 154

Walsh, Richard 104, 105-106, 211, 312-313

Waris, Heikki 62

Watt, Ian 137-138

Waugh, Patricia 46

Wayne, John 186

Weber, Max 31-33, 97, 98, 111-114, 123-127, 129-131, 137, 170-175, 177, 179, 191, 202, 208, 217, 219, 221, 236, 237, 241, 242, 245,

$272,359,360,365,398,407,411$

Veivo, Harri 105

Wells, H. G. 144, 252

Welsch, Wolfgang 126

Verronen, Maarit 149, 227

Westö, Kjell 157

Wherry, Frederick F. 168

Whitehead, Anne 385

Vickroy, Laurie 281 
Viinikainen, Antero 304

Wilde, Oscar 374

Wilhelmsson, Putte 27

Williams, Raymond 11

Winter, Rainer 363

Wittgenstein, Ludwig 142, 299, 361

Wright, G. H. von 97-98, 127, 248-249,

411, 415

Wuolijoki, Hella 38

\section{Y}

Ylönen, Merja 18-19

$\mathbf{Z}$

Zima, Peter V. 26, 31-32, 109, 365

Zola, Émile 96, 138, 140, 142 